\author{
UNIVERSIDADE DE SÃO PAULO \\ INSTITUTO DE ARQUITETURA E URBANISMO
}

Mônica Duarte Aprilanti

A experimentação construtiva em madeira como instrumento de ensino-aprendizagem nas escolas de arquitetura

São Carlos 

MÔNICA DUARTE APRILANTI

\section{A experimentação construtiva em madeira como instrumento de ensino-aprendizagem nas escolas de arquitetura}

\section{Versão Corrigida}

Tese apresentada ao Instituto de Arquitetura e Urbanismo da Universidade de São Paulo para a obtenção do título de Doutora em Arquitetura e Urbanismo.

Área de concentração: Arquitetura, Urbanismo e Tecnologia Orientador: Prof ${ }^{\mathrm{a}} \mathrm{Dr}^{\mathrm{a}}$ Akemi Ino 
AUTORIZO A REPRODUCAO TOTAL OU PARCIAL DESTE TRABALHO, POR QUALQUER MEIO CONVENCIONAL OU ELETRONICO, PARA FINS DE ESTUDO E PESQUISA, DESDE QUE CITADA A FONTE

Ficha catalográfica elaborada pela Biblioteca do Instituto de Arquitetura e Urbanismo com os dados fornecidos pelo(a) autor(a)

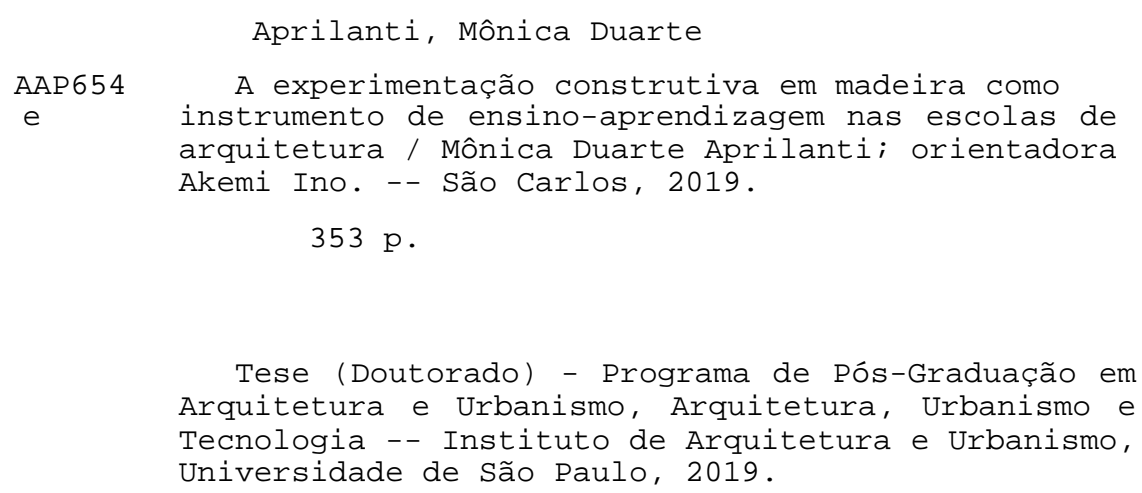

Tese (Doutorado) - Programa de Pós-Graduação em Arquitetura e Urbanismo, Arquitetura, Urbanismo e Tecnologia - - Instituto de Arquitetura e Urbanismo, Universidade de São Paulo, 2019.

1. Ensino de arquitetura. 2. Formação tecnológica.

Bibliotecária responsável pela estrutura de catalogação da publicação de acordo com a AACR2: Brianda de Oliveira Ordonho Sígolo - CRB - 8/8229 


\section{FOLHA DE JULGAMENTO}

Candidato(a): Mônica Duarte Aprilanti

Título da tese: "A experimentação construtiva em madeira como instrumento de ensino-aprendizagem nas escolas de arquitetura"

Data da defesa: 25/10/2019

Orientador: Profa. Dra. Akemi Ino

Comissão Julgád dora:

Resultado:

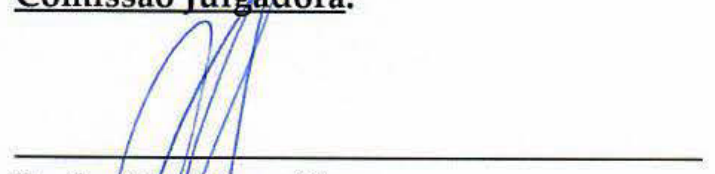

Profa. Dra. Akemi Ino

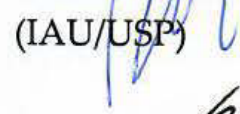

Não votante

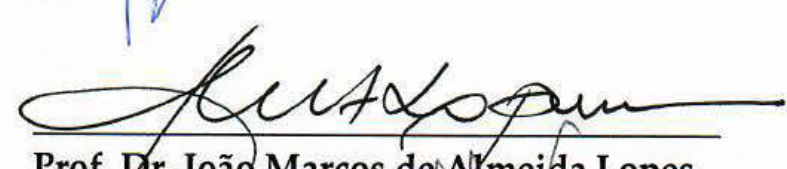

Prof. Dr. João Marcos de Almeida Lopes

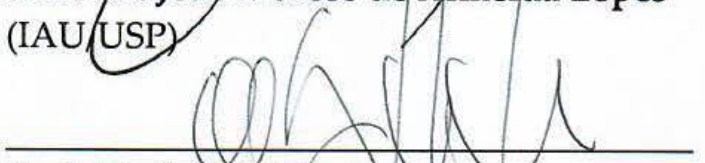

Prof. Dr. Joubert José Lancha

(IAU/USP)

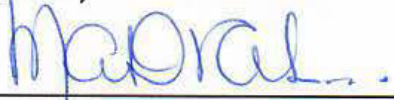

APHOVDDS

Profa. Dra. Maria Amélia Devitte Ferreira Dázevedo Leite (FIAM-FAAM)

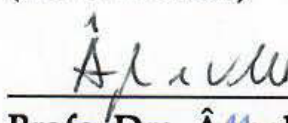

Profa.'Dra. Ângela do Valle

aprovada

(UFSC)

Prof. Dr. Lvan Manoel Rezende do Valle

APROUADA (UnB)

APROVADA

APROYADA

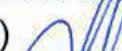



À $\mathcal{E} v a$, com todo o meu amor. 



\section{AGRADECIMENTOS}

À Coordenação de Aperfeiçoamento de Pessoal de Nível Superior - CAPES pelo apoio financeiro através das bolsas do Programa de Demanda Social e do Programa Doutorado Sanduíche no Exterior - PDSE, número de processo: 88881.187956/2018-01.

Ao Programa de Pós-Graduação em Arquitetura e Urbanismo do Instituto de Arquitetura e Urbanismo da Universidade de São Paulo - IAU-USP, aos professores e funcionários que direta ou indiretamente auxiliaram no desenvolvimento desta Tese.

Minha mais sincera gratidão à professora Akemi Ino, pelo seu entusiasmo, orientação e amizade. Sua trajetória de militância em prol do uso da madeira e de materiais e tecnologias construtivas mais amigáveis ao homem e ao meio ambiente é uma inspiração para mim.

Aos colegas e professores coordenadores do Grupo de Pesquisa em Habitação e Sustentabilidade - HABIS, pelos momentos privilegiados de partilha de conhecimentos e de celebrações, neste ambiente de troca e aprendizado irrestritos.

Ao professor João Marcos de Almeida Lopes e à professora Maria Amélia D'Azevedo Leite pelas contribuições no Exame de Qualificação, etapa decisiva para o direcionamento da investigação. Aos professores Joubert Lancha, Ângela do Valle e Ivan Manoel Rezende do Valle, membros da comissão de julgamento de Defesa da Tese, pelos valiosos comentários e aportes ao debate.

Ao professor Andrés Garcés Alzamora por sua generosidade em receber-me durante o período sanduíche na Escuela de Arquitectura y Diseño da Pontifícia Univesidad Católica de Valparaíso - e[ad] PUCV, que em muito contribuiu para a evolução da pesquisa e para meu crescimento profissional e pessoal.

Ao professor assistente Bruno Marambio da e[ad] PUCV pela parceria ao longo do Taller del Programa y Forma de la Edificación. Ao professor Cristián Schmitt da Escuela de Arquitectura da Pontifícia Universidad Católica de Chile pela disponibilidade em compartilhar sua vivência na disciplina Introducción a la Construcción.

À professora Anna Lúcia dos Santos Vieira e Silva (Lilu) pela inestimável contribuição no momento conclusivo da escrita desta Tese. Gratidão eterna pela profícua discussão e por motivar-me, com seu exemplo, à prática docente ética e crítica. À designer Glaucia Nogueira Gonçalves por sua prontidão em acolher ao meu pedido de ajuda aportando com sutis detalhes gráficos um toque final ao trabalho.

A todos os professores, aos arquitetos e engenheiros, entrevistados ao longo da investigação, que gentilmente cederam seu tempo e partilharam suas experiências.

Aos colegas de docência da Universidade Metodista de Piracicaba - UNIMEP, que me incentivaram neste ínterim e assumiram minhas atribuições durante meu afastamento.

Aos meus pais Maria Ângela e Antônio pelo apoio incondicional, sem o qual não teria sido possível chegar até aqui. À minha amada filha Eva, por me encorajar e por suportar tantas restrições no decurso desta longa jornada. 





\section{RESUMO}

APRILANTI, M. D. A experimentação construtiva em madeira como instrumento de ensino-aprendizagem nas escolas de arquitetura. 2019. Tese (Doutorado em Arquitetura e Urbanismo) - Instituto de Arquitetura e Urbanismo, Universidade de São Paulo, São Carlos, 2019.

A concepção da Arquitetura carrega, historicamente, um sistema de dualidades: teoria e prática, projeto e construção, forma e função, arte e técnica, poesia e tecnologia. A evolução da formação na profissão contribuiu para estabelecer um distanciamento entre o ato de criação do projeto arquitetônico e a execução técnica do espaço projetado. No entanto, o entrosamento entre projeto e tecnologia construtiva é fundamental para o desenvolvimento de novas perspectivas no setor da construção civil que possibilitem a produção de sistemas inovadores de menor impacto ambiental, maior viabilidade econômica e social, e que propiciem uma maior capacitação profissional. Nesse sentido, a experimentação construtiva no ensino de arquitetura oferece um caminho para aprender na prática, a partir de problemas reais, articulando os saberes teóricos e técnicos de projeto, tecnologia e construção e gerando uma conscientização e um aprendizado mais amplos. Ao mesmo tempo, o uso de tecnologias construtivas em madeira vem ganhando destaque no cenário internacional na busca por materiais de construção renováveis e alternativas mais amigáveis ao homem e ao meio ambiente. Ademais, as características de leveza e fácil trabalhabilidade da madeira permitem práticas de construção em diversas escalas: desde a produção de modelos reduzidos até a execução de protótipos em escala real, sem a necessidade de maquinário e ferramentas complexas, contribuindo para a obtenção de novas habilidades pelos estudantes. Esta Tese tem como objetivos analisar a inserção da tecnologia da madeira nos cursos de Arquitetura e Urbanismo brasileiros, os conteúdos programáticos abordados e as metodologias de ensino aplicadas, bem como identificar e analisar abordagens pedagógicas do "aprender-fazendo" em experiências didáticas nacionais e internacionais, a fim de elaborar recomendações para a implementação de cursos de projeto e construção em madeira nos quais a experimentação construtiva é proposta como instrumento de ensino-aprendizagem. Conclui-se que é premente dar à madeira um maior protagonismo na estrutura curricular mediante uma maior aproximação aos sistemas construtivos e às possibilidades de industrialização e de préfabricação, estabelecendo abordagens mais práticas, interdisciplinares e intersetoriais. Identifica-se um grande potencial de associação entre o ensino de graduação e pósgraduação por meio da integração dos alunos em projetos de pesquisa aplicados, inseridos em uma problemática da realidade social. A experimentação construtiva, contudo, não deve ser vista apenas como uma prática empírica, mas deve ser defendida como forma de produção de conhecimento a fim de favorecer a formação de profissionais melhor preparados para o uso mais extensivo da madeira na construção civil brasileira.

Palavras-chave: Ensino de arquitetura. Formação tecnológica. Experimentação construtiva. Aprender-fazendo. Arquitetura em madeira. 

APRILANTI, M. D. Experimental construction in timber as a teaching-learning tool in architecture schools. 2019. Thesis (Doctoral) - Institute of Architecture and Urbanism, University of São Paulo, São Carlos, 2019.

The conception of Architecture historically carries a system of dualities: theory and practice, architectural design and construction, form and function, art and technique, poetry and technology. The evolution of education in the profession contributed to build a gap between the creation act of the architectural project and the technical execution of designed spaces. However, the connection between design and building technologies is fundamental for the development of new perspectives in the construction industry that enables the production of innovative building systems with low environmental impact, economically viable and socially feasible, thus increasing professional training. Hence, experimental construction in architecture teaching offers a way to learn from practice, applied to real problems, articulating the theoretical and technical knowledge of design, technology and construction, and creating broader awareness and learning. At the same time, the use of timber building technologies has gained prominence in the international scenario in the search for renewable construction materials and friendly alternatives to both the environment and mankind. Furthermore, features of timber, such as lightness and easy workability, allow construction practices at various scales: from small-scale models to full-scale prototypes, without the need of complex tools and machinery, contributing to the achievement of new skills by students. This Thesis objectives are to analyse the insertion of timber technology in Brazilian Architecture and Urban Design courses, the syllabus covered and teaching methodologies applied, as well as to identify and to examine pedagogical approaches of "learning-by-making" in both national and international didactic experiences, in order to elaborate recommendations for implementation of Design-Build timber courses where experimental construction is proposed as teaching-learning tool. In conclusion, is urgent to provide timber a major role in curricular structures, through a closer approach to building systems and possibilities for industrialization and prefabrication, establishing more practical, interdisciplinary and cross-sectoral approaches. A great potential of association between undergraduate and postgraduate education has been identified through student integration in applied research projects, related with social reality issues. Experimental construction, however, should not only be seen as empirical practice, but should be defended as a form of knowledge production in order to promote the training of professionals better prepared for an extensive use of timber in Brazilian construction.

Keywords: Architecture teaching. Technological training. Experimental construction. Learn-by-Doing. Wood Architecture. 



\section{RESUMEN}

APRILANTI, M. D. Experimentación constructiva en madera como instrumento de enseñanza-aprendizaje en escuelas de arquitectura. 2019. Tesis (Doctorado) Instituto de Arquitectura y Urbanismo, Universidad de São Paulo, São Carlos, 2019.

La concepción de la Arquitectura lleva históricamente un sistema de dualidades: teoría y práctica, diseño y construcción, forma y función, arte y técnica, poesía y tecnología. La evolución de la formación en la profesión contribuyó a establecer una distancia entre el acto de creación del proyecto arquitectónico y la ejecución técnica del espacio proyectado. No obstante, la conexión entre el diseño y la tecnología constructiva es fundamental para el desarrollo de nuevas perspectivas en el sector de la construcción que permitan la producción de sistemas innovadores con menor impacto ambiental, mayor viabilidad económica y social, y proporcionen una mayor capacitación profesional. En este sentido, la experimentación constructiva en la enseñanza de la arquitectura ofrece una forma de aprender en la práctica, de problemas reales, articulando el conocimiento teórico y técnico de la enseñanza del diseño, la tecnología y la construcción y generando una conciencia y un aprendizaje más amplios. Al mismo tiempo, el uso de tecnologías constructivas en madera ha ganado protagonismo en el escenario internacional en la búsqueda de materiales de construcción renovables y alternativas más amigables con el hombre y el medio ambiente. Además, las características de ligereza y facilidad de trabajo de la madera permiten prácticas de construcción a diferentes escalas: desde la producción de modelos a escala reducida hasta la ejecución de prototipos a escala real, sin la necesidad de maquinaria y herramientas complejas, contribuyendo a que los estudiantes obtengan nuevas habilidades. Esta tesis tiene como objetivos analizar la inserción de la tecnología de la madera en los cursos de Arquitectura y Urbanismo brasileños, el programa de estudios cubierto y las metodologías de enseñanza aplicadas, así como identificar y analizar enfoques pedagógicos del "aprender-haciendo" en experiencias didácticas nacionales e internacionales, con el fin de elaborar recomendaciones para implementación de cursos de diseño y construcción en madera donde se propone la experimentación constructiva como instrumento de enseñanza y aprendizaje. Se concluye que es urgente aportar a la madera un papel más importante en la estructura curricular mediante una aproximación más estrecha a los sistemas constructivos y las posibilidades de industrialización y prefabricación, estableciendo enfoques más prácticos, interdisciplinarios e intersectoriales. Se identifica un gran potencial de asociación entre la formación de pregrado y postgrado a través de la integración de los alumnos en proyectos de investigación aplicada, incorporados en una problemática de la realidad social. La experimentación constructiva, sin embargo, no debe ser vista sólo como una práctica empírica, sino que debe ser defendida como una forma de producción de conocimiento con el fin de promover la formación de profesionales mejor preparados para el uso más extensivo de la madera en la construcción civil brasileña.

Palabras clave: Enseñanza de Arquitectura. Formación tecnológica. Experimentación constructiva. Aprender haciendo. Arquitectura en madera. 



\section{LISTA DE FIGURAS}

Figura 1 - Esquema gráfico do programa de formação da Bauhaus 61

Figura 2 - Contribuição da floresta e da madeira ao desenvolvimento sustentável ......115

Figura 3 - Emissões de $\mathrm{CO}_{2}$ durante a produção de alguns materiais de construção ....117

Figura 4 - Energia requerida na produção de uma coluna de 3 metros de altura em diferentes materiais sob o mesmo carregamento

Figura 5 - Edifício de habitação coletiva em Dornbirn, Áustria. Arq.: Hermann Kaufmann, 1997. 128

Figura 6 - Elementos pré-fabricados do sistema construtivo do edifício em Dornbirn, Áustria: painéis de parede não estruturais (esquerda e centro), pilares e painéis de piso (direita).

Figura 7 - Edifícios habitacionais Mühlweg, Viena, Áustria. Arq.: Kaufmann \& Kaufmann, 2008.

Figura 8 - Edifícios habitacionais Seefeld, Arq.: Ulrich Huhs, Anna Wickenhauser, 2014 e PopUp dorms - Student residence Seestadt Aspern, Arq.: F2 Architekten ZT $\mathrm{GmbH}, 2015$, Viena, Áustria.

Figura 9 - Escola maternal Pliezhausen, Alemanha. Arquitetos D'Inka + Scheible, 1999130

Figura 10 - Escola maternal Pliezhausen: estrutura mista associa painéis de paredes portantes, estrutura de madeira lamelada colada e painéis de paredes e não portantes.

Figura 11 - Stadthaus, Londres, Reino Unido. Arquiteto: Waugh Thistleton, 2009. 131

Figura 12 - Wood Innovation and Design Centre, Prince George, Canadá. Arq.: Michael Green, 2014.

Figura 13 - Edifício de habitação estudantil Brock Commons Tallwood House, University of British Columbia - UBC, Vancouver, BC, Canadá. Arquiteto: Acton Ostry Architects, 2014

Figura 14 - Casa Klotz, Tongoy, Chile. Arquiteto Mathias Klotz, 1991 133

Figura 15 - Pavilhão do Chile na Expo Sevilha 1992. Arquitetos José Cruz e Germán del Sol, 1990

Figura 16 - Pavilhão do Chile na Expo Milão 2015. Arquiteto Cristian Undurraga, 2013134

Figura 17 - Viña Pérez Cruz, Huelquén, Valle de Maipo Alto, Chile. Arquiteto José Cruz, 2000.

Figura 18 - Colégio San Francisco Javier, Puerto Montt, Chile. Arquiteto: Martín Hurtado, 2007.

Figura 19 - Hotel Tierra Patagonia, Torres del Paine, Chile. Arquiteta Cazú Zegers, 2011 
Figura 20 - Casa Hélio Olga Jr., São Paulo. Arquiteto: Marcos Acayaba, 1990 138

Figura 21 - Vila Taguaí, Carapicuíba. Cristina Xavier Arquitetura, 2010. Painéis modulares para paredes, lajes de piso e lajes de cobertura. 139

Figura 22 - Casa Folha, Angra dos Reis-RJ. Arquitetos: Mairenes e Patalano, 2008 140

Figura 23 - MINIMOD, Fazenda Catuçaba, São Luís do Paraitinga-SP. MAPA Arquitetura, 2015 140

Figura 24 - Moradias Infantis, Formoso do Araguaia-TO. Arq.: Aleph Zero e Rosenbaum, 2017. 141

Figura 25 - Projetos do Concurso de Arquitetura em Madeira CORMA. Semana de la Madera, Santiago de Chile, agosto de 2018 148

Figura 26 - Maquetes de projeto em três escalas para o Concurso de Arquitetura....... 148

Figura 27 - As três dimensões da aprendizagem e do desenvolvimento de competências 162

Figura 28 - Alguns dos projetos executados pelo Rural Studio da Auburn University ...... 181

Figura 29 - Cadeira Frei Egídio da arquiteta Ítalo-brasileira Lina Bo Bardi produzida por alunos no Woodshop. 189

Figura 30 - Cadeira Zig-Zag do arquiteto holandês Gerrit Thomas Rietveld produzida por alunos no Woodshop 189

Figura 31 - Butterfly House construída pelo Rural Studio em Newbern 191

Figura 32 - Glass Chapel construída pelo Rural Studio em Mason's Bend. 192

Figura 33 - Planta baixa e corte geral da Glass Chapel em Mason's Bend 192

Figura 34 - Estação de Bombeiros de Newbern estruturado por treliças de madeira e metal. 193

Figura 35 - Estação de Bombeiros de Newbern .... 194

Figura 36 - Croquis e imagem interna do Akron Boys and Girls Club \#2. 194

Figura 37 - Akron Boys and Girls Club \#2 .195

Figura 38 - Dave's Home 20Kv08, Newbern, 2009 .195

Figura 39 - 20Kv22 Dave's Revised Home uma das últimas versões das 20K Home 196

Figura 40 - Algumas versões das 20K Homes: 20Kv04 Pattern Book Home, 20Kv05 Loft Home, 20Kv06 Roundwood Home construídas em Greensboro, 2008.............. 196

Figura 41 - Detalhes de alguns projetos executados pelo Wood Program da Aalto University...... 202

Figura 42 - Estrutura curricular do Wood Program .... 203

Figura 43 - Projeto do Pavilão Säie em corte e vista lateral................................................210

Figura 44 - Montagem do pavilhão e construção finalizada................................................210

Figura 45 - Ensaios em laboratório e detalhamento das ligações..... 210 
Figura 46 - Projeto Kokoon: composição dos módulos tipo

Figura 47 - Projeto Kokoon: sequência de montagem dos módulos

Figura 48 - Construção e montagem dos módulos.

Figura 49 - Interior dos módulos de habitação Kokoon

Figura 50 - O Pavilhão A.lava concluído e instalado no centro de Helsinki

Figura 51 - Desenvolvimento do projeto A.lava: estudo de geometria, estudo em escala real e maquete de estudo da cobertura

Figura 52 - Estudo e teste das conexões, produção e instalação das paredes 214

Figura 53 - Exposição sobre o Wood Program no Museu de Arquitetura Filandesa 215

Figura 54 - Alunos da e[ad] em atividades na Ciudad Abierta, em Ritoque 222

Figura 55 - Aula ministrada na Ciudad Abierta, em Ritoque. .224

Figura 56 - Croquis de observação e maquetes de estudo da intervenção. 224

Figura 57 - Celebração do Acto de San Francisco no Teatro de la Consagración, Cuidad Abierta 224

Figura 58 - Alunos da e[ad] em atividades na Ciudad Abierta, em Ritoque 226

Figura 59 - Sala de Música, a primeira obra da Cuidad Abierta em Ritoque. 230

Figura 60 - Sala de Música da Cuidad Abierta em Ritoque 231

Figura 61 - Hospedería Taller de Obras em Ritoque .... 232

Figura 62 - Hospedería Taller de Obras, croquis de implantação, detalhes construtivos, alunos trabalhando na obra e na produção de vigas em madeira laminada

Figura 63 - Hospedería Taller de Obras em Ritoque 232

Figura 64 - Construção do Pórtico de los Huéspedes em três momentos: Summer Chantier 2014, 2015 e 2016

Figura 65 - Evolução do Pórtico de los Huéspedes: Summer Chantier 2018 .234

Figura 66 - Alunos suíços e chilenos trabalhando no Pórtico de los Huéspedes na Ciudad Abierta

Figura 67 - Localização de Marimenuco, Chile, e rota de ônibus desde Lonquimay......235

Figura 68 - Projeto Ruca para la celebración del We Tripantu, extensão da sala de aula e lugar de reunião comunitária delimitada por uma rampa espiral concêntrica ao fogo. 236

Figura 69 - Fotos da obra construída durante Travesía a Marimenuco, 2011 237

Figura 70 - Primeiro traçado da planta no chão, Travesía Tekoa Pindo-Porty 238

Figura 71 - Estudo de implantação e de fachadas para o espaço comunitário 238

Figura 72 - Detalhamento do processo construtivo do telhado em bambu 
Figura 73 - Obra construída durante a Travesía Tekoa Pindo-Porty..... 239

Figura 74 - Itinerário de viagem e implantação da obra na Praia do Amor, Conde-PB, Brasil

Figura 75 - Croquis de algumas das propostas apresentadas em maquete 241

Figura 76 - Apresentação das propostas em maquetes à comunidade de pescadores 242

Figura 77 - Construção das caiçaras na Praia do Amor, Travesía a Conde-PB, Brasil ......242

Figura 78 - Vista aérea da construção das caiçaras na Praia do Amor 243

Figura 79 - Maquetes produzidas na disciplina Materiais de Construção II da UFPR ....249

Figura 80 - Disciplina optativa de graduação "Parâmetros para Projetos Habitacionais em Madeira" do IAU-USP, abril 2017................................................................250

Figura 81 - Curso de extensão IAU-USP, maio-novembro 2013 .252

Figura 82 - Oficinas de estruturas modulares (2013) e maquetes de Sistemas Estruturais em Madeira (2015) do curso de AU da Universidade Anhembi Morumbi .... 253

Figura 83 - "Pavilhão Xuê". Workshop Estruturas Retráteis, PUC Minas, Belo Horizonte, 2017. 254

Figura 84 - Workshop Estruturas Recíprocas em Madeira. FAAP, São Paulo. 258 


\section{LISTA DE QUADROS}

Quadro 1 - Número de cursos de AU por estados e regiões do Brasil em IES públicas e privadas .77

Quadro 2 - Dados populacionais e de renda per capita por estados e regiões do Brasil 80 Quadro 3 - Estrutura programática do Design Studio do $3^{\circ}$ ano 184

Quadro 4 - Quadro síntese de análise do programa Rural Studio .....................................198

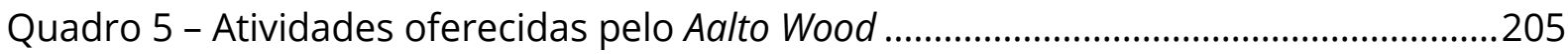

Quadro 6 - Quadro síntese de análise do Wood Program ..................................................216

Quadro 7 - Quadro síntese de análise da Escuela de Arquitectura y Diseño .......................244

Quadro 8 - Síntese propositiva para curso de projeto e construção ..................................284 



\section{LISTA DE GRÁFICOS}

Gráfico 1 - Número de cursos de AU no Brasil por região................................................... 78

Gráfico 2 - Crescimento do número de cursos de AU no Brasil por região ......................... 78

Gráfico 3 - Quantidade de cursos de AU e população por estado no ano de $2016 \ldots . . . . . . .81$

Gráfico 4 - Quantidade de cursos de AU e renda per capita por estado nos anos de 2016

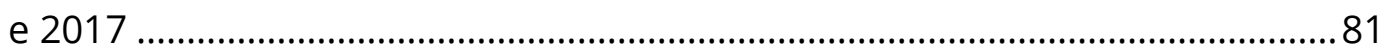

Gráfico 5 - Carga Horária total e de Tecnologia dos cursos de AU......................................96

Gráfico 6 - Carga Horária média total e de Tecnologia dos cursos de AU por região ...... 96

Gráfico 7 - Horas-aula práticas em disciplinas de Tecnologia............................................97

Gráfico 8 - Carga Horária média de horas-aula práticas em Tecnologia por região .........97

Gráfico 9 - Carga Horária disciplinas de Tecnologia e as que abordam a madeira em

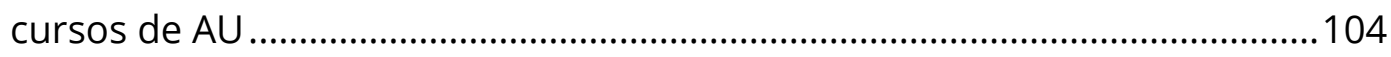

Gráfico 10 - Carga Horária média de Tecnologia e de madeira em cursos de AU por

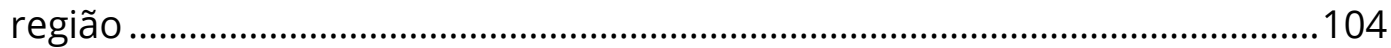

Gráfico 11 - Material predominante nas paredes externas dos domicílios brasileiros por regiões 

1 CAPÍTULO INTRODUTÓRIO .29

1.1 Contextualização temática 29

1.2 Delimitação do objeto de estudo 35

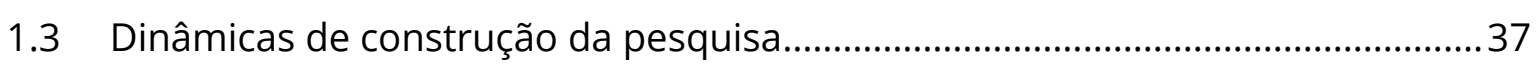

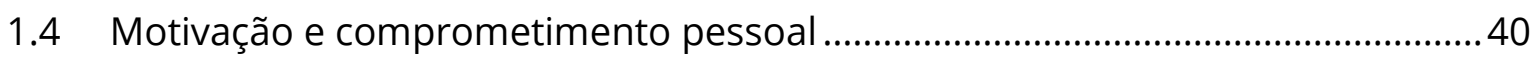

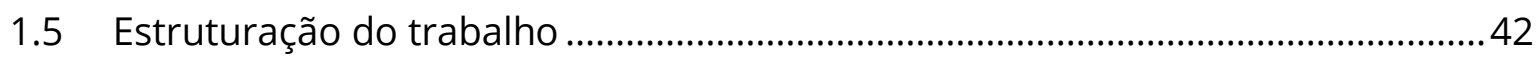

2 FORMAÇÃO TECNOLÓGICA NO ENSINO DE ARQUITETURA .................................49

2.1 Evolução histórica do ensino de Arquitetura e Urbanismo .................................. 50

2.2 Consolidação e regulamentação do ensino e da profissão no Brasil....................65

2.3 A inserção da tecnologia e da experimentação prática no currículo dos cursos de AU brasileiros 84

2.4 A inserção das tecnologias construtivas em madeira no currículo dos cursos de AU brasileiros. .102

3 A MADEIRA COMO MATERIAL CONSTRUTIVO 113

3.1 Potencialidades do uso da madeira nas construções 114

3.2 Exemplos do uso da madeira na arquitetura na atualidade 127

3.3 Potencialidades do uso da madeira no ensino de arquitetura 145

\section{PRÁTICAS DE EXPERIMENTAÇÃO CONSTRUTIVA NO ENSINO DE ARQUITETURA 157}

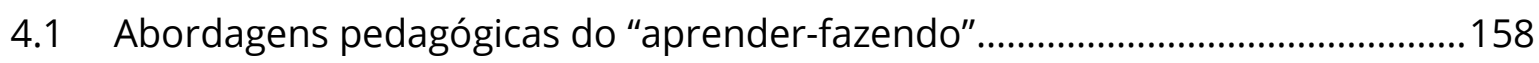

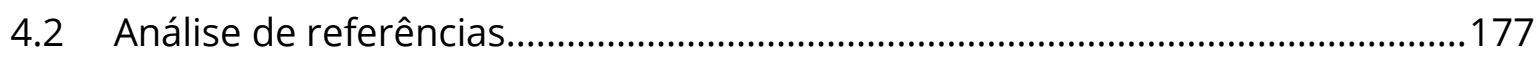

4.2.1 RURAL STUDIO - Auburn University, Estados Unidos........................................178

4.2.2 WOOD PROGRAM - Aalto University, Finlândia ..................................................200 
4.2.3 Escuela de Arquitectura y Diseño - Pontificia Universidad Católica de Valparaíso, Chile

4.3 Referências do ensino de tecnologias construtivas em madeira nos cursos de AU brasileiros

5 REFLEXÕES SOBRE A PRÁTICA DOCENTE NO BRASIL 263

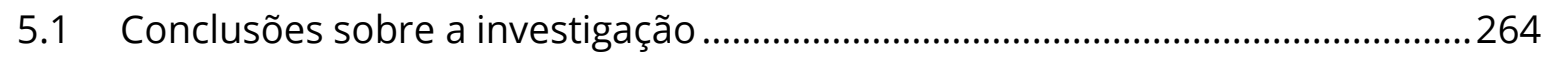

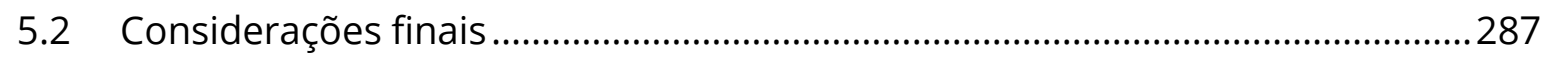

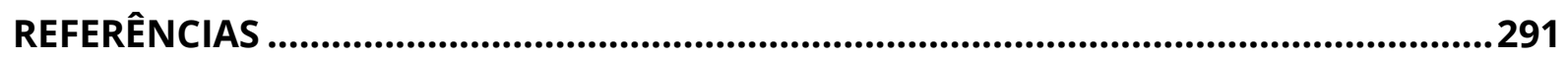

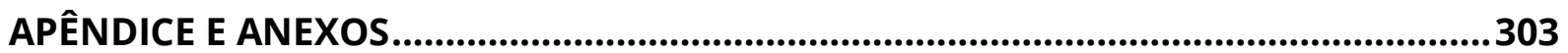

APÊNDICE: Planilha de Levantamento de Dados dos cursos de Arquitetura e Urbanismo do Brasil por regiões .................................................................304

ANEXO A: Conteúdos programáticos referentes à madeira nas disciplinas da área de Tecnologia dos cursos de Arquitetura e Urbanismo do Brasil ...............321

ANEXO B: Programa de curso do WOOD PROGRAM - Aalto University .....................344

ANEXO C: Grade curricular do curso de Arquitetura da e[ad] PUCV .........................348

ANEXO D: Curso de Especialização Lato-Sensu em Arquitetura em Madeira: Projeto e Aplicação - FAAP .350 


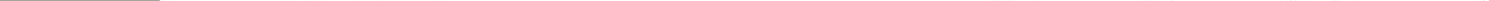





\section{CAPÍTULO INTRODUTÓRIO}

Este Capítulo Introdutório traz a apresentação do trabalho e a delimitação do objeto de estudo embasada em uma breve contextualização temática sobre a problemática investigada - a experimentação construtiva no ensino da Arquitetura. A partir desta contextualização, se elaboram as justificativas da proposta desta Tese. Expõe ainda, as dinâmicas de construção da pesquisa e a estruturação do trabalho como um todo, além da motivação e comprometimento pessoal da autora perante o tema.

\subsection{Contextualização temática}

Historicamente, há uma cisão entre projeto e construção na concepção da Arquitetura. A evolução da formação na profissão carrega uma dicotomia entre arte e técnica, teoria e prática, mas, isso não foi sempre assim. Na Idade Média o arquiteto desempenhava as duas funções: de projetista e de construtor. Aprendia o ofício guiado por um mestre através de longas práticas experimentais no canteiro de obras. Em outros momentos da evolução da profissão, essa habilidade foi valorizada e surgiram tentativas de reaproximar teoria e prática, como na icônica proposta pedagógica fomentada pela Bauhaus.

Atualmente, a crescente popularidade da abordagem Design-Build - termo em inglês utilizado internacionalmente que pode ser traduzido como "projeto e construção" parece estar preenchendo esta lacuna entre o ato de criação do projeto arquitetônico e a execução técnica do espaço projetado no ensino de arquitetura (CARPENTER, 2014).

A materialidade é um dos aspectos que distingue a Arquitetura e the confere dimensão tecnológica. O fazer arquitetônico, portanto, não pode esquivar-se da matéria. A inserção do arquiteto na lógica produtiva da construção implica na resolução material da Arquitetura. Cabe ao arquiteto, como profissional responsável pela concepção arquitetônica, a definição de um determinado partido estrutural e construtivo em consonância com as condições específicas em que se insere a edificação: “mesmo em edificações de pequeno e médio porte, a premência de se resolver a 
construção com economia transfere ao arquiteto a obrigatoriedade de consequência na concepção do projeto" (LEITE, 2005, p. 3).

A questão do domínio tecnológico ${ }^{2}$ necessário ao arquiteto para o desempenho de suas atribuições profissionais e de seu papel social é discutido por Leite (1998) ao identificar uma série de aspectos relevantes que considero conveniente citar: a necessidade do domínio tecnológico como base da liberdade no ato de projetar; como base para a relação multidisciplinar na realização da obra arquitetônica; como base para a participação do arquiteto no desenvolvimento tecnológico; e finalmente, como base para a inserção intensiva do arquiteto na atividade econômica da construção.

Neste sentido, o ato de projetar, ou seja, de conceber um objeto arquitetônico, deve então ser respaldado no conhecimento dos materiais e técnicas construtivas existentes. O ensino de arquitetura deve, portanto, “orientar os estudantes para uma apropriação de como tais materiais e sistemas se articulam, favorecendo a compreensão analítica das diversas possibilidades construtivas" (SARAMAGO; LOPES, 2012, p. 655). Saber como se comportam as estruturas, em seus adequados regimes de trabalho, é cada vez mais imperioso ao arquiteto para o desenvolvimento de novas soluções decorrentes do surgimento de técnicas de construção e materiais inéditos.

O entrosamento entre projeto arquitetônico e tecnologia construtiva ${ }^{3}$ é, desta forma, entendido como fundamental para a concepção de novas perspectivas no setor da construção civil. Deve então, ser parte da formação do arquiteto de modo a abrir caminho para o uso de sistemas inovadores que resultem em menor impacto ambiental, maior viabilidade econômica e social, e propiciem maior capacitação profissional.

A esta questão, vincula-se outra igualmente importante a qual está atrelada o objeto de estudo deste trabalho: a experimentação prática na concepção da

${ }^{2}$ Leite define o Domínio Tecnológico do Arquiteto como "o domínio e a capacidade de articular os conhecimentos científicos e técnicos necessários à implantação de processos produtivos dos bens materiais afetos à Arquitetura e ao Urbanismo" (LEITE, 1998, p. 47).

3 Por TECNOLOGIA CONSTRUTIVA entende-se que: "é um conjunto sistematizado de conhecimentos científicos e empíricos, pertinentes a um modo específico de se construir um edifício (ou uma sua parte) e empregados na criação, produção e difusão deste modo de construir" (SABBATINI, 1989, p. 48). 
materialidade. Os processos experimentais para o estudo da materialidade estiveram presentes ao longo da evolução histórica da profissão e foram amplamente explorados durante o Período Moderno.

A Escola Bauhaus, em meio às transformações ocorridas no início do século XX na Europa - de ruptura com o modelo de formação pelo sistema Politécnico e influência do movimento Arts \& Crafts - tinha como premissa formar profissionais com habilidades técnicas e artísticas. Walter Gropius enunciou com extrema intelecção a importância da experimentação como método de ensino na formação do arquiteto. Para ele, "a experiência prática é o meio mais seguro para desenvolver uma síntese de todos os fatores emocionais e intelectuais no estudante" onde a unidade na concepção do projeto e da construção é certamente resultado do fazer (GROPIUS, 2004, p. 87).

A proposta da Bauhaus já poderia ser considerada, para alguns autores, uma primeira experiência do chamado Design-Build ao promover práticas experimentais construtivas que envolvem os alunos tanto no projeto quanto na construção dos mesmos, com a intenção de "ampliar as habilidades de projeto dos alunos, estabelecendo um vínculo mais forte com a experimentação material e a construção" (CANIZARO, 2012, p. 21). Para Carpenter (2014), a Bauhaus promoveu um processo de projeto cíclico e fluido por meio de uma pedagogia inovadora, oriunda da evolução do design industrial e da produção em massa, que é a origem do Design-Build.

Entretanto, é na década de 60 que os programas Design-Build começam a se expandir destacando-se nos Estados Unidos o Yale Building Project, criado em 1967 sob a direção de Charles Moore em New Haven, o trabalho de Steve Badanes na Jersey Devil, e mais tarde, no programa Neighborhood na University of Washington, em Seattle.

Já na década de 90, Samuel Mockbee e o trabalho comunitário do Rural Studio em Newbern, programa da Auburn University, tornaram-se referência amplamente reconhecida e que até hoje continua em atividade, bem como o programa da Yale University. Também são dignos de nota os projetos desenvolvidos em escolas de arquitetura no Reino Unido por várias décadas como as de Portsmouth, Liverpool e Nottingham (FOWLES, 1984; CANIZARO, 2012; GABER, 2014). 
No Brasil, o debate em torno da prática experimental junto às escolas de Arquitetura iniciou-se com os Laboratórios de Habitação que constituíram um campo de reflexão acerca da realidade urbana e política no país a partir da década de 70 . 0 surgimento do primeiro Laboratório de Habitação, junto à Faculdade de Belas Artes FEBASP, em São Paulo, ocorreu num momento político que coincidiu com o processo de reconstrução democrática do país e de lutas ligadas aos movimentos sociais.

Sua origem e intenções convergiam a uma arquitetura 'além-muros do atelier' ${ }^{4}$, que colocava o arquiteto em contato com a realidade das cidades e integrava o ensino, a pesquisa e a prática da arquitetura às lutas da população. De acordo com Pompéia (2006, p. 6), “toda a experiência trazida pelos Laboratórios de Habitação parece apontar para uma solução efetiva do problema da cisão entre o que se supõe como teórico e aquilo que se costuma chamar de prática".

Os Laboratórios de Habitação e os Canteiros Experimentais ou Canteiros Escola que se originaram dessas experiências, carregam uma concepção de pesquisa baseada na experimentação empírica da construção e da interação com a realidade social. Entre as escolas que se envolveram nestas atividades estão a FAU-Santos, FAU-USP, PUCCampinas, UNICAMP, IAU-USP, FAU-UnB, entre outras.

Várias pesquisas e publicações nacionais discutiram a questão dos processos experimentais na concepção do projeto de arquitetura e no desenvolvimento de inovações tecnológicas, assim como da prática experimental no ensino de arquitetura no Brasil. As experiências didáticas relatadas convergem para um objetivo comum de propiciar ao estudante a possibilidade de conhecer processos de produção da construção através do enfrentamento com o mundo real, inseridos numa problemática real. Os questionamentos e as dúvidas geradas durante a experimentação construtiva articulam os saberes teóricos e técnicos do ensino de projeto, tecnologia e construção, gerando uma conscientização e um aprendizado mais amplos que fortalecem a

${ }^{4}$ Roberto Pompéia cita em sua Tese de Doutorado "O laboratório de habitação no ensino de arquitetura: uma contribuição ao processo de formação do arquiteto" o depoimento do jornalista Rubens de Almeida no artigo "Superar os limites da escola, o caminho do possível", publicado na Revista AU n 3, p.58 a 65, Editora Pini, São Paulo, em novembro de 1985. 
autonomia e as potencialidades transformadoras dos sujeitos (RONCONI, 2005; ARANTES, 2008; LOPES, 2014; LOTUFO, 2014).

Laverde (2017) realizou um levantamento qualitativo dos espaços e práticas experimentais em 21 escolas públicas de Arquitetura e Urbanismo, localizadas em diferentes regiões do país. Teve como objetivo, compreender o processo de configuração dos espaços da área técnico-construtiva implantados nessas escolas e identificar as condições essenciais para que estas práticas sejam efetivamente estabelecidas e potencializadas no contexto acadêmico nacional.

A autora constatou que os espaços experimentais na área da Tecnologia da Construção são praticamente inexistentes nas escolas visitadas e que a falta de locais adequados, recursos contínuos e de carga horária compatível com as atividades laboratoriais e práticas construtivas têm dificultado o seu desenvolvimento. Tal fato é bastante relevante ao considerarmos que, embora essa seja uma apreensão parcial, os dados levantados revelam a realidade de algumas das melhores escolas do país.

A questão se agrava frente à rápida expansão e aumento exponencial das instituições de ensino de Arquitetura e Urbanismo nas últimas décadas em território nacional ${ }^{5}$. A utilização de laboratórios como exigência para a oferta dos cursos foi indicada já em 1994 no Seminário Nacional de Avaliação promovido pela Comissão de Especialistas de Ensino de Arquitetura e Urbanismo - CEAU, resultando na publicação da Portaria 1.770/94 que fixou as diretrizes curriculares e o conteúdo mínimo do curso de graduação em Arquitetura e Urbanismo.

Não obstante, a implantação destes espaços foi realizada muitas vezes sem sua efetiva apropriação para o ensino dos conteúdos que devem contribuir para o aperfeiçoamento da qualificação profissional no tocante ao domínio tecnológico, como os conhecimentos de Tecnologia da Construção e Sistemas Estruturais.

\footnotetext{
${ }^{5}$ Ao início da realização da pesquisa de Laverde (2017), em 2013, contava-se com 280 escolas de arquitetura no país das quais 47 eram escolas públicas. Já ao início da presente pesquisa, em 2016, apenas três anos depois, o número de escolas havia praticamente duplicado aumentado para 500, sendo 60 públicas e 440 privadas. Esses números serão apresentados e atualizados mais adiante.
} 
Dentro deste contexto, o ensino de Tecnologias Construtivas nos cursos de Arquitetura e Urbanismo, e em especial as que se referem à madeira - foco de estudo deste trabalho - tem sido de uma maneira geral negligenciado em nosso país, fato que tem contribuído no pouco uso deste material como opção nos projetos de arquitetura. A carga horária e os conteúdos relativos à madeira e às estruturas em madeira são bastante restritos evidenciando a ênfase a materiais e sistemas considerados principais, como as estruturas em concreto.

O uso da madeira na arquitetura contemporânea vem ganhando destaque no cenário internacional em função da busca por materiais construtivos renováveis e menos impactantes ao homem e ao meio ambiente. Suas vantagens ambientais e tecnológicas têm sido amplamente exploradas no desenvolvimento de sistemas construtivos inovadores, associados ao uso de tecnologias digitais de projeto e produção, abrindo novos caminhos para a construção civil.

No cenário nacional, entretanto, no que tange à utilização mais corrente da madeira na Arquitetura, é comum a afirmação de que as especificações feitas por arquitetos e designers são baseadas em características estéticas de cor ou aparência, evidenciando pouco ou nenhum conhecimento quanto a informações técnicas sobre as suas características físico-mecânicas. Ao ser um material natural, a madeira possui propriedades específicas que a caracterizam como um dos mais complexos materiais utilizados em Engenharia ${ }^{6}$.

Por esse motivo, torna-se indispensável um profundo conhecimento acerca de suas propriedades para uma adequada especificação, o qual não pode limitar-se apenas a fundamentos teóricos. O entendimento da matéria deve envolver uma compreensão mais ampla do seu comportamento, o que é mais facilmente alcançado quando se associa a experimentação física aos princípios teóricos.

\footnotetext{
${ }^{6}$ Por exemplo, a anisotropia é uma propriedade que se refere ao comportamento físico e mecânico da madeira que deve ser observada em sua utilização. Ao apresentar resultados diferenciados segundo o plano que é analisado em relação à direção longitudinal de suas fibras e anéis de crescimento, conjuntamente com a variação de umidade em função da troca de água higroscópica do material com o meio, esta propriedade afeta sua estabilidade dimensional podendo ocasionar problemas como a retração e o inchamento.
} 
O presente trabalho insere-se dentro de uma perspectiva de incentivo ao uso mais extensivo da madeira como material construtivo na arquitetura brasileira a partir da identificação de uma crescente preocupação da sociedade com relação aos impactos causados pelas atividades humanas ao meio ambiente. Propõe-se à reflexão sobre quais os agentes que deveriam ser mobilizados para que a madeira seja uma opção competitiva e viável para a construção no Brasil, de forma a estabelecer-se no cenário nacional com uma expressão própria e contemporânea.

\subsection{Delimitação do objeto de estudo}

Com vistas à formação de arquitetos mais capacitados para propor a madeira como material estrutural e construtivo delimita-se como objeto desta Tese a experimentação construtiva em madeira entendida como instrumento de ensinoaprendizagem, ao oportunizar práticas de construção em diversas escalas, exercícios em escala reduzida, produção de modelos e protótipos e a execução de projetos em escala real inseridos na realidade social.

A madeira apresenta muitas vantagens para o ensino do comportamento mecânico das estruturas, particularmente através da experimentação prática. É um material leve e relativamente barato, que permite construções secas e que não requer maquinário e ferramentas complexas para seu manuseio. Viabiliza a construção de protótipos em escala real, o que muitas vezes não é possível com outros materiais. Sua utilização em projetos e pesquisa aplicada facilita processos de aprendizagem e contribui substancialmente para o sucesso das atividades práticas em termos de obtenção de habilidades pelos alunos.

Consideradas essas afirmativas, delineia-se a questão principal da pesquisa: como

a experimentação construtiva em madeira nas escolas de arquitetura pode contribuir para ampliar o conhecimento sobre o material e fomentar o seu uso na construção civil brasileira? 
No intuito de compreender os fatores que podem ajudar a responder a pergunta formulada, a investigação percorreu a temática da formação tecnológica do arquiteto buscando analisar: os processos experimentais ao longo de sua evolução histórica e na atual configuração do currículo dos cursos de AU no Brasil; a inserção da Tecnologia da Construção e, especialmente, da madeira nas estruturas curriculares; os conteúdos programáticos abordados, bem como as metodologias de ensino-aprendizagem que vem sendo aplicadas. Ao mesmo tempo, buscou levantar experiências didáticas em âmbito acadêmico internacional para compor um banco de referências sobre práticas de experimentação construtiva em madeira de forma a alimentar a reflexão sobre a questão de pesquisa.

Com base na análise destas referências e com o propósito de responder a tal questão, o presente trabalho tem como objetivo principal elaborar parâmetros didático-metodológicos sobre a experimentação construtiva nas escolas de arquitetura, propondo a madeira como instrumento de ensino-aprendizagem, a fim de potencializar o emprego mais extensivo deste material na construção civil brasileira.

A proposição desta Tese justifica-se como meio de colaborar para a compilação de referências teóricas e empíricas que sirvam de subsídio à implementação de iniciativas didáticas mais integradoras, junto aos cursos de Arquitetura e Urbanismo, com o intuito de impulsionar mudanças no atual cenário brasileiro. O trabalho proposto ganha relevância diante da escassez de bibliografia e de experiências nacionais em relação ao tema e pretende organizar um material de apoio para a elaboração de planos de ensino que envolvam o estudo, o projeto e a construção em madeira.

O referencial teórico configurado a partir da revisão bibliográfica e do desenvolvimento da pesquisa documental levaram à elaboração da hipótese principal da pesquisa de que uma maior inserção de práticas construtivas experimentais em madeira nos cursos de arquitetura, por meio de estratégias pedagógicas que articulem teoria, projeto e produção em atividades interdisciplinares, pode favorecer a formação de profissionais mais aptos para o projeto e a construção da arquitetura em madeira. 


\subsection{Dinâmicas de construção da pesquisa}

A presente pesquisa iniciou-se com o levantamento de dados em relação ao ensino de Tecnologias Construtivas em Madeira $^{7}$ e às atividades práticas associadas à Tecnologia da Construção nas escolas de Arquitetura e Urbanismo brasileiras. Os resultados levaram à constatação de que estes limitam-se a uma carga horária bastante reduzida, sendo que as práticas de experimentação construtiva são quase inexistentes ou realizadas de forma esporádica e pontual.

Paralelamente, entrevistas semi-estruturadas e conversas informais realizadas com professores e estudantes, arquitetos e engenheiros, e a participação em conferências nacionais e internacionais ligadas ao tema de investigação, permitiram a identificação de práticas didáticas diferenciadas que fomentam a compreensão das Tecnologias Construtivas por meio de abordagens pedagógicas como da Aprendizagem Baseada em Projetos e de metodologias do "aprender-fazendo".

Simultaneamente, a revisão bibliográfica sobre a experimentação construtiva em madeira trouxe referências de interessantes experiências em universidades internacionalmente reconhecidas; relatos de disciplinas, estúdios, workshops e cursos de pós-graduação direcionados à formação em tecnologia da madeira e em projetos de arquitetura em madeira que instigam a ampliar as possibilidades de utilização do material nas construções.

A participação no Grupo de Pesquisa em Habitação e Sustentabilidade - HABIS ${ }^{8}$ também foi determinante para a evolução da pesquisa, uma vez que o grupo possui diversas experiências de construção em madeira diretamente envolvidas com a

\footnotetext{
${ }^{7}$ A partir do conceito de Tecnologia Construtiva, definido por Sabbatini (1989), exposto anteriormente, este trabalho adota a seguinte definição para o termo TECNOLOGIAS CONSTRUTIVAS EM MADEIRA: Conjunto sistematizado de conhecimentos científicos e empíricos, pertinentes ao modo específico de se construir um edifício em madeira (ou uma sua parte) e empregados na criação, produção e difusão deste modo de construir.

${ }^{8} \mathrm{O}$ Grupo de pesquisa HABIS, do Instituto de Arquitetura e Urbanismo da Universidade de São Paulo - IAU-USP, coordenado pelos professores Akemi Ino, João Marcos Almeida Lopes e Lúcia Shimbo, tem como objetivo desenvolver atividades de pesquisa, ensino e extensão nas diversas dimensões da produção da Arquitetura, articulando teorias, técnicas e práticas.
} 
produção de conhecimentos aplicados e a transferência de tecnologia associada à formação de profissionais, frequentemente articuladas com a experimentação em laboratório e a produção piloto na realidade social.

Nesse sentido, o tema da presente investigação está relacionado ao Projeto Temático "Tecnologias Construtivas de Baixo Carbono: a madeira e novos paradigmas para a construção civil" ${ }^{9}$, em andamento, mais especificamente ao Eixo 4: "Formação de profissionais e trabalhadores da construção civil". O projeto busca construir novas abordagens para discussão dos paradigmas da construção civil, através de pesquisas e ensaios, e da proposição da madeira como material construtivo capaz de estabelecer-se como alternativa construtiva de baixo carbono.

As questões específicas formuladas ao longo da construção desta pesquisa foram seguidamente revisitadas e reformuladas em função dos avanços do trabalho e de novos questionamentos que surgiram no percurso. Essas questões são apresentadas a seguir e discutidas no decorrer dos capítulos em busca de respostas e de reflexões que conduzam aos objetivos da Tese.

\section{Qual a inserção das tecnologias construtivas em madeira nas estruturas curriculares atuais dos cursos de Arquitetura e Urbanismo no Brasil e como vêm sendo abordadas?}

2. Quais os conteúdos programáticos sobre tecnologias construtivas em madeira têm sido enfocados nos cursos de $A U$ brasileiros e quais as

\footnotetext{
${ }^{9}$ O projeto temático em questão tem como objetivo geral produzir conhecimentos científicos e tecnológicos no campo do design, arquitetura e construção, articulando as dimensões ambiental, do trabalho e do capital, a partir da criação, desenvolvimento, avaliação e difusão de Tecnologias Construtivas de Baixo Carbono (TCBCS). Propõe ainda, estabelecer o uso da madeira na produção industrializada de componentes construtivos como estratégia construtiva racionalmente determinada, o que pode efetivamente contribuir para a inversão da lógica desenvolvimentista da construção civil que não se compromete com a redução das emissões do Gás de Efeito Estufa - GEE. Organiza-se em seis eixos estruturantes, a saber: 1) fundamentação teórica e referências práticas sobre TCBCs; 2) desenvolvimento de projetos de componentes e sistemas construtivos pré-fabricados em madeira para utilização em habitação, equipamentos e edifícios públicos; 3) produção-piloto de tais componentes para serem aplicados em edificações da instituição-sede (USP); 4) formação de profissionais da construção civil durante processo de produção-piloto; 5) fomento para novos arranjos produtivos que priorizem pequenas empresas, grupos autogestionários e cooperativas e que promovam a disseminação de TCBCs; 6) articulação com políticas públicas e ampliação do mercado consumidor, procurando intervir nos processos sociais que hoje estruturam os paradigmas da construção civil no país.
} 
lacunas existentes? A diversidade de sistemas construtivos e suas aplicações em projetos estão sendo contempladas de alguma forma?

3. Quais metodologias de ensino-aprendizagem vêm sendo aplicadas na área tecnológica dos cursos de AU no Brasil? Qual a relevância das atividades práticas de experimentação construtiva?

4. Como as experiências de ensino internacionais podem servir de referência para formular parâmetros didático-metodológicos aplicáveis à formação do arquiteto no Brasil?

5. Quais os aspectos mais importantes a serem observados para a implementação da experimentação construtiva como instrumento de abordagens pedagógicas mais integradoras?

Diante do escasso número de casos brasileiros identificados, que poderiam fornecer dados relevantes à pesquisa, houve o questionamento da comissão de avaliação do Exame de Qualificação realizado em agosto de 2017, sobre a dimensão da parte empírica planejada e a importância da realização de um Estudo de Caso inserido em um universo experimental. Construíram-se a partir deste ponto de inflexão, outras possibilidades de direcionamento da pesquisa empírica.

Das experiências de ensino levantadas, emergiram exemplos de aplicação de metodologias ativas de aprendizagem que abriram caminho para a proposição de um estágio em pesquisa numa das instituições investigadas. A oportunidade concretizou-se através da aprovação do projeto de pesquisa “Ensino de tecnologia da madeira em escolas de arquitetura: a experimentação como instrumento de aprendizagem tecnológica" apresentado ao Programa de Doutorado Sanduíche no Exterior - PDSE, da Coordenação de Aperfeiçoamento de Pessoal de Nível Superior - CAPES, por meio do Edital n 47/2017.

O estágio foi realizado entre agosto de 2018 e janeiro de 2019, junto a Escuela de Arquitectura y Diseño da Pontifícia Universidad Católica de Valparaíso - e[ad] PUCV, no Chile, reconhecida internacionalmente por sua abordagem pedagógica poética que relaciona o fazer arquitetônico a experiências construtivas, vinculando vida, trabalho e estudo. A vivência proporcionou a reestruturação da investigação em andamento, e 
levou à alteração do título do trabalho que passou de "Ensino de tecnologia da madeira em escolas de arquitetura" para "A experimentação construtiva em madeira como instrumento de ensino-aprendizagem nas escolas de arquitetura".

A experiência constituiu-se como um Estudo de Caso inserido num universo acadêmico reconhecido por seu diferencial pedagógico e exatamente por esse fato trouxe a revisão do enfoque da pesquisa, abrindo o horizonte de investigação para o ato da experimentação como instrumento de aprendizagem, uma abordagem que vai além da experimentação do material em si e trata da experiência integral, de forma mais holística, fato que me inspirou grande motivação.

Paralelamente, o estágio permitiu a identificação e observação de distintas atividades relacionadas à experimentação construtiva em madeira, realizadas por outras escolas de arquitetura chilenas, além da participação em eventos ligados à área das construções em madeira nas cidades de Santiago e de Concepción.

\subsection{Motivação e comprometimento pessoal}

O delineamento construído ao longo do percurso de investigação motivou-se pela trajetória profissional e acadêmica desta autora. Da prática profissional em escritórios de arquitetura, vivencio a dificuldade da utilização da madeira de forma mais ampla nas construções. As dúvidas e os preconceitos são inúmeros e as respostas parecem ser

insuficientes para convencer os clientes das vantagens de utilizar a madeira como estrutura ou elemento construtivo predominante nas edificações. Ao mesmo tempo, constato em minha região de atuação, o interior do Estado de São Paulo, que são raros os profissionais especializados tanto para o cálculo de estruturas de madeira quanto para sua execução.

A busca por um engenheiro calculista que me orientasse na solução do projeto de uma cobertura não convencional em estrutura de madeira para um edifício escolar na 
cidade de Piracicaba levou-me a conhecer o professor Garcia, do Departamento de Ciências Florestais da Escola Superior de Agricultura Luiz de Queiroz - ESALQ-USP ${ }^{10}$.

Desta ocasião surgiu o interesse pela pesquisa no tema das estruturas em madeira que me levou a iniciar o mestrado na ESALQ-USP, junto ao Programa de Pós-Graduação em Recursos Florestais na área de concentração em Tecnologia de Produtos Florestais, concluído em 2010. A pesquisa versou sobre o comportamento estrutural de vigas laminadas coladas e consistiu em um estudo teórico-experimental embasado em ensaios mecânicos com corpos de prova de Eucalyptus grandis.

A experiência docente somente iniciou-se a partir de então, com disciplinas de Projeto de Arquitetura em cursos de Arquitetura e Urbanismo da região. Desde esse momento, fez-se presente uma profunda inquietação frente à dificuldade dos alunos na integração dos conteúdos tecnológicos aos projetos arquitetônicos. Como sabemos, estas disciplinas se pretendem articuladoras dos demais campos de conhecimento que compõe o currículo, porém, isso nem sempre acontece.

Da mesma forma, os conteúdos teóricos estudados durante o mestrado, embora acompanhados de experimentação prática laboratorial que em muito contribuiu para o entendimento das propriedades do material investigado, são de difícil aplicação à prática do projeto de arquitetura. Ora, como integrar então os conceitos teóricos e científicos necessários à formação intelectual e acadêmica e aplicá-los à prática profissional? Como relacionar tais conceitos à prática projetual e construtiva?

Certamente são questões que já foram amplamente discutidas, no entanto, são questões estreitamente vinculadas ao meu comprometimento pessoal com a temática desta Tese. Cabe observar que minha motivação vai além do material em si - a madeira - embora, o impulso motor desta investigação seja o de fomentar o seu emprego de

\footnotetext{
${ }^{10}$ O professor Dr. José Nivaldo Garcia é engenheiro florestal e engenheiro civil, Doutor em Engenharia de Estruturas pela Escola Politécnica da Universidade de São Paulo e professor do Departamento de Ciências Florestais na Área de Processamento e Propriedades da Madeira na ESALQ-USP. Naquela ocasião, em 2006, orientou-me no desenho e cálculo da estrutura de cobertura da Sala de Euritmia e Uso Geral da Escola Waldorf Novalis, em Piracicaba-SP, projeto que posteriormente recebeu o $2^{\circ}$ lugar da Categoria Profissional do I Concurso de Arquitetura em Madeira do XI EBRAMEM - Encontro Brasileiro em Madeiras e Estruturas de Madeira - realizado em Londrina-PR em julho de 2008.
} 
maneira nobre na Arquitetura. Independente das vantagens do uso da madeira nas construções, cada material tem uma funcionalidade e mérito próprios que devem ser observados, reconhecidos e devidamente apropriados para sua adequada proposição.

Logo, o que defendo aqui é a inserção da experimentação construtiva nas escolas de arquitetura como um potente instrumento de ensino-aprendizagem que incita ao conhecimento mais aprofundado das características e do comportamento dos materiais, vivenciado corporalmente dentro de um determinado contexto, frente a um determinado problema e vinculado a determinadas condições para o seu equacionamento.

\subsection{Estruturação do trabalho}

Esta Tese está estruturada em cinco partes principais. A primeira refere-se ao presente Capítulo Introdutório. A segunda parte trata da Formação Tecnológica no Ensino de Arquitetura e está dividida em quatro capítulos: o primeiro traz a análise da evolução histórica do ensino de Arquitetura e Urbanismo, apresenta a discussão acerca da dualidade entre teoria e prática, e do (des)entrosamento entre projeto arquitetônico e tecnologia construtiva, enfatizando a importância da experimentação prática na concepção da materialidade. O segundo capítulo, seguindo a ordem cronológica dos fatos, desdobra-se na consolidação e regulamentação do ensino e da profissão no Brasil, abordando aspectos das principais normativas instituídas no país e como estas refletem no currículo dos cursos atuais. O terceiro e o quarto capítulos discutem a inserção da área da Tecnologia e da experimentação prática nos currículos brasileiros, e especificamente, das tecnologias construtivas em madeira dentro da área, trazendo dados quantitativos referentes ao levantamento documental realizado.

A terceira parte apresenta a Madeira como Material Construtivo subdividindo-se em três capítulos. Analisa em primeiro lugar as potencialidades do uso da madeira nas construções, enfatizando suas vantagens ambientais como material renovável e alinhado à lógica do desenvolvimento sustentável. Traz, no segundo capítulo, exemplos 
do seu emprego na arquitetura na atualidade, que exploram as possibilidades formais e técnicas do material através da utilização de uma diversidade de sistemas construtivos e arranjos produtivos, resultando em importantes obras referenciais. No terceiro capítulo, aborda as potencialidades do uso da madeira no ensino de arquitetura percorrendo experiências do seu emprego como instrumento de ensino-aprendizagem.

A quarta parte desta Tese alude ao tema central da investigação: a Experimentação Construtiva no Ensino de Arquitetura. Constitui o coração do trabalho e estrutura-se em três capítulos onde o primeiro traz conceituações sobre as abordagens pedagógicas do "aprender-fazendo", aportando um referencial teórico que embasa a análise de três referências, no segundo capítulo, que envolvem diferentes práticas construtivas no ensino de arquitetura: o Rural Studio nos Estados Unidos, o Wood Program na Finlândia e a Escola de Valparaíso no Chile. No terceiro capítulo, são apresentadas algumas iniciativas brasileiras no ensino de tecnologias construtivas em madeira que propõem uma abordagem diferenciada através de atividades experimentais que apontam para um caminho de maior integração entre teoria e prática.

Finalmente, a quinta parte entitulada Reflexões sobre a Prática Docente no Brasil, trata da elaboração do pensamento no contexto construído a partir dos conteúdos abordados ao longo dos capítulos anteriores. Traz as conclusões sobre a investigação ao retomar e responder as questões específicas e principal de pesquisa além de outras questões que foram surgindo no decorrer do texto. Como síntese, apresenta um esboço conceitual-metodológico como base para a proposição de unidades de ensino em escolas de arquitetura que envolvam a experimentação construtiva em madeira. Traz ainda, as considerações finais e perspectivas de continuidade da investigação.

Por último, reunem-se as Referências Bibliográficas, que foram indicadas a cada capítulo, o Apêndice e os Anexos, onde se apresentam planilhas e quadros de compilação de dados documentais levantados durante a pesquisa. 


\section{REFERÊNCIAS}

ARANTES, P. F. Qual futuro para o Canteiro Experimental? 2008. In: RONCONI, R. L. N. et al. (org. ). Canteiro experimental: 10 anos na FAUUSP. São Paulo: FAUUSP, 2008. p. 24-33.

CANIZARO, V. B. Design-build in Architectural Education: Motivations, Practices, Challenges, Successes and Failures. ArchNet-IJAR: International Journal of Architectural Research, United Kingdom, v. 6, n. 3, p. 20-36, Nov. 2012.

CARPENTER, W. J. Digital Fabrication and the Design Build Studio. In: ACSA ANNUAL MEETING, 102, 2014, Miami, FL. Proceedings [...]. Miami, FL: Florida International University, 2014. p. 513-521.

FOWLES, B. Design-build Projects in Architectural Education. Design Studies, v, 5, n. 1, p. 07-14, Jan. 1984.

GABER, T. The Agency of Making and Architecture Education: Design-Build Curriculum in a New School of Architecture. Archnet-IJAR: International Journal of Architectural Research, United Kingdom, v. 8, n. 3, p. 21-31, Nov. 2014.

GROPIUS, W. Bauhaus: novarquitetura. Tradução J. Guinsburg e I. Dormien. São Paulo: Perspectiva, 2004.

LAVERDE, A. Os espaços experimentais das escolas públicas de arquitetura do Brasil: realidade ou utopia? 2017. Tese (Doutorado em Arquitetura e Urbanismo) Faculdade de Arquitetura e Urbanismo, Universidade de São Paulo, São Paulo, 2017.

LEITE, M. A. D. F. D' A. O ensino de tecnologia em Arquitetura e Urbanismo. 1998. Dissertação (Mestrado em Arquitetura e Urbanismo) - Faculdade de Arquitetura e Urbanismo, Universidade de São Paulo, São Paulo, 1998.

A aprendizagem tecnológica do arquiteto. 2005. Tese (Doutorado em Arquitetura e Urbanismo) - Faculdade de Arquitetura e Urbanismo, Universidade de São Paulo, São Paulo, 2005.

LOPES, J. M. A. Quando menos não é mais: tectônica e o ensino tecnológico da Arquitetura e do Urbanismo. In: ENCONTRO DA ASSOCIAÇÃO NACIONAL DE PESQUISA E PÓS-GRADUAÇÃO EM ARQUITETURA E URBANISMO - ENANPARQ, 3, 2014, São Paulo. Anais [...]. São Paulo: Universidade Presbiteriana Mackenzie, 2014.

LOTUFO, T. A. Um novo ensino para outra prática: Rural Studio e Canteiro Experimental, contribuições para o ensino de arquitetura no Brasil. 2014. Dissertação (Mestrado em Arquitetura e Urbanismo) - Faculdade de Arquitetura e Urbanismo, Universidade de São Paulo, São Paulo, 2014. 
POMPÉIA, R. A. O laboratório de habitação no ensino de arquitetura: uma contribuição ao processo de formação do arquiteto. 2006. Tese (Doutorado em Arquitetura e Urbanismo) - Faculdade de Arquitetura e Urbanismo, Universidade de São Paulo, São Paulo, 2006.

RONCONI, R. L. N. Canteiro experimental: uma proposta pedagógica para a formação do arquiteto e urbanista. Pós: Revista do Programa de Pós-Graduação em Arquitetura e Urbanismo da FAUUSP. São Paulo, n. 17, p. 142-158, 2005.

SABBATINI, F. H. Desenvolvimento de métodos processos e sistemas construtivos: formulação e aplicação de uma metodologia. 1989. Tese (Doutorado em Engenharia de Construção Civil) - Escola Politécnica, Universidade de São Paulo, São Paulo, 1989.

SARAMAGO, R. C. P.; LOPES, J. M. A. Iniciativas didáticas inovadoras aplicadas ao ensino de estruturas nas escolas brasileiras de arquitetura e urbanismo. In: FÓRUM INTERNACIONAL SOBRE PRÁTICA DOCENTE UNIVERSITÁRIA, 2012, Uberlândia. Anais [...]. Uberlândia: UFU, 2012, p. 654-663. Disponível em:

http://www.forumdocente.prograd.ufu.br/anais/anais2011/pdf/2e/rita\%20e\%20joao.PD F. Acesso em: 30 ago. 2014. 


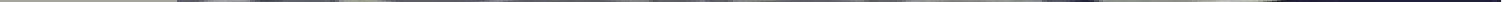





\section{FORMAÇÃO TECNOLÓGICA NO ENSINO DE ARQUITETURA}

A segunda parte desta Tese apresenta a discussão da temática da formação em Arquitetura por meio da análise de sua evolução histórica, da dualidade entre teoria e prática e do (des)entrosamento entre projeto arquitetônico e tecnologia construtiva, enfatizando a importância da experimentação prática na concepção da materialidade.

Ao abordar tais questões, investiga a consolidação da estrutura curricular vigente nos cursos de Arquitetura e Urbanismo no país e a influência da dimensão curricular na definição do perfil do Arquiteto e Urbanista brasileiro; apresenta os instrumentos normativos de regulamentação do ensino e da profissão; discute a inserção da área tecnológica e das práticas experimentais nos currículos, e particularmente, a inserção da madeira nas estruturas curriculares; identifica os conteúdos programáticos relativos às tecnologias construtivas em madeira nas disciplinas das áreas de Tecnologia das Construções e Sistemas Estruturais, com base na análise do levantamento de dados realizado na pesquisa documental.

Expõe ainda, diversas pesquisas produzidas em âmbito nacional nesta temática e traz pontos de vista de pesquisadores, docentes e profissionais que investigaram a teoria na prática ao fazer do contexto acadêmico uma extensão do seu trabalho, levando para a prática profissional a experimentação de suas teorias, e vice-versa, refletindo assim, a crença na valia do processo experimental como instrumento para a inovação construtiva e o avanço tecnológico. 


\subsection{Evolução histórica do ensino de Arquitetura e Urbanismo}

A concepção da Arquitetura carrega, historicamente, um sistema de dualidades: teoria e prática, projeto e construção, forma e função, arte e técnica. A evolução da formação na profissão contribuiu para estabelecer um comportamento de estranhamento entre o ato de criação do projeto arquitetônico e a execução técnica do espaço projetado. Frequentemente os textos que tratam do ensino em Arquitetura e Urbanismo mencionam a origem dos cursos oriunda do ensino de Belas Artes e do Politécnico como duas vertentes antagônicas que acirraram a dicotomia arte-técnica.

O estudo da história como método de prospecção objetiva estabelecer uma contextualização do problema em questão e criar um universo de referências e pressupostos teóricos que embasam a reflexão sobre a conjuntura atual do ensino de Arquitetura e Urbanismo no Brasil com vistas à proposição de novas práticas, ou ainda, a recuperação de antigas práticas, que reavaliadas, possam incorporar alternativas às vias atuais e oferecer um caminho para uma formação mais íntegra do arquiteto.

As profundas transformações socioeconômicas ocorridas na Europa no final do século XVIII e início do século XIX, na sua maioria decorrentes da Revolução Industrial, implicaram em uma aceleração do processo de urbanização caracterizado pela concentração de população nos centros urbanos, pela limitada oferta de moradias e pela deterioração das condições de higiene e segurança. Nesta época na França, o ensino de Arquitetura que até então ocorria na Académie Royale d'Architecture, primeira instituição oficialmente organizada em 1671 e fortemente marcada por uma tradição humanista, foi incorporado ao ensino de pintura e escultura na École des Beaux Arts, enquanto que para atender a necessidade de formar profissionais com novos perfis e preparar técnicos capazes de assumir os desafios dos novos tempos foi criada a École Polytechnique (SCHLEE, 2010).

Para Edgar Graeff (1995, p. 58) o divórcio em questão é antigo, tendo suas origens no Renascimento Italiano "quando o aprendizado da construção/arquitetura desloca-se do canteiro lugar por excelência do aprendizado do ofício, a verdadeira escola de formação 
dos arquitetos para os ateliês dos pintores e escultores renascentistas". Graeff fez um balanço crítico das transformações do ensino universitário de Arquitetura no Brasil traçando um panorama histórico da produção arquitetônica no mundo. Em suas palavras:

O chamado divórcio entre arte e técnica no campo da arquitetura tem sido situado, pelos historiadores e teóricos, na Europa do século XIX. Segundo esses analistas, os arquitetos não se teriam mostrado capazes de incorporar às práticas do seu ofício o desenvolvimento tecnológico facultado pela revolução científica dos séculos XVI, XVII e XVIII e requerido pela Revolução Industrial em curso no século XIX. Dessa incompetência teria resultado o referido divórcio, passando os engenheiros - recémnascidos como profissionais - a assumir a vanguarda do desenvolvimento tecnológico na área da construção e, inclusive, da arquitetura (GRAEFF, 1995, p. 9).

Maria Amélia Leite ${ }^{11}$ (1998) vai além das evidências renascentistas e dedica um capítulo de sua Dissertação de Mestrado à "Evolução Histórica da Profissão e da Formação do Arquiteto" construindo uma linha do tempo desde o Antigo Egito e Grécia Clássica até o Período Bauhaus. Analisa o papel do arquiteto na sociedade, sua atuação junto aos governantes e aos trabalhadores, e como se deu o aprendizado das artes e dos ofícios da construção ao longo da história das civilizações percorrendo autores como Kostof (1986) ${ }^{12}$, Picon (1988) ${ }^{13}$, Broadbent (1995) ${ }^{14}$, Pearce (1995) ${ }^{15}$, Banham (1975) ${ }^{16}$, Graeff (1995) ${ }^{17}$, entre outros.

${ }^{11}$ Maria Amélia D'Azevedo Leite, professora da área de tecnologia em cursos de arquitetura e urbanismo, explorou o tema do Ensino de Tecnologia em Cursos de Arquitetura no Brasil, tanto no mestrado como no doutorado, desenvolvendo em sua tese o estudo do processo de ensino-aprendizagem na formação tecnológica do arquiteto onde ressalta a "importância das decisões sobre a produção material dos ambientes projetados, da qual não podem se furtar as escolas de Arquitetura e Urbanismo na formação profissional" (LEITE, 2005, p. 3).

12 KOSTOF, S. The architect: Chapters in the history of the profession. New York: Oxford University Press, 1986.

${ }^{13}$ PICON, A. Architectes et Ingénieurs au Siècle des Lumières. Marseille: Éditions Parenthèses, 1988.

${ }^{14}$ BROADBENT, G. Architectural Education. In: PEARCE, Martin; TOY, Maggie. Educating Architects. London: Academy Editions, 1995. p. 10-23.

${ }^{15}$ PEARCE, M.; TOY, M. Educating Architects. London: Academy Editions, 1995.

${ }^{16}$ BANHAM, R. Teoria e Projeto na Primeira Era da Máquina. São Paulo: Editora perspectiva, 1975.

${ }^{17}$ GRAEFF, E. A. Arte e Técnica na Formação do Arquiteto. São Paulo: Studio Nobel, Fundação Vilanova Artigas, 1995. 
Segundo a autora, tanto no Egito Antigo como na Grécia Clássica o título atribuído ao arquiteto era equivalente a 'mestre construtor' e 'supervisor de obras' sendo que o arquiteto egípcio tinha um vínculo estreito com os faraós e era integrante da elite de poder. Atribuía-se a ele a concepção, a supervisão e a organização de grandes obras públicas. O aprendizado se dava praticamente como uma iniciação sacerdotal onde lhe eram transmitidos conhecimentos 'sagrados'. Já a iniciação do arquiteto grego na prática da arquitetura se dava pela afinidade e vivência com as artes e ofícios da construção como a carpintaria, o trabalho com metais e a escultura, através da convivência com um arquiteto experiente numa relação mestre-aprendiz. Eram-lhe atribuídos encargos de grandes responsabilidades como a construção dos templos, atuando ao lado de lideranças civis e religiosas, na esfera da arquitetura militar e no planejamento urbano.

As evidências levam a crer que o arquiteto na Grécia, assim como várias gerações sucessoras, tinha o canteiro como espaço central da prática e da formação - o que reforça a própria etimologia do termo grego 'architekton'18 - e "aprendiam a Arquitetura predominantemente na prática do ofício, sendo que esse aprendizado prático acontecia através da realização de tarefas físicas construtivas e acompanhamento de obras sob a orientação de um mestre" (LEITE, 1998, p. 67).

O Império Romano traz outros elementos à história da prática e da formação do arquiteto quando a arte de construir eleva-se à atividade de extrema importância, equivalente à Medicina e à Educação. A Arquitetura romana identificou-se por um caráter predominantemente utilitário, expresso por inúmeros edifícios públicos, anfiteatros, hospitais, banhos públicos, estádios, além de estradas, pontes, aquedutos e serviços urbanos. Diferente dos contextos anteriores, no Império Romano a Arquitetura era uma profissão considerada apropriada para pessoas de classes não aristocráticas e a formação dava-se através de três caminhos: carreira privada, com treinamento nas artes liberais junto a um mestre; treinamento militar, iniciado com conhecimentos da engenharia, construção e experiência em artilharia; ou ascensão social, através do serviço civil imperial.

\footnotetext{
${ }^{18}$ Architecton: Arkhein = dirigir, tekton = construtor, carpinteiro; entendido na Grécia Clássica como "mestrecarpinteiro" ou "mestre-construtor", antes de significar "mestre-projetista". (LEITE, 1998, p.68).
} 
Data dessa época os "Dez Livros" do tratado De Architectura de Vitrúvio, renomado arquiteto romano de carreira pública que atuou como engenheiro militar. Com seus escritos, deu grandes contribuições quanto à Arquitetura e suas regras, elaborando também princípios para a formação profissional que se refletem até os dias de hoje (SCHLEE, 2010). O arquiteto era visto por Vitrúvio como um indivíduo que deveria deter conhecimentos sobre as mais diversas ciências e artes, tidas na época como "verdadeiras":

Geometria, História, Matemática, Música, Medicina, Direito e até mesmo a Astronomia deveriam ser conhecidas pelo Arquiteto e Urbanista, que, ao contrário de outros profissionais, não deveria se especializar em um único tema, mas sim obter e ampliar seus conhecimentos nas diversas áreas do saber humano (SCHLEE, 2010, p. 21).

Efetivamente, o Período Romano foi de grande atividade e prestígio para os arquitetos, porém, seu declínio trouxe várias consequências à profissão. No Período Medieval subsequente, uma série de eventos contribuiu para mudanças substanciais na forma de atuação e no significado do arquiteto na sociedade. O abalo da economia das cidades e o fim do trabalho escravo propiciou o estabelecimento de uma economia de pequena escala fomentada pelo trabalho de pequenos artesãos e pela utilização de materiais locais.

As guildas medievais de pedreiros e carpinteiros se estabeleceram como principais espaços de aprendizado da Arquitetura onde a transmissão do conhecimento às gerações subsequentes se dava no sistema mestre-aprendiz, através da experimentação. O arquiteto realizava tanto o projeto como a construção (CARPENTER, 1997). O surgimento das guildas como forma de organização profissional e a transformação do conhecimento técnico em segredo de ofício distanciou o público em geral do universo da construção. Para alguns autores é nesse período que ocorrem os primeiros sinais de ruptura com o processo tradicional de aprendizado, até então simultaneamente teórico e prático.

No decorrer do longo milênio medieval e em consequência da divisão de poder no mundo mediterrâneo, o espectro de formas de ocorrência da profissão se amplificou 
consideravelmente. Nos séculos iniciais do Império Bizantino, bem como durante todo o conjunto da Idade Média, fez-se presente "a distinção ou dualidade entre 'projetistas letrados' e 'construtores' ou 'mestre-de-obras' com respeito à caracterização do arquiteto enquanto profissão e formação" (LEITE, 1998, p. 78).

Já o Período Gótico introduziu e promoveu uma nova tradição, trouxe à luz o papel de destaque do arquiteto em relação aos demais artífices da construção. Neste período a realização de desenhos foi utilizada para exposição de ideias, para detalhamento de partes do edifício tanto estruturais como decorativas, para consulta dos mestres-deobras e preparação de gabaritos e moldes para execução de detalhes.

O aprendizado junto ao mestre demandava sete anos iniciais, seguidos por mais três como operário, com o objetivo de adquirir experiência prática. O aprendiz era aconselhado a viajar e a observar durante esse período de estágio. Após esse percurso, deveria apresentar um trabalho que comprovasse sua qualificação e capacidade técnica. Segundo Leite, a 'performance' progressiva do arquiteto ao longo do milênio medieval comprova uma atuação profissional totalmente comprometida com a concepção e a execução dos espaços construídos, contrariando algumas opiniões que Ihe creditam uma dissociação entre projeto e canteiro de obras (LEITE, 1998).

Na opinião daquela autora, a referida separação de fato somente passa a adquirir consistência a partir do período consecutivo, o Renascimento, o que corrobora a visão de Benévolo ${ }^{19}$ (1983 apud SCHLEE, 2010) ao alegar que o projeto, entendido como a representação de um conjunto de especificações e símbolos que permitem construir o objeto representado, nasce a partir do século XV. Segundo este autor, foi este o momento em que ocorreu a separação entre os responsáveis pelo desenho dos prédios e os responsáveis por sua execução, já que a cultura medieval não distinguia entre arte e ofício, e os trabalhadores eram classificados segundo os materiais que dominavam e empregavam como, por exemplo, "mestres da pedra e mestres da madeira" formando corporações específicas.

19 BENÉVOLO, L. História da cidade. São Paulo: Pespectiva, 1983. 
No Período Renascentista verifica-se um retorno aos ideais vitruvianos da Arquitetura como ciência e do arquiteto como profissional que deveria possuir principalmente conhecimentos teóricos, e posteriormente, conhecimentos práticos relacionados à construção. Tais princípios serviram de estímulo à inserção de outros tipos de formação na prática da Arquitetura nos séculos XV, XVI e XVII, trazendo ao cenário indivíduos letrados e artistas. Na Itália, berço da Renascença, emergem nomes como Brunelleschi, Alberti, Rafael, Bramante e Michelangelo.

O tratado De re aedificatoria de Alberti retomou criticamente a obra de Vitrúvio e delineou parâmetros para uma cidade ideal com vistas a melhores condições de vida para a comunidade, trouxe discussões técnicas sobre projeto de arquitetura, materiais e construção, entre outros assuntos. Destinava-se mais especificamente a informar o cliente e não o arquiteto, o que caminhava junto ao surgimento de uma clientela elitizada e ao desejo de conquista de um 'status' social mais elevado por parte dos arquitetos. É a partir deste tratado que a Arquitetura e Urbanismo passam a se constituir de fato como um ramo do conhecimento. Para Carpenter (1997), é na Renascença que a Arquitetura emerge como uma profissão.

Os princípios integradores reunidos nas obras históricas de Vitrúvio e Alberti evidenciam o perfil de atuação, os conhecimentos necessários e as habilidades exigidas para a educação e o exercício da profissão, sendo que estes repercutem até a atualidade na estrutura dos cursos de graduação em Arquitetura e Urbanismo. Outros arquitetos renascentistas como Delorme e Palladio contribuíram com a escrita de livros e tratados de Arquitetura que acabaram por propiciar um 'novo aprendizado' estéticoconstrutivo e influenciar a caracterização da Arquitetura como categoria profissional definida e diferenciada, entendida como arte liberal, elevando o arquiteto a um status social mais privilegiado.

O panorama da profissão no Renascimento foi composto por uma diversidade de formas de atuação e de possibilidades de formação profissional, advindas da ambiguidade de sua própria conceituação entre prático, artista e intelectual. “De qualquer maneira, a assunção de padrões clássicos como base teórica da Arquitetura 
implicou no fato de que não mais poderia ser aprendida como ofício, na prática, mas deveria ser estudada" (LEITE, 1998, p. 105).

No Brasil, as raízes do ensino de Arquitetura partem da matriz portuguesa por meio dos oficiais da Colônia que, seguindo a tradição europeia, aprendiam o ofício diretamente repassado do mestre para o discípulo. As corporações de ofício, por meio das quais o conteúdo profissionalizante era passado de forma prática para os aprendizes, se fizeram presentes em território nacional desde muito cedo. Como nos demais lugares da Europa, em Portugal, a formação oficial de arquitetos e urbanistas passou a ser realizada por meio de cursos teórico-práticos ministrados por profissionais considerados habilitados, durante a fase chamada de pública, quando a necessidade pelo rápido desenvolvimento das técnicas de guerra e de navegação, exigiram a especialização em arquitetura militar (SCHLEE, 2010).

No século XVII, foram enviados para o Brasil inúmeros técnicos, portugueses e estrangeiros, especializados na arte de construir. Militares com formação muitas vezes exemplar na ciência da construção, particularmente no campo da arquitetura de fortificações. Foram instituídas as primeiras Aulas regulares de fortificação no Rio de Janeiro (1699), Salvador (1699), São Luis (1699) e Recife (1701).

As significativas transformações ocorridas desde o final do século XVII, durante o século XVIII e início do XIX, marcaram a transição para a era industrial com consequências importantes para a prática e a formação do arquiteto em todo o mundo. Com a criação da Escola Politécnica e da Academia de Belas-Artes de Paris, as atividades de projeto arquitetônico tornaram-se mais independentes da construção. Essa cisão histórica resultou na definição final de duas profissões, ambas envolvendo as atividades de edificação civil e, no caso dos engenheiros, abrangendo outras áreas como obras de infraestrutura, cálculos estruturais e instalações (REIS FILHO ${ }^{20}, 1996$ apud SCHLEE, 2010).

Com o progresso científico, os problemas técnicos da construção passaram a ser interpretados e traduzidos matematicamente. Os engenheiros, até então construtores 
de máquinas, engenhos bélicos e artifícios hidráulicos, foram afirmando-se como responsáveis pela produção de ambientes construídos, respaldados por um discurso ideológico de utilidade e de inserção implícita da tecnologia na engenharia.

A transmissão de conhecimento baseada na relação direta no local de trabalho é exemplificada pelo contexto das relações mestre-aprendiz em que a vivência do canteiro e o cotidiano da construção delineavam o universo da formação. Diferentemente desse aprendizado imediato e intenso, a educação escolarizada dos novos profissionais passou a se dar no âmbito da instituição escolar sendo esta, por excelência, um local voltado para a transmissão de saberes e símbolos.

Até o aparecimento do engenheiro civil e das escolas de Engenharia, identificadas com um novo período de racionalismo e progresso científico, o arquiteto era - ao mesmo tempo - o idealizador da forma e o único técnico capacitado para realizá-la (SCHLEE, 2010, p. 40).

A presença da corte no Brasil, a partir do ano de 1808, trouxe a necessidade de criar um sistema simbólico e funcional próprio que se expressou por meio da construção de edifícios monumentais, da modificação da arquitetura existente, do embelezamento urbano do Rio Colonial, do incentivo à atividade científica de conhecimento do país e do impulso a atividades culturais de grande alcance, ligadas à transferência de modelos europeus. A vinda da Missão Francesa em 1816 estabeleceu a adoção de sua matriz de ensino de Arquitetura coincidentemente "num período em que este vinha sendo criticado na própria França por seu conservadorismo estético e principalmente por preparar profissionais sem conhecimentos suficientes para bem resolver os aspectos funcionais e tecnológicos dos edifícios" (SOUZA ${ }^{21}, 2001$, p. 54 apud SCHLEE, 2010, p. 44).

Depois de várias denominações, em 1826, foi reorganizada e finalmente aberta a Imperial Academia de Belas-Artes no Rio de Janeiro. A instituição passou por várias fases e reformas, e mais alterações de denominação. Quando da Proclamação da República, em 1889, só existia um curso formando arquitetos no Brasil, o da Escola de Belas-Artes, e um curso formando engenheiros civis, o da Escola Politécnica do Rio de Janeiro.

O estudo da evolução da educação institucionalizada no Brasil mostra que o ensino de Arquitetura e Urbanismo tem duas vertentes principais: uma originária da Escola

\footnotetext{
${ }^{21}$ SOUSA, A. O ensino da Arquitetura no Brasil Imperial. João Pessoa: Ed. da UFPB, 2001.
} 
Nacional de Belas-Artes, no Rio de Janeiro, e outra da Escola Politécnica, em São Paulo. Entretanto, diferente de Paris ou Rio de Janeiro, onde os arquitetos se formavam em escolas integradas ao ensino artístico, em São Paulo a Arquitetura veio a ser estudada como uma especialidade da Engenharia. A Escola Politécnica de São Paulo foi fundada em 1894, dois anos depois passou a funcionar o curso de engenheiro-arquiteto que formava profissionais preparados para projetar e construir edificações (MOTTA ${ }^{22}$, 1977; FICHER ${ }^{23}$, 2005, apud SCHLEE, 2010).

Ainda no final do século XIX, outros três outros cursos passaram a formar arquitetos no Brasil. Em 1896, foi fundada a Escola de Engenharia de Porto Alegre, ofertando cinco cursos independentes, entre eles o de Arquitetura, posteriormente extinto. No mesmo ano foi fundada a Escola de Engenharia do Mackenzie College, em São Paulo, e em Salvador no ano de 1897, foi criada a Escola Politécnica da Bahia. A formação politécnica passou a incorporar conhecimentos anteriormente associados exclusivamente à Arquitetura e que foram progressivamente conduzidos para uma educação científica. O ensino de Arquitetura, por sua vez, incorporou a transmissão de conhecimentos abstratos como a arte do desenho enquanto forma separada da matéria. Em relação ao ensino de Tecnologia, Leite (1998) alega que tanto as escolas de Belas Artes quanto as Politécnicas, permaneceram afastadas do universo real da construção e da materialidade da Arquitetura.

As revoluções técnicas desse período, promovidas pela evolução científica e tecnológica, afetaram diretamente a vida cotidiana em função da interferência das máquinas nos processos da vida humana provocando reflexos também no universo da produção arquitetônica. Já durante o século XIX, as possibilidades oferecidas pelos novos materiais como o ferro e o vidro, foram amplamente exploradas e incorporadas na produção material dos profissionais.

\footnotetext{
${ }^{22}$ MOTTA, F. Subsídios para relatório sobre ensino de arquitetura UIA-Unesco, 1974. In: ASSOCIAÇÃO BRASILEIRA DE ESCOLAS DE ARQUITETURA. Sobre a história do ensino de Arquitetura no Brasil. São Paulo, 1977.

${ }^{23}$ FICHER, S. Os arquitetos da Poli: ensino e profissão em São Paulo. São Paulo: Ed. da USP, 2005.
} 
Uma série de movimentos culturais e artísticos ocorridos principalmente na Europa, à luz do Art Nouveau, como o Arts \& Crafts na Inglaterra, o De Stijl na Holanda, o Cubismo na França, o Futurismo na Itália, com rebatimentos também nos Estados Unidos através de expoentes arquitetônicos como Frank Lloyd Wright, foram impulsionados por ideais estéticos defendidos pelos ingleses John Ruskin e William Morris que propunham democratizar a beleza e socializar a arte através da crítica à industrialização e do resgate da produção artística-artesanal.

É neste contexto que surge a Bauhaus, no início do século XX na Alemanha, paralelamente aos avanços da nova ordem produtiva, como instituição de ensino voltada à formação de arquitetos com base em pressupostos pedagógicos diversos aos padrões até então estabelecidos, tanto pelas Academias de Belas Artes como pelo sistema Politécnico. Em consequência da Primeira Guerra Mundial, Walter Gropius, fundador da escola, sentiu a necessidade de marcar novamente o campo de atuação do arquiteto de forma a transpor o abismo entre realidade e idealismo. Suas reflexões o levaram a compreensão de que só seria possível lograr mudanças efetivas formando uma nova geração de profissionais em relação íntima com os novos meios de produção, em uma escola pioneira, contando com uma equipe de colaboradores a serviço de um objetivo comum.

A partir dessas ideias, em 1919 foi inaugurada a Bauhaus. "Seu escopo específico era concretizar uma arquitetura moderna que, como a natureza humana, abrangesse a vida em sua totalidade" (GROPIUS, 2004, p. 30). Para isso, Gropius, defendia o trabalho experimental em oficinas de formação onde o processo de aprendizado vinculava-se ao saber fazer. Essa formação artesanal nas oficinas da Bauhaus não constituía um fim em si, mas um meio de educação imprescindível para o conhecimento do material e dos processos de trabalho.

Era objetivo da Bauhaus formar pessoas com talento artístico para serem designers na indústria, artesãos, escultores, pintores e arquitetos. Servia de base um bem organizado adestramento manual, tanto do ponto de vista técnico como formal, tendo por meta o trabalho em equipe na construção (GROPIUS, 2004, p. 37). 
Pretendia-se minimizar as desvantagens da máquina e da mecanização, sem sacrificar as vantagens reais que esta aportava ao mundo moderno. Buscava-se criar padrões de qualidade ao invés de novidades transitórias. Na prática, a Bauhaus propôs uma comunidade de todas as formas de trabalho criativo, uma nova unidade entre as diferentes artes visuais como a pintura, escultura e arquitetura. Nas palavras de Gropius (2004, p. 32): “A experimentação tornou-se, uma vez mais, o centro da arquitetura; e isto requer um espírito aberto e coordenante, e não o tacanho e limitado especialista". Não era objetivo da Bauhaus promover um "estilo" qualquer, o que significaria recair no academismo, mas sim exercer uma influência real e viva no "design" através de uma nova postura e concepção de vida.

O estabelecimento de um laboratório de construção como centro do processo de formação, formal e prática, foi a pedra angular do programa da Bauhaus, complementando uma educação em artes e ofícios que começaria com uma introdução geral aos materiais, forma e cor, e treinamento em diferentes oficinas e estúdios de $\operatorname{artistas}^{24}$ (Figura 1).

24 "O plano de ensino da Bauhaus explorava a dimensão formal e técnica do projeto dos objetos de uso diário e das edificações. O estudo da linguagem visual ou representação do projeto formava com o ensino da técnica o núcleo das disciplinas básicas da Bauhaus. A teoria visual provinha do estudo da ótica (física) e da forma. 0 ensino da gramática visual envolvia o estudo das leis da natureza. Havia nele uma preocupação com o ensino das proporções, ilusões óticas e cores. A Bauhaus abrigava artesãos, artistas (por exemplo, escultores e pintores), engenheiros e arquitetos. A formação do estudante consistia no treinamento em equipe, por meio do trabalho experimental e manual. A primeira unidade do curso (formação básica) compreendia o estudo formal (as proporções, o ritmo, as cores, o contraste, etc.) e visava ao desenvolvimento da capacidade motora e imaginativa do estudante. As etapas subsequentes do ensino da Bauhaus aprofundavam e expandiam tais aspectos. A oficina, após a etapa preliminar do curso, era a espinha dorsal deste. Ela unia o ensino da estética ao ensino prático (técnico). O produto final dessa unidade de ensino era a produção de protótipos para a indústria. Na construção de protótipos, os estudantes empregavam trabalho artesanal, princípios industriais (por exemplo, a padronização) e comerciais (por exemplo, custos de venda). Dois mestres, um de estética e outro de técnica (trabalho manual), conduziam o ensino na oficina. Após três anos de curso na oficina, o estudante tinha duas opções profissionais. Uma delas consistia no ingresso no mercado de trabalho como artesão. A outra opção consistia na obtenção do grau de mestre. Essa fase implicava o prosseguimento e o aprofundamento dos estudos. Por intermédio desses estudos, os estudantes obtinham o grau de mestre em construção (cursos de design industrial e de engenharia) e em arquitetura (curso de arquitetura)" (ALMEIDA, 1999, p.112). 
Figura 1 - Esquema gráfico do programa de formação da Bauhaus

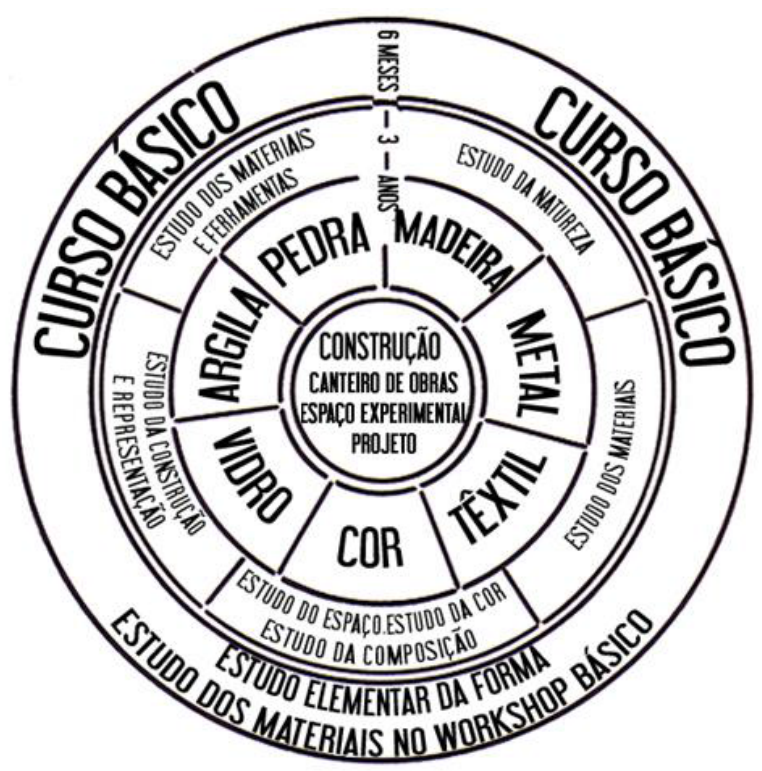

Fonte: Mattara; Nascimento (2015).

A intenção de Gropius era estabelecer um estúdio experimental de grande escala onde os problemas práticos dos escritórios profissionais pudessem ser abordados nos sentidos técnico e formal, sob a direção de um arquiteto praticante altamente qualificado. Tal estúdio experimental estaria em contato com as incumbências de arquitetura recebidas pela Bauhaus ou por ele próprio (ASCHER, 2015) ${ }^{25}$. A abordagem pedagógica no ensino de Arquitetura da Bauhaus foi de fato apenas parcialmente efetivada através das experiências realizadas ao longo das distintas fases e direções pelas quais passou a escola em seus exímios 14 anos de existência, como dos arquitetos Hannes Meyer e Mies van der Rohe.

No entanto, a noção de que a experiência prática do artesão e a experiência formal do artista deveriam ser combinadas para encontrar uma solução apropriada, introduziu uma aspiração importante para as gerações futuras na Alemanha e internacionalmente, por onde repercutiram os ideais da escola.

${ }^{25}$ Barbara Elisabeth Ascher cita Éva Forgács, ao mencionar uma oferta de emprego escrita por Gropius para o arquiteto Emil Lange, líder do Bauhütte Breslau. In: The Bauhaus Idea and Bauhaus Politics, Central European University Press (Budapest), 1995, p. 82 (tradução nossa). 
O legado da Bauhaus sem sombra de dúvidas faz-se presente e é reconhecido em todo o mundo. Passados cem anos de sua fundação, a Bauhaus Dessau Foundation comemora o seu centenário em 2019 com um projeto internacional composto por uma série de eventos em Berlim, na cidade de Weimar e no icônico edifício de Dessau, além de exposições, simpósios e debates que estão percorrendo desde 2018, países que foram influenciados pela pedagogia da escola, como Japão, China, Rússia e Brasil ${ }^{26}$.

As perguntas colocadas por Gropius naquele então continuam extremamente atuais e pertinentes ao confrontarmos revolução industrial e revolução digital:

O que devemos pois fazer a fim de preparar a geração vindoura uma via mais rica em perspectivas para a sua futura profissão de designer, artesão e arquiteto? Que institutos de formação devemos organizar para descobrir o homem de talento artístico e equipá-lo mediante profundo treino espiritual e artesanal para o trabalho criativo, independente, no seio do processo de produção industrial? (GROPIUS, 2004, p. 37).

As máquinas, ferramentas e processos são outros. As proporções do avanço tecnológico e digital abarcados no último século seriam, provavelmente, inimagináveis naquele momento. Os dispositivos digitais atualmente são regra tanto nos escritórios quanto nos ateliês. Estudantes e profissionais utilizam ferramentas digitais tridimensionais para desenvolver e modelar projetos, e através desta tecnologia, o projeto e a construção estão intrinsecamente entrelaçados em um circuito contínuo de retroalimentação que busca encontrar novas maneiras de criar e construir Arquitetura, tal como no modelo da Bauhaus Dessau.

Não obstante, a formação em arquitetura no Brasil parece não haver acompanhado tais transformações e seguimos repetindo modelos provenientes do academicismo europeu. De modo geral, a maneira como ainda se ensina muitas vezes não ajuda na compreensão dos problemas contemporâneos e na formulação de pensamentos próprios que preparem o indivíduo para uma postura criativa frente aos desafios atuais.

${ }^{26}$ Informações disponíveis em: https://www.archdaily.com.br/br/904621/sesc-pompeia-inaugura-exposicaosobre-os-100-anos-da-bauhaus. Acesso em: 31 out. 2018. 
A cisão entre arte e técnica - discussão que permeia esta investigação e será abordada seguidamente nesta Tese - produziu consequências importantes fragilizando a formação dos arquitetos, como já vimos. O ensino de Tecnologia foi a partir desta dicotomia, paulatinamente prejudicado e não mais visto como área de conhecimento essencial à Arquitetura. Da evolução histórica do ensino de arquitetura, podemos entender, entretanto, que essa fragmentação não esteve presente em suas origens, pelo contrário, a unidade entre o pensar e o fazer, entre o projeto e a construção, era desde os tempos mais remotos parte do ofício. 


\section{REFERÊNCIAS}

ALMEIDA, J. G. A formação do arquiteto e a universidade. In: GOUVÊA, L. A. C.; BARRETO, F. P.; GOROVITZ, M. (org.) et al. Contribuição ao Ensino de Arquitetura e Urbanismo. Brasília : Instituto Nacional de Estudos e Pesquisas Educacionais, 1999. p.101-119.

ASCHER, B. E. The bauhaus: Case study experiments in education. Architectural Design, London, v. 85, n. 2, p. 30-33, Mar. 2015. Disponível em: https://doiorg.ez67.periodicos.capes.gov.br/10.1002/ad.1873. Acesso em: 18 ago. 2019.

CARPENTER, W. J. Learning by Building: Design and Construction in Architectural Education. New York : Van Nostrand Reinhold, 1997.

GRAEFF, E. A. Arte e técnica na formação do arquiteto. São Paulo: Studio Nobel, 1995.

GROPIUS, W. Bauhaus: novarquitetura. Tradução J. Guinsburg e I. Dormien. São Paulo: Perspectiva, 2004.

LEITE, M. A. D. F. D' A. O ensino de tecnologia em Arquitetura e Urbanismo. 1998. Dissertação (Mestrado em Arquitetura e Urbanismo) - Faculdade de Arquitetura e Urbanismo, Universidade de São Paulo, São Paulo,1998.

MATTARA, M.; NASCIMENTO, M. A. Metodologia de ensino baseada na experimentação pelas escolas Bauhaus e VKhUTEMAS. Iniciação - Revista de Iniciação Científica, Tecnológica e Artística. Edição Temática: Comunicação, Arquitetura e Design. São Paulo, v. 5, n. 1, Jun. 2015. Disponível em:

http://www1.sp.senac.br/hotsites/blogs/revistainiciacao/index.php/vol-5-1-ano-2015/. Acesso em: 07 nov. 2018.

SCHLEE A. R. (org.). Trajetória e estado da arte da formação em Engenharia, Arquitetura e Agronomia - Volume X: Arquitetura e Urbanismo. Brasília: INEP/CONFEA. 2010. 


\subsection{Consolidação e regulamentação do ensino e da profissão no Brasil}

Em paralelo aos intensos movimentos culturais ocorridos com maior relevância na Europa e Estados Unidos no início do século XX, no decurso deste período no Brasil, a ascensão de Getúlio Vargas ao poder inaugurou uma nova etapa de nossa história. Foi realizada uma série de modificações estruturais, entre as quais se destacam as ocorridas no campo da educação. Em 1928, foi criado o Curso de Arquitetura da Academia de Belas-Artes - o primeiro a formar arquitetos e não engenheiros-arquitetos no Estado de São Paulo - e em 1930, foram fundadas a Escola de Belas-Artes e a Escola de Arquitetura de Belo Horizonte.

No mesmo ano da Revolução de 1930, o arquiteto e urbanista Lucio Costa foi nomeado diretor-interventor da Escola Nacional de Belas-Artes (Enba), no Rio de Janeiro. À frente da Escola, buscou reestruturar o ensino, tanto do ponto de vista de sua organização quanto de sua orientação. Lucio Costa pretendia "proporcionar aos seus alunos uma opção entre o ensino acadêmico, ministrado por professores catedráticos, que seriam mantidos em suas funções, e o ensino ministrado por elementos mais jovens, identificados com o espírito moderno" (BRUAND ${ }^{27}, 1981$, p. 72 apud SCHLEE, 2010, p. 56).

Embora tenha sido muito curta a permanência de Lucio Costa na Enba, de acordo com Segawa ${ }^{28}$ (1997, p. 79 apud SCHLEE, 2010, p. 56) esse período foi suficientemente marcante "para que uma geração de futuros arquitetos tivesse consciência das transformações em curso na Arquitetura e Urbanismo mundial". Cabe mencionar, pela relevância para a futura atuação e nomenclatura profissional e seu consequente efeito para a área de ensino, que foi nesta reforma que se incluiu a cadeira de Urbanismo.

\footnotetext{
${ }^{27}$ BRUAND, Y. Arquitetura contemporânea no Brasil. São Paulo: Perspectiva, 1981.

${ }^{28}$ SEGAWA, H. Arquitetura no Brasil: 1900-1990. São Paulo: Ed. da USP, 1997.
} 
Em 1931 a estrutura curricular da Escola Nacional de Belas-Artes, foi novamente modificada ${ }^{29}$. A seriação proposta buscou satisfazer "a exigência de uma base científica sólida e segura, bem como as de uma formação técnica e artística, com raízes profundas em formação cultural de amplos e claros horizontes" (FÁVERO ${ }^{30}, 2000$, p. 48 apud SCHLEE, 2010, p. 56).

Até o ano de 1933, o exercício da Arquitetura e Urbanismo no Brasil foi livre. Na década de 1920, começaram a aparecer as primeiras leis estaduais sobre regulamentação profissional. Os arquitetos e urbanistas passaram a discutir a construção de uma estrutura própria para o acompanhamento e fiscalização do exercício da profissão. Em 1932, o Sindicato Nacional de Engenharia apresentou um anteprojeto de lei e, em 11 de dezembro de 1933, foi promulgado por Getúlio Vargas, o Decreto $\mathrm{n}^{\circ}$ 23.569, que regulamentou o exercício das profissões de engenheiro, arquiteto e agrimensor ${ }^{31}$ (BRASIL, 1933 apud SCHLEE, 2010). Este Decreto definiu também a criação do Conselho Federal de Engenharia, Arquitetura e Agrimensura (CONFEA) e de seus Conselhos Regionais, para apoiar os processos de registro de licenças profissionais.

Para Vilanova $\operatorname{Artigas}^{32}$ (1977) a institucionalização da profissão não foi um fator positivo para o arquiteto e urbanista:

${ }^{29}$ A grade curricular do curso de Arquitetura da Escola Nacional de Belas-Artes (Enba/RJ) (1931) é apresentada na publicação de SCHLEE (2010, p. 57-58) em quadro elaborado a partir de: BRASIL. Decreto no 19.852, de 11 de abril de 1931. Dispõe sobre a Organização da Universidade do Rio de Janeiro. Coleção de Leis do Brasil, Rio de Janeiro, 1931.

${ }^{30}$ FÁVERO, M. L. de. Universidade do Brasil: guia dos dispositivos legais. Rio de Janeiro: Ed. da UFRJ, 2000.

${ }^{31}$ Conforme o art. 30 do Decreto no 23.569 de 11 de dezembro de 1933, ao arquiteto ou engenheiro-arquiteto cabia: a) o estudo, projeto, direção, fiscalização e construção de edifícios, com todas as suas obras complementares; b) o estudo, projeto, direção, fiscalização e construção das obras que tenham caráter essencialmente artístico ou monumental; c) o projeto, direção e fiscalização dos serviços de urbanismo; d) o projeto, direção e fiscalização das obras de arquitetura paisagística; e) o projeto, direção e fiscalização das obras de grande decoração arquitetônica; f) a arquitetura legal, nos assuntos mencionados nas alíneas a e c do artigo; e, finalmente, g) perícias e arbitramentos relativos à matéria de que tratam as alíneas anteriores (SCHLEE, 2010, p. 60).

${ }^{32}$ ARTIGAS, V. Contribuição para o relatório sobre ensino de arquitetura e urbanismo. In: ASSOCIAÇÃO BRASILEIRA DE ESCOLAS DE ARQUITETURA. Sobre a história do ensino de arquitetura no Brasil. São Paulo, 1977. 
Os arquitetos e o ensino de Arquitetura saíram deste processo bastante prejudicados. Não se compreendeu o papel que os arquitetos teriam que desempenhar nesse momento histórico. Na verdade prevaleceu o conceito que o tipo de formação da antiga Academia de Belas-Artes tinha criado para o arquiteto. Uma espécie de técnico menor, um desenhador, ignorante das exigências da lei da gravidade e do comportamento das estruturas. (ARTIGAS, 1977, p. 32 apud SCHLEE, 2010, p. 60).

Desde então, o campo da Arquitetura e Urbanismo foi em várias circunstâncias considerado como mais uma das inúmeras "modalidades" da Engenharia. As atribuições relativas à construção e ao urbanismo, definidas no Decreto de Lei 23.569, foram partilhadas com os engenheiros civis, gerando uma superposição funcional no campo da atividade das duas profissões.

Somente mais de meio século depois, como resultado da luta da categoria por um conselho uniprofissional e que defendesse os interesses da profissão, foram criados o Conselho de Arquitetura e Urbanismo do Brasil - CAU/BR e os Conselhos de Arquitetura e Urbanismo dos Estados e do Distrito Federal - CAU/UF, com a Lei n 12.378 de 31 de dezembro de 2010, que regulamenta o exercício da Arquitetura e Urbanismo no país. Uma conquista histórica para a categoria, que significa maior autonomia e representatividade para a profissão ${ }^{33}$.

De 1933 até o início da década de 1950, o ensino de Arquitetura e Urbanismo, assim como todo o sistema de organização e representação da profissão, passaram por um período de reorganização e expansão quando foram criados vários cursos em diversas partes do território nacional. Do ponto de vista da luta por sua autonomia, houve uma fase mais intensa entre 1947 a 1960, tendo se iniciado na Escola Politécnica e no Mackenzie, em São Paulo, e posteriormente estendendo-se a outros Estados. Durante esse período amadureceram as diretrizes básicas do ensino e os primeiros modelos

\footnotetext{
33 LEI No 12.378, DE 31 DE DEZEMBRO DE 2010. Regulamenta o exercício da Arquitetura e Urbanismo; cria o Conselho de Arquitetura e Urbanismo do Brasil - CAU/BR e os Conselhos de Arquitetura e Urbanismo dos Estados e do Distrito Federal - CAUs; e dá outras providências. O CAU - autarquia federal dotada de personalidade jurídica de direito público - possui a função de "Orientar, disciplinar e fiscalizar o exercício da profissão de Arquitetura e Urbanismo, zelar pela fiel observância dos princípios de ética e disciplina da classe em todo o território nacional, bem como pugnar pelo aperfeiçoamento do exercício da arquitetura e urbanismo" (BRASIL, 2010, § $1^{\circ}$ do art. 24). Disponível em: http://www.planalto.gov.br/ccivil_03/_ato20072010/2010/lei/L12378.htm. Acesso em: 10 nov. 2018.
} 
evoluíram de uma posição acadêmica e tecnocrática - oriundas da tradição Belas-Artes e Politécnica, respectivamente - para uma posição modernista, no sentido estético, influenciada pela Bauhaus e por Le Corbusier e, ao mesmo tempo, voltada para uma compreensão mais ampla dos problemas da construção no país (ARTIGAS, 1977 apud SCHLEE, 2010).

Neste contexto, destacam-se a criação de três Faculdades de relevância nacional. A criação, em 1945, da Faculdade Nacional de Arquitetura (FNA/RJ) originou-se da separação definitiva do curso de Arquitetura da Escola de Belas-Artes e demarcou simbolicamente o surgimento dos cursos autônomos na área. Somente em 1961, a Faculdade passou a ocupar seu endereço atual na llha do Fundão, chamando-se, posteriormente, Faculdade de Arquitetura e Urbanismo. É uma das maiores e mais importantes do país, responsável pela formação de eminentes profissionais tais como Oscar Niemeyer, Sérgio Bernardes, Maurício Roberto, Afonso Eduardo Reidy ${ }^{34}$.

Já a Faculdade de Arquitetura e Urbanismo da Universidade de São Paulo (FAU/USP) foi criada em 1948 e teve as suas raízes mais profundas no curso de Arquitetura da Escola Politécnica da USP. Seu fundador e primeiro diretor foi o Professor Luiz Ignácio de Anhaia Mello. Em seus primeiros anos, o curso da FAU combinava as disciplinas técnicas originais do antigo modelo, praticamente inalteradas, com elementos do currículo padrão da Escola Nacional de Belas Artes ${ }^{35}$. Em 1957, os professores Abelardo Souza, Hélio Duarte, Vilanova Artigas e Rino Levi receberam a incumbência de definir as linhas mestras para uma grande reforma do ensino na Instituição. Sugeriram uma nova estrutura, na qual o "atelier" passou a constituir a chamada "espinha dorsal" do curso, com as demais disciplinas para ele convergindo ${ }^{36}$.

\footnotetext{
34 Informação disponível em: http://www.fau.ufrj.br/a-fau/. Acesso em: 10 nov. 2018

35 Informação disponível em: http://www.fau.usp.br/a-fau/. Acesso em: 10 nov. 2018

${ }^{36}$ De acordo com Motta (1977 apud SCHLEE, 2010, p. 64) "o foco central de preocupações era a contradição entre a pouca relevância dada à "Composição Arquitetônica" no quadro do ensino e a importância do domínio dessa habilidade no campo profissional. (...) Implantou-se assim, na FAU/USP, uma concepção curricular focada em quatro áreas de interesse (Comunicação Visual, Desenho Industrial, Edifício e Urbanismo) e uma estrutura didático-pedagógica com três departamentos: o de Projeto, o de Tecnologia e o de História da Arquitetura e Estética do Projeto". MOTTA, F. Subsídios para relatório sobre ensino de arquitetura UIA-Unesco, 1974. In: ASSOCIAÇÃO BRASILEIRA DE ESCOLAS DE ARQUITETURA. Sobre a história do ensino de Arquitetura no Brasil. São Paulo, 1977.
} 
A Universidade de Brasília (UnB) foi criada no contexto da construção da nova capital do país e de plena valorização profissional do arquiteto e urbanista. Em 1962, entrou em funcionamento o curso de Arquitetura e Urbanismo da UnB tendo Oscar Niemeyer como o seu primeiro coordenador. Seu currículo foi elaborado por Edgar Albuquerque Graeff, Ítalo Campofiorito e João Filgueiras Lima (Lelé), com o conteúdo estruturado em três "troncos": teoria, composição e tecnologia. Os trabalhos então desenvolvidos por professores, mestrandos e graduandos, na maioria das vezes, implicavam em projetar e executar as edificações para a Cidade Universitária ou para outros órgãos do governo numa total integração entre teoria e prática. A experiência da nova universidade veio, entretanto, a interromper-se pelo golpe militar de 1964, sepultando o projeto imaginado por Anísio Teixeira e Darcy Ribeiro (SCHLEE, 2010).

Com a consolidação dos cursos de $A U$ e a maturação e divulgação do ideário da Arquitetura Moderna no Brasil, o empenho pela adoção de um currículo mínimo como base para uma formação unificada em nível nacional incorporou diversas reivindicações relativas ao ensino e também à prática profissional. Em um primeiro momento entre 1945 e 1962, todos os cursos do país tomavam por modelo o currículo da Faculdade Nacional de Arquitetura (FNA/RJ). Em 1962, foi aprovado um Currículo Mínimo nacional que se preocupou em não reproduzir o modelo que pretendia superar; e apontou para uma visão de formação generalista, única do arquiteto e urbanista ${ }^{37}$.

Para Graeff ${ }^{38}$ (1983, p. 22 apud SCHLEE, 2010, p. 68), este foi ponto alto do pensamento brasileiro voltado para a questão da formação profissional do arquiteto. “Dele germinou por um lado a experiência radical que se tentou realizar na Universidade de Brasília entre 1962 e 1966 e por outro, resultou no primeiro currículo mínimo para formação de arquitetos". Entretanto, a repressão imposta pelo regime

${ }^{37}$ Os conteúdos mínimos a serem observados na organização dos cursos de Arquitetura (1962) são apresentados na publicação SCHLEE (2010, p. 66). O conceito de um Currículo Mínimo efetivo, aberto para diferentes experimentações, pretendia, por um lado, garantir a manutenção da profissão do arquiteto e urbanista como uma habilitação única em todo o território nacional e, ao mesmo tempo, aceitar a incorporação de tradições culturais regionais, adequando os cursos às dimensões e ao desenvolvimento sociocultural do país.

${ }^{38}$ GRAEFF, E. A. Um balanço crítico das lutas pelo novo currículo mínimo. Revista Projeto, São Paulo, n. 54, 1983. 
militar atingiu duramente as escolas onde o processo de mudanças curriculares e metodológicas estava mais desenvolvido como a UnB, a URGS, a USP e a UMG.

A mobilização organizada em torno da adequação dos cursos pretendia a ampliação e valorização social da atividade do arquiteto e urbanista como um profissional do projeto - estabelecida como um paradigma revelado pelo movimento moderno - e culminou na promulgação do Currículo Mínimo de 1969, apesar da crítica de desvirtuamento da proposta encaminhada pela categoria.

\begin{abstract}
A implantação do currículo mínimo de 1962 objetivava adequar a formação desenvolvida nas escolas às especificidades do exercício da profissão e da atuação do arquiteto e urbanista na própria sociedade. Porém, a implantação do currículo mínimo para o ensino de Arquitetura e Urbanismo em 1969, instituído no bojo da Reforma Universitária, estava centrada em novos parâmetros. Tanto o parecer da Comissão Especial do CNE, que o circunstanciava, quanto as normas para a aplicação dos novos currículos mínimos não contemplavam o sentido e a profundidade das mudanças alcançadas nos movimentos de reforma do ensino que a antecederam (SCHLEE, 2010, p. 68).
\end{abstract}

Mais do que um instrumento homogeneizador da formação profissional que garantisse um núcleo básico comum em escala nacional, a observância do currículo mínimo foi progressivamente se reduzindo ao atendimento burocrático do disposto nas normas em detrimento da questão do ensino. A dimensão curricular desvinculou-se do contexto que lhe deu origem - como busca por uma expressão articulada de um projeto pedagógico com métodos próprios de ensino - abreviando-se à mera composição de grades curriculares por meio de disciplinas justapostas até o limite das cargas horárias previstas.

Segundo Santos Júnior ${ }^{39}$ (2013) a dimensão curricular tem uma importância crescente desde o início do século XX na definição do perfil do Arquiteto e Urbanista

\footnotetext{
${ }^{39}$ Wilson Ribeiro dos Santos Júnior explorou em sua tese de doutoramento na Faculdade de Arquitetura e Urbanismo da Universidade de São Paulo (2001) as transformações do Ensino de Arquitetura e Urbanismo sob o título: "O currículo mínimo no ensino de arquitetura e urbanismo no Brasil: 1969 -1994". Também é autor de diversos livros e artigos sobre o tema do Ensino de Arquitetura, entre os quais os livros/compêndios "Trajetória e estado da arte da formação em engenharia, arquitetura e agronomia" e "A construção de um novo olhar sobre o ensino de arquitetura e urbanismo no Brasil: os 40 anos da Associação Brasileira de
} 
brasileiro e consequentemente, na evolução do ensino de $\mathrm{AU}$, pelo fato de se constituir num instrumento político capaz de sintetizar documentalmente as demandas profissionais emergentes, e de criar renovadas expectativas de mudança no bojo de movimentos reivindicatórios.

A política de expansão do ensino superior então adotada na Reforma Universitária de 1969 consistiu, entretanto, na ampliação do número de vagas na universidade com o mínimo de comprometimento do Estado com os custos subsequentes. A omissão dos órgãos governamentais em relação à preservação de padrões de qualidade adequados acabou transformando o ensino em produto mercadológico controlado por empresas educacionais. Como era de se esperar, tal política resultou no crescimento exponencial dos cursos de Arquitetura e Urbanismo, porém, não mais como uma resposta efetiva aos problemas urbanos, espaciais e ambientais apontados nos distintos fóruns de discussão.

Até a Reforma Universitária havia dez escolas públicas e gratuitas e duas escolas privadas de Arquitetura e Urbanismo no país. Seis anos depois, em 1974, entraram em funcionamento mais doze escolas privadas e duas públicas. “Esse aumento no número de vagas, especialmente na rede privada, foi realizado sem nenhuma preparação quanto às instalações, aos equipamentos e à qualificação dos professores" (GUTIERREZ, 2013, p. 23).

A fundação da Associação Brasileira de Escolas de Arquitetura - ABEA, posteriormente denominada Associação Brasileira de Ensino de Arquitetura e Urbanismo, e da Comissão de Especialistas no Ensino de Arquitetura e Urbanismo CEAU em 1973, ocorreram como resposta a esta expansão com o objetivo de levantar dados, reunir demandas e sugestões para aprimorar a qualidade do ensino no país em atendimento a solicitação do Ministério de Educação.

Após o longo período de vigência do Currículo Mínimo, em 1994 foi convocado o Seminário Nacional de Avaliação do Ensino de Arquitetura e Urbanismo, sediado na 
Universidade de Brasília, amparado institucionalmente pela Secretaria de Educação Superior do Ministério da Educação - SESU/MEC por meio da CEAU. Naquela época já havia no Brasil 73 cursos em funcionamento. Destes, participaram no seminário 53 Instituições de Ensino Superior que analisaram e debateram o status do ensino e o Currículo Mínimo de 1969. As discussões levaram a uma proposta de novo currículo aprovada na plenária como Diretrizes Curriculares - Portaria $\mathrm{n}^{\circ}$ 1.770/94 SESu/MEC em acordo com a recém-aprovada Leis de Diretrizes e Bases da Educação - LDB (1993), a Lei Darcy Ribeiro.

A Portaria $n^{\circ}$ 1.770/94 que fixou as diretrizes curriculares e o conteúdo mínimo do curso de graduação em Arquitetura e Urbanismo significou um avanço no tocante à desvinculação da formação com base em um currículo mínimo e foi resultado de um processo de reflexão e de avaliação realizado durante o período de fevereiro de 1993 a setembro de 1994, baseado em exame aprofundado da problemática educacional da área e coordenado pela CEAU envolvendo estudos em andamento na ABEA, com apoio do CONFEA, entre outras entidades, como o Instituto de Arquitetos do Brasil - IAB e a Federação Nacional dos Arquitetos - FNA (BRASIL, 1994; SCHLEE, 2010; SANTOS JUNIOR, 2013).

As Diretrizes Curriculares de 1994 preveem a inserção no projeto pedagógico do curso, do núcleo de conteúdos profissionais que deve contribuir para o aperfeiçoamento da qualificação profissional considerando, entre outros, conhecimentos de Projeto de Arquitetura de Urbanismo e de Planejamento, Tecnologia da Construção e Sistemas Estruturais. Para tanto, inclui como exigência para sua oferta a utilização de laboratórios, maquetarias, salas de projeto, além de equipamentos correspondentes.

De acordo com Luiz Contier (2017) em artigo publicado pelo CAU/BR ${ }^{40}$, já em 1994 na avaliação da CEAU, existia uma evidente preocupação com os "fenômenos de sucateamento e barateamento dos cursos, evidenciados pela carência de espaços

\footnotetext{
${ }^{40}$ Artigo do arquiteto e urbanista, conselheiro suplente do CAU/BR por São Paulo, Luiz Contier: Ameaça à educação dos arquitetos. Publicado em 15 de fevereiro de 2017. Disponível em:

http://www.caubr.gov.br/ameaca-a-educacao-dos-arquitetos/. Acesso em: 05 mar. 2017.
} 
adequados, falta de laboratórios, bibliotecas pobres, e baixíssimo investimento nos docentes, entre outras mazelas detectadas". Esse quadro é claramente abordado no documento “Perfis \& Padrões de Qualidade: Expansão, Reconhecimento e Verificação Periódica dos Cursos de Arquitetura e Urbanismo" ${ }^{41}$, produzido pela CEAU/ SESU/MEC, que determina entre outros, as condições de oferecimento dos cursos:

A evidência do fenômeno do barateamento nos Cursos de Arquitetura e Urbanismo está presente, não só na carência de espaços adequados ao trabalho de professores e alunos, ausência ou insuficiência de equipamentos básicos, currículos extensos, fragmentados e carregados de disciplinas, como também na própria capacitação de professores comprometendo, portanto, o desenvolvimento das atividades de ensino, pesquisa e extensão na graduação.

Um dos problemas fundamentais no quadro atual do ensino de Arquitetura e Urbanismo é a dissociação existente entre ensino de projeto e o ensino da arte de construir. A atividade de construção faz parte do "métier" do arquiteto, de suas atribuições legais e de sua história como profissão. Esta carência insere-se no contexto do fenômeno de "barateamento" dos cursos de Arquitetura e Urbanismo.

Existem matérias do Currículo que não devem ter seus conteúdos ministrados sem que se propiciem práticas experimentais aos estudantes. Esta necessidade está estreitamente relacionada com as próprias habilidades que devem ser desenvolvidas no curso. Os cursos de Arquitetura e Urbanismo, embora possam genericamente compartilhar certos espaços com outros cursos, necessitam de espaços qualificados, de uso exclusivo, a fim de que os estudantes possam desenvolver seus trabalhos de concepção, sem a interferência de atividades adversas ao curso. Dentre estes espaços está o Atelier (Sala) de Projetos, que não pode ser aceito como resumindo-se a uma sala com pranchetas de desenho, mas que deve ser um espaço de domínio do estudante, onde os temas em andamento possam ser objeto de exposição, de apresentação e de discussão de casos. Um espaço que proporcione estas condições não pode ser compartilhado por outros cursos (BRASIL, 1996, p. 7).

Posteriormente, a Resolução $\mathrm{n}^{\circ} 06$ estabelecida pelo Conselho Nacional de Educação, Câmara de Educação Superior do Ministério da Educação - CNE/CES, em 02 de fevereiro de 2006, instituiu as Diretrizes Curriculares Nacionais do curso de graduação em Arquitetura e Urbanismo trazendo novos aspectos como resultado de

\footnotetext{
${ }^{41}$ PERFIS da área e padrões de qualidade: expansão, reconhecimento e verificação periódica dos cursos de arquitetura e urbanismo. Disponível em: http://portal.mec.gov.br/sesu/arquivos/pdf/ar_geral.pdf. Acesso em: 05 mar. 2017.
} 
um amplo debate e formulação de propostas consolidadas pelo Grupo de Trabalho de Ensino de Arquitetura e Urbanismo do CONFEA, protocoladas no MEC, mas também como contraponto à iniciativa da UNESCO/UIA (United Nations Educational, Scientific and Cultural Organization / International Union of Architects), no contexto internacional na formulação da Charter for Architectural Education em 2004/2005, em revisão à versão anterior de 1996.

Da Resolução n 06/2006 CNE/CES, ainda hoje vigente tendo sofrido apenas uma pequena alteração quanto ao Trabalho Final de Graduação em 2010, entendo que cabe destacar alguns pontos de especial interesse para a presente investigação os quais relato a seguir:

No que diz respeito à concepção do projeto pedagógico do curso de Arquitetura e Urbanismo institui-se que seu currículo pleno deverá contemplar, sem prejuízo de outros aspectos: formas de realização da interdisciplinaridade e modos de integração entre teoria e prática.

Quanto às competências e habilidades do futuro arquiteto e urbanista, o curso deverá possibilitar as habilidades necessárias para conceber projetos de arquitetura, urbanismo e paisagismo e para realizar construções; conhecimentos especializados para o emprego adequado e econômico dos materiais de construção e das técnicas e sistemas construtivos; compreensão dos sistemas estruturais e o domínio da concepção e do projeto estrutural.

Quanto aos conteúdos curriculares referentes ao núcleo de conhecimentos profissionais, sugerem-se métodos para a aplicação dos mesmos, através de aulas teóricas complementadas por conferências e palestras, produção em atelier, experimentação em laboratórios, elaboração de modelos, utilização de computadores, viagens de estudos, visitas a canteiros de obras, levantamento de campo, projetos de pesquisa e de extensão, escritórios-modelo, participação em atividades extracurriculares como encontros, exposições, concursos, entre outros (BRASIL, 2006, grifo nosso). 
Frente a todas as reflexões capitaneadas pela SESU/MEC e ABEA nas últimas décadas, as necessidades diagnosticadas promoveram a constante atualização das exigências legais pertinentes ao ensino e ao exercício profissional. Entretanto, recentemente há um novo cenário com significativas transformações econômicas, políticas, culturais, ambientais, tecnológicas que implicam em mudanças na prática profissional, bem como produzem impacto na prática acadêmica. A ABEA mais uma vez sinalizou apreensão ao apresentar a publicação comemorativa dos 40 anos da entidade que registrou a sua participação, desde a sua fundação em 1973, nos fatos que marcaram o ensino de Arquitetura e Urbanismo no país:

\footnotetext{
A acentuada expansão de cursos e de vagas segue cada vez mais forte como política governamental sem que o correspondente sistema de controle preconizado pela LDB e hoje sob responsabilidade quase total do INEP/MEC venha conseguindo acompanhá-la. A ausência, morosidade ou fragilidade no controle das condições de abertura e de oferta de cursos, nos processos regulatórios de autorização, reconhecimento e sua renovação vem pondo em risco todo o trabalho de construção da excelência do ensino buscado pela nossa entidade (GUTIERREZ, 2013, p. 13).
}

A política expansionista adotada pelo MEC nos anos 90, de incentivo à abertura de novos cursos, notadamente no ensino privado, permitiu que dos 72 cursos existentes no país em 1994, chegássemos ao início de 2009 - quinze anos depois - com mais de 200 cursos na área de Arquitetura e Urbanismo (SCHLEE, 2010).

O mapeamento das instituições de ensino em Arquitetura e Urbanismo no Brasil foi feito ao início da pesquisa documental através do site do Ministério de Educação (Sistema e-MEC) e do site da Associação Brasileira de Ensino de Arquitetura e Urbanismo com o intuito de levantar o número de cursos de existentes no país e analisar o cenário atual de instituições por região. Segundo a ABEA foram constatados 466 cursos de AU em todo o Brasil - dados de dezembro de 2015 - sendo que de acordo com o levantamento feito através do e-MEC - em maio de 2016 - foram contabilizados um total de 500 cursos dos quais 60 eram oferecidos por instituições públicas e 440 por instituições privadas. 
Adotando-se como fonte mais atualizada o Sistema e-MEC, os dados foram organizados em Instituições de Ensino Superior Públicas (PU) e Privadas (PR) por estados e regiões e são apresentados a seguir no Quadro 1 e no Gráfico 1. 
Quadro 1 - Número de cursos de AU por estados e regiões do Brasil em IES públicas e privadas

\begin{tabular}{|c|c|c|c|c|}
\hline REGIÃO & ESTADO & PU & PR & TOTAL \\
\hline \multirow{7}{*}{ NORTE } & ACRE-AC & 0 & 2 & 2 \\
\hline & AMAZONAS-AM & 1 & 6 & 7 \\
\hline & AMAPÁ-AP & 1 & 2 & 3 \\
\hline & PARÁ-PA & 1 & 4 & 5 \\
\hline & RONDÔNIA-RO & 0 & 7 & 7 \\
\hline & RORAIMA-RR & 1 & 0 & 1 \\
\hline & TOCANTINS-TO & 1 & 2 & 3 \\
\hline \multirow{2}{*}{\multicolumn{2}{|c|}{ TOTAL NORTE }} & 5 & 23 & 28 \\
\hline & & $18 \%$ & $82 \%$ & $6 \%$ \\
\hline \multirow{9}{*}{ NORDESTE } & ALAGOAS-AL & 2 & 5 & 7 \\
\hline & BAHIA-BA & 3 & 14 & 17 \\
\hline & CEARÁ-CE & 1 & 12 & 13 \\
\hline & \begin{tabular}{|l|} 
MARANHÃO-MA \\
\end{tabular} & 1 & 4 & 5 \\
\hline & PARAÍBA-PB & 2 & 7 & 9 \\
\hline & PERNAMBUCO-PE & 1 & 8 & 9 \\
\hline & PIAUÍ-PI & 1 & 4 & 5 \\
\hline & RIO GRANDE DO NORTE-RN & 2 & 6 & 8 \\
\hline & SERGIPE-SE & 1 & 2 & 3 \\
\hline \multirow{2}{*}{\multicolumn{2}{|c|}{ TOTAL NORDESTE }} & 14 & 62 & 76 \\
\hline & & $18 \%$ & $82 \%$ & $15 \%$ \\
\hline \multirow{4}{*}{$\begin{array}{l}\text { CENTRO- } \\
\text { OESTE }\end{array}$} & DISTRITO FEDERAL-DF & 2 & 13 & 15 \\
\hline & GOIÁS-GO & 3 & 9 & 12 \\
\hline & \begin{tabular}{|l|l} 
MATO GROSSO DO SUL-MS \\
\end{tabular} & 2 & 5 & 7 \\
\hline & MATO GROSSO-MT & 2 & 6 & 8 \\
\hline \multirow{2}{*}{\multicolumn{2}{|c|}{ TOTAL CENTRO-OESTE }} & 9 & 33 & 42 \\
\hline & & $21 \%$ & $79 \%$ & $8 \%$ \\
\hline \multirow{4}{*}{ SUDESTE } & ESPÍRITO SANTO-ES & 2 & 14 & 16 \\
\hline & MINAS GERAIS-MG & 7 & 47 & 54 \\
\hline & RIO DE JANEIRO-RJ & 4 & 28 & 32 \\
\hline & SÃO PAULO-SP & 6 & 133 & 139 \\
\hline \multirow{2}{*}{\multicolumn{2}{|c|}{ TOTAL SUDESTE }} & 19 & 222 & 241 \\
\hline & & $8 \%$ & $92 \%$ & $48 \%$ \\
\hline \multirow{3}{*}{ SUL } & PARANÁ-PR & 5 & 33 & 38 \\
\hline & RIO GRANDE DO SUL-RS & 6 & 32 & 38 \\
\hline & SANTA CATARINA-SC & 2 & 35 & 37 \\
\hline \multirow{2}{*}{\multicolumn{2}{|c|}{ TOTAL SUL }} & 13 & 100 & 113 \\
\hline & & $12 \%$ & $88 \%$ & $23 \%$ \\
\hline \multirow{2}{*}{\multicolumn{2}{|c|}{ BRASIL }} & 60 & 440 & 500 \\
\hline & & $12 \%$ & $88 \%$ & $100 \%$ \\
\hline
\end{tabular}

Fonte: Ministério da Educação - Sistema e-MEC, 2016. Disponível em: http://emec.mec.gov.br/. Acesso em 11 mai. 2016, elaborado pela autora. 
Gráfico 1 - Número de cursos de AU no Brasil por região

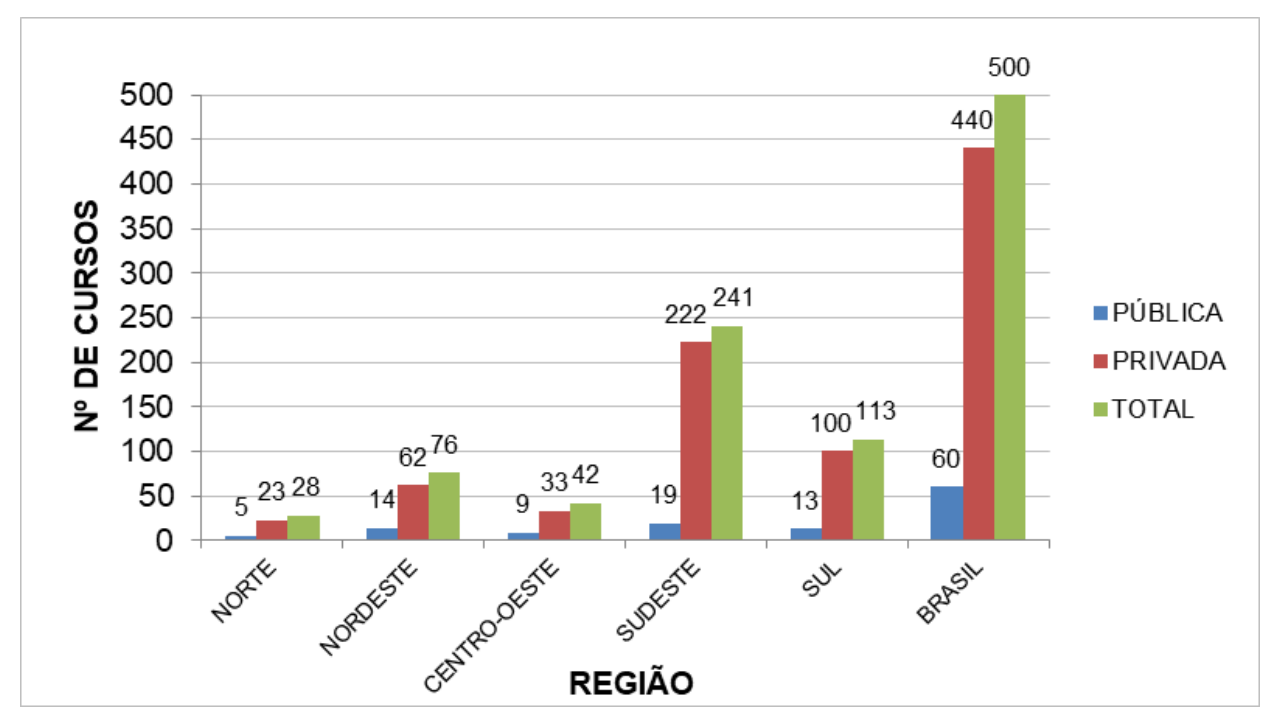

Fonte: Sistema e-MEC, 2016. Disponível em: http://emec.mec.gov.br/. Acesso em 11 mai. 2016, elaborado pela autora.

O levantamento evidenciou o grande número de cursos de arquitetura distribuídos em todo território nacional e especialmente o crescimento exponencial no número de instituições privadas na última década, concentrando-se na região Sudeste e Sul. Os números foram contrastados com dados de anos anteriores publicados pela CEAU, ABEA e INEP e são apresentados no Gráfico 2.

Gráfico 2 - Crescimento do número de cursos de AU no Brasil por região

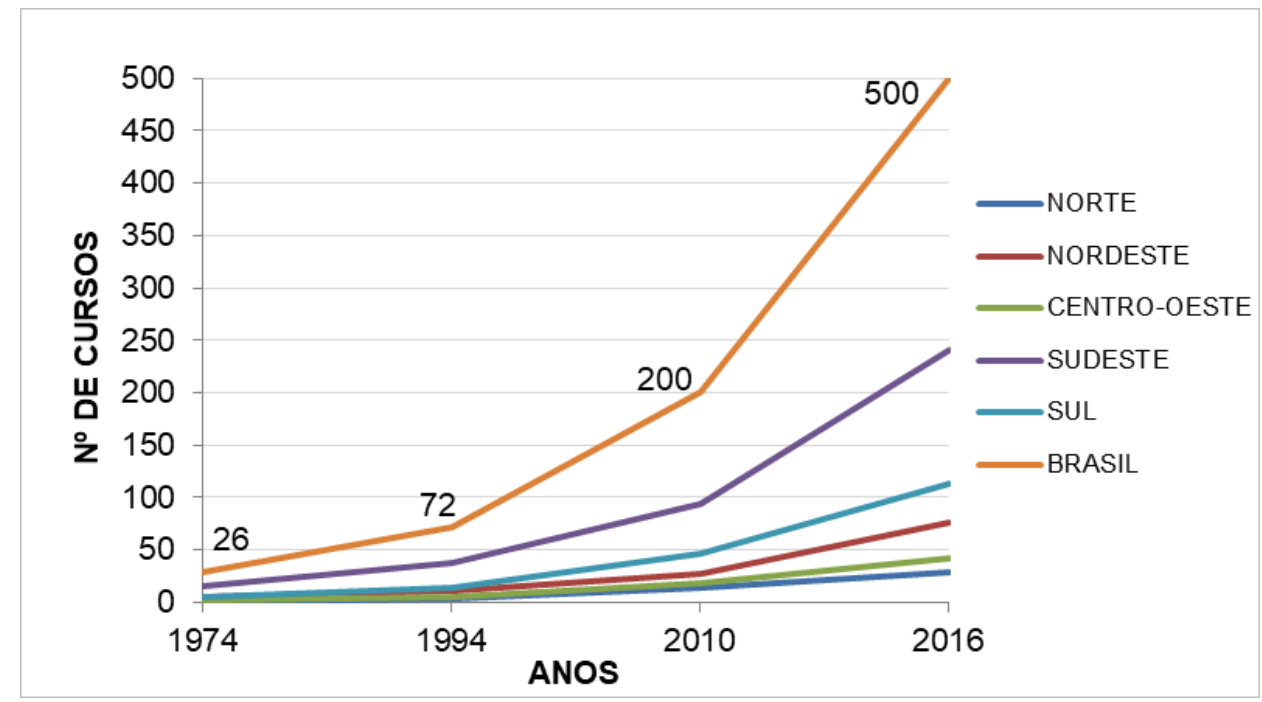

Fonte: ABEA, 2013; INEP, 2010, elaborado pela autora. 
Com o intuito de analisar o grande aumento na oferta de cursos, especialmente nas regiões Sudeste e Sul, foram levantados dados populacionais por estado e comparados com o número de cursos a fim de verificar se existe uma correlação direta entre estes. Da mesma forma, também foram levantados e comparados dados sobre o rendimento nominal mensal domiciliar per capita.

O Quadro 2 mostra estes dados organizados por estados e regiões. Referem-se à população estimada em número de pessoas no ano de 2016 - mesmo ano do levantamento de cursos apresentado no Quadro 1 - com base na projeção da população feita pelo Instituto Brasileiro de Geografia e Estatística - IBGE, a partir dos dados do último Censo de 2010. Apresenta também valores médios de rendimento per capita em reais, referentes ao ano de 2017 - disponíveis no momento da consulta realizada em março de 2018.

O Gráfico 3 relaciona o número de cursos apresentados anteriormente com os dados populacionais de cada estado brasileiro em milhões de pessoas, a partir da projeção da população estimada pelo IBGE. Já o Gráfico 4 relaciona o número de cursos com a renda per capita por estado, em centenas de reais. As unidades foram definidas para obter uma melhor visualização gráfica dos resultados, buscando correlaciona-los de forma direta e visual.

Por um lado, observa-se uma maior concentração de habitantes nos estados de São Paulo, Minas Gerais e Rio de Janeiro, na região Sudeste do país, e por outro, maiores valores de renda per capita, de uma maneira geral, nos estados da região Sul, Sudeste e Centro-Oeste, e especialmente no Distrito Federal.

A análise gráfica expõe uma provável correlação entre o número de cursos e os dados populacionais retratados, bem como com os dados de renda per capita para as regiões Norte, Nordeste e Centro-Oeste, entretanto, evidencia uma distante correlação dos dados para as regiões Sudeste e Sul. Nota-se uma exacerbada oferta de cursos nestas duas regiões que, apesar de relacionar-se a um maior contingente populacional (Gráfico 3), não corresponde proporcionalmente a este, e ainda menos quando confrontada à renda per capita (Gráfico 4). 
Quadro 2 - Dados populacionais e de renda per capita por estados e regiões do Brasil

\begin{tabular}{|c|c|c|c|}
\hline \multicolumn{4}{|c|}{$\begin{array}{l}\text { POPULAÇÃO ESTIMADA POR ESTADOS E REGIÕES DO BRASIL (2016) } \\
\text { RENDIMENTO NOMINAL MENSAL DOMICILIAR PER CAPITA (2017) }\end{array}$} \\
\hline REGIÃO & ESTADO & $\begin{array}{c}\text { POPUL } \\
\text { (milhões) }\end{array}$ & $\begin{array}{l}\text { REND } \\
\text { (Reais) }\end{array}$ \\
\hline \multirow{7}{*}{ NORTE } & $\mathrm{AC}$ & 844.137 & 769 \\
\hline & AM & 3.952 .171 & 850 \\
\hline & AP & 796.419 & 936 \\
\hline & PA & 8.334 .346 & 715 \\
\hline & $\mathrm{RO}$ & 1.717 .911 & 957 \\
\hline & $\mathrm{RR}$ & 525.967 & 1.006 \\
\hline & TO & 1.520 .448 & 937 \\
\hline \multirow{2}{*}{\multicolumn{2}{|c|}{ TOTAL/MÉDIA NORTE }} & 17.691 .399 & 936 \\
\hline & & $8,62 \%$ & \\
\hline \multirow{9}{*}{ NORDESTE } & $\mathrm{AL}$ & 3.293 .629 & 658 \\
\hline & BA & 14.689.684 & 862 \\
\hline & $\mathrm{CE}$ & 8.962 .834 & 824 \\
\hline & MA & 6.955 .099 & 597 \\
\hline & PB & 3.953 .693 & 928 \\
\hline & $\mathrm{PE}$ & 9.377 .368 & 852 \\
\hline & $\mathrm{PI}$ & 3.246 .228 & 750 \\
\hline & RN & 3.422 .843 & 845 \\
\hline & SE & 2.237 .132 & 834 \\
\hline \multirow{2}{*}{\multicolumn{2}{|c|}{ TOTAL/MÉDIA NORDESTE }} & 56.138 .510 & 834 \\
\hline & & $27,36 \%$ & \\
\hline \multirow{4}{*}{ CENTRO-OESTE } & DF & 2.890 .224 & 2.548 \\
\hline & GO & 6.726 .130 & 1.277 \\
\hline & MS & 2.685 .454 & 1.291 \\
\hline & MT & 3.356 .979 & 1.247 \\
\hline \multirow{2}{*}{\multicolumn{2}{|c|}{ TOTAL/MÉDIA CENTRO-OESTE }} & 15.658 .787 & 1.284 \\
\hline & & $7,63 \%$ & \\
\hline \multirow{4}{*}{ SUDESTE } & ES & 3.879 .376 & 1.205 \\
\hline & MG & 20.780 .264 & 1.224 \\
\hline & $\mathrm{RJ}$ & 16.947 .738 & 1.445 \\
\hline & SP & 44.760 .305 & 1.712 \\
\hline \multirow{2}{*}{\multicolumn{2}{|c|}{ TOTAL/MÉDIA SUDESTE }} & 86.367 .683 & 1.335 \\
\hline & & $42,10 \%$ & \\
\hline \multirow{3}{*}{ SUL } & PR & 11.176 .203 & 1.472 \\
\hline & RS & 11.229 .947 & 1.635 \\
\hline & SC & 6.894 .058 & 1.597 \\
\hline \multirow{2}{*}{\multicolumn{2}{|c|}{ TOTAL/MÉDIA SUL }} & 29.300 .208 & 1.597 \\
\hline & & $14,28 \%$ & \\
\hline \multirow{2}{*}{\multicolumn{2}{|c|}{ BRASIL }} & 205.156.587 & 937 \\
\hline & & $100 \%$ & \\
\hline
\end{tabular}

Fonte: IBGE, 2016; 2017. Disponível em: https://cidades.ibge.gov.br/. Acesso em 15 mar. 2018, elaborado pela autora. 
Gráfico 3 - Quantidade de cursos de AU e população por estado no ano de 2016

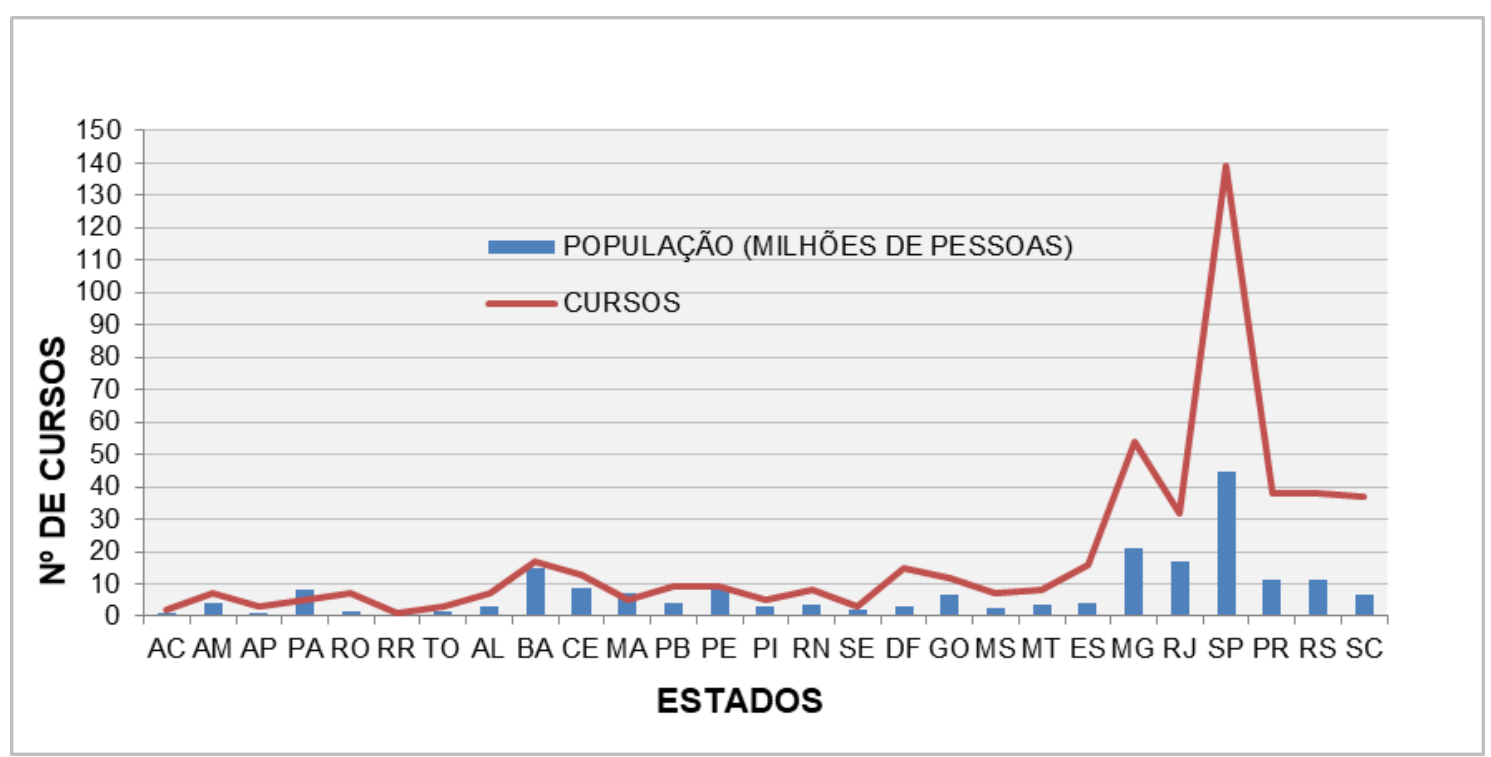

Fonte: Ministério da Educação - Sistema e-MEC ${ }^{42}, 2016$; IBGE ${ }^{43}$, 2016, elaborado pela autora.

Gráfico 4 - Quantidade de cursos de AU e renda per capita por estado nos anos de 2016 e 2017

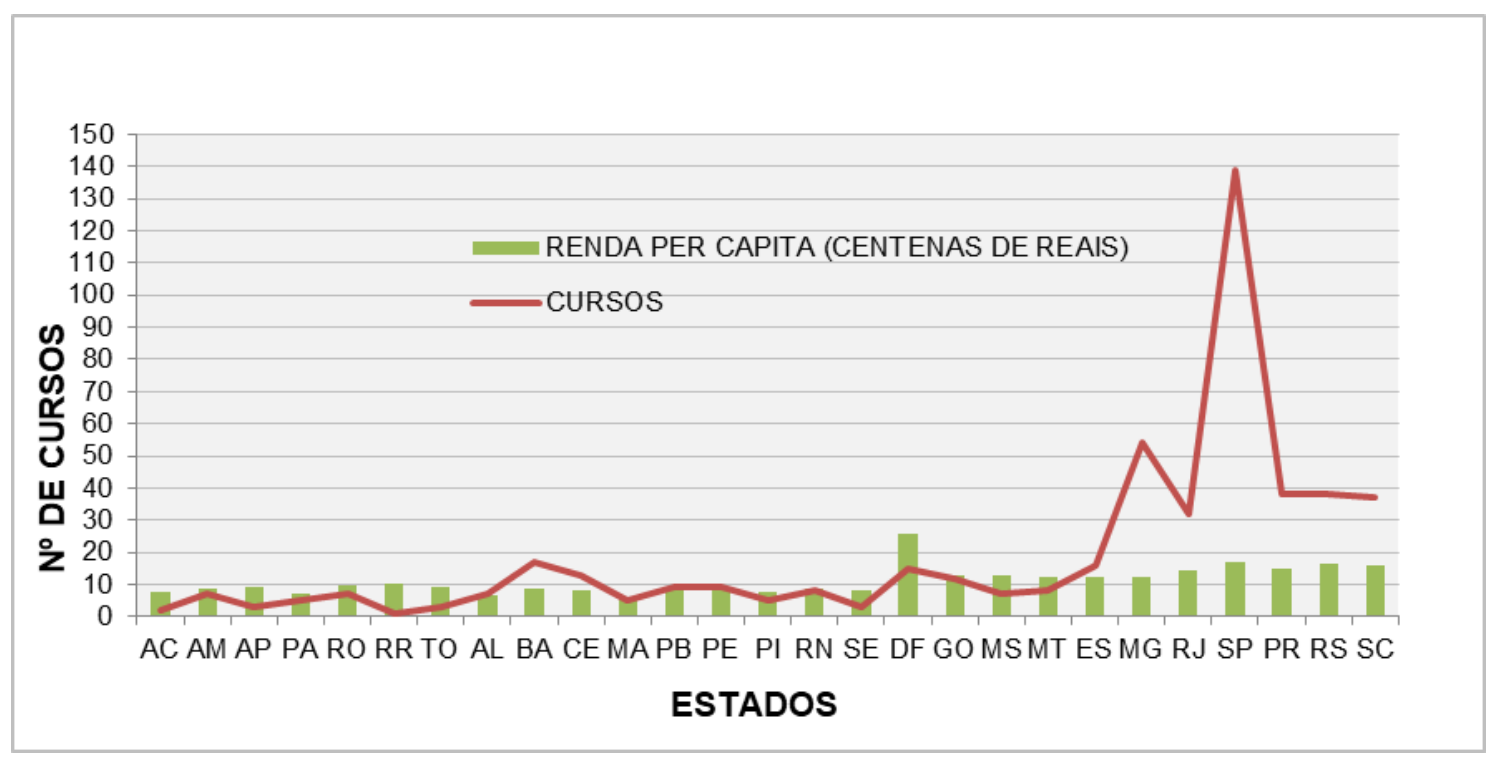

Fonte: Ministério da Educação - Sistema e-MEC ${ }^{44}, 2016$; IBGE ${ }^{45}$, 2017, elaborado pela autora.

\footnotetext{
42 Disponível em: http://emec.mec.gov.br/. Acesso em 11 mai. 2016, elaborado pela autora.

43 Disponível em: https://cidades.ibge.gov.br/. Acesso em 15 mar. 2018, elaborado pela autora.

${ }^{44}$ Disponível em: http://emec.mec.gov.br/. Acesso em 11 mai. 2016, elaborado pela autora.

45 Disponível em: https://cidades.ibge.gov.br/. Acesso em 15 mar. 2018, elaborado pela autora.
} 
Os números de cursos abertos nas últimas décadas são realmente alarmantes e não param de aumentar. Quando da finalização da escrita deste capítulo, em nova consulta ao Sistema e-MEC, o número total de cursos cadastrados "em atividade" no país havia subido de 500 para quase 750, em pouco mais de dois anos após o levantamento realizado inicialmente. Somente no estado de São Paulo existem atualmente ao redor de 32 mil vagas em aproximadamente 150 cursos oferecidos por IES privadas - e outras 4.500 vagas autorizadas em 25 novos cursos não iniciados contra 350 vagas em seis IES públicas.

Diante destes números surgem muitas dúvidas: neste ritmo, aonde vamos parar? Há demanda por tantas vagas? Quais critérios estão sendo utilizados pelo MEC para a autorização de abertura de novos cursos? De fato, estas não são perguntas de pesquisa as quais procuraremos responder, mas perguntas que nascem de minha indignação enquanto docente de uma Instituição de Ensino Superior privada, estabelecida há mais de duas décadas como referência na região de Campinas-SP, na qual presencio nos últimos anos a paulatina diminuição no número de alunos ingressantes no curso de arquitetura oferecido em período integral.

O que se verifica é uma alta oferta de cursos noturnos em diversas faculdades desta região do interior de São Paulo, com grades curriculares cada vez mais enxutas, limitadas a carga horária mínima exigida pelo MEC, e mensalidades cada vez mais econômicas. Ainda assim, há em geral uma baixa ocupação das vagas, o que muitas vezes acarreta no não oferecimento de novas turmas evidenciando uma oferta maior do que a demanda real. É evidente que o crescimento exponencial do número de cursos deriva da lógica do ensino como produto mercadológico. Porém, esse fato tem causado grande impacto no mercado educacional. 


\section{REFERÊNCIAS}

BRASIL. Ministério da Educação. Secretaria de Educação Superior. Comissão de Especialistas de Ensino de Arquitetura e Urbanismo. Perfis da Área \& Padrões de Qualidade: Expansão, Reconhecimento e Verificação Periódica dos Cursos de Arquitetura e Urbanismo. Brasília, 1996. Disponível em:

http://portal.mec.gov.br/sesu/arquivos/pdf/ar_geral.pdf. Acesso em: 05 mar. 2017.

. Portaria no 1.770, 21 de dezembro de 1994. Fixa Diretrizes Curriculares e Conteúdos Mínimos para os Cursos de Graduação em Arquitetura e Urbanismo. Diário Oficial da União, Brasília, DF, 23 dez. 1994.

. Resolução n 06, 02 de fevereiro de 2006. Institui as Diretrizes Curriculares Nacionais do Curso de Graduação em Arquitetura e Urbanismo e dá outras providências. Diário Oficial da União, Brasília, DF, 03 fev. 2006, Seção 1, p. 6.

Lei $n^{\circ}$ 12.378, de 31 de dezembro de 2010. Regulamenta o exercício da Arquitetura e Urbanismo; cria o Conselho de Arquitetura e Urbanismo do Brasil CAU/BR e os Conselhos de Arquitetura e Urbanismo dos Estados e do Distrito Federal CAUs; e dá outras providências. Diário Oficial da União, Brasília, DF, 31 dez. 2010.

CONTIER, L. Ameaça à educação dos arquitetos. Conselho de Arquitetura e urbanismo do Brasil, 15 de fev. 2017. Disponível em: http://www.caubr.gov.br/ameaca-aeducacao-dos-arquitetos/. Acesso em: 05 mar. 2017.

\section{GUTIERREZ, E. J. B. (org.) A construção de um novo olhar sobre o ensino de} arquitetura e urbanismo no Brasil: os 40 anos da Associação Brasileira de Ensino de Arquitetura e Urbanismo. Brasília: ABEA, 2013.

SANTOS JÚNIOR, W. R. dos. A ABEA e a conquista das Diretrizes Curriculares nacionais para os cursos de Arquitetura e Urbanismo em 1994: uma inflexão inovadora no ensino de Arquitetura e Urbanismo no Brasil (1985 - 1994/95). In: GUTIERREZ, E. J. B. (org.) A construção de um novo olhar sobre o ensino de Arquitetura e Urbanismo no Brasil: os 40 anos da Associação Brasileira de Ensino de Arquitetura e Urbanismo. Brasília: ABEA, 2013. p. 60-91.

SCHLEE A. R. (org.). Trajetória e estado da arte da formação em Engenharia, Arquitetura e Agronomia - Volume X: Arquitetura e Urbanismo. Brasília: INEP/CONFEA. 2010. 


\subsection{A inserção da tecnologia e da experimentação prática no currículo dos cursos} de AU brasileiros

Dado que no Brasil o diploma universitário de arquiteto e urbanista uma vez referendado pelo registro no Conselho Profissional, Ihe aufere a condição de exercício profissional da categoria, faz-se indispensável o questionamento sobre a qualidade do ensino vigente em território nacional, especialmente em decorrência da rápida expansão e do aumento expressivo das Instituições de Ensino relatado no capítulo anterior, sem que houvesse sequer uma distribuição territorial planejada ou que se contemplasse a avaliação das respectivas e reais demandas de serviços profissionais. Tal afirmação é referendada em manifestação pública do CAU/BR, na qual se expõe “preocupação e discordância com a improcedente e perigosa oferta de cursos de graduação na modalidade Educação à Distância (EAD)" (QUEIROZ, 2017) ${ }^{46}$.

Ou seja, além da descontrolada expansão também há a oferta de cursos não presenciais. O posicionamento do CAU/BR veio reiterar a manifestação feita em carta pela ABEA em defesa dos princípios contidos no documento Perfis \& Padrões de Qualidade - CEAU/SESU/MEC. A preocupação expressa em ambos documentos não fazem referência exclusiva ao ensino $E A D$, mas às condições gerais dos cursos presenciais marcadas por um quadro de crise do ensino e pelo sucateamento das Instituições de Ensino Superior, fazendo menção à "grande redução de carga horária em sala de aula, precarização das relações pedagógicas que são estabelecidas entre a teoria e a prática, e das condições de trabalho dos docentes", fatos que têm se traduzido em grandes prejuízos e um sério comprometimento da qualidade para a formação profissional, segundo o próprio Conselho.

Em Arquitetura e Urbanismo, o espaço físico adequado é parte do processo de ensino e favorece o aprendizado. Se dar sentido a espaços (físicos e reais) é o dever de ofício, como fazê-lo na virtualidade? Como

${ }^{46}$ MANIFESTAÇÃO DO PLENÁRIO DO CONSELHO DE ARQUITETURA E URBANISMO DO BRASIL SOBRE ENSINO A DISTÂNCIA EM ARQUITETURA E URBANISMO, assinada por Haroldo Pinheiro Villar de Queiroz, presidente do CAU/BR, na data de 16 de fevereiro de 2017. Disponível em: http://www.caubr.gov.br/caubr-publicamanifestacao-sobre-ensino-a-distancia-em-arquitetura-e-urbanismo/. Acesso em: 05 mar. 2017. 
aceitar que a relação professor/aluno presencial não seja importante, que a virtualidade basta? Qual seria o sentido da construção física, real e material dos espaços?

A ABEA [...] enfatiza a qualificação das condições físicas e espaciais dos ateliês e salas de aulas dos cursos de Arquitetura e Urbanismo. São espaços específicos, mas plurais, que permitem o exercício de diferentes formas de linguagem, expressão, práticas, pesquisa, concepção e desenvolvimento que fomentam o processo criativo. O Ateliê de Arquitetura e Urbanismo é o espaço facilitador da construção coletiva do conhecimento, é o espaço que permite a integração professor/aluno e aluno/aluno.

Não podemos confundir a percepção sobre o âmbito disciplinar (dos componentes curriculares) e a evolução necessária entre a fundamentação e a consolidação de habilidades e técnicas projetuais (ARRUDA, 2017, sem paginação) ${ }^{47}$.

Entre as atribuições dos arquitetos e urbanistas definidas por lei, está a direção de obras e de serviço técnico, bem como a execução, fiscalização e condução de obra, instalação e serviço técnico. A atividade da construção é atribuição direta da profissão. O arquiteto precisa não só conceber o projeto, mas também a construção do seu objeto. Isto é, "deve estar implícito no projeto como se constrói esse objeto". Esta é a percepção do arquiteto Lelé, que ao ser indagado em entrevista sobre a responsabilidade do arquiteto no atraso da construção civil brasileira, responde:

O arquiteto é muito responsável porque está abrindo mão, gradualmente, da sua função de construtor. Para mim, o arquiteto é basicamente um construtor. E com isso não quero dizer que ele vai pegar a colher de pedreiro para assentar massa. O arquiteto precisa conceber a construção do seu objeto, que precisa ficar em pé. Deve estar implícito no projeto como se constrói esse objeto. Agora, se o arquiteto está abrindo mão dessa sua prerrogativa básica para se tornar especialista em fazer fachada, fazer desenhos, isso é um problema nosso, profissional. Não adianta discutir sustentabilidade da construção se não queremos trabalhar. Isso é negligência do trabalho. É preciso enfrentar o problema da construção. A universidade deve reforçar a consciência de que o arquiteto é o responsável pela construção (LIMA entrevistado por MENDONÇA, 2007) ${ }^{48}$.

${ }^{47}$ Carta da ABEA Contra o Ensino a Distância para Graduação em Arquitetura e Urbanismo. APRENDER ARQUITETURA E URBANISMO À DISTÂNCIA NÃO FUNCIONA, publicada em 26 de janeiro de 2017 e assinada por Andrea Lúcia Vilella Arruda, então presidente da ABEA. Disponível em: http://www.abea.org.br/?p=2052. Acesso em: 05 mar. 2017.

48 João Filgueiras Lima (Lelé), em entrevista realizada por Adriano Carneiro de Mendonça, em Salvador em 18 de janeiro de 2007. Disponível em: http://entre-entre.com/Content/entrevistas/pdf/entre-lele-

20160330175704.pdf. Acesso em: 22 nov. 2018. 
De que forma, então, poderia a formação do arquiteto desvincular-se do físico e do material? Como a Educação à Distância poderia dar conta da complexidade que envolve a materialidade? Como o ensino não presencial poderia suprir a necessidade da experiência prática com materiais e ferramentas que permitem o conhecimento do processo da construção?

O distanciamento cada vez maior dos estudantes, e consequentemente dos profissionais arquitetos, dos conteúdos próprios das ciências da construção tem promovido lacunas irremediáveis na sua formação tecnológica. Como vimos, essa precariedade remonta em grande parte à história do ensino de arquitetura.

Em âmbito nacional, vários autores se dedicaram a desenvolver pesquisas acadêmicas sobre a formação tecnológica do arquiteto. Da mesma forma, a questão dos processos experimentais na concepção do projeto de arquitetura e no desenvolvimento de inovações tecnológicas ${ }^{49}$, bem como da prática experimental no ensino de arquitetura no Brasil, foram discutidas em diversas publicações. Rebello (1993; 1999), Graeff (1995), Lopes (1999; 2014), Leite (1998; 2005), Ronconi (2002; 2005), Pompéia (2006), Minto (2008; 2009), Anelli (2009), Saramago (2011), Lotufo (2008; 2014) e Laverde (2017), são algumas das referências investigadas.

Lopes (2014, p. 3) afirma que se nos dedicarmos a um levantamento aprofundado dos conteúdos ministrados nos cursos de arquitetura oferecidos no país, será possível verificar que "diversos aspectos relativos ao conhecimento tecnológico da arquitetura e urbanismo vêm sendo sistematicamente negligenciados, encolhidos ou até mesmo deliberadamente suprimidos". Em uma escala temporal mais ampliada, o professor João Marcos cita que Vilanova Artigas já identificava as insuficiências na formação de "quadros nacionais capazes de cumprir as missões técnicas que o país exigia" (ABEA, 1977, p. 31 apud LOPES, 2014, p. 3) ${ }^{50}$.

${ }^{49}$ Entende-se que "um novo produto, método, processo ou sistema construtivo introduzido no mercado, constitui-se em uma INOVAÇÃO TECNOLÓGICA na construção de edifícios quando incorporar uma nova ideia e representar um sensível avanço na tecnologia existente em termos de: desempenho, qualidade ou custo do edifício, ou de uma sua parte" (SABBATINI, 1989, p. 51).

50 O arquiteto e professor João Batista Vilanova Artigas, em contribuição para o Relatório sobre Ensino de Arquitetura para a UIA-UNESCO de 1974, comenta a disparidade entre os cursos da Escola Politécnica e a 
Para Leite (2005, p. 3) "a concepção global da obra arquitetônica e urbanística implica a resolução integrada de determinadas questões tecnológicas que, mesmo progressivamente compartilhadas com outras áreas profissionais, são de responsabilidade precípua da categoria" ${ }^{51}$.

$\mathrm{Na}$ opinião do arquiteto Siegbert Zanettini (2002), a cisão entre o ensino de arquitetura e o de engenharia no Brasil, a partir da década de 1940, trouxe sérias consequências na formação profissional:

De um lado, o curso de engenharia, predominantemente quantitativo e verificador, onde o aluno recebe uma formação castrativa a qualquer atitude inovadora, o que o impede de conceber e criar [...].

Do outro lado, o curso de arquitetura, constituído apenas com as páginas pares dos textos de engenharia, que esconde do aluno a matéria a ser trabalhada e o mantém distante da execução da obra.

[...] Faz-se necessário um curso que coloque o aluno em contato direto com o fenômeno e com a qualidade de uma solução estrutural como preocupação anterior à sua quantificação. É fundamental, então, retomar a unicidade de uma formação holística que possibilite a esses profissionais uma visão de mundo abrangente, estruturada, e sistematizada pelas ciências humanas, exatas, ambientais e biológicas, e pelas contínuas aberturas do mundo sensível da invenção, da ousadia, da paixão e do sonho responsável pela criação e pelas ideias. Que dê a este novo aluno novas ferramentas compatíveis com os novos desafios deste século que se inicia [...] (ZANETTINI, 2002, p. 443).

Daí resultou uma visão equivocada do ofício do arquiteto e do engenheiro, que foi se transformando ao longo da história, mas que fundamentalmente mantém essa dialética até os dias atuais. Ainda que seja reconhecidamente desejável, o entrelaçamento entre as duas profissões não é favorecida pelo modelo de formação acadêmica praticado nas duas áreas. O engenheiro e professor de sistemas estruturais em cursos de Engenharia e Arquitetura Yopanan Rebello, conta que na época de sua

Academia de Belas Artes do Rio de Janeiro, já nas nascentes do ofício: "naquela o curso não é completado com a precisa instrução prática, e nesta subsiste a ausência radical e mais completa de certos conhecimentos científicos, atualmente indispensáveis ao engenheiro-arquiteto, em consequência da diversidade de elementos, que a arte moderna aplica às construções" (ABEA, 1977, p. $31 / 32$ apud LOPES, 2014, p. 4).

${ }^{51}$ As questões a que a autora se refere são: as metodologias de produção tecnológica; a matematização de problemas técnicos; a organização de processos produtivos; o controle do ambiente, em macro e micro dimensões; a sustentação da forma arquitetônica; os insumos funcionais e a economia da construção. 
formação, "não havia absolutamente nenhuma discussão se existia alguma coisa entre Arquitetura e Estrutura".

Eram coisas muito separadas e que, de vez em quando, elas se juntavam assim, mas só para resolver determinado problema. Ou seja, a gente via um projeto de arquitetura sem saber por que ele era assim, sem discutir alternativas, inclusive de projeto, para melhorar a estrutura ou vice-versa (REBELLO entrevistado por SARAMAGO, 2011, p. 213).

Autor de diversos livros que versam sobre o projeto estrutural na Arquitetura, Rebello analisa a falta da concepção estrutural na formação dos engenheiros e arquitetos. Enfatiza a importância da experimentação construtiva feita em canteiro, em paralelo ao uso de modelos, como forma efetiva de motivação para o aprendizado. Defende ainda, que para que se obtenham bons resultados de aprendizagem é necessário correlacionar os conteúdos ensinados a questões da realidade, claramente identificadas pelo aluno.

Também entrevistado por Rita Saramago, o engenheiro civil e professor Adolpho Polillo, propõe estimular o sentimento estrutural do aluno através de uma metodologia de ensino que adote o uso de modelagens e experimentações, com a construção de maquetes físicas dos diversos sistemas estruturais.

Sobre o emprego de métodos empíricos, o engenheiro justifica sua validade pelo fato de promoverem uma ação ativa do estudante na construção do conhecimento, permitindo, além do desenvolvimento de sua capacidade motora, também de sua criatividade (SARAMAGO, 2011, p. 80).

Sobre os saberes tecnológicos necessários ao arquiteto, Graeff (1995) sugere:

O traço distintivo dos sistemas estruturais arquitetônicos reside no seu compromisso original com a formação do ambiente que há de caracterizar o abrigo das atividades humanas. Em outras palavras, para assegurar a qualidade arquitetônica é mais importante a adequação da estrutura ao ambiente e deste às atividades que ele vai envolver e abrigar, do que o correto equacionamento das cargas, do trabalho dos materiais e das resistências dos elementos estruturais.

É necessário e urgente, decerto, alcançar o rigoroso equilíbrio entre as cargas, as resistências e os apoios que garantem a estabilidade da formal estrutura - mas o importante, tratando-se de arquitetura, é fazer com que 
essa forma contribua para a indispensável adequação do ambiente às atividades humanas que ele deve favorecer.

Isso significa que a estrutura arquitetônica, além e acima dos compromissos técnicos com a estabilidade da construção, compromissos de caráter estático, por assim dizer, tem um compromisso maior, de caráter psicológico e estético (GRAEFF, 1995, p. 62).

O trabalho de Laverde (2017) traz contribuições de ordem teórica ao sistematizar uma bibliografia abrangente sobre o tema da utilização da experimentação construtiva ao longo da concepção da materialidade e seu papel como recurso pedagógico. Com base na análise de exemplos de projetistas como Antonì Gaudi, Felix Candela, Frei Otto, Renzo Piano, Pier Luigi Nervi, Eduardo Torroja, João Filgueiras Lima, Jean Prouvè, Eládio Dieste, entre outros, engenheiros e arquitetos que utilizaram experimentos com modelos em pequena escala e protótipos próximos à escala real para o estudo de formas e processos inovadores, a pesquisadora ressalta a importância da experimentação, e da adoção de outras estratégias complementares, pela possibilidade de ampliar a compreensão do conteúdo tecnológico, fato reconhecido e defendido pelos docentes que a praticam (ou praticaram) por ela entrevistados.

Vários dos autores citados investigaram a teoria na prática, ou seja, para além da pesquisa teórica que empreenderam, atuaram, ou ainda atuam, como docentes em cursos de arquitetura levando para a prática profissional a experimentação de suas teorias, e vice-versa. Fizeram do contexto acadêmico uma extensão do seu trabalho refletindo sua crença na valia do processo experimental como instrumento para a inovação construtiva e avanço da ciência. Assim sendo, a dialética entre arte e técnica, teoria e experimentação, estende-se também ao campo da pesquisa arquitetônica:

[...] de um lado a teoria "pensa"; de outro, a experiência "verifica". Esta dicotomia, isomórfica, à que separa projeto e execução, por si só leva ao desconhecimento do fundamento da arquitetura: arquitetura é práxis, comunhão de teoria e prática, ação racional crítica (FERRO, 2008, p. 20). 
Nenhuma teoria passa a ser válida se não for testada e verificada, nenhuma hipótese pode ser confirmada sem sua devida experimentação. Por isso, Sérgio Ferro ${ }^{52}$ (2008, p. 20) defende que as escolas de arquitetura devem intervir prática e criticamente, no campo efetivo da Arquitetura. “Esta é a pesquisa autêntica que deveria alimentar seu ensino. E a experiência, no caso, não é mais somente a que verifica a teoria: passa a ser o seu contraponto indispensável na simbiose da práxis."

Numa perspectiva mais aberta e especificamente voltada à Arquitetura, a pesquisa implica a participação ativa, crítica e experimental na produção concreta: àquela que se refere às necessidades sociais mais eminentes. Sob este ponto de vista, uma escola que prepara sujeitos para a modificação ativa do espaço construído não pode recusar a pesquisa prática por meio da iniciação do estudante à intervenção real. Nesta interação entre o agente modificador e a realidade do canteiro, reside a "fertilidade inventiva do fazer" que desvela na ação, o potencial desmistificador da experimentação.

Embora pontuais, diversas iniciativas didáticas em cursos de Arquitetura e Urbanismo do Estado de São Paulo se configuraram como experiências que permitiram certa permeabilidade entre conteúdos disciplinares, práticas de atividades de extensão e práticas de experimentação construtiva. Destaca-se o Laboratório de Habitação da Escola de Belas Artes de São Paulo (1982/1985) como marco referencial de uma iniciativa que articulou ensino de projeto, tecnologia e construção, numa atividade de extensão inserida em uma realidade social concreta - a periferia da cidade de São Paulo e seus movimentos de moradia. Naquele contexto "a aquisição do conhecimento teórico encontrava, quase sem muita mediação, o ambiente propício para o exercício prático dos conteúdos ministrados" (LOPES, 2014, p. 9).

Outras iniciativas mencionadas por Lopes (2014) referem-se à proposta de renovação pedagógica do curso de AU da Universidade São Judas Tadeu, em 1995, com a criação de duas sequências de disciplinas de Projeto Integrado e Laboratório; a

\footnotetext{
52 Depoimento para a publicação comemorativa dos 10 anos do Canteiro Experimental da FAU-USP (2008). Sérgio Ferro é arquiteto, pintor e professor aposentado da Escola de Arquitetura de Grenoble, professor da FAU-USP entre 1962 e 1970, ano em que foi preso e demitido da faculdade. Sua produção crítica foi reunida e publicada em ARANTES, P. F. (org.) Arquitetura e trabalho livre. São Paulo: Cosac Naify, 2006.
} 
atividade prática no canteiro de obras do $1^{\circ}$ ano do curso de Sistemas Estruturais da FAU-PUC Campinas (1995/2003), onde os alunos produziam modelos reduzidos que posteriormente serviriam de referência para a construção de protótipos; os exercícios de construção de abrigos/pavilhões na disciplina de Projeto do $1^{\circ}$ ano do curso de AU do IAU-USP de São Carlos (2003/atual) e do Canteiro Escola, na mesma instituição, em 2008, promovido como curso de extensão universitária envolvendo a presença de profissionais da construção civil no mesmo ambiente didático dos estudantes de arquitetura.

Sobre a experiência do Canteiro Experimental da FAU-USP, coordenado pelo professor Reginaldo Ronconi, Arantes (2008) explica que sua proposta pedagógica apoia-se na crítica ao canteiro de obras convencional, enquanto espaço de opressão e alienação do trabalho.

\footnotetext{
A pedagogia do Canteiro Experimental é, assim, um "método de conscientização", como concebia Paulo Freire: pretende instituir-se como um espaço de unidade entre o saber e o fazer, como lugar de problematização e de autonomia dos sujeitos na definição de sua ação no mundo - fortalecendo-os em suas potencialidades transformadoras (ARANTES, 2008, p. 32).
}

Desta maneira, o que está em construção nesse canteiro não são apenas formas arquitetônicas, mas um novo tipo de arquiteto (RONCONI, 2005). A proposição do Canteiro Experimental decorre na verdade mais da premissa de retomada de uma prática que foi corrente nas nascentes do ofício do que de uma ideia inovadora. A prática de experimentações construtivas nas escolas de Arquitetura são uma tentativa de reorientar e reaproximar o arquiteto da construção.

O depoimento de Arantes (2008, p. 32/33) evidencia o quão marcante é a experiência do Canteiro na formação do futuro profissional: "o arquiteto que passa por essa formação estará apto a desnaturalizar e transformar os canteiros de obra convencionais - e, por extensão, será capaz de pensar e se posicionar diante dos dilemas sociais mais amplos". Relata que os estudantes que saíram da FAU para trabalhar em canteiros de obras geridos por movimentos populares se referem ao 
Canteiro como tendo sido decisivo em sua formação e disposição crítica para reinventar a prática.

Tomaz Lotufo (2014) aborda, em sua Dissertação de Mestrado, a prática do Canteiro Experimental como possibilidade de uma "educação dialógica" 53 propondo a reflexão sobre esse espaço pedagógico como meio de estabelecer um diálogo produtivo entre educadores, educandos, técnicos e a realidade. É no Canteiro Experimental que se tem o enfrentamento do mundo real e, nesse sentido, ao enfrentar a realidade o sujeito acercar-se do problema, originando dúvidas e diferentes percepções. Em sua opinião,

[...] para transformar informação em sabedoria, é preciso um ambiente de educação que tenha um sistema composto por educadores e educandos integrados, e isso acontece quando as partes permanecem juntas, não apenas fisicamente, mas também com diálogo entre elas (LOTUFO, 2014, p. 50).

Lotufo lança então uma pergunta: "Quais são os espaços e as metodologias de ensino que podem estimular professores e alunos a degustar o conhecimento para que ele seja decifrado, incorporado e aprimorado?" (LOTUFO, 2014, p. 50).

O Canteiro Experimental certamente é um espaço que pode promover o diálogo de saberes ao possuir como característica intrínseca um elemento fundamental na educação: o confronto com o mundo real. Ainda que esse enfrentamento se inscreva dentro dos limites estéreis dos domínios territoriais da universidade (MINTO, 2018), neste espaço pedagógico as ideias podem ser materializadas, expondo erros e acertos, que através do diálogo fazem germinar uma diversidade de visões que desafia a busca por soluções.

Para além das fronteiras institucionais, a imersão em situações de demandas reais que resultem em experimentações práticas construtivas configura-se como excelente oportunidade para conhecer as qualidades emocionais dos materiais e dos canteiros de obras. Minto (2018, p. 2061) defende que o "processo transformador de sujeito leigo a

53 Lotufo refere-se à concepção de "educação dialógica" de Paulo Freire, presente quando há uma problematização motivadora do pensar crítico que se organiza em um ambiente de participação, e por isso parte do princípio de que todos sabem e podem contribuir no diálogo (LOTUFO, 2014, p. 50), cita FREIRE, P. A pedagogia do oprimido. Rio de Janeiro: Paz e Terra, 1970. 
autônomo ${ }^{54}$ somente se dá em ambientes privilegiados que alimentem a pré-diposição ao risco, ao novo".

Neste ponto, não restam dúvidas e não faltam argumentos em defesa de uma inserção mais efetiva da experimentação construtiva como instrumento de ensinoaprendizagem na formação dos arquitetos. Mas temos espaço para a experimentação em nossas escolas? Qual a nossa realidade em relação a estas práticas tão necessárias?

A Tese de Doutorado de Laverde (2017) apresentou um levantamento qualitativo dos espaços e práticas experimentais existentes em 21 escolas públicas de arquitetura brasileiras constatando um cenário bastante desanimador onde a falta de espaços adequados, recursos contínuos e de carga horária compatível com as atividades práticas construtivas e de laboratório, tem dificultado o real estabelecimento destas nos cursos. Muitos dos profissionais entrevistados pela autora alegam ser a origem de implantação dos cursos e a tradição cultural dela oriunda uma das condicionantes para que as escolas estabelecessem determinado diálogo com os cursos da Engenharia Civil e adotassem alguns modelos para a condução das disciplinas e práticas didáticas na área da Tecnologia da Construção ${ }^{55}$.

Apesar do exposto, Laverde indica que o problema da pouca utilização de práticas construtivas nas disciplinas de Tecnologia não está diretamente ligado à história de implantação de cada curso e sua associação a um modelo de ensino - Politécnico ou Belas Artes - e sim, à história construída ao longo do tempo, diante das oportunidades surgidas e da composição do quadro docente que, por conseguinte, direcionaria o curso para uma determinada vertente e daria o tom das prioridades de cada escola, fortalecendo assim a relação entre experiências práticas e iniciativa docente.

\footnotetext{
${ }^{54}$ O termo autônomo utilizado por Fernando Minto foi extraído de uma tradução livre feita pela professora Maria Amélia Devitte Ferrara d'Azevedo Leite do texto introdutório da publicação: Renzo Piano Building Workshop: In search of a ballance, Process: Architecture, n. 100, p. 8-14,1992. Albenise Laverde buscou correlacionar tais condicionantes com a heterogeneidade de configurações encontradas em sua investigação, como: a) delegar as disciplinas para o curso da Engenharia Civil; b) terem em seu quadro docente profissionais engenheiros, os quais assumem as disciplinas da Tecnologia da Construção, c) a área ser conduzida por profissionais arquitetos com formação complementar na área da Tecnologia da Construção e d) disciplinas assumidas por profissionais arquitetos sem especialização na área da Tecnologia (LAVERDE, 2017, p. 245)
} 
Uma vez mais, a habilidade docente é ressaltada como diferencial para o emprego de abordagens pedagógicas que induzem ao conhecimento da materialidade e ao entendimento da prática profissional da Arquitetura como parte integrante do ofício da Construção. Justamente a atividade que tem sido mais desvalorizada em nosso atual contexto mercadológico educacional.

Apresenta-se a seguir alguns dados dos levantamentos feitos na pesquisa documental em relação à carga horária das disciplinas de Tecnologia e atividades práticas a elas relacionadas nos cursos de Arquitetura e Urbanismo no Brasil. Dos 500 cursos levantados através do site do Ministério da Educação no ano de 2016, apresentados no capítulo anterior, aproximadamente 80 Instituições de Ensino Superior (IES) foram investigadas a fim de compor uma amostragem abrangente de Escolas Públicas e Privadas de diferentes regiões do país. A obtenção de dados específicos dos cursos foi realizada através de consulta aos sites institucionais e são apresentados na planilha do APÊNDICE e, a seguir, através de gráficos quantitativos que expõem um panorama geral da inserção da área da Tecnologia nas estruturas curriculares pesquisadas.

A seleção das instituições partiu do conjunto total das IES Públicas e das IES Privadas citadas na revisão bibliográfica, buscando identificar iniciativas de ensino diferenciadas na área tecnológica, bem como a inserção da madeira neste âmbito. Outro recurso utilizado foi o levantamento de escolas de Arquitetura participantes nas últimas edições do Encontro Brasileiro em Madeira e em Estruturas de Madeira EBRAMEM, promovidos pelo Instituto Brasileiro da Madeira e das Estruturas de Madeira - IBRAMEM, através das inscrições e de artigos publicados nos anais dos encontros de 2008 a 2016, quando também ocorreram os primeiros Concursos Brasileiros de Arquitetura em Madeira vinculados ao EBRAMEM. Além disso, consultamos a classificação das escolas através do Ranking Universitário Folha RUF 2016 como indicativo das escolas melhor avaliadas do país.

A elaboração da planilha contemplou a compilação de informações relativas às IES e aos cursos, como carga horária total, número de vagas, turno de oferecimento, entre outras; a verificação dos documentos disponíveis nos sites institucionais como grade 
curricular, projeto pedagógico, ementas e conteúdos programáticos das disciplinas; a consulta aos documentos para verificação das disciplinas da área de Tecnologia e com referência à madeira; a aferição da carga horária teórica e prática das disciplinas analisadas; o cálculo de percentuais para análise comparativa entre alguns dos dados levantados; a anotação de observações relevantes quanto a ementas e/ou conteúdos programáticos específicos à madeira e outras diferenciações curriculares.

Em relação às disciplinas de Tecnologia cabe ressaltar que foram examinadas somente aquelas do núcleo de conhecimentos profissionais que ao meu entender têm uma estreita conexão com as questões conceptivas da materialidade, a saber: Materiais de Construção, Tecnologia das Construções, Sistemas Estruturais, Sistemas Construtivos e suas variantes; não sendo consideradas as disciplinas relativas ao Conforto Ambiental, Técnicas Retrospectivas, Topografia e Instalações Prediais.

Na composição desta amostragem, a partir dos critérios utilizados na elaboração da planilha, foram investigadas 5 escolas da região Norte, 15 da região Nordeste; 9 da Centro-Oeste; 30 da Sudeste e 21 da região Sul, somando 80 IES das quais 54 são públicas e 26 privadas. Nem todas as informações tratadas se encontravam disponíveis nos sites das escolas de modo que para cada análise feita, o número de cursos comparados varia de acordo com o número de dados encontrados.

O Gráfico 5 relaciona a carga horária das disciplinas de Tecnologia e a carga horária total em 72 cursos de AU analisados e o Gráfico 6 ilustra a mesma relação para as médias por região.

A carga horária total dos cursos analisados varia de 3.600 horas-aula - mínima estabelecida pelo MEC - a 6.060 horas-aula. As disciplinas de Tecnologia somadas variaram de 195 a 750 horas-aula, algo em torno de 5\% a 16\% do total da carga horária. Verificou-se uma leve tendência a maior carga horária total dos cursos de AU na região Sudeste, seguida da região Sul, e maior carga horária das disciplinas de Tecnologia na região Sul, seguida da região Sudeste. 
Gráfico 5 - Carga Horária total e de Tecnologia dos cursos de AU

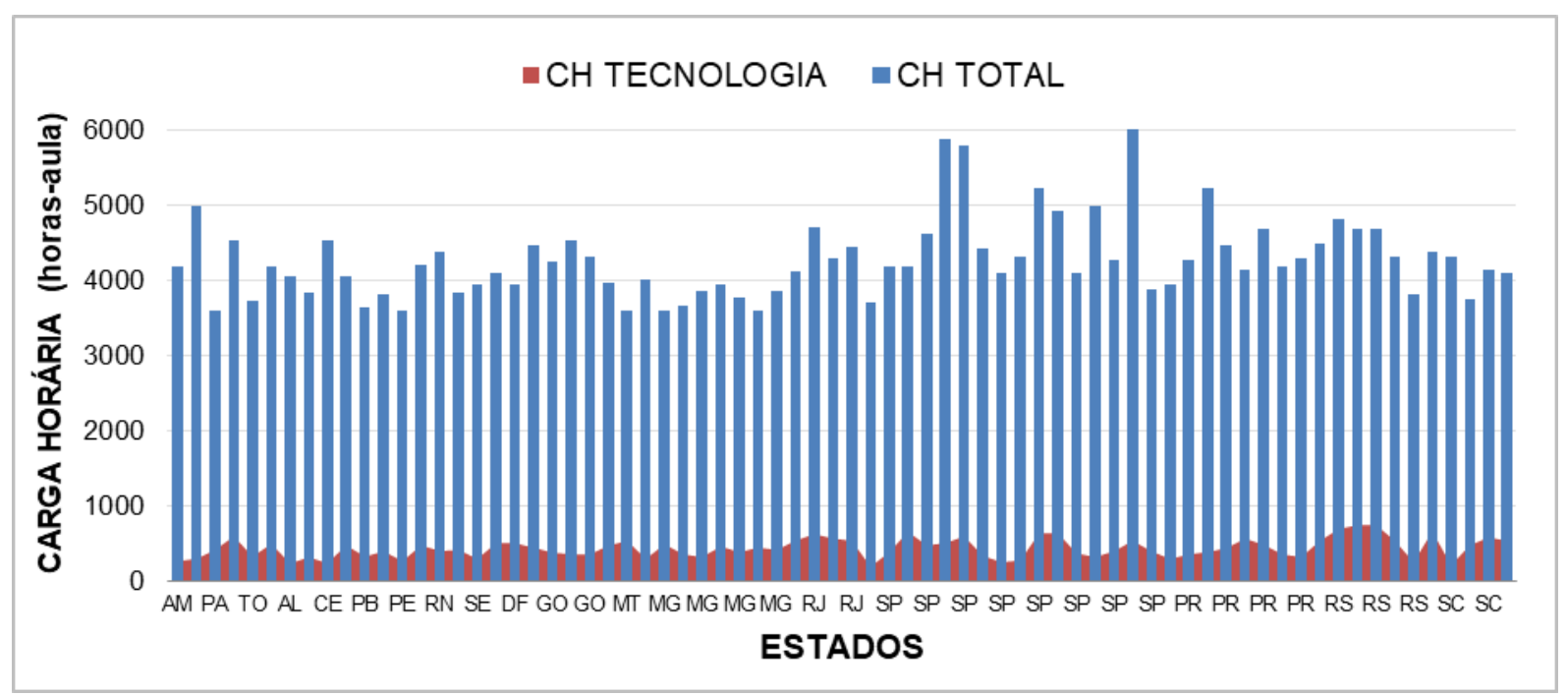

Fonte: Sites institucionais, elaborado pela autora.

Gráfico 6 - Carga Horária média total e de Tecnologia dos cursos de AU por região

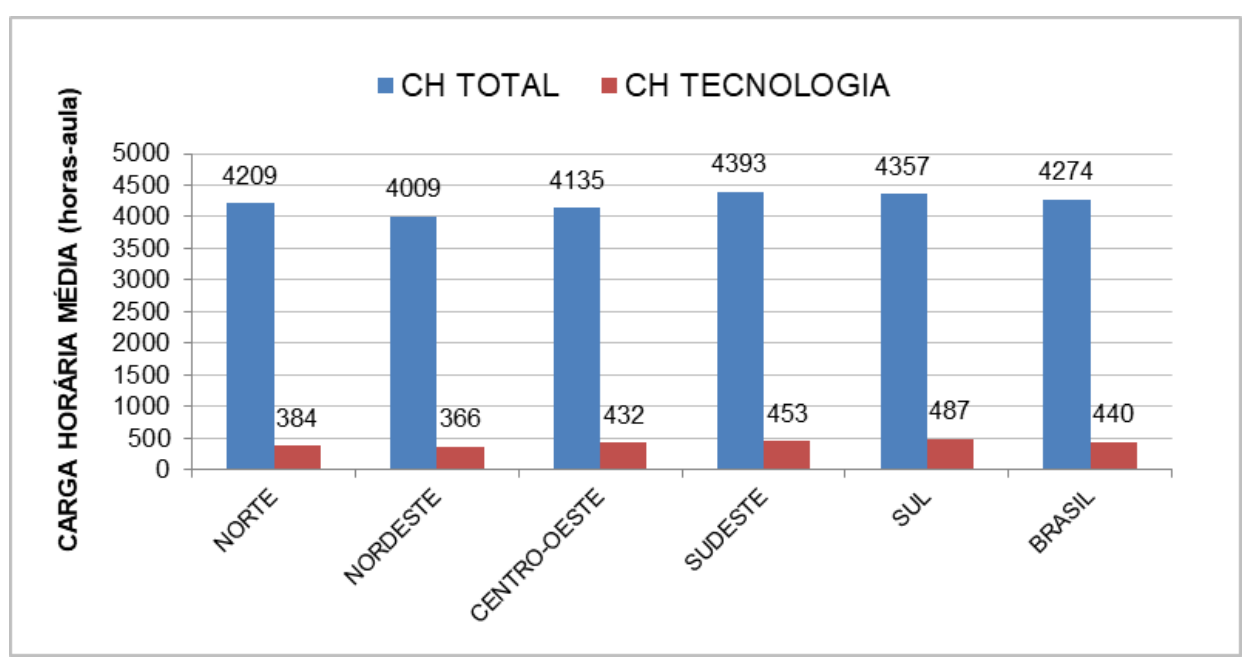

Fonte: Sites institucionais, elaborado pela autora.

Se comparados os percentuais de carga horária média da área tecnológica em relação à carga horária total dos cursos (Gráfico 6), a região Sul ainda apresenta maior média de 487 horas (11,13\%), seguida da região Centro-Oeste de 432 horas (10,57\%) sendo a média geral do Brasil de 440 horas (10,30\%), aproximadamente o mesmo percentual da região Sudeste com 453 horas (10,33\%). As médias das regiões Norte e Nordeste são um pouco inferiores à média brasileira, 384 e 366 horas (9,24\% e 9,14\%) respectivamente. 
Já o Gráfico 7 ilustra a proporção entre horas-aula práticas e teóricas nas disciplinas de Tecnologia em 26 cursos de AU e o Gráfico 8 apresenta estes dados em valores médios por região.

Gráfico 7 - Horas-aula práticas em disciplinas de Tecnologia

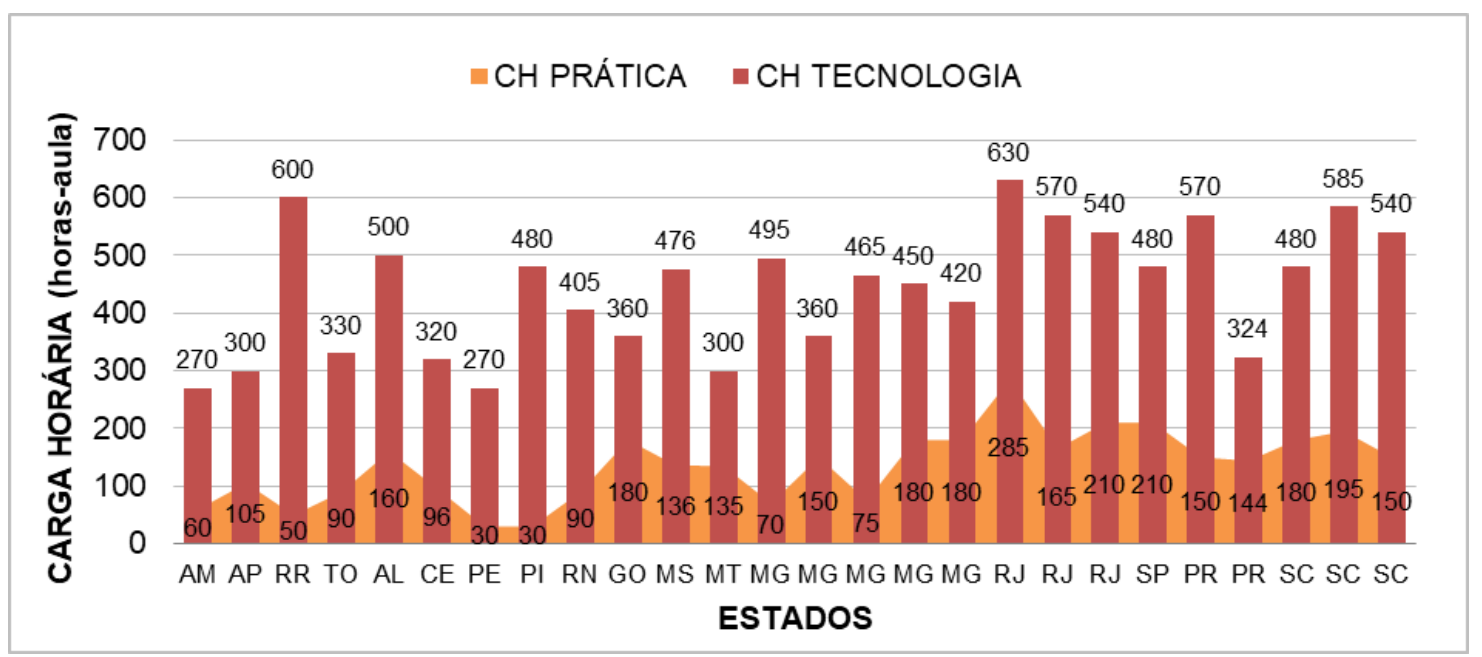

Fonte: Sites institucionais, elaborado pela autora.

Gráfico 8 - Carga Horária média de horas-aula práticas em Tecnologia por região

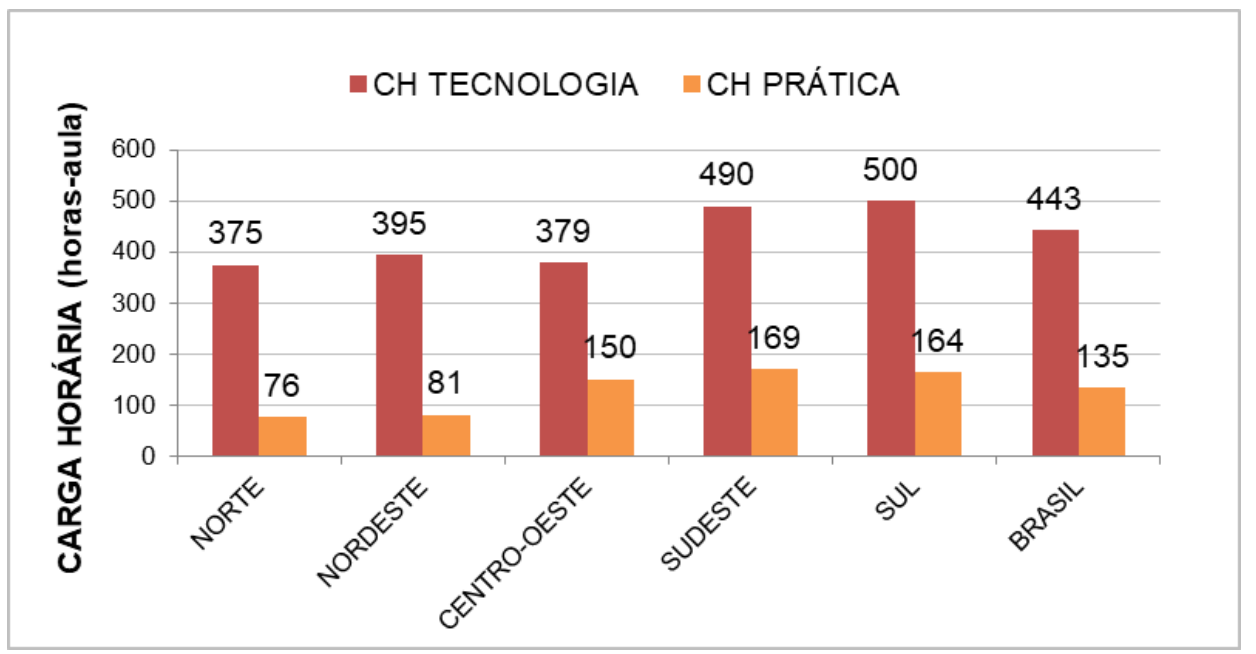

Fonte: Sites institucionais, elaborado pela autora.

Entre os cursos analisados nos dois gráficos, a carga horária de Tecnologia varia de 270 a 630 horas-aula, o que representa de 6,5\% a 13,5\% do total de horas-aula dos cursos. Destas, a carga horária dedicada a atividades práticas é de 30 a 285 horas-aula, equivalentes a um percentual entre $6,25 \%$ a $45,25 \%$ da $\mathrm{CH}$ das disciplinas tecnológicas, indicando uma grande variação entre os dados observados. Nesse sentido, cabe 
salientar que essa variação deve-se ao fato de que aproximadamente um terço dos cursos investigados indica em seus projetos pedagógicos de 40 a 50\% de horas práticas às disciplinas de Tecnologia analisadas. Verifica-se assim, uma maior concentração de carga horária prática nas regiões Sudeste e Sul, seguida da Centro-Oeste.

Estes dados, não obstante, podem não ser representativos da realidade dos cursos - ou seja, das condições efetivamente implantadas - uma vez que a observação não foi feita presencialmente e sim a partir de informações documentadas nos projetos pedagógicos. Ainda assim, esta avaliação quantitativa serve de subsídio para elaborar um panorama geral brasileiro a partir da amostragem determinada.

Em síntese, a formação tecnológica do arquiteto pode e deve diferenciá-lo como agente transformador do espaço, potencializando sua atuação na sociedade frente às demandas prementes e capacitando-o a se posicionar com maior clareza de seu papel social na construção das cidades. Entretanto, a configuração atual dos cursos, no que diz respeito a essa formação, não condiz a este propósito.

A possibilidade de materialização dos feitos projetados implica em uma construção de futuro. Do latim projectus, o projeto designa a ação de se estender, de desígnio, envolvendo a intenção e a vontade de realizar algo. A experiência de trabalhar o material através de situações reais de experimentação construtiva exige do estudante a prontidão para a resolução de problemas que muitas vezes não são reconhecidos nos desenhos ou mesmo modelos em escala reduzida, e menos ainda em fórmulas, tabelas e gráficos. O embate com a escala real abre o projeto à compreensão do fazer. Integrada à formação, a atividade de pesquisa e de experimentação da construção permite aprender, de forma sensível, as estruturas, os princípios construtivos e as etapas de produção.

Reitero as afirmações de Sérgio Ferro $(2006 ; 2008)$ de que a experimentação na escola de arquitetura é mais que necessária - é prioritária. A experimentação estimula a perceber a dimensão do trabalho e, portanto, a possível racionalização no próprio projeto. E assim sendo, insisto: a materialidade é o que distingue a Arquitetura e lhe confere dimensão tecnológica. O fazer arquitetônico, portanto, não pode esquivar-se da matéria. 


\section{REFERÊNCIAS}

ANELLI, R. L. S. O Projeto de arquitetura na pesquisa acadêmica: especificidades, limites e desafios. IV Projetar 2009 - Projeto como Investigação, Pesquisa e Prática, 2009. São Paulo: Altermarket, 2009.

ARANTES, P. F. Qual futuro para o Canteiro Experimental? 2008. In: RONCONI, R. L. N. et al. (org). Canteiro experimental: 10 anos na FAUUSP. São Paulo: FAUUSP, 2008. p. 24-33.

ARRUDA, A. L. V. Aprender arquitetura e urbanismo à distância não funciona. [s.l.] 26 de janeiro de 2017. Disponível em: http://www.abea.org.br/?p=2052. Acesso em: 05 mar. 2017.

FERRO, S. Arquitetura e trabalho livre. São Paulo: Cosac Naify, 2006.

. Experimentação em arquitetura: práxis crítica e reação conservadora. 2008. In: RONCONI, R. L. N. et al. (org). Canteiro experimental: 10 anos na FAUUSP. São Paulo: FAUUSP, 2008.p. 19-23.

GRAEFF, E. A. Arte e técnica na formação do arquiteto. São Paulo: Studio Nobel, 1995.

LAVERDE, A. Os espaços experimentais das escolas públicas de arquitetura do

Brasil: realidade ou utopia? 2017. Tese (Doutorado em Arquitetura e Urbanismo) Faculdade de Arquitetura e Urbanismo, Universidade de São Paulo, São Paulo, 2017.

LEITE, M. A. D. F.D' Azevedo. O ensino de tecnologia em Arquitetura e Urbanismo. 1998. Dissertação (Mestrado em Arquitetura e Urbanismo) - Faculdade de Arquitetura e Urbanismo, Universidade de São Paulo, São Paulo, 1998.

. A aprendizagem tecnológica do arquiteto. 2005. Tese (Doutorado em Arquitetura e Urbanismo) - Faculdade de Arquitetura e Urbanismo, Universidade de São Paulo, São Paulo, 2005.

LOPES, J. M. A. Tecnologia: arquitetura e urbanismo: escola \& ofício. 1999. Dissertação (Mestrado em Arquitetura e Urbanismo) - Escola de Engenharia de São Carlos, Universidade de São Paulo, São Carlos, 1999.

Quando menos não é mais: tectônica e o ensino tecnológico da Arquitetura e do Urbanismo. In: ENCONTRO DA ASSOCIAÇÃO NACIONAL DE PESQUISA E PÓS-GRADUAÇÃO EM ARQUITETURA E URBANISMO - ENANPARQ, 3, 2014, São Paulo. Anais [...]. São Paulo: Universidade Presbiteriana Mackenzie, 2014. 
LOTUFO, V. A. Reflexões sobre o canteiro experimental. 2008. In: RONCONI, R. L. N. et al. (org). Canteiro experimental: 10 anos na FAUUSP. São Paulo: FAUUSP, 2008. p. 52-54.

LOTUFO, T. A. Um novo ensino para outra prática. Rural Studio e Canteiro Experimental, contribuições para o ensino de arquitetura no Brasil. 2014. Dissertação (Mestrado em Arquitetura e Urbanismo) - Faculdade de Arquitetura e Urbanismo, Universidade de São Paulo, São Paulo, 2014.

MENDONÇA, A. C. João Filgueiras Lima (Lelé). Entrevistado: João Filgueiras Lima. Salvador, 18 de janeiro de 2007. Disponível em: http://entreentre.com/Content/entrevistas/pdf/entre-lele-20160330175704.pdf. Acesso em: 22 nov. 2018.

\section{MINTO, F. C. N. A experimentação prática construtiva na formação do} arquiteto. 2009. Dissertação (Mestrado em Arquitetura e Urbanismo) - Faculdade de Arquitetura e Urbanismo, Universidade de São Paulo, São Paulo, 2009.

. Canteiro Experimental: o material e o imaterial. 2008. In: RONCONI, R. L. N. et al. (org). Canteiro experimental: 10 anos na FAUUSP. São Paulo: FAUUSP, 2008. p. 40-43.

. Pensando a pluralidade no ensino tecnológico em cursos de arquitetura e urbanismo no Brasil. In: ENCONTRO DA ASSOCIAÇÃO NACIONAL DE PESQUISA E PÓSGRADUAÇÃO EM ARQUITETURA E URBANISMO - ENANPARQ, 5, 2018, Salvador. Anais [...]. Salvador: FAUFBA, 2018. p. 2061-2062. Disponível em:

http://repositorio.ufba.br/ri/handle/ri/27744. Acesso em: 17 mar. 2019.

POMPÉIA, R. A. O laboratório de habitação no ensino de arquitetura: uma contribuição ao processo de formação do arquiteto. 2006. Tese (Doutorado em Arquitetura e Urbanismo) - Faculdade de Arquitetura e Urbanismo, Universidade de São Paulo, São Paulo, 2006.

QUEIROZ, H. P. V. Manifestação do plenário do conselho de arquitetura e urbanismo do Brasil sobre ensino a distância em arquitetura e urbanismo. [s.l.] 16 de fevereiro de 2017. Disponível em: http://www.caubr.gov.br/caubr-publicamanifestacao-sobre-ensino-a-distancia-em-arquitetura-e-urbanismo/. Acesso em: 05 mar. 2017.

REBELLO, Y. C. P. Contribuição ao ensino de estrutura nas escolas de arquitetura. 1993. Dissertação (Mestrado em Arquitetura e Urbanismo) - Faculdade de Arquitetura e Urbanismo, Universidade de São Paulo, São Paulo, 1993.

Uma proposta de ensino da concepção estrutural 1999. Tese (Doutorado em Arquitetura e Urbanismo) - Faculdade de Arquitetura e Urbanismo, Universidade de São Paulo, São Paulo, 1999. 
RONCONI, R. L. N. Inserção do canteiro experimental nas faculdades de arquitetura e urbanismo. 2002. Tese (Doutorado em Arquitetura e Urbanismo) Faculdade de Arquitetura e Urbanismo, Universidade de São Paulo, São Paulo, 2002.

Canteiro experimental - uma proposta pedagógica para a formação do arquiteto e urbanista. 2005. Pós - Revista do Programa de Pós-Graduação em Arquitetura e Urbanismo da FAUUSP, São Paulo, n. 17, p.142-158, 2005. Disponível em: http://revistas.usp.br/posfau/article/viewFile/43406/47028. Acesso em: 30 ago. 2014.

SABBATINI, F. H. Desenvolvimento de métodos processos e sistemas construtivos: formulação e aplicação de uma metodologia. 1989. Tese (Doutorado em Engenharia) - Escola Politécnica, Universidade de São Paulo, São Paulo, 1989.

SARAMAGO, R. C. P. Ensino de estruturas nas escolas de arquitetura do Brasil. 2011. Dissertação (Mestrado em Arquitetura e Urbanismo) - Escola de Engenharia de São Carlos, Universidade de São Paulo, São Carlos, 2011.

ZANETTINI, S. Siegbert Zanettini: arquitetura, razão, sensibilidade. São Paulo: Edusp, 2002. 


\subsection{A inserção das tecnologias construtivas em madeira no currículo dos cursos de AU brasileiros}

Considerando-se o contexto geral da formação tecnológica do arquiteto brasileiro, exposto nos capítulos anteriores, retomamos as questões específicas de pesquisa e buscamos identificar qual a inserção das tecnologias construtivas em madeira nas estruturas curriculares atuais dos cursos de Arquitetura e Urbanismo e como o assunto vem sendo tratado. É sabido que, há tempos, a abordagem do material é negligenciada em nosso país tanto nos cursos de Arquitetura como nos de Engenharia, sendo que a carga horária destinada à madeira e às estruturas em madeira é bastante restrita evidenciando a ênfase dada a materiais e sistemas considerados principais como as estruturas em concreto e aço (CALIL JR, 1998; CÉSAR; CUNHA, 1998; PLETZ, 2002; BITTENCOURT; TERNI, 2004).

O ensino da madeira no Brasil foi retratado em artigos publicados em encontros e congressos nacionais, particularmente por docentes da área - em sua grande maioria engenheiros. Bittencourt e Terni (2004) apresentaram a análise de alguns aspectos do ensino retomando publicações anteriores ${ }^{56}$ com o intuito de compreender a forma como este se organiza, situando a madeira no contexto do sistema educacional vigente, com vistas à elaboração de propostas pedagógicas úteis a difusão do material. Realizaram uma síntese sobre quais profissionais estavam sendo formados para o setor madeireiro segundo os níveis de formação técnica - em escolas técnicas de $2^{\circ}$ grau e programas de treinamento do SENAI - superior e de pós-graduação.

Evidenciaram-se as grandes lacunas na formação escolar tanto de nível médio quanto universitário para os profissionais da área da madeira no Brasil, com

\footnotetext{
${ }^{56}$ Em BITTENCOURT, R. M. O ensino da madeira no Brasil. Anais do XX Congresso Brasileiro de Ensino de Engenharia, Universidade Federal do Rio de Janeiro - UFRJ, Rio de Janeiro-RJ, 1992, a autora enfoca o tema por meio da comparação do ensino entre Brasil e França, indagando a formação e a diversidade de profissionais desta área. E em BITTENCOURT, R. M. Diagnóstico do Ensino da Madeira nos Cursos de Engenharia. XXIX Congresso Brasileiro de Ensino de Engenharia, Anais eletrônico, NTM052, Pontifícia Universidade Católica - PUC, ISBN PUC 85-7430-217-1, Porto Alegre-RS, 2001, retoma a questão da formação profissional na área produtiva da madeira em relação ao desenvolvimento da tecnologia no setor madeireiro.
} 
pouquíssimas oportunidades de formação técnica e cursos profissionalizantes. Quanto ao ensino superior, um único profissional estava sendo formado especificamente para a área: o engenheiro industrial madeireiro, na época em apenas duas escolas onde uma era recém-criada. Hoje, são quatro as universidades públicas que oferecem esta formação: a Universidade Estadual Paulista Júlio Mesquita - UNESP, a Universidade Federal do Paraná - UFPR, a Universidade Federal do Espírito Santo - UFES e a Universidade Federal de Pelotas - EFPEL, além do Centro Universitário de União da Vitória - UNIUV, somando um total de 254 vagas anuais.

Nos cursos de Engenharia Civil, os autores citam que o estudo da madeira concentra-se normalmente nas disciplinas de Estruturas Metálicas e de Madeira, Materiais de Construção Civil e Construção Civil. Destacam que o conteúdo, quando existente, aparece de forma fragmentada e desvinculada do contexto produtivo, enfocando principalmente características físico-mecânicas do material. Condicionado à formação docente, e em função das áreas de pesquisa destes, algumas escolas oferecem disciplinas optativas ou eletivas abordando especificamente a madeira. Já nos cursos de Arquitetura, os dois professores da Faculdade de Engenharia de Guaratinguetá da UNESP, naquele então, afirmaram desconhecer que o material fosse abordado nas ementas - nem mesmo na disciplina de Sistemas Construtivos - sendo que o conteúdo programático relacionado à madeira era praticamente inexistente (BITTENCOURT; TERNI, 2004).

Da análise dos dados levantados na pesquisa documental apresentados no capítulo anterior, e especialmente referentes às disciplinas da área tecnológica, tais como Materiais de Construção, Tecnologia da Construção, Sistemas Estruturais e Sistemas Construtivos, o diagnóstico das ementas e dos conteúdos programáticos, confirmou que o ensino de tecnologias construtivas em madeira é abordado de forma pontual, desarticulado entre as demais disciplinas, sendo bastante reduzida a carga horária atribuída ao conteúdo específico sobre o material. Verificou-se um padrão comum de ênfase ao sistema construtivo do concreto armado, com carga horária até quatro vezes maior em relação ao aço e à madeira, que normalmente têm carga horária compartilhada em uma única disciplina. 
O Gráfico 9 ilustra a relação entre a carga horária das disciplinas de Tecnologia e a carga horária das disciplinas nas quais é abordado algum conteúdo sobre a madeira para 56 cursos de AU analisados. Já o Gráfico 10 apresenta a mesma relação para as médias horárias por região.

Gráfico 9 - Carga Horária disciplinas de Tecnologia e as que abordam a madeira em cursos de AU

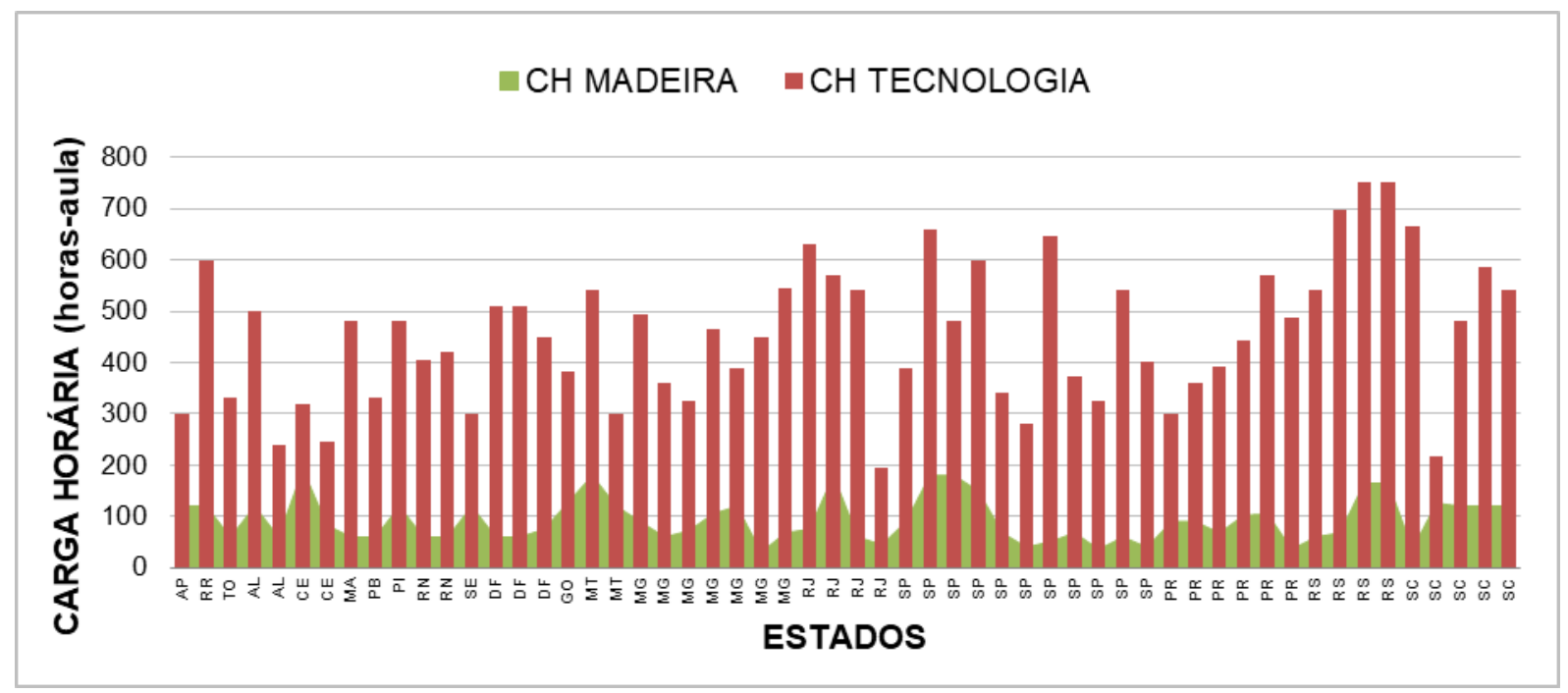

Fonte: Sites institucionais, elaborado pela autora.

Gráfico 10 - Carga Horária média de Tecnologia e de madeira em cursos de AU por região

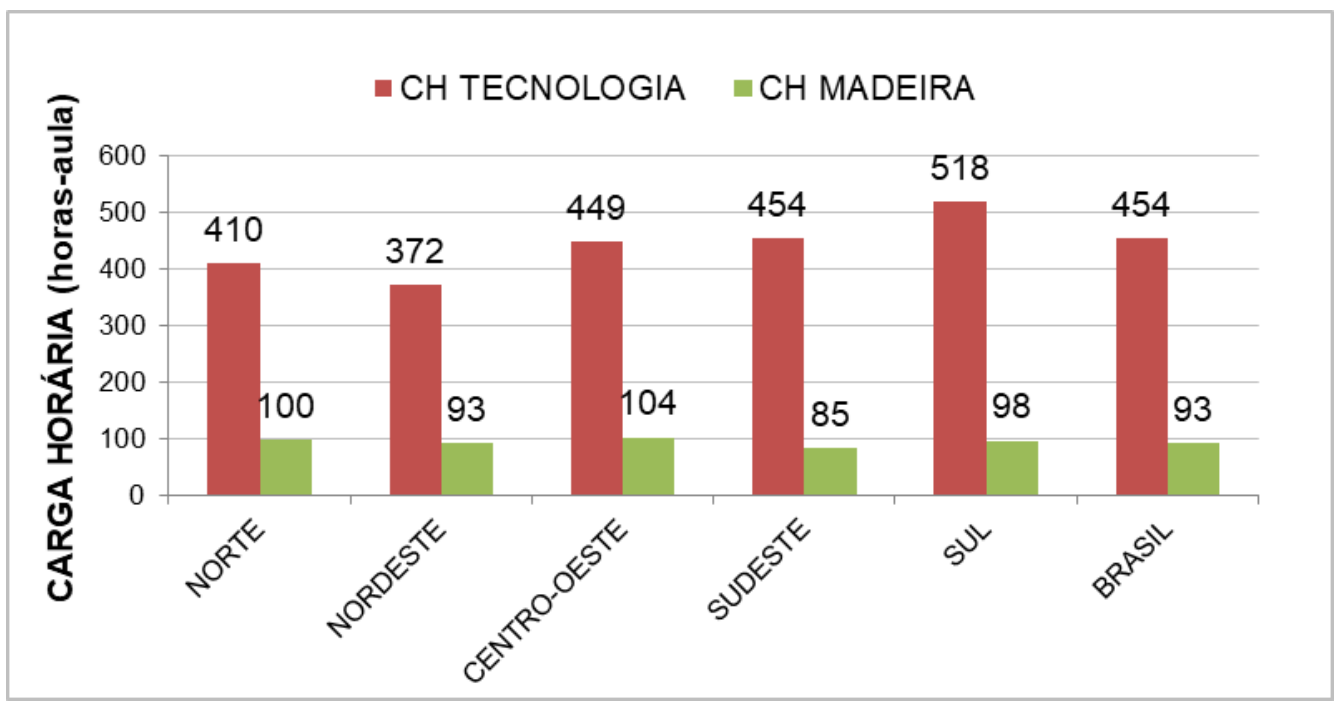

Fonte: Sites institucionais, elaborado pela autora. 
Entre os cursos analisados nos dois gráficos anteriores, a carga horária das disciplinas de Tecnologia mencionadas varia de 195 a 750 horas-aula, o que representa de $5 \%$ a $16 \%$ da carga horária total dos cursos. Destas, a carga horária onde se menciona algum conteúdo relacionado à madeira vai de 30 a 192 horas-aula, equivalentes a um percentual de $6,7 \%$ a até $60 \%$ das mesmas, indicando uma grande variação entre as disciplinas analisadas. De fato, os números aqui são novamente informativos, já que não foi discriminada a quantidade de horas dedicadas ao estudo da madeira dentro de cada disciplina, - como vimos muitas vezes compartilhadas com o aço e outros materiais - mas apenas contabilizadas as disciplinas com alguma menção ao seu estudo, ainda que a ela se dedique uma pequena parcela do conteúdo programático.

Em média, os percentuais entre carga horária das disciplinas de Tecnologia e das disciplinas que abordam a madeira para as regiões são: Sudeste 18,8\% (85 h/a); Sul 21,2\% (98 h/a); Centro-Oeste 24,5\% (104 h/a); Norte 26,1\% (100 h/a); Nordeste 26,8\% (93 h/a). Apesar da variação mencionada, verifica-se uma média similar para todas as regiões do país, em torno de 93 horas-aula, equivalentes a aproximadamente $22 \%$ da carga horária média das disciplinas de Tecnologia analisadas, e a apenas 2,2\% da carga horária total destes cursos. Neste caso, a variação do percentual da carga horária total dos cursos vai de $2,0 \%$ a 2,6\% o que evidencia o baixíssimo protagonismo do material em relação aos conteúdos abordados nos cursos de arquitetura.

Diante do panorama exposto, é óbvio que não estamos preparando profissionais capacitados pra propor a madeira como alternativa construtiva frente às novas demandas do setor produtivo. O projeto de arquitetura deve ser o ponto de partida para promover a familiarização do profissional com o material, resultando no seu uso racional e inovador na construção civil. Entretanto, a baixíssima inserção de conteúdos técnicos durante a formação, torna improvável a proposição do seu uso nos exercícios projetuais pelos estudantes por puro desconhecimento. Da mesma forma, também o desconhecimento por parte dos docentes acaba por limitar o estímulo ao uso de novas tecnologias construtivas. 
Everaldo Pletz (2002) salienta a importância da formação de recursos humanos habilitados para o trabalho com a madeira, destacando especialmente o papel do arquiteto como profissional ao qual cabe a especificação do material a ser utilizado na construção. Para o engenheiro civil e professor da Universidade Estadual de Londrina, o ensino de construções em madeira aos arquitetos deve principalmente buscar motiválos a propor o material para a construção de suas obras, capacitando-os a corretamente projetar, detalhar, construir e realizar a manutenção, dotando-os dos necessários conhecimentos sobre o material. Essa seria, em sua opinião, uma das mais importantes e estratégicas tarefas a serem realizadas para o desenvolvimento do setor no Brasil.

Mas, o que é necessário ensinar ao arquiteto, para capacitá-lo para o projeto em madeira? Tanto Pletz quanto Maria Regina Schmid ${ }^{57}$, também engenheira civil e professora do curso de arquitetura da Universidade Federal do Paraná, compartilham da opinião que ensinar a fazer cálculos de estruturas de madeira é necessário ao engenheiro, mas não é fundamental para a formação dos arquitetos: o aluno precisa saber o básico para pensar o projeto, precisa entender os esforços a que as peças de uma estrutura estão submetidas.

Os seguintes temas devem ser abordados, de acordo com Pletz (2002): propriedades físicas e mecânicas da madeira; tipos de madeira como material de construção; implicações das características e propriedades do material na concepção do projeto e dos detalhes construtivos; condições necessárias para a correta utilização da madeira como disponibilidade, mão de obra e equipamentos; estudo comparativo com outros materiais; sistemas construtivos; análise de viabilidade técnica e econômica destes sistemas; pré-dimensionamento das peças estruturais; e nível de interferência em outros elementos construtivos como paredes, estrutura e instalações em geral. Segundo o professor, o estudo deste conjunto de assuntos permitiria aos alunos de arquitetura adquirir uma visão sistêmica da utilização do material.

${ }^{57}$ Entrevista realizada no dia 22 de setembro de 2017 na UFPR em Curitiba, aos professores Maria Regina Leoni Schmid, Andrea Berriel Mercadante Stinghen e Cervantes Gonçalves Ayres Filho, todos docentes do curso de Arquitetura e Urbanismo. 
Obviamente, isso só seria possível quando, além de carga horária compatível, se associam aos processos de ensino métodos e práticas condizentes aos desafios que cada temática encerra. A questão metodológica - entendida neste trabalho como primordial - será, no entanto, tratada um pouco mais adiante.

Quanto aos conteúdos programáticos relativos às disciplinas investigadas na pesquisa documental, procuramos examinar quais os conteúdos programáticos sobre tecnologias construtivas em madeira têm sido enfocados nos cursos de AU e quais as lacunas existentes. Também buscamos averiguar se a diversidade de sistemas construtivos e suas aplicações em projetos estão sendo contempladas de alguma forma.

O levantamento realizado junto aos sites institucionais não permitiu uma visão muito abrangente quanto a esta matéria uma vez que poucas instituições disponibilizam publicamente os conteúdos programáticos das disciplinas. Entretanto, com base naqueles disponíveis - quinze disciplinas de onze instituições públicas e uma instituição privada - foi possível verificar que estes versam principalmente sobre as características físicas e mecânicas da madeira, tensões admissíveis, ações e esforços em estruturas, ligações de peças estruturais e noções de pré-dimensionamento, não contemplando a pluralidade de sistemas construtivos existentes, suas aplicações e interfaces pertinentes ao projeto arquitetônico.

Provavelmente este fato é decorrente da exígua carga horária dedicada às disciplinas tecnológicas e à carência de interdisciplinaridade entre as áreas de Tecnologia e de Projeto, porém, uma investigação mais direcionada seria necessária para afirmar que as disciplinas dedicadas ao Projeto Arquitetônico não estão de fato abrindo espaço para o desenvolvimento de exercícios projetuais que envolvam a pesquisa e aplicação de sistemas construtivos não convencionais.

O ANEXO A contém as informações levantadas em relação aos conteúdos programáticos das disciplinas da área de Tecnologia que apresentam a madeira como material construtivo. A maior parte das disciplinas analisadas trata de Sistemas Estruturais, por isso a ênfase no comportamento estrutural e pré-dimensionamento, e 
como já dito anteriormente, costumam abordar as Estruturas de Aço e de Madeira conjuntamente.

Das disciplinas que tratam especificamente das Estruturas de Madeira duas são obrigatórias e uma optativa, ou eletiva, e apresentam conteúdos mais abrangentes que as demais. As duas primeiras, a disciplina "Estruturas de Madeira" da Universidade Federal de Minas Gerais - UFMG e a disciplina de mesmo nome da Universidade Federal de Santa Catarina - UFSC, contam, porém, com apenas dois créditos equivalentes a um total de 30 e 36 horas de aulas teóricas semestrais, respectivamente, para dar conta de todos os assuntos.

Já a eletiva "Parâmetros para Projetos Habitacionais em Madeira" do Instituto de Arquitetura e Urbanismo da Universidade de São Paulo - IAU-USP, conta com 60 horas entre aulas teóricas e práticas, e trata de conteúdos referentes a sistemas construtivos diversos e ao desenvolvimento de projeto, configurando-se como uma exceção entre as disciplinas analisadas.

Cabe ressaltar ainda, outras duas que expõem uma abordagem diferenciada e interdisciplinar ao relacionar os sistemas construtivos em madeira com temáticas de projeto arquitetônico, como é o caso da disciplina "Tectônica VII" da Universidade Federal de Pernambuco - UFPE e da disciplina "Projeto V e Tecnologia" da Universidade Presbiteriana Mackenzie, de São Paulo.

No decorrer deste capítulo observamos que a inserção das tecnologias construtivas em madeira no currículo dos cursos de Arquitetura e Urbanismo brasileiros ainda é muito pequena e que essa realidade pouco tem mudado nas últimas décadas. Quando observamos esta inserção desde a área da Tecnologia, podemos verificar que as disciplinas, tanto em termos de carga horária quanto de conteúdos programáticos, são bastante limitadas não apenas em função do reduzido tempo para o estudo dos temas, mas também da falta de uma abordagem mais prática e de interdisciplinaridade com as disciplinas de Projeto.

As questões de interdisciplinaridade e de abordagens pedagógicas tornam-se neste ponto da investigação extremamente relevantes. A partir da análise do levantamento de 
dados quantitativos se faz necessário observar quais metodologias de ensinoaprendizagem vêm sendo aplicadas na área tecnológica dos cursos de AU no Brasil. E qual a relevância das atividades práticas de experimentação construtiva neste contexto.

A forma pela qual se efetiva o aprendizado da Arquitetura está diretamente relacionado à sua tangibilidade. Como já discutido, partimos do pressuposto que os conhecimentos teóricos não devem desvincular-se dos conhecimentos práticos sob o risco de uma formação medíocre.

Foram identificadas na pesquisa algumas iniciativas didáticas diferenciadas aplicadas ao ensino das tecnologias construtivas em madeira nos cursos de arquitetura brasileiros. Estes casos serão apresentados no capítulo 4.3, posteriormente à introdução de princípios teóricos relacionados às metodologias de ensino que têm sido utilizadas internacionalmente com o objetivo de reestabelecer a conexão entre teoria e prática, criando novas possibilidades de integração entre conteúdos e habilidades. 


\section{REFERÊNCIAS}

BITTENCOURT, R. M.; TERNI, A. W. Ensino de projeto de estruturas e sistemas construtivos em madeira: uma proposta didático-pedagógica. In: ENCONTRO BRASILEIRO EM MADEIRAS E EM ESTRUTURAS DE MADEIRA - EBRAMEM, 9, 2004, Cuiabá. Anais [...]. Cuiabá: IBRAMEM, 2004.

CALIL JR., C. A educação da Engenharia da madeira no Brasil: o programa do LaMEM. In: ENCONTRO BRASILEIRO EM MADEIRAS E EM ESTRUTURAS DE MADEIRA EBRAMEM, 6, 1998, Florianópolis. Anais [...]. Florianópolis: IBRAMEM, 1998.

CÉSAR, S. F.; CUNHA, R. D. A. Uma experiência para o ensino de graduação na área de estruturas, construção e tecnologia da madeira do Laboratório de Madeiras da EPUFBA. In: ENCONTRO BRASILEIRO EM MADEIRAS E EM ESTRUTURAS DE MADEIRA EBRAMEM, 6, 1998, Florianópolis. Anais [...]. Florianópolis: IBRAMEM, 1998.

PLETZ, E. Ensino de construções de madeira nos cursos de Arquitetura e Urbanismo. In: ENCONTRO BRASILEIRO EM MADEIRAS E EM ESTRUTURAS DE MADEIRA - EBRAMEM, 8, 2002, Uberlândia. Anais [...]. Uberlândia: IBRAMEM, 2002. 


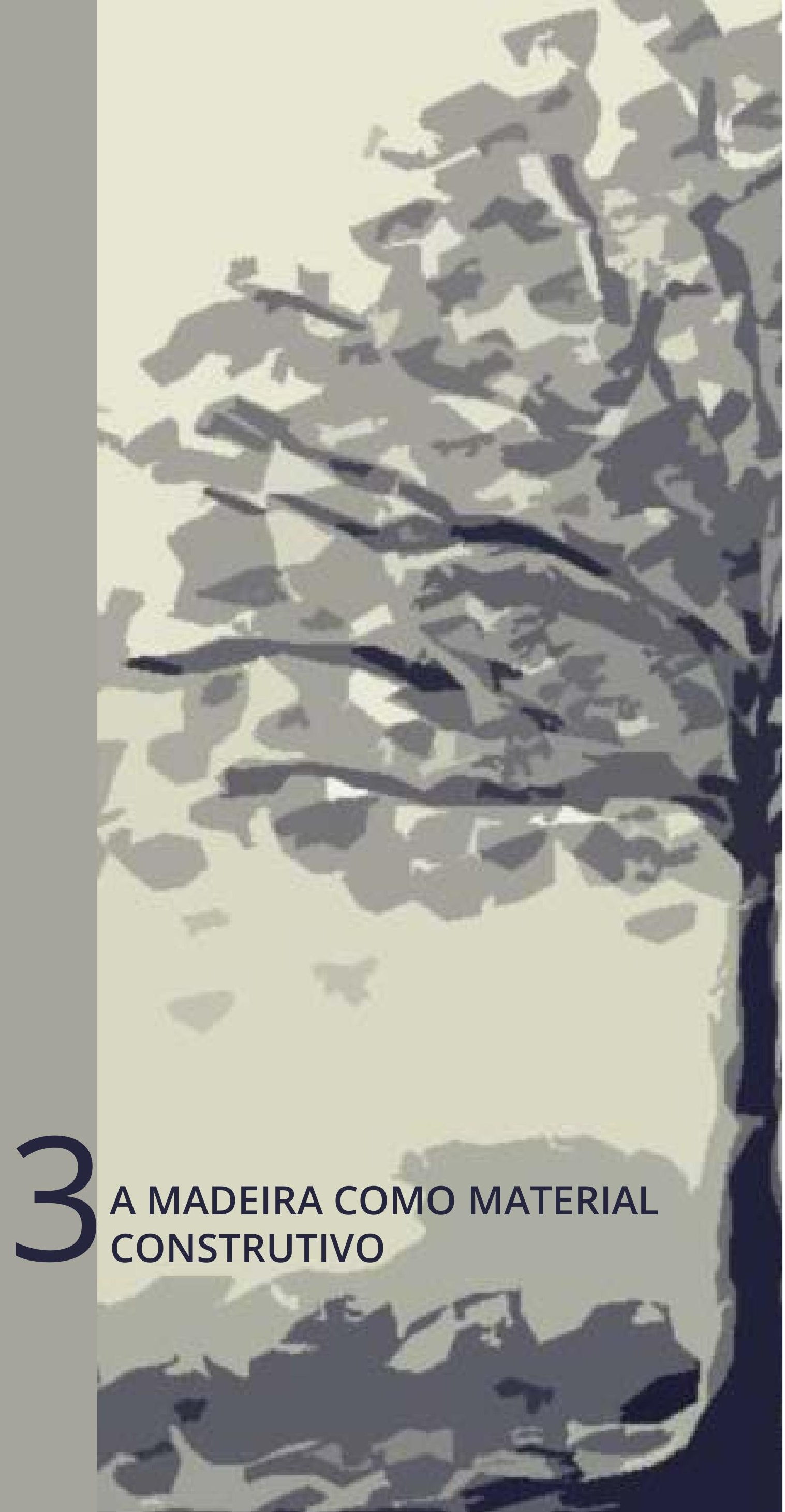





\section{A MADEIRA COMO MATERIAL CONSTRUTIVO}

A terceira parte desta Tese trata da matéria em si: a madeira como material construtivo. Apresenta a madeira como material renovável, mais amigável ao homem e ao meio ambiente, revelando seu potencial significativo para a mitigação das mudanças climáticas. Expõe dados concretos sobre as emissões de carbono e energia incorporada no processo de produção, ao longo do ciclo de vida do material, que corroboram para o entendimento do seu papel como material construtivo alinhado à lógica do desenvolvimento sustentável.

Enfatiza as vantagens ambientais do uso da madeira em detrimento de um maior aprofundamento em relação às características físicas e mecânicas que a distinguem como material de construção, uma vez que a variedade de espécies e propriedades em diferentes contextos de aplicação é tão amplo - especialmente no universo das madeiras tropicais - que demandaria um grande esforço investigativo o qual não é objetivo deste trabalho.

Em vez disso, o uso da madeira como material construtivo é ilustrado através de alguns exemplos de obras internacionais e nacionais na atualidade, em países como Áustria, Reino Unido, Canadá, Chile e Brasil, demonstrando a sua aptidão para a concepção de uma linguagem arquitetônica contemporânea e para o desenvolvimento de novos arranjos produtivos que impulsionem a implementação de novas perspectivas para a construção civil.

Aborda ainda, as vantagens do uso da madeira como instrumento de ensinoaprendizagem ao facilitar processos de experimentação prática devido à sua leveza e trabalhabilidade que permitem a construção de modelos e protótipos em escala real sem a necessidade do uso de ferramentas complexas para sua modelagem. Sua utilização em projetos práticos favorece abordagens conceptivas integradoras que fortaleçam a formação tecnológica do arquiteto. 


\subsection{Potencialidades do uso da madeira nas construções}

O homem, desde os primórdios de sua existência, tem utilizado a madeira em suas construções por razões como a disponibilidade do material, boa resistência mecânica e aparência agradável. É um material que proporciona a execução de estruturas leves e de grande durabilidade quando utilizada a partir de técnicas construtivas e de conservação adequadas. É um bem natural renovável que oferece vantagens ambientais sobre outros materiais, já que requer um baixo consumo energético tanto em sua fase de formação como durante o seu processamento. Sua capacidade de armazenamento de carbono, quando aplicada para fins de longa duração, associada a seu potencial expressivo de reciclabilidade lhe conferem vantagens significativas sobre materiais mais empregados na construção civil como o concreto, o aço e o alumínio.

Desde a década de 70, uma crescente consciência global em relação ao uso moderado dos recursos, seguindo princípios ecológicos, introduziu uma nova maneira de pensar também na indústria da construção. A madeira adquiriu uma importância como material construtivo que há anos atrás seria inimaginável. Um dos mais antigos e familiares materiais de construção traz hoje contribuições decisivas possibilitando formas inteiramente novas de projeto (KAUFMANN; NERDINGER, 2012). Em todo o mundo as políticas de incentivo ao uso da madeira e de produtos de base florestal tomam formas ambientalmente orientadas, pautadas no seu potencial de mitigação dos gases de efeito estufa (GEE) ${ }^{58}$, sendo, em função disso, considerada como “o material construtivo do século XXI" ${ }^{59}$.

${ }^{58} \mathrm{O}$ efeito estufa, determinante direto da quantidade de calor retido pela atmosfera, segundo a Agência de Proteção Ambiental dos Estados Unidos (EPA, 2016), é resultado das mudanças no comportamento dos gases lançados na atmosfera pelas atividades humanas e uma das causas das mudanças climáticas, juntamente com as variações na quantidade de energia do sol que chega à Terra e as alterações na refletividade da atmosfera e da superfície do planeta. Dentre os principais gases do efeito estufa, o dióxido de carbono é emitido e absorvido naturalmente como parte do ciclo de carbono por meio da respiração de plantas e animais, erupções vulcânicas, e trocas entre o oceano e a atmosfera. As atividades antropogênicas que resultam em mudança do uso do solo, como o desmatamento, e, principalmente, em queima de combustíveis fósseis liberam grandes quantidades de GEE.

59 Diversas publicações vêm anunciando nas últimas décadas a madeira como "material do futuro". Entretanto, já em meados do século 20, quando a maioria das pessoas pensava que a madeira era um material arcaico e de baixa tecnologia, Egon Glesinger (1907-1979), que contribuiu para a inclusão da atividade florestal na US 
Para Herzog et al. (2007, p. 47) "Construir em madeira, é construir o futuro" ${ }^{60}$. Segundo os autores, a Conferência do Rio de Janeiro em 1992 declarou critérios obrigatórios para o comércio local, regional e global, um modo de vida e um modelo econômico viável em longo prazo. Um grande número de capítulos da Agenda 21, estabelecida na Rio 92, faz referência às florestas, à silvicultura e ao uso da madeira por sua capacidade de contribuição para o desenvolvimento sustentável ${ }^{61}$, em relação aos aspectos econômicos, ecológicos e sociais (Figura 2).

Figura 2 - Contribuição da floresta e da madeira ao desenvolvimento sustentável

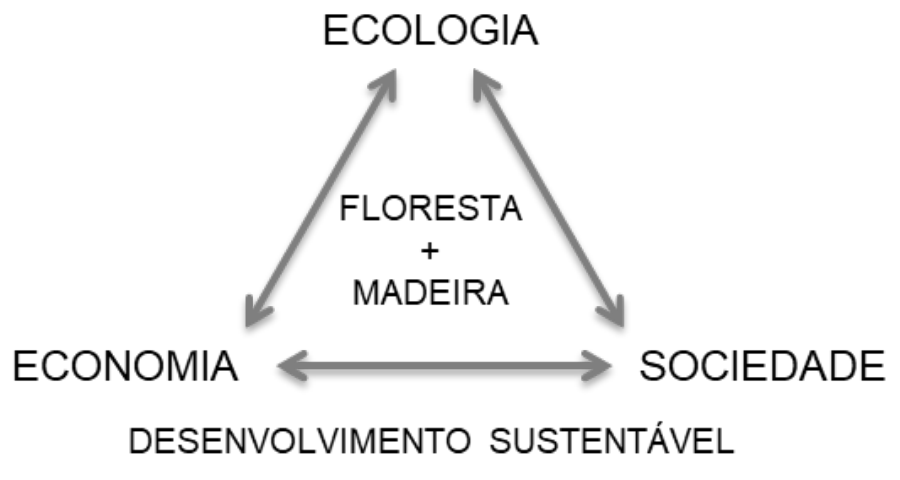

Fonte: Herzog et al. (2007, p. 47) tradução nossa.

Alguns dos desafios específicos da gestão econômica para o futuro mencionados no documento são, por exemplo, a conservação de reservas finitas de recursos fósseis através do aumento do uso de matérias-primas ou fontes de energia renováveis. O manejo florestal sustentável e o uso diversificado e eficiente da madeira podem ser

Food and Agriculture Organization (FAO) e foi fundador do Comité International du Bois (CIB), previu o papel revolucionário que ela teria como matéria prima no futuro, o qual descreve em seu livro The Coming Age of Wood de 1949, citado na matéria publicada por David N. Bengston, na Research and Development, USDA Forest Service in Forestry, em 05 de janeiro de 2018. Disponível em:

https://www.usda.gov/media/blog/2018/01/05/revolutionary-role-wood-our-future. Acesso em 20 set. 2018.

${ }^{60}$ Tradução da autora do francês: "Construire en bois, c'est construire l'avenir".

${ }^{61}$ Entende-se aqui por desenvolvimento sustentável "um processo de transformação no qual a exploração de recursos, a direção dos investimentos, a orientação do desenvolvimento tecnológico e a mudança institucional se harmonizam e reforçam o potencial presente e futuro, a fim de atender às necessidades e aspirações humanas" (BRUNDTLAND, 1991, p.49), referindo-se, dessa maneira, a uma espécie de 'nova ética produtiva global' na qual se insere o setor da construção civil, erigida em defesa do atendimento às necessidades do presente sem comprometer a capacidade de gerações futuras suprirem suas próprias necessidades. 
considerados um modelo para o bom uso da terra e para uma política de recursos confiável e durável, factível em longo prazo.

No setor da construção civil, as matérias-primas são extraídas, processadas, transportadas, montadas com outros produtos e finalmente descartadas, ou reutilizadas, ou recicladas, no final do ciclo de vida de um edifício. Todos estes processos implicam no uso da energia, custos econômicos e impactos ambientais. Por conseguinte, a seleção dos materiais construtivos constitui um fator importante para o desenvolvimento da construção em bases sustentáveis. Neste contexto, a madeira e os produtos à base de madeira, têm atraído atenção considerável como um material de construção promissor devido às suas propriedades ambientais únicas (TAKANO, 2015).

Ao aumentar o uso de materiais de base biológica nos edifícios, como os materiais à base de madeira, o armazenamento de carbono é geralmente aumentado enquanto o uso total de energia primária durante a fase de construção diminui. A partir de uma perspectiva de Análise de Ciclo de Vida ${ }^{62}$, valiosos recursos energéticos podem ser recuperados dos materiais madeireiros após a vida útil do edifício.

Segundo Kuittinen, Ludvig e Weiss (2013), o uso da madeira parece ser uma maneira prática de diminuir a pegada de carbono dos edifícios já que é a única entre os principais materiais de construção que armazena quantidades significativas de carbono da atmosfera em sua biomassa. Ao mesmo tempo, a substituição de outros materiais menos benéficos para o meio ambiente e o aumento da quantidade de madeira no setor da construção apresenta um potencial significativo para a mitigação das mudanças climáticas.

${ }^{62}$ A Análise do Ciclo de Vida (ACV) é uma estrutura analítica para determinar os impactos ambientais resultantes de processos, serviços e produtos e pode ser usada para analisar o impacto climático dos edifícios. Todos os estágios do ciclo de vida precisam ser inseridos em uma ACV completa. Uma análise formal inclui quatro fases: objetivo e definição do escopo descrevem o objetivo do estudo, os limites do sistema da análise e a unidade funcional usada para avaliação e comparação; a avaliação de inventário quantifica as entradas e saídas de massa e energia atribuíveis a processos que ocorrem dentro dos limites do sistema; a avaliação de impacto caracteriza os efeitos desses insumos e produtos considerando o esgotamento de recursos, a saúde humana, a qualidade do ecossistema e as mudanças climáticas; a interpretação dos resultados do inventário e da avaliação de impacto procura identificar conclusões, recomendações e implicações significativas para a tomada de decisões (KUITTINEN; LUDVIG; WEISS, 2013, p. 15, tradução nossa). 
A Figura 3 traz um comparativo elaborado por Kolb (2008) das emissões de dióxido de carbono $\left(\mathrm{CO}_{2}\right)$ durante a produção de vários materiais de construção. De acordo com o autor, a madeira armazena dióxido de carbono enquanto todos os outros materiais emitem $\mathrm{CO}_{2}$ na atmosfera. Quanto à energia requerida na produção destes materiais, Kolb compara a quantidade necessária para a produção de uma coluna de 3 metros de altura sob o mesmo carregamento (Figura 4).

Figura 3 - Emissões de $\mathrm{CO}_{2}$ durante a produção de alguns materiais de construção

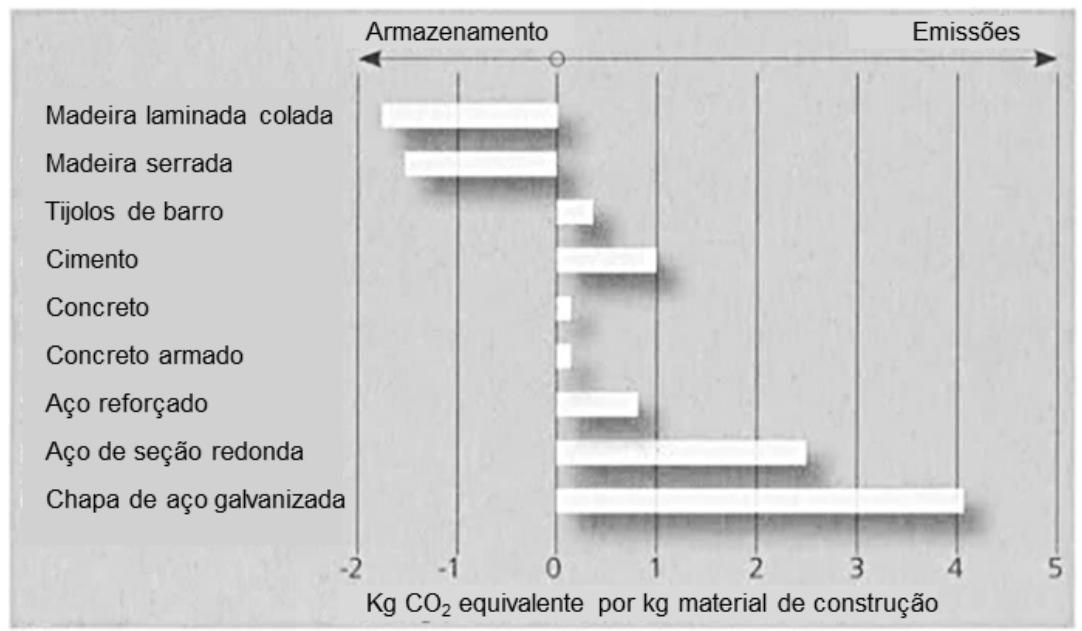

Fonte: Kolb (2008, p. 19), tradução nossa.

Figura 4 - Energia requerida na produção de uma coluna de 3 metros de altura em diferentes materiais sob o mesmo carregamento

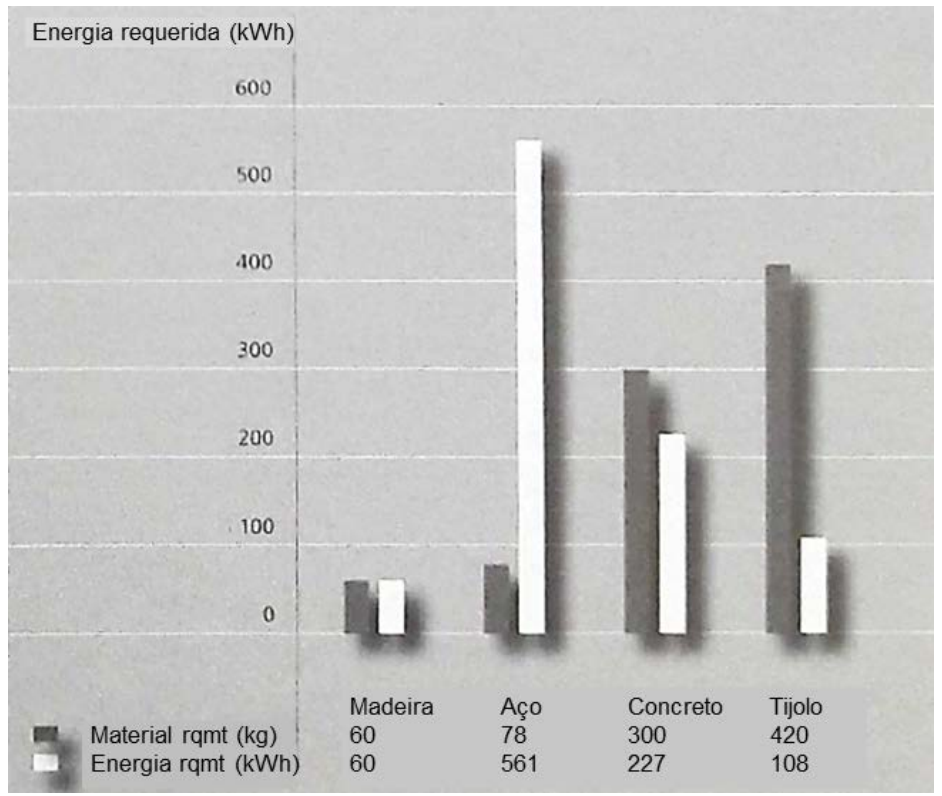

Fonte: Kolb (2008, p. 18), tradução nossa. 
Globalmente, os edifícios correspondem ao maior setor consumidor de energia da economia e representam mais de um terço do consumo de toda a energia final ${ }^{63}$ (35\% englobando os subsetores residenciais e de serviços) e quase metade da eletricidade consumida no mundo, segundo dados da publicação Transition to Sustainable Buildings: Strategies and Opportunities to 2050 da International Energy Agency - IEA ${ }^{64}$. Ao transporte são atribuídos $30 \%$ e à indústria outros $31 \%$ do consumo da energia final. Como resultado, os edifícios são também responsáveis por aproximadamente um terço das emissões globais de dióxido de carbono, levando em conta as emissões diretas e indiretas ${ }^{65}$ (IEA, 2013).

De acordo com Shimbo, Lopes e Ino (2016), nos últimos 20 anos houve um aumento de $50 \%$ no consumo global de energia. Nas cidades europeias, em torno de $50 \%$ do consumo de energia é resultante da construção e das atividades operacionais dos edifícios; outros $25 \%$ são atribuídos ao transporte e mais $25 \%$ à indústria. No Brasil, de acordo com dados da Eletrobras, os edifícios são responsáveis por $48 \%$ do consumo de eletricidade, considerando os setores residencial e comercial, sendo que a maior parte é decorrente da geração de conforto ambiental aos usuários. Apesar dos altos índices de consumo, segundo os autores, alguns estudos e estatísticas demonstram que há um potencial de conservação de energia de 30\% em edifícios existentes e de 50\% em edifícios novos.

A dinâmica de concentração populacional deve ser levada em consideração ao analisar esses números: em 1900, apenas 10\% da população mundial viviam nas

\footnotetext{
${ }^{63}$ Consumo de energia final é a soma do consumo dos diferentes usos finais como edifícios, indústria, transporte e agricultura.

${ }^{64}$ A IEA é uma agência autônoma com sede em Paris na França, estabelecida em 1974, após a $1^{\text {a }}$ crise do petróleo, para promover políticas de segurança e cooperação energética entre os países membros, através da responsabilidade coletiva por interrupções no fornecimento de petróleo, e para promover pesquisas relacionadas a formas de garantir energia limpa e acessível para os países membros e os demais. Entre os seus objetivos está a promoção de políticas de energia sustentável que estimulem o crescimento econômico e a proteção ambiental, particularmente em termos de redução das emissões dos GEE que contribuem para as mudanças climáticas. São 30 os países membros, todos membros da OECD - The Organisation for Economic Co-operation and Development - e 8 os associados, sendo que entre estes está o Brasil. A publicação Transition to Sustainable Buildings apresenta cenários e estratégias detalhadas para 2050 que visam alcançar uma grande redução de energia e emissões por meio da combinação das tecnologias disponíveis e de políticas públicas inteligentes.

${ }^{65}$ As emissões indiretas de $\mathrm{CO}_{2}$ referem-se às emissões decorrentes da geração de calor e eletricidade apenas.
} 
cidades. Em 2000, esse percentual saltou para 50\%, e as perspectivas para 2050 são de que 75\% residam em áreas urbanas (SHIMBO; LOPES; INO, 2016). Com um aumento populacional esperado de 2,5 bilhões de pessoas até 2050 , e tendo em vista desejadas melhorias no desenvolvimento econômico e nos padrões de vida, o uso de energia no setor de edifícios deve aumentar drasticamente, incidindo pressão adicional sobre o sistema energético (IEA, 2013).

Neste contexto, de uma economia eminentemente urbana, o setor da construção além de ser um grande consumidor de energia e proeminente emissor de GEE, é em contraponto, também considerado como o setor mais promissor para contribuir com a redução das emissões de $\mathrm{CO}_{2}$ e do consumo de energia. Tendo como exemplo, as tecnologias utilizadas na envolvente de um edifício e seus componentes determinam a quantidade de energia necessária para aquecer e esfriar o seu ambiente interno e, portanto, precisam ser otimizadas para obter maior eficiência energética.

Em um edifício de alto desempenho, um envoltório para um clima frio requer apenas $20 \%$ a $30 \%$ da energia necessária para aquecer uma construção convencional nos países da Organização de Cooperação Econômica e Desenvolvimento (OCDE). Em climas quentes, o potencial de economia de energia resultante da menor necessidade de energia para resfriamento é estimado entre 10\% e 40\%. Assim sendo, mais de $40 \%$ da economia esperada na demanda de energia de aquecimento e resfriamento em um cenário de baixo carbono pode ser diretamente atribuída a melhorias na envolvente do edifício (IEA, 2013).

Novas e avançadas práticas de construção começaram a se tornar normas em países europeus progressistas de clima frio. O programa Passivhaus, por exemplo, foi iniciado em 1990 na Alemanha e cresceu em todo o mundo nas últimas décadas. Nele se especificam requisitos de envoltórios de edifício muito rigorosos para garantir o conforto independente do clima. Estes edifícios requerem bem pouca energia para refrigeração e aquecimento. Isto é conseguido através de níveis extremamente altos de isolamento e infiltração de ar muito baixa. Neste âmbito, as tecnologias construtivas em madeira ganham proeminência. 
Dominique Gauzin-Muller, arquiteta e jornalista, autora de diversas publicações sobre Arquitetura em Madeira e Arquitetura Ecológica na Europa, afirma que para a maioria dos governos europeus, o combate ao efeito estufa passa pelo incremento do uso da madeira da construção. Sendo assim, incentivam o seu emprego de maneira que ela é cada vez mais utilizada em estruturas, revestimentos, painéis isolantes, fachadas externas, especialmente no setor da habitação, mas até mesmo em obras públicas. Sua utilização expressiva é uma das medidas que permitem minimizar a emissão de $\mathrm{CO}_{2}$ : “Quando transformamos uma árvore em material de construção, retardamos o momento em que o carbono, fixado pela fotossíntese, será lançado na atmosfera por decomposição ou combustão" (GAUZIN-MULLER, 2011, p. 38).

A União Europeia teve um papel motor na aplicação de alternativas ecológicas por meio da normalização comunitária e de programas experimentais sobre energia e conforto, energia solar e habitações passivas economicamente eficientes. Na Alemanha e na Áustria todos os atores - poder público, empreendedores, arquitetos e usuários se envolveram desde o final dos anos 80, com uma abordagem ambiental empírica. $\mathrm{Na}$ França, no Reino Unido e países nórdicos, a abordagem baseou-se em objetivos quantificáveis através de sistemas de avaliação que levaram em conta os resultados das obras experimentais (Ibidem, p. 33).

Visto que as exigências ambientais para as edificações estão se tornando mais estritas na legislação europeia, diversas pesquisas estão sendo conduzidas com o objetivo de avaliar e incrementar a eficiência do carbono associado aos materiais de construção e às técnicas construtivas para minimizar o consumo de energia primária e a pegada ambiental ao longo do ciclo de vida das construções. O Wood in carbon efficient construction - $\mathrm{ECO}^{66}$ foi um projeto de pesquisa coordenado pela Aalto University, entre os anos de 2010 a 2013, que envolveu vinte instituições de cinco países: Áustria,

\footnotetext{
${ }^{66}$ O principal financiador do projeto ECO2, coordenado pela Aalto University, foi o CEI-Bois. Os objetivos do projeto de pesquisa foram: 1. Criar uma compreensão holística da eficiência do carbono e do uso da energia primária no ciclo de vida completo de um edifício; 2. Definir o potencial técnico e os obstáculos para a utilização da madeira em construções eficientes em termos de carbono; 3. Desenvolver soluções práticas para calcular e otimizar a pegada de carbono de diferentes sistemas de construção em madeira, e; 4 . Divulgar os resultados científicos de forma eficiente para as partes interessadas relevantes, incluindo autoridades, legisladores e indústria da construção (KUITTINEN, LUDVIG e WEISS, 2013, p. 10, tradução nossa).
} 
Finlândia, Alemanha, Itália e Suécia, no intuito de provar cientificamente os efeitos positivos do uso da madeira na construção.

Como pressuposto, tem-se que a madeira é única entre os principais materiais de construção, por armazenar quantidades significativas de carbono da atmosfera em sua biomassa. Também requer menos energia para seu processamento e pode ser usada para bioenergia no final da vida útil do produto. Estas características naturais conferem vantagens ambientais aos materiais à base de madeira. Para conseguir isso, a eficiência do carbono e da energia primária deve ser considerada em toda a cadeia de produção de produtos, da silvicultura ao fim da vida. Por todos os motivos citados, Kuittinen (2013) sugere que o uso da madeira na construção poderia ser aumentado.

Da mesma forma, no contexto brasileiro, Punhagui (2014) defende que a inserção massiva da madeira nas edificações pode representar uma diminuição dos impactos negativos causados por grandes áreas urbanizadas. A pesquisadora tem como hipótese, em sua tese de Doutorado, que o aumento do uso da madeira na construção de habitações pode minimizar as emissões de dióxido de carbono e diminuir a energia incorporada do setor da construção civil no Brasil ${ }^{67}$.

Segundo a autora, o setor consome ao redor de $40 \%$ dos recursos naturais, $25 \%$ da água e $40 \%$ da energia, numa escala global, além de emitir entre $10 \%$ e $30 \%$ dos GEE. No Brasil, o setor de manufatura e construção é responsável por aproximadamente 27 a $29 \%$ das emissões de GEE pelo uso energético e, considerando as emissões totais do país, a mudança de uso do solo e o desmatamento foram responsáveis por 47 a 55\% dos gases de efeito estufa emitidos entre os anos de 2009 e 2010 (PUNHAGUI, 2014). Esses percentuais sofreram pequenas variações entre os anos de 2011 a 2017, segundo dados do Sistema de Estimativas de Emissões e Remoções de Gases de Efeito Estufa (SEEG) ${ }^{68}$, mas a mudança de uso da terra e florestas ainda é o maior setor emissor de $\mathrm{CO}_{2}$ do país, responsável por cerca de $50 \%$ das emissões.

\footnotetext{
${ }^{67}$ A autora cita em sua Tese diversos estudos internacionais no setor da construção civil que indicam, de um modo geral, que a madeira é um recurso com menor intensidade de energia incorporada e menor emissão de carbono quando comparada a materiais como o aço e o concreto (GARCIA, 2014).

68 Informações disponíveis em: http://plataforma.seeg.eco.br/total_emission. Acesso em: 16 jun. 2019.
} 
Com grande potencial produtivo, o Brasil tem a segunda maior superfície florestal do mundo - atrás apenas da Rússia - sendo que sua extensão ocupa aproximadamente 59\% do território nacional, entre florestas nativas e plantadas. São estimados 500 milhões de hectares de florestas nativas e 10 milhões de hectares de florestas plantadas, de acordo com dados do Serviço Florestal Brasileiro (SFB, 2018) ${ }^{69}$. Os estudos de Campos (2012) e Punhagui (2014) comparam a produção de madeira serrada proveniente de floresta nativa tropical, originária da Amazônia, por extração seletiva convencional e de plantações de espécies exóticas (pinus e eucalipto).

As emissões para o produto oriundo de madeira nativa foram de 16,26 t $\mathrm{CO}_{2} / \mathrm{t}$. No caso das madeiras obtidas a partir de florestas plantadas, os valores verificados foram bem menores, em função do curto período de formação da floresta e das estratégias de compensação e tecnologias de aproveitamento dos resíduos. A partir do conceito de carbono neutro aplicado às florestas plantadas, as emissões de $\mathrm{CO}_{2}$ na produção de uma tonelada seca de madeira serrada são da ordem de 0,15 t $\mathrm{CO}_{2} / \mathrm{t}$. Da mesma forma, considerando um processo de extração de baixo impacto, como o realizado segundo procedimentos de manejo florestal adequados, os resíduos poderiam ser considerados neutros em carbono, pois a quantidade emitida é equivalente à absorvida, o que mudaria os resultados das emissões para 0,14 t CO 2 /t (PUNHAGUI, 2014).

Se comparadas às emissões verificadas na produção do cimento, do aço e da cal que de acordo com Lima \& John (2010) e Agopyan \& John (2011) são da ordem de 0,69 a 1,0 t $\mathrm{CO}_{2} / \mathrm{t}$ - a quantidade de emissão verificada tanto na extração da madeira serrada plantada como na extração da madeira nativa por manejo florestal, apresenta valores razoavelmente menores. Desse modo, o problema das emissões de $\mathrm{CO}_{2}$ na produção de madeira nativa resulta do modelo extrativista implantado, a extração seletiva convencional, sendo que os resíduos gerados por esse processo devem, de acordo com

\footnotetext{
${ }^{69}$ A estimativa da área de florestas naturais é feita pelo Serviço Florestal Brasileiro tendo como referência o mapa de vegetação do Instituto Brasileiro de Geografia e Estatística - IBGE (2018) estimada por biomas brasileiros, que em 2017 foi equivalente a 490.251 hectares. Dados do Boletim do Sistema Nacional de Informações Florestais - SNIF 2018. Disponível em: www.florestal.gov.br/documentos/publicacoes/4092boletim-snif-2018-ed1. Acesso em: 16 jun. 2019.
} 
Punhagui (2014), ser contabilizados e considerados como o principal problema ambiental dessa cadeia de produtos.

A partir da análise desses dados é possível entender que é o modelo de exploração das florestas nativas que gera grande impacto e desequilíbrio ambiental. É também a partir desse entendimento que se podem criar perspectivas para uma maior conscientização no intuito de desmistificar a percepção equivocada de que o uso intensivo da madeira poderia colaborar com o desmatamento das florestas tropicais.

O modelo de extração convencional gera uma enorme quantidade de resíduos e deve ser substituído por práticas mais adequadas, alinhadas a um modelo de desenvolvimento comprometido com a permanência, a preservação e a sustentabilidade em todas as suas dimensões, para que, desta forma, a madeira seja efetivamente considerada como material de baixo carbono quando utilizada para fins de longa duração.

Apesar de o Brasil ser um dos maiores produtores e exportadores mundiais de produtos madeireiros, especialmente celulose, a demanda interna por produtos para a construção civil ainda é muito baixa comparada a países com florestas equivalentes, como Estados Unidos e Canadá. A pouca influência da madeira no mercado da edificação pode ser observada nos números levantados pela Pesquisa Nacional por Amostra de Domicílios - PNAD do IBGE (2018) ${ }^{70}$ em relação ao material predominante nas paredes externas dos domicílios, segundo as grandes regiões do país (Gráfico 11).

Em todas as regiões, predominam domicílios com paredes externas de alvenaria/taipa com revestimento, variando de 64,3\% na Região Norte, a 94,4\% na Região Sudeste. Nas Regiões Norte e Sul, a presença de domicílios com paredes

\footnotetext{
${ }^{70}$ A Pesquisa Nacional por Amostra de Domicílios - PNAD do Instituto Brasileiro de Geografia e Estatística IBGE, investiga, trimestralmente, as características gerais dos domicílios e dos moradores por grandes regiões do Brasil. No que diz respeito aos domicílios, o informativo traz comentários analíticos sobre as seguintes informações: tipo e condição da moradia; material predominante nas paredes, piso e telhado; serviços essenciais de saneamento básico, que abarcam o abastecimento de água, a presença de banheiro e esgotamento sanitário, o destino do lixo, e a disponibilidade de energia elétrica; bem como a posse de bens e serviços, contemplando, por exemplo, a posse de telefone móvel celular ou fixo convencional, geladeira, máquina de lavar roupa, televisão, microcomputador, carro e motocicleta. Informação disponível em: https://biblioteca.ibge.gov.br/index.php/biblioteca-catalogo?view=detalhes\&id=2101654. Acesso em: 16 jun. 2019.
} 
externas de madeira considerada apropriada para construção (aparelhada), em proporções de 22,3\% e 15,8\%, respectivamente, se mostrou bem superior à média nacional de 4,4\% (IBGE, 2018). Essas diferenças regionais se devem principalmente à disponibilidade da madeira, uma vez que as regiões Norte e Sul são regiões onde a proximidade com as florestas influenciou a cultura construtiva local.

Gráfico 11 - Material predominante nas paredes externas dos domicílios brasileiros por regiões

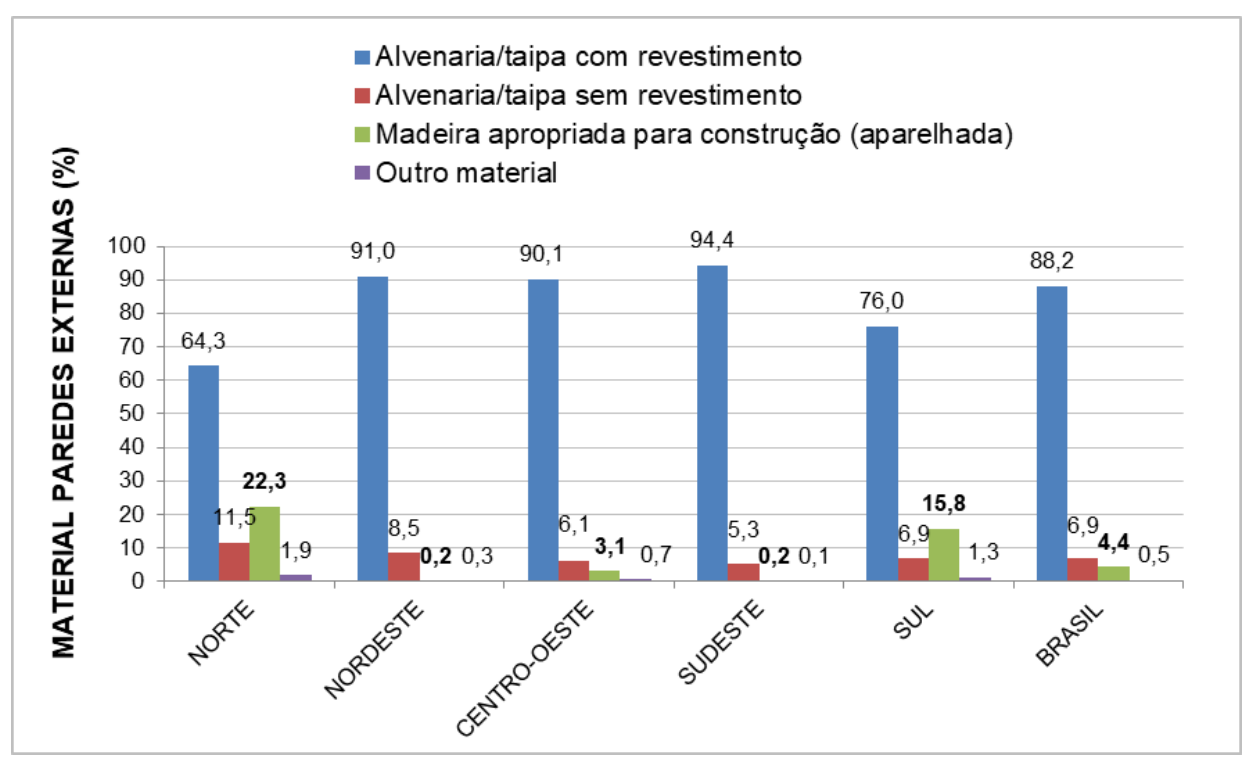

Fonte: PNAD IBGE $\left(2018\right.$, p. 3) ${ }^{71}$, adaptado pela autora.

Estes dados quantitativos são bastante expressivos, uma vez que corresponde a $88,2 \%$ dos domicílios brasileiros (62,6 milhões) construídos com paredes externas em alvenaria, ou taipa revestida, o que indica tacitamente a hegemonia deste sistema construtivo no setor habitacional.

Como enfrentar, então, a hegemonia da alvenaria e do concreto armado e propor a madeira como alternativa construtiva eficiente?

${ }^{71}$ Disponível em: https://biblioteca.ibge.gov.br/visualizacao/livros/liv101654_informativo.pdf. Acesso em: 16 jun. 2019. 


\section{REFERÊNCIAS}

AGOPYAN, V.; JOHN, V. M. O desafio da sustentabilidade na construção civil. São Paulo: Bluncher, 2011. v. 5.

BRUNDTLAND, G. H. Nosso futuro comum. Rio de Janeiro: Fundação Getúlio Vargas, 1991.

CAMPOS, E. F. Emissão de CO2 da madeira serrada da Amazônia: o caso da exploração convencional. 2012. Dissertação (Mestrado em Engenharia de Construção Civil) - Escola Politécnica da Universidade de São Paulo, São Paulo, 2012.

EPA. United States Environmental Protection Agency. Causes of Climate Change. [online]. 2016. Disponível em: http://www3.epa.gov/climatechange/science/causes.html. Acesso em: 01 fev. 2016.

GAUZIN-MULLER, D. Arquitetura Ecológica. São Paulo: Editora Senac São Paulo, 2011.

HERZOG, T. et al. Construire en bois. 3. ed. Lausanne: Presses Polytechniques et Universitaires Romandes, 2007.

IBGE. Pesquisa Nacional por Amostra de Domicílios - PNAD 2018. Rio de Janeiro, 2019. Disponível em:

https://biblioteca.ibge.gov.br/visualizacao/livros/liv101654_informativo.pdf. Acesso em: 16 jun. 2019.

IEA. Transition to sustainable buildings: strategies and Opportunities to 2050, Executive summary. 2013. Disponível em:

http://www.iea.org/media/training/presentations/etw2014/publications/Sustainable_Buil dings_2013.pdf. Acesso em: 15 ago. 2016.

KAUFMANN, H.; NERDINGER, W. Building with Timber: paths into the future. Prestel Publishing, 2012.

KOLB, J. Systems in Timber Engineering. Ed. Lignum - Holzwirtschaft Schweiz / DGfH - German Society of Wood Research, 2008.

KUITTINEN, M. The relevance of carbon footprint assessment for the woodworking and construction sectors. In: KUITTINEN, M., LUDVIG, A., WEISS, G. (ed.). Wood in Carbon Efficient Construction: tools, methods and applications. Belgium: CEI-Bois, 2013. p. 14-15. 
KUITTINEN, M., LUDVIG, A., WEISS, G. (ed.). Wood in Carbon Efficient Construction: tools, methods and applications. Belgium: CEl-Bois, 2013. Disponível em:

https://www.researchgate.net/publication/281275478_Wood_in_carbon_efficienc_constr uction_Tools_methods_and_applications. Acesso em: 09 dez. 2015.

LIMA, J. A. R.; JOHN, V. M. Avaliação das consequências da produção de concreto no Brasil para as mudanças climáticas. Boletim Técnico da Escola Politécnica da USP. São Paulo, 2010.

PUNHAGUI, K. R. G. Potencial de reducción de las emisiones de CO2 y de la energía incorporada en la construcción de viviendas en Brasil mediante el incremento del uso de la madera. 2014. Tese (Doutorado em Engenharia). Universidade Politécnica da Catalunha, Barcelona, 2014.

SERVIÇO FLORESTAL BRASILEIRO. Boletim SNIF 2018, n. 1, 2018. Disponível em: www.florestal.gov.br/documentos/publicacoes/4092-boletim-snif-2018-ed1. Acesso em: 16 jun. 2019.

SHIMBO, L. Z.; LOPES, J. M. de A.; INO, A. Low-carbon building technologies: wood and new paradigms for architecture In: INTERNATIONAL SUSTAINABLE DEVELOPMENT RESEARCH SOCIETY CONFERENCE, 22, 2016, Lisboa. Anais [...]. Lisboa: Universidade Nova de Lisboa, 2016. 


\subsection{Exemplos do uso da madeira na arquitetura na atualidade}

Ao considerar a conjuntura exposta no capítulo anterior e o potencial da madeira em responder adequadamente aos desafios dos tempos atuais, procurei elencar uma série de exemplos de obras que confirmam a existência de alternativas de projetos e de técnicas construtivas que expressam uma linguagem arquitetônica contemporânea ao mesmo tempo em que consideram os requisitos de eficiência anteriormente mencionados. Expressam ainda, possibilidades construtivas que abarcam distintas realidades e oportunidades de industrialização.

São obras realizadas em alguns países da Europa, como Áustria, Alemanha e Reino Unido, da América do Norte, Canadá em especial, e América do Sul, Chile e Brasil. Foram escolhidas principalmente em função da importância que têm dentro do contexto sociocultural em que se inserem; pelas características de experimentação no desenvolvimento de novos métodos construtivos, de aproveitamento do material e de racionalização da produção; sem perder de vista a busca pela identidade e expressividade do material na Arquitetura local.

O empreendimento experimental Olzbundt, em Dornbirn, Áustria, construído no ano de 1997, representa uma interpretação contemporânea da tradição local de construção em madeira da região do Vorarlberg (Figura 5). Experimental por seu sistema construtivo e conceito energético, o edifício de habitação coletiva com treze apartamentos associa formas simples em um volume otimizado para evitar perdas térmicas e uma tecnologia de pré-fabricação que foi capaz de reduzir o tempo de obra para quatro meses e meio. A estrutura baseia-se em um sistema padronizado de painéis de parede não estruturais, pilares e painéis de piso (Figura 6) desenvolvido pelo arquiteto Hermann Kaufmann e o escritório de projetos Merz Kaufmann Partner, com a colaboração da empresa construtora especializada em madeira Kaufmann Holz AG. 
Figura 5 - Edifício de habitação coletiva em Dornbirn, Áustria. Arq.: Hermann Kaufmann, 1997
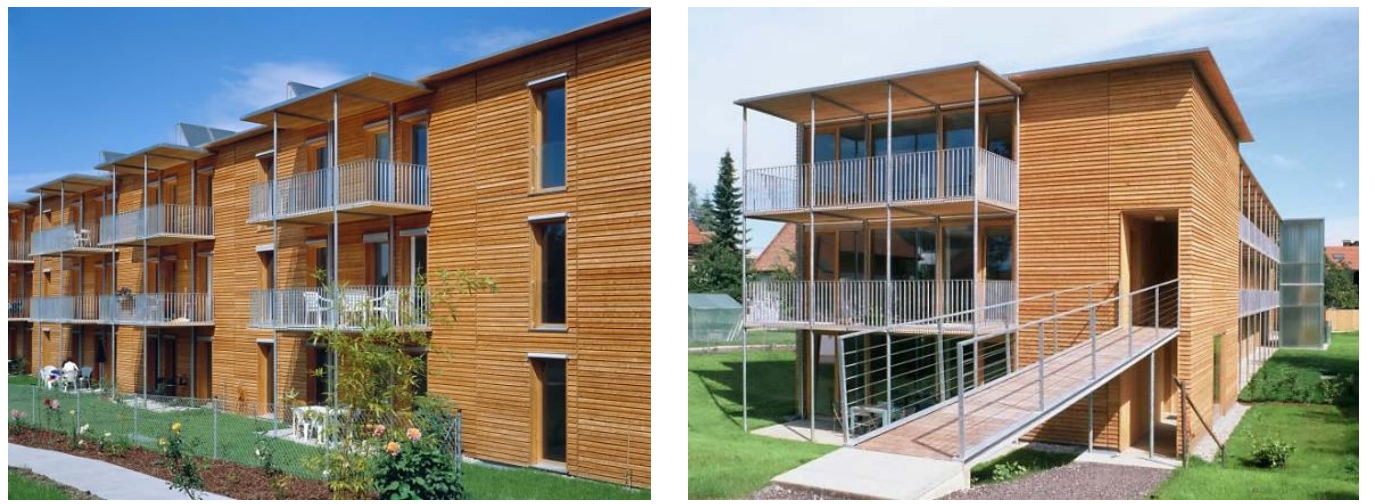

Fonte: Website HK ARCHITEKTEN. Hermann Kaufmann + Partner ZT GmbH ${ }^{72}$

Figura 6 - Elementos pré-fabricados do sistema construtivo do edifício em Dornbirn, Áustria: painéis de parede não estruturais (esquerda e centro), pilares e painéis de piso (direita)
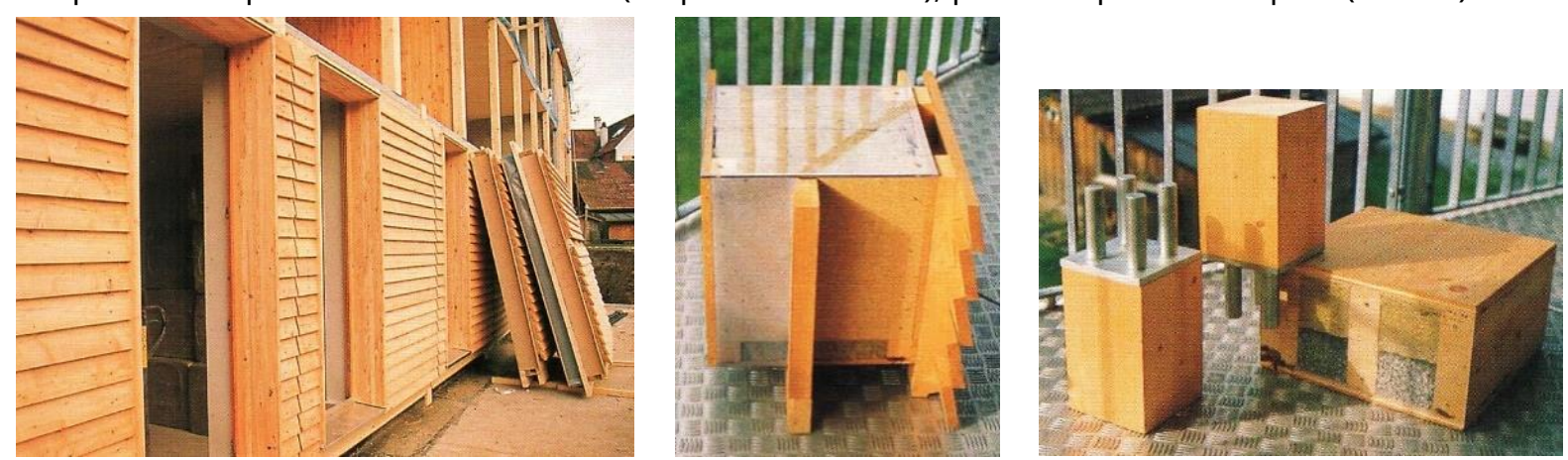

Fonte: Gauzin-Muller (2011, p. 160/161).

Este empreendimento, idealizado por um grupo de jovens autoproclamados "artistas da construção do Voralberg", desenvolveu novos modelos de Arquitetura e de Urbanismo que economizam terreno, energia e material. É um exemplo representativo de uma Arquitetura que combina produção artesanal e industrial para criar um modo de viver de acordo com as necessidades da sociedade contemporânea.

Ao ressaltar uma simplicidade que não tem nada que ver com banalidade, eles expressam sua preferência por uma arquitetura e soluções técnicas realistas. Procuram o equilíbrio entre o que é tecnicamente possível e o que é socialmente justificável, e entre o que é estruturalmente razoável e esteticamente desejável (GAUZIN-MULLER, 2011, p. 34).

\footnotetext{
${ }^{72}$ Disponível em: https://www.hkarchitekten.at/en/projects/oelzbuendt/. Acesso em: 19 out. 2018.
} 
Para Dominique Gauzin-Muller (2011) o sucesso das obras do Voralberg está ligado à competência e ao pragmatismo dos arquitetos, dos projetistas e das empresas, onde a colaboração entre esses parceiros desde os primeiros esboços favorece o surgimento de propostas criativas e inovadoras, adaptadas às condições específicas de cada projeto. De acordo com a autora, no centro e no norte da Europa o ambientalismo é um fenômeno cultural e representa um verdadeiro poder político e econômico: "constrói-se segundo uma lógica que coloca o homem e sua relação com a natureza no centro da reflexão" (Ibidem, p. 33).

Mais recentemente, outras obras de edifícios habitacionais na Áustria seguiram essas premissas. O edifício Mühlweg e a residência estudantil Seestadt Aspern, Figura 7 e Figura 8 respectivamente, são projetos de habitação coletiva social em madeira de padrão de baixa energia, construídas em ambientes urbanos nos arredores de Viena para atender à demanda de vivendas de altos padrões ecológicos tipo Passive Houses.

Figura 7 - Edifícios habitacionais Mühlweg, Viena, Áustria. Arq.: Kaufmann \& Kaufmann, 2008
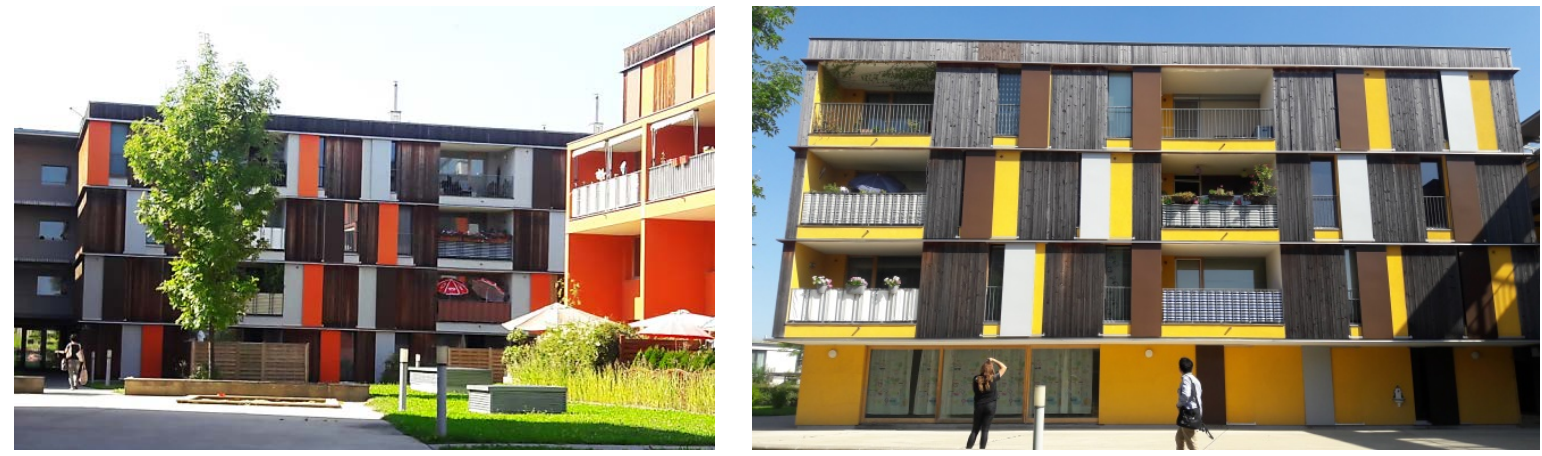

Fonte: arquivo pessoal (Visita técnica Timber in Vienna WCTE 2016).

Figura 8 - Edifícios habitacionais Seefeld, Arq.: Ulrich Huhs, Anna Wickenhauser, 2014 e PopUp dorms - Student residence Seestadt Aspern, Arq.: F2 Architekten ZT GmbH, 2015, Viena, Áustria.
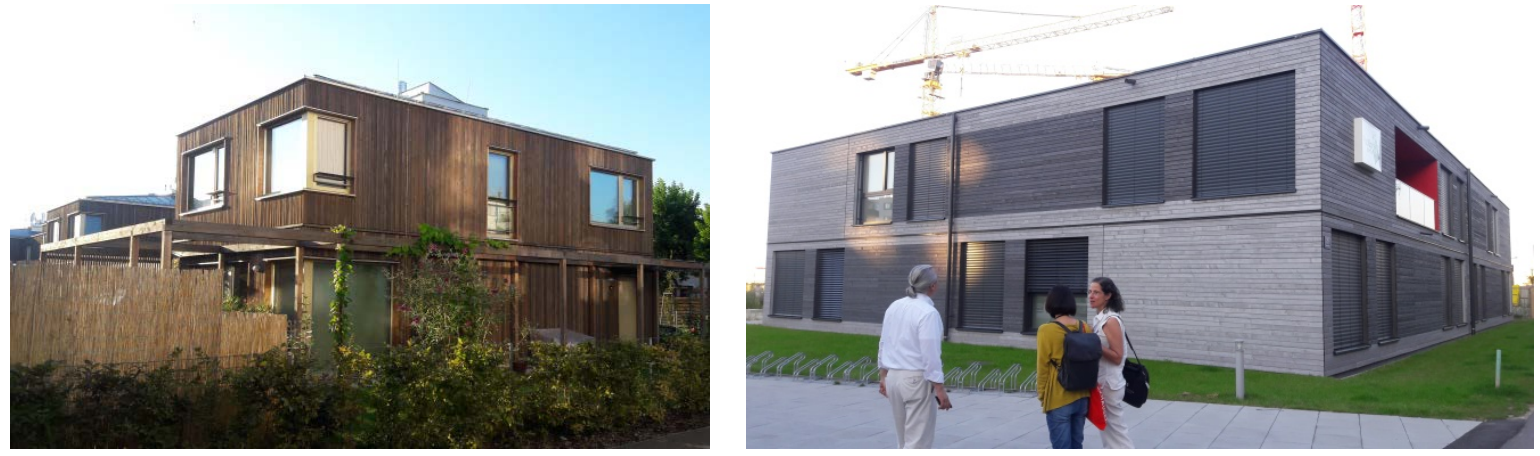

Fonte: arquivo pessoal (Visita técnica Timber in Vienna WCTE 2016). 
No que se refere a edifícios públicos, em particular os equipamentos escolares, a arquitetura também pode ter um papel pedagógico importante incentivando a formação de um espírito cívico quanto à qualidade do meio ambiente desde a infância. $\mathrm{Na}$ escola infantil de Pliezhausen, na Alemanha (Figura 9), o excedente da cisterna de recuperação das águas pluviais alimenta um biótopo que serve de apoio à educação ecológica das crianças. O projeto dos arquitetos D'Inka + Scheible, resulta do desejo de conciliar ecologia e economia. O princípio construtivo é baseado na repetição de uma trama de 1,25 m entre montantes verticais, o que facilitou a pré-fabricação e montagem, reduzindo custos e tempo de obra em seis meses. A estrutura mista associa painéis de paredes portantes com estrutura em madeira lamelada colada e painéis de paredes não portantes. Os revestimentos de paredes e tetos no interior são feitos por painéis de compensado e no exterior, por elementos de fechamento de lâminas remontadas de madeira de lariço aparelhado, sem nenhum tratamento químico nem acabamento superficial, bem como nos brises e pisos dos terraços (Figura 10).

Figura 9 - Escola maternal Pliezhausen, Alemanha. Arquitetos D'Inka + Scheible, 1999

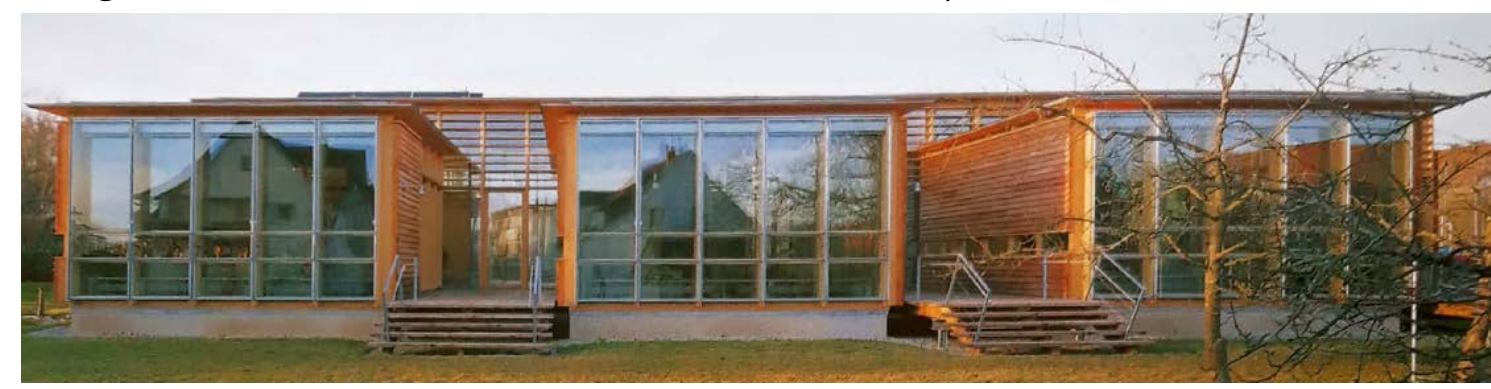

Fonte: Gauzin-Muller (2011, p. 194).

Figura 10 - Escola maternal Pliezhausen: estrutura mista associa painéis de paredes portantes, estrutura de madeira lamelada colada e painéis de paredes e não portantes
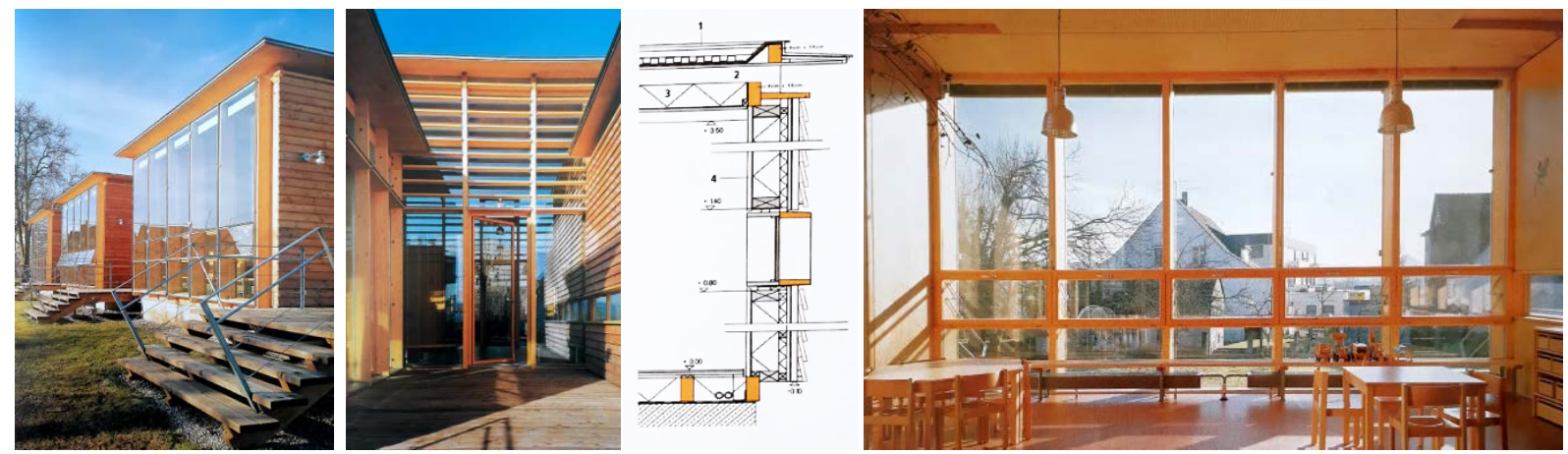

Fonte: Gauzin-Muller (2011, p. 193/196). 
As tecnologias em madeira sólida abriram caminho a novos projetos, como os edifícios em altura construídos a partir de estruturas mistas de MLC (Madeira Lamelada Colada ou, em inglês, GLULAM - Glued Laminated Timber) e painéis de madeira sólida como o CLT (Cross Laminated Timber ou Madeira Lamelada Cruzada). Entre eles os icônicos Stadthaus em Londres, Reino Unido, com nove andares (Figura 11), o Wood Innovation and Design Centre em Prince George (Figura 12) e o recém-concluído edifício de moradia estudantil da University of British Columbia - UBC, Brock Commons Tallwood House, em Vancouver, com 18 andares (Figura 13), ambos no Canadá.

Figura 11 - Stadthaus, Londres, Reino Unido. Arquiteto: Waugh Thistleton, 2009
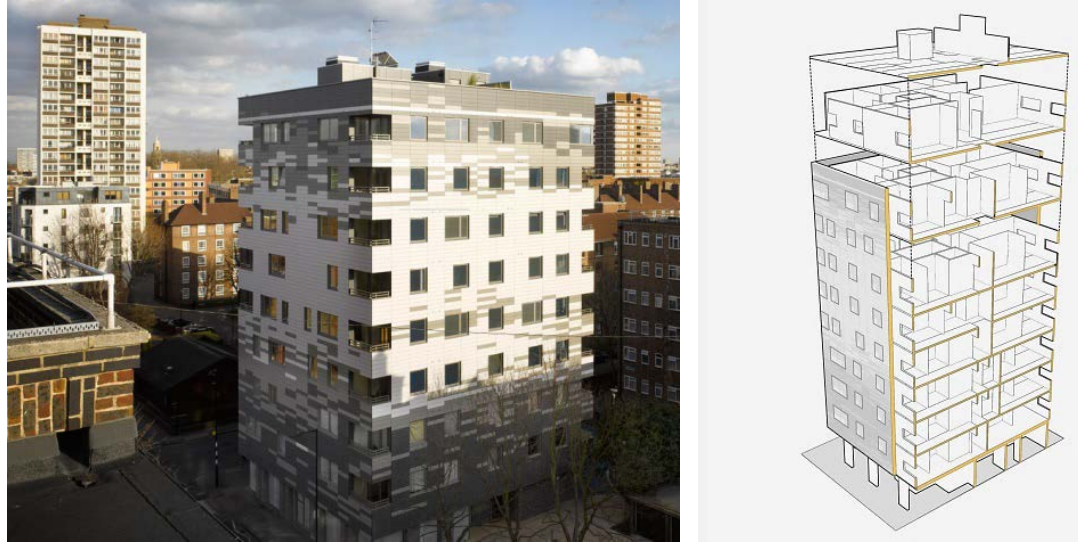

Fonte: Website WAUGH THISTLETON ARCHITECTS ${ }^{73}$.

Figura 12 - Wood Innovation and Design Centre, Prince George, Canadá. Arq.: Michael Green, 2014
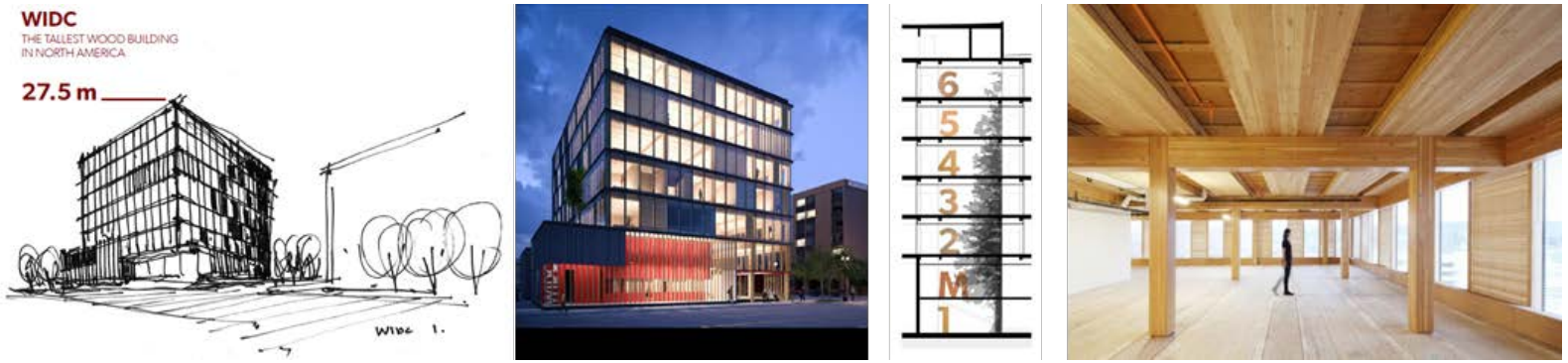

Fonte: Website MICHAEL GREEN ARCHITECTURE ${ }^{74}$.

\footnotetext{
73 Disponível em: http://waughthistleton.com/murray-grove/. Acesso em: 08 set. 2018.

74 Disponível em: http://mg-architecture.ca/work/wood-innovation-design-center/. Acesso em: 08 ago. 2017.
} 
Figura 13 - Edifício de habitação estudantil Brock Commons Tallwood House, University of British Columbia - UBC, Vancouver, BC, Canadá. Arquiteto: Acton Ostry Architects, 2014
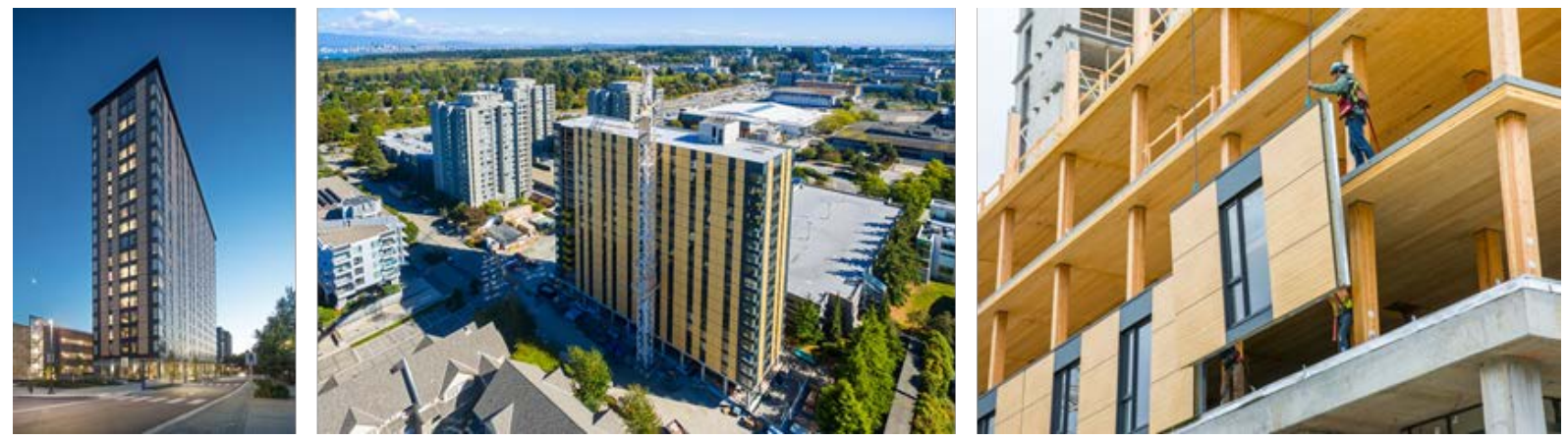

Fonte: Website ACTON OSTRY ARCHITECTS e ArchDaily ${ }^{75}$.

Os edifícios retratados compõe um referencial de obras contemporâneas que expõe soluções tecnológicas diversas as quais buscam responder às premissas de uma construção em bases mais sustentáveis, não apenas em termos ambientais e econômicos, mas também em sua dimensão social que envolve a organização do trabalho. A tendência à padronização e à pré-fabricação gera a possibilidade de transferência de horas de canteiro de obras para a fábrica, na qual o trabalho é realizado em condições técnicas controladas e os resíduos são mais facilmente geridos.

Novos arranjos produtivos podem ser explorados em face às mais distintas realidades territoriais e culturais em que a obra se insere. Sob esse ponto de vista, procura-se desviar de discursos que usam os sistemas de construção sustentáveis como alternativas suficientes em si, isoladas do processo social que eles determinam. A tecnologia deve ser abordada desde uma perspectiva de construção social que engloba a compreensão da cadeia produtiva como um processo de transformação social através da capacitação e da formação laboral.

Se por um lado a padronização e a pré-fabricação são tendências no cenário europeu e norte-americano, em continente sul-americano esta ainda não é uma realidade, o que não necessariamente representa uma limitação. O emprego de baixa tecnologia na produção não significa menor qualidade de projeto e construção. Os sistemas chamados de low-tech permitem maior acessibilidade ao método de produção

\footnotetext{
75 Disponível em: https://www.actonostry.ca/project/brock-commons-tallwood-house/ e http://www.archdaily.com.br/br/879671. Acesso em: 08 ago. 2017
} 
e consequentemente maior pulverização de produtores e democratização da tecnologia, fatores fundamentais para obtenção de um equilibrado tripé sustentável (AFLALO, 2011).

A arquitetura chilena é um exemplo disso e tem se destacado no cenário internacional como produção material de sua identidade sociocultural e territorial. Não foram poucos os edifícios emblemáticos concebidos e construídos em madeira nas últimas três décadas em território chileno, nas mais diversas escalas. Desde os pequenos formatos como a Casa de Tongoy de Mathias Klotz (Figura 14), aos Pavilhões para a Expo Sevilha 1992, de José Cruz e Germán del Sol (Figura 15) e a mais recente Expo Milão 2015, de Cristián Undurraga, edifício reconstruído em Temuco no Sul do Chile (Figura 16).

Figura 14 - Casa Klotz, Tongoy, Chile. Arquiteto Mathias Klotz, 1991
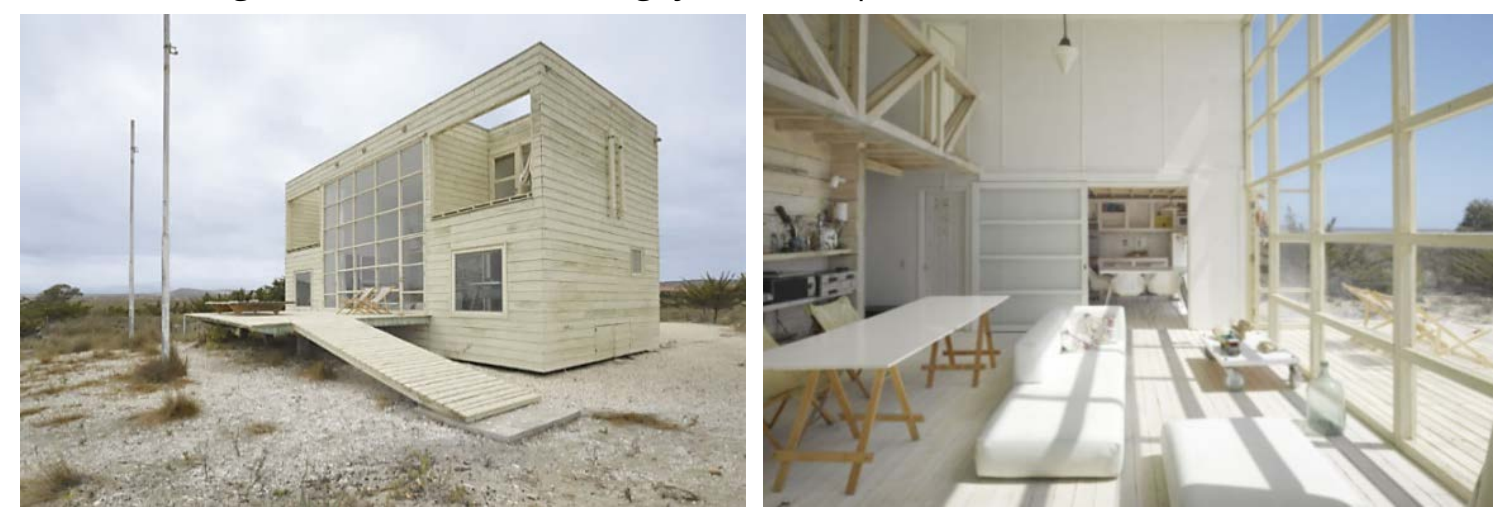

Fonte: Website Matias KLOTZ ${ }^{76}$.

Figura 15 - Pavilhão do Chile na Expo Sevilha 1992. Arquitetos José Cruz e Germán del Sol, 1990
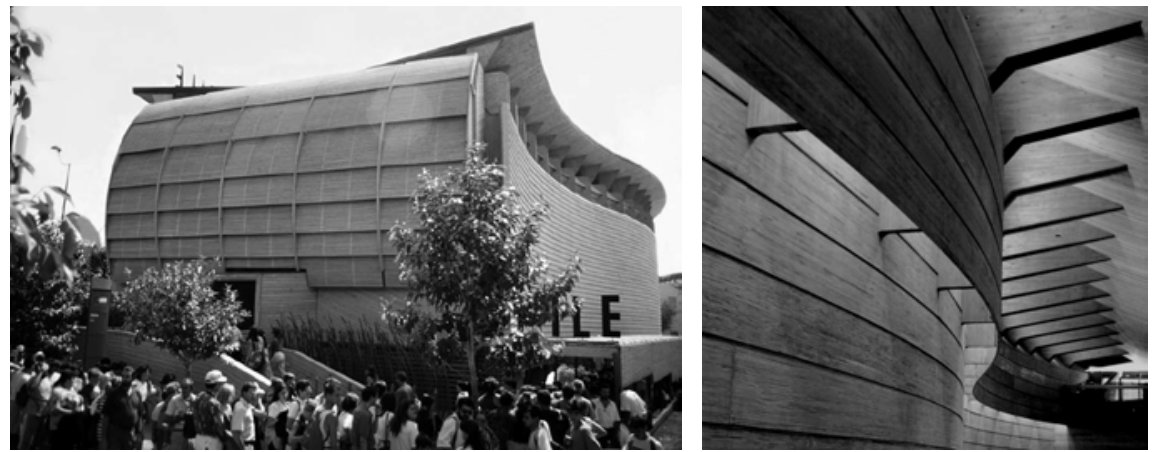

Fonte: Torrent (2010, p. 143/144).

${ }^{76}$ Disponível em: https://www.mathiasklotz.com/es/casa-klotz/. Acesso em: 19 out. 2018. 
Figura 16 - Pavilhão do Chile na Expo Milão 2015. Arquiteto Cristian Undurraga, 2013

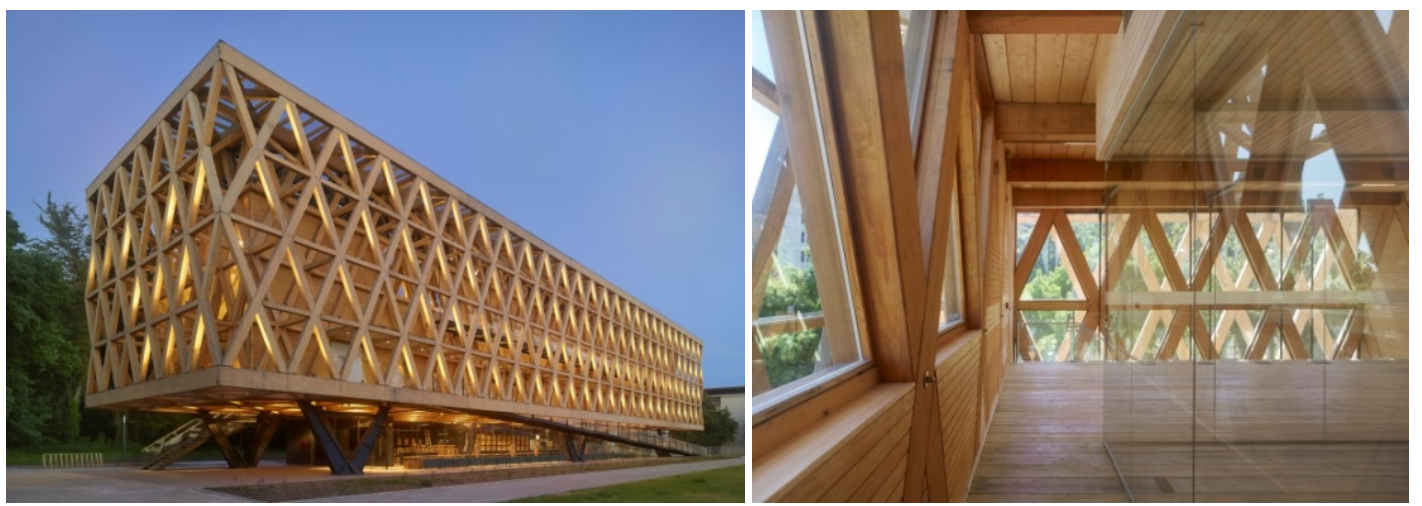

Fonte: Website Plataforma Arquitectura ${ }^{77}$.

O pavilhão chileno na Feira Mundial de Sevilha foi emblemático não apenas pela preocupação com as formas de regionalismo e de tradição da madeira, mas também porque era um signo do Estado da Arte, exibindo uma concepção diferente da cultura arquitetônica. Na opinião de Horácio Torrent (2010), acadêmico da Pontifícia Universidade Católica do Chile, o pavilhão transpôs as virtudes da madeira no espaço ao mostrar sua dialética entre o tato e a visão. Tectonicamente, relacionou o método de construção diretamente à expressividade do material e superou, através do tratamento da luz, as razões pelas quais a forma se mantém aberta a um entendimento claro, resultando em uma experiência distraída e participativa.

O uso deste material de essência nobre de múltiplas formas foi parte do empenho para tratar de incorporar a madeira de forma definitiva à consciência arquitetônica local, o que ocorreu conjuntamente com a definição do Chile como um país madeireiro e seu consequente impulso no plano industrial e econômico (TORRENT, 2017). No caso chileno, a madeira tem sido um material com forte protagonismo durante séculos, onde boa parte da Arquitetura popular, tradicional e regional foi construída em terra e madeira, assim como grandes conjuntos patrimoniais foram erguidos em madeira, como as igrejas de Chiloé, declaradas Patrimônio da Humanidade pela UNESCO.

77 Disponível em: https://www.plataformaarquitectura.cl/cl/892049/pabellon-de-chile-expo-milan-2015undurraga-deves-arquitectos. Acesso em: 19 out. 2018. 
Embora embasada numa prática estabelecida historicamente, para Torrent (2017) a tradição recente do uso da madeira na arquitetura chilena se suporta em uma prática de tradição moderna, constituída desde meados do século XX. Nela, a materialidade da madeira é potencializada pela relação direta da resolução técnica das partes e conexões com sua capacidade expressiva, nas dimensões tátil e cultural. A forma de utilização do material, a partir daí, resultou em uma nova dimensão espacial que soube explorar a sensibilidade que a madeira traduz.

Essa tradição recente foi forjada em seus primórdios em uma relação um
tanto esquiva e pragmática, no âmbito de uma consideração parcial - a
partir de suas possibilidades de montagem - para incrementar-se mais
tarde como uma expressão tectônica e numa retórica cultural que só um
material como a madeira poderia propiciar, tencionando a relação entre a
abstração moderna e sua situação territorial, e para afirmar-se
definitivamente na busca de uma nova espacialidade e uma originalidade
formal advinda da sublimação da madeira como material estrutural e
superficial simultâneo; algo palpável em alguns dos seus principais casos
paradigmáticos (TORRENT, 2017, p. 70, tradução nossa).

Obras industriais, institucionais e corporativas destacam-se no atual cenário da arquitetura chilena em madeira como a Vinícola Pérez Cruz no Vale do Maipo Alto, de José Cruz Ovalle (Figura 17), o Colégio San Francisco Javier em Puerto Montt, de Martín Hurtado Covarrubias (Figura 18) e o Hotel Tierra Patagonia no Parque Nacional de Torres del Paine, de Cazú Zegers (Figura 19).

Figura 17 - Viña Pérez Cruz, Huelquén, Valle de Maipo Alto, Chile. Arquiteto José Cruz, 2000

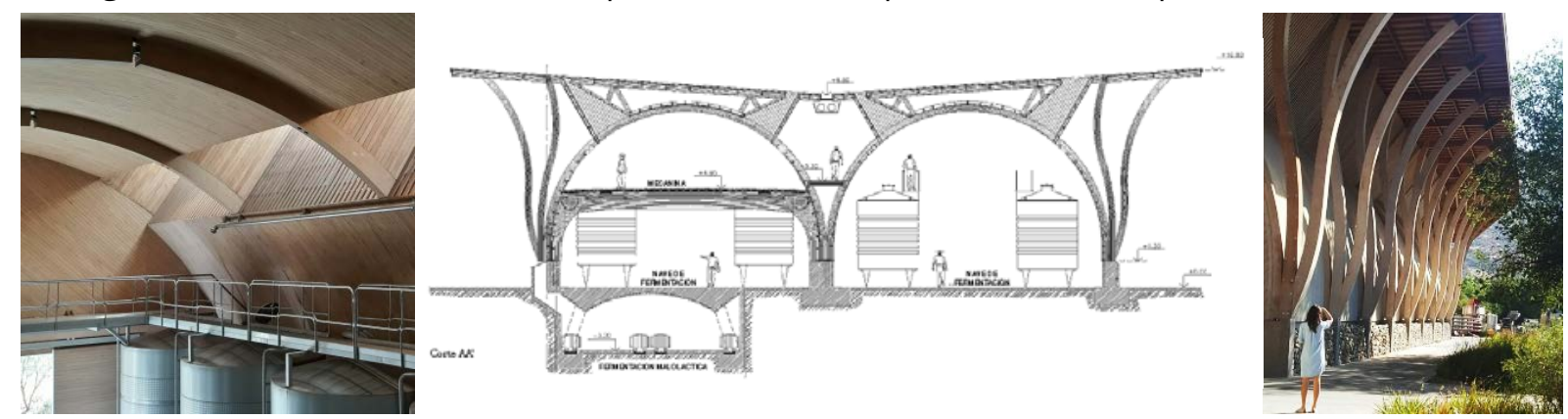

Fonte: Revista $\mathrm{ARQ}^{78}$ e arquivo pessoal.

${ }^{78}$ Disponível em: https://scielo.conicyt.cl/pdf/arq/n51/art15.pdf. Acesso em: 12 jul. 2019. 
Figura 18 - Colégio San Francisco Javier, Puerto Montt, Chile. Arquiteto: Martín Hurtado, 2007
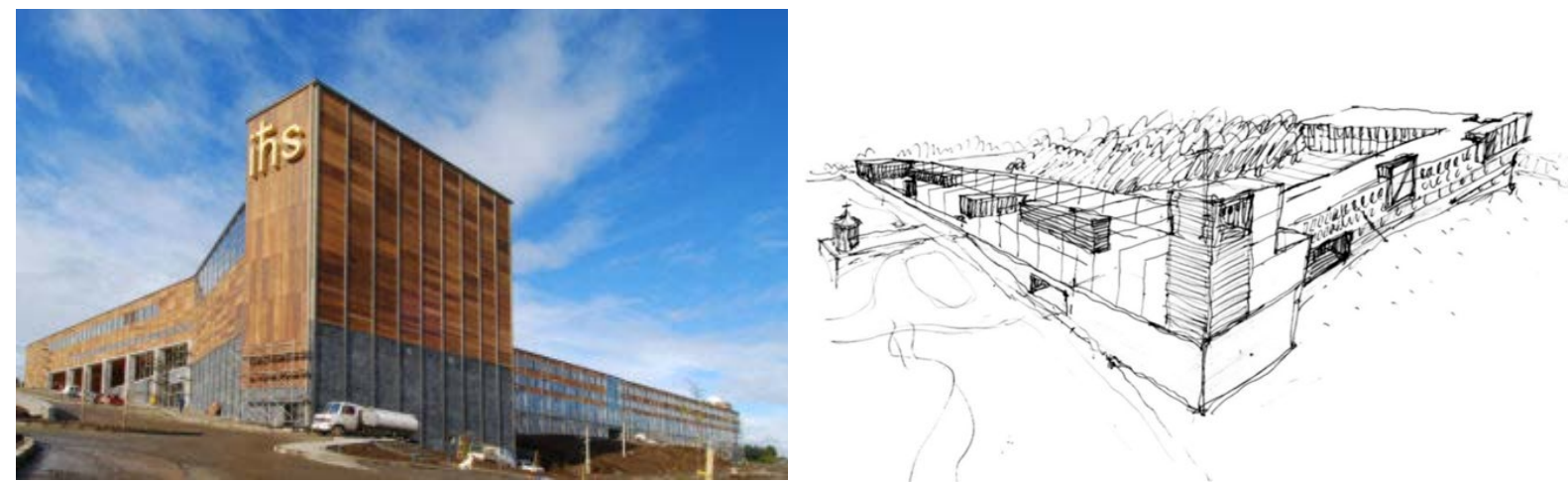

Fonte: Website de Martín Hurtado Arquitectos ${ }^{79}$.

Figura 19 - Hotel Tierra Patagonia, Torres del Paine, Chile. Arquiteta Cazú Zegers, 2011
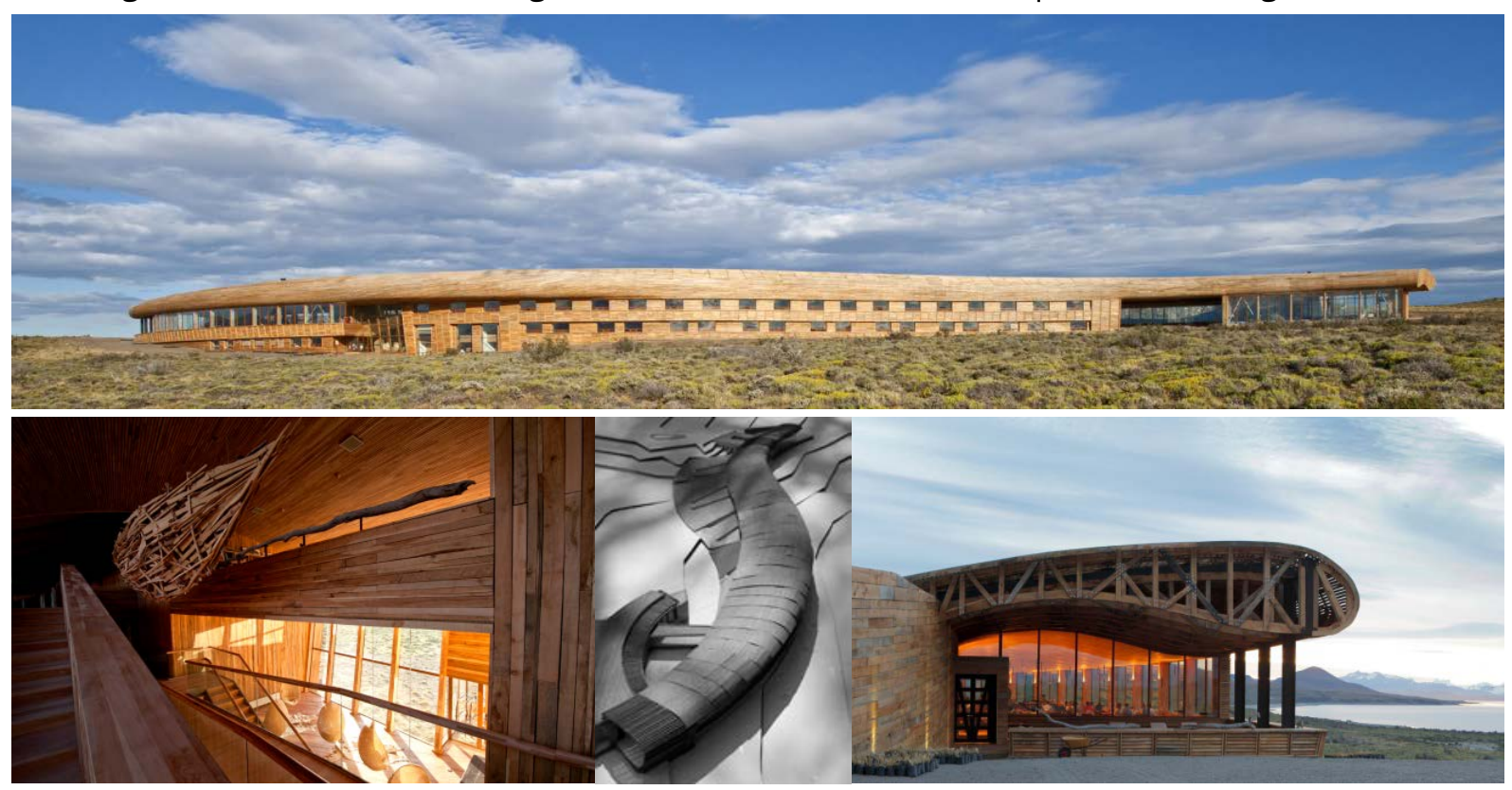

Fonte: Website de Cazú Zegers ${ }^{80}$.

As obras trazem uma linguagem contemporânea de utilização da madeira, que exploram a expressividade do material através de uma significação que busca uma identidade com o território. Na obra da vinícola Pérez Cruz, José Cruz inspirou-se na vegetação nativa e sua apertada ramagem no desenho da estrutura tripla de pilares curvos de MLC no perímetro do edifício que, junto ao fechamento curvo, formam abóbodas permeadas por um ritmo de ar e luz em tramas de ventilação e iluminação.

\footnotetext{
79 Disponível em: http://www.martinhurtado.cl/. Acesso em: 12 jul. 2019.

80 Disponível em: https://www.cazuzegers.cl/proyectos/hotel-tierra-patagonia. Acesso em: 12 jul. 2019.
} 
No Hotel Tierra Patagônia - Hotel del Viento - o gesto do edifício surge das formas que desenha o vento, elemento natural característico da zona. Cazú Zegers buscou não invadir a paisagem metafísica do lugar, senão somar-se a ela. Para a arquiteta, formada pela Escola de Valparaíso, a imagem do edifício é a de um antigo fóssil de um animal pré-histórico encalhado na margem do lago.

Tanto no Chile como na região do Voralberg, na Áustria, a madeira fazia parte da cultura construtiva local como material tradicionalmente empregado nas edificações, mas passou por uma ressignificação onde novos valores foram agregados ao material somando-se à suas qualidades naturais. O que chama a atenção nos dois casos é a perspectiva de elaboração de uma arquitetura que combina produção artesanal e industrial para criar um novo modo de construção e de identidade pautado nas condições locais de produção material.

\section{E no Brasil? Quais as condições necessárias para o desenvolvimento de uma} arquitetura contemporânea em madeira de identidade nacional?

Em um momento em que a madeira destaca-se internacionalmente com uma linguagem e expressão própria e ganha proeminência na pesquisa por materiais construtivos renováveis como alternativa alinhada à lógica do desenvolvimento sustentável, o Brasil pouco investe para viabilizar o uso do material de forma mais extensiva na construção de edifícios.

A tradição construtiva em alvenaria de tijolos cerâmicos e concreto ainda é um fator limitante ao emprego eficiente da madeira em construções, normalmente utilizada para fins não nobres e de curto ciclo de vida como, por exemplo, escoras e formas de concreto armado, sendo posteriormente descartada. Na opinião do arquiteto Marcelo Aflalo "ainda está longe o dia em que o legado colonial na construção do Brasil será substituído por uma visão mais ampla e com valores mais adequados ao desenvolvimento de uma cultura sustentável" (AFLALO, 2011, p. 14).

Apesar da vasta superfície florestal e potencial produtivo, o interesse pela madeira como matéria prima para a construção foi bastante reduzido também durante o período moderno. A madeira, até então associada à rusticidade e a construção 
artesanal, parecia incompatível com o esforço de modernização do país. No entanto, o descompasso entre uma arquitetura que aparentava extrema modernidade e as condições em que se dava sua produção evidenciava as profundas contradições de sua condição social de desigualdade.

Na passagem dos anos 80 para os 90, a casa Hélio Olga Jr. em São Paulo (Figura 20), projetada por Marcos Acayaba, e executada pela ITA Construtora, abriu um caminho arquitetônico capaz de explorar características essenciais da madeira como resistência, leveza e capacidade de articulação, afastando-se de atributos pitorescos de robustez e rusticidade normalmente associados ao material. Dado o impacto que teve no meio arquitetônico paulista, nacional e mesmo internacional, essa casa terminou por revelar possibilidades formais e construtivas novas, que se desdobraram de modo frutífero (WISNIK, 2005).

Figura 20 - Casa Hélio Olga Jr., São Paulo. Arquiteto: Marcos Acayaba, 1990

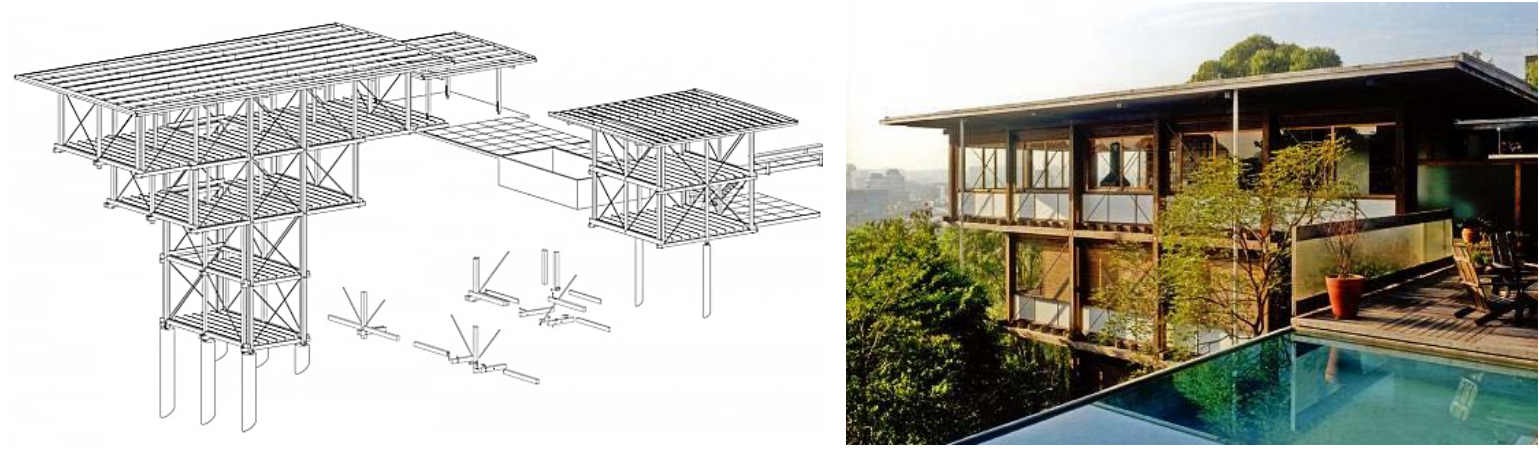

Fonte: Aflalo (org.) (2005, p. 65).

A partir dessa experiência a madeira passou a ser progressivamente aceita no rol dos sistemas construtivos empregados por arquitetos paulistas, mas ainda assim, sendo empregada essencialmente em edificações de segunda residência, associada às construções de praia e de montanha.

A Vila Taguaí em Carapicuíba, projeto da arquiteta Cristina Xavier, é um empreendimento imobiliário que foi concebido como uma alternativa inovadora de construção de espaços de moradia e ocupação de áreas verdes na periferia de São Paulo. A Vila conta com oito residências elevadas do solo implantadas de modo a 
manter o máximo possível do terreno e da vegetação natural; as edificações utilizam o máximo de iluminação e ventilação natural e possuem aquecimento de água com energia solar.

Uma estreita colaboração entre Engenharia e Arquitetura viabilizou a proposição do sistema construtivo, que se baseia em painéis modulares de madeira para paredes, lajes de piso e lajes de cobertura (Figura 21), pensados a partir do aproveitamento de peças de madeira nativa de pequenas dimensões. As dimensões finais de cada painel facilitam a pré-fabricação na oficina, o armazenamento, o transporte e a montagem em obra.

Figura 21 - Vila Taguaí, Carapicuíba. Cristina Xavier Arquitetura, 2010. Painéis modulares para paredes, lajes de piso e lajes de cobertura

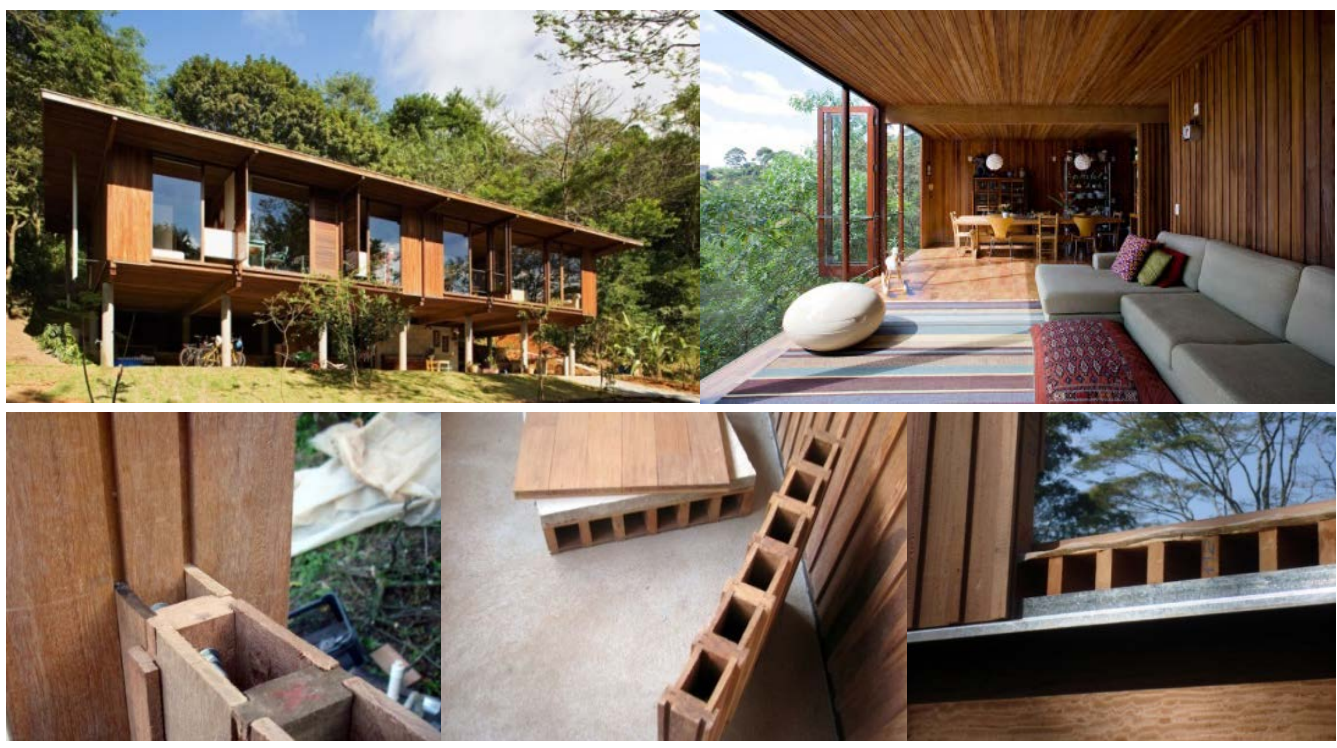

Fonte: Website ArchDaily. Fotografia Daniel Ducci ${ }^{81}$

Outras obras da arquitetura brasileira podem ser citadas como exemplos da busca por uma interpretação contemporânea do uso da madeira e do uso de tecnologias construtivas industrializadas, entre elas a Casa Folha dos arquitetos Mairenes e Patalano, em Angra dos Reis-RJ (Figura 22), construída em estrutura de madeira lamelada colada pela Esmara Estruturas de Madeira; a MINIMOD da MAPA arquitetos (Figura 23) - uma exploração projetual, tecnológica e experiencial que se apresenta

${ }^{81}$ Disponível em: https://www.archdaily.com.br/br/627775/vila-taguai-cristina-xavier-arquitetura. Acesso em: 12 ago. 2017. 
como uma releitura contemporânea do abrigo primitivo - construído em painéis de madeira lamelada cruzada pela Crosslam/CG Sistemas, em São Luís do Paraitinga-SP; e a recente obra das Moradias Infantis da Fundação Bradesco, projeto dos arquitetos Rosenbaum e Aleph Zero, em Formoso do Araguaia-TO (Figura 24), construída em madeira lamelada colada de eucalipto pela ITA Construtora, a qual destaca-se por receber vários prêmios de Arquitetura nacionais e internacionais.

Figura 22 - Casa Folha, Angra dos Reis-RJ. Arquitetos: Mairenes e Patalano, 2008

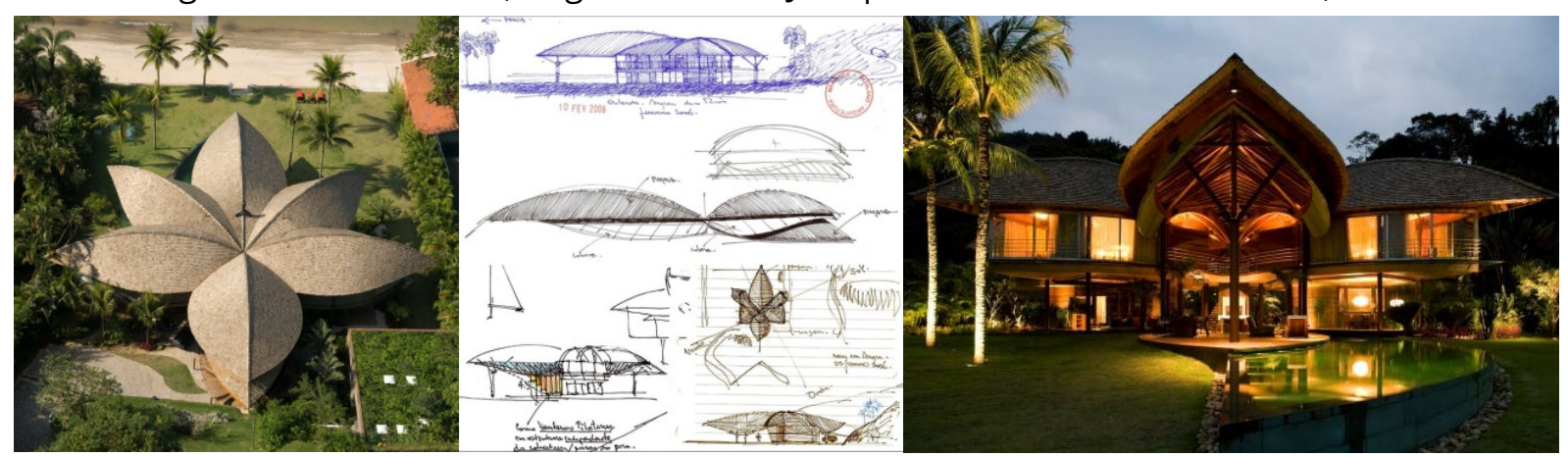

Fonte: Website ArchDaily. Fotografia Leonardo Finotti ${ }^{82}$

Figura 23 - MINIMOD, Fazenda Catuçaba, São Luís do Paraitinga-SP. MAPA Arquitetura, 2015
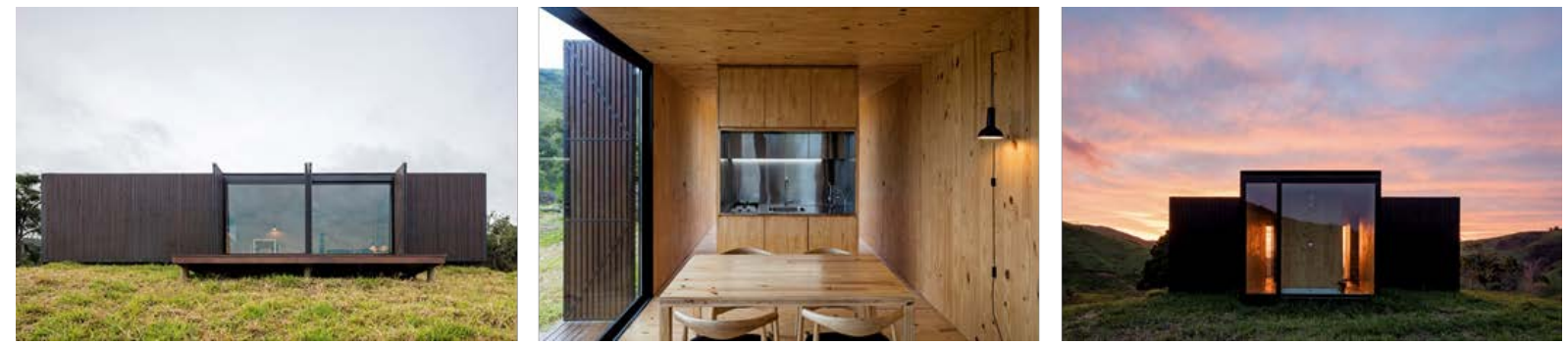

Fonte: Website ArchDaily. Fotografia Leonardo Finotti ${ }^{83}$

${ }^{82}$ Disponível em: https://www.archdaily.com.br/14796/casa-folha-mairenes-mais-patalano. Acesso em: 12 jul. 2019.

${ }^{83}$ Disponível em: https://www.archdaily.com.br/br/802165/minimod-catucaba-mapa. Acesso em: 12 jul. 2019. 
Figura 24 - Moradias Infantis, Formoso do Araguaia-TO. Arq.: Aleph Zero e Rosenbaum, 2017

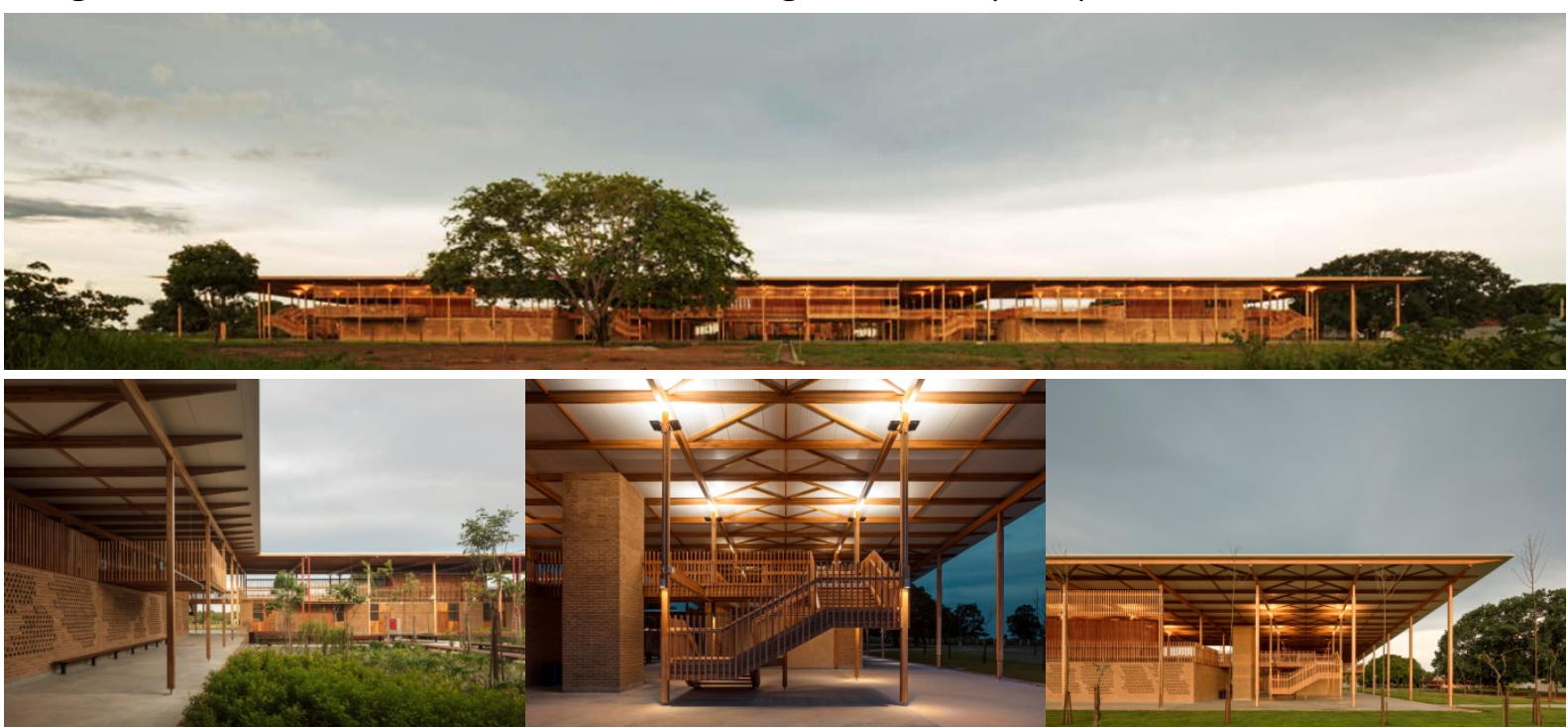

Fonte: Website ArchDaily. Fotografia Leonardo Finotti ${ }^{84}$

Para além da questão cultural que envolve a tradição construtiva brasileira, que de uma maneira geral não promove a madeira como material construtivo de identidade nacional, estão outras questões ligadas a lacunas na cadeia produtiva industrial madeireira, a falta de políticas públicas de incentivo ao setor e a escassez de formação e capacitação profissional para o projeto e a construção com madeira. Entende-se que falta uma visão mais ampla das suas possibilidades de aplicação estrutural e construtiva por parte daqueles que projetam, calculam, especificam e constroem.

Os exemplos aqui ilustrados, no entanto, deixam claro o potencial de projeto e de construção que temos em mãos. Frente a isso, cabe a reflexão: quais os agentes devem ser mobilizados para que a madeira seja uma opção competitiva e economicamente viável para a construção civil no Brasil?

Não restam dúvidas de que o impulso da construção em madeira requer a formação de técnicos especializados, arquitetos, engenheiros e construtores, e também de fornecedores, empresas, investigadores e acadêmicos capacitados para movimentar o setor. Mas essa não é uma carência brasileira apenas.

${ }^{84}$ Disponível em: https://www.archdaily.com.br/br/879961/moradias-infantis-rosenbaum-r-plus-aleph-zero. Acesso em: 12 jul. 2019. 
Dominique Gauzin-Muller já alertava para essa mesma questão quando da publicação original de seu livro L'architecture Écologique, em $2001^{85}$, ao mencionar que a oferta de arquitetos, construtores e empresas francesas era insuficiente para suprir a demanda crescente de mercado. Neste ínterim, porém, a França criou diversos programas específicos de formação técnica, acadêmica e profissional com vistas a responder a essa demanda. Em 2013, o governo francês identificou o setor da construção em madeira como um setor de desenvolvimento chave para o país lançando o programa Nouvelle France Industrielle (NFI), uma estratégia do setor público-privado para garantir o futuro econômico do país com base em indústrias modernas e progressistas (LANATA; MICHAUD, 2018).

De acordo com estes autores, o programa nacional tem a ambição de impulsionar a construção em madeira em grande escala, de alta e média altura nos próximos anos. Para impulsionar a iniciativa, o setor da construção em madeira lançou a ADIVBOIS Associação para o Desenvolvimento da Construção de Madeira Residencial. Isso inclui provedores de madeira e produtos madeireiros, empresas de construção especializadas em madeira, arquitetos, designers, pesquisadores, acadêmicos e representantes de governos locais e centrais, em uma sinergia comum.

Da mesma forma, o Chile enfrenta desafios similares, e têm organizado ações no sentido de envolver todos os elos da cadeia produtiva da construção em madeira, de maneira colaborativa e intersetorial, articulando as três hélices propulsoras da inovação: estado, indústria e academia. Para isso, foi criado o Centro de Innovación en Madera CIM UC, com o objetivo de estabelecer relações estratégicas de médio e longo prazo entre as empresas, o setor público e as universidades, que permitam alcançar resultados de alto impacto social ${ }^{86}$.

Alguns dos resultados de pesquisa apontam para uma coerência entre a abordagem de ensino diferenciada praticada pelas escolas de arquitetura e a alta

\footnotetext{
${ }^{85}$ Traduzido para o português sob o título "Arquitetura Ecológica" e publicado pela Editora SENAC, em 2011.

${ }^{86}$ Informação proferida pelo professor da PUC Chile, Juan José Ugarte, diretor do CIM UC e presidente de CORMA, em palestra durante o XVI EBRAMEM + III CLEM realizado de 26 a 28 de março de 2018 em São Carlos-SP
} 
qualidade da emergente arquitetura contemporânea chilena. Da mesma forma, os exemplos europeus e canadenses acompanham essa correspondência. Nos capítulos que seguem, e especialmente na Parte 4 desta Tese, serão abordados aspectos relacionados ao ensino através de exemplos de práticas didáticas realizadas em diversos países com o objetivo de promover a formação de profissionais mais aptos para a arquitetura das construções em madeira. 


\section{REFERÊNCIAS}

AFLALO, M. (org.) Madeira como estrutura: a história da Ita. São Paulo: Paralaxe, 2005.

. Prefácio à edição brasileira. In: GAUZIN-MULLER, D. Arquitetura

Ecológica. São Paulo: Editora Senac São Paulo, 2011. p. 9-21.

GAUZIN-MULLER, D. Arquitetura Ecológica. São Paulo: Editora Senac São Paulo, 2011.

LANATA, F.; MICHAUD, F. Teaching timber construction in learn-by-doing format through the construction of a full-scale house. In: WORLD CONFERENCE ON TIMBER ENGINEERING - WCTE, 2018, Seoul. Proceedings [...]. Seoul, Republic of Korea : Mondial Congress \& Events, 2018.

TORRENT, H. Abstraction and Tectonics in Chilean Architecture since 1950. In: OYARZÚN, F. P.; PÉREZ DE ARCE, P.; TORRENT, H. Chilean Modern Architecture since 1950. Texas: A\&M University Press, 2010. p. 91-155.

. Madera: materia de la arquitectura moderna. Materia Arquitectura, Santiago, n.15, p. 68-81. 2017.

WISNIK, G. Industrialização e flexibilidade: arquitetura em São Paulo a partir de componentes em madeira. In: AFLALO, M. (org.) Madeira como estrutura: a história da Ita. São Paulo: Paralaxe, 2005. p. 35-57. 


\subsection{Potencialidades do uso da madeira no ensino de arquitetura}

A madeira é considerada por muitos autores como um material fundamental para a construção de projetos experimentais uma vez que aborda satisfatoriamente uma série de objetivos educacionais. Apresenta muitas vantagens para o ensino do comportamento mecânico das estruturas através da experimentação prática; é um material leve e relativamente barato, que permite construções secas e não requer maquinário e ferramentas complexas para sua modelagem; viabiliza a construção de modelos e protótipos em escala real, o que muitas vezes não é possível com outros materiais; permite processos mais precisos, mesmo considerando ferramentas de baixa tecnologia e construção em canteiro de obra. Sua utilização em projetos práticos facilita processos de aprendizagem e contribui em grande parte para o sucesso das atividades em termos de obtenção de habilidades pelos alunos (DESCAMPS et al., 2018; SCHMITT; ARROYO, 2018; SCHULITZ; GERSHFELD, 2016).

Além destas vantagens, os projetos estruturados em madeira têm uma particularidade em relação a outros materiais que é a capacidade de ser representado em escala reduzida usando o mesmo material de sua concepção, com grande fidelidade ao projeto original, expressando com clareza o sistema construtivo escolhido, bem como sua concepção estrutural. Esta particularidade pode, em níveis mais avançados de pesquisa, encontrar uma proporcionalidade de resistência do material do projeto real com o modelo (VALLE, 2000).

Assim como defende o professor Ivan do Valle, para o professor Cervantes ${ }^{87}$, a madeira é o melhor material para aprendizagem com modelos reduzidos: é possível reduzir uma peça de madeira mantendo ainda suas características enquanto elemento. É difícil fazer isso com aço, com concreto ou com agregados. O comportamento da madeira é similar em 1:1 e em escala reduzida.

\footnotetext{
${ }^{87}$ Os professores Ivan do Valle, da Universidade de Brasília, e Cervantes Ayres Filho, da Universidade Federal do Paraná, são arquitetos e professores das áreas de Projeto e de Tecnologia e foram entrevistados pela autora. Mais detalhes das entrevistas serão abordados no capítulo 4.3 desta Tese.
} 
O arquiteto chileno José $\mathrm{Cruz}^{88}$, autor de importantes obras retratadas no capítulo anterior, destaca a dimensão tátil da madeira que permite uma relação de medida com nosso próprio corpo, sempre a partir de peças que se unem, facilitando o seu entendimento e manuseio.

Quando digo tátil quero dizer que se você estudou a madeira, você
entende que um par de linhas paralelas na planta de uma construção de
madeira não tem consistência, não é capaz de representar a sua realidade.
No concreto, ou na alvenaria, essas duas linhas paralelas representam
perfeitamente uma parede, enquanto na madeira não são nada, porque a
madeira está constituída por peças: milhares de peças, milhares de juntas e
descontinuidades. Neste sentido, é preciso ir a cada peça, a cada uma, e
por maiores que sejam as peças de madeira nunca perdem relação com o
nosso próprio corpo, porque mesmo na madeira laminada, onde as peças
podem ser muito longas, a sua secção não deixa de estar relacionada em
tamanho com o nosso corpo (CRUZ O., 2012, p. 15, tradução nossa).

Se por um lado, o fato de uma obra em madeira sempre se apresentar a partir de sua decomposição - ou seja, de peças que a conformam - facilita o seu entendimento, por outro lado, traz uma maior complexidade em termos de sua representação. Duas linhas paralelas em planta que numa obra de alvenaria ou concreto representam uma parede, em uma obra de madeira não representam nada. A construção em madeira é basicamente pura descontinuidade: múltiplas peças para unir e, portanto, múltiplos encontros para resolver. Para Cruz, essa relação com a unidade e com os tamanhos de cada unidade constitui uma espécie de ordem tátil, palpável, uma vez que essa unidade de cada peça possui uma dimensão corporal.

Em conversa com outro arquiteto chileno, Martin Hurtado ${ }^{89}$, professor da Pontificia Universidad Católica de Chile e conferencista do XV EBRAMEM - evento no qual apresentou destacados projetos de seu escritório - Ihe perguntei a respeito da formação dos estudantes de arquitetura em relação a conteúdos técnicos específicos sobre a madeira, uma vez que, como vimos, o Chile é hoje reconhecido por sua importante produção arquitetônica em madeira. Relatou-me sobre sua experiência

\footnotetext{
88 Em entrevista concedida ao arquiteto Phillipe Blanc, publicada na Revista CA 150, edição de outono de 2012.

${ }^{89}$ Em entrevista informal realizada durante o Encontro Brasileiro em Madeiras e em Estruturas de Madeira - XV EBRAMEM, em Curitiba, no dia 09 de março de 2016.
} 
docente na PUC Chile onde a cada semestre um dos Talleres - ateliês de projeto oferecidos pelo curso é dedicado exclusivamente à elaboração de um projeto temático em madeira, com o objetivo de desenvolver propostas que serão selecionadas para participação em concurso nacional envolvendo todas as universidades do país.

Segundo Hurtado, um dos organizadores do concurso, a iniciativa faz parte da Semana de la Madera - evento anual organizado pela Corporación Chilena de la Madera $\operatorname{CORMA}^{90}$, em Santiago - aberto a participação de estudantes universitários e de institutos profissionais de todo o país. O Concurso de Arquitetura em Madeira tem entre os seus objetivos: reconhecer na arquitetura uma ferramenta fundamental para a utilização da madeira em condições de habitabilidade, através de propostas que realizem um aporte a sustentabilidade nos projetos arquitetônicos; fomentar a investigação, inovação e aplicação de novas tecnologias em madeira; estimular a criatividade nos estudantes, visualizando o material em todo seu espectro de possibilidades; promover o trabalho de profissionais e futuros profissionais com a madeira, potencializando o Chile como um país destacado na construção em madeira inovadora e de qualidade ${ }^{91}$.

A Figura 25 traz imagens da exposição dos projetos apresentados no Concurso de Arquitetura de 2018, durante a Semana de la Madera realizada no Centro Cultural Gabriela Mistral em Santiago do Chile. Nesta ocasião, ao redor de 100 projetos concorreram entre as categorias Arquitetura, Design, Engenharia e Inovação. Além das pranchas de apresentação gráfica, os participantes devem entregar maquetes físicas do projeto em três escalas distintas: uma de implantação e contextualização com a escala

${ }^{90}$ CORMA é uma associação gremial chilena que reúne cerca de 170 atores do setor florestal, cobrindo mais de 55\% de hectares plantados do país y 85\% das exportações florestais. Foi fundada em 1952, com o objetivo de fomentar o sector florestal, a indústria baseada em recursos renováveis mais importante do país. Disponível em: http://www.corma.cl/quienes-somos. Acesso em: 15 abr. 2016.

${ }^{91}$ Tradução da autora. Além do Concurso de Arquitetura em Madeira, que em 2016 teve sua $11^{a}$ edição, também ocorreu o Concurso de Design, em sua $5^{a}$ edição, com os temas Jardines Infantiles y Salas Cuna para Chile e Equipamiento para Jardines Infantiles y Salas Cuna para Chile respectivamente. As bases do Concurso Arquitectura en Madera 2016 estão disponíveis em: http://www.semanadelamadera.cl/wpcontent/uploads/2016/07/Bases-Concurso-Arquitectura-Corma-2016.pdf. Acesso em: 15 abr. 2016. 
urbana, uma da solução proposta para o edifício, e outra de um detalhe construtivo relevante explicando as soluções construtivas do projeto ${ }^{92}$ (Figura 26).

Figura 25 - Projetos do Concurso de Arquitetura em Madeira CORMA. Semana de la Madera, Santiago de Chile, agosto de 2018
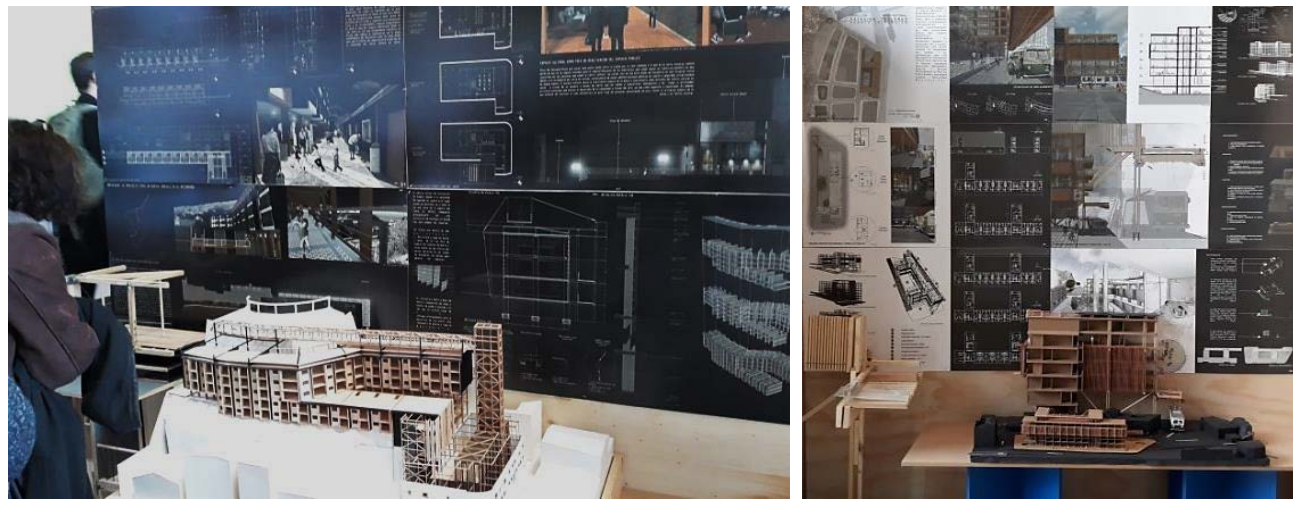

Fonte: arquivo pessoal.

Figura 26 - Maquetes de projeto em três escalas para o Concurso de Arquitetura

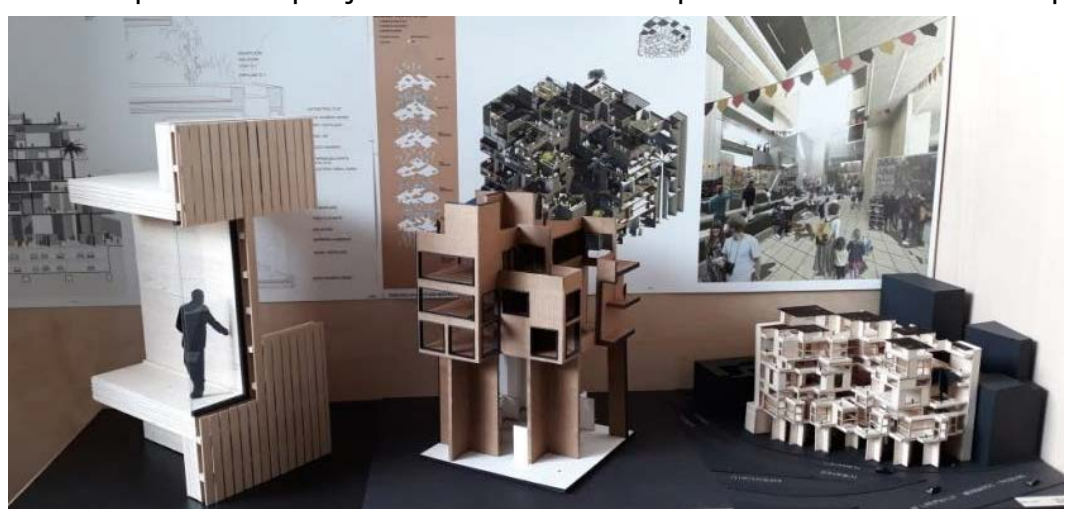

Fonte: arquivo pessoal.

Martin Hurtado enfatizou a importância do desenvolvimento de projeto como método de pesquisa e aprofundamento sobre as tecnologias disponíveis e as possibilidades de uso da madeira. Em sua opinião, a apresentação de conteúdos sem o envolvimento com a prática de projeto, sem o embate com o problema real, não pode resultar numa aprendizagem efetiva sobre o uso da madeira na arquitetura. Ressaltou, ainda, a importância da experiência prática do professor, ou seja, de sua atuação

92 Os projetos ganhadores do Concurso da Semana de la Madera 2018, no Chile, podem ser vistos no website da ArchDaily. Disponível em: https://www.archdaily.com.br/br/900624/projetos-ganhadores-do-concurso-dasemana-da-madeira-2018-no-chile?ad_medium=gallery. Acesso em: 07 jul. 2019. 
profissional no mercado, para uma abordagem mais realista dos problemas e soluções técnicas envolvidos na construção.

Os concursos da Semana de la Madera no Chile são um importante incentivo ao uso da madeira na arquitetura e, a meu ver, uma potente ferramenta para o ensino das tecnologias construtivas em madeira e suas aplicações. Embora já exista uma iniciativa similar no Brasil, junto aos Encontros Brasileiros em Madeiras e em Estruturas de Madeira, criada no XI Encontro realizado em Londrina-PR em 2008, ela ainda é pouco conhecida e a participação dos estudantes tem sido muito pequena. Sua última edição, $6^{\mathrm{a}}$ do concurso, foi realizada no XVI EBRAMEM na cidade de São Carlos-SP, em março de 2018, e contou com a participação de 36 estudantes e 28 profissionais, representando um relativo aumento frente às edições anteriores.

O potencial do uso da madeira no ensino pode e deve ser explorado de formas bastante diversas. Para o professor Richard Harris, da University of Bath no Reino Unido, o sucesso futuro das estruturas de madeira depende da incorporação do ensino de tecnologia da madeira no currículo básico dos estudantes de graduação. Idealmente, o curso deveria incluir algum elemento de "projeto e produção" ${ }^{93}$, mas o formato das aulas pode impedir isso na graduação.

No entanto, nos projetos de final de curso desenvolvidos em conjunto pelos estudantes de arquitetura e engenharia civil da Universidade de Bath, os alunos são estimulados a ser criativos e a desafiarem os limites dos materiais que escolhem trabalhar. "Mais da metade de 32 grupos escolheram trabalhar com a madeira", celebrou o professor. Embora essa ainda não seja a proporção das construções no mundo real, capacitá-los para a proposição de soluções viáveis, os encoraja a continuar usando essas habilidades depois de formados (HARRIS; CHANG, 2014).

\footnotetext{
93 Tradução livre do inglês do termo Design and Make. Harris se refere à abordagem também conhecida como Learning by Making que envolve uma prática emergente em escolas de arquitetura de incorporar um elemento prático de "aprender-fazendo" à educação arquitetônica. Cita como exemplos os cursos da Aalto University, na Finlândia, que oferece um ano de programa intensivo focado na madeira e na arquitetura da madeira, e do Rural Studio, no Alabama, Estados Unidos, onde estudantes de arquitetura do último ano da Auburn University dedicam dois períodos letivos para projetar e construir um edifício para a comunidade em Hale County.
} 
Ainda em sua opinião, tanto aos arquitetos, como aos engenheiros, cabe o desafio da articulação entre as duas áreas, uma vez que o projeto de engenharia estrutural não trata apenas do dimensionamento de elementos, mas da escolha de um sistema estrutural adequado, coordenado com a arquitetura, e da escolha de materiais e de métodos de fundação e construção apropriados. Aprender como os edifícios funcionam, envolve o estudo de precedentes, tanto em abstrato através de visitas a obras, como na prática, através do trabalho de projeto.

Seu depoimento soma-se aos de vários outros docentes que estão empreendendo o ensino da madeira mundialmente. As iniciativas didáticas mapeadas durante o World Conference on Timber Engennering - WCTE 2016, no mês de agosto em Viena, Áustria, envolveram unidades de ensino como disciplinas, cursos e workshops onde a interdisciplinaridade e as abordagens pedagógicas de "aprendizagem baseada em problemas" e de "aprender-fazendo" foram extensivamente defendidas.

Os estúdios de projeto interdisciplinares entre os cursos de arquitetura e engenharia voltados para a construção em madeira foram relatados com grande entusiasmo pelo professor Marc Schulitz (2016) da California State Polytechnic University Pomona, nos Estados Unidos: a natureza interdisciplinar do estúdio é benéfica para ambos os estudantes, de arquitetura e de engenharia, e os ajuda a aprender usos criativos e eficazes da madeira e explorar a colaboração entre duas disciplinas, como parte de sua educação.

Para Thomas Tannert (2016) o método de aprendizagem Team-Based-Learning - TBL, utilizado nas disciplinas de Projeto em Madeira da University of British Columbia, no Canadá, é uma abordagem comprovada e bem sucedida que ajuda os alunos a desenvolver o trabalho em equipe, além de habilidades de resolução de problemas e de autoaprendizagem ao longo da vida, para aplicá-las em suas tarefas e projetos.

Sobre a experiência de integração entre ensino, pesquisa e prática da arquitetura, John Chapman (2016) professor do curso de Tecnologia da Madeira do mestrado profissional em Arquitetura da University of Auckland, na Nova Zelândia, relata: 
Há várias razões pelas quais estudantes de arquitetura devem ser envolvidos tanto na concepção como na construção de pequenos projetos comunitários em escala real. [...] Os estudantes de arquitetura quando trabalham diretamente com materiais de construção aprendem as capacidades e limitações destes. Em sua vida profissional, arquitetos escrevem especificações e frequentemente supervisionam obras de construção. Através da realização de projetos de pequenas construções, mas reais, os estudantes ganham uma apreciação mais profunda das atividades dos trabalhadores no setor da construção. Projetos comunitários também ajudam os alunos a compreender o papel do arquiteto e como eles ajudam a sociedade e o ambiente construído (CHAPMAN; BARRIE; PATEL, 2016, sem paginação, tradução nossa).

O WCTE 2018, realizado em Seoul na Korea, trouxe novos testemunhos. Os professores Francesca Lanata e Frank Michaud (2018) apresentaram a abordagem educacional desenvolvida no Instituto Internacional de Educação Superior em Ciências e Tecnologia da Madeira, Ecole Supérieure du Bois - ESB, em Nantes, na França, que baseiase em resultados de aprendizagem ligados a competências profissionais. Isso requer um equilíbrio entre o ensino teórico, alto padrão de conhecimento acadêmico, e a aquisição de importantes habilidades e experiência práticas. Esta última implica ser alcançada através de projetos práticos, onde os alunos podem experimentar-se diante de uma determinada situação e um determinado contexto.

Cristián Schmitt e Diogo Arroyo (2018) descrevem a experiência da abordagem Design/Build aplicada à disciplina Introdución a la Construción, no primeiro ano do curso de arquitetura da Pontificia Universidad Católica de Chile, como um conceito educacional alinhado com as características de desenvolvimento de sistemas construtivos em madeira, permitindo que uma variedade de tipos de estrutura seja produzida com base em componentes pré-fabricados de baixo custo. Dessa forma, o uso da madeira proporciona uma oportunidade para a inovação através da pré-fabricação.

Esta metodologia parte de um projeto low-tech, ou seja, que utiliza baixa tecnologia, para incitar um grande potencial de exploração da forma e da matéria, bem como de soluções técnicas, reavaliando tradições locais de construção e desenvolvendo novas possibilidades de aplicação da madeira em projetos contemporâneos. 
Frente às iniciativas didáticas identificadas, que envolvem a experimentação construtiva em madeira, retomamos a pergunta: como as experiências de ensino internacionais podem servir de referência para formular parâmetros didáticometodológicos aplicáveis à formação do arquiteto no Brasil?

Para respondê-la, outras experiências serão apresentadas na próxima parte desta Tese, bem como serão examinadas as aplicações de abordagens pedagógicas que abrangem o "aprender-fazendo" no ensino de arquitetura. Pretende-se estabelecer um referente teórico-conceitual que embase a análise das referências selecionadas para uma observação mais aprofundada. 


\section{REFERÊNCIAS}

CHAPMAN, J. B.; BARRIE, A.; PATEL, Y. Teaching timber technology to architecture students: real buildings and digital technologies. In: WORLD CONFERENCE ON TIMBER ENGINEERING - WCTE, 2016, Vienna. Proceedings [...]. Vienna, Austria: Vienna University of Technology, 2016.

CRUZ O., J. Construir en madera. Entrevista Arquitecto José Cruz Ovalle. Revista Ciudad y Arquitectura. Santiago, n. 150, 2012.

DESCAMPS, T.; LAPLUME, D.; DATOUSSAID, S.; VAN PARYS, L. Structural engineering and teaching by doing: how wood contributes to the implementation of new pedagogical approaches. In: WORLD CONFERENCE ON TIMBER ENGINEERING - WCTE, 2018, Seoul. Proceedings [...]. Seoul, Republic of Korea: Mondial Congress \& Events, 2018.

HARRIS, R.; CHANG, W. S. Teaching timber engineering. In: WORLD CONFERENCE ON TIMBER ENGINEERING - WCTE, 2014, Quebec. Proceedings [...]. Quebec: Salenikovich, 2014. Disponível em:

http://opus.bath.ac.uk/42189/1/WCTE_2014_Teaching_Timber_Engineering_Harris_Chan g.pdf. Acesso em: 03 abr. 2016.

LANATA, F.; MICHAUD, F. Teaching timber construction in learn-by-doing format through the construction of a full-scale house. In: WORLD CONFERENCE ON TIMBER ENGINEERING - WCTE, 2018, Seoul. Proceedings [...]. Seoul, Republic of Korea: Mondial Congress \& Events, 2018.

SCHMITT, C.; ARROYO, D. Timber in Design/Build architectural education in Chile: experiences from the course "Introduccion a la Construcción". In: WORLD CONFERENCE ON TIMBER ENGINEERING - WCTE, 2018, Seoul. Proceedings [...]. Seoul, Republic of Korea: Mondial Congress \& Events, 2018.

SCHULITZ, M.; GERSHFELD, M. Interdisciplinary design studio - timber; collaboration between architecture and engineering disciplines in higher education. In: WORLD CONFERENCE ON TIMBER ENGINEERING - WCTE, 2016, Vienna. Proceedings [...]. Vienna, Austria: Vienna University of Technology, 2016.

TANNERT, T.; GERBER, A. Teaching timber design in team-based-learning format and in interdisciplinary settings. In: WORLD CONFERENCE ON TIMBER ENGINEERING - WCTE, 2016, Vienna. Proceedings [...]. Vienna, Austria: Vienna University of Technology, 2016.

VALLE, I. M. R. Modelo Reduzido no Ensino de Construção em Madeira. In: ENCONTRO BRASILEIRO EM MADEIRAS E EM ESTRUTURAS DE MADEIRA - EBRAMEM, 7, 2000, São Carlos. Anais [...]. São Carlos: IBRAMEM, 2000. 


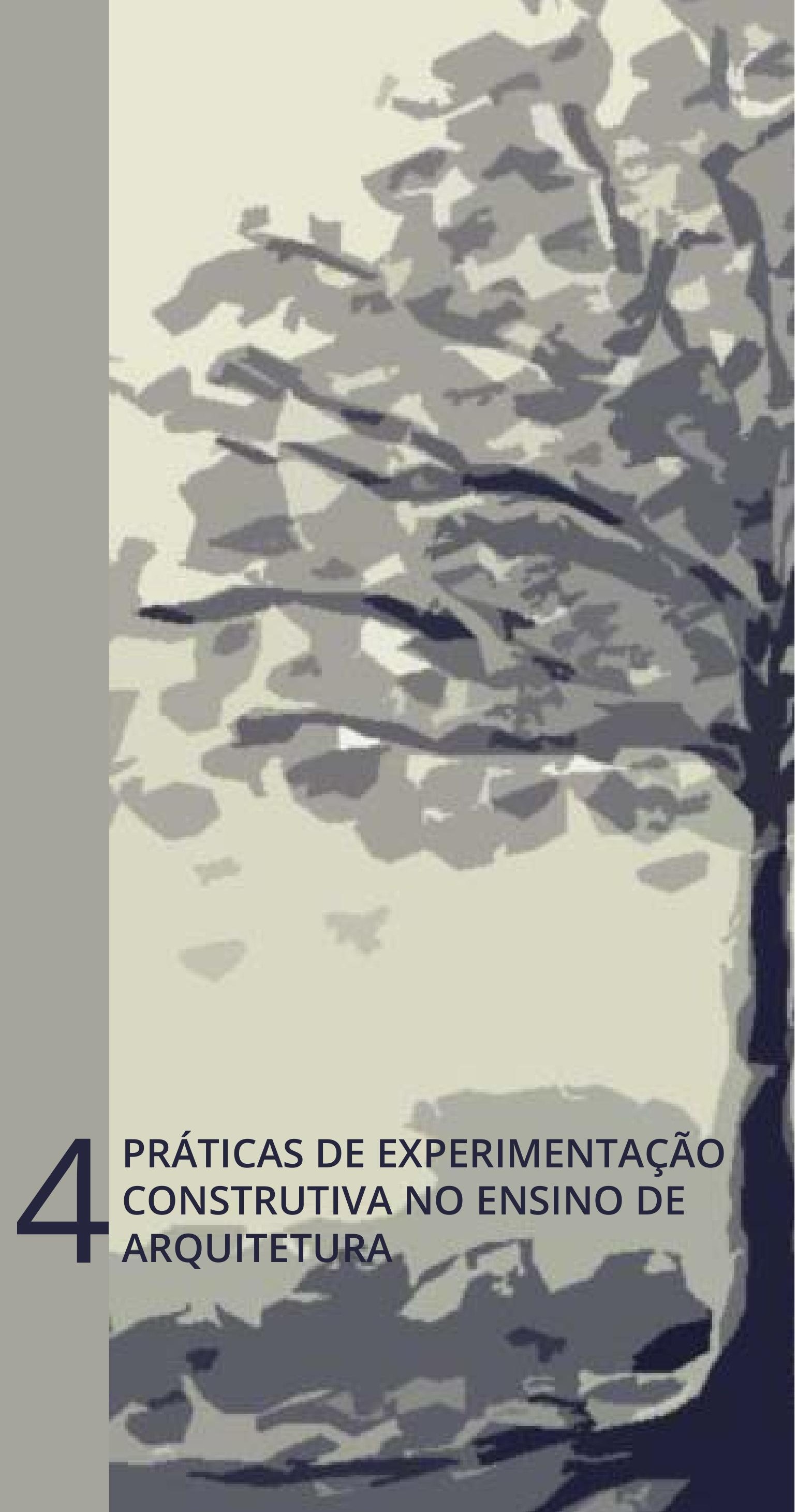





\section{PRÁTICAS DE EXPERIMENTAÇÃO CONSTRUTIVA NO ENSINO DE ARQUITETURA}

A parte quatro desta Tese trata da percepção e observação do fenômeno - tema da investigação: a experimentação construtiva no ensino-aprendizagem da Arquitetura. A abordagem pedagógica do "aprender-fazendo".

Traz um referencial teórico sobre as metodologias ativas de ensino-aprendizagem, abordagens pedagógicas que vem sendo amplamente difundidas nas mais diversas áreas do saber. No que tange ao ensino de arquitetura, o engajamento dos estudantes no desenho e construção de projetos reais é hoje uma importante dimensão em numerosas universidades ao redor do mundo. Neste contexto, expõem-se algumas das experiências mais destacadas apontando vantagens e desafios da utilização do método Design-Build.

Apresenta a análise de experiências didáticas referenciais envolvendo práticas construtivas em três escolas de arquitetura: o Rural Studio da Auburn University, nos Estados Unidos, o Wood Program da Aalto University, na Finlândia, e a Escuela de Arquitectura y Diseño da Pontificia Universidad Católica de Valparaíso, no Chile. Traz ainda, algumas experiências de ensino na área das tecnologias construtivas em madeira nas escolas de arquitetura brasileiras.

Ao examinar experiências didáticas diversas, que abarcam a experimentação construtiva com a madeira, tanto no Brasil como no exterior, pretende-se suscitar a reflexão sobre o uso deste material como ferramenta de ensino-aprendizagem. 


\subsection{Abordagens pedagógicas do "aprender-fazendo"}

A tendência para a aplicação de metodologias ativas de ensino-aprendizagem vem sendo amplamente debatida em várias esferas do ensino no Brasil e no exterior. Tais metodologias possibilitam o aprender a aprender e asseguram um modo de "aprenderfazendo". O termo é derivado do inglês Learning by Making, ou ainda, Learn-by-Doing. São métodos centrados no estudante onde estes são vistos como sujeitos do processo de ensino-aprendizagem, bem como cidadãos. Partem de uma concepção pedagógica crítica e reflexiva e têm como eixo central a participação ativa dos estudantes em todo o processo, que abrange todos os novos e diferentes cenários da prática.

A dinâmica das constantes mudanças sociais onde somos bombardeados com uma complexidade de informações disseminadas pela internet e pela mídia em geral, que as disponibilizam de forma extremamente rápida, traz de forma imperativa a necessidade de avaliação dos métodos tradicionais de ensino e do desenvolvimento e aplicação de práticas pedagógicas mais adequadas aos atuais anseios da sociedade. Novos modelos de aprendizagem buscam formar um profissional que combine conhecimento técnico com habilidades mais amplas, como capacidade de trabalhar em equipe, criatividade, comunicação, empreendedorismo, entre outros.

Em âmbito acadêmico internacional, destacam-se os laboratórios práticos de ensino baseados em projetos. Novos espaços e práticas de ensino e aprendizagem voltados ao desenvolvimento de ambientes colaborativos, em laboratórios multidisciplinares avançados que permitem aos alunos o acesso aos mais modernos meios tecnológicos, confirmando a tendência à cultura da inovação e do empreendedorismo. Neste ambiente, o papel do professor passa a ser o de mediador pedagógico: aquele que estimula a aprendizagem como processo, que valoriza a parceria como estímulo ao processo educacional. 
Para o professor da Escola de Comunicações e Artes - ECA-USP José Moran ${ }^{94}$, "as metodologias ativas são caminhos para avançar para um currículo mais flexível, mais centrado no aluno, nas suas necessidades e expectativas". Afirma que assim estão experimentando algumas organizações educacionais ao flexibilizar currículos e centrar esforços em que os alunos aprendam a integrar conhecimentos amplos, valores e projetos de vida através de problemas reais e relevantes, desafios, jogos, atividades e leituras individuais e em grupo, presenciais e digitais ${ }^{95}$.

O modelo de ensino da Aprendizagem Baseada em Projetos - ABP permite que os estudantes enfrentem questões e problemas do mundo real, significativos dentro do contexto pessoal dos estudantes, e que determinem a forma de abordá-los estabelecendo uma ação cooperativa em busca de soluções (BENDER ${ }^{96}$, 2015). Este modelo é uma abordagem metodológica muito recomendada por educadores, ao permitir combinar mudanças e atualizações tecnológicas que estão em constante modificação, servindo de interface para que os alunos desenvolvam habilidades e inovações no uso da tecnologia.

Com advento da interconectividade virtual e instantânea das pessoas no século XXI, o estudante chega à escola com mais informações do que esta possa, eventualmente, fornecer. Bender aborda dois desafios, nesse contexto: primeiro o de mobilizar a conexão interna deste estudante com o mundo externo; e segundo, o desafio enfrentado pelas próprias escolas para ensinar estes estudantes com recursos muitas vezes extremamente limitados.

94 Jose Moran foi palestrante na $2^{a}$ edição do Congresso de Graduação da Universidade de São Paulo em julho de 2016. É professor aposentado de Novas Tecnologias na USP, cofundador do Projeto Escola do Futuro da USP (1989) e coordenou alguns programas de educação semipresencial (blended learning) e à distância. Gerencia projetos de inovação, com pedagogias ativas e tecnologias digitais. É autor do livro A educação que desejamos: novos desafios e como chegar lá. $5^{a}$ ed Campinas: Papirus, 2012. Mantém o blog Educação Humanista Inovadora. Disponível em: http://www2.eca.usp.br/moran/. Acesso em: 27 jul. 2016.

95 In: Metodologias ativas para realizar transformações progressivas e profundas no currículo. Disponível em: <http://www2.eca.usp.br/moran/wp-content/uploads/2013/12/transformacoes.pdf> Acesso em: 27 jul. 2016.

${ }^{96}$ William Bender é um dos mais dedicados educadores norte-americanos do final dos anos 90 até a atualidade. Recebeu o título de Doutor em Educação pela Universidade da Carolina do Norte e lecionou em algumas das melhores universidades dos Estados Unidos, como a Universidade Rutgers e Universidade da Geórgia. Escreveu 23 livros, entre eles "Aprendizagem Baseada em Projetos: a educação diferenciada para o século XXI" (tradução: Fernando de Siqueira Rodrigues, Porto Alegre: Penso, 2015) originalmente publicado sob o título "Project-Based Learning: differentiating instruction for the 21st century", 1st edition, 2012. 
$\mathrm{Na}$ lógica da educação pensada sob duas paridades, ciência/técnica ou teoria/prática, do ponto de vista da relação entre ciência e técnica, os profissionais educadores são concebidos como sujeitos técnicos, especialistas, que aplicam com maior ou menor eficácia as diversas tecnologias pedagógicas produzidas por cientistas sob uma perspectiva positiva e disciplinadora que não abre espaço à reflexão crítica. Já sob o ponto de vista da relação entre teoria e prática, estes profissionais surgem como sujeitos críticos que propõe uma reflexão sobre a prática através de estratégias reflexivas e práticas educativas concebidas muitas vezes sob uma perspectiva política e crítica (BONDIA, 2002).

No campo pedagógico, há uma dicotomia entre os chamados técnicos e os chamados críticos, aqueles que são partidários da educação como ciência aplicada e aqueles partidários da educação como práxis política. Parece-me correto afirmar que essa bifurcação certamente se reflete em nossos sistemas avaliativos produzindo consequências diretas sobre nossas práticas acadêmicas. A experiência pessoal do aluno e a experiência profissional do professor parecem ser irrelevantes dentro da lógica do sujeito técnico-científico.

No campo da Arquitetura, a separação entre teoria e prática, entre o que se projeta e o que se constrói, implica também num distanciamento entre o desenho e a obra, entre o discurso e o que efetivamente é produzido, contribuindo assim para a desvalorização da profissão. Formam-se profissionais supérfluos, arquitetos desenhadores ineptos a construir.

Para o espanhol Jorge Bondia (2002, p. 23), "existe um clichê segundo o qual nos livros e nos centros de ensino se aprende teoria, o saber que vem dos livros e das palavras, e no trabalho se adquire a experiência, o saber que vem do fazer ou da prática". Esta distinção também está explícita ao se redigir um currículo pessoal onde se diferencia formação acadêmica e experiência profissional. O autor propõe explorar outra possibilidade de pensar a educação - a partir da relação entre experiência e sentido - que a meu ver é extremamente assertiva dentro da reflexão a que se dispõe esta Tese. 
Num mundo caracterizado pelos excessos de informação, de opinião e de trabalho, onde a velocidade dos acontecimentos e a obsessão por novidade impedem a conexão significativa entre os fatos, nunca se passaram tantas coisas, mas a experiência de fato é cada vez mais rara. Uma sociedade constituída sob o signo da informação é uma sociedade na qual a experiência é impossível:

A experiência é o que nos passa, o que nos acontece, o que nos toca. Não o que se passa, não o que acontece, ou o que toca.

[...] A experiência, a possibilidade de que algo nos aconteça ou que nos toque, requer um gesto de interrupção, um gesto que é quase impossível nos tempos que correm: requer parar para pensar, parar para olhar, parar para escutar, pensar mais devagar, olhar mais devagar, e escutar mais devagar; parar para sentir, sentir mais devagar, demorar-se nos detalhes, suspender a opinião, suspender o juízo, suspender a vontade, suspender o automatismo da ação, cultivar a atenção e a delicadeza, abrir os olhos e os ouvidos, falar sobre o que nos acontece, aprender a lentidão, escutar aos outros, cultivar a arte do encontro, calar muito, ter paciência e dar-se tempo e espaço.

[...] o sujeito da experiência se define não por sua atividade, mas por sua passividade, por sua receptividade, por sua disponibilidade, por sua abertura. (BONDIA, 2002, p. 21).

O sujeito da experiência para Bondia define-se por uma disponibilidade e passividade enquanto abertura ao novo, à exposição, à transformação, ao desconhecido. A mesma disposição ao risco para a qual nos abrimos ao experimentar um trabalho de imersão junto a uma realidade social concreta, quando nos dispomos a explorar algo que não conhecemos. A experiência não é, portanto, o caminho até um objetivo ou meta prevista, ela abre espaço ao imprevisto, ao inexplorado. Nisso reside a capacidade de formação e de transformação do indivíduo. Somente o sujeito da experiência está aberto à sua própria transformação. O saber da experiência é, portanto, particular, subjetivo e pessoal.

Para Illeris (2013) toda aprendizagem se dá na integração de dois processos bem diferentes. Um processo externo de interação entre o indivíduo e seu meio social, cultural ou material, e um processo psicológico interno de eleboração e aquisição individual. Esses dois processos fundamentais, envolvem, por sua vez, três dimensões da aprendizagem. Uma primeira dimensão diz respeito ao conteúdo, aquilo que é 
aprendido, descrito como conhecimento e habilidades, envolvendo outras questões, como as opiniões, os valores, a postura, os significados, os modos de agir, os métodos e as estratégias; uma segunda dimensão se refere ao incentivo que direciona a energia mental necessária ao processo de aprendizagem e está relacionada a elementos como sentimentos, emoções, motivação e vontade; uma terceira dimensão é a da interação que propicia impulsos que dão início ao processo de aprendizagem. Serve à integração entre indivíduo, comunidade e sociedade, construindo a experiência social. A Figura 27 representa o campo de tensão do processo de aprendizagem no qual o triângulo relaciona o desenvolvimento das competências individuais da funcionalidade, sensibilidade e sociabilidade.

Figura 27 - As três dimensões da aprendizagem e do desenvolvimento de competências

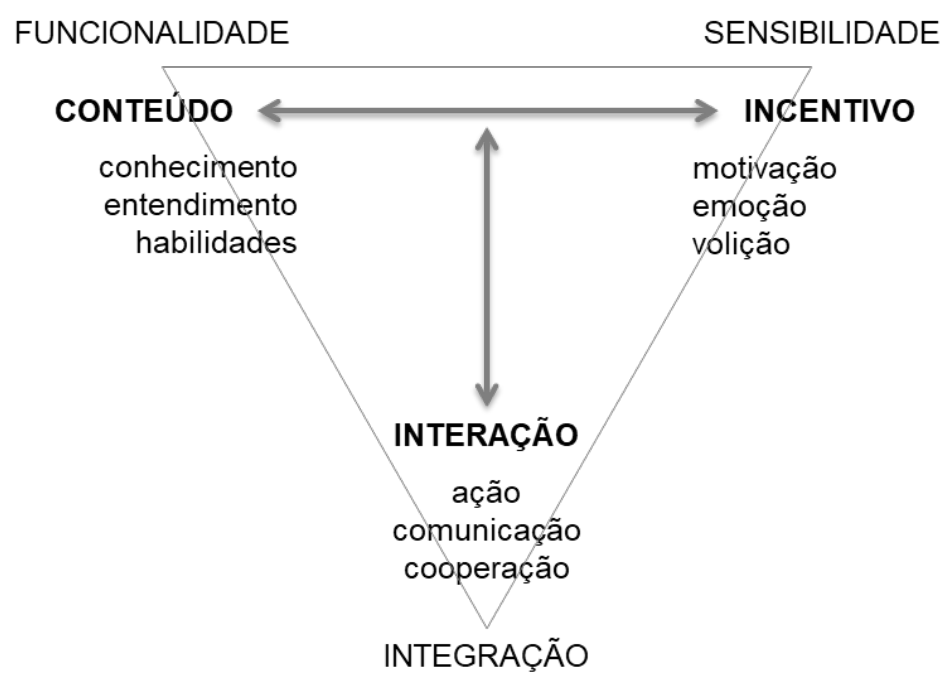

Fonte: ILLERIS (2013, p. 19) adaptado pela autora.

Da mesma forma, o experimento exploratório é considerado por Donald Schön uma atividade lúdica e investigativa que abre a possibilidade da "reflexão-na-ação", na qual somos capazes de obter uma impressão das coisas. O conceito de Schön refere-se a como, no decorrer da atuação, improvisamos, mudando nosso comportamento para lidar com novas condições inesperadas (SCHÖN, 2000; KURT, 2009). Ao prestar atenção ao fenômeno, percebido como único, o sujeito faz vir à tona sua compreensão intuitiva: "sua experimentação é, ao mesmo tempo, exploratória, teste de ações e teste de 
hipóteses. As três funções são preenchidas pelas mesmas ações. E desse fato deriva o caráter distintivo da experimentação na prática" (SCHÖN, 2000, p. 65).

Com um maior foco na experiência individual de aprendizagem, construída através da integração de processos internos e externos, e potencializados pela interação social, as metodologias ativas propiciam uma postura mais pró-ativa do estudante, menos dependente do professor, e estimulam processos de pensar e agir - thinking and making, do inglês. As aulas práticas envolvem em sua maioria grupos de estudantes que são, muitas vezes, tão importantes um para o outro quanto o próprio instrutor, cumprindo às vezes o papel destes. Schön (2000) afirma que aprender uma prática por conta própria tem a vantagem da liberdade de experimentar sem a limitação das visões recebidas de outros, porém, essa mesma liberdade oferece também a desvantagem de demandar que cada aluno reinvente a roda, ganhando pouco ou nada da experiência acumulada dos demais.

Algo similar acontece na Aprendizagem Baseada em Projetos defendida por Bender (2015), que assemelha-se aos problemas confrontados na vida, já que muitas vezes não há uma estrutura organizada aparente que permita que se chegue a uma solução. Essa estrutura deve ser criada pelos próprios alunos que se vêm forçados a trabalhar em equipes cooperativas, criarem significado a partir do caos do excesso de informações, a fim de articularem uma solução eficaz para a questão enfrentada.

Por este ângulo, as práticas construtivas ou "estúdios de construção" inseridos no ensino de arquitetura - designados pelo termo em inglês Design-Build - oferecem um caminho para aprender na prática, a partir de problemas reais, sintetizando áreas complexas do conhecimento. Mais do que apenas propiciar o contato direto com os materiais, os cursos Design-Build são experiências de aprendizado que dão ênfase à proximidade dos estudantes com os processos de tomada de decisão, projeto e construção. Oferecem oportunidades para expandir e integrar as habilidades intelectuais, técnicas e práticas para além das limitações do ensino de construção tradicional (CARPENTER, 1997; FOWLES, 1984; CANIZARO, 2012; BALY-SMITH, 2011). 
A origem dos programas Design-Build certamente remontam ao paradigma da Bauhaus Dessau onde os estudantes eram encorajados a construir de modo a melhor explorar as intenções de projeto (CARPENTER, 1997, 2014).

Retomo neste ponto, as observações de Gropius (2004) a respeito da proposição do trabalho experimental durante a formação acadêmica:

A razão para o generalizado método de formação do arquiteto por meio de setores separados de ensino parece-me provir da acentuação excessiva do intelectual-acadêmico e da falta de oportunidade, daí oriunda, de trabalho experimental no canteiro e na oficina. Por que há de ser o conhecimento por si só a meta principal da educação, se a experiência imediata já demonstrou ter a mesma importância como base para uma formação correta? O ensino teórico é superestimado. O livro e a prancheta não podem substituir a valiosa experiência na oficina e no canteiro. [...] A experiência prática é o meio mais seguro para desenvolver uma síntese de todos os fatores emocionais e intelectuais na concepção do estudante. Ela o impede de perder-se em projetos imaturos, que não estejam suficientemente esteados no mister da construção. Sem dúvida a separação total entre formação científica e conhecimento acadêmico isolou o arquiteto da obra durante o desenvolvimento da era técnica. A vinculação correta entre formação científica e prática é um problema crucial no nosso sistema de ensino (GROPIUS, 2004, p. 86).

E vai além: em sua proposta de currículo para formação de arquitetos na Bauhaus expressou suas ideias com a convicção de que o homem e suas necessidades espirituais e materiais em relação à vida da comunidade devem ser o centro da educação. Destaco alguns pontos que considero mais pertinentes aqui:

O saber só pode tornar-se vivo através da experiência pessoal. Por isso projeto e processo de construção, prancheta e obra precisam estar profundamente ligados em todas as fases do estudo. [...]

A construção precisa ser ensinada como parte integrante do projeto. Ambos dependem um do outro, ambos têm a mesma importância. [...]

Os mais valiosos fundamentos de uma escola, a "atmosfera" intensiva e o vigor intelectual, resultam da participação conjunta de professores e alunos em todas as tarefas; [...]

A eficácia do ensino depende muito do número de alunos que o professor tem a seu cargo. A formação de um arquiteto exige treino individual centrado no talento específico do estudante e no estágio de seu desenvolvimento (GROPIUS, 2004, p. 94). 
Gropius (2004) enfatiza ainda a importância da formação do professor e de sua experiência profissional tanto no projeto como na construção, salientando que somente professores com vasta experiência estão capacitados a estimular o aluno constantemente e conduzi-lo à iniciativa própria. Consequentemente, defende que todo professor de arquitetura, assim como de engenharia, deveria ter o direito de realizar trabalho privado como forma de revigorar as forças criativas. Mas, que excelente discussão propõe Gropius!

Assim como na proposta da Bauhaus, nos estúdios de construção Design-Build o processo de produção é inseparável da concepção do projeto. Isso permite a experimentação, a aprendizagem e a colaboração. Esta metodologia de ensino pode fornecer aos alunos um contexto de aprendizado experimental que estabelece uma ponte entre os assuntos teóricos e os ateliês de projeto criando uma conexão muito necessária entre o mundo abstrato e o mundo real.

Essas práticas podem proporcionar aos estudantes possibilidades de abordagem interdisciplinar e de desenvolvimento de habilidades de comunicação com seus colegas de equipe e com clientes reais, bem como de elaboração de projetos que atendam a comunidades necessitadas. Acima de tudo, os estudantes aprendem que a Arquitetura é um esforço colaborativo e não um exercício isolado (CARPENTER, 1997).

Os estúdios de projeto são o cerne da educação em arquitetura e o primeiro exemplo de um ambiente de ensino experiencial colaborativo, construtivista e centrado na resolução de problemas, permitindo aos estudantes aprender como ouvir, como inovar e como praticar no mais amplo sentido da palavra, através de desenhos e da construção de modelos, aulas e avaliações críticas do corpo docente e da interação com outros estudantes (CARPENTER, 1997; KURT, 2009).

Para o professor da Southern Polytechnic State University, William Carpenter ${ }^{97}$, os estúdios de construção trazem uma complementação dos estúdios de projeto por meio

\footnotetext{
${ }^{97}$ William Carpenter é arquiteto pela Mississippi State University, mestre em Arquitetura pela Virginia Polytechnic Institute and State University e doutor pelo Birmingham Institute of Art and Design no Reino Unido. Educador e autor reconhecido nos Estados Unidos inspirou uma geração de estudantes e profissionais no ensino DesignBuild e em práticas sustentáveis. Ao longo de sua carreira, estudou sob várias vozes acadêmicas
} 
da dimensão real que incorpora o processo de pensar e agir: clientes reais, orçamentos efetivos e trabalho palpável. Pensar e desenvolver ideias de projeto em escala real oferece uma nova maneira de ver o projeto.

Em seu livro Learning by Building: Design and Construction in Architectural Education, Carpenter apresentou detalhadamente dez projetos precursores do Design-Build em escolas de arquitetura norte-americanas, como resultado do esforço de alguns acadêmicos que acreditam na importância de aprender-fazendo. São projetos de diferentes escalas, complexidades e abordagens que emergem de distintos interesses de estudantes, de demandas de clientes e de recursos das escolas ${ }^{98}$. Dentre eles, destacam-se o Yale Building Project, criado em 1967 sob a direção de Charles Moore em New Haven, o trabalho de Steve Badanes na University of Washington, em Seattle, e o trabalho comunitário do Rural Studio, estabelecido nos anos 90 em Newbern, programa da Auburn University, coordenado por Samuel Mockbee.

Alguns pesquisadores como Canizaro (2012) e Abdullah (2014) investigaram a inserção e evolução dos programas Design-Build nos Estados Unidos através de entrevistas com membros diretivos, professores e alunos dos cursos, bem como por meio de pesquisa documental e revisão bibliográfica. Bayl-Smith (2011) também investigou universidades na Austrália, Nova Zelândia, Países Baixos, Alemanha, Suíça, Reino Unido e América do Norte.

O foco do projeto de pesquisa de Bayl-Smith foi o de fornecer uma revisão internacional das abordagens que fornecem o ensino-aprendizado integrado em Tecnologia da Construção e, em particular, enfocar as escolas de arquitetura para as quais os estúdios e a pesquisa Design-Build são uma parte valiosa do programa.

\footnotetext{
proeminentes como o arquiteto Nova Yorquino Norman Jaffe, cujo trabalho está profundamente enraizado em seu lugar. Foi sob a orientação de Norman que William aprendeu a entender e apreciar a relação da Arquitetura com seu território e a desenvolver uma abordagem prática de projeto e construção. Outras influências incluem obras e ensinamentos do renomado arquiteto Samuel Mockbee e Christopher Rischer. É autor do influente livro "Learning By Building, Design and Construction in Architectural Education" (Wiley, 1997) e do "Modern Sustainable Residential Design" (Wiley, 2009).

${ }^{98}$ As instituições e os projetos Design-Build apresentados por Carpenter (1997) são: Yestermorrow Design/Build School; Cranbrook Academy of Art; University of Washington; Yale University; Auburn University Rural Studio; The Catholic University of America; Clemson University; The University of Oregon; The University of Michigan; Woodbury University; Southern Polytechnic State University.
} 
Com base nos resultados da investigação ${ }^{99}$, a autora delineou algumas recomendações direcionadas a revisão dos cursos de arquitetura australianos, mas que podem ser interpretados de forma mais ampla. São elas: permitir que as escolas invistam em projetos de integração através de financiamento terciário, programas cooperativos entre as profissões e a indústria da construção em geral, melhores estúdios e oficinas e pessoal de perfis diversificados; criar uma ampla base de apoio ao estabelecimento de um currículo em Tecnologia da Construção que permita aos estudantes desenvolver "ideias de fazer" juntamente com o "fazer de ideias"; revisitar, repensar e realinhar os desejáveis atributos de pós-graduação e os padrões de competência profissional, melhorando o engajamento entre as principais partes interessadas - academia, órgãos de registro, órgãos profissionais, estudantes, empregadores; incentivar oportunidades de ampliar o aprendizado de Tecnologia da Construção no nível de mestrado, tanto nos programas que envolvem estúdios de projeto quanto em disciplinas eletivas (BAYL-SMITH, 2011).

Já o estudo de Abdullah (2014) explorou qualitativamente vários aspectos dos cursos Design-Build norte-americanos: como eles evoluíram, o número de escolas que os oferecem, a eficácia dessa abordagem pedagógica, objetivos e resultados de aprendizagem e outras experiências relatadas pelos participantes da pesquisa. Os dados levantados pelo autor indicaram que 30 escolas de arquitetura, entre 114 existentes em 2010 nos Estados Unidos, ofereciam cursos Design-Build, destas porém, apenas 15 especificaram que os adotavam plenamente em seus currículos ${ }^{100}$.

\footnotetext{
${ }^{99}$ As escolas e instituições investigadas por Melonie Bayl-Smith (2011) são: Unitec Auckland; University of Canberra; University of Melbourne; Monash University; University of Newcastle; University of New South Wales; RMIT; University of Sydney; TAFE NSW - Architectural Technology; University of Tasmania; University of Technology Sydney; University of South Australia; Victoria University Wellington; TU Delft ; TU Stuttgart; Stuttgart SAAD; TU Berlin; TU Muenchen; ETH Zurich; University of Toronto; University of Michigan; MIT; Harvard GSD; University of Bath; University of Cambridge; Architectural Association; University of East London; and London Metropolitan University.

100 Estas são as escolas de arquitetura investigadas por Zunaibi B. Abdullah (2014): 1) University of Auburn; 2) University of Southern Florida; 3) University of Arkansas; 4) University of Colorado; 5) Rice University; 6) University of Utah; 7) University of Houston; 8) University of Kansas; 9) California Polytechnic State University; 10) Frank Lloyd Wright School; 11) University of Louisiana; 12) University of Arizona; 13) University of Washington; 14) Tulane University; and 15) University of Idaho.
} 
De aproximadamente 10 escolas constatadas nos anos 80, ao final da pesquisa de Abdullah em 2014, esse número aumentou para 70 escolas mostrando o quanto esse tipo de abordagem tem sido valorizada no país. A partir dos resultados, o aspecto mais importante sugerido pelo autor é que os cursos Design-Build são altamente relevantes para a educação arquitetônica em função do seu potencial e das oportunidades para aprimorar o aprendizado dos alunos.

Vicent Canizaro, professor da University of Texas, em Santo Antonio, relacionou uma série de motivações pedagógicas das instituições que ofertam os programas DesignBuild. Discutiu tais motivações e como elas podem influenciar em vários aspectos dos cursos, desde os processos internos vivenciados pelos alunos e professores, os tipos e locais de projetos selecionados, até o prazo factível para a realização do trabalho. Essas intenções são: a experiência construtiva como motivação primeira; o trabalho como uma forma de serviço comunitário; a apresentação de uma visão mais ampla da prática profissional; a crítica à Academia e aos estúdios de projeto fictícios; o reconhecimento mais aprimorado do lugar; o desenvolvimento de habilidades de colaboração; a pesquisa sobre novos métodos de avaliação de projetos; a pesquisa sobre materiais, materialidade e suas possibilidades tectônicas (CANIZARO, 2012).

Para realizar os propósitos mencionados, Canizaro apresenta algumas "táticas pedagógicas" adotadas pelos programas. Cita duas metodologias de processo de projeto: o colaborativo, onde os alunos ou grupos desenvolvem propostas em busca das melhores ideias, e o competitivo, onde as propostas são submetidas à seleção. Comenta que a abordagem dominante combina as melhores qualidades dos dois modelos em fases subsequentes.

Quanto aos clientes, a pesquisa do professor Canizaro mostrou que a tendência é trabalhar com entidades públicas ou organizações sem fins lucrativos que atuam em serviço aos necessitados, como organizações comunitárias de desenvolvimento habitacional. Já em relação ao escopo de projeto, estes variam bastante entre os programas e ao longo do tempo dentro de cada programa. Tanto Carpenter (1997) quanto Canizaro (2012) apontam que muitos constroem pavilhões, estruturas recreativas de parques e outras estruturas externas, como capelas, em função da 
visibilidade destes projetos de uso público, da facilidade de construção, de menores restrições normativas, maior capacidade dos alunos explorarem questões estruturais, materiais e tectônicas, e para que os projetos se encaixem dentro de um período acadêmico. Pequenas casas modulares também podem se ajustar aos estúdios. Cabe destacar, no entanto, a experiência do Rural Studio que também projetou e construiu edifícios públicos complexos.

Outras questões foram exploradas por Canizaro (2012) em seu artigo como a atuação dos docentes no gerenciamento dos projetos e na supervisão do trabalho dos alunos, e a eventual necessidade de contratação de consultores ou subcontratação de serviços especializados e de operação de equipamentos complexos. Contudo, um dos temas mais difíceis enfrentados pelos programas Design-Build é o financiamento dos projetos. Frequentemente o dinheiro disponibilizado pelas instituições é insuficiente.

Carpenter (1997) sugeriu que um mínimo de dois mil dólares são necessários para começar. Muitos programas tentam trabalhar com organizações sem fins lucrativos e outras agências de levantamento de fundos, o que é mais recomendado, mas alguns prosperam de maneira mais empreendedora, como o Studio 804 afiliado a University of Kansas, que vende os projetos concluídos. Outros, incluem a captação de recursos como parte do processo educacional, mas os estudantes tendem a ter mais sucesso com doações de materiais e produtos.

Ainda em relação ao financiamento dos projetos Design-Build, o curso Introducción a la Construcción da PUC Chile de Santiago, coordenado pelos professores Cristián Schmitt e Diogo Arroyo, utiliza recursos arrecadados entre os próprios estudantes. Em entrevista, relataram que cada aluno contribui com 50 dólares, que para uma turma de 60 alunos gera o valor total de três mil dólares, para a realização de todo o projeto, entre materiais, equipamentos, transporte e outros itens necessários.

Quanto ao planejamento do cronograma, a maioria dos programas pesquisados tenta se adequar a um período acadêmico único ou duplo sendo que metade deles utilizou apenas um semestre, normalmente o de primavera, para o projeto e a construção, contando com o verão como prazo de segurança. Daqueles que utilizaram dois semestres, alguns usaram o primeiro para pesquisa e projeto, com construção no 
período seguinte. Outros foram obrigados a usar os dois semestres devido à complexidade dos projetos.

Os programas Design-Build tendem a adaptar o tipo, a localização, o tamanho e o escopo dos projetos de acordo com o que poderia ser concluído dentro de um prazo de 15 semanas. São mais raros os programas que usam menos do que um período acadêmico, estes geralmente oferecem cursos durante algumas semanas no verão. Normalmente os estúdios estão localizados no quarto ano de um curso de cinco anos. Isso permite que os estudantes tenham um conhecimento de projeto e uma maturidade para trabalhar em grupo. Mas, em alguns casos, como na Yale University, os estúdios ocorrem no início da graduação (CANIZARO, 2012; CARPENTER, 1997).

Quanto à composição das equipes, Carpenter (1997) indicou que grupos de sete estudantes, escolhidos por eles mesmos, são grandes o suficiente para permitir que o trabalho seja realizado e delegado. Cada grupo deve designar uma pessoa encarregada do projeto, documentos de construção, aquisição de materiais, arrecadação de fundos, relações públicas, projeto de segurança e programação. O projeto deve ser o foco central dos grupos permeando cada parte do processo, e as reuniões entre os membros da equipe devem ser curtas e bem planejadas. Sugeriu ainda, que workshops ou oficinas de formação de equipes são excelentes atividades iniciais antes de começar um projeto, pois costumam permitir que os membros do grupo conheçam suas fraquezas e fortalezas. Uma aula de segurança do trabalho, orientada ao uso e limpeza de ferramentas para iniciantes, deve ser planejada e cada aluno deve assinar um termo afirmando que participou da atividade.

Em relação à materialidade, ainda na opinião de Carpenter (1997) os materiais podem ser apresentados no currículo de Arquitetura como ferramentas para o projeto, incluindo o conhecimento destes materiais em escala real. Esse entendimento deve envolver as técnicas construtivas, as possibilidades formais e as qualidades simbólicas dos materiais, apresentadas de forma articulada em disciplinas tipo "materiais e método" e ateliês de projeto nos dois anos iniciais do curso. Recomendou a seguinte ordem de apresentação: madeira, pedra, tijolo, aço, concreto, materiais experimentais como compósitos e plásticos. 
Visitas à fábricas de produção são aconselhadas pelo autor para que os estudantes entendam que cada material tem seu potencial, como são obtidos, como são unidos e quais são cada uma das suas possibilidades estruturais e estéticas. Os estúdios de construção podem ser a síntese desse aprendizado, especialmente ao mostrar o papel dos detalhes como um princípio gerador do projeto, como a unidade mínima que dá significado e identidade à Arquitetura.

Parece-me interessante referenciar a menção feita pelo professor Carpenter aos rituais de reconstrução de alguns templos japoneses como rituais de grande significado para a cultura e identidade daquele povo, sendo o exemplo mais famoso os monumentais templos Naiku e Geku em Ise, que, devido à relativa perecibilidade da madeira não tratada, são reconstruídos a cada 20 anos.

Para Carpenter um tipo similar de ritual é criado através dos estúdios de construção onde cada curso deixa sua marca pessoal, representando simbolicamente o aprendizado dos alunos. Uma linhagem é estabelecida. Quando esse aprendizado está conectado à construção de um artefato comunitário, esta linhagem vai além do trabalho construtivo em si. O processo de aprendizagem continua a ensinar, não apenas por meio do objeto de construção, mas através das construções mentais dos estudantes. “O ritual de construção é um processo cíclico, da ideia à construção, e de volta à ideia. O diálogo começa com o desenho, modelagem e protótipos na escala real. Cada ação é catalizadora para a próxima" (CARPENTER, 1997, p. 15, tradução nossa).

Em uma publicação mais recente, Carpenter (2014) analisa a incorporação da fabricação digital nos cursos Design-Build com a introdução de técnicas e materiais inovadores, modelagem CATIA ${ }^{101}$ e construção automatizada revigorando o processo arquitetônico, do conceito à produção. Através do uso destas tecnologias digitais, os estudantes projetam em três dimensões desde o princípio, incorporando ao processo de projeto considerações sobre como melhor fabricar, expandindo e aprimorando,

101 O termo CATIA é um acrônimo de computer-aided three-dimensional interactive application e se refere a um software multi-plataforma para desenho assistido por computador (CAD), fabricação assistida por computador (CAM), engenharia assistida por computador (CAE), PLM e 3D, desenvolvido pela empresa francesa Dassault Systèmes. 
assim, os resultados educacionais. Neste artigo, examina quatro distintos casos: Georgia Institute of Technology, ETH Zurich, Berkeley University e Carnegie Mellon University.

Nos estúdios Design-Build digitais, os estudantes de Arquitetura aprendem a lidar com problemas através de ferramentas de representação tridimensional e softwares de produção, o que traz melhorias ao processo de projeto fortalecendo o benefício mais imediato dos estúdios: a conexão direta com a prática. A inclusão de ferramentas digitais dentro da sequência de projeto e construção, incentiva a inovação e amplia os limites da educação e da prática arquitetônica, assim como fizeram os cursos da Bauhaus (CARPENTER, 2014).

Como vimos até aqui, são consideráveis as vantagens mencionadas pelos acadêmicos, pesquisadores e estudantes que defendem as iniciativas Design-Build, mas não é nada fácil conduzí-las. Há várias questões e desafios a serem encarados para completar até mesmo projetos simples. Canizaro (2012) alega que talvez a principal dificuldade enfrentada pelos programas Design-Build diz respeito à sua aceitação dentro da própria instituição:

Entre os colegas, a resistência aos programas Design-Build não surpreende ninguém que esteja familiarizado com a política do corpo docente. Há uma falta de apoio que parece resultar de ciúmes e críticas legítimas. Grande parte do ciúme parece derivar do sucesso dos próprios projetos DesignBuild. Eles costumam ser populares na comunidade e entre os administradores porque são projetos tangíveis, visíveis e fotogênicos que aparecem em jornais, livros e revistas. Eles também são populares entre os estudantes que desejam fazer parte de projetos "reais" depois de tantos projetos teóricos (CANIZARO, 2012, p. 31).

Apesar destes programas estarem em evidente expansão, ganhando a cada dia maior visibilidade no cenário internacional, eles ainda são vistos como marginais aos currículos acadêmicos. As críticas são várias, mas alega-se que frequentemente os cursos ficam aquém das metas de projeto exemplar e de impacto social duradouro, sendo que raramente são integrados a iniciativas universitárias ou nacionais mais amplas quanto ao desenvolvimento da comunidade.

Obviamente, tal fato é decorrente da própria falta de apoio institucional declarada. O conservadorismo institucional é certamente um dos desafios explícitos que acarretam 
em impedimentos administrativos e dificuldades mesmo quando há apoio da comunidade ou, até mesmo, financiamento disponível.

Outra questão importante diz respeito às instalações, ferramentas e manutenção adequadas. Ter um lugar com condições apropriadas para trabalhar são a chave para o sucesso de qualquer programa. Não é incomum que estudantes e professores, muitas vezes financiem os cursos secretamente, fornecendo suas próprias ferramentas e substituindo itens consumíveis como lixas e brocas com seus próprios fundos. Canizaro (2012) comenta que programas mais estabelecidos aprenderam essa lição e levantaram esse financiamento em seus orçamentos, ou já conseguiram as instalações necessárias.

Em síntese, este capítulo traz à tona muitos argumentos a favor do uso de metodologias ativas no ensino de arquitetura. São explorados vários autores no intuito de compreender a conceituação e a aplicação destas metodologias ao longo do tempo e no atual contexto de evolução tecnológica em que se inserem. Os exemplos nos remetem à reflexão sobre as práticas pedagógicas vigentes e nos impõe urgência na proposição de mudanças.

Ao mesmo tempo, essa inquietação é decorrente de uma maior compreensão em relação às oportunidades de ensino-aprendizagem que se abrem através do "aprenderfazendo". Em função disso, pergunto: quais os aspectos mais importantes a serem observados para que a experimentação construtiva seja implementada como instrumento de abordagens pedagógicas mais integradoras?

As inúmeras experiências relatadas pelos educadores, servem de subsídio para arriscar traçar um caminho. Pretende-se, a partir dos dados levantados, estabelecer alguns parâmetros que orientem a formulação de práticas educacionais mais coerentes com as demandas da sociedade, com os anceios dos estudantes e com as condicionantes do meio. O exame da literatura deixa claro que a abordagem pedagógica dos programas Design-Build estabelece uma ponte entre a escola e a prática profissional, entre professores e alunos, entre alunos e a comunidade.

William Carpenter enfatiza quatro pontos fundamentais da experiência do DesignBuild: o pensar e agir, a colaboração, a devolução à sociedade, e as habilidades de 
comunicação. Todos estes aspectos são potencializados pela oportunidade de experimentar em escala real, a partir de problemas reais. Ver decisões de projeto realizadas em escala 1:1 permite a avaliação e retroalimentação do processo projetual, reduzindo a distância entre a teoria e a prática. A experiência construtiva aproxima o saber criativo e o saber técnico, incentiva a ação e o desenvolvimento de habilidades e competências mais amplas e integrativas. A colaboração e o trabalho em equipe junto à comunidade é um fator decisivo para uma mudança efetiva, não só no ensino, mas na própria abrangência e relevância da Arquitetura na atualidade. 


\section{REFERÊNCIAS}

ABDULLAH, B. Z. Exploring the evolution of design-build courses in architectural schools: a qualitative study. 2014. Dissertation (Doctor of Philosophy) - University of Nebraska, Lincoln, 2014.

BAYL-SMITH, M. BuildAbility: the future of construction education. Research Report: 2009 Byera Hadley Travelling Scholarship, May, 2011. Disponível em: https://www.academia.edu/806805/BuildAbility_the_future_of_construction_education. Acesso em: 27 set. 2018.

BENDER, W. N. Aprendizagem baseada em projetos: educação diferenciada para o século XXI. Porto Alegre: Penso, 2015.

BONDIA, J. L. Notas sobre a experiência e o saber de experiência. Revista Brasileira de Educação. Rio de Janeiro, n.19, p.20-28, 2002. DOI: http://dx.doi.org/10.1590/S141324782002000100003. Disponível em:

http://www.scielo.br/scielo.php?script=sci_arttext\&pid=S1413-

$24782002000100003 \&$ Ing=pt\&tlng=pt. Acesso em: 18 mar. 2019.

CANIZARO, V. B. Design-build in architectural education: motivations, practices, challenges, successes and failures. ArchNet-IJAR: International Journal of Architectural Research, United Kingdom, v. 6, n. 3, p. 20-36, Nov. 2012.

CARPENTER, W. J. Learning by Building: Design and Construction in Architectural Education. New York : Van Nostrand Reinhold, 1997.

Digital Fabrication and the Design Build Studio. In: ACSA ANNUAL MEETING, 102, 2014, Miami. Proceedings [...]. Miami: Florida International University, 2014. p. 513-521.

FOWLES, B. Design-build Projects in Architectural Education. Design Studies, Netherlands, v. 5, n.1, p. 07-14, Jan. 1984.

GROPIUS, W. Bauhaus: novarquitetura. Tradução J. Guinsburg e I. Dormien. São Paulo: Perspectiva, 2004.

ILLERIS, K. Uma compreensão abrangente sobre a aprendizagem humana. Teorias contemporâneas da aprendizagem. Porto Alegre: Penso, 2013.

KURT, S. An analytic study on the traditional studio environments and the use of the constructivist studio in the architectural design education. Procedia Social and

Behavioral Sciences, Netherlands, v. 1, n.1, p. 401-408, 2009. DOI:

https://doi.org/10.1016/j.sbspro.2009.01.072. Disponível em: 
https://www.sciencedirect.com/science/article/pii/S1877042809000743. Acesso em: 12 set. 2018.

MORAN, J. Metodologias ativas para realizar transformações progressivas e profundas no currículo. 2013. Disponível em: <http://www2.eca.usp.br/moran/wpcontent/uploads/2013/12/transformacoes.pdf> Acesso em: 27 mai. 2016.

SCHÖN, D. A. Educando o profissional reflexivo: um novo design para o ensino e a aprendizagem. São Paulo: Artmed, 2000. 


\subsection{Análise de referências}

Como discutido anteriormente, a experimentação dos materiais associada à abordagem pedagógica do "aprender-fazendo" é um instrumento bastante oportuno para o aprendizado tecnológico, que vem sendo utilizado em algumas das mais reconhecidas universidades do exterior. Junto a isso, somam-se as características de trabalhabilidade da madeira que fazem com que sua utilização em projetos práticos facilite processos de aprendizagem, contribuindo para o sucesso das atividades em termos de obtenção de habilidades pelos alunos.

Os casos referenciais apresentados neste capítulo envolvem a experimentação construtiva em madeira em abordagens bastante diversas. Tratam de aspectos relacionados à educação e a pesquisa aplicadas, mas somente um dos casos versa sobre a formação específica em tecnologia da madeira. No decurso do levantamento das experiências evidenciaram-se práticas pedagógicas nas quais a madeira é amplamente utilizada na fabricação de modelos, protótipos e em construções em escala real inseridas na realidade social, e neste caso, utilizada como material construtivo predominante muitas vezes associado a outros materiais como aço, concreto, alvenaria, terra, entre outros.

As referências serão analisadas através de categorias elaboradas a partir das questões específicas de pesquisa, envolvendo a estrutura curricular, os conteúdos programáticos e as metodologias de ensino, além de trazer exemplos dos projetos construídos pelos alunos em cada um dos casos. Busca-se trazer à tona referências que contribuam para alcançar os objetivos desta Tese, bem como, que sirvam de inspiração a futuras iniciativas educacionais.

O primeiro caso retratado - o Rural Studio - estabelecido na América do Norte distingue-se pela formação de cidadãos arquitetos que além de um conhecimento aprofundado sobre materiais e técnicas construtivas, manuais e artesanais, adquirem uma formação orientada à atuação junto à realidade social de uma comunidade carente do interior dos Estados Unidos. O segundo caso - o Wood Program - trata-se de um 
curso de formação focado especificamente na Madeira e na Arquitetura em Madeira, localizado nos países nórdicos no Continente Europeu, onde há boa disponibilidade de recursos e laboratórios equipados com alta tecnologia. O terceiro caso - a Escuela de Valparaíso - insere-se num contexto distinto, a América Latina, e apresenta características bastante peculiares nas quais o ensino de arquitetura parte de uma visão poética do ofício da Arquitetura para estender-se a um espaço de experimentação que vincula vida, trabalho e estudo.

Os diferentes contextos geográficos e socioculturais selecionados ressaltam a pluralidade das experiências pedagógicas e enriquecem os resultados da pesquisa.

\subsubsection{RURAL STUDIO - Auburn University, Estados Unidos}

O Rural Studio é um programa da School of Architecture, Planning and Landscape Architecture da Auburn University. Está localizado em Hale County, Newbern, 225 km a oeste da cidade de Auburn, onde atuam junto da comunidade local. É um off-campus design-build program, ou seja, é um programa de "projeto e construção" realizado fora do campus da universidade que oferece aos estudantes de graduação em arquitetura e recentemente também de pós-graduação - uma experiência educacional mais prática, ao mesmo tempo em que prestam assistência a uma população carente na região do Cinturão Negro do West Alabama.

O programa, criado em 1993 por Dennis K. Ruth e Samuel Mockbee, em seus primeiros anos tornou-se conhecido por estabelecer um espírito de reciclagem, reutilização e reconstrução. Em 2001, após o falecimento de Samuel Mockbee, Andrew Freear o sucedeu como diretor. Desde então, o Rural Studio expandiu o escopo e a complexidade de seus projetos, concentrando-se principalmente no trabalho orientado para a comunidade.

Para Freear e Barthel (2014), ambos professores do programa, o projeto deve começar da observação do contexto e do aprendizado a partir deste. O Rural Studio, por sua vez, foi profundamente moldado pela arquitetura e pelo território desta zona rural 
do oeste do Alabama, assim como, por suas necessidades, preocupações e anseios de sua gente. Sua relação com Hale County é o que o diferencia de todos os outros programas de arquitetura Design-Build dos Estados Unidos.

A filosofia do Rural Studio sugere que todos, ricos e pobres, merecem o benefício de um bom design. Para cumprir com essa ética, o programa adota uma metodologia de ensino voltada a projetos de orientação comunitária através de esforços multianuais, de várias fases, percorrendo três municípios. Os alunos trabalham dentro da comunidade para definir soluções, angariar fundos, projetar e, em última análise, construir projetos notáveis questionando continuamente o que deve ser construído, e não o que pode ser construído, tanto em relação ao desempenho quanto ao funcionamento dos projetos. Até o momento, o Rural Studio construiu mais de 200 projetos e educou mais de 1.000 "Cidadãos Arquitetos" 102.

O arquiteto Tomas Lotufo traçou um paralelo entre as experiências do Rural Studio e dos Canteiros Experimentais no ensino de Arquitetura no Brasil, em sua dissertação de mestrado, defendida na FAU-USP. Em sua opinião, apesar dos desafios de trabalhar com recursos doados e limitados, mão de obra não qualificada e projetos desenvolvidos por estudantes de arquitetura, as casas e os centros comunitários construídos têm um bom acabamento e trazem soluções formais e espaciais criativas, que buscam resgatar aspectos simbólicos e de uso que fazem parte da cultura da população atendida (LOTUFO, 2014).

Lotufo contextualiza o Rural Studio como consequência de uma série de ações oriundas de alguns movimentos de contestação e lutas sociais da década de 1960 nos Estados Unidos que forneceram a base para um movimento que resultou em grande aprendizado para o modo de fazer Arquitetura e Urbanismo comunitários nos Estados Unidos: os Community Design Centers (CDC). Segundo ele, esses centros concentraram esforços em como fazer o possível para que as pessoas de uma comunidade beneficiada fossem envolvidas no planejamento, concepção e gestão do espaço,

\footnotetext{
102 Informações referentes aos objetivos e a história do Rural Studio disponíveis em: http://www.ruralstudio.org/about/purpose-history. Acesso em 20 ago. 2018.
} 
acreditando que com isso o projeto possa refletir melhor as necessidades dos usuários, de forma que a comunidade se aproprie do ambiente que foi construído, o mantenha e tenha autonomia para melhorá-lo.

Nos anos 1990, após mais de 30 anos de experiências práticas com os CDC, a participação da sociedade em projetos públicos se tornou lei nos Estados Unidos oficializando os conselhos de cidadãos como instâncias que decidem e aprovam. De acordo com Lotufo (2014), essas metodologias e ideais foram incorporados em projetos da universidade com a comunidade, como é o caso do Rural Studio, um espaço pedagógico que faz parte do currículo da Universidade de Auburn, envolvendo conjuntamente arquitetos, estudantes e a comunidade em eventos de construção não só de edifícios, mas também de espaços simbólicos e de melhoria da qualidade de vida social. Segundo o autor, os objetivos do programa são:

1. Aproximar o aluno da realidade social que está distante da vida no espaço protegido da universidade;

2. Desenvolver habilidades no aluno para utilizar a sua competência como arquiteto a serviço da qualidade de vida social como comunidade. Nas palavras de Samuel Mockbee: "formar além de um arquiteto, um cidadão";

3. Empoderar o estudante e futuro arquiteto por meio do projeto e da construção dentro da comunidade. O aluno pode perceber a capacidade que tem de transformar a realidade com as ferramentas que conhece. Desenvolve também, através de acertos e erros, uma capacidade crítica de entender quando o projeto pode melhorar ou não.

Para alcançar estes objetivos propõe-se uma imersão na realidade social como método pedagógico. O fato do programa se desenvolver em um campus satélite contribui não só para conhecer o que existe fora da universidade e passar um momento do curso separado das distrações rotineiras, mas também para observar de longe o que existe dentro do campus sede. Ao sair da realidade cotidiana, forma-se um novo olhar sobre o conhecido, um olhar externo que promove uma nova forma de entendimento. A experiência também permite experimentar outro estilo de vida e cultura. A Figura 28 ilustra alguns dos projetos realizados pelo Rural Studio. 
Figura 28 - Alguns dos projetos executados pelo Rural Studio da Auburn University

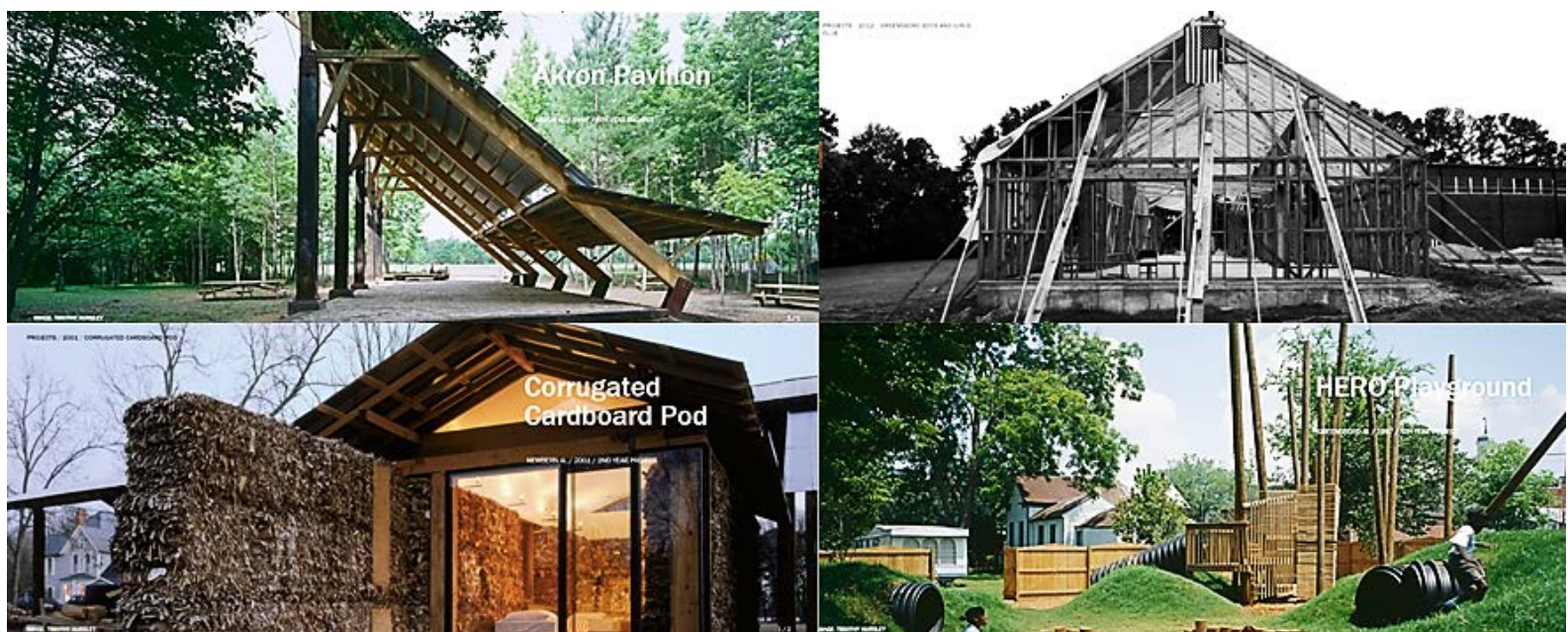

Fonte: Website Rural Studio ${ }^{103}$.

\subsubsection{Estrutura curricular e conteúdos programáticos}

O currículo do Rural Studio se estrutura em basicamente três programas distintos que envolvem alunos de $3^{\circ}$ e de $5^{\circ}$ anos da Escola de Arquitetura de Auburn e também alunos de fora da Universidade e estrangeiros. Ao início eram voltados predominantemente para construções de casas individuais, mas com o tempo os programas naturalmente começaram a tratar de questões comunitárias. Segundo Andrew Freear, diretor do Rural Studio entrevistado por Lotufo (2014), as mudanças foram parte de um processo pedagógico somado ao relacionamento criado com a comunidade. De 1993 até aquele momento não haviam ocorrido muitas mudanças na metodologia de ensino, mas houve transformações no tipo de projeto e escala de atuação. Na medida em que a confiança entre os agentes aumentou, os projetos puderam ser mais abrangentes incluindo os projetos de capelas, espaços públicos comunitários e assim por diante.

A seguir, apresentam-se os programas e seus conteúdos programáticos ${ }^{104}$.

\footnotetext{
103 Disponível em: http://www.ruralstudio.org/. Acesso em: 22 ago. 2018.

104 Informações disponíveis em: http://www.ruralstudio.org/programs.html. Acesso em: 22 ago. 2018.
} 


\section{3rd-YEAR STUDIO - Terceiro ano}

Historicamente, o Rural Studio aceitou em torno de 12 a 16 alunos do $2^{\circ}$ ano por semestre para projetar e construir uma obra de caridade, geralmente uma casa. No outono de 2009, o programa foi transferido para o terceiro ano acadêmico devido a uma reestruturação do curso na Universidade de Auburn. O curso do $3^{\circ}$ ano no Rural Studio é eletivo, a cada semestre são abertas de 10 a 20 vagas e o critério de seleção é baseado no desempenho escolar, utilizando como base o histórico de notas, sendo que as vagas são bastante disputadas. As turmas na escola de arquitetura têm de 40 a 50 alunos e o ano escolar é dividido em dois semestres, o primeiro, chamado de Fall Semester ou Outono, se inicia em agosto e termina em dezembro; o segundo, chamado de Spring Semester ou Primavera, tem início em janeiro e acaba em maio.

Dentro da proposta pedagógica do curso de arquitetura, o $3^{\circ}$ ano é visto como a etapa em que os alunos devem conhecer o mundo além dos limites da universidade para desenvolver uma visão mais crítica sobre a Arquitetura. Além do Rural Studio os alunos têm outras opções de realizar estudos fora do campus, como um intercâmbio internacional em Roma, na Itália, ou em Istambul, na Turquia. O objetivo principal do programa no exterior, o Study Abroad, é que o aluno reconheça a vida fora do campus e fortaleça uma visão crítica sobre a própria realidade, seu estilo de vida, sua cultura e comunidade (LOTUFO, 2014).

Desde a reestruturação do curso em 2009, o Design Studio do $3^{\circ}$ ano vem trabalhando com um projeto de múltiplas fases focado no redesenho do campus. Esse projeto é chamado de Rural Studio Farm e objetiva a requalificação da propriedade Morrisette, onde está situada a administração, a cozinha, o refeitório e as Pods ${ }^{105}$ onde os estudantes de $3^{\circ}$ ano vivem, na Morrisette House. Este plano estratégico foi traçado com o intuito de promover a sustentabilidade do campus em termos do abastecimento de alimentos, da produção de energia e de madeira para construção. "It was the Rural Studio (R)evoltution" (FREEAR; BARTHEL, 2014, p. 28).

\footnotetext{
${ }^{105}$ As Pods são pequenas células de habitação projetadas por alunos do quinto ano e construídas sob uma grande cobertura, a Supershed construída por alunos do terceiro ano na propriedade Morrisette. São um campo de testes para materiais experimentais.
} 
De acordo com Lotufo (2014), que acompanhou as atividades do Rural Studio como parte de sua pesquisa de mestrado, todos os trabalhos a serviço da coletividade são feitos por equipes de alunos que se revezam ao longo da semana.

\begin{abstract}
Quando o aluno está aqui, é para que seja uma experiência não só de ensino, mas também de vida, então procuramos trabalhar o sentido de comunidade. Por isso os alunos moram aqui, dividem quarto, banheiro, constroem e convivem com a comunidade. Então eles têm um semestre para vivenciar isso tudo e sentir o que é fazer parte de uma comunidade. (Elena Barthel, professora do $3^{\circ}$ ano, entrevistada por Lotufo, 2014, p. 101).

A proposta foi implantar ao longo dos anos um sítio de produção de alimentos. O projeto é baseado no propósito educativo de instigar um novo estilo de vida dentro do Rural Studio e de sua comunidade local. O objetivo é aprender a viver da terra, isto é, produzir parte do alimento e material de construção, servindo como um sistema paralelo ao ensino de arquitetura, criar relações simbióticas que motivem uma ética com uma visão de mundo mais ampla, entender que para ser um bom arquiteto é preciso ser um bom cidadão e saber que vivemos em um sistema integrado (LOTUFO, 2014, p. 102)
\end{abstract}

Por meio dessa proposta conceitual é que o curso utiliza as ferramentas pedagógicas do Design Build para aprender arquitetura, buscando o equilíbrio entre o projeto em ateliê e a prática construtiva. Além do estúdio de projeto e construção, os alunos também têm aulas de história e teoria, atividades de desenho e aquarela, e aulas no Woodshop, oficina de madeira, onde aprendem habilidades de marcenaria fazendo réplicas de cadeiras icônicas.

A estrutura programática ao longo de um semestre de $3^{\circ}$ ano é de aulas durante todo o dia (Quadro 3). As disciplinas são as mesmas do restante da turma que fica em Auburn, "a diferença é metodológica: no Rural Studio, todos os cursos utilizam a pedagogia da prática. [...] é uma escola de arquitetura onde a abordagem metodológica central é o projeto somado à construção" (LOTUFO, 2014, p. 101). 
Quadro 3 - Estrutura programática do Design Studio do $3^{\circ}$ ano

\begin{tabular}{|c|c|c|c|c|c|}
\hline Período & Segunda & Terça & Quarta & Quinta & Sexta \\
\hline $\begin{array}{c}8 \text { h00- } \\
12 \mathrm{~h} 00\end{array}$ & Marcenaria & Revisão & $\begin{array}{c}\text { Construção } \\
\text { (Build) }\end{array}$ & $\begin{array}{c}\text { Construção } \\
\text { (Build) }\end{array}$ & $\begin{array}{c}\text { Construção } \\
\text { (Build) }\end{array}$ \\
\hline $\begin{array}{c}13 \mathrm{~h} 15- \\
18 \mathrm{~h} 00\end{array}$ & $\begin{array}{c}\text { História/ } \\
\text { Aquarela }\end{array}$ & $\begin{array}{c}\text { Ateliê } \\
\text { (Design) }\end{array}$ & $\begin{array}{c}\text { Ateliê } \\
\text { (Design) }\end{array}$ & Revisão & $\begin{array}{c}\text { Ateliê } \\
\text { (Design) }\end{array}$ \\
\hline
\end{tabular}

Fonte: Lotufo (2014, p. 101).

\section{5th-YEAR STUDIO - Quinto ano}

Aproximadamente doze estudantes de arquitetura de quinto ano de Auburn vão ao Rural Studio anualmente concentrando-se particularmente em trabalhar junto aos municípios e conselhos consultivos para realizar projetos comunitários. Os projetos são normalmente concluídos de 18 a 24 meses e são construídos por equipes de três a cinco alunos. Isso significa que os alunos passam todo o $5^{\circ}$ ano do curso em Hale County e geralmente ficam um ano após a formatura para construir o projeto.

Durante os estúdios os alunos formulam programas de construção sustentável, escrevem subsídios, fazem apresentações na comunidade, projetam e constroem seus projetos desde a fundação até o telhado. Os alunos do $5^{\circ}$ ano também desenvolvem um Projeto de Tese e fazem aulas de desenho a mão livre.

Para participar do Thesis no $5^{\circ}$ ano não é necessário ter cursado o Rural Studio no $3^{\circ}$ ano. No entanto, a expectativa é que os alunos já tenham um elevado espírito comunitário, e isso se coloca como um pré-requisito. A seleção é feita por meio de um portfólio apresentado à equipe de professores. Diferente do $3^{\circ}$ ano, com critério baseado no desempenho acadêmico, no Programa de Tese, o critério de ingresso traz também aspectos mais subjetivos que podem ser apresentados no portfólio: lugares que estagiou, trabalhos extracurriculares, textos e áreas de interesse (LOTUFO, 2014).

O objetivo é formar um arquiteto que, antes de entrar no mercado, tenha vivenciado a realidade profissional, por isso, precisa dialogar com clientes reais, com limite de orçamento, um terreno e fazer algo que será construído por eles mesmos. Um segundo objetivo é formar um arquiteto cidadão, capaz de dialogar com a comunidade e reconhecer o papel que exerce dentro da sociedade. Para isso, por meio do projeto de arquitetura busca-se ter um impacto positivo na comunidade (LOTUFO, 2014, p. 110). 
Dessa vontade de dialogar com a comunidade e do tempo dedicado pelos professores e alunos para isso, resultaram as construções das Teses de $5^{\circ}$ ano formando um amplo repertório de projetos de arquitetura, muitos reconhecidos nos EUA e na comunidade internacional, sendo que alguns já receberam premiações, exposições e publicações.

Ainda de acordo com a descrição de Lotufo (2014), com relação ao processo de trabalho no Rural Studio, este é bastante intenso, começando às 8 da manhã e muitas vezes se estendendo até tarde da noite. Durante os primeiros meses, o $5^{\circ}$ ano e o Outreach Program ${ }^{106}$ trabalhavam juntos em uma série de exercícios rápidos de projeto e revisão já focados na demanda a ser trabalhada. Esses exercícios servem para que os estudantes exercitem a agilidade de pensar em uma série de propostas ao mesmo tempo para um único projeto e também para que formulem diversas questões. Dessa forma iniciam qualquer linha de raciocínio por perguntas, e na medida em que as respostas se manifestam surgem novas perguntas. As ideias nunca se fecham já que sempre existe espaço para uma resposta diferente.

Depois dessa etapa, os alunos formulam os programas de projeto para então se dividirem em equipes de três a cinco pessoas que trabalharão juntas diariamente, e para isso, seus integrantes devem ter afinidade entre si e características complementares. Inicia-se a partir daí a etapa do projeto básico, quando ocorrem consultas e apresentações à comunidade com revisões semanais dos professores locais e visitantes. Na seguinte etapa desenvolve-se o executivo: nessa fase muitos consultores são convidados para assessorar os diversos aspectos técnicos do projeto, como conforto térmico, estrutura, elétrica, hidráulica e materiais. Em geral, o momento de visita desses consultores é também aproveitado para a realização de workshops com os alunos de $3^{\circ}$ ano, $5^{\circ}$ ano e Outreach Program.

A partir do projeto executivo pronto, a equipe de alunos troca a lapiseira por ferramentas de obra dedicando-se diariamente à obra, com bastante disciplina, para cumprir com "um incrível desafio na vida de um estudante de Arquitetura: construir

106 O Outreach Program é o programa de extensão do Rural Studio e será apresentado a seguir. 
aquilo que imaginou e desenhou no papel, da fundação ao telhado" (LOTUFO, 2014, p. 114). Diversas entrevistas realizadas pelo pesquisador com arquitetos formados no Rural Studio confirmaram que essa experiência marcou profundamente suas vidas profissional e pessoal.

\section{OUTREACH PROGRAM - Extensão}

O Outreach Program foi concebido como uma maneira de trazer estudantes e colaboradores de fora da Universidade de Auburn para o Rural Studio. O grupo deveria ser composto por alunos de diferentes universidades e, além de arquitetos, alunos de outras áreas de formação como sociólogos, biólogos, pedagogos, designers. Por essa diversidade de conhecimentos, o Outreach poderia pesquisar questões mais amplas relativas à comunidade mantendo a mesma base pedagógica de projeto e construção.

Desde a sua criação em 1999, o programa evoluiu de projetos muitas vezes individualizados e voltados para a comunidade para um projeto de equipe única: a $20 \mathrm{~K}$ House. Aproximadamente quatro vagas de Outreach estavam disponíveis a cada ano sendo que esses alunos eram incorporados no estúdio do $5^{\circ}$ ano, entretanto, o Rural Studio encerrou as inscrições para este programa em 2018.

Idealizado por Samuel Mockbee e D. K. Ruth, o programa praticamente não teve tempo de ser consolidado em função da morte de Mockbee em 2001 e da aposentadoria de Ruth em 2002. No seu formato original, cada estudante desenvolvia um projeto específico o que gerava para os instrutores uma alta demanda de trabalho com custos elevados. Por esse motivo, em 2004 o programa foi reestruturado, já com Andrew Freear como diretor, dando início a um desenvolvimento mais focado em pesquisa e extensão na área de Habitação Social (LOTUFO, 2014).

A 20K House, um dos projetos mais desafiadores de todos os estúdios, buscou oferecer para a comunidade local uma alternativa de moradia acessível e bem 
construída à onipresente Casa Trailer ${ }^{107}$. As casas são construídas por US\$20.000, onde cerca de US\$12.000 são alocados para materiais e os US\$8.000 restantes cobrem os custos trabalhistas e o lucro do contratado. Ao contrário de outros projetos do Rural Studio, o objetivo da Casa de 20 mil dólares é criar uma linha de residências que poderia ser construída por empreiteiras e ter um maior impacto nas comunidades locais.

Dessa forma, a 20K House surgiu para repensar o paradigma da Casa Trailer, trabalhando em um protótipo habitacional que poderia ser replicado fora do Rural Studio. A partir dessa demanda social definida, desde 2004, a cada ano uma nova versão foi elaborada. Os princípios utilizados para a concepção da casa foram os mesmos, como num processo contínuo de pesquisa, sendo que cada versão buscou aperfeiçoar a anterior e trazer novas problemáticas. Cada modelo apresenta suas próprias ideias quanto ao sistema estrutural, o processo de construção, decisões projetuais e interação com o cliente, no caso, pessoas da comunidade ${ }^{108}$.

\section{GRADUATE PROGRAM - Pós-graduação}

O Rural Studio acaba de lançar um novo programa, ao que tudo indica, em substituição ao Outreach Program. É um programa de pós-graduação que se iniciará no outono de 2019: um mestrado em Arquitetura com opção em Design de Interesse Público ${ }^{109}$. Este programa de três semestres é oferecido para portadores de título de grau profissional em Arquitetura (Bacharelado em Arquitetura ou Mestrado em Arquitetura) ou seu equivalente internacional. O programa pretende abordar questões sistêmicas subjacentes à acessibilidade da habitação na zona rural do Alabama. Irá cultivar a liderança nos domínios do interesse público, a tectônica do projeto e a documentação e disseminação de projetos arquitetônicos através de estratégias de

\footnotetext{
${ }^{107}$ A proposta, segundo Tomas Lotufo (2014), é apresentar soluções que substituam a principal alternativa existente para a população mais pobre do oeste do Alabama - as Casas Trailer - que, para os professores do Outreach, são uma solução muito ruim como habitação definitiva.

108 Lotufo (2014, p. 119/120) apresenta em sua dissertação uma linha do tempo com a evolução das 20K House de 2005 a 2013. Em 2008 as equipes de Thesis também participaram e desenvolveram as versões V04/V05/ V06/ V07.

${ }^{109}$ Master of Science in Architecture / Option in Public Interest Design (MS Arch) degree. Informações disponíveis em: http://www.ruralstudio.org/programs/masters. Acesso em: 05 jul. 2019.
} 
design e inovação na área da habitação rural. Os alunos do Rural Studio MS Arch participarão integralmente do programa Rural Studio Design-Build e trabalharão em colaboração com um pequeno grupo de estudantes no desenvolvimento de um projeto de pesquisa em moradias rurais, com o objetivo de projetar e construir uma casa em Hale County.

\subsubsection{Disciplinas do currículo}

\section{WOODSHOP - Oficina e pesquisa em madeira}

O Rural Studio incentiva o uso da madeira como um material renovável, sustentável e prontamente disponível em todos os estúdios. "We like wood at Rural Studio. It can be locally sourced, it is renewable, and it is sustainable" (FREEAR; BARTHEL, 2014, p. 32). A oficina Woodshop tem o papel de desenvolver as habilidades dos estudantes para trabalhar artesanalmente com a madeira, um dos recursos de construção mais encontrados no Alabama. Com esse ímpeto, o Rural Studio expandiu sua marcenaria para oferecer uma aula para cada programa - Terceiro ano, Thesis e Outreach.

Segundo os professores Freear e Barthel, mesmo que pudessem não se encontraria uma roteadora CNC ou uma cortadora a laser na marcenaria do Rural Studio. "Nós pensamos que as ferramentas de alta tecnologia de hoje encorajam aos alunos a ver a madeira como um material homogêneo ao invés de apreciar suas qualidades especiais e sua versatilidade" (FREEAR; BARTHEL, 2014, p. 32, tradução nossa).

Os alunos do $3^{\circ}$ ano adquirem uma sólida compreensão das habilidades de marcenaria em um curso prático de fabricação de móveis. Eles são desafiados a desenvolver e projetar um processo de recriação de cadeiras icônicas por meio de pesquisa, desenho, modelagem e construção. Os produtos finais rendem muitos desenhos, gabaritos, maquetes e a reprodução real da cadeira (Figura 29 e Figura 30). A partir do processo de desenho do objeto, os alunos podem se concentrar na execução técnica da construção e na habilidade do ofício. 
Figura 29 - Cadeira Frei Egídio da arquiteta Ítalo-brasileira Lina Bo Bardi produzida por alunos no Woodshop

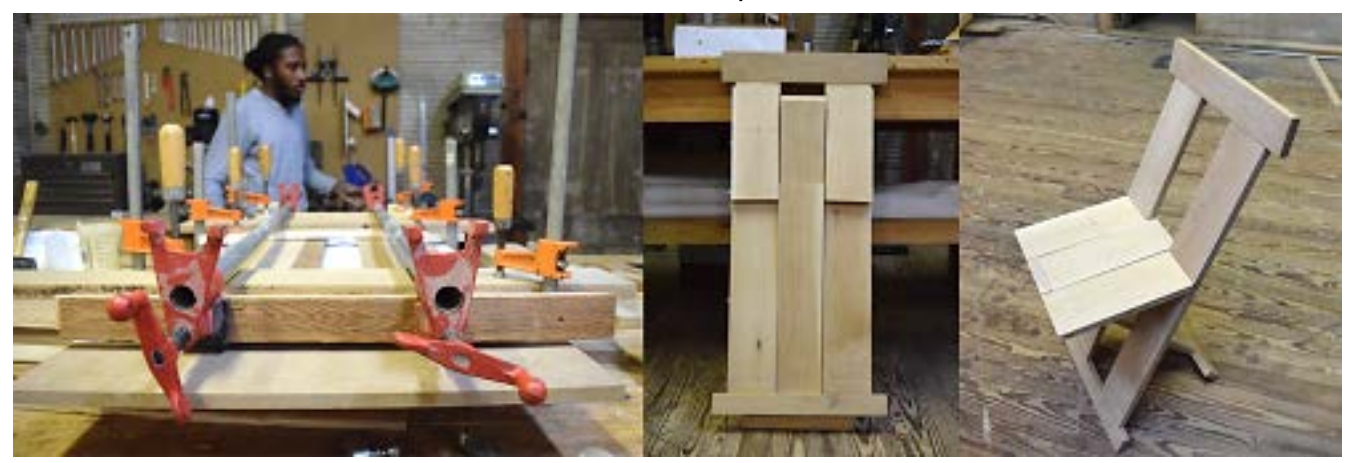

Fonte: Website Rural Studio ${ }^{110}$.

Figura 30 - Cadeira Zig-Zag do arquiteto holandês Gerrit Thomas Rietveld produzida por alunos no Woodshop

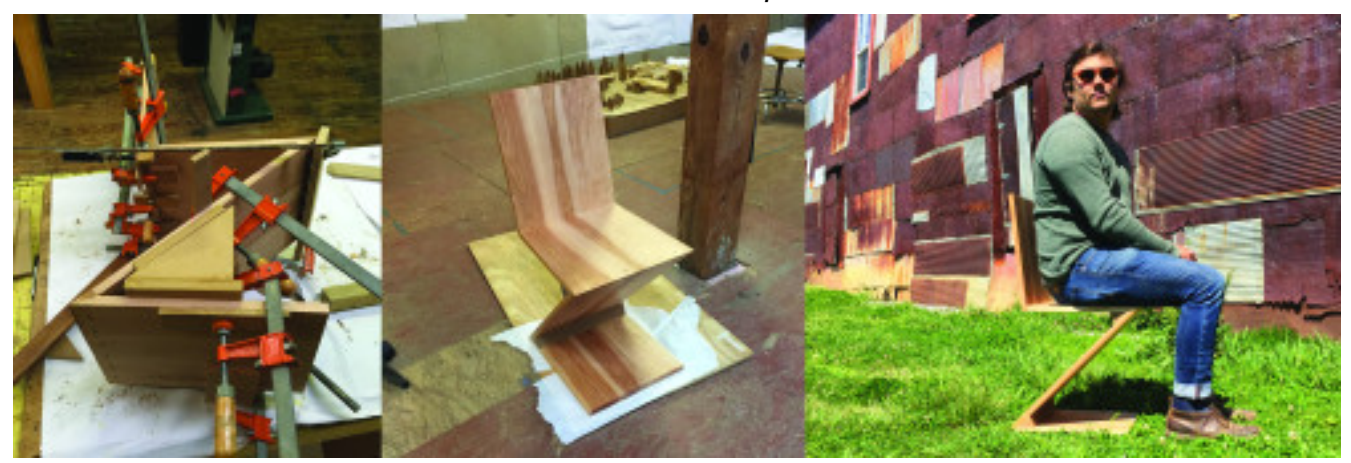

Fonte: Website Rural Studio ${ }^{111}$.

Os estudantes de $5^{\circ}$ ano e de extensão do Rural Studio se reuniam semanalmente em um grupo de pesquisa que discute a importância da indústria madeireira no Alabama e como ela influencia a profissão de Arquitetura. Em equipes de duas pessoas, os alunos eram responsáveis por selecionar assuntos relevantes de estudo, coordenar visitas aos fabricantes de produtos madeireiros, documentar suas descobertas e apresentar suas pesquisas para revisão e discussão. As informações coletadas pelas equipes fornecem um catálogo da indústria de produtos florestais existente no Alabama.

110 Disponível em: http://ruralstudiofarm.ruralstudioblogs.org/. Acesso em: 22 ago. 2018.

${ }^{111}$ Disponível em: http://ruralstudiofarm.ruralstudioblogs.org/. Acesso em: 22 ago. 2018. 


\section{Aquarela}

O objetivo do Seminário de História e Teoria no Rural Studio é familiarizar os alunos com o ambiente construído do oeste do Alabama e obter entendimento do contexto dos edifícios, quando eles foram construídos e como eles se relacionam com o mundo hoje. Os ambientes físicos, sociais e culturais devem ser compreendidos para contextualizar esses edifícios, tanto nacional como internacionalmente. O curso, direcionado aos alunos do $3^{\circ}$ ano, consiste em visitas semanais em edifícios históricos, discussão e desenhos a mão livre de cada edifício visitado e também a produção de uma aquarela "Beaux Arts" de um edifício histórico do Black Belt.

Segundo o professor Dick Hudgens, entrevistado por Lotufo (2014, p. 102) a metodologia utilizada no seminário "é conhecer duas edificações, desenhar e conversar sobre elas: como os materiais foram usados, como eles sobreviveram ao longo do tempo, como as pessoas se relacionavam com a construção e o trabalho que tinham para construir". A intenção é que os alunos não olhem apenas para a decoração, mas também para o espaço e a luz, conheçam aspectos relativos ao material e às técnicas utilizadas e os aspectos sociais, que remetem aos costumes e à cultura da época da construção abordada.

\section{Desenho à mão}

As aulas de Desenho à mão são trabalhadas sobre o tema da Cadeira e visam complementar e melhorar a experimentação gráfica dos alunos do $5^{\circ}$ ano e do Outreach com métodos de desenho à mão livre. A disciplina introduz o método "learning by making", ou seja, aprender-fazendo, concentrando-se em executar o trabalho com inteligência, habilidades manuais e alta qualidade. Os alunos devem escolher uma única cadeira para desenvolver três trabalhos em escala real: um desenho bidimensional focado na construção da cadeira, um desenho tridimensional para registrar as suas proporções e um desenho em técnica mista, uma interpretação pessoal em escala quatro vezes maior que o tamanho da cadeira real. 


\subsubsection{Alguns projetos executados}

\section{Butterfly House}

Local e ano de projeto: Newbern, 1996

Programa: $2^{\circ}$ ano

A Butterfly House ou Casa Borboleta (Figura 31) foi construída para Anderson e Ora Lee Harris e atualmente está ocupada pela filha do casal. Seu nome se dá em função da estrutura do telhado angular que recolhe a água da chuva e abriga um alpendre. A casa é em grande parte aquecida e resfriada passivamente, com a ajuda de um fogão a lenha. Boa parte da madeira utilizada na obra foi proveniente de uma igreja que estava sendo demolida na época em uma cidade vizinha. A solução estrutural do telhado em madeira resultou num amplo volume interno e aberturas que trouxeram boa iluminação natural além de um espaço arquitetônico interessante.

Figura 31 - Butterfly House construída pelo Rural Studio em Newbern
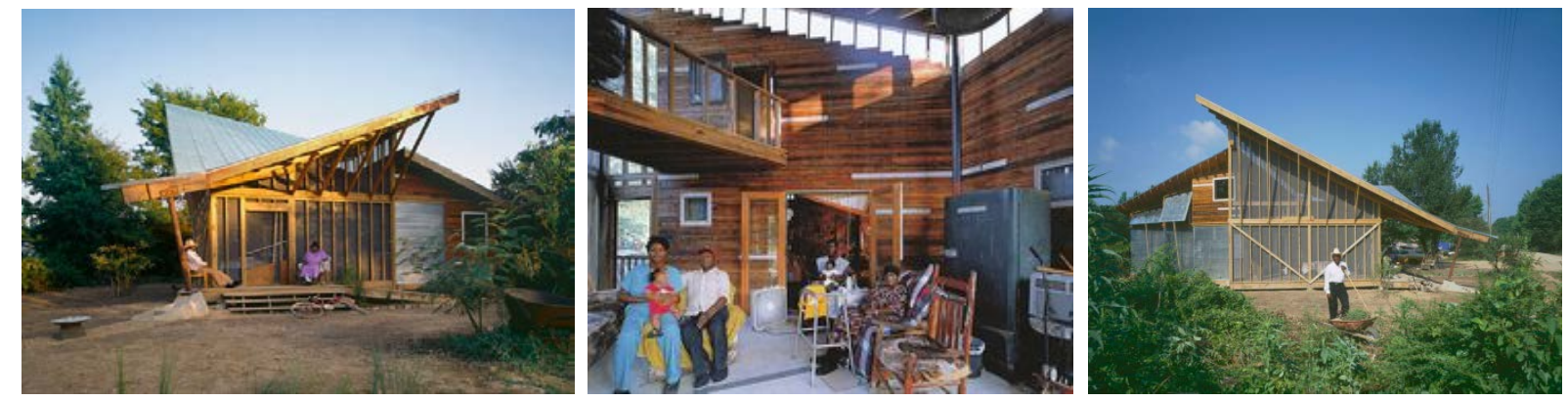

Fonte: Website Rural Studio ${ }^{112}$.

\section{Glass Chapel}

Local e ano de projeto: Mason's Bend, 2000

Programa: $5^{\circ}$ ano

Situada num local central em Mason's Bend, a Glass Chapel serve como ponto de parada de transporte, espaço para reuniões comunitárias, capela para o grupo de coral

112 Disponível em: http://www.ruralstudio.org/projects/harris-butterfly-house. Acesso em: 22 ago. 2018. 
local e centro de distribuição de refeições escolares no verão. É um espaço público multifuncional, que atende as demandas da comunidade, construído em um terreno privado. Anderson Harris, dono da Casa Borboleta, doou a terra para a obra antes de sua morte. A reutilização inovadora de materiais junto a técnicas de construção improvisadas combinam a linguagem formal vernacular a uma nova linguagem local. Vidros automotivos resgatados de um pátio de sucata fornecem o material de cobertura no lado norte, e são apoiados sobre uma estrutura de madeira laminada que descansa sobre paredes de terra batida. A Figura 32 e a Figura 33 mostram imagens internas e externas da obra concluída e também detalhes, planta baixa e corte geral do projeto.

Figura 32 - Glass Chapel construída pelo Rural Studio em Mason's Bend
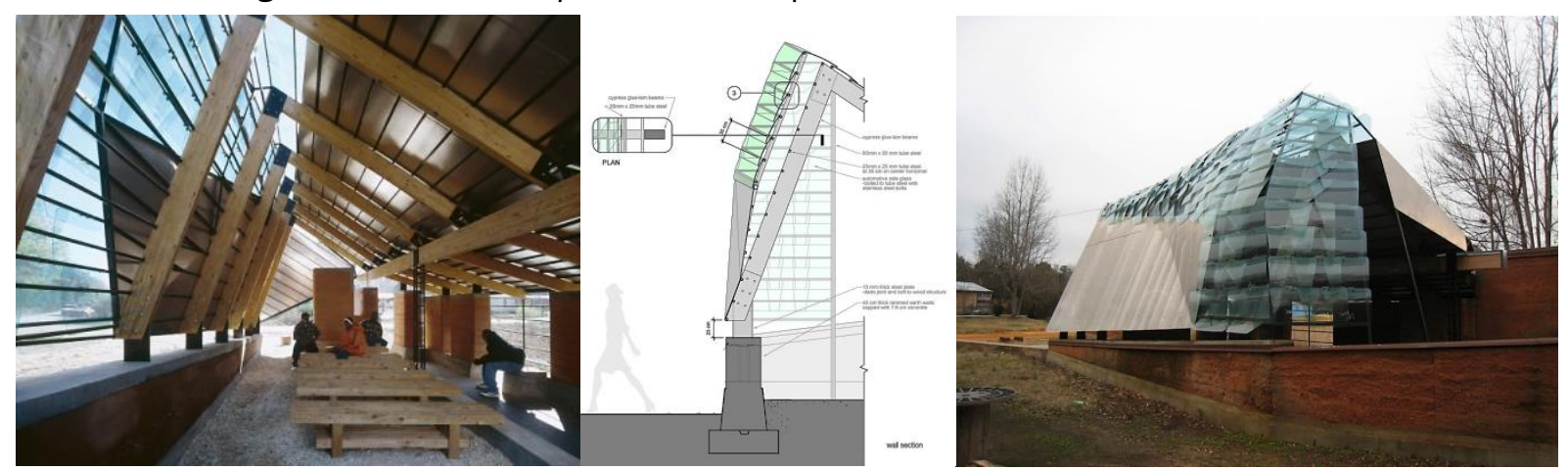

Fonte: Website Rural Studio e Archello ${ }^{113}$.

Figura 33 - Planta baixa e corte geral da Glass Chapel em Mason's Bend
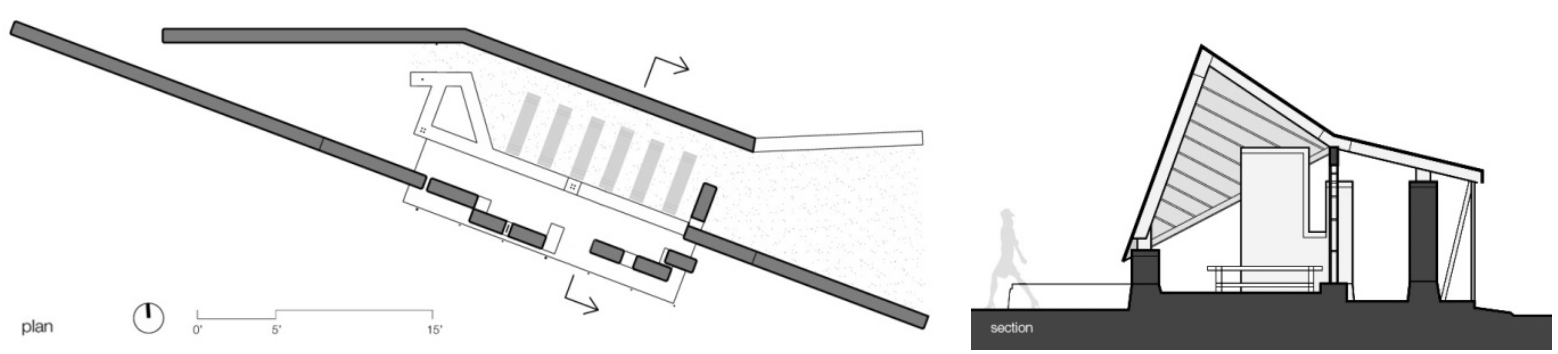

Fonte: Website Archello ${ }^{114}$.

113 Disponível em: http://www.ruralstudio.org/projects/glass-chapel. Acesso em: 22 ago. 2018 e https://archello.com/project/masons-bend-community-center\#stories. Acesso em: 02 ago. 2019.

114 Disponível em: https://archello.com/project/masons-bend-community-center\#stories. Acesso em: 02 ago. 2019. 


\section{Newbern Fire Station}

Local e ano de projeto: Newbern, 2004

Programa: $5^{\circ}$ ano

O Corpo Voluntário de Bombeiros de Newbern juntamente com a Prefeitura, são os primeiros edifícios públicos construídos novos na cidade nos últimos 110 anos. Abriga três caminhões de bombeiros e serve de abrigo para satisfazer algumas necessidades da cidade como um lugar para a realização de eleições, reuniões do conselho, classes de bombeiros voluntários, arrecadação de fundos e reuniões comunitárias. O edifício é estruturado por uma de treliça de madeira e metal, fechado por painéis de policarbonato translúcido, protegido do sol por ripas de cedro e coberto com um telhado de alumínio galvanizado (Figura 34). No interior existe um mezanino para as aulas de combate a incêndios e no pavimento térreo um banheiro e uma cozinha. $\mathrm{O}$ projeto foi concebido e construído em apenas dois anos e ao mesmo tempo em que a equipe arrecadou US\$100.000 em doações de materiais. A Figura 35 traz alguns croquis do edifício da estação de bombeiros.

Figura 34 - Estação de Bombeiros de Newbern estruturado por treliças de madeira e metal
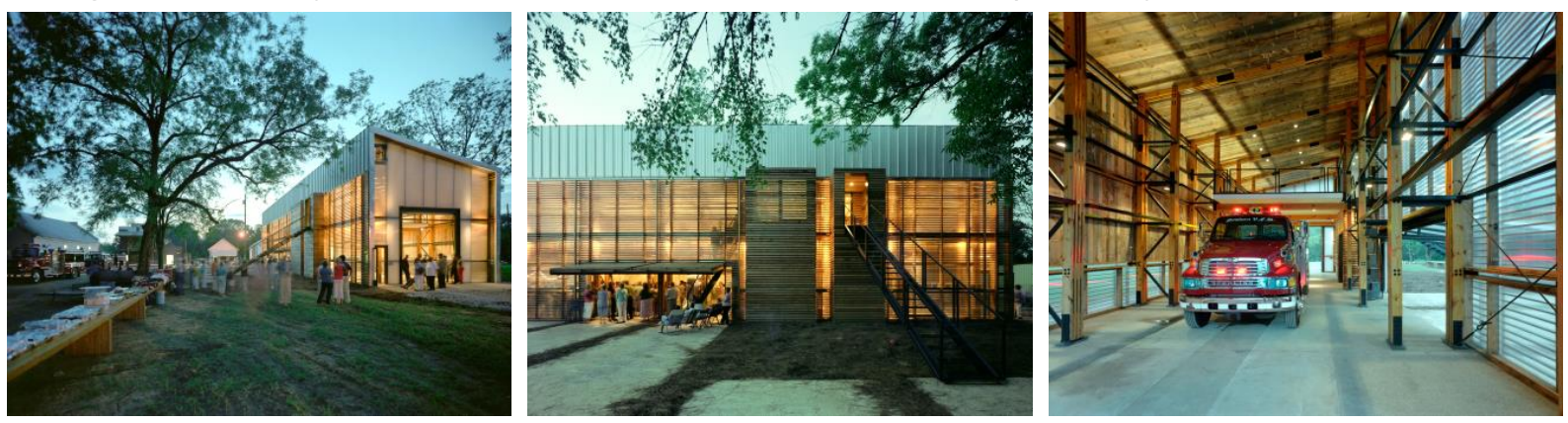

Fonte: Website Rural Studio ${ }^{115}$.

${ }^{115}$ Disponível em: http://www.ruralstudio.org/projects/newbern-fire-station. Acesso em: 22 ago. 2018. 
Figura 35 - Estação de Bombeiros de Newbern
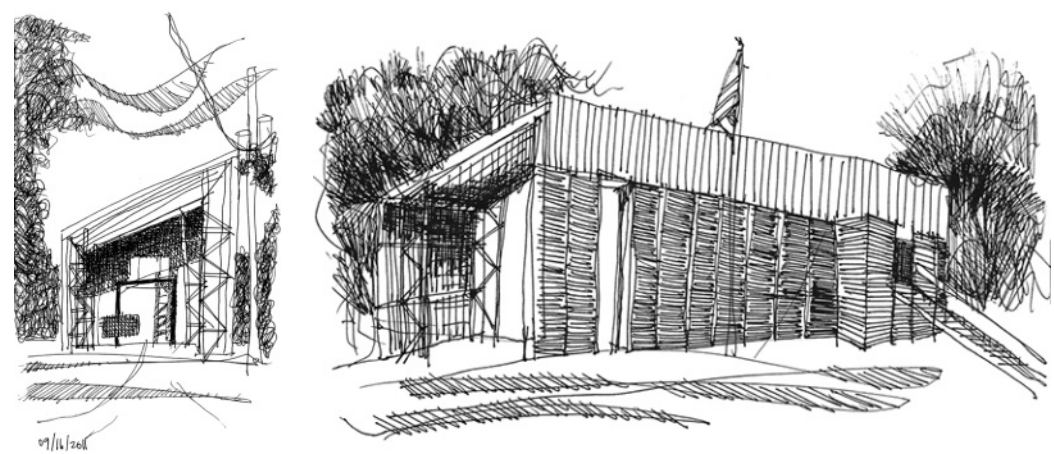

Fonte: Website Behance Student Show ${ }^{116}$.

\section{Akron Boys \& Girls Club 2}

\section{Local e ano de projeto: Akron, 2007}

\section{Programa: $5^{\circ}$ Ano}

Quatro alunos de quinto ano projetaram e construíram um Clube de Meninos e Meninas atendendo aos contínuos pedidos dos moradores da cidade para um espaço seguro de atividades educacionais e recreativas para as crianças de Akron. Uma estrutura lamelar de madeira de grande extensão cobre uma quadra de basquete e conecta-se a um espaço de recreação. Todo o complexo tem uma área aproximada de $230 \mathrm{~m}^{2}$. A Figura 36 ilustra o espaço interior de recreação e exterior através de croquis e a Figura 37 Traz imagens do edifício já em uso.

Figura 36 - Croquis e imagem interna do Akron Boys and Girls Club \#2
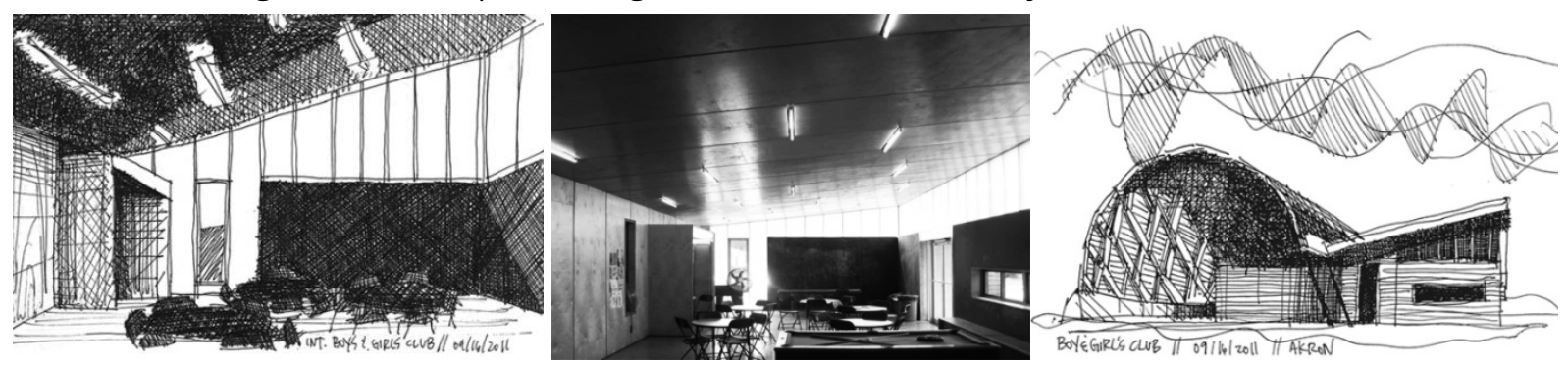

Fonte: Website Behance Student Show ${ }^{117}$.

\footnotetext{
116 Disponível em: http://www.studentshow.com/gallery/2273086/Rural-Studio. Acesso em: 22 ago. 2018.

117 Disponível em: http://www.studentshow.com/gallery/2273086/Rural-Studio. Acesso em: 22 ago. 2018.
} 
Figura 37 - Akron Boys and Girls Club \#2

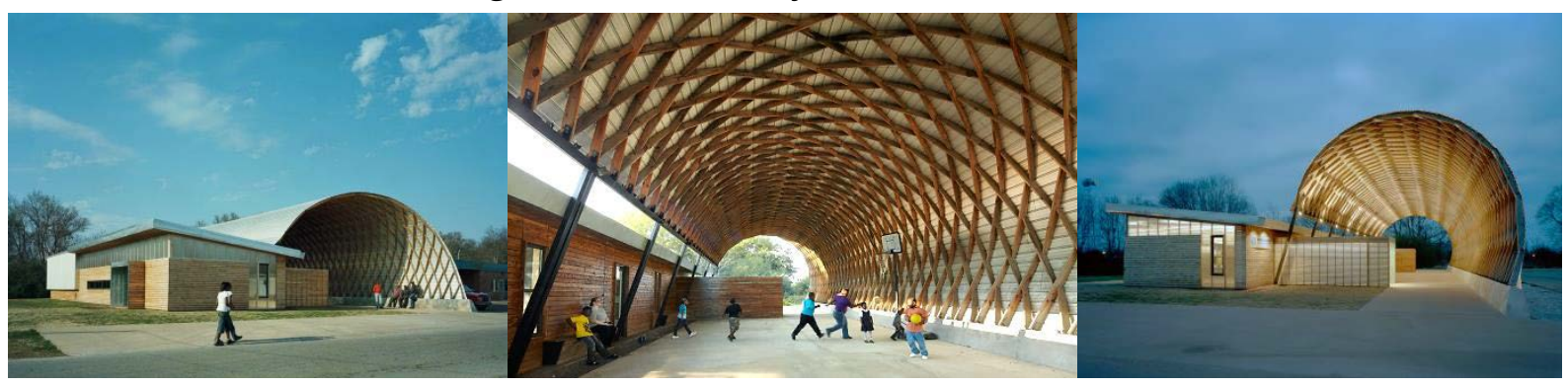

Fonte: Website Rural Studio ${ }^{118}$.

\section{Kv22 Home}

Local e ano de projeto: Newbern, 2018

Programa: $5^{\circ}$ Ano

A Casa 20Kv22, uma das últimas versões das 20K Home, foi proposta como uma casa não só acessível para construir, mas também para se viver. As versões anteriores do projeto 20K Home se concentraram na redução do custo de hipoteca, mas essa versão esforçou-se para reduzir os custos de serviços públicos e seguro residencial. Essas economias foram determinadas comparando o consumo de energia de uma casamodelo, a Dave's Home 20Kv08 construída em 2009 (Figura 38), com o consumo de energia da versão revisada da casa.

Figura 38 - Dave's Home 20Kv08, Newbern, 2009
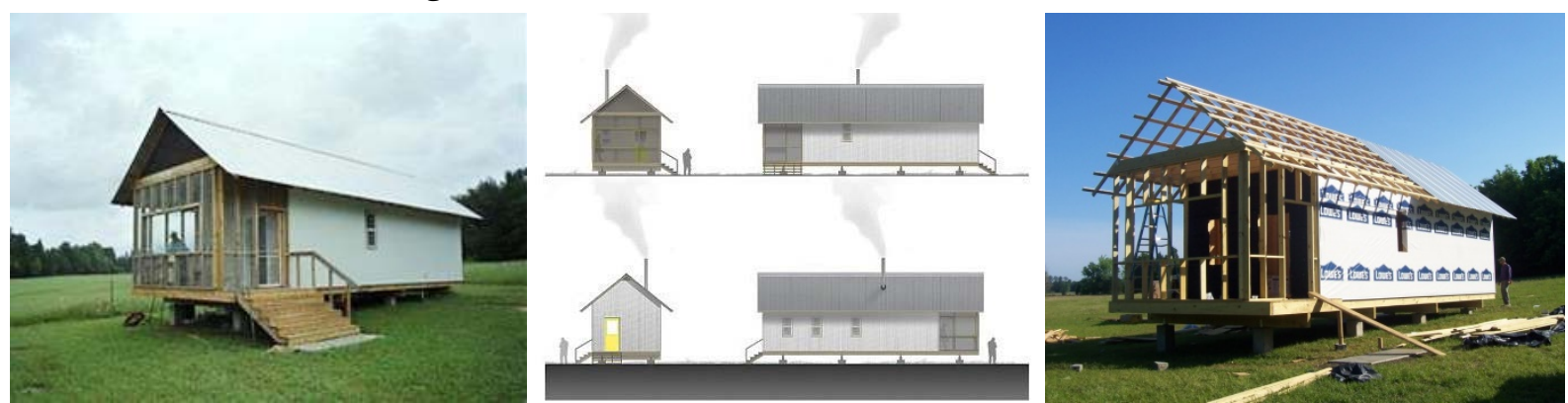

Fonte: Website Rural Studio ${ }^{119}$.

118 Disponível em: http://www.ruralstudio.org/projects/akron-boys-girls-club. Acesso em: 22 ago. 2018.

119 Disponível em: http://www.ruralstudio.org/projects/20k-v8-daves-house. Acesso em: 22 ago. 2018. 
Na versão original as técnicas de construção foram padronizadas para reduzir o tempo de construção, permitindo que mais dinheiro fosse utilizado para materiais, em vez de mão de obra. A estrutura utilizada foi do tipo Wood Frame. O projeto da casa revisada baseou-se nos resultados de experimentos e testes da casa-modelo que determinaram o contexto ambiental ideal, a envolvente do edifício e as estratégias de conforto térmico. Além disso, a casa revisada foi aprimorada para estar em conformidade com as Fortified Standards, um conjunto de diretrizes delineadas para melhorar residências para que cumpram os requisitos mínimos das normativas, a fim de reduzir os danos causados por tornados, furacões e granizo, e por sua vez, reduzir os custos de seguros. A Figura 39 ilustra o grupo de alunos trabalhando na 20Kv22 Dave's Revised Home e a Figura 40 apresenta algumas das versões anteriores das 20K Homes.

Figura 39 - 20Kv22 Dave's Revised Home uma das últimas versões das 20K Home
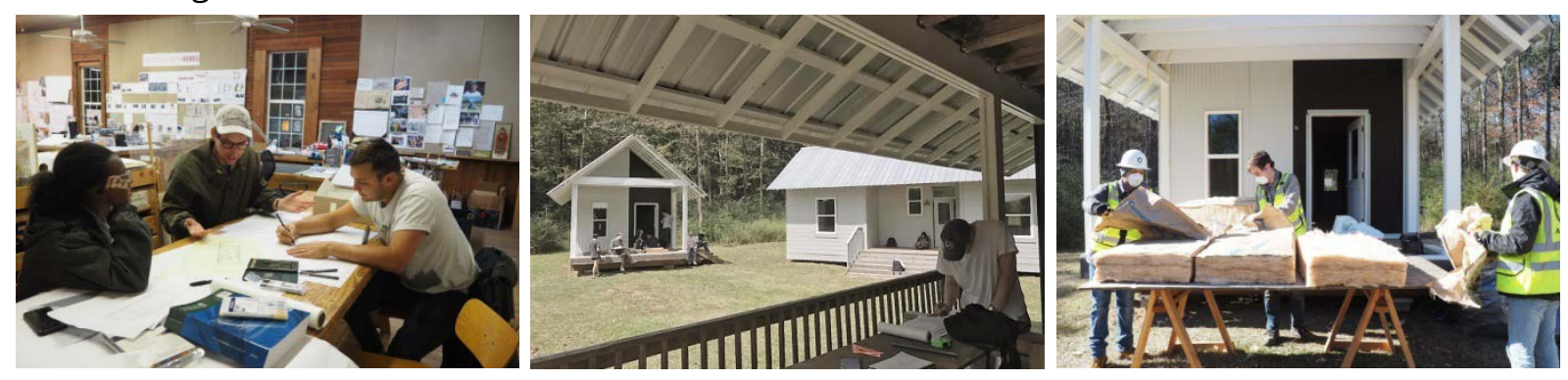

Fonte: Website Rural Studio ${ }^{120}$.

Figura 40 - Algumas versões das 20K Homes: 20Kv04 Pattern Book Home, 20Kv05 Loft Home, 20 Kv06 Roundwood Home construídas em Greensboro, 2008
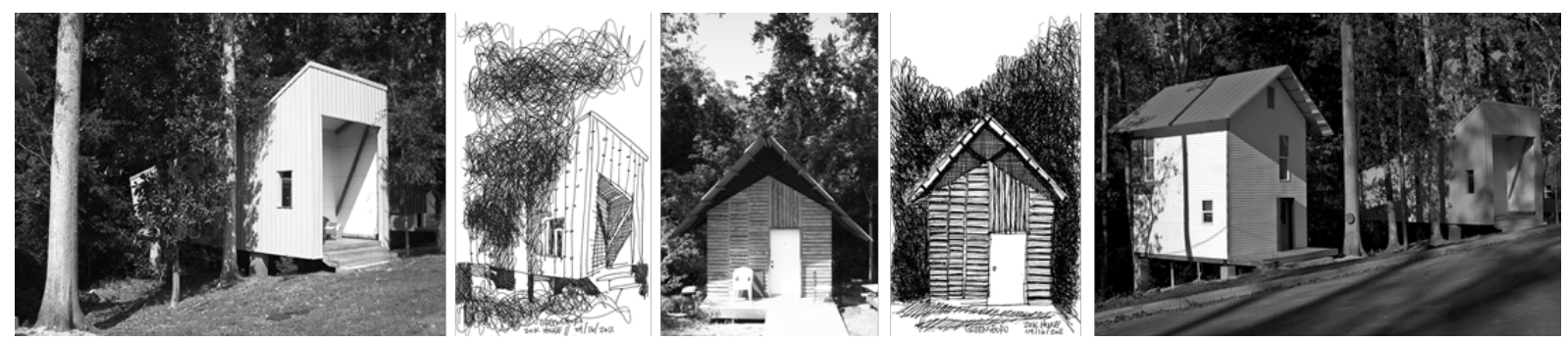

Fonte: Website Rural Studio e Behance Student Show ${ }^{121}$.

\footnotetext{
120 Disponível em: http://www.ruralstudio.org/projects/20kv22-home. Acesso em: 02 ago. 2019.

${ }^{121}$ Disponível em: http://www.ruralstudio.org/projects.html e

http://www.studentshow.com/gallery/2273086/Rural-Studio. Acesso em: 22 ago. 2018.
} 
As casas foram equipadas com sensores e registradores de dados para monitoramento do microclima, consumo de energia, temperatura interna e umidade relativa, temperatura e umidade relativa da parede interna e qualidade do ar interno. Além disso, ambas as casas são habitadas pelos estudantes para analisar detalhadamente as experiências e conforto térmico em todas as quatro estações do ano - uma novidade para o programa Rural Studio. A cada semana, são coletados dados quantitativos, analisados e correlacionados com as observações qualitativas.

Ao projetar, construir e depois morar na casa-modelo e na casa revisada, pretendese reunir os dados quantitativos do estudo completo de pós-ocupação e a experiência qualitativa do que é realmente viver em uma 20K Home. Certamente, essa é uma experiência muito relevante ao envolver além da concepção e construção de um projeto feito pelos estudantes, também a avaliação pós-ocupação, de modo a realizar ainda a produção de dados científicos abarcando as premissas de ensino, pesquisa e extensão uma experiência completa de ensino-aprendizado aplicado à arquitetura.

A seguir é apresentada uma síntese da análise dos programas do Rural Studio segundo as categorias indicadas anteriormente (Quadro 4). 
Quadro 4 - Quadro síntese de análise do programa Rural Studio

\section{RURAL STUDIO - Auburn University}

\section{Estrutura Curricular}

O Rural Studio oferece três tipos de programas, sendo que dois deles são voltados a alunos de graduação em arquitetura de $3^{\circ}$ e $5^{\circ}$ anos, oferecidos como cursos eletivos com aproximadamente 15 vagas, um terço em relação ao número de alunos das turmas. A seleção é feita prioritariamente por desempenho acadêmico. O programa de $3^{\circ}$ ano é de um semestre e possui uma estrutura curricular com atividades distribuídas durante os períodos matutino e vespertino. O programa de $5^{\circ}$ ano abarca um ano acadêmico completo, podendo estender-se em mais um ano. Os dois programas são organizados em estúdios de projeto e construção, além de uma oficina voltada ao trabalho com madeira e disciplinas de representação gráfica em técnicas aquarela e à mão livre. Recentemente criado, em substituição ao Outreach Program - programa de extensão descontinuado pelo Rural Studio - o programa de pósgraduação Rural Studio MS Arch conta com três semestres e é direcionado a titulados na área de arquitetura, com foco de pesquisa em habitação rural.

\section{Conteúdos Programáticos}

Os conteúdos programáticos trabalhados no Design Studio do $3^{\circ}$ ano relacionam-se com um projeto de múltiplas fases chamado de Farm Rural Studio que foca no redesenho do campus, envolvendo as estruturas administrativas, de produção de alimentos e de moradia dos próprios estudantes. O projeto é baseado no propósito educativo de vivenciar um estilo de vida integrado à comunidade local. Já os conteúdos do $5^{\circ}$ ano, relacionam-se ao trabalho junto aos municípios e conselhos consultivos para realizar projetos comunitários. Desenvolvem-se projetos de Tese, projetos de construção sustentável, e constroem-se os projetos desde a fundação até o telhado. Nas oficinas de madeira são elaborados projetos de recriação de cadeiras icônicas por meio de pesquisa, desenho, modelagem e construção, que permitem a aquisição de habilidades de marcenaria num curso prático de fabricação de móveis. Simultaneamente, se desenvolvem exercícios de representação gráfica destes projetos por meio de desenhos à mão livre. A representação artística também é explorada em Seminários de História e Teoria com o objetivo de familiarizar os alunos com o ambiente construído do Alabama e obter entendimento do contexto arquitetônico dos edifícios.

\section{Metodologia de Ensino}

A proposta pedagógica do Rural Studio parte da premissa de que os estudantes, ao saírem da realidade cotidiana para conhecerem o mundo além dos limites da universidade, desenvolvem uma visão mais crítica sobre a Arquitetura. Ao experimentar outro estilo de vida e cultura, forma-se um novo olhar sobre o conhecido, um olhar externo que promove uma nova forma de entendimento. Por meio dessa proposta conceitual é que o curso utiliza as ferramentas pedagógicas do Design Build para aprender Arquitetura, buscando o equilíbrio entre o projeto em ateliê e a prática construtiva. A metodologia de ensino volta-se para projetos de orientação comunitária através de esforços multianuais, de várias fases, percorrendo três municípios. Os alunos trabalham dentro da comunidade para definir soluções, angariar fundos, projetar e construir.

Durante o início de um trabalho, $05^{\circ}$ ano e o Outreach Program trabalhavam juntos em uma série de exercícios rápidos de projeto e revisão já focados na demanda estudada. Esses exercícios serviam para que os estudantes exercitassem a agilidade de pensar em uma série de propostas e questões ao mesmo tempo para um único projeto. Depois dessa etapa, e da formulação dos programas de projeto, equipes de três a cinco pessoas trabalhavam juntas no desenvolvimento do projeto básico e depois, do executivo: nessa fase muitos consultores são 
convidados para assessorar os diversos aspectos técnicos. A partir do projeto executivo pronto, a equipe de alunos troca a lapiseira por ferramentas de obra dedicando-se diariamente à obra, com bastante disciplina.

O método do learning by making, ou seja, aprender-fazendo permeia todo o currículo e é introduzido desde as disciplinas de representação gráfica que estimulam técnicas manuais de desenho e expressão artística, passando pelas oficinas de marcenaria e finalmente as construções em escala real, com a premissa de executar o trabalho com inteligência, habilidades manuais e alta qualidade. Os alunos de pós-graduação participarão integralmente do programa Rural Studio Design-Build e trabalharão em colaboração com um pequeno grupo de estudantes no desenvolvimento de um projeto de pesquisa em moradias rurais, com o objetivo de projetar e construir uma casa em Hale County.

\section{Considerações}

Embora o Rural Studio não seja um programa focado no ensino da madeira, incentiva-se amplamente o seu uso como recurso renovável, sustentável e um dos materiais de construção mais encontrados na região, de modo que está prontamente disponível em todos os estúdios. Os exercícios práticos realizados na oficina Woodshop encorajam o uso da madeira na Arquitetura por meio do desenvolvimento de habilidades para trabalhar artesanalmente com - material, estimulando o conhecimento mais aprofundado de suas características e fortalecendo a formação prática dos estudantes através da experimentação.

O programa reconhece o potencial da madeira como material construtivo e mantém um grupo de pesquisa que discute a importância da indústria madeireira no Alabama e como ela influencia a profissão de Arquitetura. Coordena visitas a fabricantes de produtos de madeira, documentando as informações coletadas para elaboração de um catálogo da indústria de produtos florestais existente em toda a região. As atividades do grupo de pesquisa certamente são muito relevantes para articular a cadeia produtiva da região na medida em que se conectam diversos atores, desde o setor florestal até o setor da construção, impulsionando novas possibilidades de arranjos produtivos vinculados à formação de profissionais.

A análise detalhada do programa traz contribuições importantes:

Em relação à inserção no currículo do curso de arquitetura, indica que a possibilidade de trabalhar com grupos de alunos em dois distintos momentos e maturidades, aporta grande valia à vivência como forma de experimentação em distintas gradações temporais e temáticas. Um segundo momento é oferecido como oportunidade de aprofundar os conhecimentos e o envolvimento com as questões comunitárias.

Quanto aos conteúdos, estes estão diretamente relacionados com os problemas reais e locais, favorecendo a compreensão do contexto e o desenvolvimento de práticas que interconectam a realidade da comunidade e as habilidades que se pretendem desenvolver. Dessa forma, teoria e prática estão intrinsecamente relacionadas.

Já os aspectos relativos às metodologias de ensino, vinculam-se diretamente aos objetivos do programa de aprender-fazendo, dentro da realidade social, e são muito peculiares à própria experiência. Não ficam claros os aspectos relativos aos processos desenvolvidos junto à comunidade e como se gerenciam as demandas. Mas, quanto às etapas de projeto e construção, parece ser o próprio processo de projeto o roteiro determinante, através dos fluxos que abarcam desde os estudos preliminares até o projeto executivo. Quanto à etapa construtiva, no que se refere ao trabalho com a madeira, certa capacitação técnica é fornecida previamente aos alunos para o manuseio de ferramentas e máquinas. 


\subsubsection{WOOD PROGRAM - Aalto University, Finlândia}

O Wood Program é um programa intensivo de um ano com foco em Madeira e Arquitetura em Madeira oferecido pelo Department of Architecture, School of Arts, Design and Architecture da Aalto University. O curso explora as propriedades ecológicas, técnicas e arquitetônicas da madeira, proporcionando uma visão completa e abrangente de toda a cadeia de construção em madeira, começando com a árvore na floresta e terminando com um edifício experimental de madeira.

É um programa internacional vinculado a Aalto Wood que, por sua vez, é um centro de pesquisa, educação e conhecimento em construção de madeira na Universidade de Aalto. A Aalto Wood combina arquitetura em madeira com engenharia estrutural e ciência da madeira para fornecer uma abordagem holística para o desenvolvimento da construção em madeira. Na sua coordenação estão membros do corpo docente e equipe de pesquisa da Aalto University School of Arts, Design and Architecture (ARTS), Chemical Technology (CHEM), e Engineering (ENG) (CRONHJORT; VAHTIKARI; TAKANO, 2016).

Durante o evento Semana de la Madera ${ }^{122}$ que ocorreu em Santiago do Chile de 8 a 12 de agosto de 2018, um dos Seminários realizados contou com a presença de arquitetos chilenos e argentinos que cursaram o Wood Program em três períodos consecutivos e que apresentaram o programa do curso e os projetos desenvolvidos e executados durante os estudos na Finlândia.

O Wood Program in Architecture and Design é um curso de pós-graduação ministrado no idioma inglês, pago através de uma taxa de matrícula anual, projetado para atrair estudantes de todo o mundo para um período de estudo intensivo sobre madeira e o uso da madeira dentro do ambiente arquitetônico finlandês. É destinado a candidatos que possuem grau de bacharel em arquitetura ou áreas afins, como engenharia, arquitetura paisagística ou design de interiores e corresponde ao nível de mestrado

122 Para maiores informações consultar a página web: http://www.semanadelamadera.cl/. 
europeu. Os candidatos com experiência profissional equivalente e/ou com três anos de estudo também podem se inscrever, mas devem demonstrar suas qualificações específicas na inscrição e através de portfólio.

Os conteúdos abordados no Wood Program são os seguintes:

- A importância ecológica das florestas e da madeira;

- As propriedades técnicas da madeira e dos materiais à base de madeira;

- A madeira como material de construção;

- A tradição e o desenvolvimento de edifícios de madeira;

- A madeira no ambiente construído contemporâneo;

- Preocupações e potencialidades futuras para a arquitetura em madeira.

As aulas proporcionam um panorama teórico a partir de projetos que enfatizam questões práticas. As disciplinas são desenvolvidas através de tutoria pessoal e trabalho em grupos e, além disso, o aprendizado é realizado através de visitas a indústrias madeireiras, a diversos edifícios e áreas habitacionais. O programa é organizado em cooperação com o Departamento de Tecnologia de Produtos Florestais e o Departamento de Engenharia Civil e Ambiental e acontece no Departamento de Arquitetura, no Campus Otaniemi, em instalações projetadas por Alvar Aalto e com espaços de estúdios e oficinas bem equipados ${ }^{123}$.

A Figura 41 ilustra alguns dos projetos realizados no programa. 
Figura 41 - Detalhes de alguns projetos executados pelo Wood Program da Aalto University

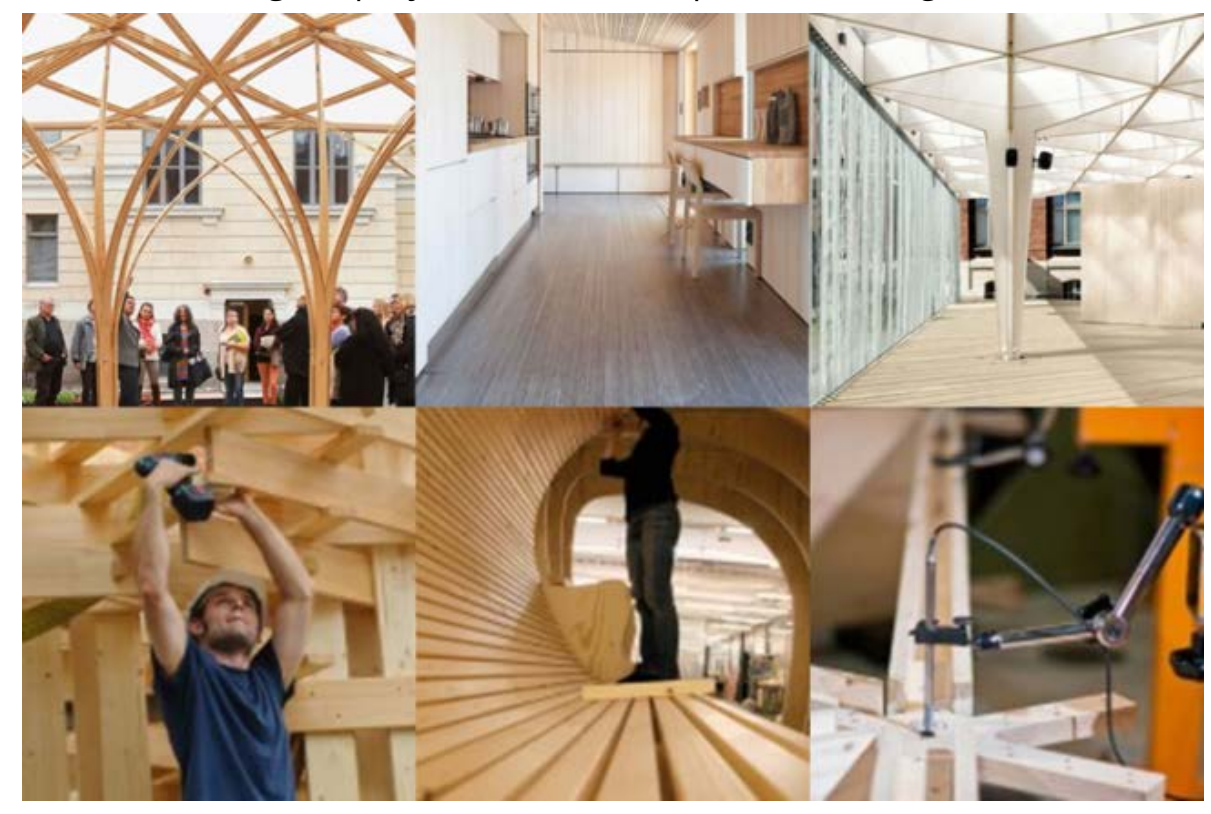

Fonte: Website do Wood Program ${ }^{124}$.

\subsubsection{Estrutura Curricular}

O Wood Program está estruturado em dois semestres, de outono e de primavera, com disciplinas de até 62 créditos (ECTS) no total. Estas incluem estúdios de projeto, aulas, seminários e cursos baseados em projetos, entre estes excursões, conforme a grade curricular apresentada na Figura 42.

O DESIGN STUDIO, ou estúdio de desenho/projeto, é o coração do curso e envolve exercícios em forma de workshops bem como um projeto de construção na escala 1:1. Corresponde às disciplinas em amarelo (Figura 42).

ARK-E4002 Wood Program Design Studio

ARK-E4010 Wood Program Building Project

124 Disponível em: http://woodprogram.fi/projects/. Acesso em 24 ago. 2018. 
Figura 42 - Estrutura curricular do Wood Program

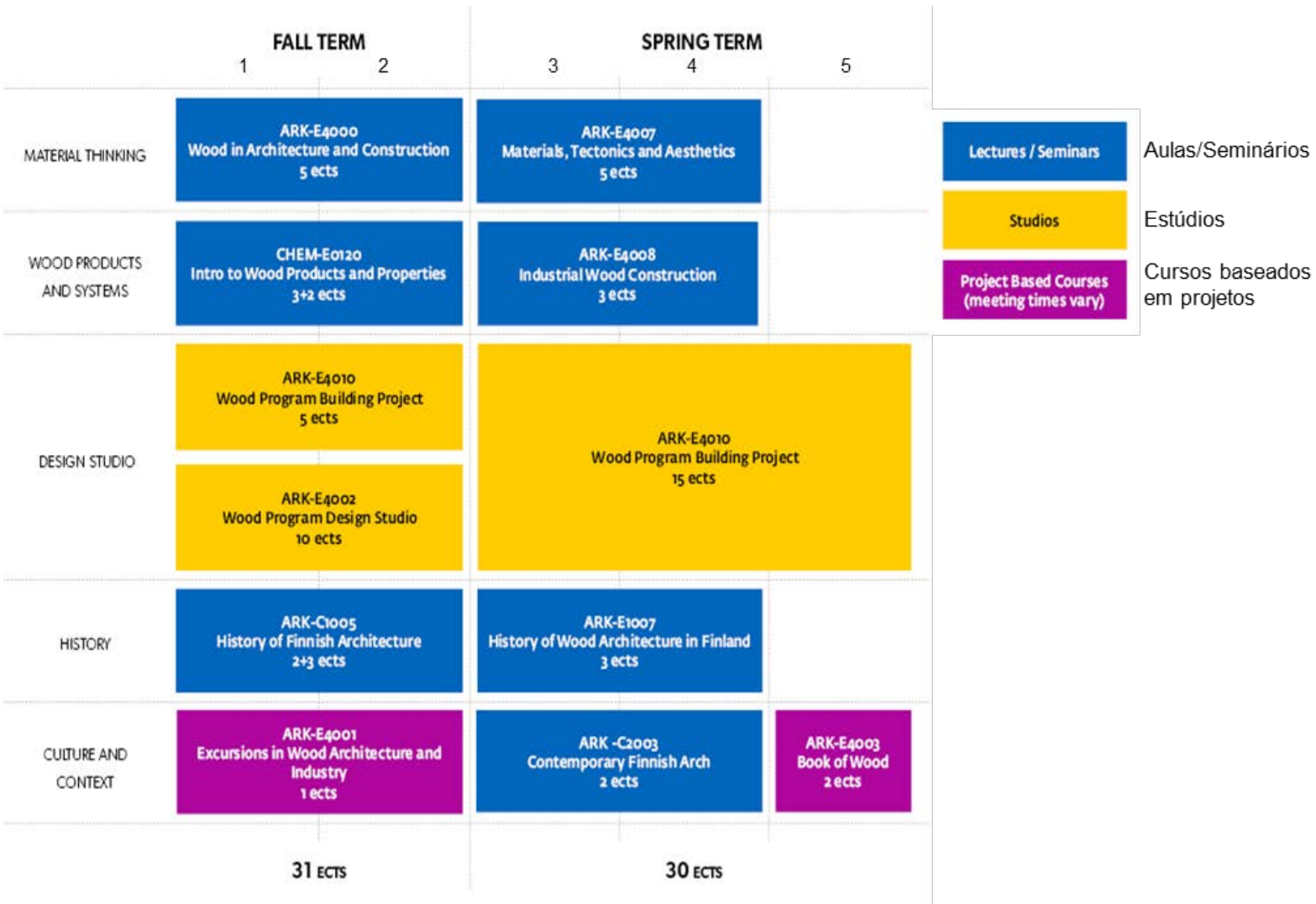

Fonte: Website do Wood Program ${ }^{125}$, editado pela autora.

Paralelamente ao DESIGN STUDIO, os estudantes cursam disciplinas sobre tecnologia da madeira e construção e assistem a aulas e seminários sobre arquitetura histórica e contemporânea na Finlândia, organizadas em áreas temáticas, conforme exposto a seguir:

MATERIAL THINKING:

ARK-E4000 Wood in Architecture and Construction
ARK-E4007

WOOD PRODUCTS AND SYSTEMS:

CHEM-E0120 Introduction to Wood Products and Properties

ARK-E4008 Industrial Wood Construction

${ }^{125}$ Disponível em: http://woodprogram.fi/courses/. Acesso em 24 ago. 2018. 
HISTORY:

ARK-C1005 History of Finnish Architecture

ARK-E1007 History of Wood Architecture in Finland

CULTURE AND CONTEXT:

ARK-C2003 Contemporary Finnish Architecture

ARK-E4001 Excursions in Wood Architecture

ARK-E4003 The Book of Wood

Estudantes com conhecimento prévio em tecnologia da madeira podem cursar disciplinas adicionais eletivas, como:

CHEM-E2105 Wood and Wood Products

CHEM-E2200 Polymer Blends and Composites

A estrutura curricular para o período de 2018-2019 e o calendário do curso são apresentados no ANEXO B.

Além do Wood Program, a Aalto Wood promove cursos interdisciplinares para alunos de graduação e atividades de cooperação transnacional, por exemplo, programas de pesquisa, desenvolvimento e inovação, projetos e seminários públicos de disseminação de resultados de pesquisas para a indústria e outras partes interessadas. As atividades da Aalto Wood estão listadas no Quadro 5 conforme apresentadas por Cronhjort, Vahtikari e Takano (2016) durante o evento WCTE $2016^{126}$ em Viena, Áustria. 
Quadro 5 - Atividades oferecidas pelo Aalto Wood

\begin{tabular}{|l|l|}
\hline Atividade & Nível \\
\hline $\begin{array}{l}\text { Palestras abertas a alunos de outras escolas e } \\
\text { departamentos da Aalto }\end{array}$ & Mestrado, pós-graduação \\
\hline Cursos abertos de Design & Mestrado \\
\hline $\begin{array}{l}\text { Possibilidade de Tese de Doutorado multi-científica com } \\
\text { instrutores de várias escolas de Aalto }\end{array}$ & Pós-graduação \\
\hline Apresentação no seminário anual Aalto Wood & $\begin{array}{l}\text { Pós-graduação, } \\
\text { pesquisadores, } \\
\text { professores }\end{array}$ \\
\hline Participação no seminário Aalto Wood & Todos os níveis \\
\hline Participação em eventos internacionais para doutorandos & $\begin{array}{l}\text { Pós-graduação, } \\
\text { professores }\end{array}$ \\
\hline $\begin{array}{l}\text { Participação em projetos nacionais e internacionais de } \\
\text { pesquisa, desenvolvimento e inovação }\end{array}$ & $\begin{array}{l}\text { Dissertaçães de Mestrado, } \\
\text { pós-graduação, } \\
\text { professores }\end{array}$ \\
\hline Publicações multi-científicas & Todos os níveis \\
\hline
\end{tabular}

Fonte: Cronhjort; Vahtikari; Takano (2016), tradução nossa.

\subsubsection{Conteúdos programáticos}

A seguir são apresentados os conteúdos desenvolvidos em cada uma das disciplinas do Curso Wood Program ${ }^{127}$ conforme grade curricular da Figura 42.

\section{WOOD IN ARCHITECTURE AND CONSTRUCTION}

\section{A madeira na Arquitetura e Construção}

O curso consiste em uma série de aulas que introduzem a madeira e as várias maneiras nas quais ela é usada como material de construção. Espécies de madeira, estruturas, produtos e sistemas são examinados sob uma perspectiva técnica, ecológica e estética. O objetivo da disciplina é familiarizar-se com as questões especiais de 
projetar um edifício em madeira e perceber as propriedades e possibilidades da madeira como material de construção no futuro ambiente construído.

Pontos-chave: proficiência em construção em madeira, questões ecológicas de arquitetura em madeira, tradição de construções em madeira, estratégias de construção contemporâneas e técnicas e estética em madeira.

\section{EXCURSIONS IN WOOD ARCHITECTURE}

\section{Excursões na arquitetura em madeira}

Ao longo do ano, são organizadas excursões a locais de interesse natural, industrial e histórico para apresentar aos alunos a floresta finlandesa, espécies de madeira, construção tradicional em madeira, cidades em madeira, arquitetura contemporânea em madeira, produção industrial e pesquisa.

\section{1:1 DESIGN EXCERCISES}

\section{Exercícios de projeto 1:1}

Este estúdio constitui o núcleo dos estudos do ano para os alunos do Wood Program. Centra-se nas características e utilização da madeira como material de construção moderno, com ênfase em modelos e maquetes em escala.

\section{THE BOOK OF WOOD}

\section{O livro da madeira}

No final do período, cada aluno apresenta um portfólio pessoal documentando sua experiência ao longo do ano.

WOOD PROGRAM BUILDING PROJECT

Projeto de construção “Wood Program” 
No outono, os alunos desenvolvem vários exercícios de projeto em escala real. Primeiro individualmente, e depois em pequenos grupos, estas tarefas introduzem diferentes materiais e técnicas de construção em madeira. O semestre termina com um concurso de projeto em que cada aluno faz uma proposta individual para um pequeno edifício de madeira. No período de primavera, os alunos realizam um edifício experimental em escala um para um.

\section{MATERIALS, TECTONICS AND AESTHETICS}

\section{Materiais, Tectônica e Estética}

Este curso fornece uma visão geral da construção não apenas como uma aplicação técnica e prática, mas também como um assunto de investigação teórica - uma maneira particular de pensar e trabalhar. As aulas são organizadas tematicamente a partir de uma série de períodos históricos e práticas contemporâneas. Através de leituras e análises de textos e edifícios selecionados, os estudantes trabalham para uma melhor compreensão das maneiras pelas quais as teorias da arquitetura, representação e julgamento estético se cruzam com as preocupações materiais e técnicas da construção.

A cada semana, espera-se que os alunos concluam o material de leitura e algumas pequenas tarefas de casa atribuídas. Para a conclusão do curso, os alunos serão solicitados a estudar um único prédio em profundidade e entregar uma análise na forma de um livreto.

\section{HISTORY OF WOOD ARCHITECTURE IN FINLAND}

\section{História da arquitetura em madeira na Finlândia}

A disciplina familiariza os alunos com as tradições e construções vernáculas finlandesas e carelianas em madeira. Aborda também a cidade finlandesa em madeira e o desenvolvimento da tradicional igreja em madeira, bem como temas variados na arquitetura em madeira dos anos 1800 a 1970. 


\section{HISTORY OF FINNISH ARCHITECTURE}

\section{História da arquitetura finlandesa}

Esta disciplina apresenta uma visão geral da arquitetura finlandesa, com ênfase nos desenvolvimentos e principais figuras do século XX.

\section{CONTEMPORARY FINNISH ARCHITECTURE}

\section{Arquitetura contemporânea finlandesa}

Esta disciplina consiste em palestras de visitantes, profissionais contemporâneos da Finlândia apresentando seu próprio trabalho.

\section{AN INTRODUCTION TO WOOD PROPERTIES AND WOOD PRODUCTS}

\section{Introdução às propriedades da madeira e produtos em madeira}

A disciplina consiste em aulas acompanhadas de experimentos em laboratório e exercícios sobre as características da madeira finlandesa e produtos de madeira finlandesa. Os estudantes ganham uma compreensão das propriedades químicas e físicas da madeira que afetam seu comportamento da escala celular à arquitetônica.

\section{INDUSTRIAL WOOD CONSTRUCTION}

\section{Construção industrializada em madeira}

A disciplina serve como uma introdução à construção em madeira do ponto de vista industrial, com foco nos impactos ecológicos e ambientais da produção e montagem em escala industrial. As sessões são organizadas em palestras, exercícios e um diário de curso. 


\subsubsection{Alguns projetos executados}

Em seguida são apresentados três dos projetos executados pelo Wood Program nos períodos de 2014-2015, 2015-2016 e 2016-2017 nos quais participaram a arquiteta argentina Laura Zubillaga, atual coordenadora do programa, e os arquitetos chilenos Eduardo Wiegand e Loreto Mancilla, conferencistas da Semana de la Madera 2018, em Santiago do Chile, que relataram suas experiências de projeto e construção.

\section{Säie}

Ano: $2014-2015$

Instrutores: Pekka Heikkinen, Philip Tidwell and Hannu Hirsi

Materiais: estrutura - lamelas de Pinus de 12,5 mm; juntas - madeira compensada de Bétula com corte CNC de 12 mm; decks - Pinus tratado termicamente; cobertura têxtil revestida em PVC.

O pavilhão Säie foi projetado para fornecer um espaço coberto para workshops, palestras, refeições e descanso no centro da cidade de Helsinque. A arquitetura do pavilhão faz referência a pergolados e gazebos de jardim inspirados na arquitetura gótica e no espaço denso da floresta. É composto por elementos curvos de madeira que criam uma intrincada treliça estrutural formando uma marquise acolhedora para uma variedade de atividades. Na Figura 43 observa-se o projeto do pavilhão em corte e vista lateral e na Figura 44, as etapas de montagem. A geometria complexa do edifício é obtida pela a curvatura do pinus de alta qualidade, fixado com juntas de contraplacado de bétula cortado em máquina CNC. O detalhamento das ligações foi desenvolvido simultaneamente a ensaios em laboratório que garantem a interação entre a arquitetura e a engenharia estrutural (Figura 45).

O pavilhão foi inicialmente construído no pátio do Museu de Arquitetura Finlandesa, em Helsinque, concluído em maio de 2015. No ano seguinte, a estrutura foi transferida para a uma localização permanente na praça principal da cidade de Tuusula, em frente à prefeitura. A reconstrução foi administrada pelos ex-alunos do Wood Program Laura 
Zubillaga, Hiroko Mori e James Stanier, que coordenaram o trabalho com os alunos da Keuda Vocational School em Järvenpää.

Figura 43 - Projeto do Pavilão Säie em corte e vista lateral
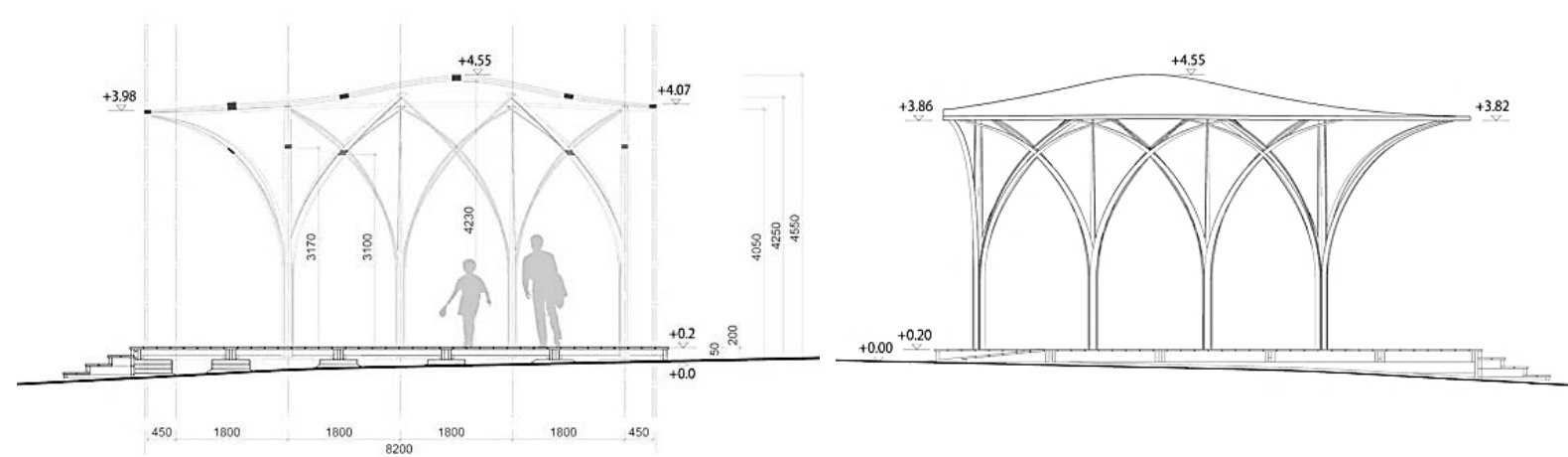

Fonte: Website Wood Program ${ }^{128}$.

Figura 44 - Montagem do pavilhão e construção finalizada
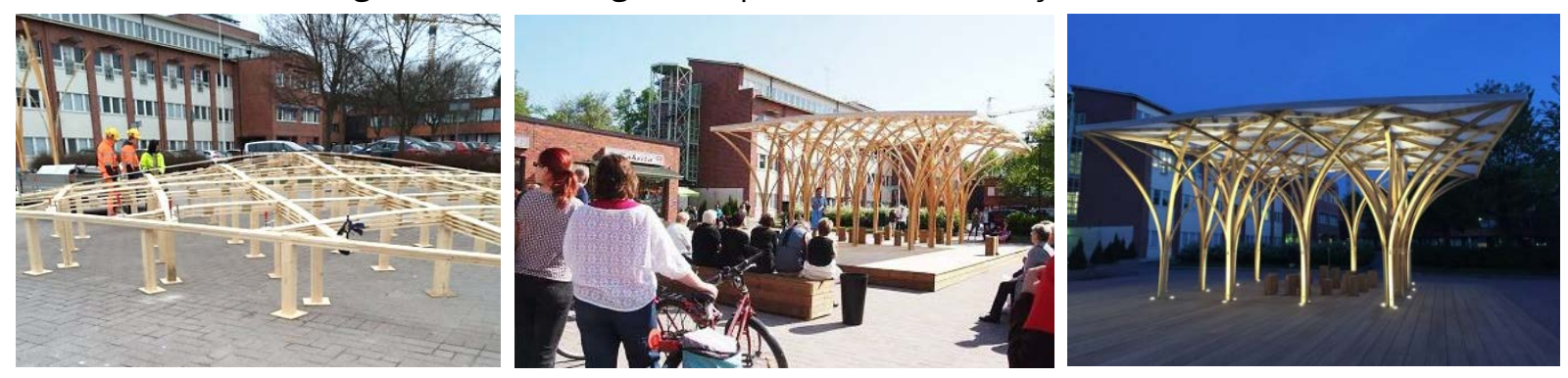

Fonte: Website Wood Program ${ }^{129}$.

Figura 45 - Ensaios em laboratório e detalhamento das ligações
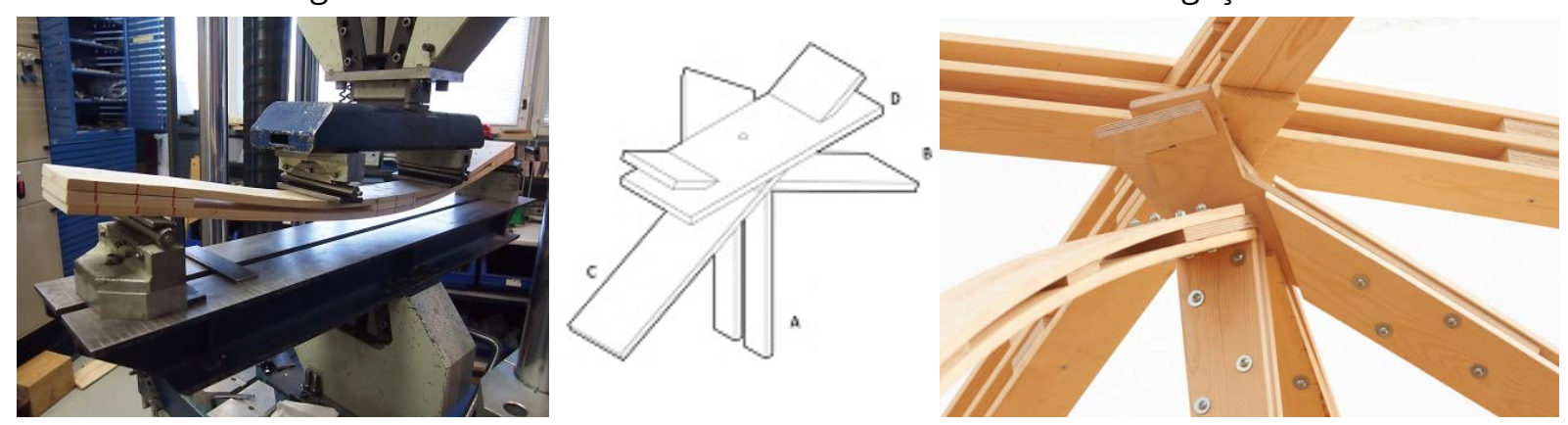

Fonte: Website Wood Program ${ }^{130}$.

\footnotetext{
${ }^{128}$ Disponível em: http://woodprogram.fi/portfolios/saie/. Acesso em 24 ago. 2018.

129 Disponível em: http://woodprogram.fi/portfolios/saie/. Acesso em 24 ago. 2018.

130 Disponível em: http://woodprogram.fi/portfolios/saie/. Acesso em 24 ago. 2018.
} 


\section{Kokoon}

Ano: $2015-2016$

Instrutores: Pekka Heikkinen, Philip Tidwell and Willem van Bolderen

Materiais: moldura e mobiliário fixo - painéis Kerto (LVL); revestimento - Abeto serrado com pintura à base de óleo; isolamento - fibra de celulose; impermeabilização do banheiro - poliuretano emborrachado; piso do banheiro - Aspen tratado termicamente.

O projeto Kokoon é uma unidade habitacional modular construída para resolver a situação atual da habitação na Finlândia, em função de uma grande escassez de acomodações temporárias para refugiados, estudantes e residentes desalojados pela reforma de edifícios. Os módulos pré-fabricados da Kokoon são projetados como uma solução de curto prazo (até um ano) que podem ser facilmente transportados e empilhados em várias configurações, conforme ilustram a Figura 47 e Figura 48, a fim de se implantar em vários locais em contextos urbanos e suburbanos. A estrutura dos módulos tipo é uma composição de painéis de $L V L$, vigas em LVL e maciças e colunas de MLC com conexões de aço para içamento e fixação (Figura 46).

Figura 46 - Projeto Kokoon: composição dos módulos tipo

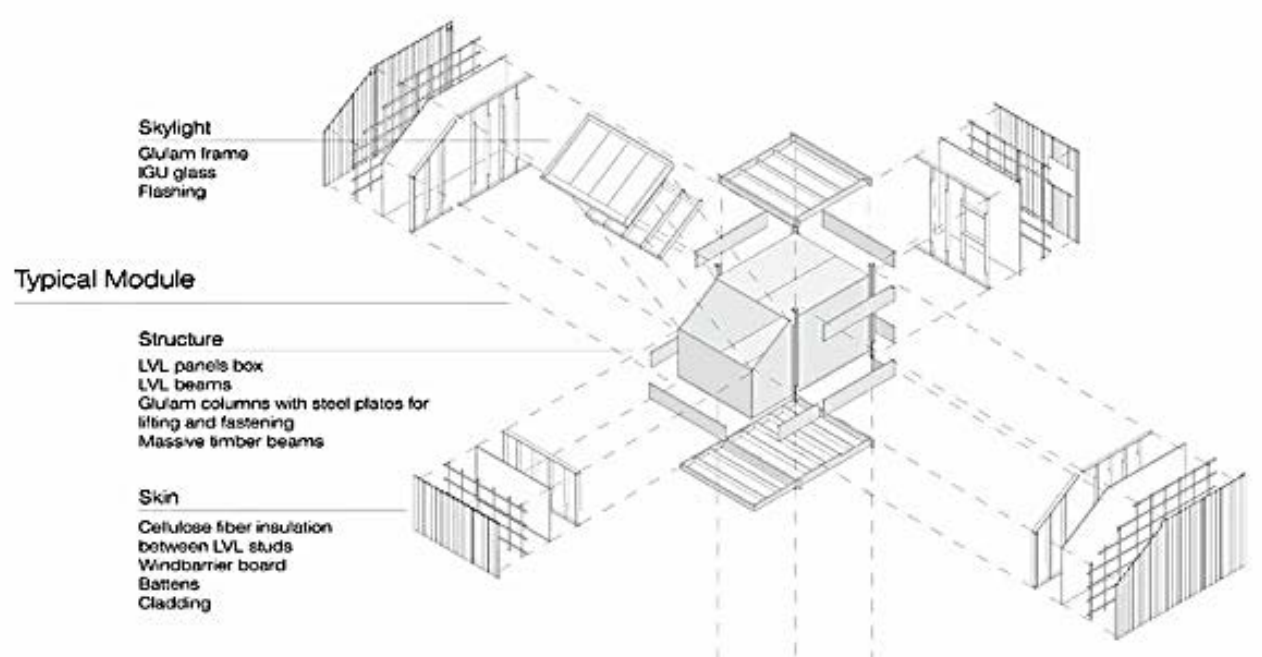

Fonte: Website Wood Program ${ }^{131}$.

${ }^{131}$ Disponível em: http://woodprogram.fi/portfolios/kokoon/. Acesso em 24 ago. 2018. 
Figura 47 - Projeto Kokoon: sequência de montagem dos módulos
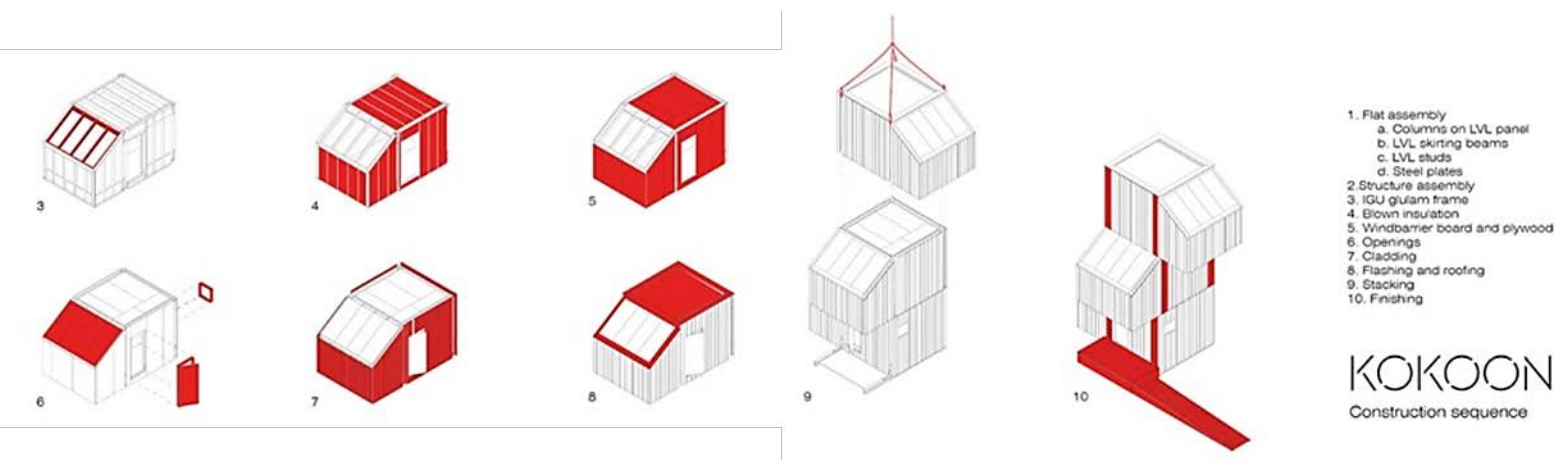

Fonte: Website Wood Program ${ }^{132}$.

Figura 48 - Construção e montagem dos módulos

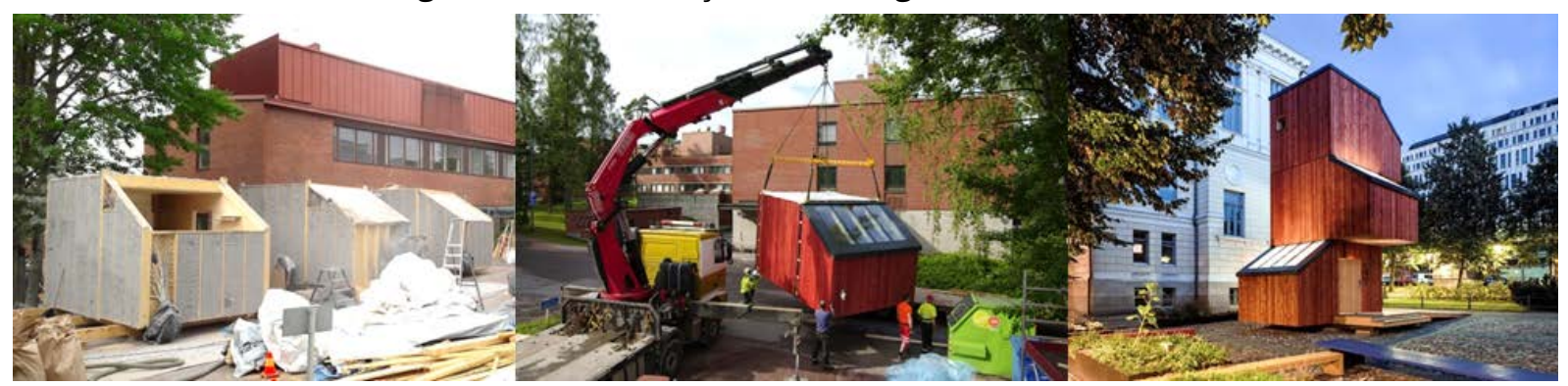

Fonte: Website Wood Program ${ }^{133}$.

Três unidades de protótipos foram concluídas em Otaniemi na primavera de 2016, depois transportadas e montadas em um dia no Museu de Arquitetura Finlandesa e no Museu do Design (Figura 48). As unidades foram abertas à visitação durante o verão e logo usadas em vários locais da Finlândia. A Figura 49 mostra o interior das habitações.

Figura 49 - Interior dos módulos de habitação Kokoon
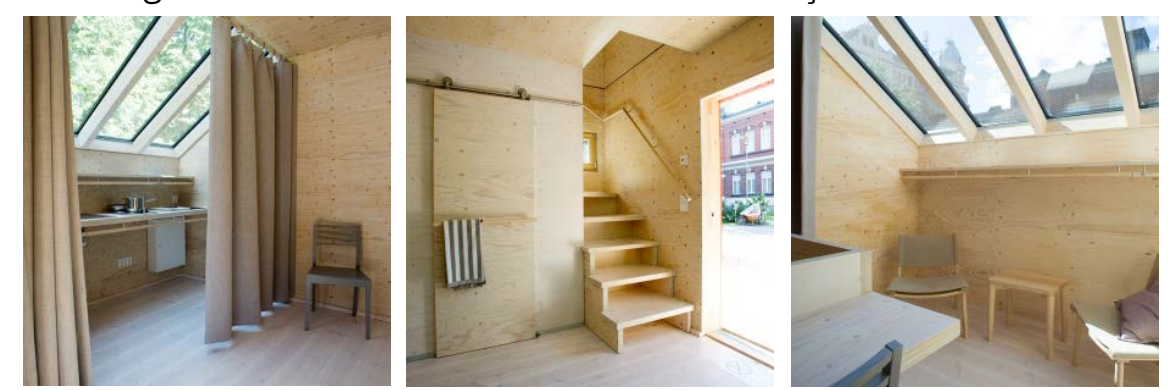

Fonte: Website Wood Program ${ }^{134}$.

\footnotetext{
132 Disponível em: http://woodprogram.fi/portfolios/kokoon/. Acesso em 24 ago. 2018.

133 Disponível em: http://woodprogram.fi/portfolios/kokoon/. Acesso em 24 ago. 2018.

134 Disponível em: http://woodprogram.fi/portfolios/kokoon/. Acesso em 24 ago. 2018.
} 


\section{A•Lava}

Ano: $2016-2017$

Instrutores: Pekka Heikkinen, Philip Tidwell e Willem van Bolderen

Materiais: paredes - Abeto dimensional (sem tratamento); vigas de cobertura Abeto laminado colado; forro - contraplacado revestido; cobertura - têxtil revestido em PVC; decks - Pinus tratado termicamente.

O Projeto A.lava é um pavilhão pensado como um teatro de verão para servir de espaço de exibição e performance ao ar livre e atender ao Centro de Artes Juvenil Annantalo, em Helsinque. Teve início em dezembro de 2016 e foi concluído em maio de 2017. O pavilhão é baseado em uma planta de forma quadrada e uma variação de formas triangulares que determinam as paredes e a abertura do palco. O telhado segue os mesmos princípios, levantando-se para enfatizar a localização do palco. Inclinado em relação à malha da cidade, o edifício se mostra como uma singularidade no tecido urbano, tanto em volume quanto em materialidade (Figura 50).

Figura 50 - O Pavilhão A.lava concluído e instalado no centro de Helsinki

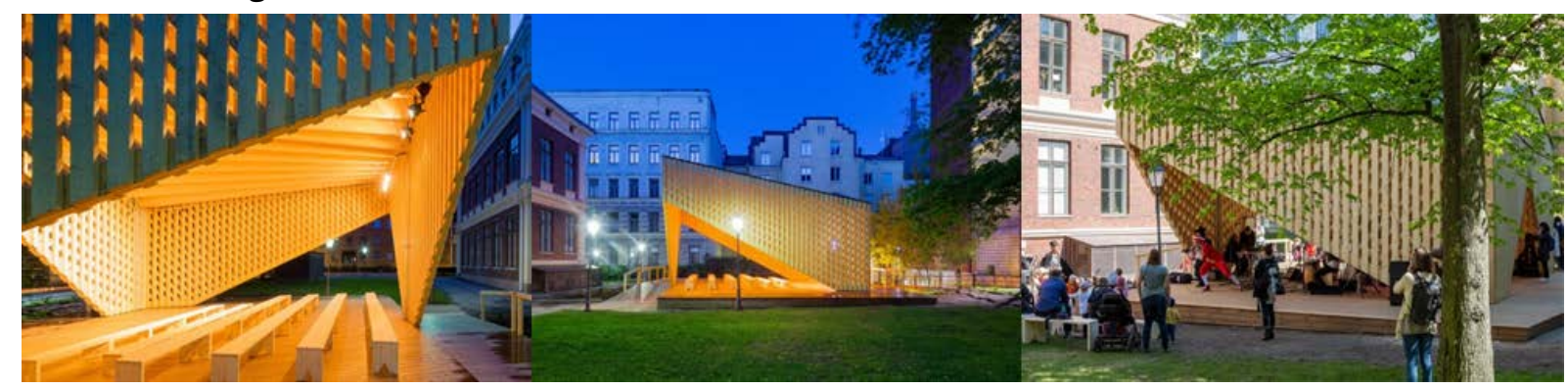

Fonte: Website Wood Program ${ }^{135}$.

O desenvolvimento do projeto iniciou-se com a proposição individual de soluções projetuais através de um concurso de ideias, processo metodológico normalmente utilizado no curso. Entre as propostas apresentadas pelos alunos foi eleita uma vencedora e a partir desta, foram desenvolvidas as seguintes etapas de projeto em grupos de trabalho divididos para o estudo da forma e geometria, estrutura, parede,

135 Disponível em: https://www.a-lava.com/A-lava. Acesso em 24 ago. 2018. 
cobertura, plataforma de piso, conexões, etc. As Figura 51 e Figura 52 ilustram algumas das etapas de desenvolvimento do projeto.

Figura 51 - Desenvolvimento do projeto A.lava: estudo de geometria, estudo em escala real e maquete de estudo da cobertura

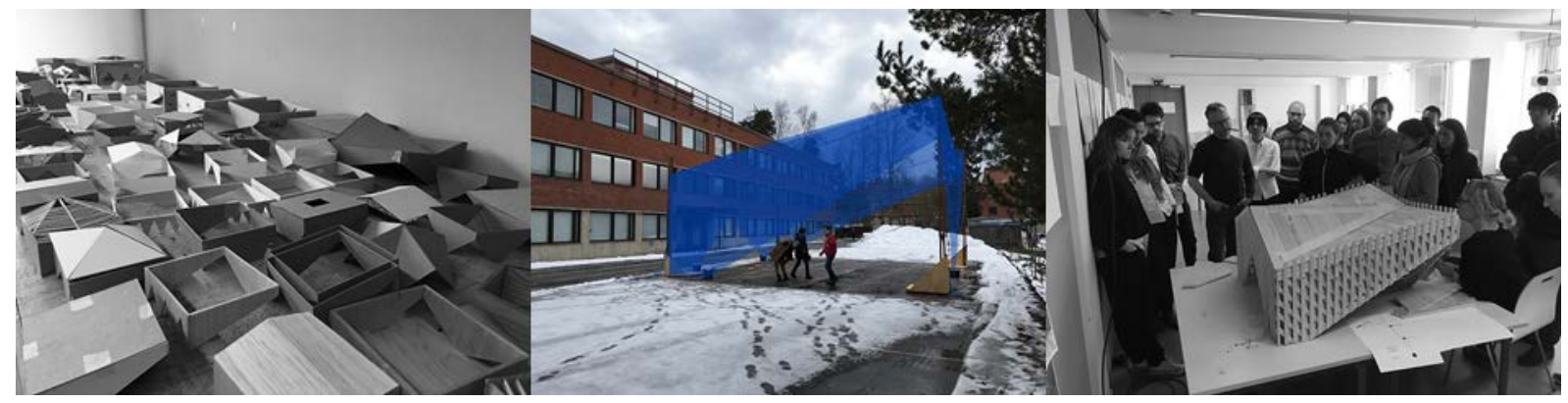

Fonte: Website Wood Program ${ }^{136}$.

Figura 52 - Estudo e teste das conexões, produção e instalação das paredes

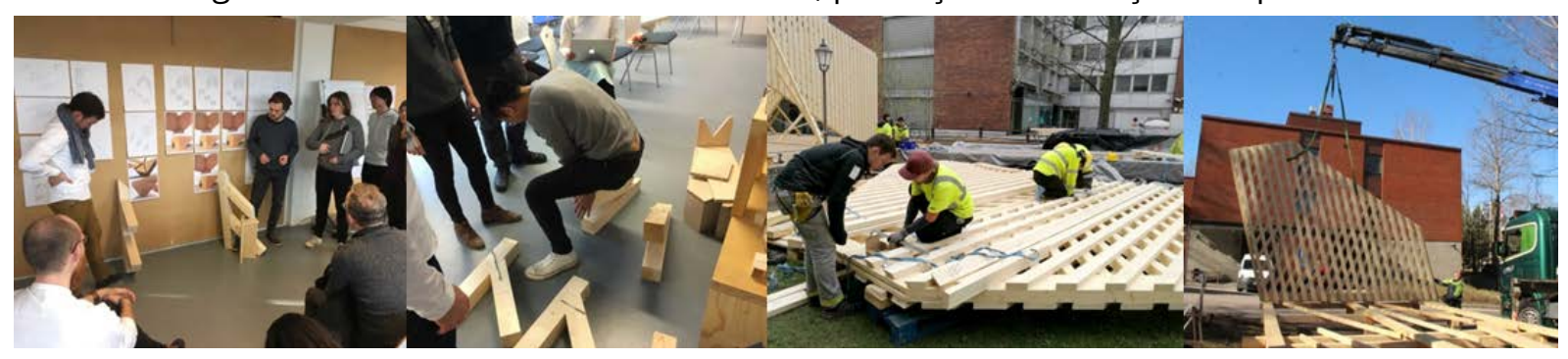

Fonte: Website Wood Program ${ }^{137}$.

\subsubsection{Pesquisa}

O trabalho de pesquisa contínuo do Wood Program em vários sistemas de construção foi documentado em publicações e em uma exposição itinerante que foi exibida pela primeira vez no Museu de Arquitetura Finlandesa em $2014^{138}$ (Figura 53). A exposição retratou os vinte anos de ensino do Wood Program no intuito de entender, manusear e utilizar a madeira como material de construção em arquitetura a estudantes estrangeiros e finlandeses.

\footnotetext{
136 Disponível em: https://www.a-lava.com/A-lava. Acesso em 24 ago. 2018.

137 Disponivel em: https://www.a-lava.com/A-lava. Acesso em 24 ago. 2018.

${ }^{138}$ Raízes fortes, tronco robusto e coroa verdejante: Anéis anuais da arquitetura em madeira no Museu de Arquitetura Finlandesa. Disponível em: http://www.finnisharchitecture.fi/2014/10/strong-roots-a-sturdy-trunkand-verdant-crown-wood-architectures-annual-rings-at-the-museum-of-finnish-architecture/. Acesso em: 18 ago. 2018.
} 
Figura 53 - Exposição sobre o Wood Program no Museu de Arquitetura Filandesa

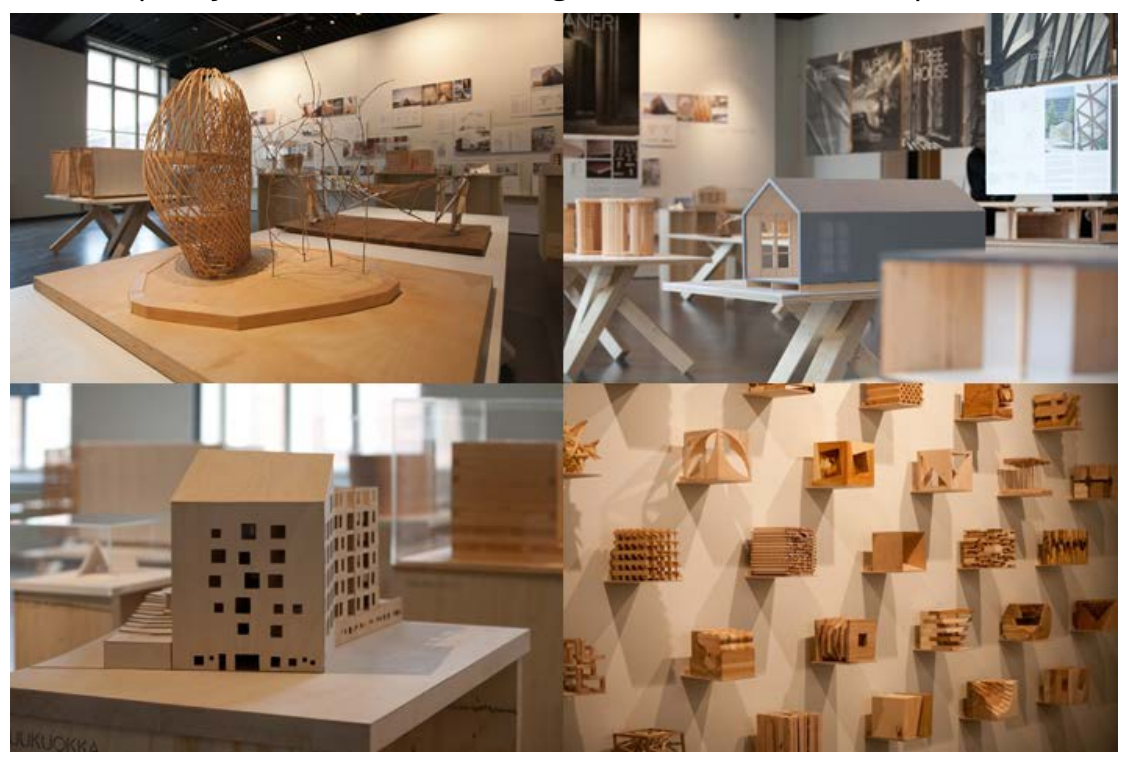

Fonte: Website Finnisharchitecture. fi $^{139}$

Além do trabalho nos estúdios de projeto, os alunos do Wood Program às vezes colaboram com projetos de pesquisa em andamento no Departamento de Arquitetura, no Departamento de Tecnologia de Produtos Florestais e no Departamento de Engenharia Civil e Estrutural. Este trabalho é organizado pela equipe de pesquisa e doutorandos da Aalto University, que estão realizando investigações em disciplinas específicas em Ciência dos Materiais, Construção em Madeira e Impacto Ambiental de vários materiais e técnicas de construção ${ }^{140}$. Algumas das pesquisas são realizadas em colaboração com universidades e instituições europeias envolvendo países como Suécia, Noruega, Áustria, Bélgica, Reino Unido, França, Alemanha e Suíça.

A síntese de análise do Wood Program segundo as categorias indicadas anteriormente é apresentada a seguir no Quadro 6.

\footnotetext{
139 Disponivel em: http://www.finnisharchitecture.fi/2014/10/page/2/. Acesso em: 18 ago. 2018.

${ }^{140}$ Os projetos de pesquisa atuais podem ser consultados através dos sites: http://www.wood2new.org/; http://www.holz.ar.tum.de/leanwood/home/; http://energyefficiency.aalto.fi/en/research/woodlife/; http://energyefficiency.aalto.fi/en/research/townhouse/. Os projetos recentemente concluídos também podem ser encontrados em: www.e2rebuild.eu/en/; www.tesenergyfacade.com/. Disponível em: http://woodprogram.fi/research/. Acesso em: 18 ago. 2018.
} 
Quadro 6 - Quadro síntese de análise do Wood Program

\section{WOOD PROGRAM - Aalto University, Finland}

\section{Estrutura Curricular}

O Wood Program é um curso internacional de pós-graduação de um ano de estudo intensivo sobre madeira e o uso da madeira no ambiente arquitetônico finlandês. Vincula-se a Aalto Wood, um centro de pesquisa, educação e conhecimento em construção em madeira da Aalto University. Destina-se a arquitetos e profissionais áreas afins, como engenharia, arquitetura paisagística ou design de interiores. O programa é organizado em cooperação entre os departamentos de Tecnologia de Produtos Florestais, Engenharia Civil e Ambiental e Arquitetura, sendo realizado neste último, no Campus Otaniemi.

Estrutura-se em dois semestres com disciplinas que incluem estúdios de projeto, aulas teóricas, seminários e cursos baseados em projetos, entre estes excursões a locais de interesse natural, histórico-cultural e industrial. O Design Studio, ou Estúdio de Projeto, é o coração do curso e envolve exercícios em forma de workshops e um projeto de construção na escala 1:1. Paralelamente ao estúdio, organizam-se as disciplinas sobre tecnologia da madeira e construção em áreas temáticas, bem como as disciplinas sobre arquitetura histórica e contemporânea na Finlândia, ministradas em aulas e seminários. Também são oferecidas disciplinas eletivas na área da tecnologia da madeira.

\section{Conteúdos programáticos}

Os conteúdos abordados no Wood Program exploram a importância ecológica das florestas e da madeira; as propriedades técnicas da madeira e dos materiais à base de madeira; a madeira como material de construção em suas várias aplicações; a tradição, construções vernáculas finlandesas e a evolução dos edifícios em madeira; a madeira no ambiente construído contemporâneo, a construção em madeira do ponto de vista industrial, com foco nos impactos ecológicos e ambientais da produção e montagem em escala industrial; os desafios e potencialidades futuras para a arquitetura em madeira.

O curso preocupa-se em proporcionar uma visão completa e abrangente de toda a cadeia de construção em madeira, começando desde a árvore na floresta, as espécies, estruturas, produtos e sistemas, terminando com um edifício experimental de madeira. As visitas e excursões têm como objetivo apresentar aos alunos a floresta finlandesa, espécies de madeira, construção tradicional, cidades em madeira, arquitetura contemporânea em madeira, produção industrial e pesquisa.

\section{Metodologia de Ensino}

O curso é focado na abordagem pedagógica do Design-Build, onde as atividades de projeto e construção compõe o eixo estruturante do programa. No Design Studio os estudantes desenvolvem vários exercícios de projeto em escala real durante o primeiro período, no outono, individualmente, e depois em pequenos grupos. Os exercícios introduzem diferentes materiais e técnicas de construção em madeira, com ênfase na utilização de modelos e maquetes em escala. Ao final do semestre realiza-se um concurso de projeto em que cada aluno faz uma proposta individual para um pequeno edifício de madeira.

No período seguinte, de primavera, os alunos desenvolvem as seguintes etapas de projeto em grupos de trabalho divididos, por exemplo, em estudo da forma e geometria, estrutura, parede, cobertura, plataforma de piso, conexões, etc. e executam um edifício experimental em escala um para um. Produzem ainda, ao final do período, um portfólio pessoal documentando sua experiência ao longo do ano.

As disciplinas desenvolvem-se através de aulas e seminários que proporcionam um 
panorama teórico a partir de projetos que enfatizam questões práticas, e através de tutoria pessoal e de trabalhos em grupos. Também são propostas leituras e análises de textos para o estudo de edifícios selecionados, além de palestras de visitantes, profissionais contemporâneos da Finlândia apresentando seu próprio trabalho. As aulas ainda são acompanhadas de experimentos em laboratório e exercícios sobre as características da madeira e produtos de madeira finlandesa e são programadas visitas a indústrias madeireiras e a diversos edifícios e áreas habitacionais como método de aprendizado.

Além do Wood Program, o Aalto Wood promove cursos interdisciplinares para alunos de graduação, atividades de cooperação internacional como programas de pesquisa, desenvolvimento e inovação, projetos e seminários públicos de disseminação de resultados de pesquisas para a indústria e outras partes interessadas.

\section{Considerações}

O programa da Aalto University é reconhecido internacionalmente, e é provavelmente o exemplo mais citado na literatura sobre o ensino especializado de Arquitetura em Madeira. Possui laboratórios e espaços didáticos de experimentação construtiva altamente equipados com maquinário arrojado e tecnologia de ponta. Destaca-se o fato do programa estar associado a um centro de pesquisa interdisciplinar que integra as áreas da Arquitetura, Engenharia Estrutural e Ciências Florestais, promovendo atividades de pesquisa e de difusão de conhecimentos entre as partes, para fornecer uma abordagem holística ao desenvolvimento da construção em madeira. Desta cooperação criam-se possibilidades de interação entre os estudantes do Wood Program e da pós-graduação, especialmente doutorandos dos departamentos associados, gerando novas perspectivas de colaboração, continuidade e expansão das investigações.

Do exame detalhado do programa destacamos algumas contribuições importantes:

Como curso de especialização focado na Madeira e na Arquitetura em Madeira, o programa propõe uma imersão no universo das construções em madeira em uma abordagem interdisciplinar que contempla o conhecimento do material em todo o seu ciclo de vida, desde a floresta até sua aplicação em edificações.

A grade curricular é composta de 33 semanas de atividades em tempo integral, sendo 13 semanas no período de outono e 20 na primavera, as quais se alternam entre aulas teóricas, visitas externas e exercícios práticos onde estes são o cerne da proposta pedagógica.

Os conteúdos programáticos das disciplinas da área de história, contexto e estudos de casos seguem uma ordem cronológica, enquanto as disciplinas da área técnica seguem uma progressão de complexidade em relação ao estudo das características do material e dos produtos industrializados.

Quanto à metodologia de ensino, o aprender-fazendo é o ponto de partida e é explorado em todo o processo desde os modelos em escala reduzida, na proposição de ideias de projeto, passando por protótipos e mock-ups parciais em escala 1:1, no estudo e teste de conexões, até a produção e montagem de um edifício experimental em escala real. Ao longo de toda a sequência de atividades práticas de projeto e construção o processo de ensino-aprendizagem é permeado por momentos de análise e revisão dos trabalhos desenvolvidos pelos alunos. Esse tipo de prática didática demanda um acompanhamento direto, envolvendo a interação entre estudantes e corpo docente e entre os próprios estudantes nos grupos de trabalho, o que concorre para o sucesso do resultado final que exibe obras de alta qualidade técnica e de soluções projetuais. 


\subsubsection{Escuela de Arquitectura y Diseño - Pontificia Universidad Católica de Valparaíso, Chile}

A abordagem pedagógica da Escola de Valparaíso, frequentemente descrita como "não usual", relaciona o ensino e o fazer arquitetônico em experiências como os Talleres de Obra e as Travesías, vinculando vida, trabalho e estudo em atividades de experimentação caracterizadas pela construção de instalações normalmente efêmeras mas às vezes permanentes - projetadas por alunos e professores. Os espaços onde ocorrerem essas intervenções se encontram na Ciudad Abeirta e também em vários lugares da América do Sul visitados durante as viagens de Travesía.

A Ciudad Abeirta é um espaço que serve à educação, eventos e moradia e que pode ser entendido - de certa forma - como um laboratório de extensão da Escola. Alguns dos edifícios chamados de Hospederías, abrigam professores, funcionários e hóspedes em um terreno localizado em Ritoque, a aproximadamente $20 \mathrm{~km}$ ao norte de Viña del Mar onde se encontra o edifício sede da Escuela de Arquitectura y Diseño da Pontificia Universidad Católica de Valparaíso - e[ad] PUCV. Ali ocorrem semanalmente atividades didáticas relacionadas ao currículo dos cursos de Arquitetura e de Design, bem como atividades de construção vinculadas ao Taller de Obra e outras intervenções eventuais vinculadas aos Talleres, ou ateliês/estúdios de Projeto.

As Travesías são viagens pedagógicas realizadas anualmente durante a primavera pelos alunos e professores. São experiências poéticas, sensitivas e criativas, que duram aproximadamente quinze dias nas quais se realizam obras em algum ponto do continente americano, definido através do estudo e âmbito que desenvolve cada Taller. Propõem a concepção e realização de uma estrutura efêmera pra o lugar visitado, como uma oferenda ao continente, à paisagem e a sociedade.

Diferente das referências analisadas anteriormente, a experiência da Escola de Valparaíso foi vivenciada em corpo presente. Constitui-se como um Estudo de Caso realizado por meio do estágio em pesquisa do Programa de Doutorado Sanduíche no Exterior - PDSE/CAPES e teve como objetivo investigar o projeto pedagógico da Escola 
através da participação no Taller Disciplinar del Programa y Forma de la Edificación, e na Travesía realizada por este Taller, ministrado pelo professor Andrés Garcés Alzamora, coorientador do estágio no exterior, durante o segundo semestre de 2018. Em paralelo, a estadia permitiu a investigação acerca das atividades de experimentação construtiva em madeira realizadas no âmbito da Escola e da Ciudad Abierta.

\subsubsection{Contexto de fundação da Escola}

A Escola de Valparaíso foi fundada em 1952 por poetas, filósofos, escultores, pintores, arquitetos e designers, que propunham uma outra forma de ensinar arquitetura em contraposição ao modelo vigente na época e em consonância com o contexto internacional de movimentos vanguardistas. Este grupo propôs uma abordagem original acerca da concepção da poesia, da arte e do ofício de Arquitetura, uma abordagem que guiaria e configuraria os estudos e a pedagogia da Escola desde sua fundação e que permanece até hoje.

A partir da visão poética de seus fundadores, em 1970 os professores da Escola de Valparaíso adquirem o terreno da Ciudad Abierta - terras que incluem um campo de dunas e pântanos, uma praia de mais de três quilômetros, desfiladeiros e florestas onde se constrói a relação da palavra com o lugar para que esta se estenda à Arquitetura e habite a cidade.

\footnotetext{
Ela nasceu da poesia para se tornar um lugar que abriga todos os ofícios dentro de sua existência mais criativa. Do ponto de vista do ensino, tem sido uma cidade laboratório desde a sua fundação até os dias de hoje. É um campo de experimentação para a arquitetura onde se trabalha em laboratório, segundo um conceito chamado Ronda, que dá origem a projetos arquitetônicos nos moldes de um Ateliê de obras (SAAVEDRA, 2017, p.22).
}

De acordo com Hermansen, Jolly e Hensel (2015), o trabalho da Escola despertou o interesse nacional e internacional: "ele é ímpar ao oferecer uma concepção única de arquitetura, um modelo didático correspondente e sua realização na Ciudad Abierta". Como tal, constitui o exemplo mais claro de uma "escola do pensamento" 
comprometida com a busca de uma arquitetura local e experimental. Para os autores, o que é atraente na busca contínua de materialização do trabalho é a redefinição perpétua do que a arquitetura da Ciudad Abierta poderia ser ao invés de procurar definir uma imagem e identidade no tempo. A questão torna-se, assim, uma agenda e um processo contínuos movidos pela vontade de buscar uma arquitetura local que é específica para o seu cenário em evolução e para a sua comunidade.

Em um primeiro momento da Escola, sua pedagogia baseou-se em uma corrente fenomenológica, impulsionada pelo arquiteto Alberto Cruz Covarrubias ${ }^{141}$, um dos fundadores da e[ad] e do Instituto de Arquitectura da PUCV. Conforme relatou o professor Iván Ivélic ${ }^{142}$, Alberto Cruz propunha sair à cidade para observação do fenômeno direto: a percepção do território é feita através de croquis e da descrição escrita, manifestados na experiência aos sentidos humanos e à consciência imediata. Os desenhos acompanhados de anotações manifestam uma descrição da experiência vivida por meio da descrição filosófica dos fenômenos, em sua natureza aparente e abstrata. Essa é uma característica da Escola de Valparaíso que a distingue e que se mantém forte ainda nos dias atuais.

Num segundo momento, com o início das Travesías em 1984, abre-se um novo campo de desenvolvimento de experimentação e construção 1:1 ao longo das viagens pelo continente americano e no terreno da Ciudad Abierta. Para o professor Iván, este espaço configurou-se como um campo de experimentação muito importante ao princípio das atividades da escola, mas depois da implementação das Travesías como parte das práticas pedagógicas, e nos últimos dez anos com a crescente complexidade e exigências das transformações na Universidade, têm sido mais difícil manter todas as atividades que antes se concentravam ali.

\footnotetext{
${ }^{141}$ Uma breve biografia do arquiteto Alberto Cruz Covarrubias pode ser encontrada na página web da e[ad] PUCV: https://www.ead.pucv.cl/2013/biografia-alberto-cruz-covarrubias-1917-2013/.

${ }^{142}$ Iván Ivélic Yanes é professor e atual diretor da Escuela de Arquitectura y Diseño da Pontificia Universidad Católica de Valparaíso - e[ad] PUCV. Entrevista concedida a autora na sede da escola em Viña del Mar, Chile, em 02 de agosto de 2018.
} 


\subsubsection{Contexto atual e estrutura curricular}

Recentemente, no início do ano de 2018, a e[ad] implantou uma alteração curricular com o objetivo de consolidar a Escola mantendo sua orientação poética original e projetando-a para os próximos 15 anos, fortalecendo seu sentido proativo, disruptivo e visionário através da formação de arquitetos e designers chamados para liderar, propor e materializar tais visões para a cidade, o país e do mundo. Tal mudança curricular buscou promover a cultura da transversalidade disciplinar, abrindo espaço para levar a tradição criativa de "pensar-fazendo" e "estudar por projeto" para um espaço universitário mais amplo direcionado a formalização em pesquisa e desenvolvimento ${ }^{143}$.

Em termos de avanço curricular, o projeto é pensado com uma visão de formação contínua, em três ciclos formativos, que nesta ocasião atendem a graduação, mas permitirá uma articulação com a pós-graduação. Nesta linha, o currículo permitirá saídas intermediárias através da criação de um grau de Bacharelado e redução de tempo de titulação para a concessão de um grau de Licenciatura. A grade curricular do curso de arquitetura da e[ad] PUCV é apresentada no ANEXO C.

Os três ciclos de formação são: Ciclo do Ofício, Ciclo Disciplinar e Ciclo Profissional e de Magister (Mestrado). Os dois primeiros ciclos correspondem a quatro semestres cada um - sendo que ao final do primeiro obtém-se o grau de Bacharelado e do segundo o grau de Licenciatura - e o terceiro ciclo corresponde a três semestres quando se alcança o título profissional de Arquiteto.

A área Taller é a espinha dorsal do curso, assim como na grande maioria dos cursos de arquitetura. O diferencial relaciona-se a área Artístico Humanista na qual os alunos cursam durante sete semestres as disciplinas Taller de Amereida e Cultura del Cuerpo, realizadas semanalmente durante as manhãs de quarta-feira na Ciudad Abierta, em Ritoque $^{144}$. A Figura 54 ilustra atividades praticadas pelos alunos dos cursos de

\footnotetext{
143 Informações disponíveis em: http://wiki.ead.pucv.cl/Cambio_Curricular_2018. Acesso em: 25 ago. 2018.

144 Uma breve história sobre a Ciudad Abierta e as atividades realizadas com a participação dos alunos da Escola pode ser encontrada na página web da e[ad] PUCV. Consultar: https://www.ead.pucv.cl/escuela/ciudadabierta/.
} 
Arquitetura e de Design: à esquerda, os estudantes são recepcionados com um Ato Poético no campo de dunas no início das aulas do Taller de Amereida, e à direita, realizam atividades em grupos como parte da disciplina Cultura del Cuerpo.

Figura 54 - Alunos da e[ad] em atividades na Ciudad Abierta, em Ritoque

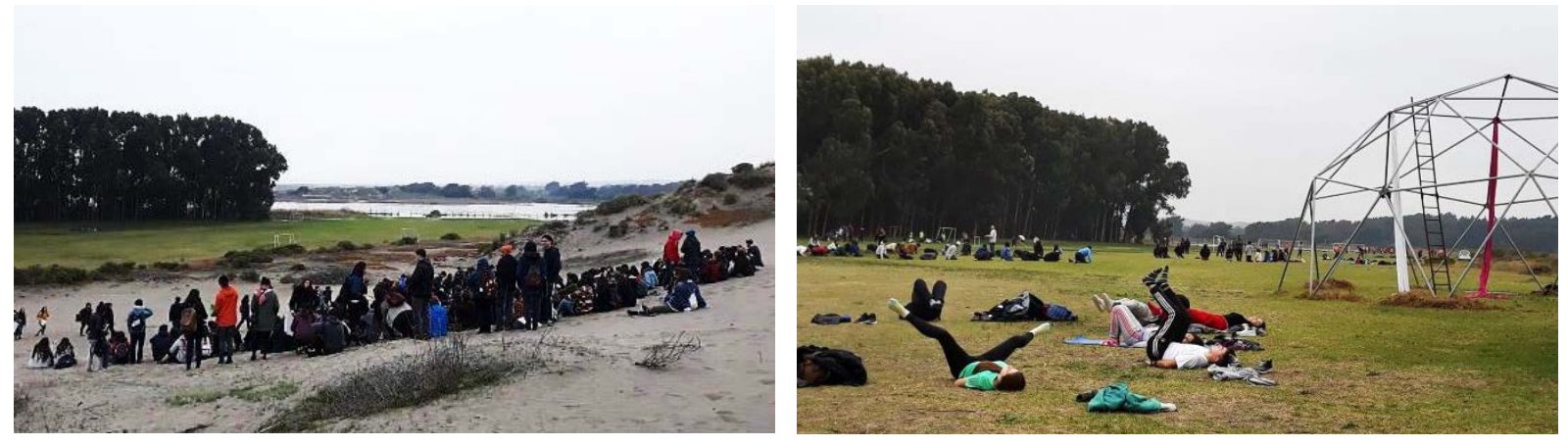

Fonte: arquivo pessoal.

O Taller de Amereida traz à mente a existência da condição poética do homem e anseia por despertá-la. Reflete e discute as questões sobre o fazer e o agir dos ofícios em sua relação com a poesia, à luz de Amereida ${ }^{145}$, o que dá lugar à construção da visão poética da Escola. Cultura del Cuerpo, por sua vez, tem como objetivo ligar o aluno ao seu espaço através do corpo, considerando que o ofício de arquitetura tem uma relação evidentemente próxima com a ocupação do ambiente, o qual cria. Este método corresponde a uma estratégia educacional que a Escola desenvolveu desde o seu início e tem a ver com o aprendizado em gerúndio: se aprende a desenhar, desenhando; se aprende a observar, observando; se aprende a entender o espaço, ocupando-o.

Por sua vez, estas estratégias são parte essencial da abordagem pedagógica da Escola e permeiam toda a estrutura curricular. A esta Tese, entretanto, interessa

\footnotetext{
145 Amereida é um poema épico que reúne em seu nome a descoberta da América e a aventura latina do piedoso Enéias escrito na Eneida. É a Eneida da América. Dois anos após a chamada primeira Travesía de 1965, diversos textos, anotações, poemas, cartas dos primeiros cronistas americanos, brancos inteiros, recortes e desenhos foram coletados e uma edição do material foi feita para moldar um livro intitulado Amereida, sem assinatura de autor, páginas não numeradas e sem maiúsculas. Informação disponível em: https://www.ead.pucv.cl/escuela/vision-poetica/amereida/. Acesso em: 25 ago. 2018.
} 
direcionar maior atenção às práticas de experimentação construtiva desenvolvidas no contexto dos Talleres, do Taller de Obra e das Travesías.

\section{TALLERES}

Os Talleres dos Ciclos do Ofício e Disciplinar trabalham com projetos temáticos de inserção local e urbana - sempre a partir da observação do território - que vão aumentando em escala e complexidade e se relacionam com as demais disciplinas do semestre, como das linhas de Presentación e de Construcción. As temáticas envolvem, por exemplo, espaços públicos, o espaço arquitetônico interior de um jardim infantil, a habitabilidade e riscos naturais no litoral, habitação coletiva em imóveis de patrimônio urbano histórico, equipamentos de infraestrutura urbana, etc.

No âmbito do Taller Disciplinar del Programa y Forma de la Edificación, ministrado pelo professor Andrés Garcés e pelo professor ajudante Bruno Marambio, no qual participei como professora convidada, a temática abordada foi o projeto de um Teatro para a Ciudad Abierta. O primeiro ciclo do programa da disciplina desenvolveu-se por meio da observação e análise do espaço urbano e de espaços cênicos da cidade de Valparaíso, e do terreno na Ciudad Abierta, o que ocorreu em paralelo às aulas teóricas e culminou em uma atividade prática de experimentação construtiva. A finalidade da atividade foi a preparação do espaço cênico do Teatro de la Consagración para uma apresentação de dança contemporânea no Acto de San Francisco, evento tradicional que celebra anualmente o patrono da Escola.

A intervenção proposta partiu da observação, leitura e levantamento do lugar, contemplando a estrutura já existente e consistiu na fabricação de treliças, pilares e painéis acústicos em madeira de Pinus, que recolheram o que já havia sido construído em anos anteriores, fazendo uma releitura espacial e técnica de suas geometrias, vínculos e tensões. O trabalho se deu de forma bastante empírica, desvinculada de cálculos e dimensionamentos, mas diretamente conectada a exploração factível do material: dispúnhamos apenas de madeira de Pinus de pequenas seções e deveríamos vencer vãos relativamente grandes. 
A Figura 55 e a Figura 56 ilustram a primeira etapa de leitura do local de intervenção em aula realizada no terreno, desenhos de observação e anotações, apresentação e correção das maquetes de estudo em aula e adaptação dos projetos no local da obra.

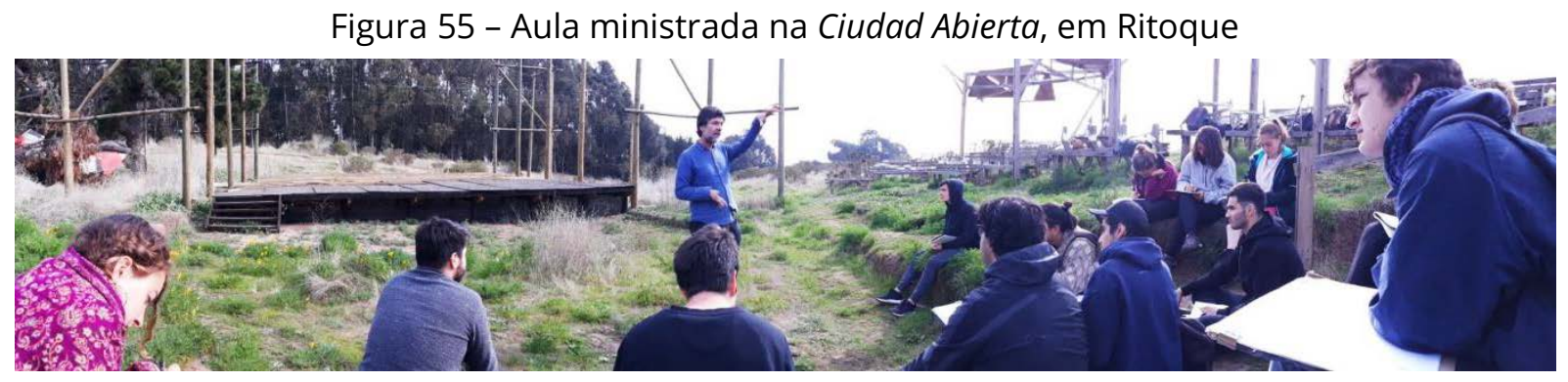

Fonte: arquivo pessoal.

Figura 56 - Croquis de observação e maquetes de estudo da intervenção

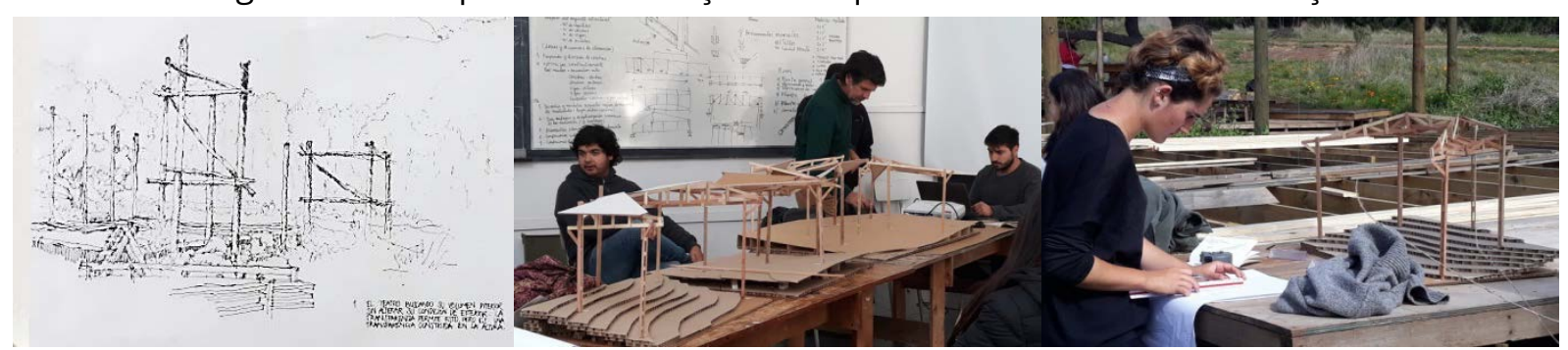

Fonte: arquivo pessoal.

O processo de construção das instalações ocorreu durante duas semanas nas quais as equipes se organizaram para a execução do trabalho com ferramentas próprias e limitado maquinário disponível no lugar da obra. A Figura 57 mostra as estruturas já finalizadas durante a celebração do Acto de San Francisco, na Ciudad Abierta.

Figura 57 - Celebração do Acto de San Francisco no Teatro de la Consagración, Cuidad Abierta
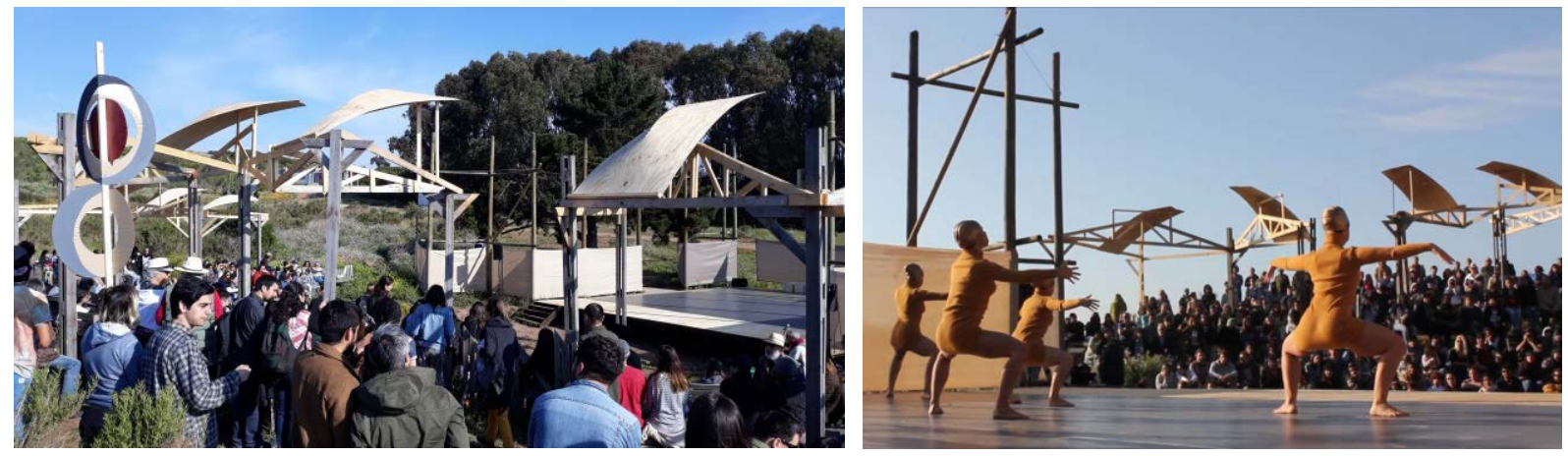

Fonte: arquivo pessoal. 
O segundo ciclo do programa do Taller ocorreu em torno ao desenvolvimento do projeto arquitetônico e se deu com base num processo de experimentação com maquetes, delineado a partir do conceito de Estrutura Radical da Extensão (ERE) processo catalisador da forma que é original da Escola. Esse exercício consistiu em tridimensionalizar um papel de média gramatura na busca de uma síntese formal da leitura do lugar, expressa também através da palavra.

Devem-se considerar alguns parâmetros na confecção do ERE: reconhecer o lugar e sua extensão, em escalas proporcionais; conformar elementos (estrutura) através de uma geometria (ordem) coerente com o Acto (ato de habitar); na qual o nome do Acto se expressa através da forma; e o nome da forma responde à geometria; o grau de abstração deve representar o lugar e seu Acto; onde a radicalidade se dá através da síntese. Este processo metodológico de desenvolvimento projetual é característico dos Talleres da Escola e busca estabelecer uma relação direta entre o lugar, o ato de habitar e a forma arquitetônica. Para Alberto Cruz, "La arquitectura es la extensión orientada que dá cabida". Segundo sua visão, a arquitetura nasce do ato humano e dá forma ao ato de habitar, onde a forma emerge da observação do lugar.

Depois de uma grande quantidade de maquetes que deveriam equilibrar as relações entre volumes, cheios e vazios, opacidades e transparências, os estudantes evoluem com as definições programáticas do projeto e propõe suas primeiras maquetes do edifício, que acima de tudo deve manter sua lealdade ao ERE, com o propósito de fazer emergir do lugar a sua "geometria intangível" plasmada no conceito do Acto. A insistência nesse exercício, que foi evoluindo em escalas junto com a proposta do programa, é notória no resultado final dos projetos que exibem uma compreensão acurada do lugar e uma radicalidade na forma, ainda que, por vezes, em detrimento da funcionalidade espacial.

Além da exaustiva experimentação com maquetes em escala reduzida, alguns Talleres desenvolvem paralelamente práticas construtivas na escala 1:1 como parte do programa definido a cada semestre. O Taller Habitabilidad en Infraestructura Urbana, ministrado pelo professor David Lusa, por exemplo, propôs um exercício prático de projeto e construção de uma estrutura de ponte, El puente del Megaterio, que foi 
construída pelos alunos com madeira de Pinus no laboratório de maquetes e protótipos da escola em Viña del Mar (Figura 58), e posteriormente instalado na Ciudad Abierta.

Figura 58 - Alunos da e[ad] no laboratório de maquetes e protótipos da escola, em Viña del Mar
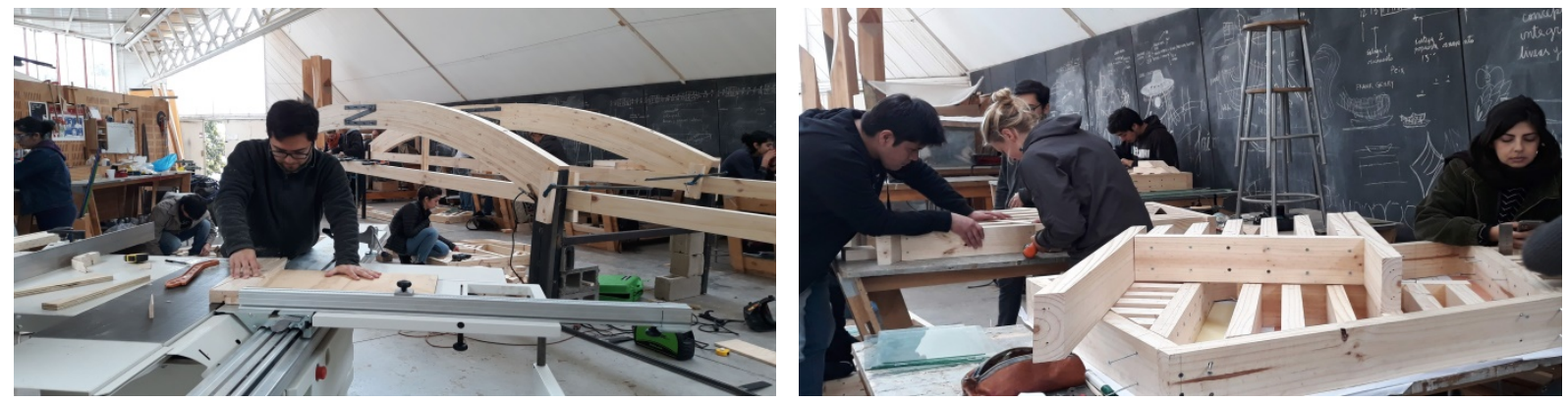

Fonte: arquivo pessoal.

\section{TALLER DE OBRA}

O Taller de Obra é uma experiência que foi concebida desde a fundação da Ciudad Abierta, mas somente na última década adquiriu uma estrutura acadêmica dentro do currículo regular da Escola de Valparaíso. Segundo os professores Espósito e Luza (2015) o Taller só era ativado quando existia uma demanda da Ciudad Abierta em função de um projeto e uma obra. Portanto, era uma participação ocasional e limitada em termos do número de alunos que poderia receber e seus níveis. Essa configuração, entretanto, foi revisada em função da alteração curricular de 2018, quando o Taller de Obra passou a ser oferecido como uma disciplina optativa, assim como os demais Talleres.

O Taller de Obras é dedicado à construção de um fragmento de uma obra de arquitetura na Ciudad Abierta, que proporciona um campo de vida, trabalho e estudo. A obra, portanto, conta com uma dimensão que é uma ocasião única, onde sua origem em uma ágora e em atos poéticos permite que ela se desenvolva como uma obra de término aberto. Essa realidade é o que permite uma ligação entre o estudo e a realização de um edifício em escala natural. O escopo da Ciudad Abierta fornece a visão de Amereida, onde a obra arquitetônica se destina a desvendar nossa possível realidade de Americanos a partir do trabalho que pretende aproximar-se da origem da obra. Isto se realiza construindo a fidelidade ao ouvido, na tentativa da rima da palavra e da ação. Trata-se de aprender-fazendo, ao participar da construção atual de um edifício, bem como o que ele representa e abre em um ato coletivo. O Taller constitui-se em uma comunidade de construtores ligados pela forma da obra. Esta é a experiência de uma vida em comum junto com a experiência espacial do lugar. O estudante tem a oportunidade de conhecer diretamente os materiais de construção, os sistemas e a 
realidade de como implantar uma obra e construí-la. Através dessas dimensões, o aluno consegue uma maior compreensão dos detalhes nos quais inferem a materialidade e sistemas ao momento de considerar um projeto $^{146}$.

Uma obra construída na Ciudad Abierta pode levar vários anos. Então, os Talleres que participam podem ser muitos e podem ter experiências diferentes. Assim também ocorre na "prática". Nesta cronologia, porém, seja qual for a obra, é sempre possível seguir um fio condutor e uma fidelidade ao fundamento inicial, numa espécie de testemunho criativo e construtivo que começa com um jogo e um ato poético de abertura e interpretação do lugar, continua com a construção, de modo que cada passo vai herdando um sentido do anterior, sempre aberto, e culmina com a obra habitada (ESPÓSITO; LUZA, 2015).

Para o professor David Jolly, responsável pelo Taller de Obra, há duas dimensões que o distingue dos Talleres de qualquer escola de arquitetura:

En la enseñanza de arquitectura, lo normal de todos los talleres, de todas las
escuelas de arquitectura, es que está centrado en el estudiante. [...] Aquí, se trata
de vivir unos hechos, que lleguen a ser una experiencia, donde el centro no está
en el estudiante sino que está en la obra. [...] Entonces hay que someterse a la
realidad de la obra. Ahora, eso hace que no coincidan los periodos académicos
[...] entonces cada uno participa construyendo un fragmento, no la totalidad.
La segunda dimensión que es bastante dura en eso de que está antes la obra, es
que lo cada uno hace no es una expresión de sí mismo. En los talleres todo es
expresión de ellos, y aquí no. Proponen una cosa y si es mala, no, no se hace [...]
entonces es más duro en ese sentido. [...] ahora hay un punto [...] hay un paso
que es importante, que es cuando un estudiante registra lo que ha hecho, se le
transforma en una experiencia, porque se la puede contar a otro ${ }^{147}$.

Estas dimensões referem-se ao fato da experiência não estar centrada no aluno e sim na obra, o que implica que cada um construa uma parte e não a totalidade. Essa parte não é expressão de si mesmo, senão de um todo que é coletivo.

\footnotetext{
${ }^{146}$ Descrição do Taller de Obras disponível na página Wiki Casiopea, tradução da autora. Disponível em: http://wiki.ead.pucv.cl/Taller_de_Obra. Acesso em: 25 ago. 2018.

147 Transcrição de trecho de entrevista com o professor David Jolly concedida à autora no dia 17 de agosto de 2018 na Ciudad Abienta, em Ritoque no Chile, juntamente com a professora da Escola Politécnica Federal de Lausanne - EPFL, Patricia Guaita, por acasião do Summer Chantier 2018.
} 


\section{TRAVESÍAS}

As Travesías são viagens poéticas através da América, realizadas anualmente durante a primavera, pelos alunos e professores dos cursos de Arquitetura e Design da e[ad] PUCV desde 1984 (PÉREZ DE ARCE, 2003). São experiências sensitivas e criativas, que duram aproximadamente quinze dias nas quais se realizam obras em algum ponto do continente americano, definido através do estudo e âmbito que desenvolve cada Taller $^{148}$. Ao longo do curso os estudantes podem realizar ao menos quatro ou cinco dessas viagens, mas ao ser uma atividade financiada pelos próprios estudantes, não se configura como uma atividade curricular obrigatória.

A primeira Travesía realizada pelos fundadores da Escola em 1965 abriu o horizonte dentro dos processos de ensino e aprendizagem no campo acadêmico. Segundo a visão da e[ad], a América tem que ser conhecida em sua extensão: “É necessário ir ao continente, ir a ele para reconhecê-lo e habitar sua emergência" [...] "O continente estende-se e nós vamos à ele para habitar sua intimidade e seu mar interior ao qual Amereida canta" (GARCÉS; MANSÚ, 2018, p. 195).

A experiência de aprender observando, habitando e construindo através da vivência sensitiva de viajar e fazer arquitetura, de projetar e construir ao mesmo tempo é uma das premissas da proposta pedagógica da Escola. Para o professor Rodrigo Saavedra (2017, p. 30), provocar no estudante um conhecimento amoroso da matéria "é transmitir a realidade de que arquitetura se faz com materiais e só assim aparecerá um amor pela matéria, porque ao final é a matéria, o material, que nos transmite os estímulos para os nossos sentidos".

A possibilidade de experimentar o processo completo de um projeto proporciona uma dimensão justa deste. Isto ocorre ao se verificar e avaliar os fatores que incidem na materialização - passagem da forma como ideia para a forma como obra - desde fatores materiais, que implicam em conhecimentos físicos, a fatores imateriais, que implicam em conhecimentos objetivos da cultura e das ações humanas (SAAVEDRA, 2017, p.30).

\footnotetext{
148 Sobre as Travesías a página Wiki Casiopea dispõe de informações referentes a muitas das viagens realizadas pelos Talleres da e[ad]. Consultar: http://wiki.ead.pucv.cl/Categoría:Travesía.
} 
O uso da viagem transcontinental como suporte pedagógico é uma das características do ensino de Valparaíso. Segundo Guaita e Tapparelli (2015), o não planejado e o inesperado são abraçados nas Travesías como aspectos importantes da abordagem pedagógica que vincula a ideia do projeto fundamentalmente à vida, enquanto experimentação e expressão. Além de experienciar diferentes lugares do continente americano, as Travesías propõem a concepção e realização de uma estrutura efêmera pra o lugar visitado, como uma oferenda ao continente, à paisagem e a sociedade. Construídas em material leve - principalmente madeira - o aspecto efêmero das intervenções distingue os exercícios construtivos onde os materiais utilizados são encontrados, adquiridos ou recebidos em doação no lugar, ou ainda, carregados pelos estudantes em suas viagens, e sua preparação constitui um importante elemento do projeto que, junto ao desenvolvimento e realização da estrutura, geram uma experiência abrangente de aprendizagem.

Na etimologia da palavra, experiência deriva do latim experiri: provar, experimentar. Então, primeiramente relaciona-se com algo que se encontra, que se prova ou experimenta. O radical periri relaciona-se a perigo, e a raiz per traz a ideia de travessia e de prova. Temos então que "o sujeito da experiência tem algo desse ser fascinante que se expõe atravessando um espaço indeterminado e perigoso, pondo-se nele à prova e buscando nele sua oportunidade, sua ocasião" (BONDIA, 2002, p. 25). Assim como propõe as viagens pedagógicas de Travesía pela América da Escola de Valparaíso, o sujeito se abre a experimentação, se abre a novas vivências, ao desconhecido.

\subsubsection{Algumas obras construídas}

A seguir são apresentadas algumas das obras projetadas e construídas por professores e alunos da e[ad] em diferentes períodos de sua história, tanto na Cuidad Abierta como em Travesías pela América. 


\section{Sala de Música}

\section{Local e ano: Ciudad Abierta, 1972}

\section{Âmbito: Ronda de la Ciudad Abierta}

Materialidade: fundações em concreto armado, estrutura, fechamentos e revestimentos externo e interno em madeira.

A Sala de Música projetada por Alberto Cruz e Juan Purcell em 1972 foi a primeira obra a ser construída na Ciudad Abierta. É uma caixa branca retangular, diagonalmente revestida em madeira, sem nenhuma abertura, exceto onde estão localizadas as entradas. Virando as costas para a visão de seus arredores, ela se concentra em si mesma para priorizar sua função comunitária. O interior de 160 metros quadrados é dominado pelos tons quentes da madeira onde a luz natural é introduzida através de um lanternim central que vai do chão ao teto, proporcionando ventilação e o murmúrio das ondas do Pacífico, articulando a relação entre espaço e música (Figura 59). As divisórias móveis das paredes perimetrais têm faces reflexivas e absorventes cobertas com juncos trançados colhidos no rio local e podem ser posicionadas em ângulo para exercerem função acústica. Neste espaço acontecem semanalmente reuniões dos professores da Escola e da Corporação Cultural Amereida, ocasião em que é organizado um almoço coletivo no local (Figura 60).

Figura 59 - Sala de Música, a primeira obra da Cuidad Abierta em Ritoque

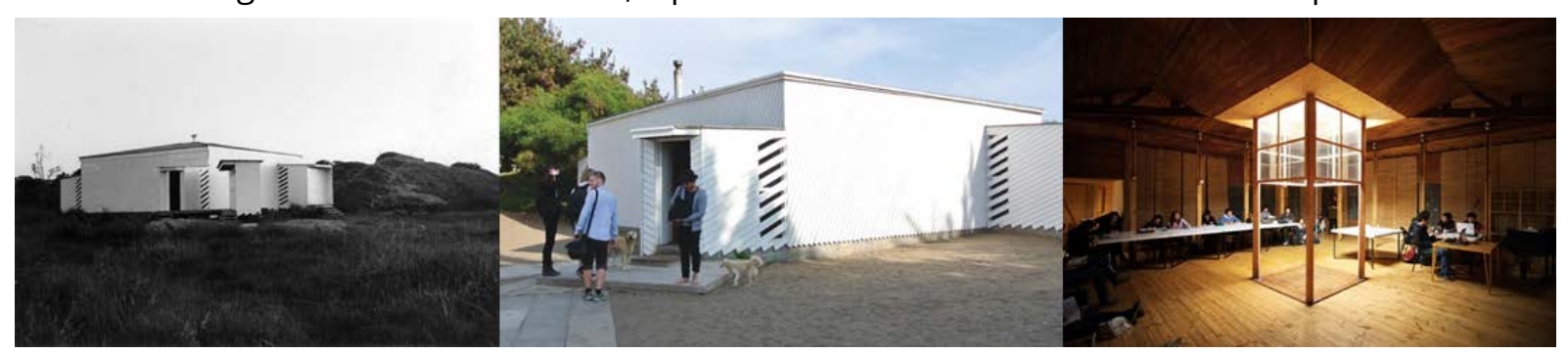

Fonte: Hermansen, Jolly e Hensel (2015) e Website Casiopea ${ }^{149}$.

149 Disponível em: https://wiki.ead.pucv.cl/Sala_de_Música. Acesso em: 25 ago. 2018. 
Figura 60 - Sala de Música da Cuidad Abierta em Ritoque
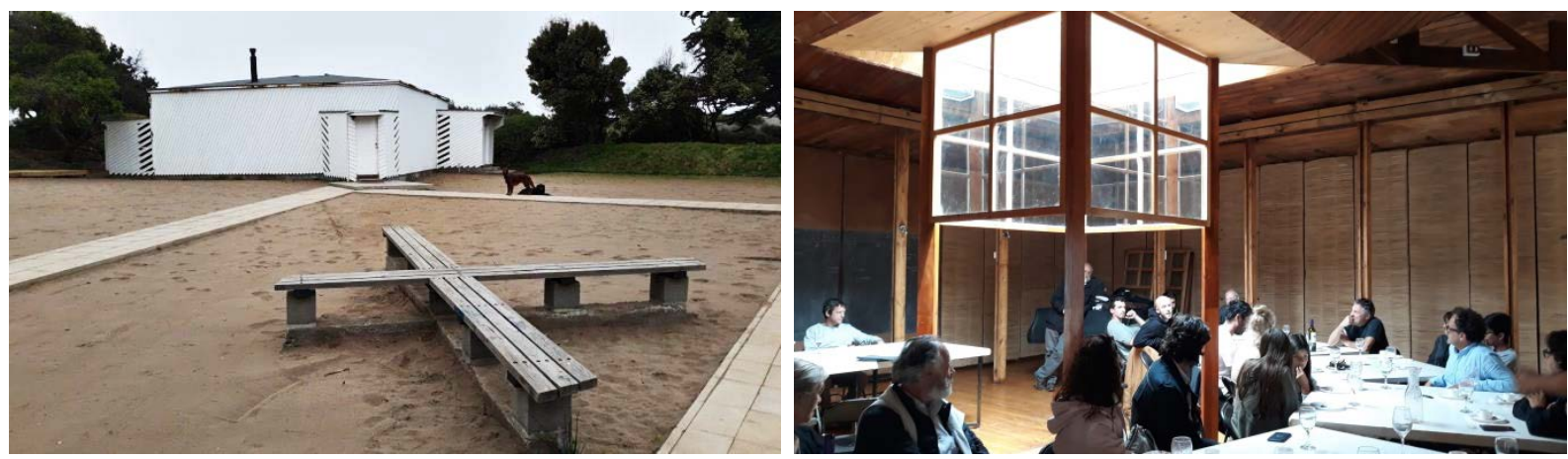

Fonte: arquivo pessoal.

\section{Hospedería del Taller de Obras}

Local e ano: Ciudad Abierta, 2002-2006

Âmbito: Ronda de la Ciudad Abierta

Materialidade: fundações de concreto armado, estrutura de madeira em chapas e madeira laminada; revestimento em painéis de folha de estanho com isolante.

A Hospedaría del Taller de Obras ou Hospedaría Colgante está localizada perto do local onde foi construído o Palácio no início da Ciudad Abierta, no meio de uma grande duna de areia que é uma das características do solo natural do lugar. Este trabalho começa com um ato poético que foi desenvolvido como um jogo realizado nesse mesmo local. Assim, a interpretação do jogo e a presença da areia deram origem a um interior suspenso (Figura 61 e Figura 63). A obra pendura-se de uma estrutura que repousa sobre a areia, sem interrompê-la, valorizando sua existência e ao mesmo tempo, considera uma condição inevitável nesta parte da América que é o terremoto. Ao ser pendurada em uma macroestrutura, a obra não transmite a energia do terremoto ao prédio. Sua eficiência foi provada no terremoto de 27 de fevereiro de 2010, onde o edifício não sofreu nenhum dano. Sua espacialidade é de um interior temperado, iluminado pelo sol do norte e pela presença da areia abaixo dela. A Figura 62 traz alguns desenhos de projeto e fotos da execução da estrutura treliçada e das vigas em madeira laminada pelos alunos. 
Figura 61 - Hospedería Taller de Obras em Ritoque

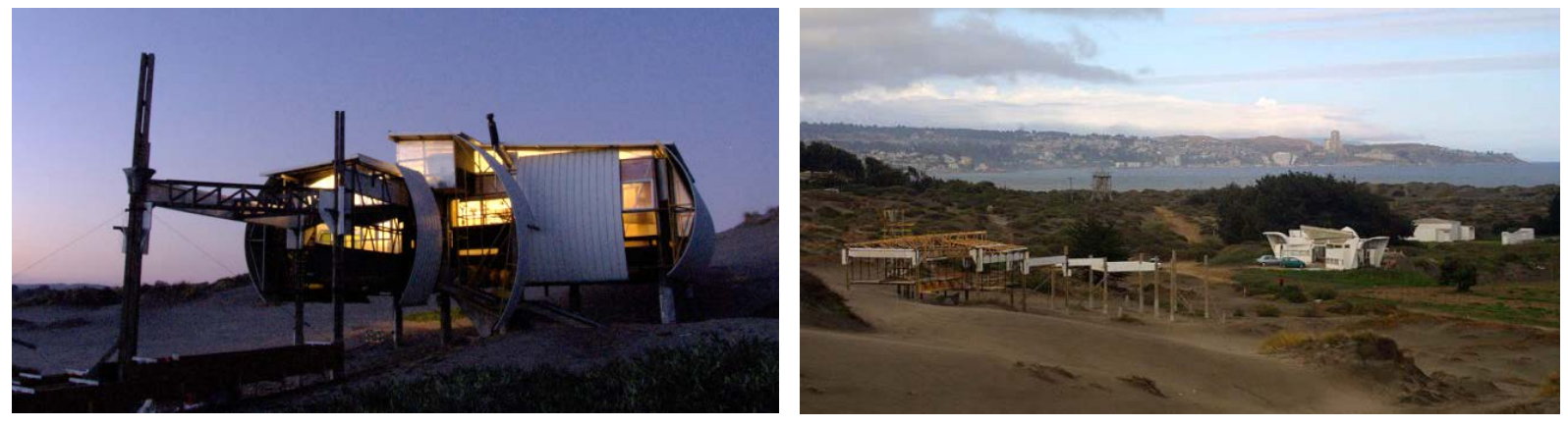

Fonte: Website Casiopea ${ }^{150}$.

Figura 62 - Hospedería Taller de Obras, croquis de implantação, detalhes construtivos, alunos trabalhando na obra e na produção de vigas em madeira laminada
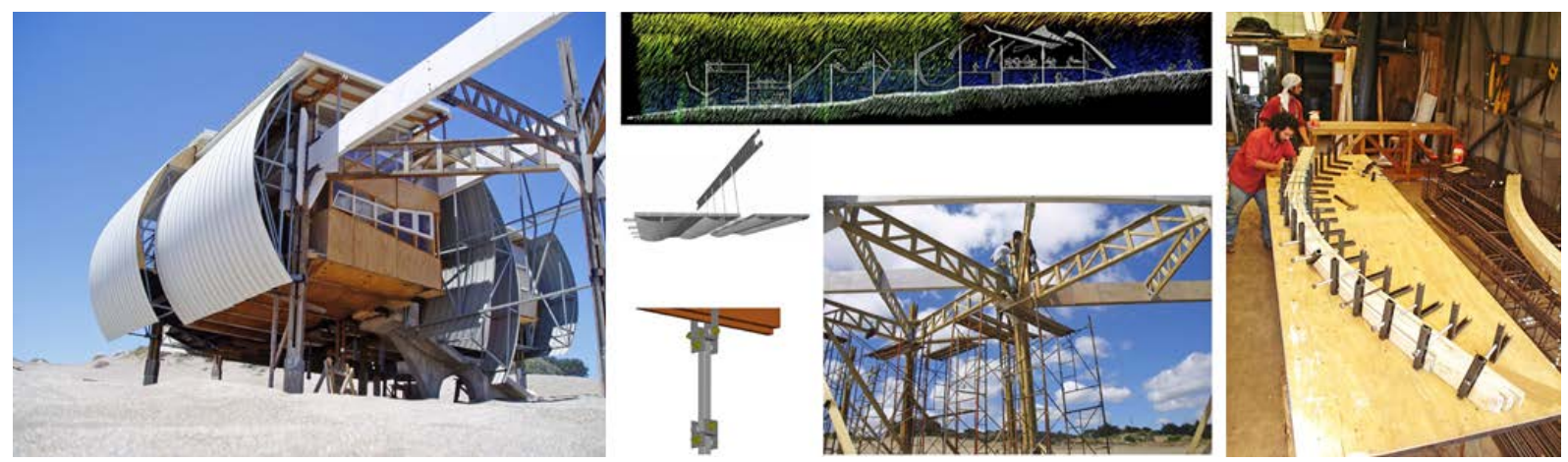

Fonte: Espósito e Luza (2015).

Figura 63 - Hospedería Taller de Obras em Ritoque

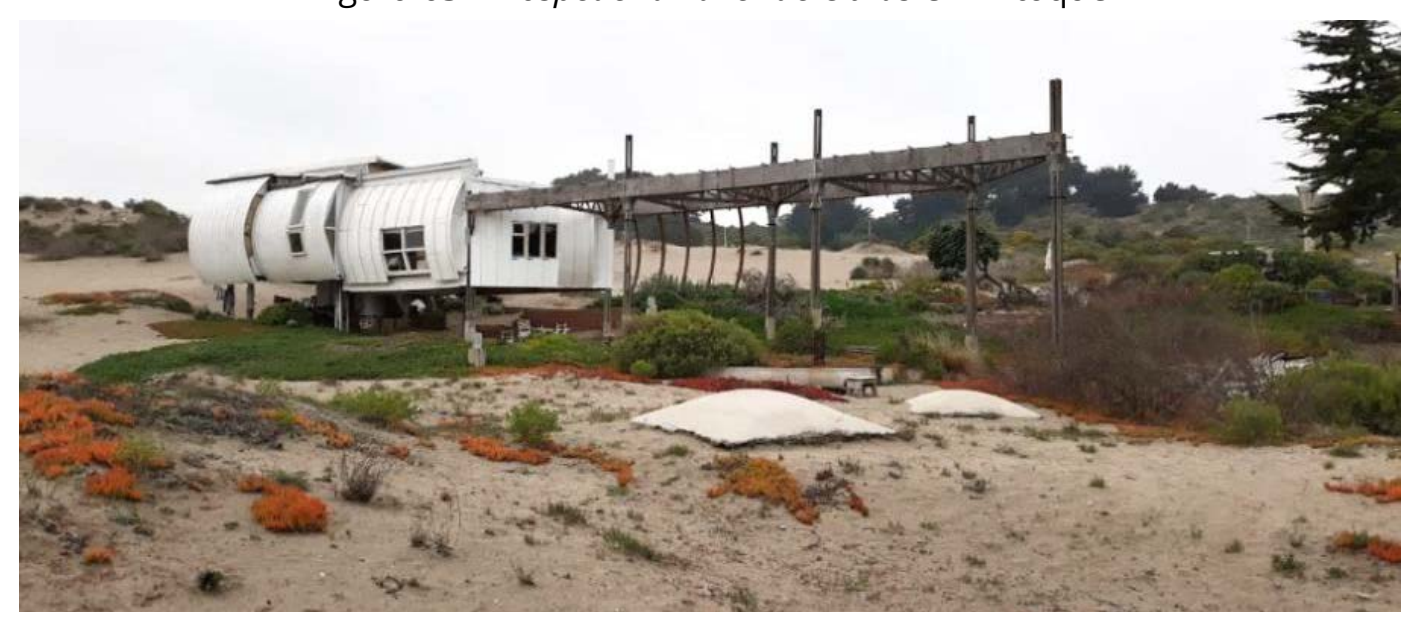

Fonte: arquivo pessoal. 


\section{Pórtico de los Huéspedes}

Local e ano: Ciudad Abierta, 2014-2019 (não concluída)

Âmbito: Taller de Obra

Materialidade: fundações e pilares em concreto armado, estrutura de cobertura, fechamentos e revestimento externo em madeira.

A obra do Pórtico de los Huéspedes vem sendo construída ao longo dos últimos cinco anos através de vários Talleres de Obra internacionais (Figura 64) realizados em parceria entre a e[ad] PUCV e universidades suíças de Lausanne, Zürich y Mendrisio, sendo organizados por professores da Escola Politécnica Federal de Lausanne - EPFL. Têm como objetivo constituir uma experiência formativa disciplinar através da construção de uma obra em verdadeira magnitude, agrupando as disciplinas involucradas.

O projeto, desenhado e executado conjuntamente entre as escolas de arquitetura, será um local de acesso e recepção para todos aqueles que chegam à Ciudad Abierta e abrigará a secretaria da Corporação Cultural Amereida. O professor da e[ad] David Jolly é responsável pelo Taller, juntamente com a professora da EPFL Patricia Guaita. Segundo Patricia, essa experiência é enriquecedora para os alunos porque aprendem o espírito de grupo, o trabalho em conjunto. Na Suíça, os estudantes trabalham muito com a tecnologia, e esta é uma oportunidade de trabalhar com as mãos e com a terra, de modo a complementar a sua formação. São iniciados na contemplação do espaço habitável, que é a "observação" e têm a experiência de realizar uma obra em tamanho real 1: $1^{151}$. A Figura 65 e a Figura 66 mostram a etapa de obra durante o Summer Chantier 2018, quando alunos suíços e chilenos trabalharam no fechamento do recinto lateral que abrigará a secretaria e no piso de acesso ao local.

\footnotetext{
${ }^{151}$ Notícia publicada na página web da Escola de Arquitetura e Design da PUCV, traduzida pela autora. Disponível em: https://www.ead.pucv.cl/2014/escuela-de-arquitectura-y-diseno-inicia-taller-en-conjunto-conescuela-politecnica-general-de-lausanne/. Acesso em: 28 ago. 2018.
} 
Figura 64 - Construção do Pórtico de los Huéspedes em três momentos: Summer Chantier 2014, 2015 e 2016

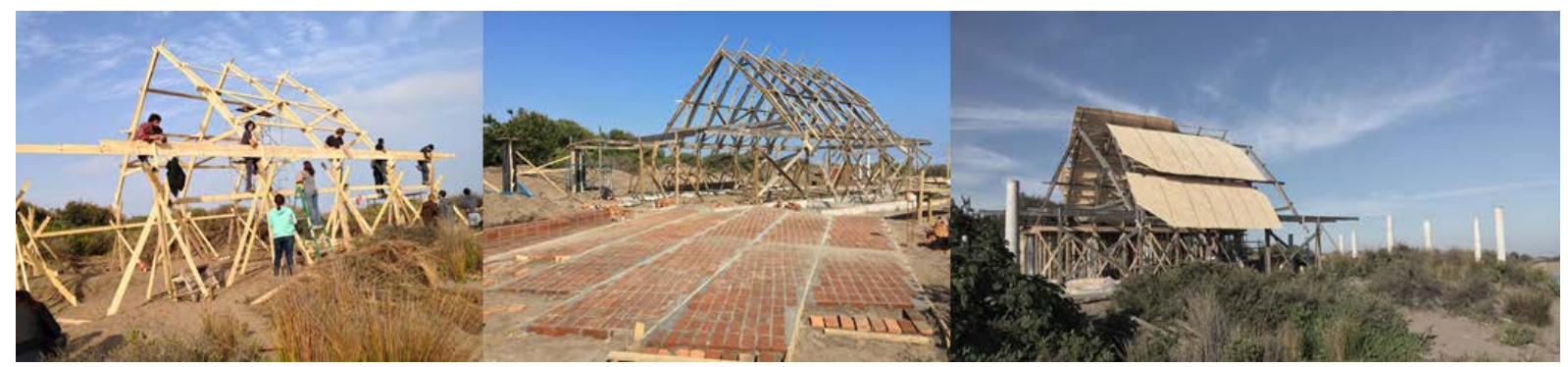

Fonte: Website da Enac EPFL ${ }^{152}$.

Figura 65 - Evolução do Pórtico de los Huéspedes: Summer Chantier 2018
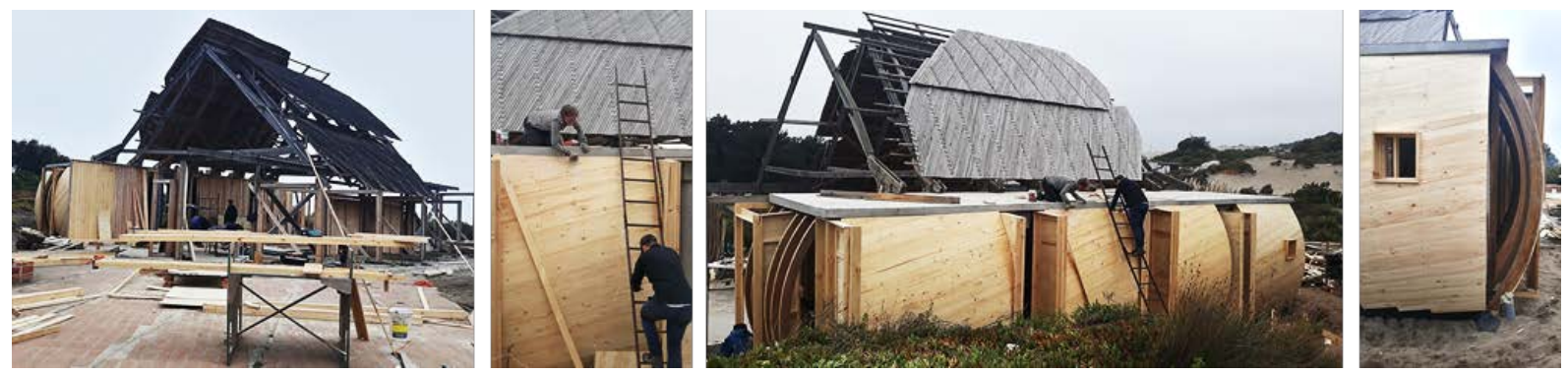

Fonte: arquivo pessoal.

Figura 66 - Alunos suíços e chilenos trabalhando no Pórtico de los Huéspedes na Ciudad Abierta

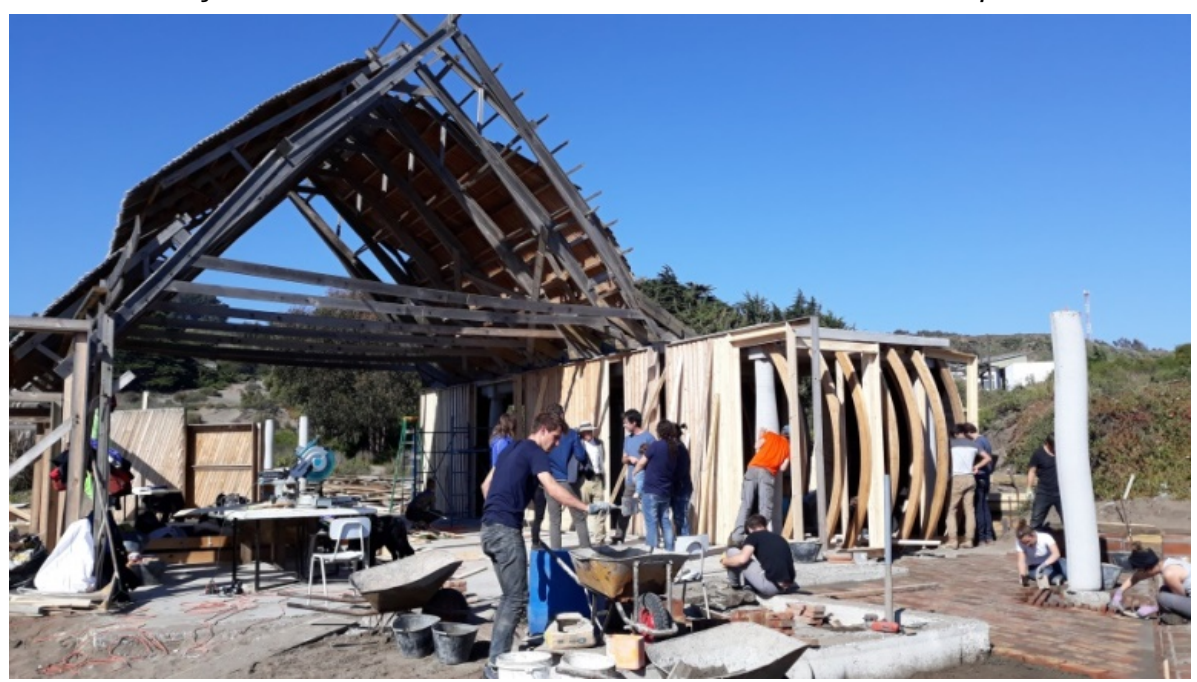

Fonte: arquivo pessoal.

152 Disponível em: https://enac.epfl.ch/enseignement/architecture/summer-school. Acesso em: 25 ago. 2018. 


\section{Travesía à Marimenuco}

Obra: Ruca para la celebración del We Tripantu

Local e ano: Marimenuco, Lonquimay, Chile, 2011

Âmbito: Travesía - Taller ARQ $3^{\circ}$

Materialidade: predominantemente madeira

Marimenuco, cujo nome na língua mapuche significa "os dez pântanos", é um povoado de aproximadamente 200 pessoas, localizado no leste da região da Araucanía, a 55 km de Lonquimay (Figura 67), onde há uma comunidade originária da América. 0 lugar faz parte de um setor anteriormente habitado pelos Pehuenches, cujo significado vernacular é "Povo de Pehuén”. O Pehuén (pinhão) é o fruto da Araucaria araucana, uma árvore milenar endêmica do sul do Chile cuja longevidade ultrapassa os 1.500 anos de idade. A Araucaria, junto com seus frutos, faz parte desta região desde suas origens, e por isso são um componente fundamental na busca da identidade do lugar e seus habitantes, tanto na área econômica como no sentido mítico-religioso. Essa identidade é enaltecida na obra projetada e construída in situ a partir das observações espaciais e culturais do lugar, para a celebração do We Tripantu, o Ano Novo Mapuche festejado cada 24 de junho, dia do solstício de inverno, que significa "nova saída do sol".

Figura 67 - Localização de Marimenuco, Chile, e rota de ônibus desde Lonquimay
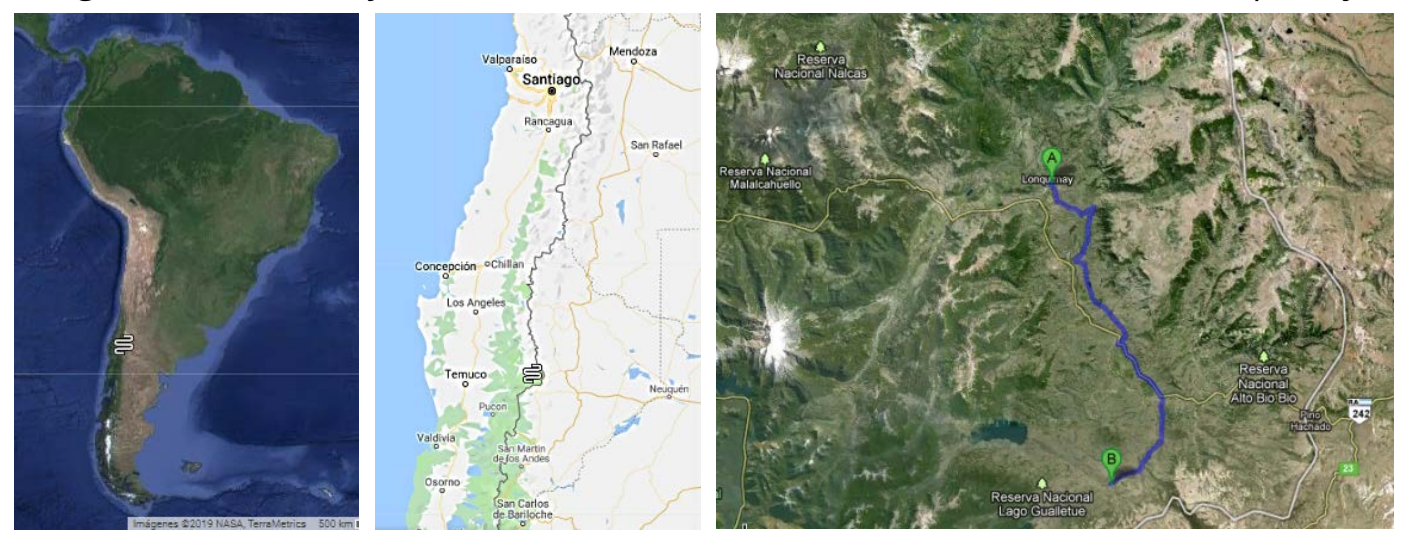

Fonte: Website Casiopea ${ }^{153}$.

153 Disponível em: https://wiki.ead.pucv.cl/Travesía_Marimenuco\#D.C3.ADa_9. Acesso em: 29 jul. 2019. 
A Travesía foi realizada por um grupo de 22 pessoas num período de dez dias. A obra construída próxima à Escola Rural Intercultural de Marimenuco é uma sala de aula ao ar livre concebida como um local onde as crianças podem aprender sua cultura, transmiti-la e preservá-la. Intitulada de Ruca, encuentro y re-unión que alberga la celebración ${ }^{154}$, baseou-se no conceito da extensão da sala de aula e partiu de uma "rampa de extensão em espiral escalonada". A rampa nasce da terra e começa a subir; a altura da rampa gera um tamanho que dá suporte às costas de quem está no interior da Ruca; é espiral porque, enquanto se eleva, aproxima-se do seu centro, lugar do fogo; o topo do caminho ascendente gera uma vista à extensão do território; os bancos exteriores oferecem um tempo de prelúdio à intimidade do interior (Figura 68). A estrutura de forma concêntrica foi executada com madeira de Pinus de pequenas dimensões e ferramentas manuais e elétricas ${ }^{155}$ levadas pelo grupo na viagem realizada em ônibus com itinerário de Viña del Mar - Santiago - Lonquimay - Marimenuco. Na Figura 69 vemos a obra construída em Marimenuco.

Figura 68 - Projeto Ruca para la celebración del We Tripantu, extensão da sala de aula e lugar de reunião comunitária delimitada por uma rampa espiral concêntrica ao fogo
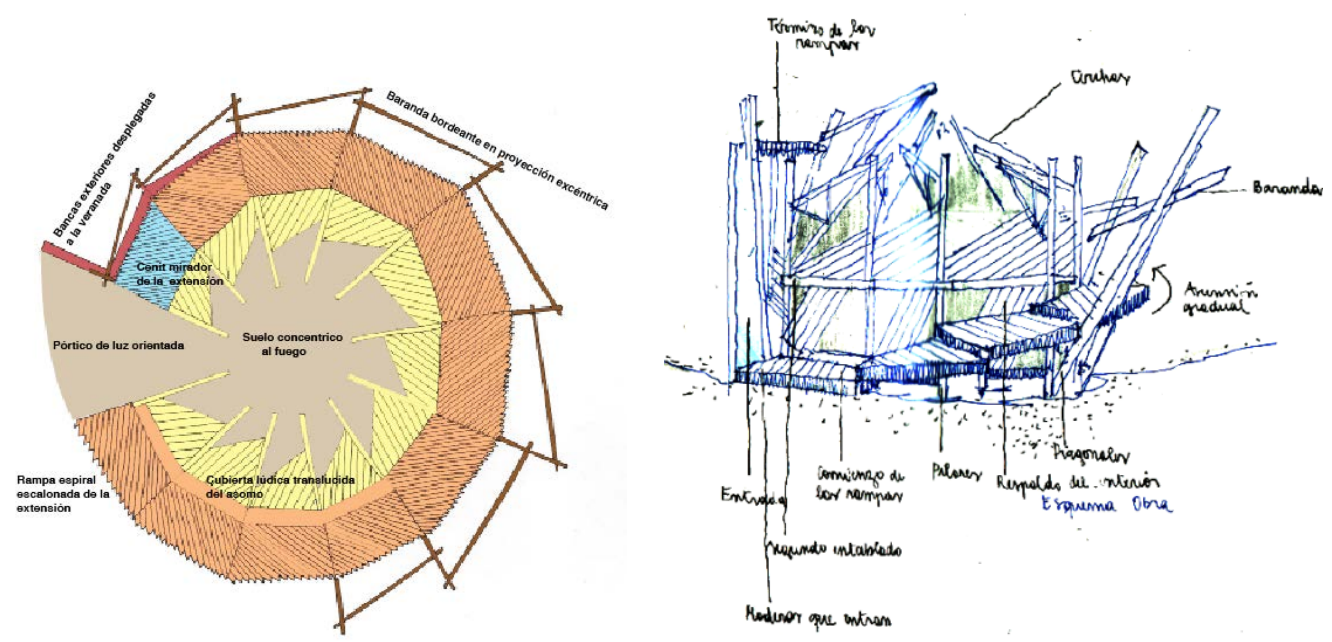

Fonte: Website Casiopea ${ }^{156}$.

\footnotetext{
154 Ruca é uma casa rural tosca e rústica, uma choça ou choupana. Optei por não traduzir este termo e utilizá-lo como nome próprio de modo que a tradução do título da obra seria: Ruca, encontro e re-união que hospeda a celebração.

${ }^{155}$ A relação de ferramentas manuais e elétricas carregadas pelo grupo na viagem de Travesía, e outros detalhes da viagem estão disponíveis no website Casiopea: https://wiki.ead.pucv.cl/Travesía_Marimenuco\#D.C3.ADa_9.

156 Disponível em: https://wiki.ead.pucv.cl/Travesía_Marimenuco\#D.C3.ADa_9. Acesso em: 29 ago. 2018.
} 
Figura 69 - Fotos da obra construída durante Travesía a Marimenuco, 2011
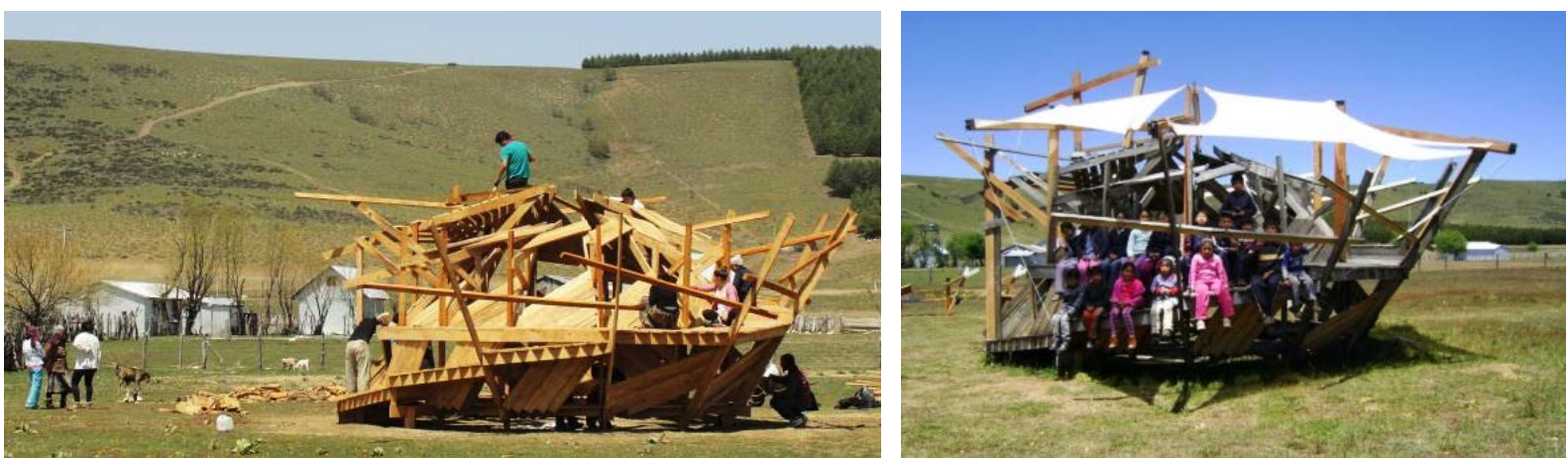

Fonte: Saavedra (2017) e Website Casiopea ${ }^{157}$.

\section{Travesía à Tekoa Pindo-Porty}

Obra: Comedor Comunitario Guaraní

Local e ano: Lamí, Porto Alegre, Brasil, 2014

Âmbito: Travesía - Taller ARQ $3^{\circ}$

Materialidade: predominantemente madeira e bambu

Nesta Travesía, composta por 44 estudantes e dois professores, o grupo viajou de ônibus de Valparaíso até a comunidade indígena Tekoa Pindo-Porty - que significa bosque de palmeiras floridas - localizada a 30 quilômetros ao sudeste de Porto Alegre, no Brasil. Em uma vizinhança periférica chamada Lamí, o grupo realizou o seu projeto, construindo um espaço de encontro para a comunidade, um local de reunião em torno ao acto de comer. Ao percorrer a aldeia logo na chegada, o cacique explicou que uma tarefa comunitária fundamental para eles é o cozinhar e o comer em comunidade.

Cada uma das oito famílias da aldeia tinha sua própria casa, que eram equivalentes a dormitórios - espaços da intimidade familiar - mas eles compartilhavam o espaço de refeições. O presente para a comunidade foi um comedor onde poderiam beber mate e onde muitas pessoas pudessem se reunir e receber visitas de outras comunidades. Um quadrado e um círculo foram desenhados; o círculo foi dado pela roda que formava o Taller; essa foi a sua dimensão. A partir daí, quatro pontos foram tomados: a terra,

157 Disponível em: https://wiki.ead.pucv.cl/ Travesía_Marimenuco\#D.C3.ADa_9. Acesso em: 29 ago. 2018. 
apontando para o oeste; a água para o norte; o fogo para o sul e a luz para o leste. Com esses pontos, uma figura foi desenhada e se começou a projetar (Figura 70). A Figura 71 ilustra os desenhos produzidos pelos alunos no levantamento da comunidade e estudo de fachadas para o projeto do espaço comunitário.

Figura 70 - Primeiro traçado da planta no chão, Travesía Tekoa Pindo-Porty

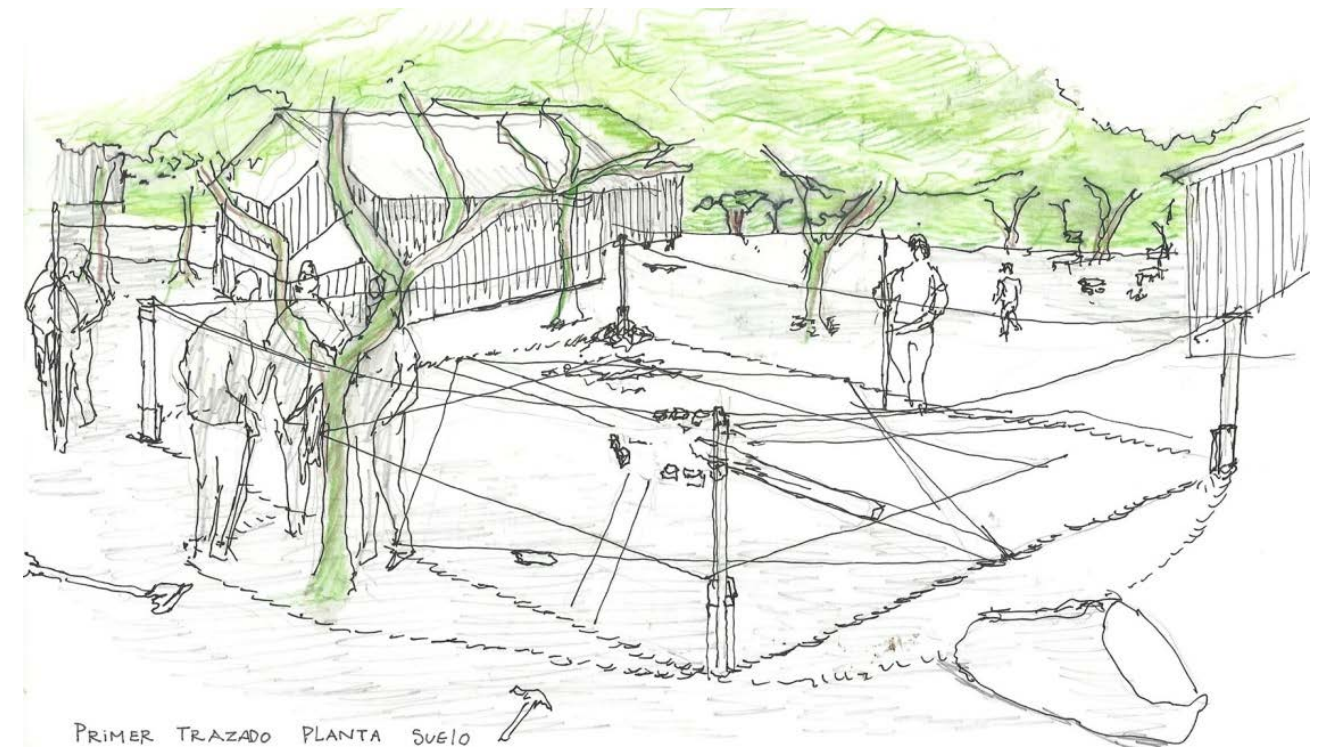

Fonte: Website $\mathrm{e}[\mathrm{ad}]^{158}$.

Figura 71 - Estudo de implantação e de fachadas para o espaço comunitário

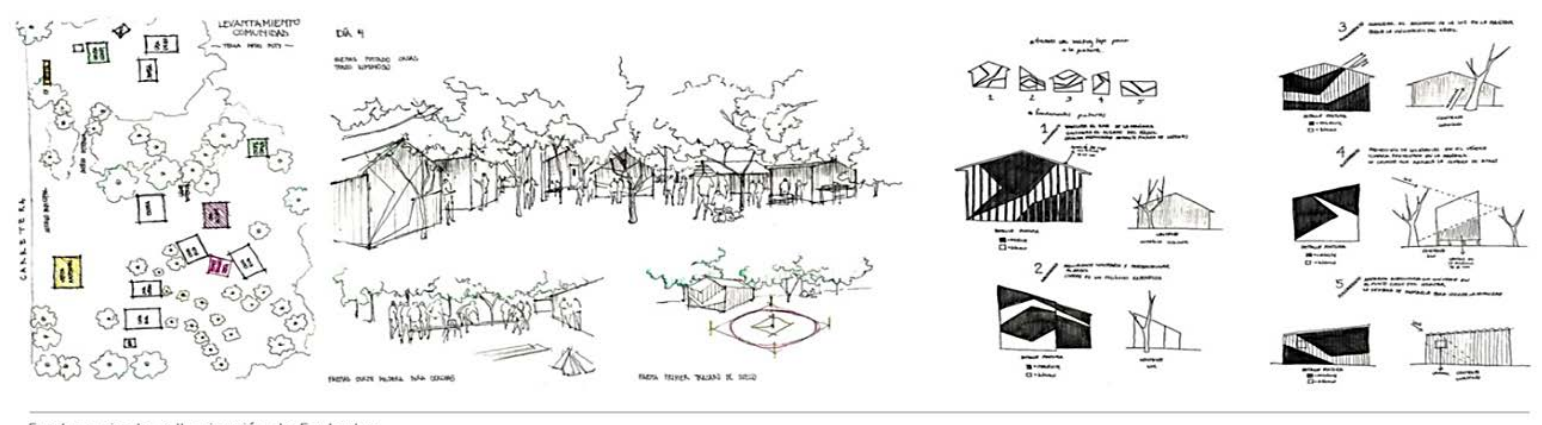

Fonte: Website Archdaily ${ }^{159}$.

${ }^{158}$ Notícia publicada no website da Escuela de Arquitectura y Diseño em 22 de dezembro de 2014. Disponível em: https://www.ead.pucv.cl/2014/travesia-tekoa-pindo-poty-rio-grande-do-sul/. Acesso em: 02 ago. 2019.

159 Disponível em: https://www.archdaily.com.br/br/771270/the-best-student-work-worldwide-archdaily-readersshow-us-their-studio-projects. Acesso em: 25 ago. 2018. 
Com o projeto definido, a obra se dividiu em três tarefas: a confecção de treliças de madeira, que deram altura à estrutura; o telhado e o piso. O telhado foi feito com bambu que estava disponível no local e era fácil de manusear e cortar. Foi produzida uma espécie trama e um tipo de tecido a partir de elementos finos amarrados à trama. A Figura 72 mostra o detalhamento das etapas do processo construtivo do telhado em bambu e a Figura 73 traz imagens da obra construída.

Figura 72 - Detalhamento do processo construtivo do telhado em bambu
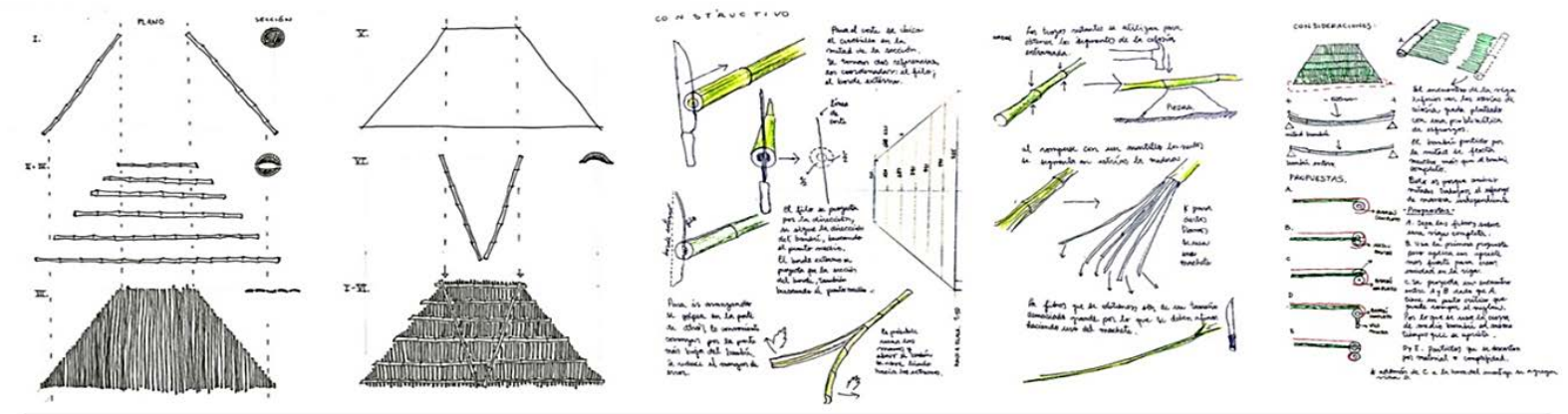

Proceso constructivo techumbre de bambú

Fonte: Website Archdaily ${ }^{160}$.

Figura 73 - Obra construída durante a Travesía Tekoa Pindo-Porty
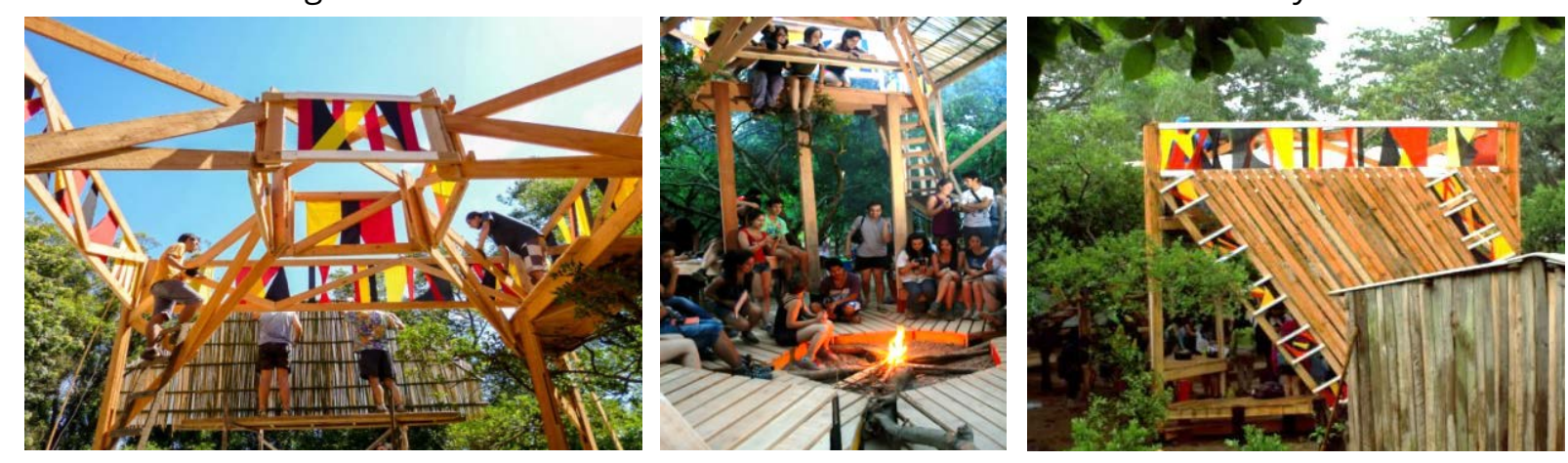

Fonte: Website Archdaily ${ }^{161}$.

160 Disponível em: https://www.archdaily.com.br/br/771270/the-best-student-work-worldwide-archdaily-readersshow-us-their-studio-projects. Acesso em: 25 ago. 2018.

${ }^{161}$ Disponível em: https://www.archdaily.com.br/br/771270/the-best-student-work-worldwide-archdaily-readersshow-us-their-studio-projects. Acesso em: 25 ago. 2018. 


\section{Travesía à Conde, Praia do Amor}

Obra: Caiçara coletiva para comunidade de pescadores

Local e ano: Conde, Paraíba, Brasil, 2018

Âmbito: Travesía - Taller ARQ $3^{\circ}, \mathrm{ARQ} 4^{\circ}, \mathrm{ARQ} 5^{\circ}$

Materialidade: predominantemente madeira, pilaretes, vigotas e ripas em Massaramduba e tábuas de Pinus.

A Travesía a Conde, realizada durante o terceiro ciclo do Taller Disciplinar del Programa y Forma de la Edificación, com a participação desta autora, teve como objetivo atender a solicitação da Prefeitura Municipal para o projeto e construção de uma caiçara coletiva para a comunidade de pescadores da Praia do Amor. Um grupo de três professores e 37 alunos chilenos e europeus em intercâmbio esteve durante 14 dias junto à comunidade local para construir uma obra que abarcasse os requisitos estabelecidos por ambos interlocutores e que cumprisse com as restrições ambientais. O itinerário de viagem - realizado em ônibus de Viña del Mar a Santiago, de avião de Santiago a Recife e de ônibus Recife a Conde - e o local de implantação da obra na Praia do Amor são mostrados na Figura 74.

Figura 74 - Itinerário de viagem e implantação da obra na Praia do Amor, Conde-PB, Brasil
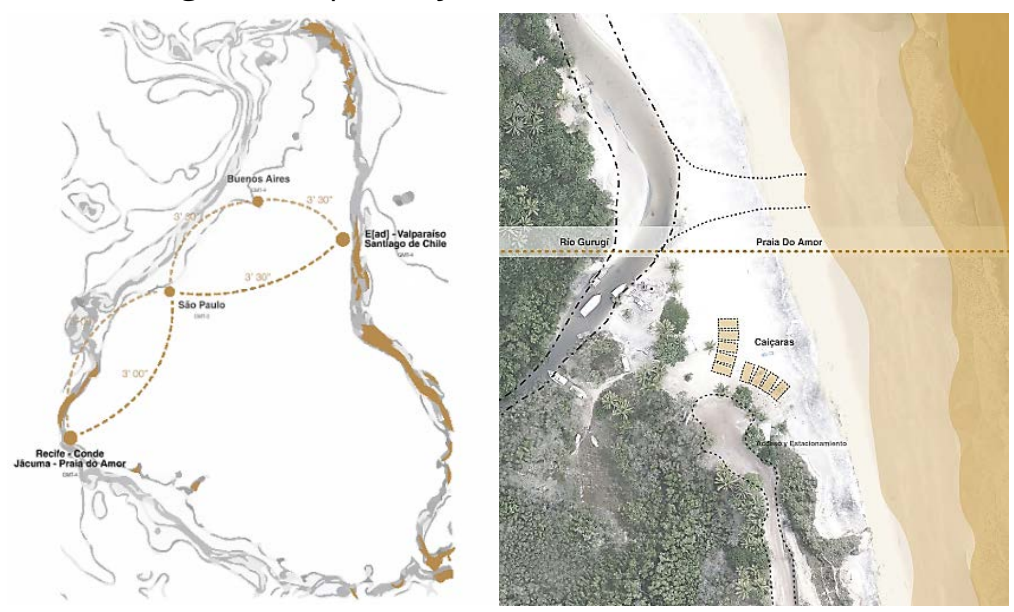

Fonte: Website Casiopea ${ }^{162}$.

162 Disponível em: https://wiki.ead.pucv.cl/Travesía_Conde,_Praia_do_Amor. Acesso em: 19 mai. 2019. 
O termo caiçara tem origem no vocábulo Tupi-Guarani caá-içara - 'caa' = pau, mato + 'içara' = armadilha - isto é, armadilha feita de galhos e varas entrelaçadas, utilizada pelos índios. Com o tempo, o termo passou a identificar pescadores que utilizavam esse sistema artesanal de pesca e também passou a ser o nome dado às palhoças construídas nas praias para abrigar canoas e apetrechos de pesca usados pelos pescadores, assim como para o seu descanso antes ou depois de ir ao mar.

Logo de ter ouvido as demandas e limitações de todos os agentes envolvidos, o grupo sentou-se a desenhar para compreender o lugar, suas qualidades geográficas, espaciais e de iluminação. Foram elaboradas sete propostas de projeto em maquetes (Figura 75), uma por grupo, que davam conta de toda a informação recopilada para conformar as caiçaras individuais que cada pescador solicitava, mas ao mesmo tempo as unificasse e gerasse um espaço coletivo que cumprisse com as condicionantes do Ministério Público. Estas foram apresentadas à comunidade e contrastadas in situ com a realidade do lugar (Figura 76). A implantação final partiu da proposta escolhida pelos pescadores, adaptada às três dimensões territoriais locais: o rio que vem do interior e forma uma pequena marina de barcos abrigada das marés; um estacionamento de veículos que dá acesso à praia desde o balneário de Jacumã; a praia e o Oceano Atlântico onde os pescadores realizam suas atividades de pesca e os turistas tomam sol, praticam esportes e contemplam o horizonte.

Figura 75 - Croquis de algumas das propostas apresentadas em maquete

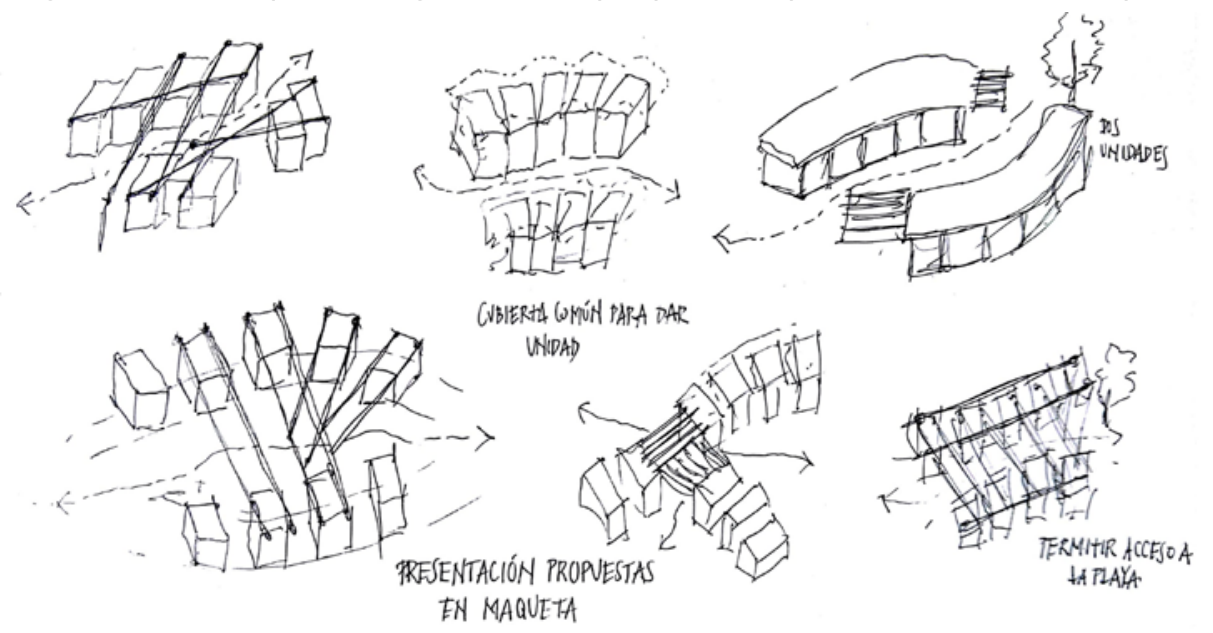

Fonte: caderno de viagem da aluna Adriana Parcerisa. 
Figura 76 - Apresentação das propostas em maquetes à comunidade de pescadores

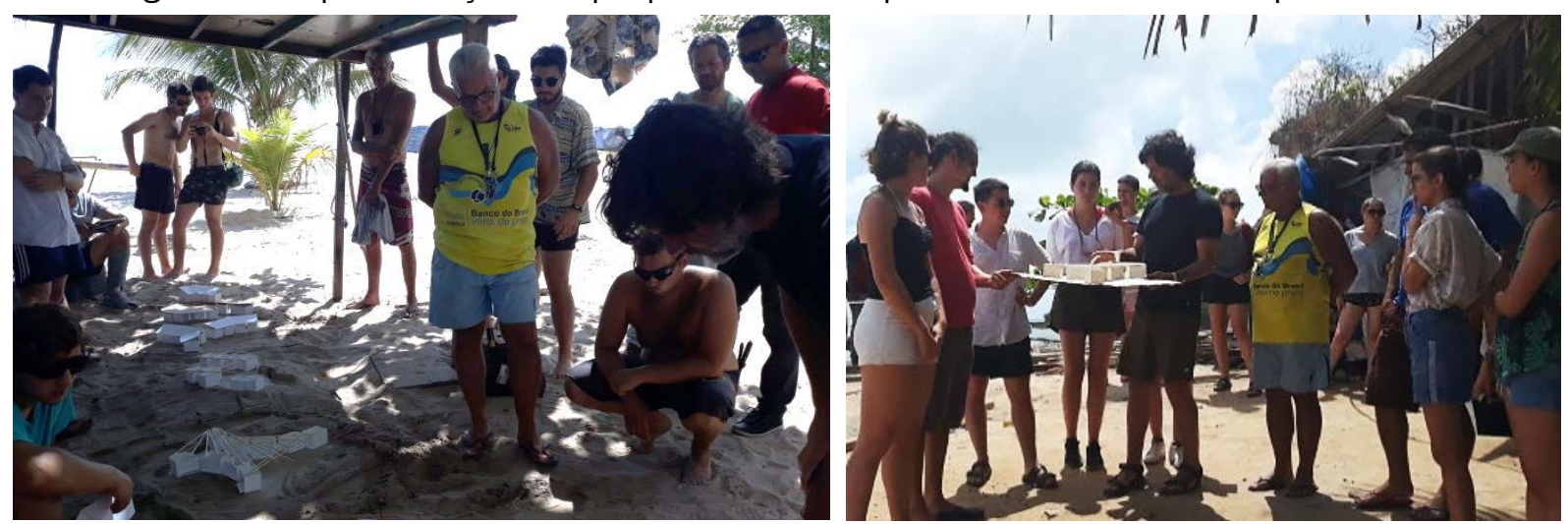

Fonte: arquivo pessoal.

A construção se deu em seis dias de trabalho intensivo com materiais e algumas máquinas leves fornecidas pela Prefeitura de Conde, em parceria com a Oficina Espacial de João Pessoa, enquanto que a maioria das ferramentas manuais e elétricas foi transportada pelos próprios alunos. A madeira disponibilizada para a obra foram tábuas de Pinus, vigotas e ripas de Massaranduba de dimensões variadas e pré-definidas, o que determinou as soluções construtivas que foram sendo elaboradas "sobre la marcha", ou seja, ao mesmo tempo que se desenvolvia o projeto, os grupos se organizavam para executar os componentes definidos. As Figura 77 e Figura 78 ilustram etapas da construção das caiçaras.

Figura 77 - Construção das caiçaras na Praia do Amor, Travesía a Conde-PB, Brasil
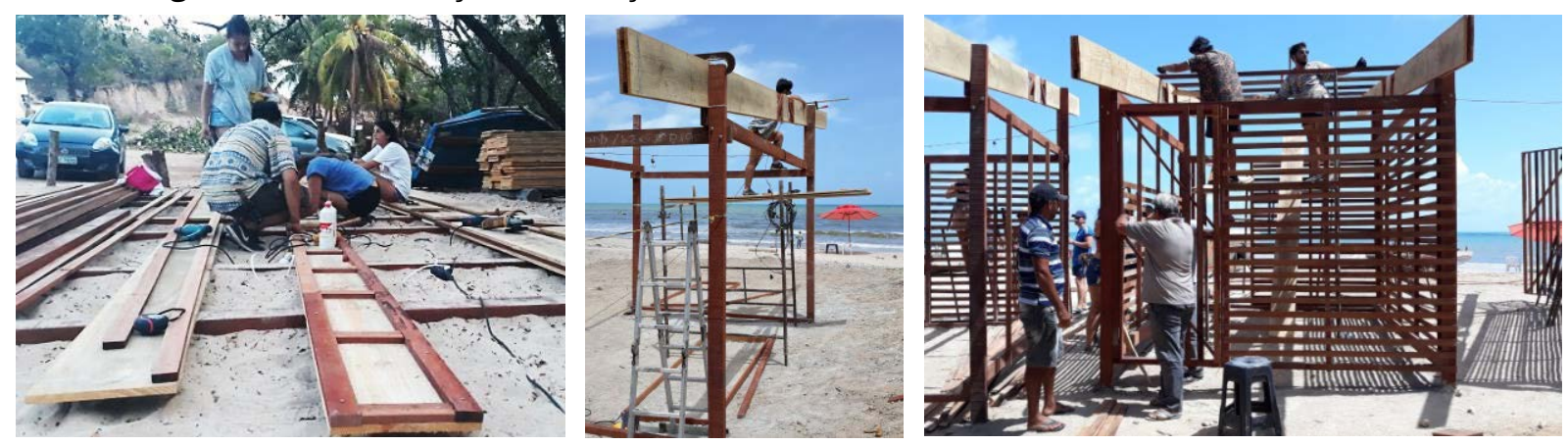

Fonte: arquivo pessoal. 
Figura 78 - Vista aérea da construção das caiçaras na Praia do Amor

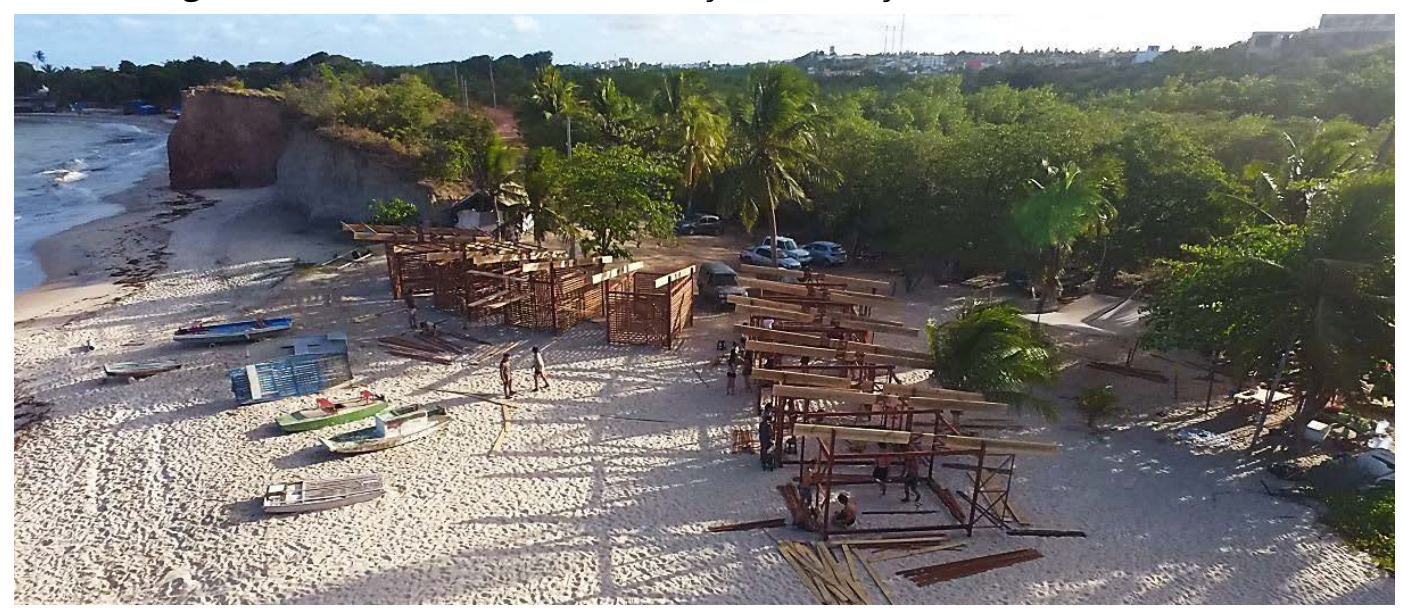

Fonte: Prefeitura de Conde-PB.

Finalmente chegamos ao dia do banquete de inauguração, na véspera do retorno ao Chile, com uma obra que não estava completamente acabada, o que implicou na frustração de vários do grupo. A finalização foi assumida pela Prefeitura que entregou as caiçaras à comunidade em 28 de fevereiro de 2019.

As Travesías nunca tiveram a finalidade de atender a demandas das comunidades visitadas, mas essa tem sido uma solicitação cada vez mais frequente e que tem gerado reflexão entre o corpo docente da Escola. A oportunidade ímpar de vivenciar essa experiência de "vida comprimida", de projetar e construir ao mesmo tempo, de pensar e realizar um projeto entre todos, conjugando relações humanas, diversidades culturais e territoriais, adquire um valor extraordinário que se incorpora à experiência pessoal e coletiva. Ao dar conta de todas as dimensões que envolvem a reciprocidade entre o trabalho teórico e prático, desenvolve-se um processo de origem poética que se torna social, cultural e arquitetônico em escala real, permitindo atravessar todos os âmbitos do ofício da arquitetura em um contexto concreto e factível ${ }^{163}$.

No Quadro 7 a seguir, apresenta-se uma síntese da análise das atividades da Escola de Valparaíso segundo as categorias anteriormente indicadas.

${ }^{163}$ A experiência da Travesía a Conde foi apresentada durante o I Congresso Internacional Pensamento e Pesquisa sobre a América Latina, realizado em maio de 2019 na Universidade de São Paulo, em São Paulo. O artigo "Travessia a Conde-PB: construção de caiçara coletiva na Praia do Amor" está em vias de publicação nos Anais deste Congresso. 
Quadro 7 - Quadro síntese de análise da Escuela de Arquitectura y Diseño

\section{Escuela de Arquitectura y Diseño - PUC de Valparaíso, Chile}

\section{Estrutura Curricular}

A estrutura curricular do curso de arquitetura da Escola de Valparaíso é composta de três ciclos formativos - do Ofício, Disciplinar e Profissional - onde a cada ciclo atribui-se um grau de titulação: Bacharelado, Licenciatura e Arquiteto.

A área Taller é a espinha dorsal da estrutura do curso ocupando a maior parte da carga horária dos estudantes. A transversalidade disciplinar é proposta através de atividades que articulam as demais áreas científico-técnica e artístico-humanista aos Talleres, no intuito de levar a tradição criativa de "pensar-fazendo" e "estudar por projeto" para um espaço universitário mais amplo. O diferencial do currículo relaciona-se a área artístico-humanista na qual os alunos cursam durante sete semestres as disciplinas Taller de Amereida e Cultura del Cuerpo em atividades semanais no espaço da Ciudad Abierta. Também nesse espaço ocorrem práticas vinculadas aos Talleres e Taller de Obra, oferecidos como uma disciplinas eletivas.

As Travesías são viagens pedagógicas que ocorrem no âmbito de cada Taller, embora não se configurem como atividades curriculares obrigatórias, realizadas anualmente durante a primavera, com duração aproximada de quinze dias a um local do Continente Americano.

\section{Conteúdos programáticos}

Os Talleres tratam de projetos temáticos de inserção local e urbana que vão aumentando em escala e complexidade. Propõe sair à cidade para observação do fenômeno direto onde a percepção do território é feita através de croquis e da descrição escrita, manifestados na experiência aos sentidos humanos e à consciência imediata.

O Taller de Obras dedica-se à construção de um fragmento de uma obra de arquitetura na Ciudad Abierta, que proporciona um campo de vida, trabalho e estudo. Essa experiência não é centrada no aluno e sim na obra, o que implica que cada um construa uma parte da totalidade da obra, que se constitui não como expressão de si mesmo, mas de um todo que é coletivo.

As Travesías propõem a observação do território em busca da identidade do ser americano e culminam na concepção e realização de uma estrutura efêmera para o lugar visitado, como uma oferenda ao continente, à paisagem e a sociedade. A preparação da viagem envolve a organização de diversos aspectos como finanças, deslocamento, alojamento, saúde, alimentação, âmbito social e obra que são de responsabilidade dos estudantes.

O Taller de Amereida trata da condição poética do homem, reflete e discute as questões sobre o fazer e o agir dos ofícios em sua relação com a poesia, à luz de Amereida, o que dá lugar à construção da visão poética da Escola.

Cultura del Cuerpo tem como objetivo vincular o aluno ao seu espaço através do corpo, desde o ponto de vista de que o ofício de arquitetura relaciona-se diretamente com a ocupação do ambiente, o qual cria.

\section{Metodologia de Ensino}

A abordagem original acerca da concepção da poesia, da arte e do ofício de Arquitetura, proposta pelos fundadores da Escola de Valparaíso, é certamente o que a distingue. Embora a dimensão poética não tenha sido enfatizada nesta análise, ela está presente nos fundamentos da Escola e permeia toda a estrutura curricular. Os Atos Poéticos são marcos de partida tanto para as práticas construtivas dos Talleres de Obra quanto das viagens de Travesía.

A base de sua concepção pedagógica está na proposta de vincular vida, trabalho e estudo em atividades de experimentação caracterizadas pela construção de instalações efêmeras, e às vezes permanentes, projetadas por alunos e professores. Tal concepção faz da Escola um 
exemplo ímpar de uma "escola do pensamento", comprometida com a busca de uma arquitetura local e experimental, ao estabelecer um modelo didático próprio e sua realização na Ciudad Abierta. As atividades didáticas desenvolvidas neste espaço, como as do Taller de Obras e de Cultura del Cuerpo, partem de métodos que correspondem a uma estratégia educacional que a Escola desenvolveu desde o seu início e que tem a ver com o aprendizado em gerúndio: se aprende a desenhar, desenhando; se aprende a observar, observando; se aprende a entender o espaço, ocupando-o.

Da mesma forma, o desenvolvimento do projeto arquitetônico nos Talleres, com base em um processo exaustivo de experimentação com maquetes, delineado a partir do conceito de Estrutura Radical da Extensão (ERE), pretende catalisar a síntese formal da leitura do lugar através da dimensão do fazer.

As práticas construtivas do Taller de Obras instituem uma comunidade de construtores ligados pela forma da obra, propiciando a experiência de uma vida em comum junto com a experiência espacial do lugar. O estudante tem a oportunidade de conhecer diretamente os materiais de construção, os sistemas e a realidade de como implantar uma obra e construí-la.

Nas Travesías o não planejado e o inesperado são abraçados como aspectos importantes da abordagem pedagógica vinculando a ideia do projeto fundamentalmente à vida, enquanto experimentação e expressão.

\section{Considerações}

As atividades desenvolvidas durante o estágio em pesquisa realizado no âmbito da Escola de Valparaíso permitiram formar uma compreensão mais precisa acerca de sua abordagem pedagógica. Minha participação no Taller del Programa y Forma de la Edificación foi decisiva para isso, uma vez que pude vivenciar de perto, como pesquisadora e como docente, o dia a dia em sala de aula bem como em outros espaços de aprendizagem.

A metodologia proposta no $2^{\circ}$ ciclo do Taller, para o desenvolvimento dos exercícios de projeto arquitetônico, foi catalizadora dos resultados alcançados pelos alunos. A observação, plasmada em croquis e textos, toma uma dimensão muito importante neste processo, bem como a experimentação com maquetes conduzida através do ERE, desencadeando uma maior apreensão do território e de suas qualidades inerentes, que são traduzidas na forma arquitetônica por intermédio da palavra e da intenção poética do ato de habitar.

As atividades práticas de experimentação construtiva proporcionaram a articulação das dimensões do pensar e do fazer. No $1^{\circ}$ ciclo do Taller a utilização da madeira na produção de maquetes em escala reduzida e depois na execução de instalações na escala 1:1, realizadas na Ciudad Abierta, serviram de aproximação tátil ao material, de observação do seu comportamento na prática e de treino ao uso de ferramentas. O $3^{\circ}$ ciclo de Travesía trouxe a oportunidade ímpar de vivenciar uma experiência de "vida comprimida", onde se projeta e se constrói ao mesmo tempo e entre todos, conjugando relações humanas e diversidades culturais e territoriais, fato que adquire um valor extraordinário que se incorpora à experiência pessoal e coletiva. O uso da madeira na obra presenteada à comunidade corroborou o seu potencial como instrumento factível de ensino-aprendizagem.

Traduzir a observação da realidade do lugar, de sua geografia e identidade, em uma ação prática de construção abre a possibilidade de conhecer a materialidade própria do ofício da Arquitetura. Esta premissa de ensinar através de uma experiência sensorial compartilhada e transmitida, entre professor e aluno, e sustentada por um conteúdo emocional que estimula a ação, parece ser o ponto chave para uma aprendizagem significativa. 


\section{REFERÊNCIAS}

CRONHJORT, Y.; VAHTIKARI K.; TAKANO A. Aalto Wood: interdisciplinary teaching and research. In: WORLD CONFERENCE ON TIMBER ENGINEERING - WCTE, 2016, Vienna.

Proceedings [...]. Vienna: Vienna University of Technology, 2016.

ESPÓSITO G., F.; LUZA C., D. Talleres de Obra en Ciudad Abierta de Amereida. Revista AUS. Valdívia, Chile, Jul./dic., 2015. Disponível em: http://www.redalyc.org/articulo.oa?id=281744668007. Acesso em: 24 ago. 2018.

FREEAR, A.; BARTHEL, E. Rural Studio at twenty: designing and building in Hale County, Alabama. New York: Princeton Architectural Press, 2014.

GARCÉS A., A.; MANSÚ, M. Travessia Porto do Capim, João Pessoa. In: ROMANO, E. et. al. (org.) Centralidades periféricas. João Pessoa: Editora da UFPB, 2018. p. 181-209.

GUAITA, P.; TAPPARELLI, C. El camino no es camino: some reflections on the valparaiso school and its architectural teaching. In: DEVABHAKTUNI, S.; GUAITA, P.; TAPPARELLI, C. (ed.) Building Cultures Valparaiso: pedagogy practice and poetry at valparaiso school of architecture and design. Lausanne, Switzerland: EPFL Press, 2015. p. 17-29.

HERMANSEN, C.; JOLLY M., D.; HENSEL, M. The Open City and the e[ad] School of Architecture and Design. Architectural Design. London, v. 85, n. 2, 2015. DOI: 10.1002/ad.1874. Disponível em: https://www.researchgate.net/publication/273391101. Acesso em: 24 ago. 2018.

LOTUFO, T. A. Um novo ensino para outra prática: Rural Studio e Canteiro Experimental, contribuições para o ensino de arquitetura no Brasil. 2014. Dissertação (Mestrado em Arquitetura e Urbanismo) - Faculdade de Arquitetura e Urbanismo, Universidade de São Paulo, São Paulo, 2014.

PENDLETON-JULIAN, A. M. The road that is not a road and the Open City, Ritoque, Chile. Cambrige, Massachusetts: MIT Press, 1996.

PÉREZ DE ARCE, R. Tan lejos y tan cerca: la Ciudad Abierta y las Travesías. In: PÉREZ DE ARCE R.; PÉREZ OYARZÚN F. Escuela de Valparaíso: Grupo Ciudad Abierta. Madrid: Tanais Ediciones, 2003. p. 13-17.

SAAVEDRA V., R. As travessias pela América: aprender arquitetura e design através de uma experiência poética. PRUMO: Revista online do Departamento de Arquitetura e Urbanismo da PUC-Rio, Rio de Janeiro, v. 2, n. 2, p.16-33, 2017. Disponível em: http://periodicos.puc-rio.br/index.php/ revistaprumo/issue/view/edi\%C3\%A7\%C3\%A30\%20completa. Acesso em: 06 jul. 2017. 


\section{SITES CONSULTADOS}

http://www.semanadelamadera.cl

http://woodprogram.fi

https://saiepavilion.wordpress.com

https://www.facebook.com/saiepavilion2015

https://www.archdaily.com/793534/kokoon-aalto-university-wood-program

https://www.a-lava.com

https://www.instagram.com/a.lava.woodprogram

https://www.archdaily.com/875577/a-star-lava-aalto-university-wood-program

http://www.finnisharchitecture.fi/2014/10/strong-roots-a-sturdy-trunk-and-verdantcrown-wooden-architectures-annual-rings-at-the-museum-of-finnish-architecture

https://www.instagram.com/ruralstudio

https://www.facebook.com/rural.studio

http://ruralstudiofarm.ruralstudioblogs.org

https://www.designboom.com/architecture/the-rural-studio-08

https://www.designboom.com/architecture/the-rural-studio-morrisette-tea-house

https://www.archdaily.com/508534/classic-architecture-with-a-social-agenda-1960today

https://www.archdaily.com/541376/lions-park-scouts-rural-studio

http://www.studentshow.com/gallery/2273086/Rural-Studio

https://www.ead.pucv.cl/

https://wiki.ead.pucv.cl/Casiopea

https://www.plataformaarquitectura.cl/cl/02-257144/ciudad-abierta-de-ritoquepaisaje-habitado-44-anos-despues

https://www.archdaily.com.br/br/771270/the-best-student-work-worldwidearchdaily-readers-show-us-their-studio-projects

https://enac.epfl.ch/enseignement/architecture/summer-school 


\subsection{Referências do ensino de tecnologias construtivas em madeira nos cursos de} AU brasileiros

Retomamos neste capítulo os resultados do levantamento de dados documentais apresentados no capítulo 2.4 referentes à inserção das tecnologias construtivas em madeira no currículo dos cursos de graduação em Arquitetura e Urbanismo brasileiros. Frente à limitada carga horária e restrita interdisciplinaridade da área de Tecnologia e de Projeto verificadas, ganham pertinência as questões relativas às abordagens pedagógicas. Neste contexto, qual a relevância das atividades práticas de experimentação construtiva nos cursos de AU no Brasil? Quais as metodologias de ensino-aprendizagem vêm sendo aplicadas na área tecnológica?

Algumas das experiências aqui relatadas foram identificadas através de entrevistas com docentes, outras por meio da revisão bibliográfica, outras ainda, vivenciadas em corpo presente. Como produto, não alcançam uma amostragem expressiva, e certamente trazem uma visão parcial da realidade do ensino em nosso país de dimensões continentais. Refletem, porém, abordagens práticas em algumas das escolas consideradas referências para a área de investigação.

Cervantes Ayres Filho, arquiteto e professor da área de Tecnologia da Universidade Federal do Paraná, aposta na aprendizagem por competências. Em entrevista concedida no mês de setembro de $2017^{164}$, falou sobre as experiências que tem realizado nas disciplinas de Materiais de Construção e Construção Civil do curso de Arquitetura e Urbanismo nas quais propõe uma abordagem pedagógica de Aprendizagem Baseada em Projetos ${ }^{165}$.

\footnotetext{
${ }^{164}$ Entrevista concedida a autora no dia 22 de setembro de 2017 na UFPR em Curitiba, juntamente com os professores Andrea Berriel Mercadante Stinghen e Maria Regina Leoni Schmid, todos docentes do curso de Arquitetura e Urbanismo.

${ }^{165}$ Cervantes se refere à prática da Aprendizagem Baseada em Projetos (ABP) - em inglês, Project Based Learning (PBL) - também conhecida como Aprendizagem Baseada em Problemas - Problem Based Learning - que, como vimos, tem sido largamente utilizada na atualidade em diversas áreas educacionais, especialmente em universidades dos Estados Unidos. "A ABP é um formato de ensino empolgante e inovador, no qual os alunos selecionam muitos aspectos de sua tarefa e são motivados por problemas do mundo real que podem, e em muitos casos irão, contribuir para a sua comunidade" (BENDER, 2014, p. 15).
} 
Segundo Cervantes, a base pedagógica proposta é invertida: ao invés de mostrar abstrações, conceitos e características dos materiais que devem ser memorizados, parte-se do princípio de mostrar o que é concreto, mostrar a aplicação do material utilizando-se da confecção de modelos reduzidos de sistemas construtivos - para então estimular os alunos a pesquisarem os detalhes e as abstrações de cada técnica, ou seja, aprofundarem-se nos conceitos e características dos materiais e de suas aplicações. Os alunos se interessam mediante a competência adquirida ao explorar o material e buscam a resolução de dúvidas que vão surgindo durante o processo. A Figura 79 mostra as maquetes produzidas na disciplina de graduação Materiais de Construção II, do $2^{\circ}$ período do curso de AU da UFPR, na qual os alunos investigaram os sistemas Steel Frame e Wood Frame.

Figura 79 - Maquetes produzidas na disciplina Materiais de Construção II da UFPR

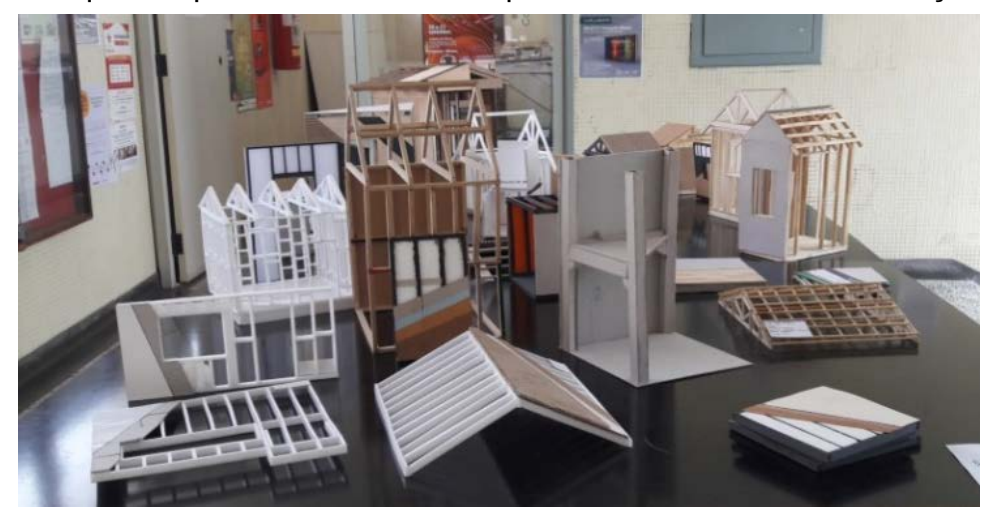

Fonte: arquivo pessoal.

A partir deste ponto de vista, uma formação mais aprofundada em Tecnologia não tem a ver com apresentar uma infinidade de conteúdos e sistemas possíveis, mas com oferecer um grau de liberdade e informação suficiente para que os alunos façam escolhas e conectem os valores de seu universo cultural, criando identidade e tornandose cada vez mais competentes. A metodologia ativa impulsiona através da experimentação prática o desenvolvimento de competências por meio da constituição de categorias de informações duráveis, vividas corporalmente, que posteriormente serão aplicadas em projetos. É necessário criar desafios voltados para o entendimento individual e a busca de soluções para somente então, a partir do estímulo pessoal, chegar à construção de soluções projetuais e à elaboração de detalhes construtivos. 
Também pautada em uma abordagem de Aprendizagem Baseada em Projetos, a disciplina optativa de graduação "Parâmetros para Projetos Habitacionais em Madeira" do Instituto de Arquitetura e Urbanismo da Universidade de São Paulo, ministrada pela professora Akemi Ino, é oferecida anualmente com temáticas bastante variadas onde se propõe a resolução de problemas reais.

No primeiro semestre de 2017 teve como objetivo exercitar a prática do desenvolvimento de projeto com grupos de alunos, através do projeto de painéis de revestimento externo em madeira para a substituição do revestimento da Unidade Habitacional Experimental 002, que abriga a sede do Grupo HABIS. Seguiu as seguintes etapas: 1) aulas teóricas e expositivas para a definição de base conceitual comum e compartilhamento de dados e materiais disponíveis; 2) levantamento técnico da edificação e seu entorno para a coleta de dados para o projeto; 3) desenvolvimento de projeto executivo para sistema de vedação e revestimento; 4) produção de protótipo do painel; 5) revisão e finalização de detalhamento construtivo e projeto de produção (APRILANTI; TAVARES; INO, 2018). A Figura 80 ilustra as etapas 3 e 4, respectivamente.

Figura 80 - Disciplina optativa de graduação “Parâmetros para Projetos Habitacionais em Madeira" do IAU-USP, abril 2017
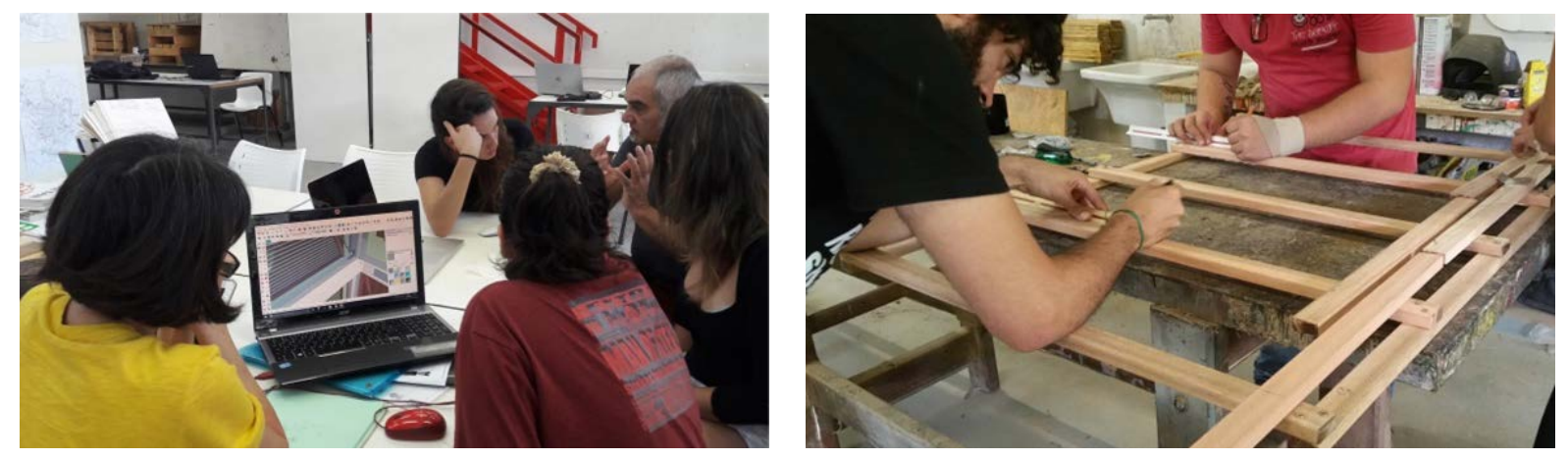

Fonte: arquivo pessoal e Simone Tavares.

Ivan do Valle, arquiteto e professor da Universidade Nacional de Brasília, ressalta as potencialidades do modelo reduzido como meio para representar e expressar os projetos estruturados em madeira. Cita que a elaboração de modelos reduzidos estão contemplados nas Propostas de Diretrizes Curriculares para Arquitetura e Urbanismo da Secretaria de Ensino Superior (SESu-MEC) como conteúdo essencial, desenvolvido em 
atividade prática e teórica. Ivan apresenta o resultado de sua experiência na disciplina eletiva de graduação "Oficina de Maquete" da Faculdade de Arquitetura e Urbanismo da UnB como subsídio ao público interessado em construção em madeira para compreender mais sobre estas construções pelo caminho da confecção de modelos.

\footnotetext{
O simples ato de projetar em madeira exercita o raciocínio do projetista e estimula sua percepção dos elementos estruturais. O modelo reduzido se revela uma ferramenta para aprimorar essa compreensão, com o desenvolvimento do raciocínio espacial e da capacidade de transposição do objeto de estudo para espaços tridimensionais (VALLE, 2000).
}

Em entrevista concedida pelo professor $\operatorname{Ivan}^{166}$, ele relata que o tema de estudo proposto é variável, e também as escalas dos modelos em função dos projetos, mas são sempre utilizadas referências de obras emblemáticas como, por exemplo, os projetos construídos de Zanine Caldas. Uma das temáticas propostas na disciplina é estudar detalhes construtivos como beirais de cobertura, escadas, fachadas, varandas, janelas e portas, e realizar maquetes, nesse caso, na escala 1:10 e 1:20.

A metodologia aplicada parte do estudo e entendimento do projeto para, em um segundo momento, representá-lo através de desenhos técnicos. O terceiro passo é o planejamento do processo de produção do modelo que se dá pelo estudo detalhado dos elementos estruturais que compõe o objeto e do desenho destes, o que possibilita a listagem de quantidades e dimensões dos materiais a serem utilizados, ou seja, o romaneio de materiais que se aproxima muito da prática real do projeto de construções em madeira. Passa-se então para a etapa de preparação dos materiais, corte e lixamento das varetas nas especificações definidas. Com o material pronto se estabelece a mesa de trabalho onde serão dispostos os desenhos que servirão de base para montagem dos modelos com o uso de alfinetes e cola. Os produtos finais da disciplina são, além dos modelos físicos, um caderno com a pesquisa inicial, fotografias e desenhos técnicos do projeto estudado, registros do processo de execução dos modelos e um pôster para exposição.

\footnotetext{
${ }^{166}$ Entrevista COM O PROFESSOR Ivan do Valle realizada nos dias 20 e 21 de fevereiro de 2017, em São Carlos, na sede do Grupo de Pesquisa em Habitação e Sustentabilidade - HABIS no Instituto de Arquitetura e Urbanismo da Universidade de São Paulo, IAU-USP.
} 
A avaliação sobre o processo de aprendizagem dos alunos nesta disciplina é extremamente positiva, uma vez que eles se envolvem efetivamente com a produção e veem o resultado do produto. Comparativamente à prática do desenho de projeto, onde muitas dúvidas surgem durante o seu desenvolvimento sem chegar a uma resolução, principalmente em relação à estrutura, o modelo permite ao aluno o entendimento mais aprofundado do objeto arquitetônico, das técnicas construtivas e dos sistemas estruturais, além de constituir-se em um instrumento de motivação (VALLE, 2000, 2014).

Durante o ano de 2013, o professor Ivan ministrou junto com a professora Akemi Ino o curso de extensão, modalidade difusão, “Modelo Reduzido como instrumento para concepção, registro e divulgação da cultura construtiva em madeira" no IAU-USP, em São Carlos (Figura 81). A proposta do curso, dirigido a alunos de graduação, a partir do terceiro ano, e graduados das áreas de arquitetura, engenharia civil e áreas afins, consistiu em reproduzir através de modelos reduzidos os principais trabalhos realizados pelo Grupo HABIS nos últimos 20 anos. O objetivo foi desenvolver nos alunos a compreensão sobre o processo de concepção estrutural de uma edificação de madeira e seu processo produtivo através da montagem dos modelos. O material resultou na exposição itinerante "Mostra HABIS 21" que promoveu a divulgação cultural dos projetos arquitetônicos e das tecnologias inovadoras desenvolvidas em madeira ${ }^{167}$.

Figura 81 - Curso de extensão IAU-USP, maio-novembro 2013
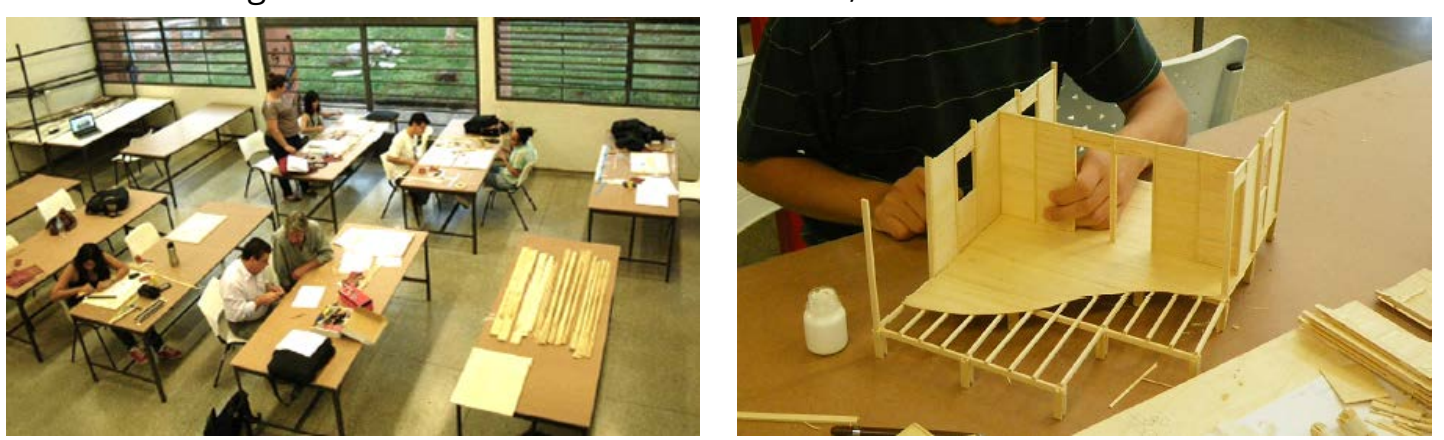

Fonte: Valle (2014).

${ }^{167}$ Informações disponíveis em:

https://www.iau.usp.br/index.php?option=com_content\&view=article\&id=172:curso-de-difusao-modeloreduzidos-no-iau\&catid=36\&ltemid=185 e em:

https://www.iau.usp.br/index.php?option=com_content\&view=article\&id=274:exposicao-itinerante-mostrahabis-21\&catid=36\&ltemid=185. Acesso em: 12 jul. 2018. 
Para o professor de Sistemas Estruturais Roberto Pompéia, as oficinas de modelagem tridimensional que ministra em escolas de Arquitetura, entre elas a Escola da Cidade e a Universidade Anhembi Morumbi, ambas em São Paulo, trazem uma percepção muito boa dos fenômenos físicos relacionados às proporções das construções. Essas oficinas permitem o uso de todos os sentidos na resolução de um problema construtivo.

São fruto de um processo associativo entre matéria, forma e concepção da forma arquitetônica, e se acompanhadas por boas referências, permitem aos alunos estabelecer relações imediatas com a obra arquitetônica executada (POMPÉIA, 2017). Nestas experiências práticas, de "fazer reflexivo", podem ser vivenciados aspectos como Ordem, Repetição, Ritmo e Harmonia, relacionando-os às proporções nas formas da natureza e estimulando o entendimento do caminho das forças nas estruturas espaciais. A Figura 82 ilustra algumas das experiências didáticas relatadas pelo autor.

Figura 82 - Oficinas de estruturas modulares (2013) e maquetes de Sistemas Estruturais em Madeira (2015) do curso de AU da Universidade Anhembi Morumbi
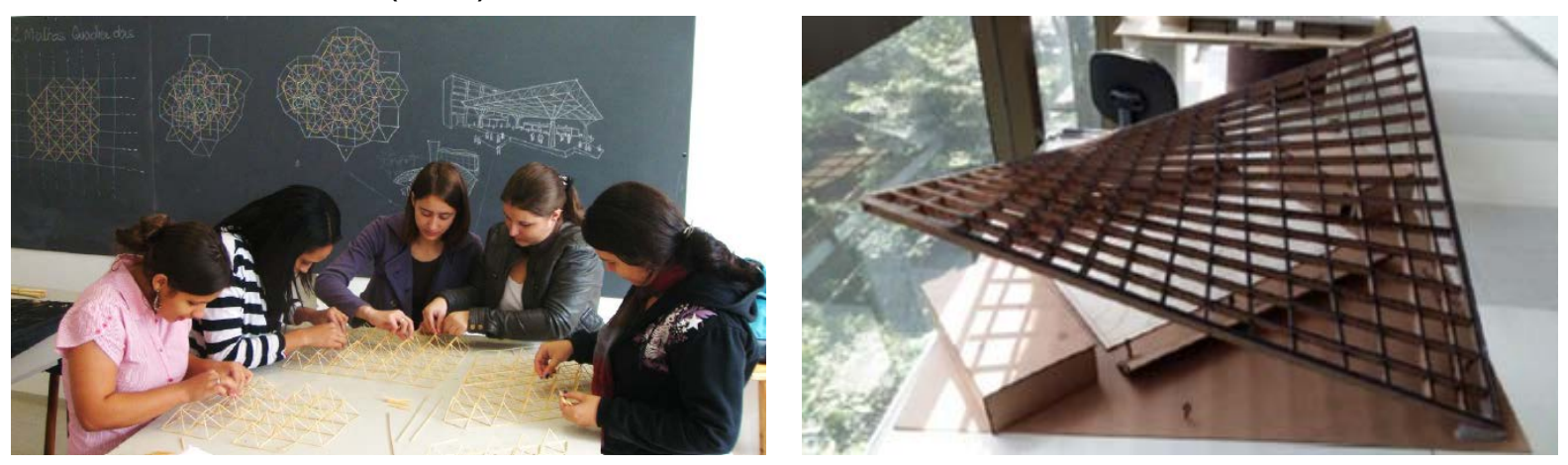

Fonte: Pompéia (2017).

Outras experiências didáticas que utilizaram a madeira em atividades práticas experimentais foram identificadas, como é o caso do "Workshop Internacional Estruturas Retráteis" conduzido pelos arquitetos e professores Hugo Alkmim de Matos da Pontifícia Universidade Católica de Minas Gerais e Natalia Torres Londoño da Universidade Politécnica de Catalunha, pesquisadores do grupo SMiA (Structural Morphology in Architecture). O workshop realizado em outubro de 2017, em Belo Horizonte, trabalhou a temática das estruturas retráteis por meio de um projeto 
concebido para um processo de montagem e desmontagem ágil, que pudesse ser realizado utilizando ferramentas de fácil acesso.

A construção do protótipo chamado de "Pavilhão Xuê" foi realizada pelos estudantes do curso de Arquitetura e Urbanismo em madeira Angelim e foi instalado em uma praça pública com o objetivo proporcionar um espaço de permanência que fomentasse o convívio e a troca de experiências entre as pessoas (Figura 83). O projeto foi contemplado com Menção Honrosa no Prêmio IBRAMEM AMATA de Arquitetura em Madeira, na categoria Estudantes, promovido pelo XVI EBRAMEM - Encontro Brasileiro em Madeiras e em Estruturas de Madeira, em março de 2018 em São Carlos-SP.

Figura 83 - "Pavilhão Xuê". Workshop Estruturas Retráteis, PUC Minas, Belo Horizonte, 2017

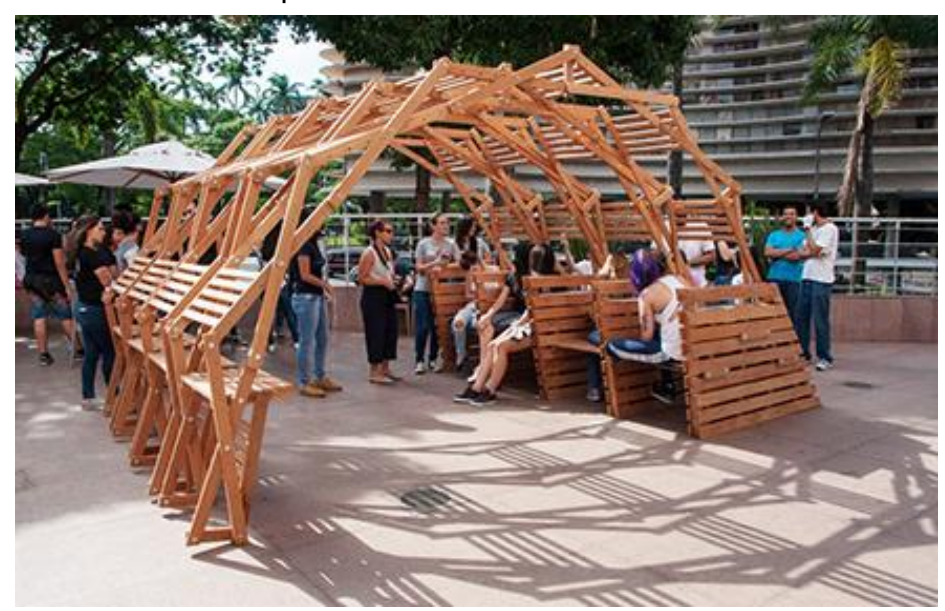

Fonte: Prêmio IBRAMEM AMATA de Arquitetura em Madeira $2018^{168}$.

As iniciativas relatadas apontam para um caminho de maior inserção de metodologias ativas de ensino-aprendizagem na formação do arquiteto. Embora pontuais e pouco significativas numericamente em relação ao cenário nacional, servem como exemplo e estímulo à prática da experimentação na graduação. Este é um caminho no qual não há receitas nem certezas. Pelo contrário, é um caminho que gera muitas dúvidas e que exige que docentes e estudantes se arrisquem. Mas, é justamente 
a dúvida que gera a busca por respostas. E o aprendizado significativo depende disso: do estímulo constante e do interesse por encontrar respostas.

É fato que o sistema educacional vigente pouco tem contribuído para romper com a ignorância tecnológica acerca da madeira, de seus derivados e de suas aplicações. Como vimos, tanto em nível técnico como superior, a madeira não tem tido nenhum protagonismo. Na formação em nível de pós-graduação, existe um único curso de mestrado e doutorado stricto sensu em Ciência e Tecnologia da Madeira na Universidade Federal de Lavras-MG. Nele, os estudantes envolvem-se em diferentes projetos tendo a madeira como tema central de pesquisa. O curso tem como objetivo treinar profissionais em nível de excelência, capacitando-os em atividades de docência, pesquisa e desenvolvimento no campo da Ciência e Tecnologia da Madeira ${ }^{169}$.

Outros programas de pós-graduação stricto sensu, vinculados às Ciências Florestais - área básica de Recursos Florestais e Engenharia Florestal ${ }^{170}$ - também desenvolvem pesquisas na área de concentração de Tecnologia de Produtos Florestais, como é o caso da Escola Superior de Agronomia Luiz de Queiroz - ESALQ-USP, Universidade de Brasília - UnB, Universidade Federal de Santa Maria - UFSM, Universidade Federal de Viçosa UFV, Universidade Federal do Espírito Santo - UFES, Universidade Federal do Paraná UFPR e Universidade Federal do Rio de Janeiro - UFRJ.

Vinculado à área da Engenharia Civil, o programa do LaMEM - Laboratório de Madeiras e de Estruturas de Madeira da Escola de Engenharia de São Carlos - EESC-USP, é uma referência na área sendo um dos mais importantes centros de ensino e pesquisa no Brasil (CALIL JR., 1998). Com atividades desenvolvidas tanto na graduação em Engenharia Civil como na pós-graduação nas áreas de Engenharia de Estruturas, Tecnologia do Ambiente Construído e Ciência e Engenharia dos Materiais, o LaMEM é responsável pela formação de inúmeros mestres e doutores que hoje se encontram, em

\footnotetext{
169 Informações consultadas na página web do programa de Pós-Graduação em Ciência e Tecnologia da Madeira da Universidade Federal de Lavras. Disponível em: http://prpg.ufla.br/_ppg/ct-madeira/. Acesso em: 20 jul. 2018.

170 Informações consultadas na Plataforma Sucupira, disponível em: https://sucupira.capes.gov.br/sucupira/public/consultas/coleta/programa/quantitativos/quantitativoles.jsf?are aAvaliacao=42\&areaConhecimento=50200003. Acesso em 22 jul. 2018.
} 
sua maioria, exercendo atividades de docência e de pesquisa junto a diversas universidades públicas e privadas do território brasileiro.

Outros centros de pesquisas e laboratórios de universidades da região Sudeste, também vinculados às áreas de Engenharia, desenvolvem investigações e ensaios sobre a madeira, como o Centro de Tecnologia de Recursos Florestais - CT FLORESTA do Instituto de Pesquisas Tecnológicas - IPT, localizado na Cidade Universitária da Universidade de São Paulo, e o Laboratório de Madeiras - LABMAD da Universidade Estadual de Campinas - UNICAMP.

No âmbito dos programas de pós-graduação em Arquitetura e Urbanismo, observase a produção de pesquisas e o oferecimento de disciplinas ligadas à área de concentração em Tecnologia, por interesse de docentes e pesquisadores da madeira, como é o caso da Faculdade de Arquitetura e Urbanismo da Universidade de Brasília UnB, professor Ivan Rezende do Valle; da Universidade Estadual de Londrina - UEL, professor Jorge Daniel Moura; da Universidade Estadual de Maringá - UEM, professor Ricardo Dias Silva; da Universidade Federal do Rio Grande do Norte - UFRN, professora Edna Moura Pinto; do Instituto de Arquitetura e Urbanismo da Universidade de São Paulo - USP, professora Akemi Ino; da Universidade Federal de Santa Catarina - UFSC, professoras Ângela do Valle e Poliana Dias de Moraes. Nestas duas últimas universidades, as investigações relacionam-se aos interesses dos grupos de pesquisa: o Grupo de Pesquisa em Habitação e Sustentabilidade - HABIS e o Grupo Interdisciplinar de Estudos da Madeira - GIEM, respectivamente, sendo que o GIEM vincula-se aos departamentos de Engenharia Civil e de Arquitetura e Urbanismo.

Diversas pesquisas acadêmicas e publicações foram produzidas no âmbito dos programas de pós-graduação brasileiros. Destacam-se algumas pesquisas aplicadas que resultaram na construção de protótipos e de unidades experimentais, como: o "Sistema Stella-UFSC", coordenado pela professora Carolina Palermo da Universidade Federal de Santa Catarina em parceria com a Empresa Batistella (2006); o “Projeto Educação em Madeira" da Universidade Estadual Paulista Júlio de Mesquita - UNESP de Itapeva, coordenado pelo então professor Guilherme Stamato (2006); o protótipo de habitação térrea com estrutura tipo plataforma desenvolvido por Rubens Campos na Universidade 
Estadual de Londrina (2006); o protótipo de habitação social em madeira de reflorestamento realizado por Christine Laroca na Universidade Federal do Paraná, mediante parceria com a Companhia de Habitação do Estado de Santa Catarina COHAB-SC (2007) (ESPÍNDOLA, 2017). Destacam-se ainda, as Unidades de Habitação Experimentais 001 e 002 como resultado do projeto de pesquisa "Habitação Social: Concepção Arquitetônica e Produção de Componentes em Madeira de Reflorestamento e em Terra Crua", construídas no ano de 1999 no campus da Universidade de São Paulo em São Carlos, atual sede do Grupo HABIS, sob a coordenação da professora Akemi Ino.

Também no campo da Arquitetura, o curso de pós-graduação lato sensu "Arquitetura em Madeira: Projeto e Aplicação" foi criado em 2017 pela Fundação Armando Álvares Penteado - FAAP, em São Paulo, sob a coordenação do arquiteto e professor Marcelo Aflalo ${ }^{171}$. Uma iniciativa pioneira que tem por objetivo impulsionar a formação continuada de arquitetos, engenheiros e técnicos especialistas no uso intensivo da madeira na construção civil, através de uma visão tecnológica contemporânea e industrializada.

De acordo com Aflalo ${ }^{172}$, existe uma demanda crescente por construções em madeira no mercado brasileiro, especialmente por parte de alguns setores específicos de projeto, mais do que por parte do cliente final. Há um interesse por parte dos projetistas, primeiro em função das questões ambientais em que se veem obrigados a considerar hipóteses como o uso de materiais mais amigáveis ao meio ambiente. No entanto, não existe uma fonte de referências, não existe formação e não existe um caminho claro através de pesquisa, de publicações, de cursos e de outras coisas que possam cumprir essas lacunas hoje. Acrescenta ainda que se quisermos consolidar uma demanda, um mercado da Arquitetura em Madeira, é importante nesse momento

\footnotetext{
${ }^{171}$ Marcelo Aflalo é arquiteto formado pela FAU-USP em 1978, designer com mestrado pela The School of the Art Institute of Chicago, sócio-fundador da Univers Design, professor da Fundação Armando Álvares Penteado - FAAP desde 1998. Criou a exposição itinerante "Arquitetura da Madeira para o Século XXI" com o objetivo de divulgar as conquistas e a evolução da arquitetura contemporânea da madeira no mundo. Atualmente é presidente do Núcleo de Referência em Tecnologia da Madeira, uma iniciativa sem fins lucrativos de representantes de diversos setores da cadeia construtiva da madeira.

172 Em entrevista realizada no dia 16 de janeiro de 2017, em sua residência e escritório em São Paulo-SP.
} 
formar gente que tenha habilidades para entender a cadeia, as motivações por trás disso e carregar valores, bandeiras.

O curso de especialização da FAAP tem foco na aplicação dos conhecimentos em curto prazo. No ANEXO D é apresentado o programa do curso "Arquitetura em Madeira: Projeto e Aplicação". Como parte deste curso, foi realizado em maio de 2018 o “Workshop em Estruturas Recíprocas em Madeira", ministrado pelo arquiteto e professor convidado Udo Thonninsen, do Instituto Federal de Tecnologia de Zurique ETH Zurich, no qual participei como aluna externa (Figura 84).

Figura 84 - Workshop Estruturas Recíprocas em Madeira. FAAP, São Paulo
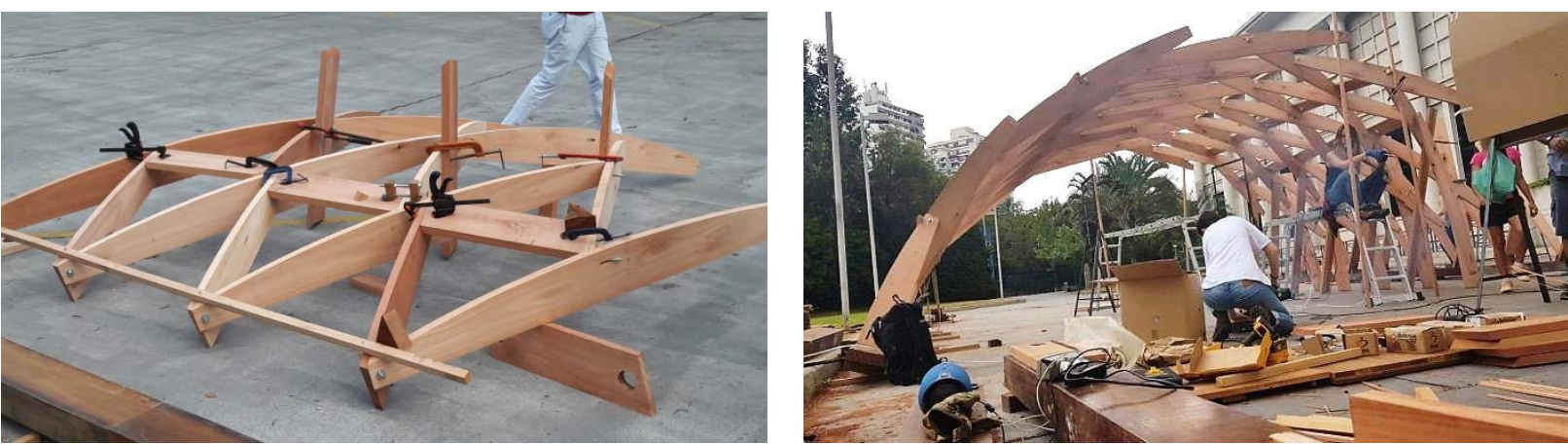

Fonte: arquivo pessoal.

Como vemos, pouco a pouco vão sendo disseminadas iniciativas por parte de professores, pesquisadores e profissionais junto a importantes centros de formação. Dentre elas ainda podemos citar o curso de curta duração "Estruturas em Wood Frame" ${ }^{173}$ promovido pelo Departamento de Engenharia Civil da Universidade Federal de São Carlos - UFSCar, ministrado pelo engenheiro Guilherme Stamato durante o segundo semestre de 2018, e o curso de extensão "Fundamentos de Arquitetura em Madeira" ${ }^{174}$ que será oferecido no segundo semestre de 2019, pela Universidade Presbiteriana Mackenzie, ministrado pelo engenheiro Alan Dias.

\footnotetext{
173 Informações disponíveis em: https://woodframe.faiufscar.com/\#/. Acesso em: 22 ago. 2018.

174 Informações disponíveis em: https://www.mackenzie.br/es/cursos-curta-duracao/universidade/arquitetura-edesign/fundamentos-de-arquitetura-em-madeira/. Acesso em: 15 jun. 2019.
} 
As experiências didáticas citadas reúnem exemplos de práticas que envolvem a experimentação em diferentes escalas, graus de interdisciplinaridade, recursos materiais e humanos. Os resultados alcançados ainda são tímidos se compararmos às referências internacionais analisadas. Porém, a percepção sobre o envolvimento dos estudantes nas atividades de construção e a satisfação que demonstram pela participação ativa no processo e no resultado, é o que de fato se evidencia como grande benefício das práticas.

A experimentação construtiva mostra-se como uma ferramenta fundamental de conexão e interação entre a formação acadêmica e a prática profissional. Será necessário investir esforços para implementar espaços de experimentação mais adequados em nossas escolas de arquitetura, e também de engenharia, bem como, garantir recursos materiais e humanos que permitam efetivar práticas cada vez mais estruturadas e apoiadas em objetivos de aprendizagem claros. Comprometidas, assim, com a formação de profissionais melhor preparados para atuar no setor da construção civil, de forma a romper paradigmas cristalizados e concretizar novos caminhos de desenvolvimento. 


\section{REFERÊNCIAS}

APRILANTI, M. D., TAVARES, S. T., INO, A. Avaliação de Projetos de Painéis em Madeira para Revestimento de Fachadas - Recomendações para o Detalhamento Construtivo. In: ENCONTRO BRASILEIRO EM MADEIRAS E EM ESTRUTURAS DE MADEIRA EBRAMEM, 16, 2018, São Carlos. Anais [...]. São Carlos: IBRAMEM, 2018.

BENDER, W. N. Aprendizagem baseada em projetos: educação diferenciada para o século XXI. Porto Alegre: Penso, 2015.

CALIL JR., C. A educação da Engenharia da madeira no Brasil: o programa do LaMEM. In: ENCONTRO BRASILEIRO EM MADEIRAS E EM ESTRUTURAS DE MADEIRA EBRAMEM, 6, 1998, Florianópolis. Anais [...]. Florianópolis: IBRAMEM, 1998.

ESPÍNDOLA, L. R. O wood frame na produção de habitação social no Brasil. 2017. Tese (Doutorado em Arquitetura e Urbanismo) - Instituto de Arquitetura e Urbanismo, Universidade de São Paulo, São Carlos, 2017.

POMPÉIA, R. A. Estruturas Invisíveis: Reflexão e Prática. In: ENCONTRO NACIONAL DE ENSINO DE ESTRUTURAS EM ESCOLAS DE ARQUITETURA, 3, 2017, Ouro Preto. Anais [...]. Ouro Preto: Editora da UFOP, 2017.

VALLE, I. M. R. Modelo Reduzido no Ensino de Construção em Madeira In: ENCONTRO BRASILEIRO EM MADEIRAS E EM ESTRUTURAS DE MADEIRA - EBRAMEM, 7, 2000, São Carlos. Anais [...]. São Carlos: IBRAMEM, 2000.

VALLE, I. M. R. do; Ino, A.; PERRIN, A. G. Small scale models, timber construction and the teaching of architecture: a brazilian experience. In: WORLD CONFERENCE ON TIMBER ENGENEERING WCTE, 2014, Quebec. Proceedings [...]. Quebec: Salenikovich, 2014. 



\section{REFLEXÕES SOBRE A PRÁTICA DOCENTE NO BRASIL}

A quinta e última parte desta Tese trata da elaboração do pensamento a partir da reflexão construída ao longo dos capítulos anteriores. Retoma cada uma das perguntas de pesquisa, elabora respostas e conclusões sobre os assuntos investigados ao longo dos quatro últimos anos. A trajetória percorrida entremeia-se ao da prática profissional e docente, as quais serviram de suporte, de campo de experimentação e de observação constante sobre o tema da pesquisa.

Estas reflexões se estendem na proposição de uma síntese propositiva que busca sistematizar conceitos apreendidos na investigação. Ainda que de forma esquemática, esta síntese pode servir de apoio para a elaboração de disciplinas e cursos relacionados ao projeto e construção em madeira ou para o planejamento de atividades práticas experimentais que abram caminho a uma experiência formativa mais integrada e comprometida com a realidade em que se insere, aportando uma inovação às práticas de ensino correntes.

Traz ainda as considerações finais e perspectivas de continuidade da investigação. Espera-se que esta Tese possa aportar contribuições ao oferecer exemplos de abordagens pedagógicas integradoras que fortalecem a formação do arquiteto e que venham a impulsionar a formação de profissionais mais aptos para o emprego extensivo da madeira na construção civil brasileira. 


\subsection{Conclusões sobre a investigação}

O caminho de investigação percorrido ao longo dos 48 meses de pós-graduação foi permeado pelas inquietações desta autora enquanto pesquisadora, docente e profissional. Na teoria, não deveria haver essa separação entre os termos "docente" e “profissional", nem mesmo "docente" e "pesquisadora". Mas, como disse Bondia (2012), a dicotomia presente na nossa formação estende-se inclusive à apresentação de nossa experiência entre "acadêmica" e "profissional". É fato! Na prática, qual o professor que nunca ouviu a pergunta: “Professor, você só dá aula, não trabalha”?

E essa contradição vai mais longe. Ao mesmo tempo em que o ensino teórico é superestimado, a docência é desvalorizada. Mais do que nunca - em função do atual obscurantismo pelo qual a Educação e a Ciência passam em nosso país - precisamos defender a relevância do ensino técnico e universitário, da produção de conhecimentos empíricos e científicos, da formação de profissionais e cidadãos progressistas e da formação de docentes comprometidos com a produção do saber crítico.

Neste capítulo conclusivo da Tese procuro trazer de forma objetiva, mas também pessoal, um posicionamento crítico frente às questões de pesquisa. Retomo a seguir, as cinco questões específicas formuladas ao longo da investigação e discutidas no decorrer dos capítulos, revisando assim, os resultados obtidos, elaborando respostas e conduzindo às conclusões. Da mesma forma, outras questões complementares que foram surgindo neste caminho são retomadas e respondidas, não em ordem sequencial, mas em função de uma coerência temática.

\section{Qual a inserção das tecnologias construtivas em madeira nas estruturas curriculares atuais dos cursos de Arquitetura e Urbanismo no Brasil e como vêm sendo abordadas?}

Mediante ao levantamento de dados (APÊNDICE), comprova-se o que já era uma hipótese: as tecnologias construtivas em madeira têm uma inserção muito pequena e limitada nas estruturas curriculares dos cursos de Arquitetura e Urbanismo brasileiros. 
Em termos quantitativos, verificou-se que é bastante reduzida a carga horária destinada à madeira e aos sistemas construtivos em madeira dentro das disciplinas examinadas da área tecnológica - especificamente aquelas que têm uma estreita conexão com as questões conceptivas da materialidade tais como: Materiais de Construção, Tecnologia da Construção, Sistemas Estruturais e Sistemas Construtivos.

Aproximadamente $22 \%$ da carga horária média nacional das disciplinas de Tecnologia analisadas para 56 cursos de AU (Capítulo 2.4 - Gráficos 9 e 10), em torno de 93 horas-aula - o que equivale a apenas 2,2\% da carga horária total destes cursos - é dedicada a algum conteúdo relacionado à madeira. Essa média em horas-aula é similar para todas as regiões do Brasil, mas em percentuais relativos às horas da área de Tecnologia as regiões Nordeste $(26,8 \%)$ e Norte $(26,1 \%)$, seguidas da Centro-Oeste $(24,5 \%)$ apresentam médias superiores que a nacional.

Se comparada aos sistemas construtivos em concreto armado - evidentemente enfatizado nos conteúdos curriculares analisados - a carga horária dedicada à madeira, normalmente compartilhada com o aço, é em torno de quatro vezes menor. Também é bastante reduzida a carga horária destinada a esta área específica da Tecnologia em relação à carga horária total dos cursos, variando entre 5\% e 16\% para 72 cursos analisados (Capítulo 2.3 - Gráficos 5 e 6). Em média, esses percentuais variam de 9\% a 11\% com maior média verificada na região Sul $(11,13 \%)$, seguida da Centro-Oeste $(10,57 \%)$, ambas acima da média nacional de 10,3\%, aproximadamente a mesma da região Sudeste (10,33\%).

A abordagem que tem prevalecido nestas disciplinas onde são apresentadas as tecnologias construtivas, independente do material a que se referem, é predominantemente teórica. Há uma grande variação entre os dados observados, nos quais o percentual de horas práticas em relação à carga horária total das disciplinas varia de $6 \%$ a $45 \%$ \% para 26 cursos analisados (Capítulo 2.3 - Gráficos 7 e 8). Embora a análise destes dados tenha se restringido às fontes documentais, não sendo observados de forma presencial, averiguou-se que as horas destinadas à prática dentro dos projetos pedagógicos dos cursos podem ser consideradas até relevantes chegando, em alguns casos, a representar $50 \%$ da carga horária. 
A questão, porém, é que esta indicação pode ser meramente prescritiva, onde essas horas práticas são alocadas para cumprir com as normativas e regulamentações sugeridas por lei não sendo, muitas vezes, de fato implementadas.

Conclui-se que é necessário dar à madeira um maior protagonismo dentro da grade curricular, enfrentando a hegemonia do concreto armado e criando novas possibilidades para o estudo e a aplicação do material. Da mesma forma, é indispensável estabelecer abordagens mais práticas no ensino das tecnologias construtivas no intuito de contribuir para uma formação profissional mais conectada à materialidade da Arquitetura.

Embora a pesquisa documental tenha se restringido à área de Tecnologia, pelas razões já apresentadas, a temática das construções em madeira não deve limitar-se a essa área apenas, mas deve ser abordada nas demais áreas de Projeto, Teoria e História e também de Representação e Linguagem possibilitando uma visão histórica e holística sobre a produção da Arquitetura vernacular e contemporânea em madeira.

E, com essa constatação surgem novas perguntas:

Como enfrentar, então, a hegemonia da alvenaria e do concreto armado e propor a madeira como alternativa construtiva eficiente?

Quais as condições necessárias para o desenvolvimento de uma arquitetura contemporânea em madeira de identidade nacional?

E, ainda, quais os agentes devem ser mobilizados para que a madeira seja uma opção competitiva e economicamente viável para a construção civil no Brasil?

A hegemonia do concreto armado é uma questão histórica que envolve grandes interesses econômicos e políticos na disputa pelo controle da cadeia produtiva do espaço construído. É considerado conveniente às condições brasileiras ao ser relativamente pouco exigente quanto à qualificação da mão de obra, o que faz aumentar o descompasso entre a prática da construção civil e o desenvolvimento tecnológico do setor. Toda e qualquer modificação nas técnicas construtivas predominantes, e na linguagem arquitetônica associada a estas técnicas, consequentemente reflete na organização do trabalho nos canteiros de obra. 
Obviamente, enfrentar a predominância do concreto armado na construção envolve uma diversidade de interesses, setores e agentes que impõe um desafio muito mais amplo ao campo da pesquisa e do ensino de arquitetura e engenharia. A proposição da madeira como uma alternativa construtiva eficiente, ambientalmente amigável e economicamente viável parece ser decisiva para uma mudança de paradigmas na construção civil brasileira. Somente a articulação entre academia, indústria e governo, pode alavancar novos processos de formação e de produção e a geração de políticas públicas engajadas com este propósito.

Uma série de gargalos deverá ser confrontada para estabelecer as condições necessárias à promoção de uma arquitetura de identidade nacional em madeira tais como: a exploração adequada das florestas tropicais e de florestas plantadas, através de práticas sustentáveis, voltadas à construção civil; a falta de produtos industrializados e de componentes que atendam a demanda de forma satisfatória; a falta de profissionais de projeto, de cursos de formação e de pesquisa na área; as barreiras culturais que dificultam a geração de demanda por parte do público consumidor; a falta de normativas técnicas e regulamentações específicas de controle de qualidade.

Entretanto, entende-se que há condições suficientes, não só materiais, como a disponibilidade de matéria prima e o potencial de desenvolvimento de tecnologias para o beneficiamento e industrialização da madeira, mas também condições humanas para a capacitação de mão de obra: técnicos, arquitetos, engenheiros, mestres, doutores e professores. Sem dúvidas, a formação de profissionais é um dos grandes gargalos a ser enfrentado, porém, mesmo com as restrições materiais hoje existentes, os exemplos de obras construídas observados nos dão sinais claros de que é possível estabelecer uma arquitetura brasileira em madeira, contemporânea, expressiva e de qualidade.

2. Quais os conteúdos programáticos sobre tecnologias construtivas em madeira têm sido enfocados nos cursos de AU brasileiros e quais as lacunas existentes? A diversidade de sistemas construtivos e suas aplicações em projetos estão sendo contempladas de alguma forma? 
Com base nos conteúdos programáticos das disciplinas examinadas - quinze disciplinas de onze instituições públicas e uma instituição privada (ANEXO A) - foi possível constatar que estes versam principalmente sobre as características físicas e mecânicas da madeira, tensões admissíveis, ações e esforços em estruturas, ligações de peças estruturais e noções de pré-dimensionamento, não contemplando a pluralidade de sistemas construtivos existentes, suas aplicações e interfaces pertinentes ao projeto arquitetônico. Quando se menciona a proposição de projetos, é mais comum a menção a projetos de coberturas.

A maior parte destas disciplinas versa sobre os Sistemas Estruturais e costuma tratar das Estruturas de Aço e de Madeira conjuntamente. Com isso, é dada maior ênfase ao comportamento estrutural e ao pré-dimensionamento de pilares e vigas. Mesmo nas disciplinas que versam exclusivamente sobre a madeira, e apresentam conteúdos mais abrangentes, as ações e esforços, e o dimensionamento são os assuntos principais. O grande problema quanto a essa ênfase é a sua abordagem verificativa, feita através de exercícios de cálculo, em detrimento de uma interpretação mais aprofundada das questões relativas à concepção das estruturas - assunto fundamental à formação dos arquitetos.

Outra questão que corrobora para essa situação é a própria formação dos professores que ministram aulas na área tecnológica dos cursos de Arquitetura, em sua maioria engenheiros. A aproximação entre a Arquitetura e a Engenharia é muito profícua e deve ser incentivada desde a graduação, porém, as abordagens pedagógicas e os conteúdos programáticos das disciplinas formativas devem ser diferenciados em cada um dos cursos. O ideal seria que essa interação se desse por meio de projetos interdisciplinares e atividades complementares que envolvessem os dois cursos.

Foram encontrados poucos exemplos de disciplinas que abordam as possibilidades de aplicação da madeira em projetos e a multiplicidade de sistemas construtivos existentes. É rara a alusão a sistemas industrializados e pré-fabricados - um dos importantes diferenciais para o projeto de construções em madeira - identificando-se, assim, como uma lacuna temática que deve ser explorada em futuras proposições. 


\section{Mas, o que é necessário ensinar ao arquiteto, para capacitá-lo para o projeto em madeira?}

Pletz (2002) sugere uma diversidade de assuntos importantes à compreensão da madeira como material construtivo, abordados no Capítulo 2.4, mas é essencial enfatizar as questões relativas às implicações das características e propriedades da madeira na concepção de projetos e de detalhes construtivos, e também o nível de interferência dos elementos construtivos em madeira com outros elementos e materiais como paredes, estrutura e instalações em geral.

Em conclusão, entende-se que falta uma maior aproximação aos sistemas construtivos em madeira existentes abordando as possibilidades de industrialização e de pré-fabricação com vistas à aplicabilidade em projetos. Porém, mais relevante que os conteúdos programáticos trabalhados nos cursos de arquitetura, são as abordagens metodológicas propostas que podem resultar em um diferencial significativo de aprendizagem. A diversidade das tecnologias construtivas existentes, assim como as oportunidades de inovação, só pode ser discutida e apreendida de forma consequente quando inserida em uma abordagem interdisciplinar e prática, o que necessariamente envolve sua aplicação no desenvolvimento de projetos.

\section{Quais metodologias de ensino-aprendizagem vêm sendo aplicadas na área tecnológica dos cursos de AU no Brasil? Qual a relevância das atividades práticas de experimentação construtiva neste contexto?}

Observa-se ao longo do levantamento documental a baixa carga horária destinada a atividades práticas nas disciplinas da área tecnológica dos cursos de Arquitetura e Urbanismo brasileiros, apontando para uma abordagem predominantemente teórica e verificativa. Embora alguns dos projetos pedagógicos investigados assumam como princípio uma maior integração entre teoria e prática, em diversas áreas do currículo, não foram identificadas um número relevante de experiências didáticas no âmbito da graduação na temática específica desta investigação. 
As atividades práticas na área de Tecnologia dos cursos de AU normalmente se restringem à verificação do comportamento dos materiais em ensaios laboratoriais, quando estes existem. Não há muitas iniciativas, ou não há muita visibilidade, de práticas experimentais de construção em escala real, seja em canteiros experimentais na produção de protótipos em ambiente acadêmico, ou em práticas de extensão que resultem na intervenção junto a comunidades. Isso me leva a concluir que não há relevância destas práticas nos nossos cursos de arquitetura.

Entretanto, algumas das iniciativas observadas ganham interesse como exemplos da aplicação de metodologias ativas no ensino de arquitetura como é o caso da Aprendizagem Baseada em Projetos utilizada na Universidade Federal do Paraná e na Universidade de São Paulo; do uso de maquetes e modelos reduzidos na Universidade de Brasília, Escola da Cidade e Universidade Anhembi Morumbi; da abordagem DesignBuild na construção de protótipos na Pontifícia Universidade Católica de Minas Gerais. Outras experiências no âmbito da pós-graduação resultaram na construção de protótipos e unidades experimentais em escala real na Universidade Federal de Santa Catarina, Universidade Estadual Paulista Júlio de Mesquita, Universidade Estadual de Londrina, Universidade Federal do Paraná, Universidade de São Paulo e na Fundação Armando Álvares Penteado.

As atividades práticas de experimentação construtiva no contexto dos cursos de graduação mostram-se extremamente relevantes ao criar desafios que geram nos alunos um grande estímulo pessoal na busca da resolução de problemas. O uso de maquetes permite um entendimento mais aprofundado do objeto arquitetônico através do "fazer reflexivo" num processo que associa matéria, forma e concepção estrutural. A construção de protótipos gera uma experiência vivida corporalmente que requer, tanto dos estudantes como dos docentes, sair da zona de conforto incentivando atitudes proativas e a formação de competências.

Identifica-se um enorme potencial de associação entre o ensino de graduação e de pós-graduação por meio da integração dos estudantes em projetos de pesquisa aplicados - especialmente se inseridos em uma problemática da realidade social podendo configurar-se dessa forma como projetos de extensão universitária. Essa é a 
maneira pela qual a abordagem Design-Build tem ganhado forças ao redor do mundo e formado além de arquitetos, cidadãos que compreendem o papel da Arquitetura na sociedade e no ambiente construído.

Conclui-se que é premente incentivar e estabelecer práticas construtivas nos cursos de AU brasileiros. Apesar do reduzido número de exemplos identificados, e dos limitados resultados alcançados, entende-se que as metodologias de ensinoaprendizagem de "aprender-fazendo" vêm sendo paulatinamente incorporadas, impulsionadas pelo interesse e iniciativa dos docentes. Essas práticas são extremamente pertinentes ao atual contexto de distanciamento do arquiteto de suas atribuições construtivas inerentes e podem constitui-se como uma ponte entre a formação acadêmica e a prática profissional.

Quanto à infraestrutura e outros aspectos, nos perguntamos:

Mas temos espaço para a experimentação em nossas escolas? Qual a nossa realidade em relação a estas práticas tão necessárias?

Com espaço me refiro tanto ao espaço físico como temporal, e a todo espaço político e administrativo que precisa ser aberto para que estas práticas possam se efetivar. Como vimos, Laverde (2017) nos mostrou um quadro bastante desanimador em relação às escolas públicas de arquitetura por ela investigadas, as quais representam a realidade de um terço das escolas públicas brasileiras. Detectou-se a falta de espaços adequados, de carga horária compatível e de recursos contínuos.

De minha experiência pessoal, tenho assistido ao total descaso por parte da instituição onde leciono frente à manutenção do canteiro experimental de nossa escola consolidado ao longo de duas décadas, dotado de vasto espaço físico, equipado com máquinas e ferramentas, amparado por pessoal técnico de laboratório com capacidade de trabalho em vários materiais. Provavelmente não há interesse econômico institucional, já que os interesses pedagógicos não estão sequer sendo levados em consideração na atual conjuntura de crise do mercado educacional. E o que dizer do interesse político? 
Canizaro (2012) alegou que provavelmente a principal dificuldade enfrentada pelos programas Design-Build diz respeito à sua aceitação dentro da própria instituição onde o conservadorismo é certamente um dos desafios explícitos que acarretam em impedimentos administrativos e dificuldades, inclusive quando há apoio da comunidade ou, até mesmo, financiamento disponível.

Sim, temos espaço físico e interesse por parte de docentes na criação de laboratórios de construção, canteiros experimentais e no estabelecimento de práticas engajadas à realidade social. Muitos são os profissionais envolvidos com pesquisas e iniciativas de extensão universitária neste sentido, porém, não temos apoio institucional e político para promover as necessárias mudanças em nossas escolas.

Será necessário enfrentar a muitos desafios, administrativos, financeiros e pessoais, em todos os âmbitos, mas principalmente ter a ciência de que as dificuldades deverão ser confrontadas com profissionalismo, através da comprovação de resultados e não apenas com boas intenções. A experimentação não deve ser encarada apenas como uma prática empírica, com fim em si mesma, mas deve ser defendida como forma de produção de conhecimento.

\section{Como as experiências de ensino internacionais podem servir de referência para formular parâmetros didático-metodológicos aplicáveis à formação do arquiteto no Brasil?}

Foram identificadas diversas experiências didáticas internacionais envolvendo a experimentação com a madeira que servem de subsídio à análise sobre os aspectos envolvidos nas práticas de construção experimental: desde a formatação dos cursos em termos de estrutura, cronograma, interdisciplinaridade, conteúdos e metodologias, até a necessidade de recursos materiais e humanos, de infraestrutura e de gestões políticoadministrativas e sociais de dimensão prática e holística.

Os estúdios de projetos interdisciplinares entre alunos de Arquitetura e de Engenharia da University of Bath, no Reino Unido, e da California State Polytechnic University Pomona, nos Estados Unidos, trazem à tona interessantes exemplos que 
estimulam à criatividade e a colaboração entre as duas profissões. Ainda que o formato destes estúdios não envolva a experimentação construtiva, considerada ideal pelos professores, a experiência transdisciplinar é muito positiva e viável, e poderia ser explorada também em nossas universidades.

Exemplos como os da University of Auckland, na Nova Zelândia, e da Pontificia Universidad Católica de Chile, expõe possibilidades de inserção da experimentação construtiva no currículo dos cursos de arquitetura em diferentes momentos. Em Auckland, a disciplina Timber Technology do $4^{\circ}$ ano, equivalente ao primeiro ano do mestrado profissional, envolve também alunos do $5^{\circ}$ ano, no desenvolvimento de projetos de conclusão de curso na temática de abrigos para escolas e pequenos equipamentos urbanos que serão construídos e instalados pelos alunos de ambos os anos. Na PUC Chile, em Santiago, a construção de protótipos experimentais ocorre no primeiro ano do curso, na disciplina Introdución a la Construción, onde uma variedade de tipos de estrutura são produzidas com base em componentes pré-fabricados de baixo custo, e utilizando baixa tecnologia, como uma oportunidade de exploração da forma e da matéria, bem como de soluções técnicas inovadoras.

Quanto às três referências analisadas em maior profundidade no Capítulo 4.2, se assemelham por sua essência de experimentação prática construtiva em escala real, mas diferenciam-se em suas abordagens pedagógicas bastante peculiares ao contexto sociocultural no qual se inserem.

O Rural Studio traz um exemplo consolidado de formação de arquitetos comprometidos com os valores da cidadania e da sustentabilidade por meio da atuação junto a uma comunidade humilde da zona rural do Alabama, nos Estados Unidos. Essa atuação se consolida através de três programas distintos envolvendo o terceiro e o quinto ano do curso de graduação e recentemente também de pós-graduação. A madeira é amplamente explorada por seu potencial de trabalhabilidade em oficinas onde os estudantes aprendem a trabalhar com o material de maneira artesanal. O lowtech é entendido como a forma mais adequada de viabilizar os projetos dentro daquele contexto. Como resultado, têm-se obras que utilizam materiais alternativos, às vezes 
reaproveitados, mas que apresentam resolução formal e técnica muito interessantes, alcançando grande repercussão internacional e benéficos impactos locais.

O Wood Program é uma referência importante como curso de especialização em madeira e arquitetura em madeira que atrai arquitetos e profissionais de áreas afins do mundo todo para a Finlândia. Ao ser o único exemplo estudado de formação específica, aporta contribuições principalmente em relação à estrutura curricular e aos conteúdos programáticos abrangendo toda a cadeia produtiva que envolve as construções em madeira, desde a floresta até a fabricação de componentes e sua aplicação em arquitetura. Em oposição ao Rural Studio, os recursos high-tech são aqui um instrumento amplamente explorado em laboratórios bem equipados que servem de apoio ao desenvolvimento de modelos e protótipos em várias escalas, no estudo e ensaio de conexões e na produção e instalação das construções 1:1. Os resultados se diferenciam por obras tecnicamente bem resolvidas e inovadoras em soluções formais, alcançadas pelo uso de máquinas e de tecnologias construtivas avançadas.

A Escuela de Valparaíso no Chile traz um aporte especial à Tese pelo fato de ter sido uma escola observada e vivenciada presencialmente. Sua abordagem poética peculiar sobre o "ser e o fazer americano" relacionam as experiências construtivas com a busca de uma identidade local. Na Ciudad Abierta atividades didáticas vinculam vida, trabalho e estudo, assim como ocorre nas Travesías pelo Continente Americano, onde a vivência de viajar, observar, habitar e construir o território, e de oferecer uma obra efêmera como presente à comunidade visitada, aporta um valioso significado ao processo pedagógico. As construções experimentais não são um fim em si, mas sim, parte de um processo de construção coletiva. Por isso, a formação técnica não é enfatizada na experiência, a obra é constituída "sobre la marcha" em conjunto à resolução do projeto. É a vivência mais aguçada do "aprender-fazendo" onde se trabalha o conhecimento tátil do material. Os resultados são projetos e obras formalmente sensíveis, únicas e radicais que emergem da observação do território e da interpretação de sua geometria intangível.

Por fim, cada uma das experiências de ensino-aprendizagem estudadas traz aspectos, mais gerais ou mais específicos, que quando contrastados à realidade brasileira podem ser assimilados aportando uma contribuição própria, servindo de 
suporte para a proposição de parâmetros que se adequem a nosso contexto sociocultural e territorial. O contexto low-tech, ou seja, de baixa tecnologia, ainda é a realidade da maioria das escolas brasileiras. A falta de equipamentos e de espaços adequados, bem como as questões sócio territoriais nas quais as escolas estão inseridas, nos aproxima mais das experiências chilena e do interior norte-americano. Esse fato, porém, não deve ser entendido como uma limitação. Os casos relatados abrem horizonte a imensas possibilidades, visto os resultados alcançados.

5. Quais os aspectos mais importantes a serem observados para a implementação da experimentação construtiva como instrumento de abordagens pedagógicas mais integradoras?

As práticas construtivas experimentais oferecem a oportunidade de expandir e integrar habilidades intelectuais, técnicas e práticas e mais do que apenas propiciar o contato com os materiais, enfatizam processos de tomada de decisão, projeto e construção. A partir da revisão bibliográfica e da análise das referências, abordadas especialmente na Parte 4 desta Tese, ressaltam-se alguns aspectos considerados mais relevantes, a saber:

- A inserção da prática numa dimensão real incorpora o processo de pensar e agir: clientes reais, orçamentos efetivos, trabalho factível. A realidade territorial, cultural, social e econômica favorece o envolvimento dos estudantes e a apreensão das condicionantes de projeto;

- A articulação de programas cooperativos interdisciplinares, entre áreas do conhecimento, profissões e pessoal de perfil diversificado, e intersetoriais envolvendo academia, indústria e estado, se faz necessária para uma agenda de transformação e inovação;

- A articulação entre o ensino de graduação e de pós-graduação, entre projetos de pesquisa e de extensão, deve ser incentivada e fortalecida, ao mesmo tempo em que também é necessário fazer valer os padrões de competência acadêmica e profissional definidos por lei. 
Algumas das recomendações sugeridas por Carpenter (1997) e Canizaro (2012), apresentadas no Capítulo 4.1, tratam de aspectos diretamente relacionados à implementação de projetos Design-Build. Com base nessas recomendações, a seguir, pontuam-se questões que devem ser observadas com o propósito de verificar impedimentos, antecipar dificuldades e tomadas de decisões:

- Quanto à dimensão real: uma possibilidade é trabalhar em parceria com entidades públicas e organizações não governamentais e sem fins lucrativos que atuam em serviço a comunidades carentes, de forma a atender demandas já detectadas, porém, demandas específicas de pequenas comunidades locais podem ser exploradas; outra possibilidade é atuar junto à própria instituição de ensino em projetos que atendam às demandas de infraestrutura do campus universitário, por exemplo;

- Quanto ao escopo de projeto: a construção de pavilhões, estruturas recreativas de parques e outras estruturas externas como equipamentos em espaços públicos, favorecem a exploração de questões estruturais, materiais e tectônicas, bem como a visibilidade dos projetos construídos e, por vezes, a redução de prazos de execução, além de menores restrições normativas; os pavilhões oferecem flexibilidade de uso podendo atender a diversas exigências e funcionalidades, como a possibilidade de serem desmontáveis;

- Quanto ao financiamento: a captação de recursos pode ser incluída como parte do processo educacional uma vez que os recursos provenientes da instituição, quando existentes, normalmente são insuficientes; podem ser complementados por meio de parcerias com agências de financiamento, indústrias e fornecedores de materiais, bem como por contribuições dos próprios participantes; como o orçamento necessário à execução do projeto depende de sua definição, sugere-se partir de uma estimativa de custo total que varia entre dois e três mil dólares;

- Quanto ao cronograma: grande parte dos programas adequa o período das práticas construtivas dentro de um semestre letivo, normalmente 15 semanas, podendo chegar a dois semestres, e nesse caso, o primeiro pode ser usado 
para pesquisa e projeto e o segundo para a construção, sempre em função da complexidade dos projetos; alguns programas oferecem cursos curtos de poucas semanas, workshops concentrados, mas nesse caso é importante adequar o escopo de projeto ao tempo de execução previsto;

- Quanto à inserção no currículo: geralmente as práticas de projeto e construção são oferecidas no quarto ano dos cursos, quando os estudantes já têm maiores conhecimentos gerais e maturidade para o trabalho em grupo; em alguns casos, ocorrem logo no primeiro ano de graduação; a possibilidade de inserção das práticas em mais de um momento do curso é extremamente positiva, pois num primeiro momento, desperta o interesse dos alunos para o aprendizado através do fazer e num segundo momento, para um maior aprofundamento das questões técnicas envolvidas na construção;

- Quanto à composição das equipes: grupos muito grandes podem ser contraproducentes; recomenda-se a definição de grupos de estudantes onde cada um deve responsabilizar-se por segmentos como projeto, documentação da construção, aquisição de materiais, arrecadação de fundos, relações públicas, segurança e programação; a dinâmica de trabalho e a comunicação entre os membros do grupo, e entre as equipes, devem ser planejadas cuidadosamente e verificadas periodicamente;

- Quanto à materialidade: diversos materiais podem ser associados nas experiências construtivas como forma de articulação e síntese do aprendizado de conteúdos relacionados à área de tecnologia e de projeto; entendidos como ferramentas de projeto, o contato direto com a matéria proporciona um conhecimento tátil sobre seu comportamento, dimensionamento, formas de processamento, utilização e conexão; o manuseio e a trabalhabilidade são aspectos importantes a serem considerados, e por isso, a madeira têm sido amplamente utilizada e recomendada;

- Quanto às instalações e ferramentas: ter um local em condições apropriadas e equipado para trabalhar é fundamental ao sucesso de qualquer iniciativa; idealmente, o financiamento dos recursos para aquisição e/ou locação das ferramentas e equipamentos em quantidade suficiente para o número de 
participantes deve fazer parte do orçamento dos cursos; a relação destes itens deve ser especificada com antecedência para que todo o material esteja disponível ao início da prática.

Respondidas as questões específicas, ainda restam algumas perguntas:

De que forma, então, poderia a formação do arquiteto desvincular-se do físico e do material? Como a Educação à Distância poderia dar conta da complexidade que envolve a materialidade? Como o ensino não presencial poderia suprir a necessidade da experiência prática com materiais e ferramentas que permitem o conhecimento do processo da construção?

De forma nenhuma. Não restam dúvidas de que é impossível colher bons resultados do ensino à distância, não só em Arquitetura, mas também em outras áreas que envolvem um aprendizado prático experiencial, como por exemplo, Medicina, Odontologia ou Engenharia. O aprendizado é uma construção conjunta de estudantes e professores, um processo que depende da troca de saberes em sala de aula, em laboratórios, em espaços de discussão coletivos, em espaços públicos, e também em ateliês de projeto, espaço único na formação do arquiteto.

Ao longo de todas as experiências analisadas destacam-se o protagonismo dos professores no ensino da profissão. Especialmente as iniciativas que envolvem a experimentação construtiva inserida em comunidades demandam grande motivação e determinação dos docentes para a realização dos projetos. Eles são agentes articuladores de todo o processo pedagógico. Walter Gropius (2004) enfatizou a importância da formação do professor e de sua experiência profissional tanto no projeto como na construção, ressaltando que apenas professores com vasta experiência estão capacitados a estimular o aluno constantemente e conduzi-lo à iniciativa própria. É nesse intercâmbio de experiências e conhecimentos que ocorre o aprendizado. Neste espaço de construção coletiva do saber.

Corroborando com essa premissa e em defesa da qualidade de ensino no Brasil o Conselho de Arquitetura e Urbanismo - CAU tem se posicionado contrário à abertura de cursos de Arquitetura na modalidade de Educação à Distância, aprovados pelo 
Ministério de Educação - MEC, e também ao reconhecimento e registro de profissionais egressos dos cursos EaD, defendendo que a responsabilidade pelo ensino da profissão deve ser compartilhada entre MEC e CAU e não atribuída de forma unilateral como vem ocorrendo.

Finalmente, retoma-se a questão principal da pesquisa:

Como a experimentação construtiva em madeira nas escolas de arquitetura pode contribuir para ampliar o conhecimento sobre o material e fomentar o seu uso na construção civil brasileira?

A madeira é um material primordial para a construção de projetos experimentais. As vantagens da sua utilização com objetivos educacionais são várias: as características de fácil manuseabilidade e leveza; o fato de não requerer maquinário nem ferramentas complexas para sua modelagem facilitando processos de aprendizagem e obtenção de habilidades pelos alunos; o custo relativamente barato, no caso de espécies menos nobres. Na produção de modelos em escala reduzida permite manter a fidelidade à concepção estrutural dos projetos e uma relação direta com o comportamento mecânico das estruturas. Na construção de protótipos em escala real, viabiliza obras que muitas vezes não são possíveis com outros materiais.

Todas essas características acabam por contribuir para o conhecimento empírico do material favorecido por meio do trabalho manual e do contato direto, tátil, que aguça a percepção sobre suas qualidades. A experimentação prática deve ser concomitante à apresentação de fundamentos teóricos básicos acerca das propriedades físicas, anatômicas e mecânicas da madeira e das implicações destas na concepção do projeto estrutural e de arquitetura, assim como nos detalhes construtivos, com o intuito de garantir um aprendizado mais aprofundado e holístico.

Como integrar então, os conceitos teóricos e científicos necessários à formação intelectual e acadêmica e aplicá-los à prática profissional? Como relacionar tais conceitos à prática projetual e construtiva?

Como já exposto, as práticas construtivas constituem-se como uma ponte entre a formação acadêmica e a prática profissional oferecendo a oportunidade de expandir e 
de integrar habilidades intelectuais e técnicas enfatizando processos de tomada de decisão. As etapas de análise, síntese e avaliação, associadas ao processo de projeto, são sempre seguidas por momentos de tomada de decisão onde as definições levam a novas etapas de projeto. Quando à estas etapas são associadas atividades de produção e teste das ideias de projeto, através de modelos, protótipos e/ou construções experimentais, se estabelecem nexos entre o que foi idealizado e a solução executada, tornando possível uma avaliação verossímil sobre o resultado alcançado.

Entretanto, a experimentação não deve ser um fim em si, e sim um meio. O conhecimento empírico é fundamental, mas se não for sintetizado e apreendido de tal forma que possa ser sistematizado, interpretado e reproduzido, esse conhecimento limita-se à experiência pessoal não sendo incorporado a um conhecimento mais amplo e coletivo, limitando seu potencial de expansão e produção de inovação.

Da experiência vivenciada na Escola de Valparaíso, onde a experimentação construtiva é parte de um processo de construção coletiva que culmina muitas vezes numa obra efêmera, o resultado final parece não ser tão importante quanto o próprio processo. Talvez porque estas intervenções não têm o compromisso de perdurar no tempo. Digo isso me referindo ao resultado técnico-construtivo e não ao resultado formal e estético. Observa-se, porém, uma demanda crescente por obras que atendam às necessidades específicas de comunidades, como de fato ocorreu na Travesía a Conde, impondo a reflexão sobre outros aspectos não contemplados como prioritários ao longo das travessias realizadas pela escola.

Os programas Design-Build direcionados a atender a demandas de comunidades precisam assumir um maior compromisso com o resultado final da obra em termos técnicos e funcionais, e por esse motivo, devem também dar maior enfoque aos processos formativos e de capacitação técnica durante a execução das construções.

Às praticas de experimentação, devem somar-se momentos de síntese e avaliação, criando possibilidades de retroalimentação da experiência e do próprio processo educativo. Os métodos e estratégias devem prever momentos de reflexão sobre a prática e de integração entre a conceituação e a operacionalização, ou seja, de conexão entre a práxis e a teoria. Para o educador José Pacheco (2014, p. 109) "a formação deve 
oferecer oportunidades de cultivar saberes passíveis de utilização em situações correntes".

A apropriação de saberes empíricos dilui a separação entre concepção e execução e, a meu ver, corrobora para a validade da experimentação como ferramenta de ensinoaprendizagem na Arquitetura. Este poderia ser um caminho para fomentar o uso da madeira na construção civil brasileira: a formação de profissionais com conhecimentos práticos embasados na apropriação de saberes teóricos e de competências técnicas.

Da pergunta principal, desdobra-se enfim, o objetivo principal desta Tese: elaborar parâmetros didático-metodológicos sobre a experimentação construtiva nas escolas de arquitetura, propondo a madeira como instrumento de ensinoaprendizagem, a fim de potencializar o emprego mais extensivo deste material na construção civil brasileira.

A proposição de tais parâmetros pretendia, inicialmente, servir de auxílio para a elaboração de unidades de ensino tais como disciplinas curriculares e eletivas, cursos de curta duração, oficinas, workshops, etc, e para o planejamento de atividades práticas de experimentação construtiva em madeira. Neste ponto da escrita, porém, respondidas todas as perguntas de pesquisa, que muitas vezes conduziram a novas questões e reflexões, entende-se que alguns parâmetros já foram sugeridos nas respostas às perguntas específicas, especialmente a de número 5, última questão formulada justamente em decorrência dos resultados da pesquisa.

Naquela resposta são listados aspectos importantes a serem observados para a implementação da experimentação construtiva como ferramenta de abordagens pedagógicas mais integradoras e, ainda que não sejam aspectos específicos às práticas em madeira, podem ser entendidos como diretrizes gerais aplicáveis ao uso da madeira como instrumento de ensino-aprendizagem, o que contribui para alcançar o objetivo principal desta investigação.

A partir de uma maior compreensão em relação a temática estudada, conclui-se que a elaboraração de parâmetros didático-metodológicos, de fato, deveria envolver um trabalho multidisciplinar e o estabelecimento de um maior vínculo com a área da 
Educação. A determinação de tais parâmetros demanda um tipo de pesquisa e prática que não exatamente a conduzida ao longo desta investigação, carecendo de uma maior aproximação com a área pedagógica para definição de métodos, técnicas e recursos, que não necessariamente são parte intrínseca ao ofício da Arquitetura.

A proposição de um novo sistema construtivo, por exemplo, impõe etapas de pesquisa, desenvolvimento de projeto, construção de protótipos, teste, avaliação, revisão de projeto, implicando em novos protótipos, testes, avaliações e revisões, nas quais deveriam participar arquitetos e engenheiros conjuntamente, bem como, profissionais mestres do ofício. Analogamente, a proposição de um curso de formação implica em etapas de definição de conceitos, desenvolvimento de metodologias e técnicas, preparação de recursos didáticos, aplicação e teste das técnicas, avaliação dos resultados, aprimoramento de métodos e revisões, nas quais deveriam participar pedagogos.

É premente entendermos que precisamos formar professores. A Educação é uma área de conhecimento tão vasta quanto a Arquitetura ou a Engenharia e precisamos nos capacitar para o exercício comprometido da docência.

Citando José Pacheco (2014, p. 13): “será indispensável alterar a organização das escolas, interrogar práticas educativas dominantes. É urgente interferir humanamente no íntimo das comunidades humanas, questionando convicções e, fraternalmente, incomodar os acomodados".

Para Paulo Freire (1996, p. 22), "A reflexão crítica sobre a prática se torna uma exigência da relação Teoria/Prática sem a qual a teoria pode ir virando blábláblá e a prática, ativismo". Sob esse ponto de vista, "É preciso, [...] que o formando (docente), [...] se convença definitivamente de que ensinar não é transmitir conhecimento, mas criar as possibilidades para a sua produção ou a sua construção".

Gropius (2014) defendia que todo professor de arquitetura, assim como de engenharia, deveria ter o direito de realizar trabalho privado como forma de revigorar as forças criativas. Uma excelente discussão! 
As universidades públicas brasileiras muitas vezes priorizam a contratação de professores em regime de dedicação exclusiva ao ensino, pesquisa, extensão e gestão institucional limitando sua atuação profissional privada, fato que acaba inevitavelmente afastando-os da prática do projeto e, especialmente da construção. A produção acadêmica, medida em publicações de artigos científicos de alto impacto internacional, é um dos principais aspectos qualificados - e supervalorizados - em concursos docentes e sistemas de avaliação dos programas de pós-graduação em detrimento de experiências didáticas, por exemplo, vinculadas a práticas de construção ou mesmo de extensão universitária.

Como colocou Canizaro (2012), o conservadorismo acadêmico acarreta obstáculos explícitos aos programas de projeto e construção dentro das próprias instituições. Não há dúvidas de que são muitos os desafios a enfrentar, e especialmente, frente à desvalorização da prática docente no Brasil dos dias atuais.

Ainda assim, a convicção de que a experimentação construtiva é uma ferramenta efetiva de ensino-aprendizagem, a ser amplamente explorada nas escolas de arquitetura, motiva-me a rascunhar uma proposição que, a priori, apenas sugere um caminho a ser explorado. O Quadro 8 traz uma síntese propositiva para um curso de projeto e construção, ou seja, um curso pautado na abordagem pedagógica do "aprender-fazendo".

A intenção desta síntese foi de sistematizar conceitualmente uma série de etapas que podem ser aplicadas a exercícios de diversos escopos, cronogramas e equipes. Inicialmente, o fluxograma alude às etapas cíclicas do processo de projeto (análise, síntese e avaliação) associadas a atividades de produção e teste das ideias de projeto, através de modelos, protótipos e/ou construções experimentais. Sugere possíveis abordagens em cada uma das etapas onde a busca por conhecimentos teóricos e técnicos deriva de uma necessidade específica resultante do entendimento do problema, e não o contrário. Sendo assim, enfatiza-se a etapa de problematização como fase determinante em todo o processo. A compreensão da temática e a formulação do problema irá nortear a pesquisa por soluções de projeto. 
Quadro 8 - Síntese propositiva para curso de projeto e construção

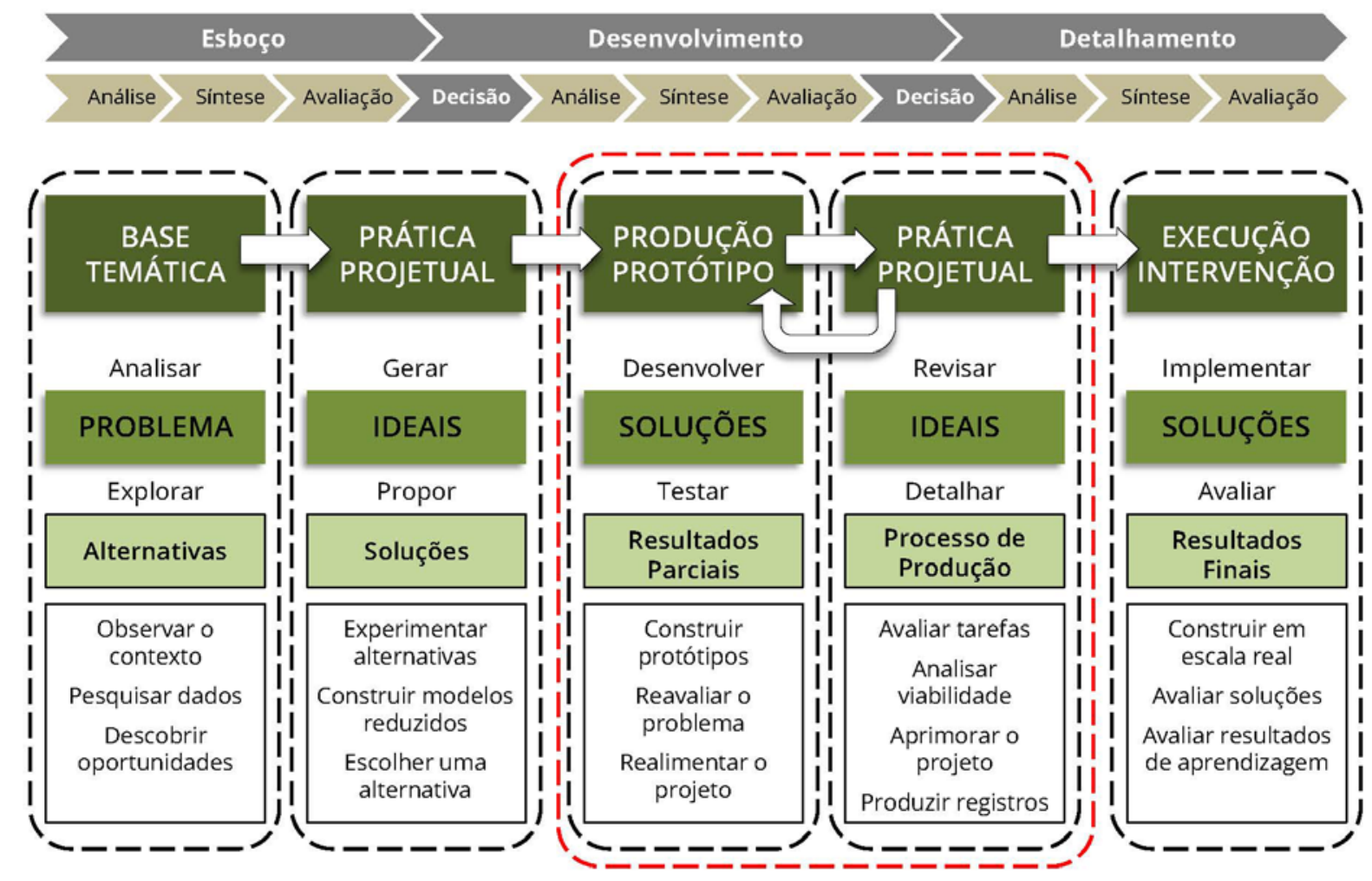

Fonte: elaborado pela autora.

A proposição dessa síntese, leva em consideração os quatro pontos fundamentais dos cursos de projeto e construção preconizados por Carpenter (2012): o pensar e agir, a colaboração, as habilidades de comunicação e a devolução à sociedade. A oportunidade de experimentar em escala real, a partir de problemas reais, aproxima o saber criativo e o saber técnico e motiva a busca pelos saberes teóricos. A partir deste esquema geral se faz necessário definir métodos (plano operacional), técnicas (para realização das práticas) e recursos (materiais e humanos) a serem utilizados.

No caso da experimentação em madeira, o uso de espécies "moles", de menor densidade, como por exemplo o Pinus, facilita o trabalho manual e o uso de ferramentas de baixa complexidade, mas a definição da espécie adequada deve estar atrelada a questões como a duração da obra, a exposição à interpéries, ao maquinário disponível e ao custo, entre outros.

A relevância da madeira para a viabilização de atividades práticas de experimentação é inegável. As referências didáticas apresentadas corroboram para 
evidenciar o seu potencial como instrumento de ensino-aprendizagem em cursos de projeto e construção, e ao mesmo tempo, fundamentam a hipótese de pesquisa de que uma maior inserção de práticas construtivas experimentais em madeira nos cursos de arquitetura, por meio de estratégias pedagógicas que articulem teoria, projeto e produção em atividades interdisciplinares, pode favorecer a formação de profissionais mais aptos para o projeto e a construção da arquitetura em madeira.

Os resultados expostos através dos projetos construídos pelas escolas de arquitetura analisadas, de certa forma, indicam a validação de tal hipótese. Porém, esta comprovação demanda uma avaliação mais aprofundada quanto à produção arquitetônica destes profissionais. Esta abordagem de pesquisa é indicada nas considerações finais como uma possível continuidade da investigação. 


\section{REFERÊNCIAS}

BONDIA, J. L. Notas sobre a experiência e o saber de experiência. Revista Brasileira de Educação. Rio de Janeiro, n.19, p.20-28, 2002. DOI: http://dx.doi.org/10.1590/S141324782002000100003. Disponível em: http://www.scielo.br/scielo.php?script=sci_arttext\&pid=S141324782002000100003\&lng=pt\&tlng=pt. Acesso em: 19 ago. 2019.

CANIZARO, V. B. Design-build in Architectural Education: Motivations, Practices, Challenges, Successes and Failures. ArchNet-IJAR: International Journal of Architectural Research, United Kingdom, v. 6, n. 3, p. 20-36, Nov. 2012.

CARPENTER, W. J. Learning by Building: Design and Construction in Architectural Education. New York: Van Nostrand Reinhold, 1997.

FREIRE, P. Pedagogia da autonomia: saberes necessários à prática educativa. São Paulo: Paz e Terra, 1996.

GROPIUS, W. Bauhaus: novarquitetura. Tradução J. Guinsburg e I. Dormien. São Paulo: Perspectiva, 2004.

LAVERDE, A. Os espaços experimentais das escolas públicas de arquitetura do Brasil: realidade ou utopia? 2017. Tese (Doutorado em Arquitetura e Urbanismo) Faculdade de Arquitetura e Urbanismo, Universidade de São Paulo, São Paulo, 2017.

PACHECO, J. Escola da Ponte: formação e transformação da educação. Petrópolis, RJ: Vozes, 2014.

PLETZ, E. Ensino de construções de madeira nos cursos de Arquitetura e Urbanismo. In: ENCONTRO BRASILEIRO EM MADEIRAS E EM ESTRUTURAS DE MADEIRA - EBRAMEM, 8, 2002, Uberlândia. Anais [...]. Uberlândia: IBRAMEM, 2002. 


\subsection{Considerações finais}

Finalmente, tem-se como tese, que a experimentação construtiva no ensino de arquitetura deve ser amplamente defendida como meio de oportunizar a conexão entre os conhecimentos teóricos e práticos e de estabelecer uma ponte entre a experiência acadêmica e profissional. A prática experimental não deve, entretanto, limitar-se ao puro experimento empírico de materiais e técnicas, senão que deve orientar-se à produção de conhecimentos que, validados e sistematizados, abram caminho a inovações no campo da construção.

Por sua vez, a utilização da madeira como instrumento de ensino-aprendizagem mostra-se extremamente promissora ao permitir processos de experimentação manuais, sem a necessidade de ferramentas complexas, viabilizando a aquisição de competências e o entendimento mais aprofundado do material. Abordagens pedagógicas que associam a prática projetual à produção de protótipos, em uma dinâmica cíclica de análise, síntese e avaliação, favorecem a retroalimentação do processo de projeto e a geração de novos componentes construtivos e de novos arranjos produtivos, essenciais à evolução do setor.

O desenvolvimento e implementação de tecnologias produtivas alinhadas às aspirações de uma sociedade mais consciente e comprometida a enfrentar os desafios globais depende da formação e capacitação de recursos humanos com esse objetivo. Entretanto, sem a articulação de interesses entre academia e indústria, sem a definição de políticas públicas de incentivo à expansão da construção civil, sob essas premissas, "sem o concurso da força da lei, esses planos ideais não passarão de símbolos. De belos sonhos e impotência prática", como já visionava Walter Gropius há um século.

Esta Tese explora uma temática pouco estudada em âmbito nacional e sob esse enfoque, reune referências importantes e exemplos de abordagens pedagógicas que estimulam a formação de profissionais melhor preparados para o emprego mais amplo da madeira na construção civil brasileira. Oferece perspectivas de continuidade da investigação a partir de alguns direcionamentos possíveis que são expostos a seguir. 
No decorrer da análise de referências das escolas de arquitetura selecionadas surgiu o interesse em estabelecer uma relação mais direta entre os sistemas de ensino e a produção arquitetônica contemporânea nos países onde estas se inserem, orientada especialmente, à atuação dos arquitetos egressos destas escolas. Apesar de constatada uma possível correlação, não foi este, a princípio, o critério determinante de seleção das obras apresentadas.

Desta forma, delinea-se como uma possibilidade de continuidade da pesquisa a análise mais aprofundada desta relação entre o sistema de formação dos arquitetos, dentro do contexto das abordagens pedagógicas estudadas, e a produção arquitetônica resultante de tal formação.

Quanto às experiências didáticas brasileiras, certamente é possível ampliar o mapeamento realizado trazendo à tona outros exemplos de iniciativas docentes, de pesquisas e de centros de investigação aplicada, para compor um banco de dados nacional. A criação de uma rede de investigação poderia fomentar a conexão e colaboração entre instituições em prol de um objetivo comum e mais ambicioso.

Outro direcionamento possível, como desdobramento direto desta pesquisa, relaciona-se ao desenvolvimento de métodos e técnicas pedagógicas para capacitação de professores na área específica do ensino de tecnologias construtivas em madeira e da experimentação construtiva em madeira. A carência de capacitação docente nessa área advém das especificidades que demandam conhecimentos mínimos relacionados ao material e seu processamento, envolvendo tanto questões técnicas como projetuais.

Da mesma forma, a produção de recursos e materiais didáticos específicos, como publicações, plataformas e canais de disseminação de informações para auxílio ao desenvolvimento de projetos, tanto no âmbito da Arquitetura quanto da Engenharia, são de extrema relevância dentro deste cenário, bem como ações voltadas à divulgação e incentivo ao uso nobre da madeira na construção, junto a profissionais projetistas e ao público consumidor. 


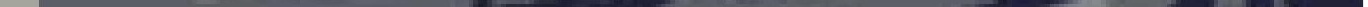





\section{REFERÊNCIAS}

ABDULLAH, B. Z. Exploring the evolution of design-build courses in architectural schools: a qualitative study. 2014. Dissertation (Doctor of Philosophy) - University of Nebraska, Lincoln, 2014. 2005.

AFLALO, M. (org.) Madeira como estrutura: a história da Ita. São Paulo: Paralaxe, Prefácio à edição brasileira. In: GAUZIN-MULLER, D. Arquitetura Ecológica. São Paulo: Editora Senac São Paulo, 2011. p. 9-21.

AGOPYAN, V., JOHN, V. M. O desafio da sustentabilidade na construção civil. São Paulo: Bluncher, 2011. v. 5.

ALMEIDA, J. G. A formação do arquiteto e a universidade. In: GOUVÊA, L. A. C.; BARRETO, F. P.; GOROVITZ, M. (org.) et al. Contribuição ao Ensino de Arquitetura e Urbanismo. Brasília : Instituto Nacional de Estudos e Pesquisas Educacionais, 1999. cap. 6, p.101-119.

ANELLI, R. L. S. O Projeto de arquitetura na pesquisa acadêmica: especificidades, limites e desafios. IV Projetar 2009 - Projeto como Investigação, Pesquisa e Prática, 2009. São Paulo: Altermarket, 2009.

APRILANTI, M. D., TAVARES, S. T., INO, A. Avaliação de Projetos de Painéis em Madeira para Revestimento de Fachadas - Recomendações para o Detalhamento Construtivo. In: ENCONTRO BRASILEIRO EM MADEIRAS E EM ESTRUTURAS DE MADEIRA EBRAMEM, 16, 2018, São Carlos. Anais [...]. São Carlos: IBRAMEM, 2018.

ARANTES, P. F. Qual futuro para o Canteiro Experimental? In: RONCONI, R. L. N. et al. (org). Canteiro experimental: 10 anos na FAUUSP. São Paulo: FAUUSP, 2008. p. 24-33.

ARRUDA, A. L. V. Aprender arquitetura e urbanismo à distância não funciona. [s.l.] 26 de janeiro de 2017. Disponível em: http://www.abea.org.br/?p=2052. Acesso em: 05 mar. 2017.

ASCHER, B.E. The bauhaus: Case study experiments in education. Architectural Design, London, v. 85, n. 2, p. 30-33, Mar. 2015. Disponivel em: https://doiorg.ez67.periodicos.capes.gov.br/10.1002/ad.1873. Acesso em: 18 ago. 2019.

BAYL-SMITH, M. BuildAbility: the future of construction education. Research Report: 2009 Byera Hadley Travelling Scholarship, May. 2011. Disponível em: https://www.academia.edu/806805/BuildAbility_the_future_of_construction_education. Acesso em: 27 set. 2018. 
BENDER, W. N. Aprendizagem baseada em projetos: educação diferenciada para o século XXI. Porto Alegre: Penso, 2015.

BITTENCOURT, R. M.; TERNI, A. W. Ensino de projeto de estruturas e sistemas construtivos em madeira: uma proposta didático-pedagógica. In: ENCONTRO BRASILEIRO EM MADEIRAS E EM ESTRUTURAS DE MADEIRA - EBRAMEM, 9, 2004, Cuiabá. Anais [...]. Cuiabá: IBRAMEM, 2004.

BONDIA, J. L. Notas sobre a experiência e o saber de experiência. Revista Brasileira de Educação. Rio de Janeiro, n.19, p.20-28, 2002. DOI: http://dx.doi.org/10.1590/S141324782002000100003. Disponível em: http://www.scielo.br/scielo.php?script=sci_arttext\&pid=S141324782002000100003\&lng=pt\&tlng=pt. Acesso em: 18 mar. 2019.

BRASIL. Ministério da Educação. Secretaria de Educação Superior. Comissão de Especialistas de Ensino de Arquitetura e Urbanismo. Perfis da Área \& Padrões de Qualidade: Expansão, Reconhecimento e Verificação Periódica dos Cursos de Arquitetura e Urbanismo. Brasília, 1996. Disponível em:

http://portal.mec.gov.br/sesu/arquivos/pdf/ar_geral.pdf. Acesso em: 05 mar. 2017.

. Portaria $n^{\circ}$ 1.770, 21 de dezembro de 1994. Fixa Diretrizes Curriculares e Conteúdos Mínimos para os Cursos de Graduação em Arquitetura e Urbanismo. Diário Oficial da União, Brasília, DF, 23 dez. 1994.

. Resolução n 06, 02 de fevereiro de 2006. Institui as Diretrizes Curriculares Nacionais do Curso de Graduação em Arquitetura e Urbanismo e dá outras providências. Diário Oficial da União, Brasília, DF, 03 fev. 2006, Seção 1, p. 6.

. Lei $n^{\circ} 12.378$, de 31 de dezembro de 2010. Regulamenta o exercício da Arquitetura e Urbanismo; cria o Conselho de Arquitetura e Urbanismo do Brasil CAU/BR e os Conselhos de Arquitetura e Urbanismo dos Estados e do Distrito Federal CAUs; e dá outras providências. Diário Oficial da União, Brasília, DF, 31 dez. 2010.

BRUNDTLAND, G. H. Nosso futuro comum. Rio de Janeiro: Fundação Getúlio Vargas, 1991.

CALIL JR., C. A educação da Engenharia da madeira no Brasil: o programa do LaMEM. . In: ENCONTRO BRASILEIRO EM MADEIRAS E EM ESTRUTURAS DE MADEIRA EBRAMEM, 6, 1998. Florianópolis. Anais [...]. Florianópolis: IBRAMEM, 1998.

CAMPOS, E. F. Emissão de CO2 da madeira serrada da Amazônia: o caso da exploração convencional. 2012. Dissertação (Mestrado em Engenharia de Construção Civil) - Escola Politécnica da Universidade de São Paulo, São Paulo, 2012. 
CANIZARO, V. B. Design-build in Architectural Education: Motivations, Practices, Challenges, Successes and Failures. ArchNet-IJAR: International Journal of Architectural Research, United Kingdom, v. 6, n. 3, p. 20-36, Nov. 2012.

CARPENTER, W. J. Learning by Building: Design and Construction in Architectural Education. New York : Van Nostrand Reinhold, 1997.

Digital Fabrication and the Design Build Studio. In: ACSA ANNUAL MEETING, 102, 2014, Miami, FL. Proceedings [...]. Miami, FL: Florida International University, 2014. p. 513-521.

CÉSAR, S. F.; CUNHA, R. D. A. Uma experiência para o ensino de graduação na área de estruturas, construção e tecnologia da madeira do Laboratório de Madeiras da EPUFBA. In: ENCONTRO BRASILEIRO EM MADEIRAS E EM ESTRUTURAS DE MADEIRA EBRAMEM, 6, 1998, Florianópolis. Anais [...]. Florianópolis: IBRAMEM, 1998.

CHAPMAN, J. B.; BARRIE, A.; PATEL, Y. Teaching timber technology to architecure students: real buildings and digital technologies. In: WORLD CONFERENCE ON TIMBER ENGINEERING - WCTE, 2016, Vienna. Proceedings [...]. Vienna, Austria, 2016.

CONTIER, L. Ameaça à educação dos arquitetos. Conselho de Arquitetura e urbanismo do Brasil, 15 de fev. 2017. Disponível em: http://www.caubr.gov.br/ameaca-aeducacao-dos-arquitetos/. Acesso em: 05 mar. 2017.

CRONHJORT, Y.; VAHTIKARI K.; TAKANO A. Aalto Wood: interdisciplinary teaching and research. In: World Conference on Timber Engineering (WCTE), 2016. Vienna.

Proceedings [...], Vienna: Vienna University of Technology, 2016.

CRUZ O., J. Construir en madera. Entrevista Arquitecto José Cruz Ovalle. Revista Ciudad y Arquitectura. Santiago, n. 150, 2012.

DESCAMPS, T. et al. Structural engineering and teaching by doing: how wood contributes to the implementation of new pedagogical approaches. In: WORLD CONFERENCE ON TIMBER ENGINEERING - WCTE, 2018, Seoul. Proceedings [...]. Seoul, Republic of Korea: Mondial Congress \& Events, 2018.

EPA. United States Environmental Protection Agency. Causes of Climate Change. [online]. 2016. Disponível em: http://www3.epa.gov/climatechange/science/causes.html. Acesso em: 01 fev. 2016.

ESPÍNDOLA, L. R. O wood frame na produção de habitação social no Brasil. 2017. Tese (Doutorado em Arquitetura e Urbanismo) - Instituto de Arquitetura e Urbanismo, Universidade de São Paulo, São Carlos, 2017. 
ESPÓSITO G., F.; LUZA C., D. Talleres de Obra en Ciudad Abierta de Amereida. Revista AUS Valdívia, Chile, Jul./dic. 2015. Disponível em:

<http://www.redalyc.org/articulo.oa?id=281744668007>. Acesso em: 24 ago. 2018.

FERRO, S. Arquitetura e trabalho livre. São Paulo: Cosac Naify, 2006.

. Experimentação em arquitetura: práxis crítica e reação conservadora. In: RONCONI, R. L. N. et al. (org). Canteiro experimental: 10 anos na FAUUSP. São Paulo: FAUUSP, 2008. p. 19-23.

FOWLES, B. Design-build Projects in Architectural Education. Design Studies, Netherlands, v. 5, n. 1, p. 07-14, Jan. 1984.

FREEAR, A.; BARTHEL, E. Rural Studio at twenty: designing and building in Hale County, Alabama. New York: Princeton Architectural Press, 2014.

FREIRE, P. Pedagogia da autonomia: saberes necessários à prática educativa. São Paulo: Paz e Terra, 1996.

GABER, T. The Agency of Making and Architecture Education: Design-Build Curriculum in a New School of Architecture. Archnet-IJAR: International Journal of Architectural Research, United Kingdom, v. 8, n. 3, p. 21-31, Nov. 2014.

GARCÉS A., A.; MANSÚ, M. Travessia Porto do Capim, João Pessoa. In: ROMANO, E. et. al. (org.) Centralidades periféricas. João Pessoa: Editora da UFPB, 2018. p. 181-209.

GAUZIN-MULLER, D. Arquitetura Ecológica. São Paulo: Editora Senac São Paulo, 2011.

GRAEFF, E. A. Arte e técnica na formação do arquiteto. São Paulo: Studio Nobel, 1995.

GROPIUS, W. Bauhaus: novarquitetura. Tradução J. Guinsburg e I. Dormien. São Paulo: Perspectiva, 2004.

GUAITA, P.; TAPPARELLI, C. El camino no es camino: Some Reflections on the Valparaiso School and Its Architectural Teaching. In: DEVABHAKTUNI, S.; GUAITA, P.; TAPPARELLI, C. (ed.) Building Cultures Valparaiso: Pedagogy Practice and Poetry at Valparaiso School of Architecture and Design. Lausanne, Switzerland: EPFL Press, 2015. p. 17-29.

GUTIERREZ, E. J. B. (org.) A construção de um novo olhar sobre o ensino de arquitetura e urbanismo no Brasil: os 40 anos da Associação Brasileira de Ensino de Arquitetura e Urbanismo. Brasília: ABEA, 2013. 
HARRIS, R.; CHANG, W. S. Teaching timber engineering. In: WORLD CONFERENCE ON TIMBER ENGINEERING - WCTE, 2014, Quebec. Proceedings [...]. Quebec: Salenikovich, 2014. Disponível em:

http://opus.bath.ac.uk/42189/1/WCTE_2014_Teaching_Timber_Engineering_Harris_Chan g.pdf. Acesso em: 03 abr. 2016.

HERMANSEN, C.; JOLLY M., D.; HENSEL, M. The Open City and the e[ad] School of Architecture and Design. Architectural Design. London, v. 85, n. 2, 2015. DOI: 10.1002/ad.1874. Disponível em: https://www.researchgate.net/publication/273391101. Acesso em: 24 ago. 2018.

HERZOG, T. et al. Construire en bois. 3. ed. Lausanne: Presses Polytechniques et Universitaires Romandes, 2007.

IBGE. Pesquisa Nacional por Amostra de Domicílios - PNAD 2018. Rio de Janeiro, 2019. Disponível em:

https://biblioteca.ibge.gov.br/visualizacao/livros/liv101654_informativo.pdf. Acesso em: 16 jun. 2019.

IEA. Transition to sustainable buildings: Strategies and Opportunities to 2050, Executive summary. 2013. Disponível em:

http://www.iea.org/media/training/presentations/etw2014/publications/Sustainable_Buil dings_2013.pdf. Acesso em: 15 ago. 2016.

ILLERIS, K. Uma compreensão abrangente sobre a aprendizagem humana. Teorias contemporâneas da aprendizagem. Porto Alegre: Penso, 2013.

KAUFMANN, H.; NERDINGER, W. Building with Timber: Paths into the Future. Prestel Publishing, 2012.

KOLB, J. Systems in Timber Engineering. Ed. Lignum - Holzwirtschaft Schweiz / DGfH - German Society of Wood Research, 2008.

KUITTINEN, M. The relevance of carbon footprint assessment for the woodworking and construction sectors. In: KUITTINEN, M., LUDVIG, A., WEISS, G. (ed.). Wood in Carbon Efficient Construction: tools, methods and applications. Belgium: CEI-Bois, 2013. p. 14-15.

KUITTINEN, M., LUDVIG, A., WEISS, G. (ed.). Wood in Carbon Efficient Construction: tools, methods and applications. Belgium: CEl-Bois, 2013. Disponível em: https://www.researchgate.net/publication/281275478_Wood_in_carbon_efficienc_constr uction_Tools_methods_and_applications. Acesso em: 09 dez. 2015.

KURT, S. An analytic study on the traditional studio environments and the use of the constructivist studio in the architectural design education. Procedia Social and

Behavioral Sciences, Netherlands, v. 1, n. 1, p. 401-408, 2009. DOI: 
https://doi.org/10.1016/j.sbspro.2009.01.072. Disponível em: https://www.sciencedirect.com/science/article/pii/S1877042809000743. Acesso em: 12 set. 2018.

LANATA, F.; MICHAUD, F. Teaching timber construction in learn-by-doing format through the construction of a full-scale house. In: WORLD CONFERENCE ON TIMBER ENGINEERING - WCTE, 2018, Seoul. Proceedings [...]. Seoul, Republic of Korea: Mondial Congress \& Events, 2018.

LAVERDE, A. Os espaços experimentais das escolas públicas de arquitetura do Brasil: realidade ou utopia? 2017. Tese (Doutorado em Arquitetura e Urbanismo) Faculdade de Arquitetura e Urbanismo, Universidade de São Paulo, São Paulo, 2017.

LEITE, M. A. D. F.D' Azevedo. O ensino de tecnologia em Arquitetura e Urbanismo. 1998. Dissertação (Mestrado em Arquitetura e Urbanismo) - Faculdade de Arquitetura e Urbanismo, Universidade de São Paulo, São Paulo, 1998.

A aprendizagem tecnológica do arquiteto. 2005. Tese (Doutorado em Arquitetura e Urbanismo) - Faculdade de Arquitetura e Urbanismo, Universidade de São Paulo, São Paulo, 2005.

LIMA, J. A. R., JOHN, V. M. Avaliação das consequências da produção de concreto no Brasil para as mudanças climáticas. Boletim Técnico da Escola Politécnica da USP, São Paulo, 2010.

LOPES, J. M. A. Tecnologia: arquitetura e urbanismo: escola \& ofício. 1999. Dissertação (Mestrado em Arquitetura e Urbanismo) - Escola de Engenharia de São Carlos, Universidade de São Paulo, São Carlos, 1999.

. Quando menos não é mais: tectônica e o ensino tecnológico da Arquitetura e do Urbanismo. In: ENCONTRO DA ASSOCIAÇÃO NACIONAL DE PESQUISA E PÓS-GRADUAÇÃO EM ARQUITETURA E URBANISMO - ENANPARQ, 3, 2014, São Paulo.

Anais [...]. São Paulo: Universidade Presbiteriana Mackenzie, 2014.

LOTUFO, V. A. Reflexões sobre o canteiro experimental. In: RONCONI, R. L. N. et al. (Orgs). Canteiro experimental: 10 anos na FAUUSP. São Paulo: FAUUSP, 2008. p. 52-54.

LOTUFO, T. A. Um novo ensino para outra prática. Rural Studio e Canteiro Experimental, contribuições para o ensino de arquitetura no Brasil. 2014. Dissertação (Mestrado em Arquitetura e Urbanismo) - Faculdade de Arquitetura e Urbanismo, Universidade de São Paulo, 2014.

MATTARA, M.; NASCIMENTO, M. A. Metodologia de ensino baseada na experimentação pelas escolas Bauhaus e VKhUTEMAS. Iniciação - Revista de Iniciação Científica, Tecnológica e Artística, v. 5, n. 1, Jun. 2015. Disponível em: 
http://www1.sp.senac.br/hotsites/blogs/revistainiciacao/index.php/vol-5-1-ano-2015/. Acesso em: 07 nov. 2018.

MENDONÇA, A. C. João Filgueiras Lima (Lelé). Entrevistado: João Filgueiras Lima. Salvador, 18 de janeiro de 2007. Disponível em: http://entreentre.com/Content/entrevistas/pdf/entre-lele-20160330175704.pdf. Acesso em: 22 nov. 2018.

MINTO, F. C. N. A experimentação prática construtiva na formação do arquiteto. 2009. Dissertação (Mestrado em Arquitetura e Urbanismo) - Faculdade de Arquitetura e Urbanismo, Universidade de São Paulo, São Paulo, 2009.

Canteiro Experimental: o material e o imaterial. In: RONCONI, R. L. N. et al. (org). Canteiro experimental: 10 anos na FAUUSP. São Paulo: FAUUSP, 2008. p. 40-43.

. Pensando a pluralidade no ensino tecnológico em cursos de arquitetura e urbanismo no Brasil. In: ENCONTRO DA ASSOCIAÇÃO NACIONAL DE PESQUISA E PÓSGRADUAÇÃO EM ARQUITETURA E URBANISMO - ENANPARQ, 5, 2018, Salvador. Anais [...]. Salvador: FAUFBA, 2018. p. 2061-2062. Disponível em: http://repositorio.ufba.br/ri/handle/ri/27744. Acesso em: 17 mar. 2019.

MORAN, J. Metodologias ativas para realizar transformações progressivas e profundas no currículo. 2013. Disponível em: <http://www2.eca.usp.br/moran/wpcontent/uploads/2013/12/transformacoes.pdf> Acesso em: 27 mai. 2016.

PACHECO, J. Escola da Ponte: formação e transformação da educação. Petrópolis, RJ: Vozes, 2014.

PENDLETON-JULIAN, A. M. The road that is not a road and the Open City, Ritoque, Chile. Cambrige, Massachusetts: MIT Press, 1996.

PÉREZ DE ARCE, R. Tan lejos y tan cerca: la Ciudad Abierta y las Travesías. In: PÉREZ DE ARCE R.; PÉREZ OYARZÚN F. Escuela de Valparaíso: Grupo Ciudad Abierta. Madrid: Tanais Ediciones, 2003. p. 13-17.

PLETZ, E. Ensino de construções de madeira nos cursos de Arquitetura e Urbanismo. In: ENCONTRO BRASILEIRO EM MADEIRAS E EM ESTRUTURAS DE MADEIRA - EBRAMEM, 8, 2002, Uberlândia. Anais [...]. Uberlândia: IBRAMEM, 2002.

POMPÉIA, R. A. O laboratório de habitação no ensino de arquitetura: uma contribuição ao processo de formação do arquiteto. 2006. Tese (Doutorado em Arquitetura e Urbanismo) - Faculdade de Arquitetura e Urbanismo, Universidade de São Paulo, São Paulo, 2006. 
Estruturas Invisíveis - Reflexão e Prática. In: ENCONTRO NACIONAL DE ENSINO DE ESTRUTURAS EM ESCOLAS DE ARQUITETURA, 3, 2017, Ouro Preto. Anais [...]. Ouro Preto: Editora da UFOP, 2017.

PUNHAGUI, K. R. G. Potencial de reducción de las emisiones de CO2 y de la energía incorporada en la construcción de viviendas en Brasil mediante el incremento del uso de la madera. 2014. Tese (Doutorado em Engenharia). Universidade Politécnica da Catalunha, Barcelona, 2014.

QUEIROZ, H. P. V. Manifestação do plenário do conselho de arquitetura e urbanismo do Brasil sobre ensino a distância em arquitetura e urbanismo. [s.l.] 16 de fevereiro de 2017. Disponível em: http://www.caubr.gov.br/caubr-publicamanifestacao-sobre-ensino-a-distancia-em-arquitetura-e-urbanismo/. Acesso em: 05 mar. 2017.

REBELLO, Y. C. P. Contribuição ao ensino de estrutura nas escolas de arquitetura. 1993. Dissertação (Mestrado em Arquitetura e Urbanismo) - Faculdade de Arquitetura e Urbanismo, Universidade de São Paulo, São Paulo, 1993.

. Uma proposta de ensino da concepção estrutural. 1999. Tese

(Doutorado em Arquitetura e Urbanismo) - Faculdade de Arquitetura e Urbanismo, Universidade de São Paulo, São Paulo, 1999.

RONCONI, R. L. N. Inserção do canteiro experimental nas faculdades de arquitetura e urbanismo. 2002. Tese (Doutorado em Arquitetura e Urbanismo) Faculdade de Arquitetura e Urbanismo, Universidade de São Paulo, São Paulo, 2002.

- Canteiro experimental - uma proposta pedagógica para a formação do arquiteto e urbanista. 2005. Pós. Revista do Programa de Pós-Graduação em Arquitetura e Urbanismo da FAUUSP. São Paulo, p.142-158, 2005. Disponível em: http://revistas.usp.br/posfau/article/viewFile/43406/47028. Acesso em: 30 ago. 2014.

SAAVEDRA V., R. As travessias pela América: aprender arquitetura e design através de uma experiência poética. PRUMO: Revista online do Departamento de Arquitetura e Urbanismo da PUC-Rio, Rio de janeiro, v. 2, n. 2, p.16-33, 2017. Disponível em: http://periodicos.puc-rio.br/index.php/ revistaprumo/issue/view/edi\%C3\%A7\%C3\%A30\%20completa. Acesso em: 06 jul. 2017.

SABBATINI, F. H. Desenvolvimento de métodos processos e sistemas construtivos: formulação e aplicação de uma metodologia. 1989. Tese (Doutorado em Engenharia) - Escola Politécnica, Universidade de São Paulo, São Paulo, 1989.

SANTOS JÚNIOR, W. R. dos. A ABEA e a conquista das Diretrizes Curriculares nacionais para os cursos de Arquitetura e Urbanismo em 1994: uma inflexão inovadora no ensino de Arquitetura e Urbanismo no Brasil (1985 - 1994/95). In: GUTIERREZ, E. J. B. (org.) A construção de um novo olhar sobre o ensino de Arquitetura e Urbanismo 
no Brasil: Os 40 anos da Associação Brasileira de Ensino de Arquitetura e Urbanismo. Brasília: ABEA, 2013. p. 60-91.

SARAMAGO, R. C. P. Ensino de estruturas nas escolas de arquitetura do Brasil. 2011. Dissertação (Mestrado em Arquitetura e Urbanismo) - Escola de Engenharia de São Carlos, Universidade de São Paulo, São Carlos, 2011.

SARAMAGO, R. C. P.; LOPES, J. M. A. Iniciativas didáticas inovadoras aplicadas ao ensino de estruturas nas escolas brasileiras de arquitetura e urbanismo. In: FÓRUM INTERNACIONAL SOBRE PRÁTICA DOCENTE UNIVERSITÁRIA, 2012, Uberlândia. Anais [...]. Uberlândia: UFU, 2012, p. 654-663. Disponível em:

<http://www.forumdocente.prograd.ufu.br/anais/anais2011/pdf/2e/rita\%20e\%20joao.P DF> Acesso em: 30 ago. 2014.

SCHLEE A. R. (org.). Trajetória e estado da arte da formação em Engenharia, Arquitetura e Agronomia - Volume X: Arquitetura e Urbanismo. Brasília: INEP/CONFEA. 2010.

SCHMITT, C.; ARROYO, D. Timber in Design/Build architectural education in Chile: experiences from the course "Introduccion a la Construcción". In: WORLD CONFERENCE ON TIMBER ENGINEERING - WCTE, 2018, Seoul. Proceedings [...]. Seoul, Republic of Korea: Mondial Congress \& Events, 2018.

SCHÖN, D. A. Educando o profissional reflexivo: um novo design para o ensino e a aprendizagem. São Paulo: Artmed, 2000.

SCHULITZ, M.; GERSHFELD, M. Interdisciplinary design studio - timber; collaboration between architecture and engineering disciplines in higher education In: WORLD CONFERENCE ON TIMBER ENGINEERING - WCTE, 2016, Vienna. Proceedings [...]. Vienna: Vienna University of Technology, Austria, 2016.

SERVIÇO FLORESTAL BRASILEIRO. Boletim SNIF 2018, Ed. 1, 2018. Disponível em: www.florestal.gov.br/documentos/publicacoes/4092-boletim-snif-2018-ed1. Acesso em: 16 jun. 2019.

SHIMBO, L. Z.; LOPES, J. M. de A.; INO, A. Low-carbon building technologies: wood and new paradigms for architecture. In: INTERNATIONAL SUSTAINABLE DEVELOPMENT RESEARCH SOCIETY CONFERENCE, 22, Lisboa: Universidade Nova de Lisboa, 2016.

TANNERT, T.; GERBER, A. Teaching timber design in team-based-learning format and in interdisciplinary settings. education In: WORLD CONFERENCE ON TIMBER ENGINEERING - WCTE, 2016, Vienna. Proceedings [...]. Vienna: Vienna University of Technology, Austria, 2016. 
TORRENT, H. Abstraction and Tectonics in Chilean Architecture since 1950. In: OYARZÚN, F. P.; PÉREZ DE ARCE, P.; TORRENT, H. Chilean Modern Architecture since 1950. Texas: A\&M University Press, 2010. p. 91-155.

Madera: materia de la arquitectura moderna. Materia Arquitectura, Santiago, n.15, p. 68-81. 2017.

VALLE, I. M. R. Modelo Reduzido no Ensino de Construção em Madeira. In: VII EBRAMEM - Encontro Brasileiro em Madeiras e em Estruturas de Madeira, 2000. São Carlos. Anais [...], São Carlos: IBRAMEM, 2000.

VALLE, I. M. R. do; Ino, A.; PERRIN, A. G. Small scale models, timber construction and the teaching of architecture: a brazilian experience. education In: WORLD CONFERENCE ON TIMBER ENGINEERING - WCTE, 2014, Quebec. Proceedings [...]. Quebec:

Salenikovich, 2014.

ZANETTINI, S. Siegbert Zanettini: arquitetura, razão, sensibilidade. São Paulo: Edusp, 2002.

WISNIK, G. Industrialização e flexibilidade: arquitetura em São Paulo a partir de componentes em madeira. In: AFLALO, M. (org.) Madeira como estrutura: a história da Ita. São Paulo: Paralaxe, 2005. p. 35-57. 


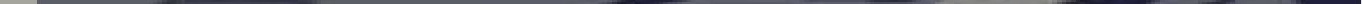





\section{APÊNDICE E ANEXOS}

APÊNDICE: Planilha de levantamento de dados dos cursos de Arquitetura e Urbanismo do Brasil por regiões

ANEXO A: Conteúdos programáticos referentes à madeira nas disciplinas da área de Tecnologia dos cursos de Arquitetura e Urbanismo do Brasil

ANEXO B: Programa de curso do WOOD PROGRAM - Aalto University

ANEXO C: Grade curricular do curso de Arquitetura da e[ad] PUCV

ANEXO D: Curso de Especialização Lato-Sensu em Arquitetura em Madeira: Projeto e Aplicação - FAAP 
APÊNDICE: Planilha de Levantamento de Dados dos cursos de Arquitetura e Urbanismo do Brasil por regiões

Fonte: Sistema e-MEC (http://emec.mec.gov.br/) e sites das Instituições de Ensino Superior (IES). Levantamento realizado entre maio de 2016 e julho de 2017. Elaborado pela autora.

\section{LEGENDA:}

CAT: CATEGORIAS ADMINISTRATIVAS

PÚBLICAS (PU): Pública Federal (PF); Pública Estadual (PE); Pública Municipal (PM);

PRIVADAS (PR): Privada com Fins Lucrativos (PRCL); Privada sem Fins Lucrativos (PRSL);

GRAD CURR: grade curricular

EMENTAS: ementas das disciplinas

PROJ PEDAG: projeto pedagógico

CONT PORG: conteúdos programáticos das disciplinas

GRADE/CARGA HORÁRIA (CH): Disciplinas da grade curricular referentes a Materiais de Construção, Tecnologia da Construção, Sistemas Estruturais e Sistemas Construtivos; CH Disciplinas em horas Teóricas (T) e Práticas (P); CH TOTAL (Total horas disciplinas listadas/Total horas Práticas) $\mathrm{CH}$ total do curso;

\% CH TECN: Percentual de horas das disciplinas de Tecnologia listadas em relação à carga horária total do curso

\% CH PRAT: Percentual de horas práticas em relação à carga horária total das disciplinas listadas

\% CH MAD: Percentual de horas das disciplinas que abordam a madeira em relação à carga horária total do curso

OBSERVAÇÕES: Anotações em relação às ementas e/ou conteúdos programáticos, e menção à madeira, verificadas nas disciplinas obrigatórias e optativas.

Laranja: Disciplinas, inclusive optativas, com conteúdos específicos sobre a madeira;

Verde: Disciplinas com conteúdo diferenciado ou viés prático, por exemplo, canteiro experimental, técnicas construtivas industrializadas ou alternativas, modelos e maquetes;

Amarelo: Cursos que faltam informações mais específicas, mas que se pretende investigar. 


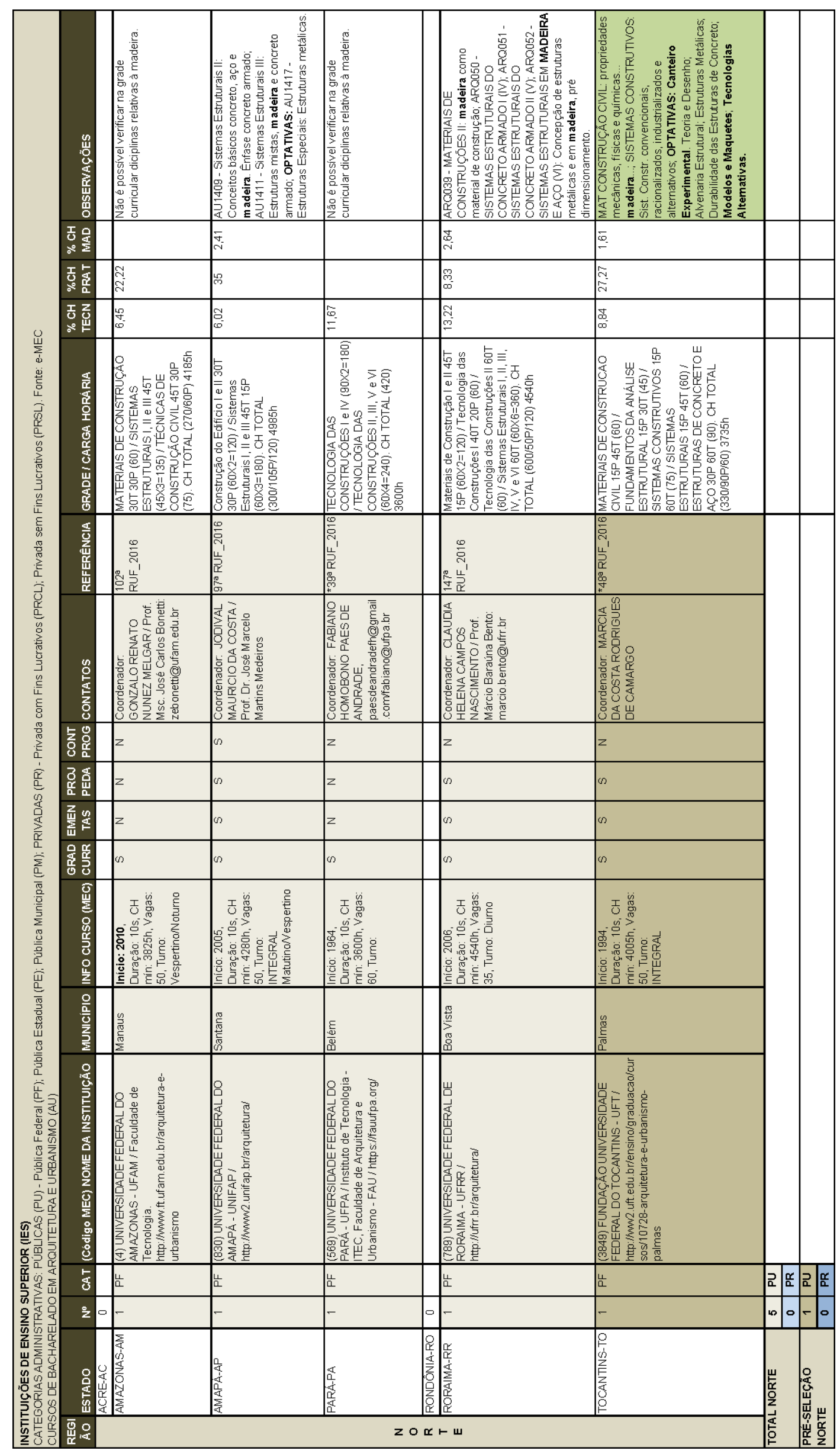




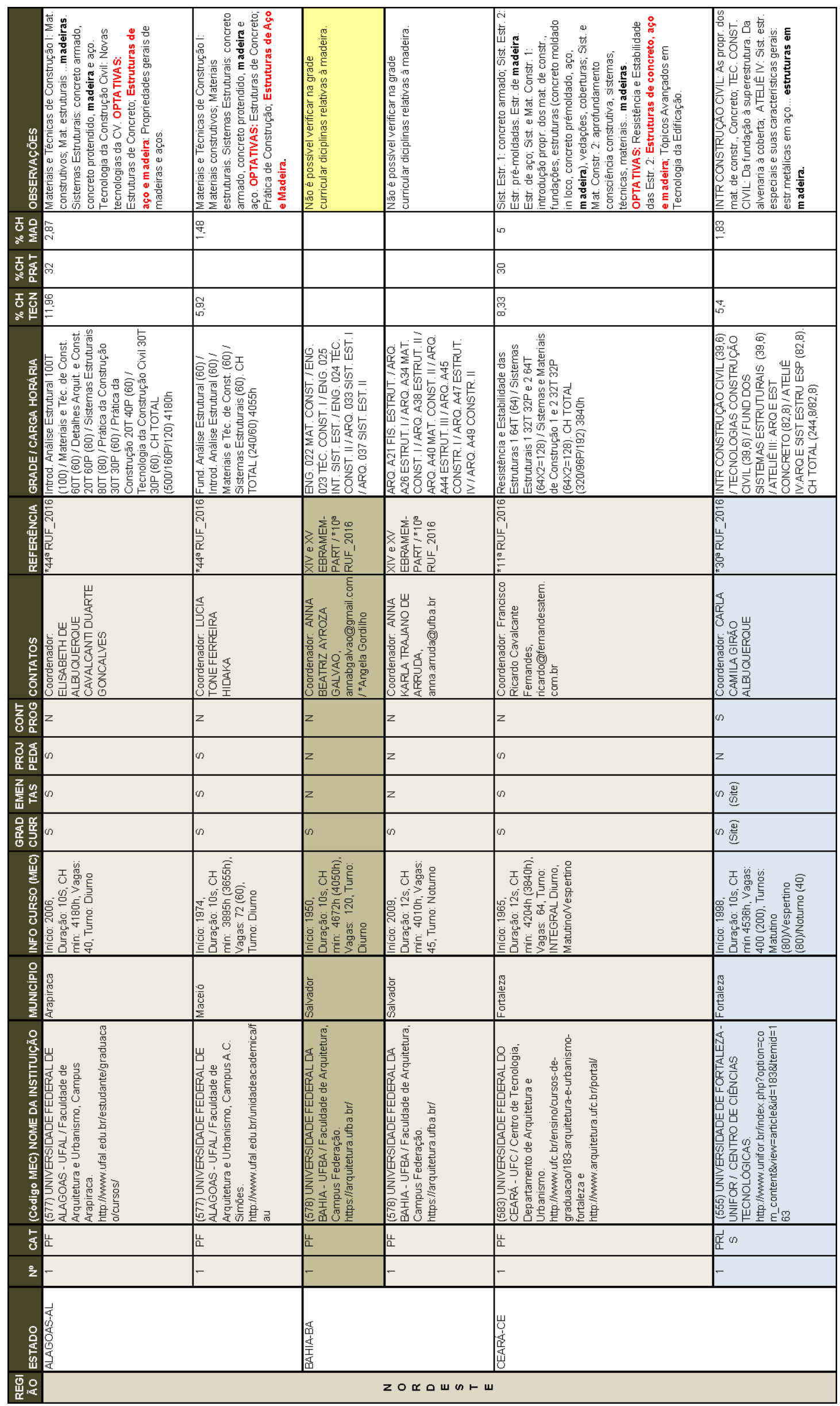




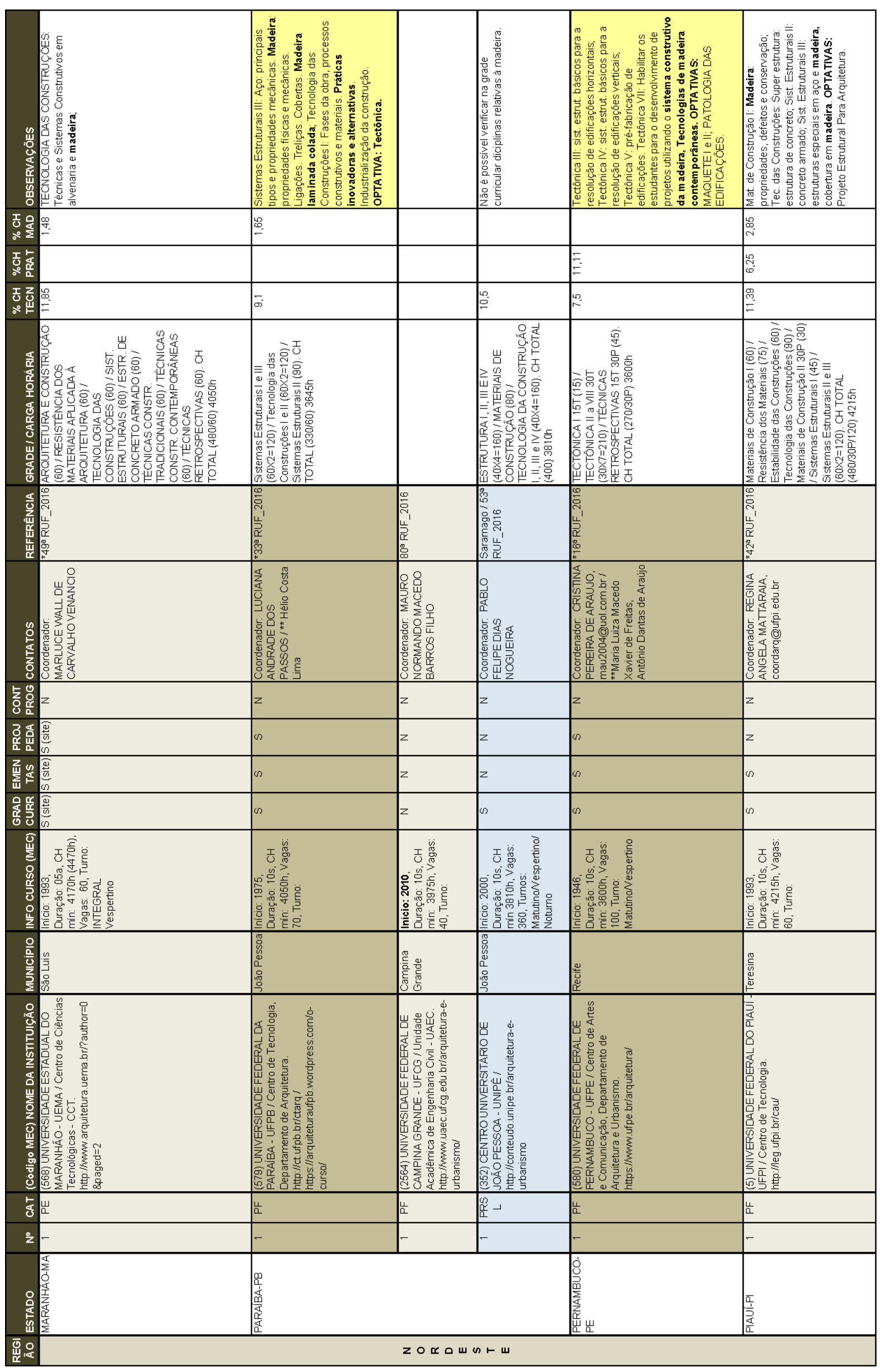




\begin{tabular}{|c|c|c|c|c|c|c|c|}
\hline 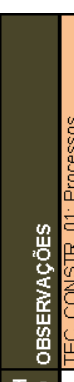 & 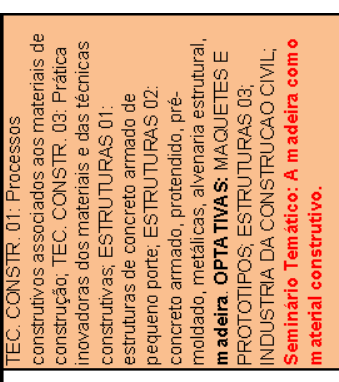 & 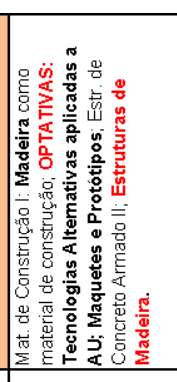 & 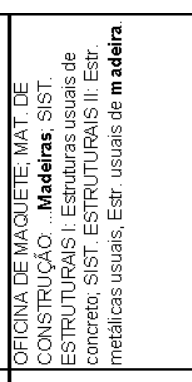 & & 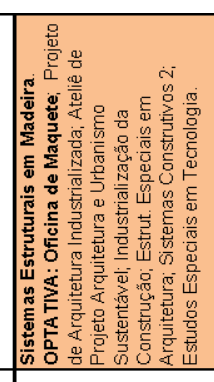 & & 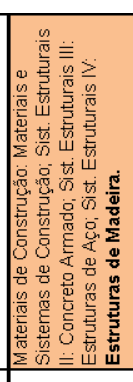 \\
\hline 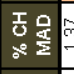 & & 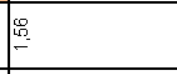 & 嚁 & & 里 & 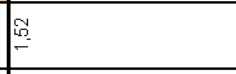 & 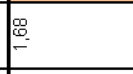 \\
\hline 75 & & & & & & & \\
\hline 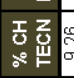 & 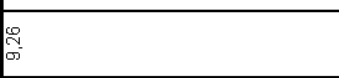 & 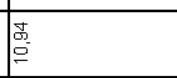 & 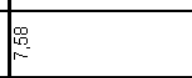 & & 底 & 悉 & 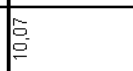 \\
\hline 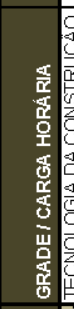 & 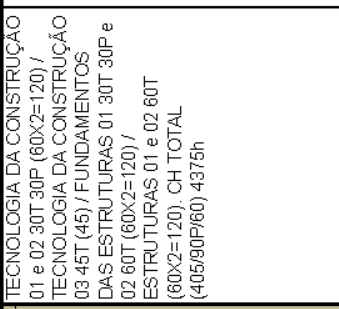 & 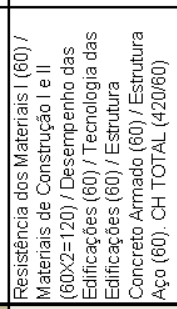 & 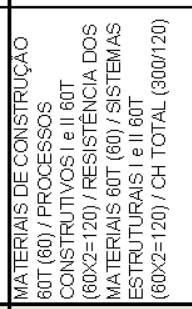 & & 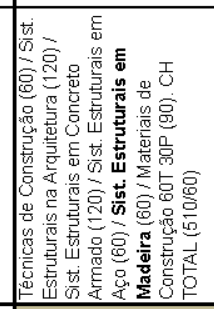 & 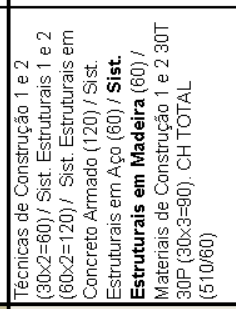 & 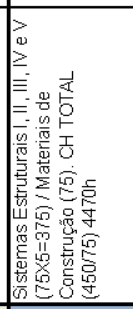 \\
\hline 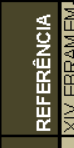 & 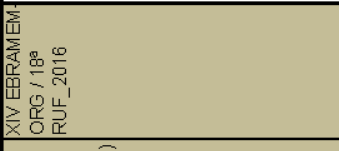 & & 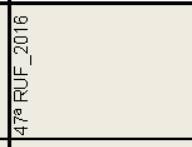 & & 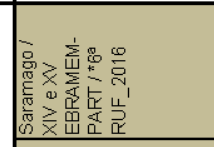 & 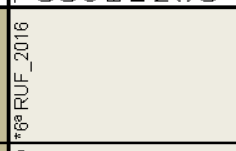 & 宸 \\
\hline 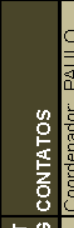 & 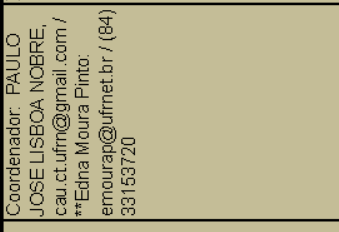 & 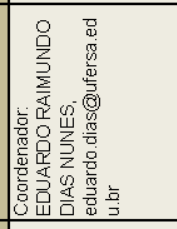 & 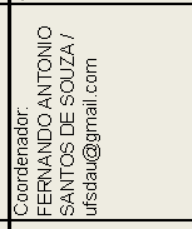 & & 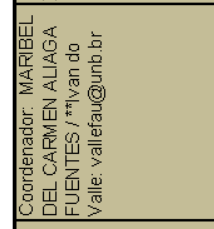 & 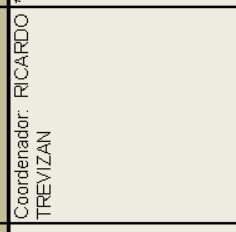 & 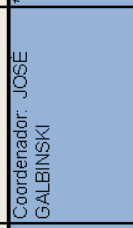 \\
\hline $\begin{array}{ll} \\
\\
0 \\
0 \\
0\end{array}$ & & $z$ & $z$ & & $z$ & $z$ & $z$ \\
\hline 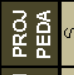 & & $\infty$ & $z$ & & $z$ & $z$ & $z$ \\
\hline 篦过 & $0 \frac{\bar{g}}{30}$ & $\infty$ & $\infty \frac{\bar{g}}{3}$ & & $z$ & $z$ & 的営 \\
\hline 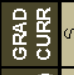 & 的璦 & $\infty$ & 的獣 & & 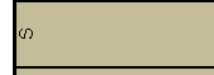 & $\infty$ & $\infty$ \\
\hline 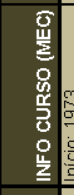 & 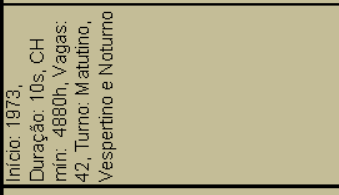 & 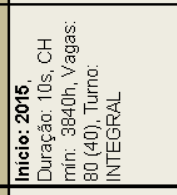 & 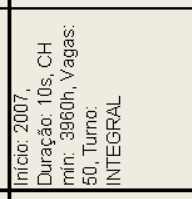 & & 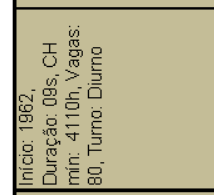 & 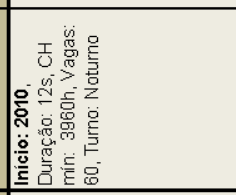 & 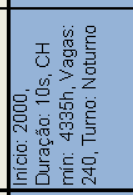 \\
\hline $\begin{array}{l}\frac{0}{\frac{0}{0}} \\
\frac{0}{2} \\
\frac{2}{2}\end{array}$ & & 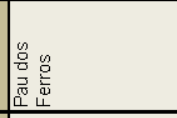 & 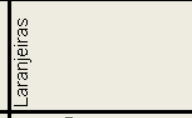 & & 悉 & 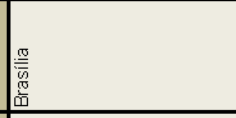 & 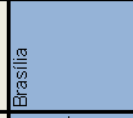 \\
\hline 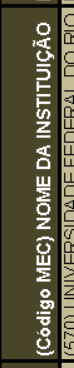 & 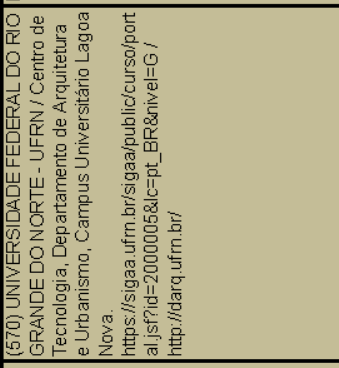 & 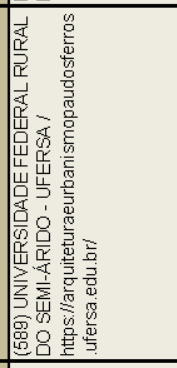 & 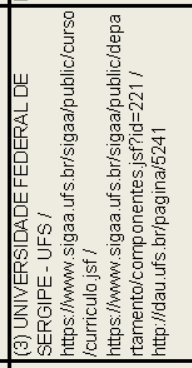 & & 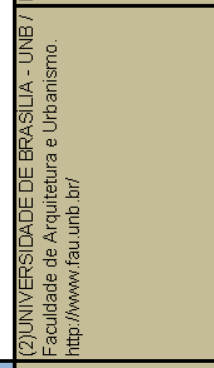 & 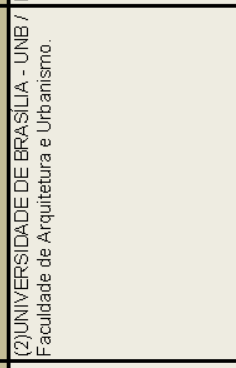 & 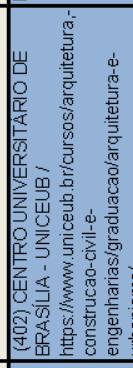 \\
\hline 占㟧 & & 㟧 & 㟧 & \begin{tabular}{|l|l|l|l|l|}
2 & $\alpha$ & 2 \\
\end{tabular} & 4 & 㟧 & 造 \\
\hline 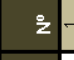 & & I- & $E$ & $\div a+$ & $E$ & I & $E$ \\
\hline $\begin{array}{l}1 \\
\\
0\end{array}$ & 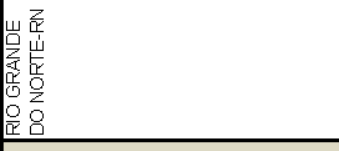 & & 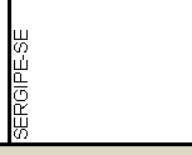 & \multirow{2}{*}{ 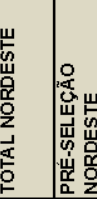 } & \multirow{2}{*}{ 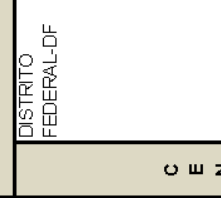 } & & \\
\hline 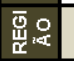 & & யのトய & & & & & \\
\hline
\end{tabular}




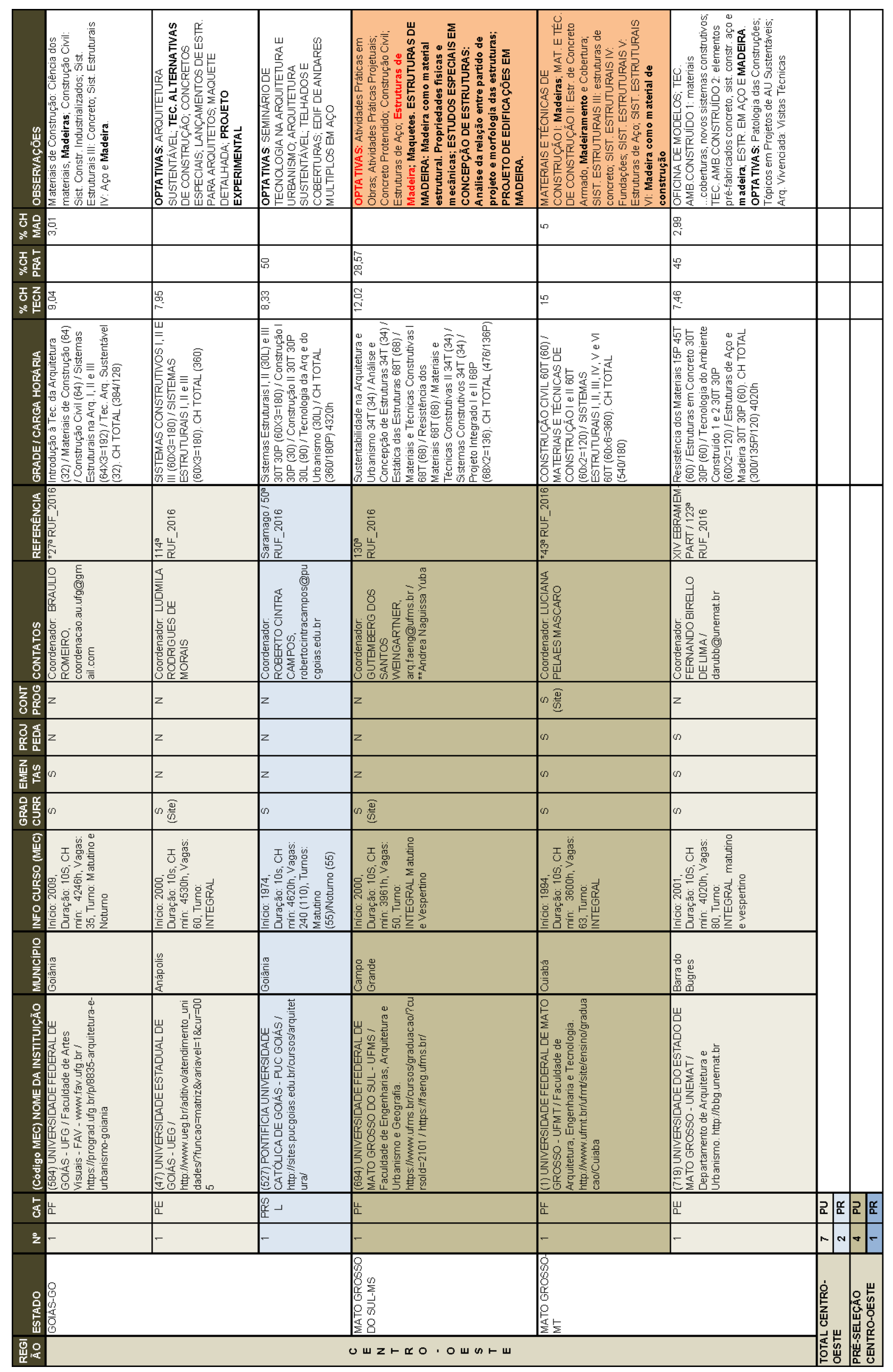




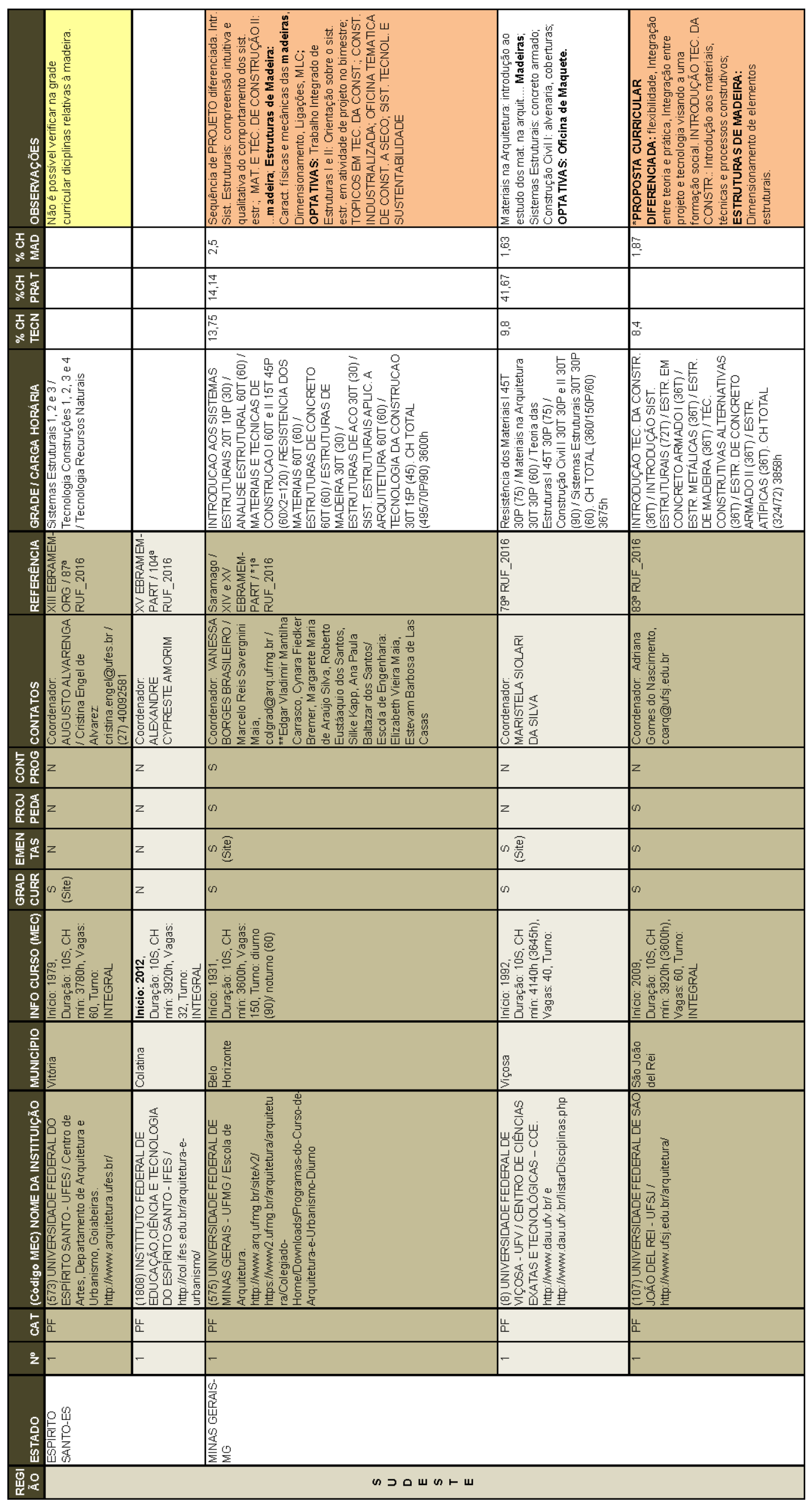




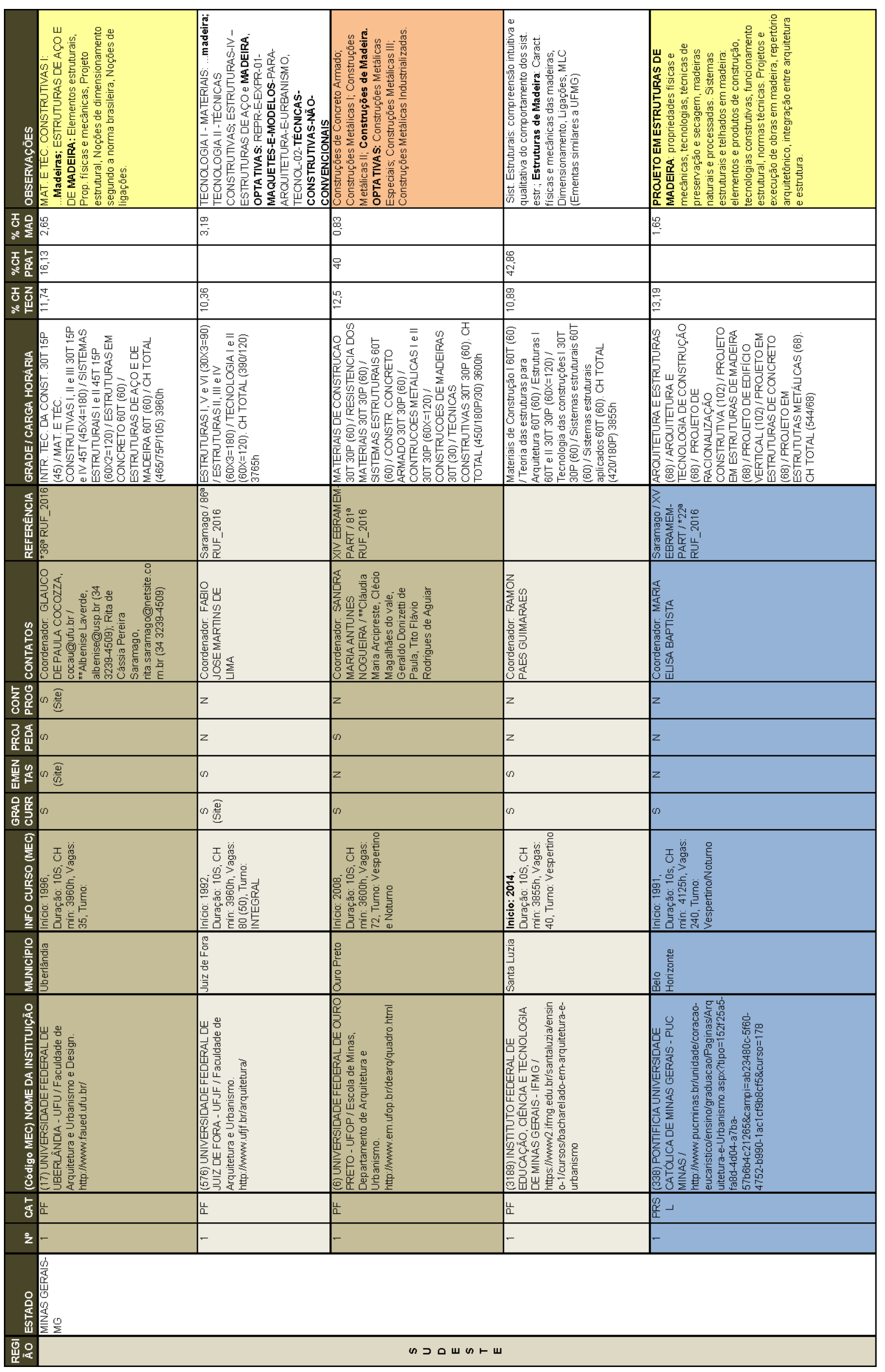




\begin{tabular}{|c|c|c|c|c|c|}
\hline 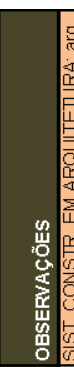 & 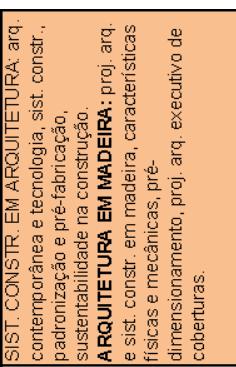 & 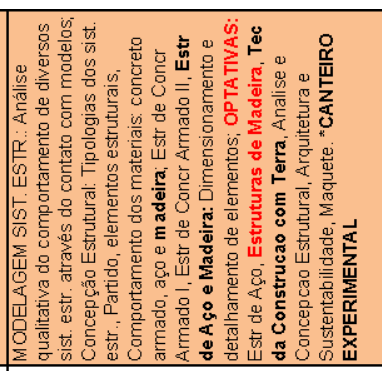 & 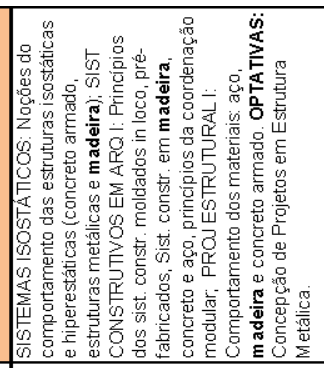 & 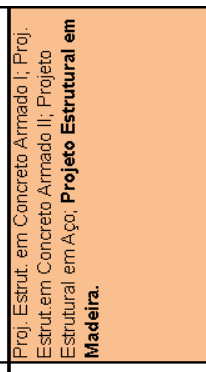 & 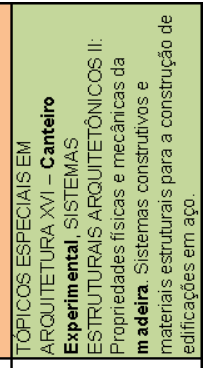 \\
\hline \begin{tabular}{l|l|r}
$\frac{T}{0}$ \\
0 \\
0
\end{tabular} & & 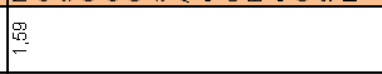 & $\frac{9}{5}$ & 象 & $\overline{1}$ \\
\hline 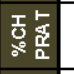 & & 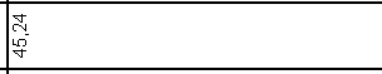 & 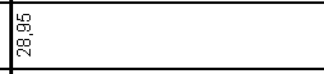 & 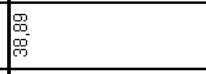 & \\
\hline \begin{tabular}{ll}
\multicolumn{1}{|c}{$z_{0}$} \\
입
\end{tabular} & & 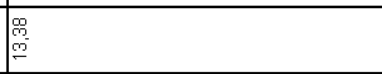 & 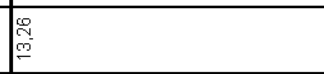 & $\frac{O}{2}$ & is \\
\hline 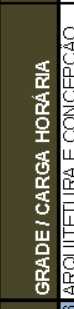 & 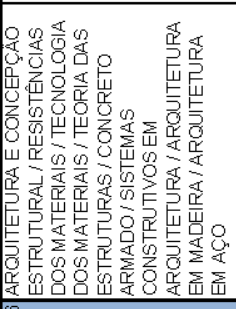 & 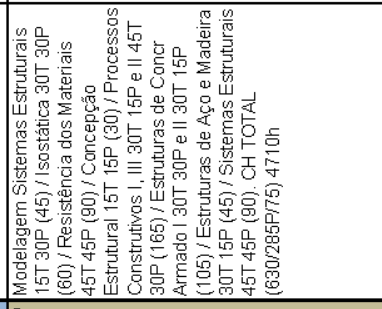 & 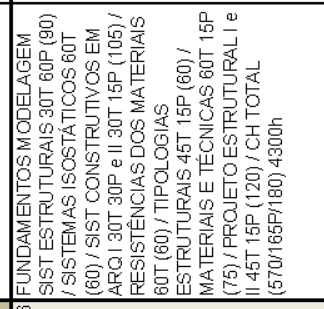 & 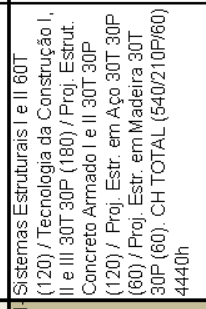 & 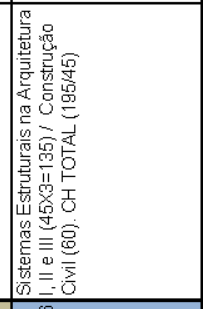 \\
\hline 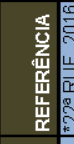 & & 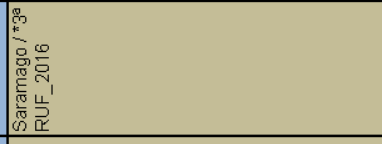 & 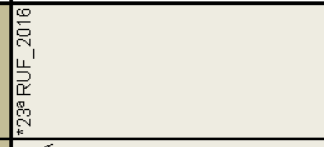 & & 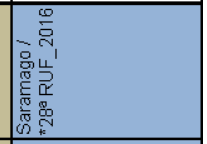 \\
\hline 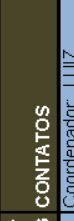 & & 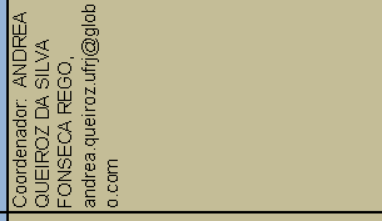 & 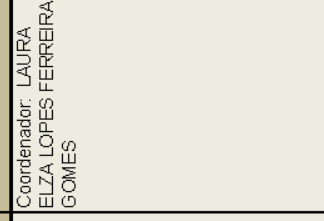 & 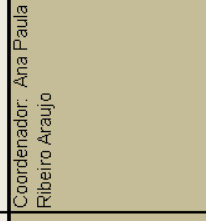 & 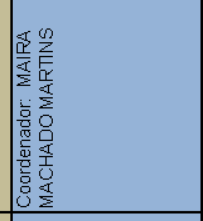 \\
\hline $\begin{array}{ll} \\
50 \\
0\end{array}$ & $z$ & क事 & $z$ & $z$ & $z$ \\
\hline 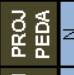 & & $z$ & $z$ & $\infty$ & $z$ \\
\hline 爵造 & $0 \frac{9}{0}$ & 的临 & $\infty \overline{\frac{9}{3}}$ & z & $\infty$ \\
\hline 要 & & $\infty$ & $\infty$ & $\infty$ & $\infty$ \\
\hline 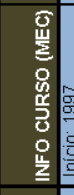 & 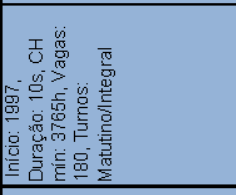 & 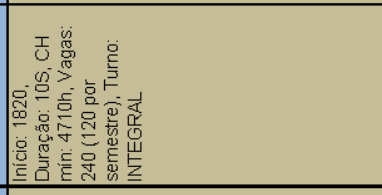 & 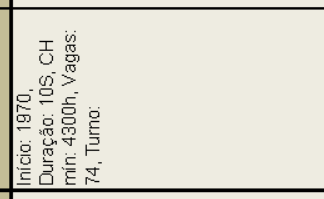 & 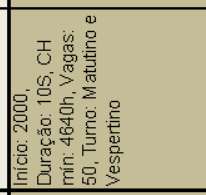 & 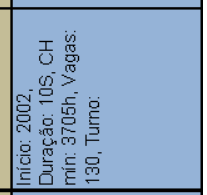 \\
\hline 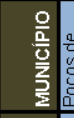 & 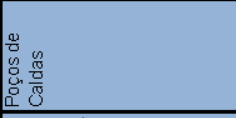 & 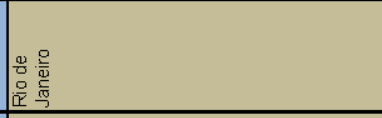 & 就 & 遂 & 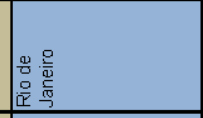 \\
\hline 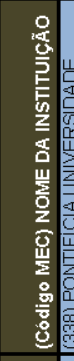 & 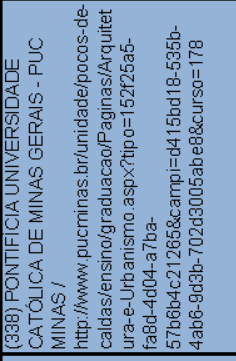 & 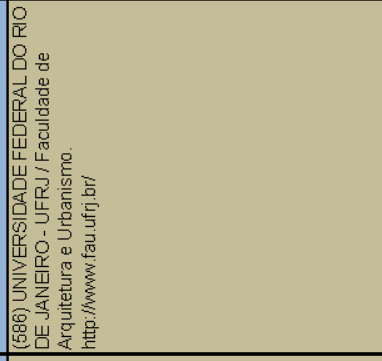 & 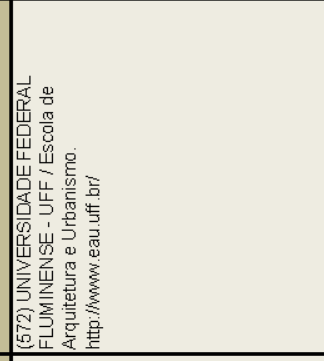 & 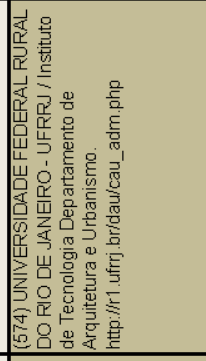 & 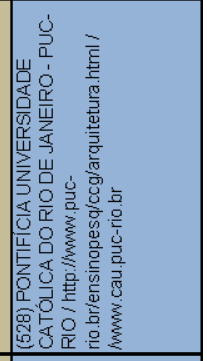 \\
\hline 5 & 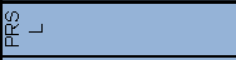 & 娄 & 㟧 & ث & 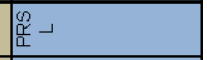 \\
\hline$\approx-$ & & - & I & $E$ & I \\
\hline & & 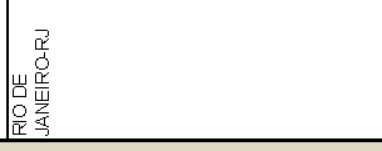 & & & \\
\hline 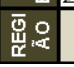 & \multicolumn{5}{|c|}{ のつロயのトய } \\
\hline
\end{tabular}




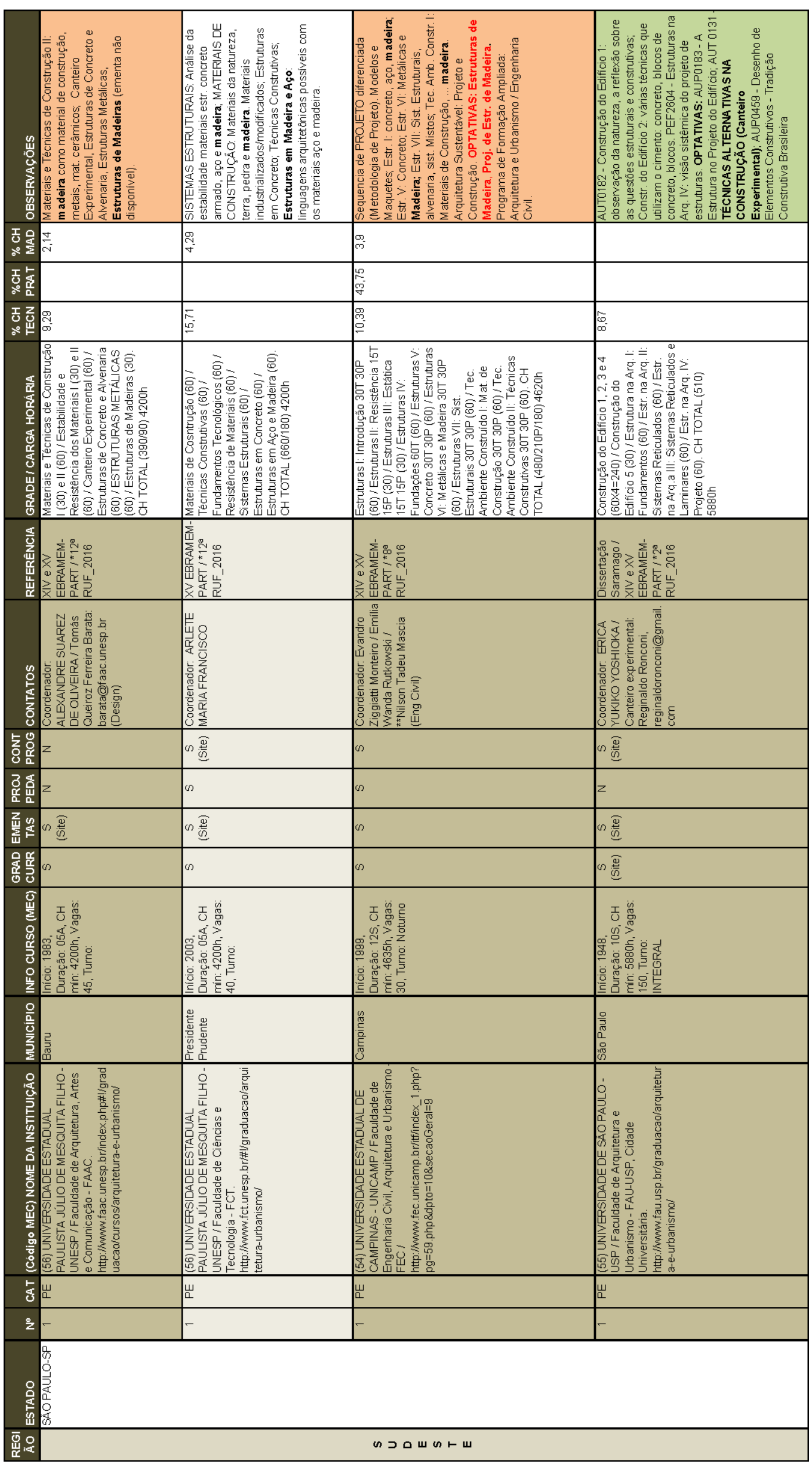




\begin{tabular}{|c|c|c|c|c|c|}
\hline & 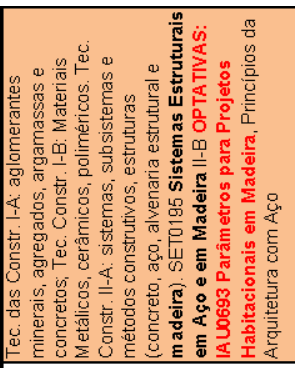 & 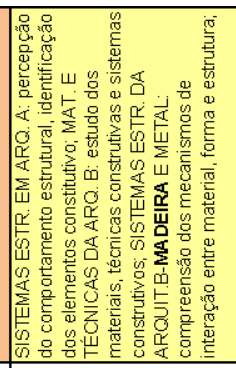 & 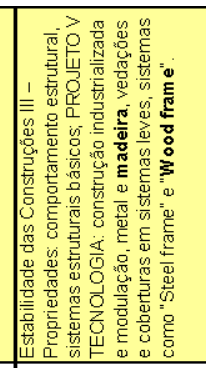 & 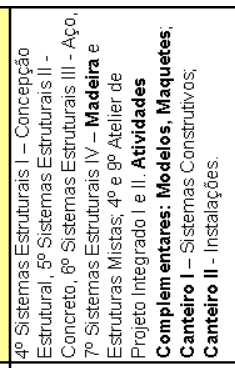 & 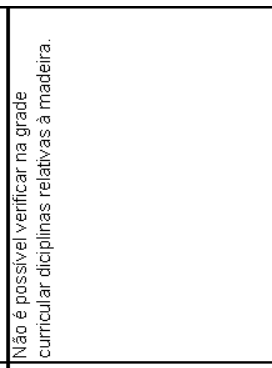 \\
\hline 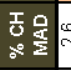 & & 类 & & $\begin{array}{ll}9 \\
0 \\
0\end{array}$ & \\
\hline \begin{tabular}{ll}
\multicolumn{1}{c}{$\frac{}{\mathrm{f}}$} \\
0
\end{tabular} & & & & & \\
\hline 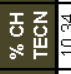 & & $\begin{array}{l}\text { 兽 } \\
\end{array}$ & $\begin{array}{c}\approx \\
\vdots \\
\infty\end{array}$ & 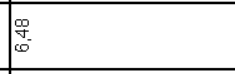 & 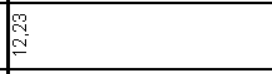 \\
\hline 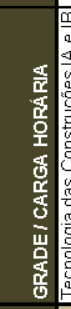 & 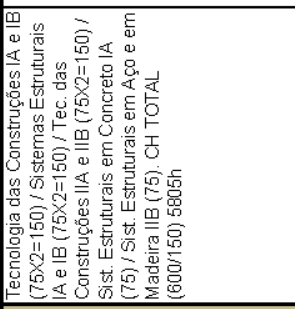 & 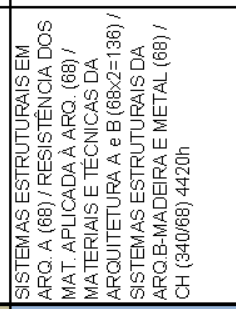 & 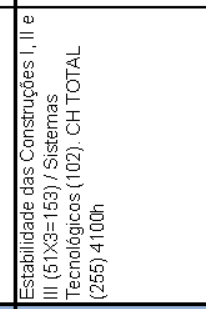 & 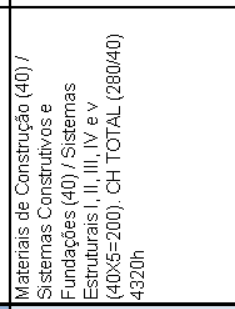 & 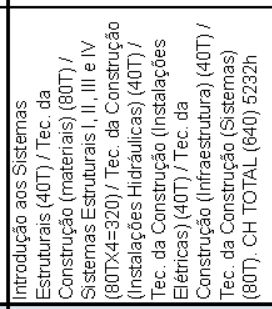 \\
\hline 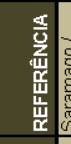 & 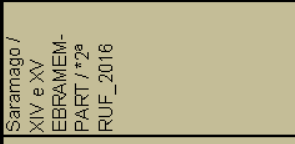 & 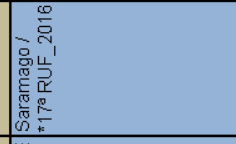 & 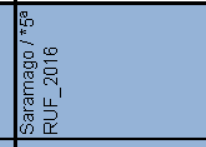 & 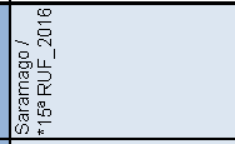 & 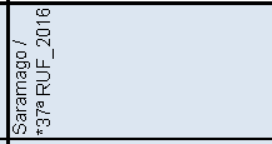 \\
\hline & 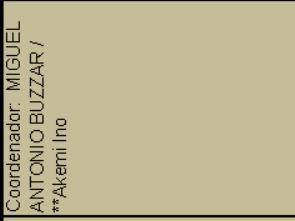 & 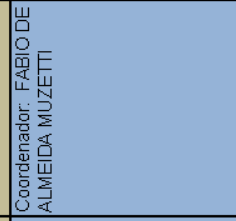 & 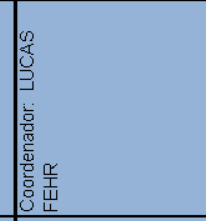 & 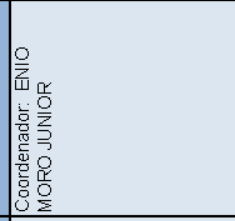 & 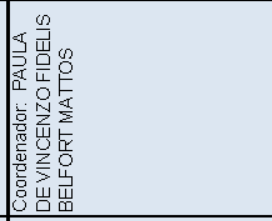 \\
\hline $\begin{array}{ll}5 \\
50 \\
0 \\
0\end{array}$ & 的璦 & $z$ & $\omega$ & $z$ & $z$ \\
\hline 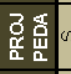 & 的璦 & $z$ & $\infty$ & $z$ & $z$ \\
\hline 覓题 & $\omega \frac{\widehat{Q}}{00}$ & $\infty$ & os & $z$ & $z$ \\
\hline 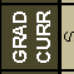 & & $\infty$ & $\infty$ & $\infty$ & $\infty$ \\
\hline 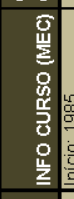 & 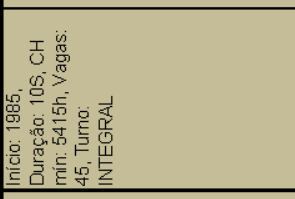 & 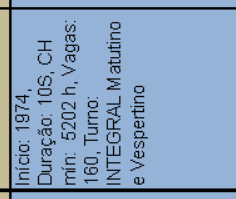 & 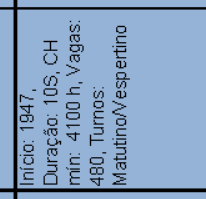 & 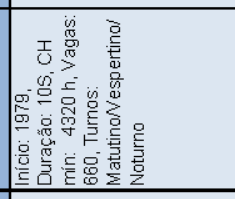 & 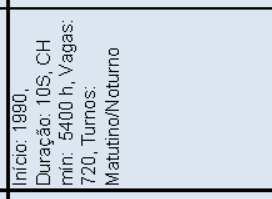 \\
\hline 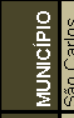 & & 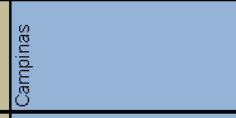 & 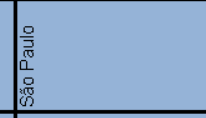 & 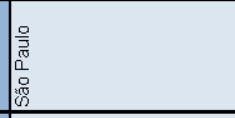 & 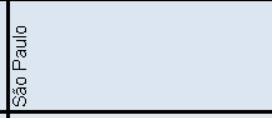 \\
\hline 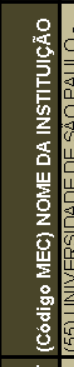 & 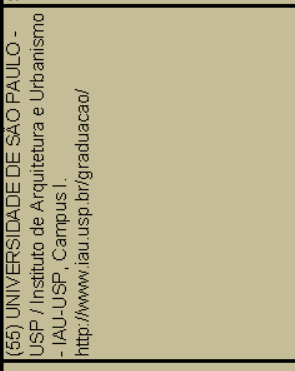 & 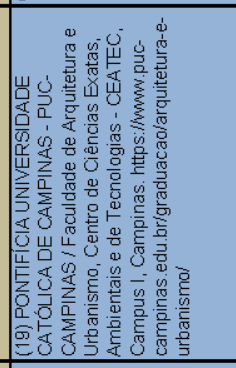 & 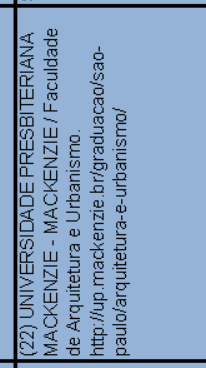 & 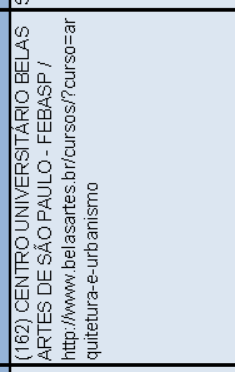 & 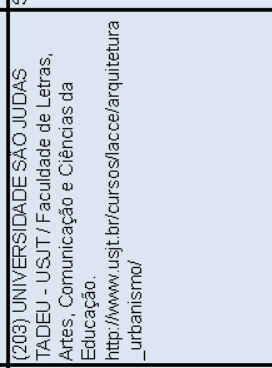 \\
\hline 5 & 世 & 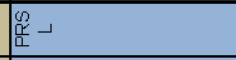 & 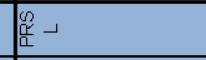 & 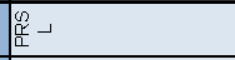 & $\frac{\alpha}{\alpha}+$ \\
\hline$£$ & & - & $E$ & E & - \\
\hline 这 & & & & & \\
\hline 䊲这 & \multicolumn{5}{|c|}{ のつロயのトய } \\
\hline
\end{tabular}




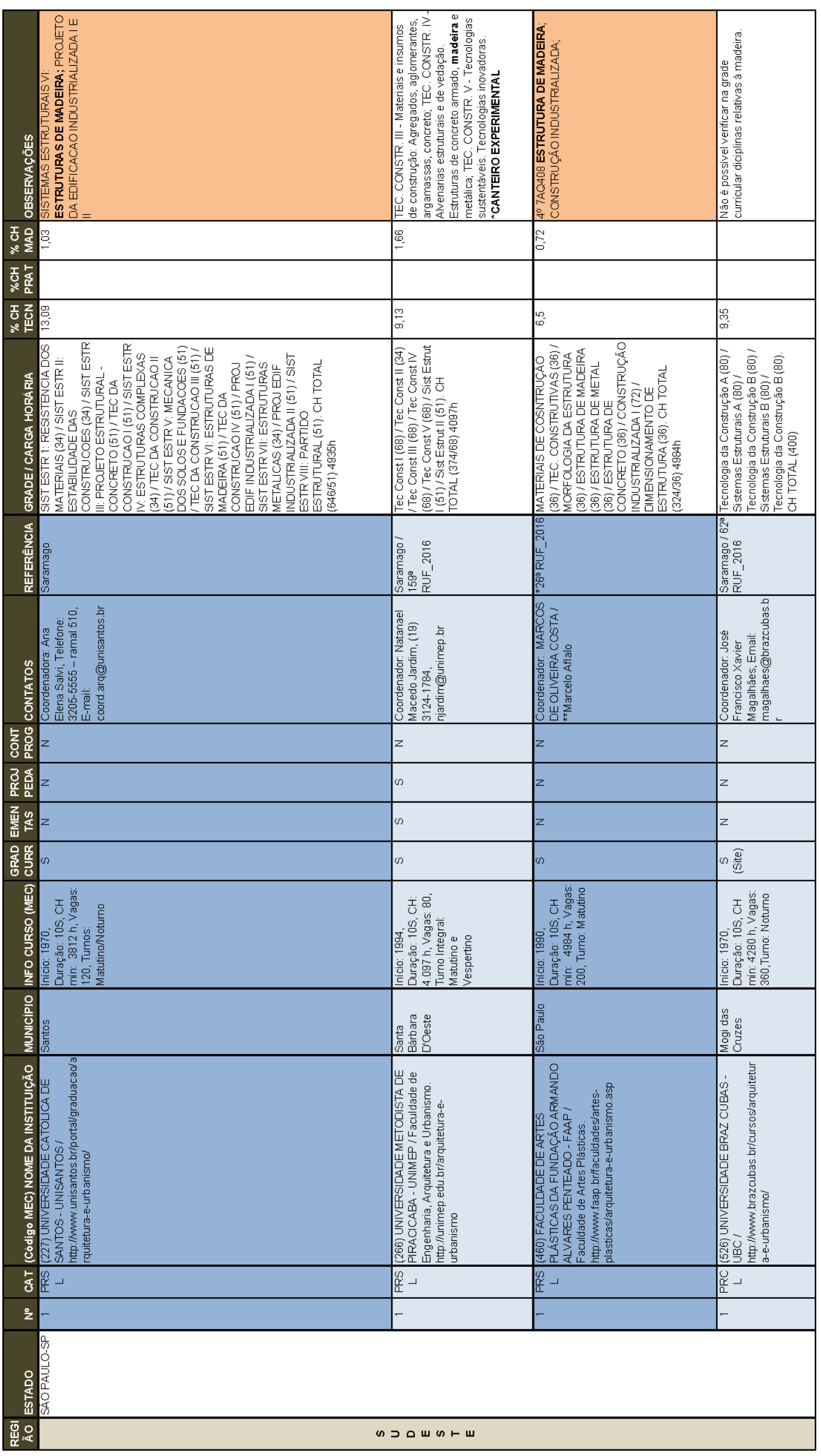




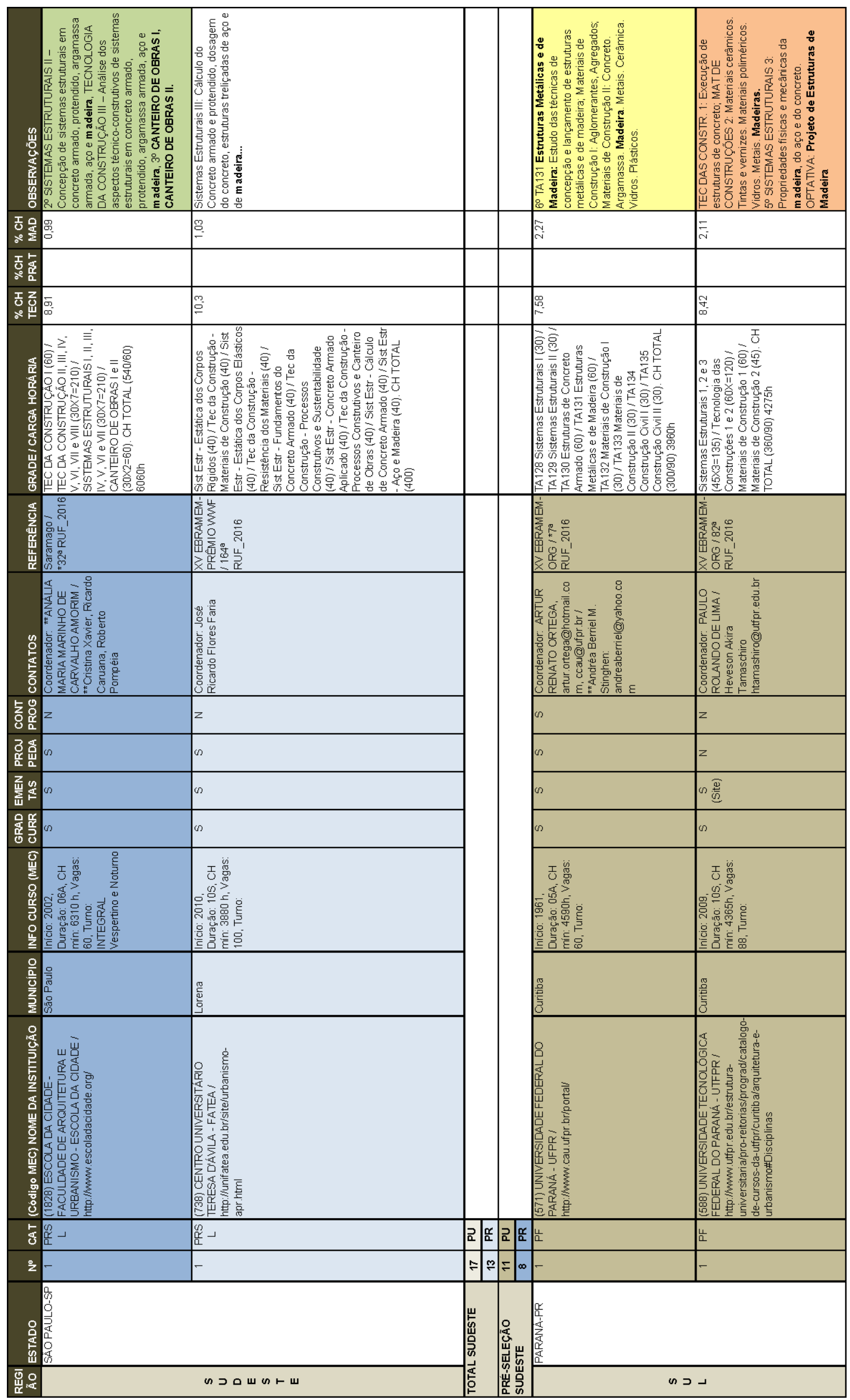




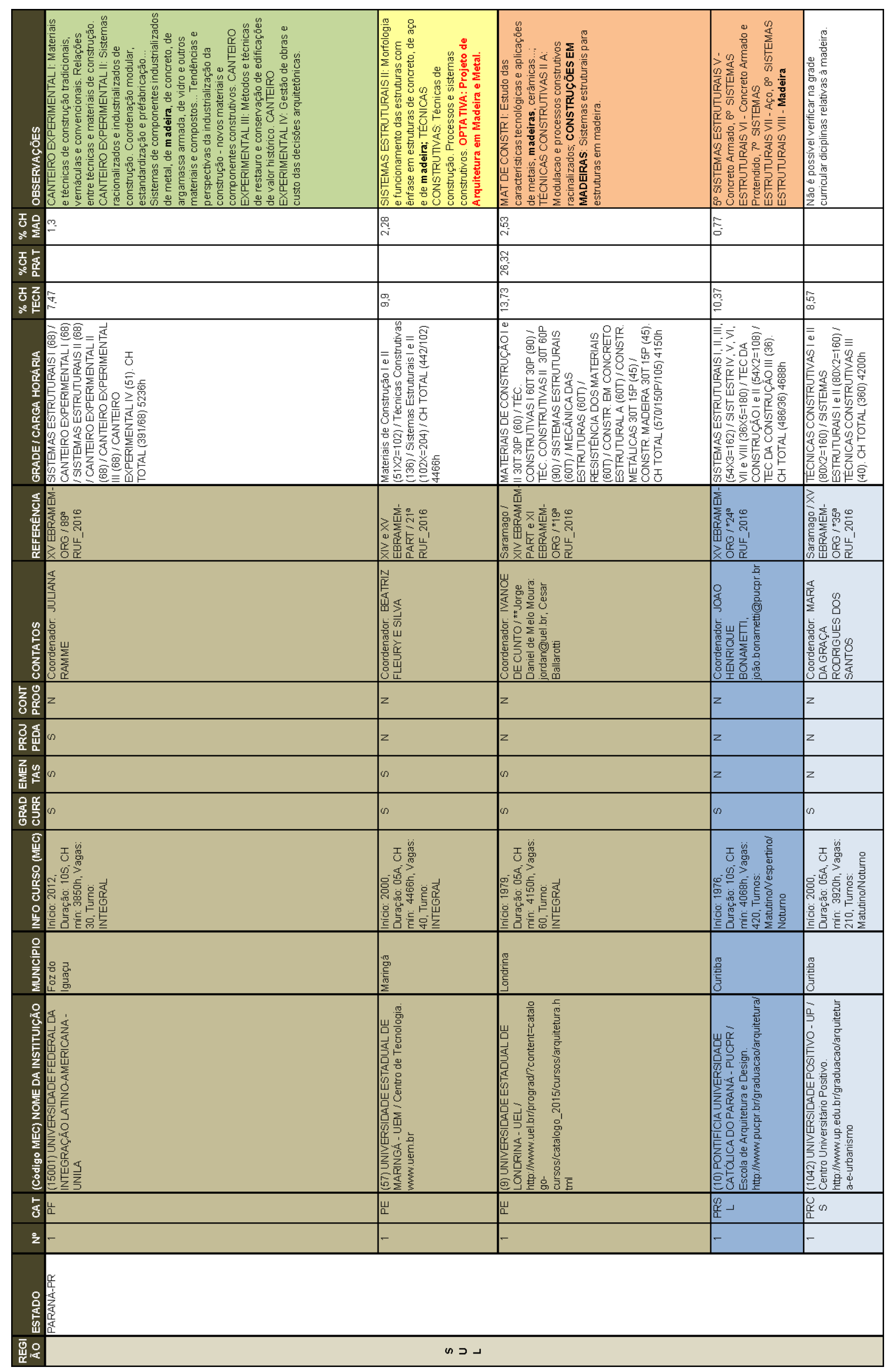




\begin{tabular}{|c|c|c|c|c|c|}
\hline 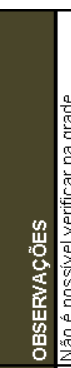 & 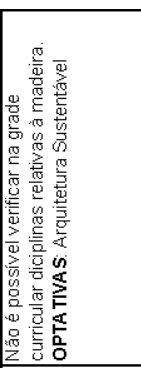 & 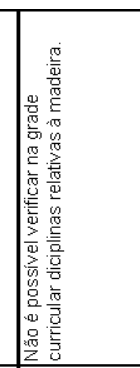 & 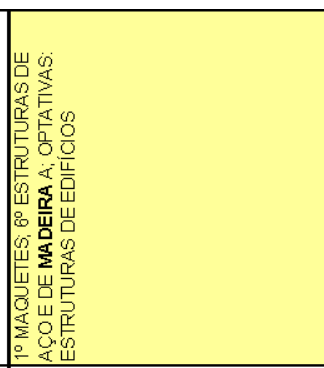 & 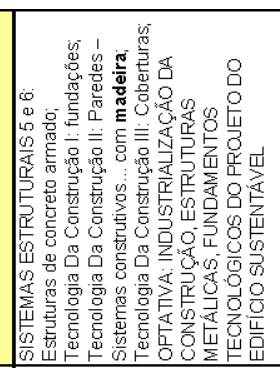 & 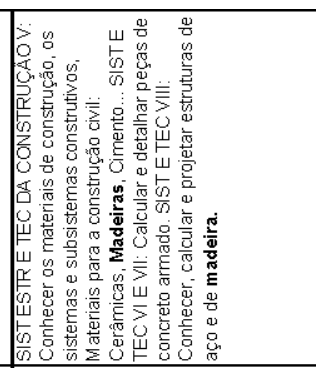 \\
\hline$\frac{T}{0} \frac{1}{2}$ & & & 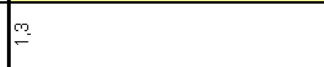 & $\Xi$ & 的 \\
\hline 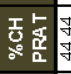 & & & & & \\
\hline 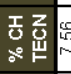 & & & $\simeq$ & $\begin{array}{l}g \\
\end{array}$ & 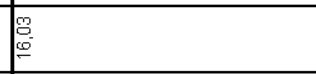 \\
\hline 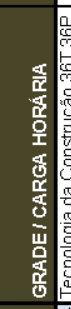 & 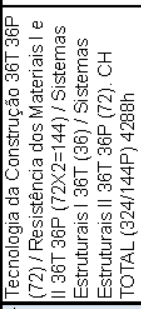 & 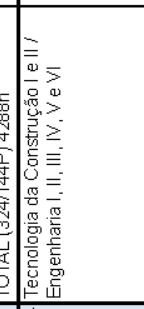 & 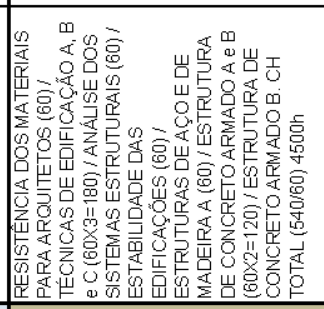 & 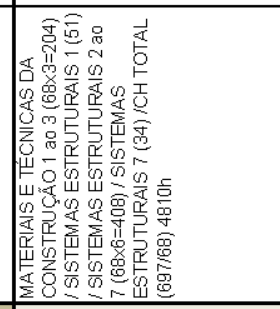 & 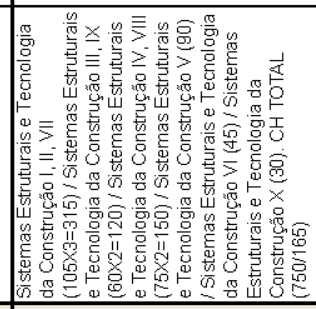 \\
\hline & 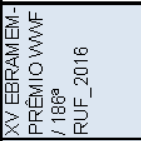 & 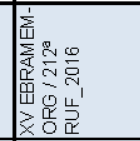 & 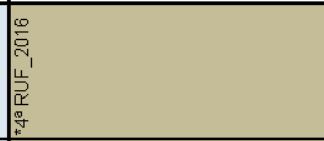 & 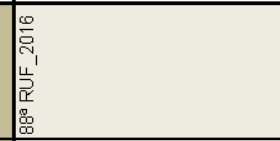 & 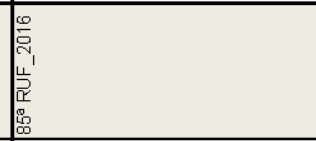 \\
\hline & 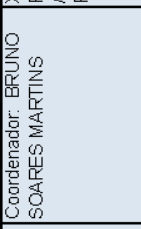 & 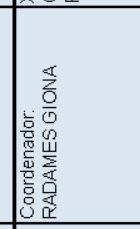 & 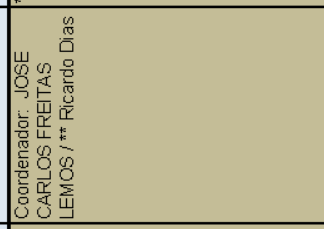 & 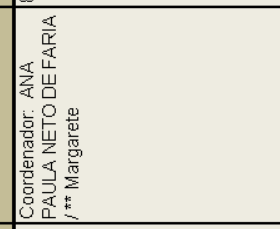 & 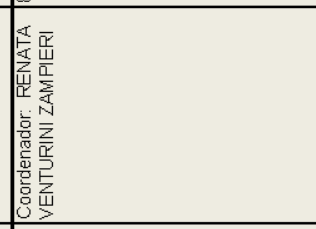 \\
\hline 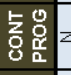 & $z$ & $z$ & $z$ & $z$ & $\infty$ \\
\hline 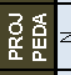 & & $z$ & $z$ & $\infty$ & $z$ \\
\hline 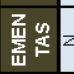 & & $z$ & $z$ & $\cos \frac{\overline{8}}{0}$ & $\infty$ \\
\hline 号总 & & $\infty$ & $\infty$ & $\infty$ & $\infty$ \\
\hline 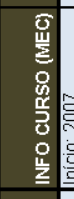 & 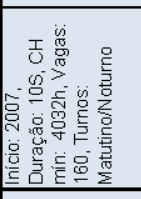 & 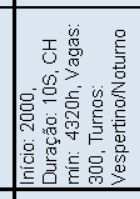 & 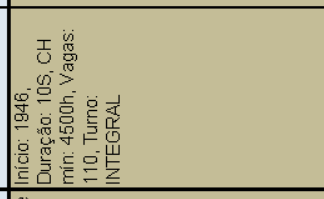 & 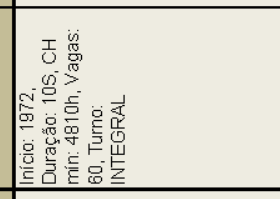 & 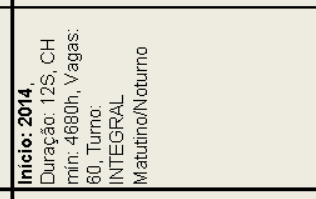 \\
\hline 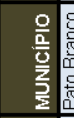 & & 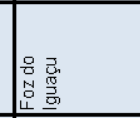 & 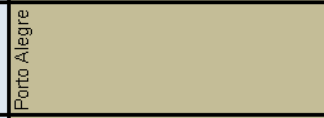 & 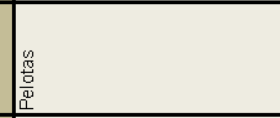 & 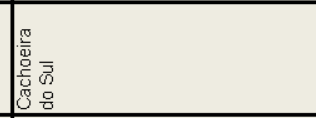 \\
\hline 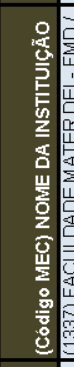 & 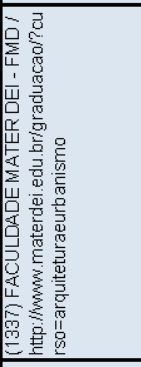 & 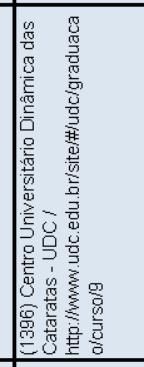 & 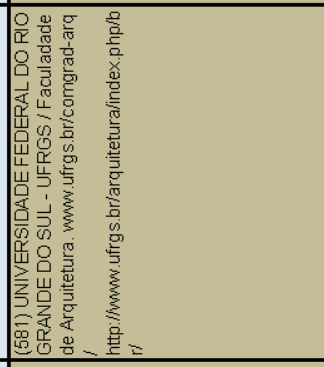 & 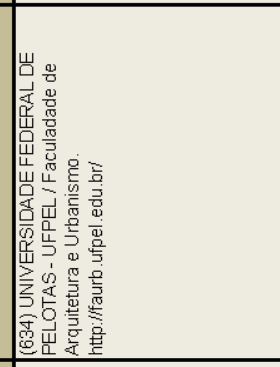 & 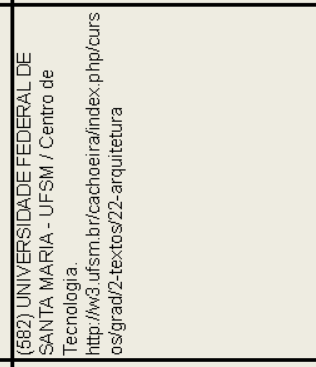 \\
\hline 歌 & $\begin{array}{l} \\
\end{array}$ & 酋」 & 㟧 & 茫 & 茫 \\
\hline$\approx$ & & I & - & I & \pm \\
\hline 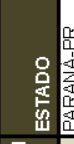 & & & \multicolumn{3}{|c|}{ 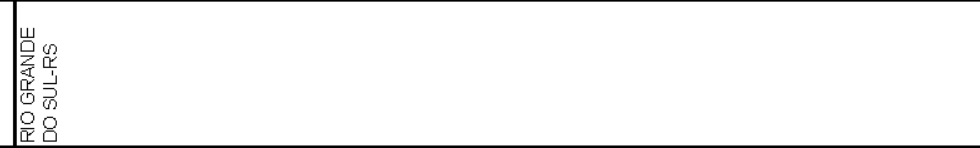 } \\
\hline 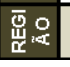 & \\
\hline
\end{tabular}




\begin{tabular}{|c|c|c|c|c|c|c|}
\hline & 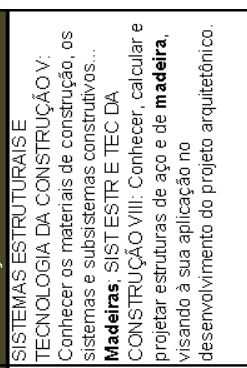 & 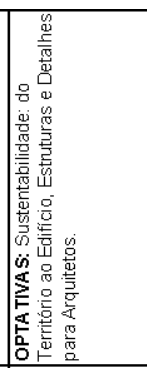 & 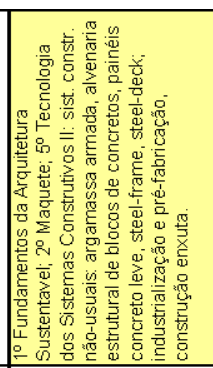 & 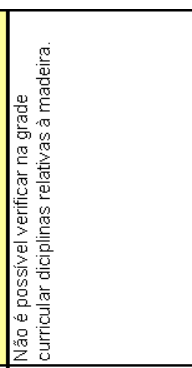 & 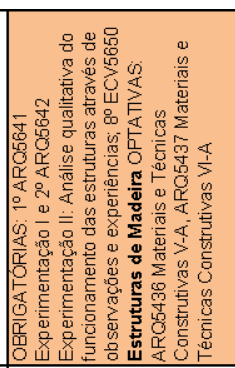 & 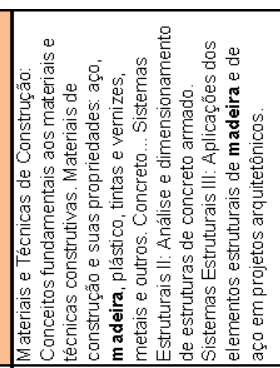 \\
\hline $\begin{array}{ll}\tau & 0 \\
0 & 0\end{array}$ & & & & & & $\underset{\sim}{2}$ \\
\hline 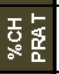 & & & & & & \\
\hline 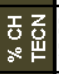 & & 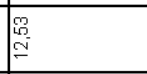 & 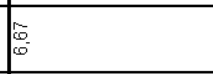 & & 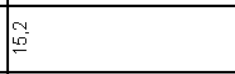 & $\infty$ \\
\hline & 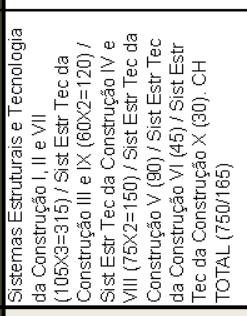 & 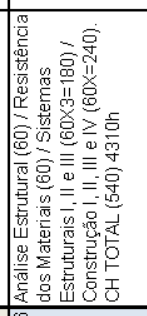 & 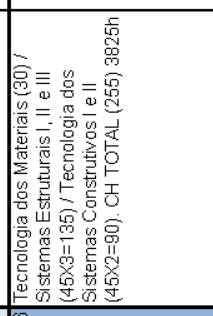 & 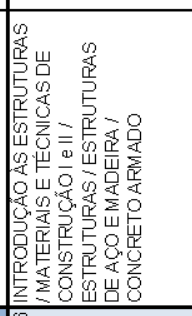 & 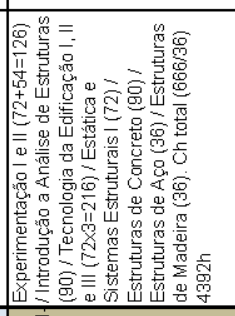 & 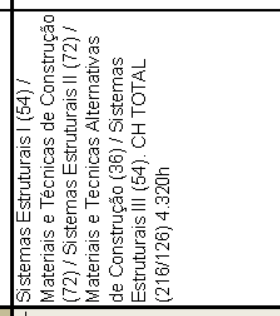 \\
\hline 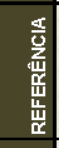 & & 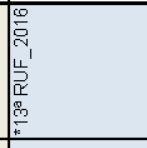 & 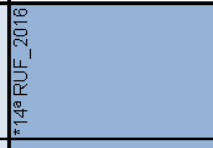 & 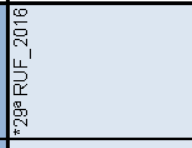 & 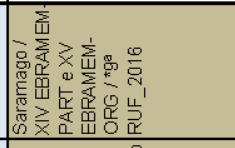 & 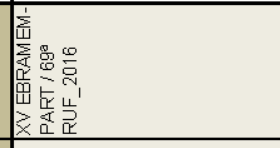 \\
\hline & & 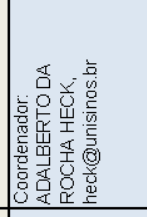 & 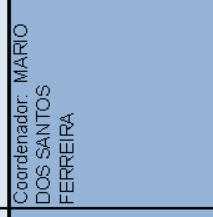 & 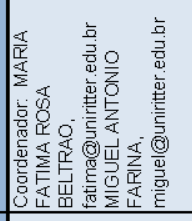 & 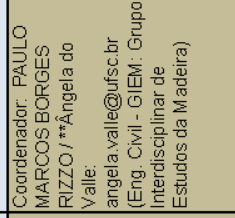 & 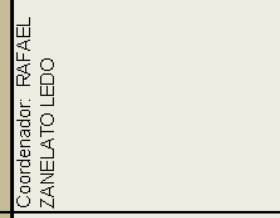 \\
\hline $\begin{array}{l}50 \\
\end{array}$ & $\omega_{0} \frac{\bar{s}}{\frac{9}{6}}$ & $z$ & $z$ & $z$ & $\infty$ & $z$ \\
\hline 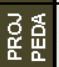 & & z & $z$ & z & $z$ & $\infty$ \\
\hline 睡踪 & $\operatorname{si\frac {9}{0}}$ & $z$ & $\infty$ & $z$ & $\infty$ & $\infty$ \\
\hline $\begin{array}{ll}0 \\
\end{array}$ & $0 \frac{\sqrt{6}}{60}$ & $\infty$ & $\infty$ & 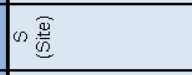 & $\infty$ & $\infty$ \\
\hline 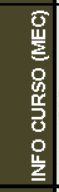 & 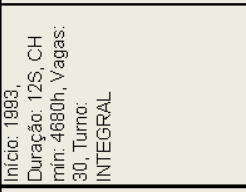 & 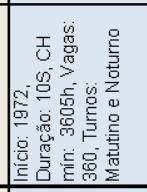 & 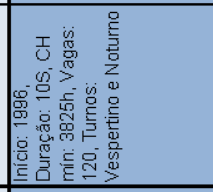 & 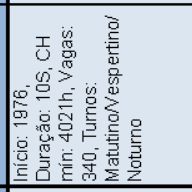 & 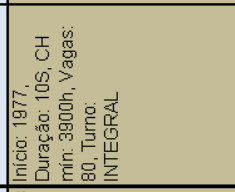 & 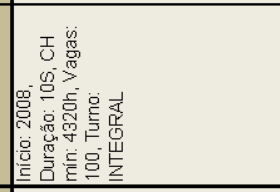 \\
\hline \begin{tabular}{l|l}
$\frac{0}{\frac{0}{0}}$ \\
$\frac{\mathrm{c}}{2}$ \\
$\frac{2}{2}$
\end{tabular} & & 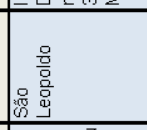 & 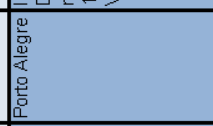 & 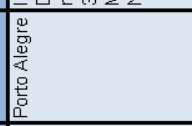 & 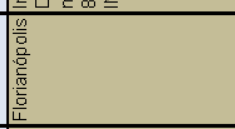 & $\mid$ \\
\hline 웅 & 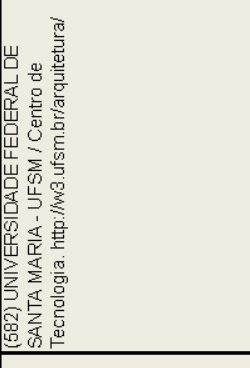 & 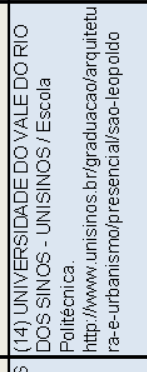 & 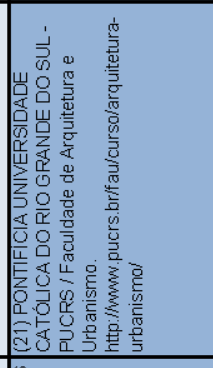 & 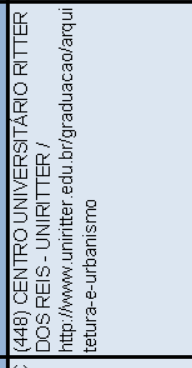 & 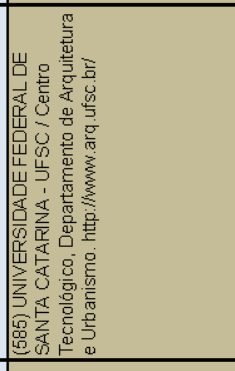 & 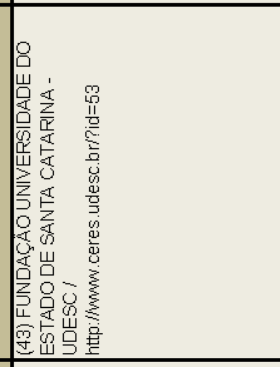 \\
\hline 8 & & 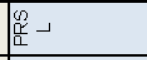 & 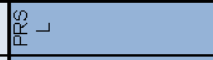 & $\begin{array}{l} \\
\end{array}$ & 㟧 & ш \\
\hline 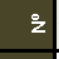 & & - & \pm & I & - & $E$ \\
\hline & 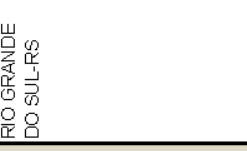 & & & & 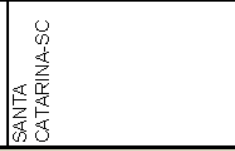 & \\
\hline 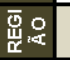 & & & & ڤ & & \\
\hline
\end{tabular}




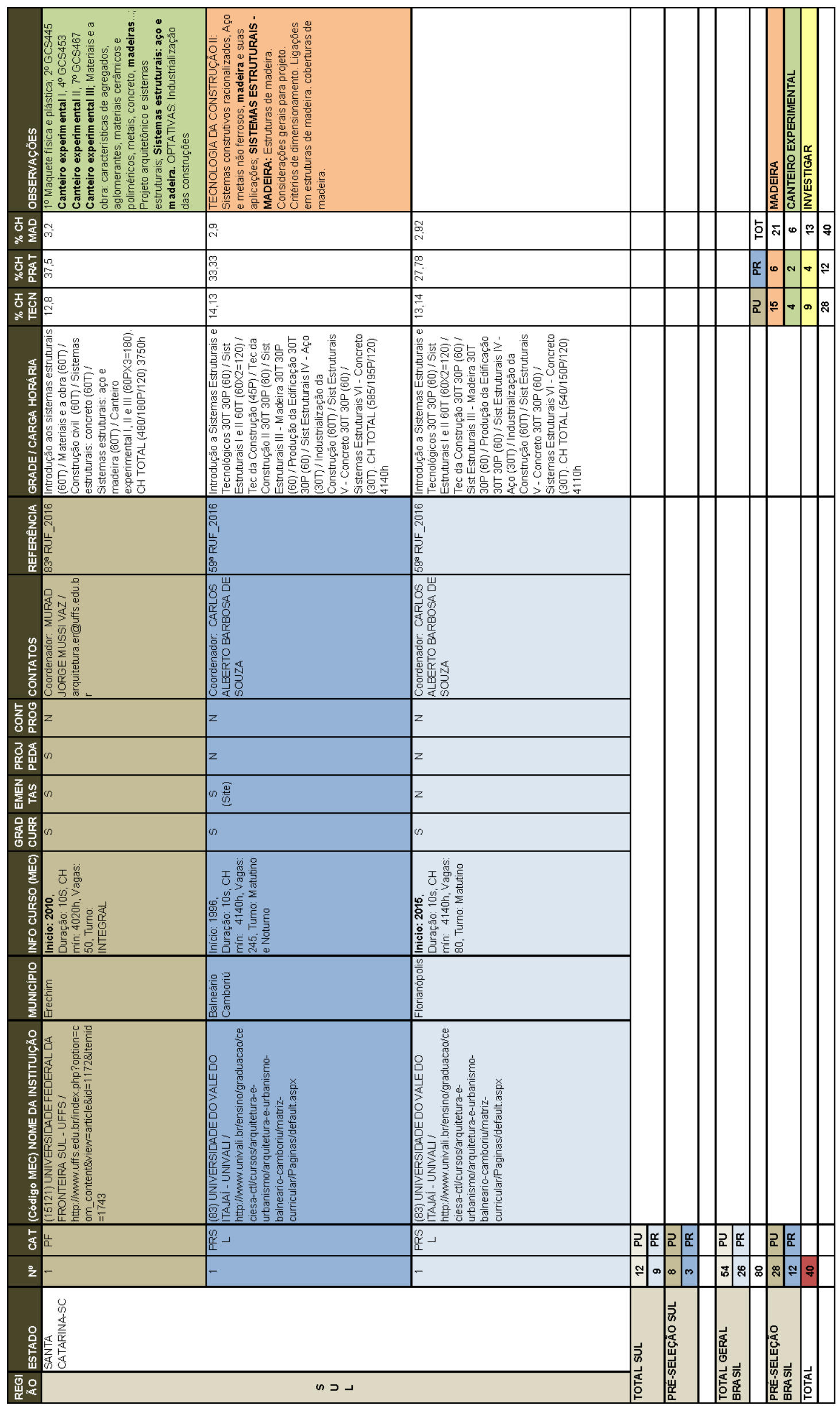


ANEXO A: Conteúdos programáticos referentes à madeira nas disciplinas da área de Tecnologia dos cursos de Arquitetura e Urbanismo do Brasil

Fonte: Sites das Instituições de Ensino Superior (IES). Levantamento realizado entre dezembro de 2016 e abril de 2017. Elaborado pela autora.

1. UNIVERSIDADE FEDERAL DO AMAPÁ - UNIFAP

2. UNIVERSIDADE FEDERAL DE PERNAMBUCO - UFPE

3. UNIVERSIDADE FEDERAL DE MATO GROSSO - UFMT

4. UNIVERSIDADE FEDERAL DE MINAS GERAIS - UFMG

5. UNIVERSIDADE FEDERAL DE UBERLÂNDIA - UFU

6. UNIVERSIDADE ESTADUAL PAULISTA JÚLIO DE MESQUITA FILHO - UNESP

7. UNIVERSIDADE ESTADUAL DE CAMPINAS - UNICAMP

8. UNIVERSIDADE DE SÃO PAULO - USP

9. UNIVERSIDADE PRESBITERIANA MACKENZIE

10. UNIVERSIDADE FEDERAL DO PARANÁ - UFPR

11. UNIVERSIDADE FEDERAL DE SANTA MARIA - UFSM

12. UNIVERSIDADE FEDERAL DE SANTA CATARINA - UFSC 


\begin{tabular}{|c|c|}
\hline IES: & UNIVERSIDADE FEDERAL DO AMAPÁ - UNIFAP \\
\hline MUNICÍPIO: & Santana \\
\hline DOC/DATA: & Projeto Político Pedagógico 2008 \\
\hline DISCIPLINA: & AU1409 - SISTEMAS ESTRUTURAIS II (4º período) \\
\hline CH/CRED: & $45 \mathrm{~T} / 15 \mathrm{P}=60$ horas (04 créditos) \\
\hline EMENTA: & $\begin{array}{l}\text { Conceitos básicos sobre os sistemas estruturais mais usados nas } \\
\text { estruturas de concreto armado: aço e madeira. Dimensionar detalhar e } \\
\text { interpretar projetos estruturais de edificações de pequeno porte em } \\
\text { concreto armado. }\end{array}$ \\
\hline OBJETIVOS: & $\begin{array}{l}\text { Capacitar o aluno na resolução de problemas referentes aos sistemas } \\
\text { estruturais mais usados nas estruturas de concreto armado: aço e } \\
\text { madeira. Dimensionar, detalhar e interpretar projetos estruturais de } \\
\text { edificações de pequeno porte em concreto armado. }\end{array}$ \\
\hline \multicolumn{2}{|l|}{ CONTEÚDO: } \\
\hline \multicolumn{2}{|c|}{ UNID. I - Introdução: } \\
\hline \multicolumn{2}{|c|}{ 1.1. Estruturas de aço; concreto e madeira: } \\
\hline \multicolumn{2}{|c|}{ 1.1.2. Principais utilizações; } \\
\hline \multicolumn{2}{|c|}{ 1.1.3. Vãos usuais; } \\
\hline \multicolumn{2}{|c|}{ 1.1.4. Seções mais usadas; } \\
\hline \multicolumn{2}{|c|}{ 1.1.5. Vantagens e desvantagens; } \\
\hline \multicolumn{2}{|c|}{ UNID. II - Estruturas de concreto armado: } \\
\hline \multicolumn{2}{|c|}{ 2.1. Generalidades; } \\
\hline \multicolumn{2}{|c|}{ 2.2. Estruturas comuns de edifícios; } \\
\hline \multicolumn{2}{|c|}{ 2.3. Regras para a escolha da estrutura de um prédio; } \\
\hline \multicolumn{2}{|c|}{ 2.4. Detalhes construtivos; } \\
\hline \multicolumn{2}{|c|}{ UNID. III - Lajes: } \\
\hline \multicolumn{2}{|c|}{ 3.1. Considerações gerais; } \\
\hline \multicolumn{2}{|c|}{ 3.2. Classificação das lajes; } \\
\hline \multicolumn{2}{|c|}{ 3.2.1. Laje convencional; } \\
\hline \multicolumn{2}{|c|}{ 3.2.2. Lajes especiais: } \\
\hline \multicolumn{2}{|c|}{ 3.2.2.1. Lajes cogumelos; } \\
\hline \multicolumn{2}{|c|}{ 3.2.2.2. Lajes nervuradas; } \\
\hline \multicolumn{2}{|c|}{ 3.2.2.3. Lajes pré-fabricadas; } \\
\hline \multicolumn{2}{|c|}{ 3.2.2.4. Lajes mistas; } \\
\hline \multicolumn{2}{|c|}{ 3.3. Carga por m2 das lajes; } \\
\hline \multicolumn{2}{|c|}{ 3.4. Momentos nas lajes armadas em uma direção; } \\
\hline \multicolumn{2}{|c|}{ 3.4.1. Lajes isoladas; } \\
\hline \multicolumn{2}{|c|}{ 3.4.2. Lajes contínuas; } \\
\hline \multicolumn{2}{|c|}{ 3.5. Momento das lajes em cruz pelo processo de Marcus; } \\
\hline \multicolumn{2}{|c|}{ 3.5.1. lajes isoladas; } \\
\hline \multicolumn{2}{|c|}{ 3.5.2. Lajes contínuas; } \\
\hline
\end{tabular}


3.6. Determinação da espessura das lajes;

3.6.1. Lajes armadas em uma direção;

3.6.2. lajes armadas em cruz;

3.7. Cálculo das flechas para peças sujeitas a cargas uniformemente distribuídas;

3.8. Condições de engastamento;

3.9. Armaduras das lajes;

3.9.1. Diâmetros das barras;

3.9.2. Espaçamentos das barras;

3.9.3. Contrafiamento da ferragem positiva;

3.9.4. Quantidades de ferros;

3.9.5. Armadura de canto;

3.10. Detalhamento das lajes;

UNID, IV - Flexão simples de secções retangulares de concreto armado:

4.1. Estádios no concreto armado;

4.2. Cálculo no Estádio III;

4.3. Aços empregados no concreto armado;

4.4. Tipos de ruptura;

4.5. Fórmulas gerais para o cálculo das secções retangulares com armadura simples no Estádio III.

UNID. V - Vigas:

5.1. Cálculo das cargas nas vigas;

5.2. Cálculo dos esforços nas vigas isostáticas;

5.3. Dimensionamento de vigas;

5.4. Noções de vigas hiperestáticas.

UNID. VI - Cisalhamento:

6.1. Dimensionamento de peças ao cisalhamento;

6.2. Tensão de cisalhamento máxima;

6.3. Tensão de cisalhamento convencional;

6.4. Limites da tensão de cisalhamento;

6.5. Armaduras de cisalhamento.

UNID. VII - Pilares:

7.1. Dimensionamento de pilares de secções retangulares à compressão axial;

7.2. Detalhamento;

UNID. VIII - Fundações:

8.1. Fundações superficiais;

8.1.1. Blocos de concreto ciclópico;

8.1.2. Sapatas;

8.1.3. Alicerce corrido;

8.2. Noções de fundações profundas;

8.2.1. Estacas;

8.2.2. Tubulões; 
UNID. IX - Interpretação de projeto estrutural:

9.1. Interpretação de uma forma estrutural;

9.2. Leitura de plantas de ferragem;

9.3. Formulações de quantitativos de ferragem, forma e concreto;

\section{BIBLIOGRAFIA BÁSICA:}

BOTELHO, Manoel Henrique Campus. Concreto Aramado, Eu Te Amo (Para Arquiteto) Vol. I a VI. Edgard Blucher. São Paulo. 2008.

NASH, William Arthur. Resistência dos Materiais. McGraw-Hill do Brasil. São Paulo. 1982. BEER, Ferdinand Pierre. Resistência dos Materiais. Pearson Mark Book. São Paulo. 1995

\section{BIBLIOGRAFIA COMPLEMENTAR:}

Associação Brasileira de Normas Técnicas. Projeto e Execução de Obras de Concreto Armado. NB - 1. Rio de Janeiro, 1978

FUSCO, Péricles Brasiliense. Estruturas de Concreto: Fundamentos do Projeto Estrutural. São Paulo: McGraw-Hill, 1976.

PFEIL, Walter. Estruturas de Madeira. Rio de Janeiro: Livros Técnicos e Científicos, 1978.

ROCHA, Aderson Moreira da. Novo Curso Prático de Concreto Armado. Rio de Janeiro: Científica, 1978.

SANTOS, Lauro Modesto dos. Cálculo de Concreto Armado. São Paulo: Edgar Blucher, 1977. PFEIL, Walter. Estruturas de Aço, Dimensionamento Prático. Rio de Janeiro: Livros Técnicos e Científicos - 1986.

\begin{tabular}{|c|c|}
\hline DISCIPLINA: & AU1411 - SISTEMAS ESTRUTURAIS III (5º período) \\
\hline CH/CRED: & $45 \mathrm{~T} / 15 \mathrm{P}=60$ horas (04 créditos) \\
\hline EMENTA: & $\begin{array}{l}\text { Conceitos básicos sobre o dimensionamento de projeto com proposição } \\
\text { de estruturas consideradas mistas, como madeira e concreto, verificando } \\
\text { a propriedade e o tipo de material mais adequado e resistente. }\end{array}$ \\
\hline OBJETIVOS: & $\begin{array}{l}\text { Capacitar o aluno na resolução de problemas referentes aos sistemas } \\
\text { estruturais mais usados nas estruturas de madeira e concreto. } \\
\text { Dimensionar, detalhar e interpretar projetos estruturais de edificações de } \\
\text { madeira e concreto. }\end{array}$ \\
\hline \multicolumn{2}{|l|}{ CONTEÚDO: } \\
\hline \multicolumn{2}{|c|}{ UNID. I - Estruturas de madeira e concreto armado } \\
\hline \multicolumn{2}{|c|}{ 1.1. Generalidades; } \\
\hline \multicolumn{2}{|c|}{ 1.2. Estruturas comuns; } \\
\hline \multicolumn{2}{|c|}{ 1.2. Regras para a escolha da estrutura; } \\
\hline \multicolumn{2}{|c|}{ 1.3. Detalhes construtivos; } \\
\hline \multicolumn{2}{|c|}{ UNID. II - Lajes mista de concreto e madeira: } \\
\hline \multicolumn{2}{|c|}{ 2.1. Considerações gerais; } \\
\hline \multicolumn{2}{|c|}{ 2.2. Classificação das lajes; } \\
\hline \multicolumn{2}{|c|}{ 2.3. Laje convencional; } \\
\hline \multicolumn{2}{|c|}{ 2.4 Lajes especiais; } \\
\hline
\end{tabular}


UNID. III - Flexão simples de secções retangulares de concreto armado:

3.1. Estádios no concreto armado;

3.2. Cálculo no Estádio III;

3.3. Aços empregados no concreto armado;

3.4. Tipos de ruptura;

3.5. Fórmulas gerais para o cálculo das secções retangulares com armadura simples no Estádio III.

UNID. IV - Vigas de madeira:

4.1. Cálculo das cargas nas vigas;

4.2. Cálculo dos esforços nas vigas isostásticas;

4.3. Dimensionamento de vigas;

4.4. Noções de vigas hiperestáticas;

UNID. V - Cisalhamento:

5.1. Dimensionamento de peças ao cisalhamento;

5.2. Tensão de cisalhamento máxima;

5.3. Tensão de cisalhamento convencional;

5.4. Limites da tensão de cisalhamento;

5.5. Armaduras de cisalhamento;

UNID. VI - Pilares de madeira:

6.1. Dimensionamento de pilares de secções retangulares à compressão axial;

6.2. Detalhamento.

UNID. VII - Fundações para projetos de madeira:

7.1. Fundações;

7.2. Blocos de concreto ciclópico;

7.3 Sapatas;

7.4 Alicerce corrido;

7.5. Noções de fundações profundas;

7.6. Estacas;

7.7. Tubulações;

UNID. VIII - Interpretação de projeto estrutural com madeira e concreto:

8.1. Interpretação de uma forma estrutural;

8.2. Leitura de plantas;

8.3. Formulações de quantitativos e estruturas de telhados em madeira;

\section{BIBLIOGRAFIA BÁSICA:}

BOTELHO, Manoel Henrique Campus. Concreto Aramado, Eu Te Amo (Para Arquiteto) Vol. I À VI. Edgard Blucher. São Paulo. 2008.

NASH, William Arthur. Resistência dos Materiais. McGraw-Hill do Brasil. São Paulo. 1982.

BEER, Ferdinand Pierre. Resistência dos Materiais. Pearson Mark Book. São Paulo. 1995. 


\section{BIBLIOGRAFIA COMPLEMENTAR:}

Associação Brasileira de Normas Técnicas. Projeto e Execução de Obras de Concreto Armado. NB - 1. Rio de Janeiro, 1978.

FUSCO, Péricles Brasiliense. Estruturas de Concreto: Fundamentos do Projeto Estrutural. São Paulo: McGraw-Hill, 1976.

PFEIL, Walter. Estruturas de Madeira. Rio de Janeiro: Livros Técnicos e Científicos, 1978.

ROCHA, Aderson Moreira. Novo Curso Prático de Concreto Armado. Rio de Janeiro: Científica, 1978.

SANTOS, Lauro Modesto dos. Cálculo de Concreto Armado. São Paulo: Edgar Blucher, 1977.

PFEIL, Walter. Estruturas de Aço, Dimensionamento Prático. Rio de Janeiro: Livros Técnicos e Científicos - 1986.

\begin{tabular}{|c|c|}
\hline IES: & UNIVERSIDADE FEDERAL DE PERNAMBUCO - UFPE \\
\hline MUNICÍPIO: & Recife \\
\hline DOC/DATA: & Programa de Componente Curricular \\
\hline DISCIPLINA: & IN 785 - TECTÔNICA VII (7º periodo) \\
\hline CH/CRED: & $30 \mathrm{~T}$ = 30 horas (02 créditos) \\
\hline EMENTA: & $\begin{array}{l}\text { A recuperação de edificações históricas. Recuperação e consolidação de } \\
\text { estruturas históricas (alvenaria, coberta, esquadria, fundações). } \\
\text { Construção de novas edificações em sítios históricos. }\end{array}$ \\
\hline OBJETIVOS: & $\begin{array}{l}\text { Habilitar os estudantes para o desenvolvimento de projetos utilizando o } \\
\text { sistema construtivo da madeira. Tipos de madeira maciça, de } \\
\text { reflorestamento e processadas. Tecnologias de madeira } \\
\text { contemporâneas: madeira lamelada colada, protendida, vagonada. Usos } \\
\text { como telhados, painéis, estrutura. A materialização da arquitetura: a } \\
\text { lógica montagem dos edifícios, sua manutenção e conservação. }\end{array}$ \\
\hline \multicolumn{2}{|l|}{ CONTEÚDO: } \\
\hline \multicolumn{2}{|c|}{ 1. A tectônica da arquitetura contemporânea e a madeira } \\
\hline \multicolumn{2}{|c|}{$\begin{array}{l}\text { 2. Madeira: características físicas e biológicas, tipos de madeira estrutural e formas de } \\
\text { conexões }\end{array}$} \\
\hline \multicolumn{2}{|c|}{$\begin{array}{l}\text { 3. Madeira: procedimentos de projeto, formas de montagem e especificações técnicas } \\
\text { (normas) }\end{array}$} \\
\hline \multicolumn{2}{|c|}{ 4. Madeira: uso (telhado e cobertas, estrutura principal, painéis) } \\
\hline \multicolumn{2}{|c|}{ 5. Madeira: principais tecnologias (protensão, vagonamento e lamelado colado) } \\
\hline \multicolumn{2}{|c|}{ 6. Madeira: o projeto de cobertas } \\
\hline \multicolumn{2}{|c|}{ 7. A conservação e consolidação de estruturas tradicionais de madeira } \\
\hline \multicolumn{2}{|c|}{ 8. Madeira: o canteiro de obra } \\
\hline \multicolumn{2}{|c|}{ METODOLOGIA: } \\
\hline \multicolumn{2}{|c|}{$\begin{array}{l}\text { Aulas expositivas e desenvolvimento de exercícios práticos em sala de aula e no Laboratório e } \\
\text { Canteiro de Tectônica da Arquitetura. Desenvolvimento da intuição estrutural a partir de } \\
\text { exercícios em sala de aula e trabalhos. }\end{array}$} \\
\hline
\end{tabular}




\section{BIBLIOGRAFIA BÁSICA:}

MOLITERNO, A. Caderno de projetos de telhados em estruturas de madeira. $4^{a}$ ed. São Paulo: Ed. Blucher, 2010.

REBELLO, Y.C. P. Estrutura de Aço, Concreto e Madeira. Atendimento da Expectativa Dimensional. São Paulo: Zigurate, 2005.

REBELLO, Y. C. P. Bases para projeto estrutural de arquitetura. São Paulo: Zigurate Editora, 2007.

\section{BIBLIOGRAFIA COMPLEMENTAR:}

ACAYABA, M. Marcos Acayaba. Cosac \& Naify Edições. São Paulo, SP. 2007.

CALIL JUNIOR, C; MOLINA, J. C. Coberturas em estruturas de madeira. São Paulo: Editora Pini, 2010.

NENNEWITZ, I; NUTSCH, W; PESCHEL, P; SEIFERT, G. Manual de Tecnologia de Madeira. 2a. Ed. São Paulo: Ed. Blucher, 2011.

RIZZINI, C. T. Árvores e madeiras úteis do Brasil. Manual de Dendrologia brasileira. 2a. ed. São Paulo: Ed. Blucher, 1978.

ZWERGER, K. Wood and Wood Joints. Building Traditions of Europe and Japan. Suíça: Birkhäuser, 2000.

\begin{tabular}{|c|c|}
\hline IES: & UNIVERSIDADE FEDERAL DE MATO GROSSO - UFMT \\
\hline MUNICÍPIO: & Cuiabá \\
\hline DOC/DATA: & Plano de ensino de disciplina 1S 2016 \\
\hline DISCIPLINA: & 30129316 - SISTEMAS ESTRUTURAIS VI ( $9^{\circ}$ semestre) \\
\hline CH/CRED: & $60 \mathrm{~T}=60$ horas \\
\hline EMENTA: & $\begin{array}{l}\text { Madeira como material de construção; produtos de madeira e sistemas } \\
\text { estruturais; propriedades mecânicas - bases de cálculo; ligações de peças } \\
\text { estruturais; peças tracionadas - emendas; peças comprimidas - } \\
\text { flambagem; elementos fletidos - vigas; e vigas em treliças. }\end{array}$ \\
\hline OBJETIVOS: & $\begin{array}{l}\text { Geral: Apresentar aos alunos o projeto de estruturas de madeiras, bem } \\
\text { como os critérios de dimensionamento. } \\
\text { Específicos: Habilitar o aluno nas especificidades da disciplina, } \\
\text { desenvolvendo e estimulando a capacidade técnica necessária ao } \\
\text { desenvolvimento dos conceitos fundamentais para o entendimento dos } \\
\text { sistemas estruturais de madeira e dos conceitos e procedimentos básicos } \\
\text { para análise de sistemas estruturais de madeira sob as mais diversas } \\
\text { formas de solicitações. }\end{array}$ \\
\hline
\end{tabular}




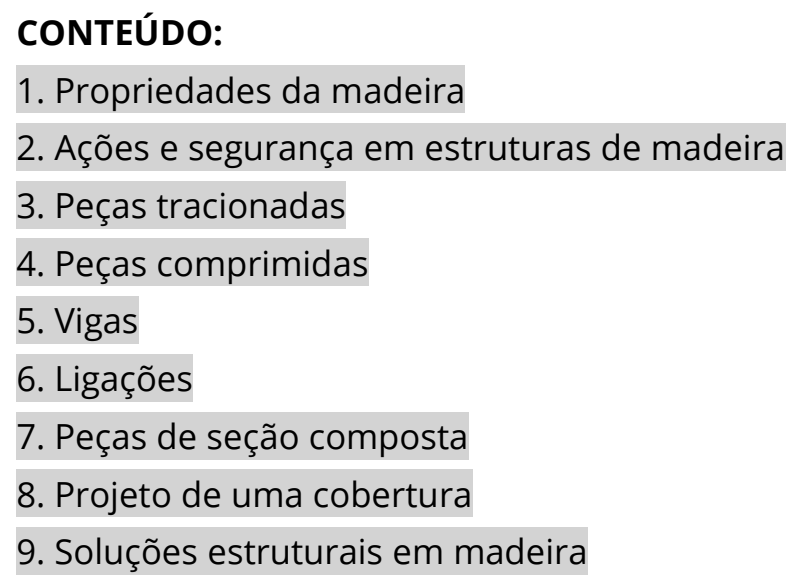

1. Propriedades da madeira

2. Ações e segurança em estruturas de madeira

3. Peças tracionadas

4. Peças comprimidas

5. Vigas

6. Ligações

7. Peças de seção composta

8. Projeto de uma cobertura

9. Soluções estruturais em madeira

\section{METODOLOGIA:}

Aula expositiva, com a utilização de quadro negro e projeto multimídia.

\section{BIBLIOGRAFIA BÁSICA:}

REBELLO, Yopanan Conrado Pereira. A Concepcao estrutural e a arquitetura.

PFEIL, Walter. Estruturas de madeira.

\section{BIBLIOGRAFIA COMPLEMENTAR:}

REBELLO, Yopanan Conrado Pereira. Estruturas de aço, concreto e madeira: atendimento da expectativa dimensional.

ABNT NBR 7190 - Projeto de estruturas de madeira.

MOLITERNO, Antonio. Caderno de projetos de telhados em estruturas de madeira.

CALIL JÚNIOR, Carlito; LAHR, Francisco Antônio Rocco; DIAS, Antonio Alves. Dimensionamento de elementos estruturais de madeira.

RODRIGUES JÚNIOR, Manoel Santinho. Estruturas de Madeira - Notas de Aula.

\begin{tabular}{|l|l|}
\hline IES: & UNIVERSIDADE FEDERAL DE MINAS GERAIS - UFMG \\
\hline MUNICÍPIO: & Belo Horizonte \\
\hline DOC/DATA: & Programa de disciplina \\
\hline DISCIPLINA: & EES012 - ESTRUTURAS DE MADEIRA (5 período) \\
\hline CH/CRED: & 30 T = 30 horas (02 créditos) \\
\hline EMENTA: & $\begin{array}{l}\text { Características físicas e mecânicas das madeiras. Dimensionamento de } \\
\text { peças solicitadas à tração, compressão, flexão e cisalhamento. Ligações } \\
\text { estruturais e detalhes construtivos. Peças compostas. Treliças. Madeira } \\
\text { laminada colada. }\end{array}$ \\
\hline OBJETIVOS: & $\begin{array}{l}\text { O objetivo desta disciplina é fornecer aos futuros Arquitetos noções } \\
\text { básicas sobre a concepção, análise e dimensionamento de estruturas de } \\
\text { madeira. }\end{array}$ \\
\hline
\end{tabular}




\section{CONTEÚDO:}

UNIDADE I - Introdução

1.1 - Apresentação do curso;

1.2 - Sistema de avaliação;

1.3 - Bibliografia.

UNIDADE II - Conhecendo a Madeira

2.1 - Valor estrutural da madeira;

2.2 - Constituição da madeira;

2.3 - Estrutura macro e microscópica da madeira;

2.4 - Constituição química da madeira;

2.5 - Características físicas e mecânicas da madeira;

2.6 - Produtos comerciais.

UNIDADE III - Usando a Madeira

3.1 - Aplicação estrutural;

3.2 - Aplicação arquitetônica;

3.3 - Aplicação em revestimentos.

UNIDADE IV - Conhecendo a madeira a esforços mecânicos

4.1 - Metodologia de dimensionamento;

4.2 - Peças solicitadas à tração;

4.3 - Peças solicitadas à compressão;

4.4 - Peças solicitadas à flexão.

UNIDADE V - Estruturas Convencionais de Madeira

5.1 - Coberturas de grandes vãos;

5.2 - Coberturas residenciais;

5.3 - Coberturas pontaletadas.

UNIDADE VI - A Madeira Laminada Colada

6.1 - Princípios de fabricação;

6.2 - Tipos de estruturas;

6.3 - Potencial plástico de madeira laminada colada;

6.4 - Detalhes.

UNIDADE VII - Conservação da Madeira

7.1 - Tratamentos preservativos;

7.2 - Secagem da madeira.

\section{METODOLOGIA:}

O método de ensino consiste em aulas teóricas para exposição do conteúdo da disciplina. Concomitantemente os alunos resolvem exercícios para fixação dos conceitos apresentados.

\section{BIBLIOGRAFIA BÁSICA:}

Apostila de Estruturas de Madeira - Prof. Edgar Vladimiro Mantilla Carrasco

Construción e Carpintaria - Fernando Cassinelo 
BIBLIOGRAFIA COMPLEMENTAR:

Caderno de projetos de telhados em estruturas de madeira - Antônio Moliterno

\begin{tabular}{|c|c|}
\hline IES: & UNIVERSIDADE FEDERAL DE UBERLÂNDIA - UFU \\
\hline MUNICÍPIO: & Uberlândia \\
\hline DOC/DATA: & Ficha de disciplina \\
\hline DISCIPLINA: & MATERIAIS E TÉCNICAS CONSTRUTIVAS I ( $3^{\circ}$ período) \\
\hline CH/CRED: & $30 \mathrm{~T} / 15 \mathrm{P}=45$ horas \\
\hline EMENTA: & $\begin{array}{l}\text { Normalização. Ciência dos materiais. Materiais metálicos. Madeiras. } \\
\text { Tintas. Vidros. Polímeros. Pedras. Apresentação dos elementos } \\
\text { construtivos de edificações de pequeno e médio porte. }\end{array}$ \\
\hline OBJETIVOS: & $\begin{array}{l}\text { - Compreender a evolução histórica da tecnologia e as possibilidades } \\
\text { construtivas; } \\
\text { - Conhecer os materiais de construção civil e suas propriedades para uma } \\
\text { correta especificação; } \\
\text { - Ser capaz de indicar e solicitar ensaios de controle da qualidade, } \\
\text { conforme normas brasileiras; } \\
\text { - Ser capaz de identificar e conceituar os sub-sistemas construtivos } \\
\text { conforme as fases de desenvolvimento da edificação. }\end{array}$ \\
\hline \multicolumn{2}{|l|}{ CONTEÚDO: } \\
\hline $\begin{array}{l}\text { 1. Normalização: finalidade, entidades normalizadoras, normas brasileiras, tipos de normas, } \\
\text { normas de outros países. }\end{array}$ & $\begin{array}{l}\text { 2. Ciência dos materiais: princípios gerais, principais propriedades dos corpos sólidos, } \\
\text { principais esforços mecânicos. }\end{array}$ \\
\hline \multicolumn{2}{|c|}{$\begin{array}{l}\text { 3. Materiais metálicos: metais ferrosos e não ferrosos, principais características e produtos. } \\
\text { Ensaios demonstrativos em aço para concreto armado. }\end{array}$} \\
\hline \multicolumn{2}{|c|}{$\begin{array}{l}\text { 4. Madeiras: origem, espécie, características principais, fisiologia, anatomia, propriedades, } \\
\text { aplicações, produtos. Ensaios demonstrativos. }\end{array}$} \\
\hline \multicolumn{2}{|c|}{ 5. Tintas e vernizes: constituição, características principais, aplicações, produtos. } \\
\hline \multicolumn{2}{|c|}{ 6. Vidros: constituição, características principais, aplicações, produtos. } \\
\hline \multicolumn{2}{|c|}{ 7. Materiais betuminosos: constituição, características, produtos e aplicações. } \\
\hline \multicolumn{2}{|c|}{ 8. Polímeros: constituição, características, produtos e aplicações. } \\
\hline \multicolumn{2}{|c|}{$\begin{array}{l}\text { 9. Pedras naturais: tipos de rochas, classificação, tipos de exploração, principais pedras } \\
\text { empregadas na construção civil. }\end{array}$} \\
\hline \multicolumn{2}{|c|}{ 10. Apresentação das partes de uma edificação: } \\
\hline \multicolumn{2}{|c|}{ 10.1 Fundação: definição, classificação e tipos. } \\
\hline \multicolumn{2}{|c|}{ 10.2 Estrutura: definição, tipos e finalidade. } \\
\hline \multicolumn{2}{|c|}{ 10.3 Vedações: definição, classificação e finalidade. } \\
\hline \multicolumn{2}{|c|}{ 10.4 Esquadrias: definição e finalidade. } \\
\hline \multicolumn{2}{|c|}{ 10.5 Revestimentos: definição, tipos e finalidade. } \\
\hline
\end{tabular}


10.6 Coberturas: definição, finalidade e elementos fundamentais.

11. Visitas a obras, lojas e/ou indústrias.

\section{METODOLOGIA: AULAS PRÁTICAS}

1. Madeiras: exame de lâminas ao microscópio; ensaios físicos e mecânicos para demonstração;

2. Aço: ensaio demonstrativo de tração.

BIBLIOGRAFIA BÁSICA:

ASSOCIAÇÃO BRASILEIRA DE NORMAS TÉCNICAS. Diversas normas. Rio de Janeiro.

AZEVEDO, H. O edifício até sua cobertura. São Paulo: Edgard Blücher, 2009.

AZEVEDO, H. O edifício e seu acabamento. São Paulo: Edgard Blücher, 2008.

BAUER, L. A. F. Materiais de construção. Rio de Janeiro: LTC, 1995. 1 v.

\section{BIBLIOGRAFIA COMPLEMENTAR:}

BAUER, L. A. F. Materiais de construção. Rio de Janeiro: LTC, 1995. 2 v.

BORGES, L. A. F. Prática das pequenas construções. São Paulo: Edgard Blücher, 2009.

CHIAVERINI, V. Aços e Ferros fundidos. 4. ed. São Paulo: Associação Brasileira de Metais, 1981.

\begin{tabular}{|c|c|}
\hline DISCIPLINA: & ESTRUTURAS DE AÇO E DE MADEIRA ( $6^{\circ}$ período) \\
\hline CH/CRED: & $60 \mathrm{~T}=60$ horas \\
\hline EMENTA: & $\begin{array}{l}\text { Estruturas de aço: Histórico e aplicações. Elementos estruturais. Aços } \\
\text { estruturais e produtos de aço. Perfis estruturais. Projeto estrutural - } \\
\text { pórticos, treliças, galpões, coberturas, estruturas de contraventamento, } \\
\text { edifícios de múltiplos pavimentos. Escolha do perfil. Noções de } \\
\text { dimensionamento segundo a norma brasileira. Noções de ligações. } \\
\text { Carregamento aproximado dos elementos estruturais. Noções de ações e } \\
\text { segurança nas estruturas de aço. Pré-dimensionamento - peças } \\
\text { tracionadas, comprimidas e sob flexão. } \\
\text { Estruturas de madeira: Histórico e aplicações. Elementos estruturais. } \\
\text { Madeiras empregadas em estruturas: tipos, perfis e derivados. } \\
\text { Propriedades físicas e mecânicas. Projeto estrutural - pórticos, treliças, } \\
\text { galpões, pisos e coberturas, estruturas de contraventamento. Noções de } \\
\text { dimensionamento segundo a norma brasileira. Noções de ligações. } \\
\text { Carregamento aproximado dos elementos estruturais. Noções de ações e } \\
\text { segurança nas estruturas de madeira. Pré-dimensionamento - peças } \\
\text { tracionadas, comprimidas e sob flexão. Temas complementares de } \\
\text { estruturas de aço e de madeira: noções de estruturas com treliças } \\
\text { espaciais, estruturas para coberturas do tipo casca e tensoestruturas } \\
\text { (membranas tensionadas). }\end{array}$ \\
\hline OBJETIVOS: & $\begin{array}{l}\text { Compreender, conceber, e pré-dimensionar estruturas de aço e de } \\
\text { madeira. Reconhecer a interação projeto arquitetônico - projeto } \\
\text { estrutural. Aplicar os fundamentos de cálculo do carregamento, das } \\
\text { solicitações e da segurança das estruturas de aço e de madeira. Ter } \\
\text { noções do dimensionamento e do detalhamento de estruturas de aço e } \\
\text { de madeira segundo as normas brasileiras. }\end{array}$ \\
\hline
\end{tabular}




\section{CONTEÚDO:}

1 Estruturas de aço

1.1 Histórico e aplicações

1.2 Elementos estruturais

1.3 Aços estruturais e produtos de aço

1.4 Perfis estruturais

1.5 Projeto estrutural - pórticos, treliças, galpões, coberturas, estruturas de contraventamento,

edifícios de múltiplos pavimentos

1.6 Escolha do perfil

1.7 Noções de dimensionamento segundo a norma brasileira

1.8 Noções de ligações

1.9 Carregamento aproximado dos elementos estruturais

1.10 Noções de ações e segurança nas estruturas de aço

1.10.1 Ações, segurança e estados limites

1.10.2 Verificação dos Estados Limites de Utilização

1.10.3 Ação do vento

1.11 Pré-dimensionamento - peças tracionadas, comprimidas e sob flexão

2 Estruturas de madeira

2.1 Histórico e aplicações

2.2 Elementos estruturais

2.3 Madeiras empregadas em estruturas - tipos, perfis e derivados

2.4 Propriedades físicas e mecânicas

2.5 Projeto estrutural - pórticos, treliças, galpões, pisos e coberturas, estruturas de contraventamento

2.6 Noções de dimensionamento segundo a norma brasileira

2.7 Noções de ligações

2.8 Carregamento aproximado dos elementos estruturais

2.9 Noções de ações e segurança nas estruturas de madeira

2.9.1 Ações, segurança e estados limites

2.9.2 Verificação dos Estados Limites de Utilização

2.9.3 Ação do vento

2.10 Pré-dimensionamento - peças tracionadas, comprimidas e sob flexão

3 Temas complementares de estruturas de aço e de madeira

3.1 Noções de estruturas com treliças espaciais

3.2 Noções de estruturas para coberturas do tipo casca

3.3 Noções de tensoestruturas (membranas tensionadas)

4 Visita técnica

Visita técnica à obra em fase construtiva ou concluída, onde a estrutura possa ser observada. 


\section{BIBLIOGRAFIA BÁSICA:}

ASSOCIAÇÃO BRASILEIRA DE NORMAS TÉCNICAS: NBR 6120; NBR 8681; NBR 6123; NBR 8800; NBR 7190.

MARGARIDO, A. F. Fundamentos de estruturas: um programa para arquitetos e engenheiros que se iniciam no estudo das estruturas. São Paulo: Zigurate, 2003.

PFEIL, W. Estruturas de aço: dimensionamento prático de acordo com a NBR 8800:2008. 8 ed. Rio de Janeiro: LTC, 2009.

PFEIL, W.; PFEIL, M. Estruturas de madeira. 6. ed. Rio de Janeiro: LTC, 2003.

REBELLO, Y.C.P. A concepção estrutural e a arquitetura. São Paulo: Zigurate, 2000.

REBELLO, Y.C.P. Bases para projeto estrutural na arquitetura. São Paulo: Zigurate, 2007.

REBELLO, Y.C.P. Estruturas de aço, concreto e madeira: atendimento da expectativa dimensional. São Paulo: Zigurate, 2005.

SILVA, D.M.; SOUTO, A.K. Estruturas: uma abordagem arquitetônica. 2. ed. Porto Alegre: Sagra Luzzatto, 2000.

\begin{tabular}{|c|c|}
\hline IES: & UNIVERSIDADE ESTADUAL PAULISTA JÚLIO DE MESQUITA FILHO - UNESP \\
\hline MUNICÍPIO: & Presidente Prudente \\
\hline DOC/DATA: & Programa de ensino 1S 2017 \\
\hline DISCIPLINA: & ESTRUTURAS EM MADEIRA E AÇO (OPTATIVA 9º período) \\
\hline CH/CRED: & $40 \mathrm{~T} / 08 \mathrm{P} / 12 \mathrm{O}=60$ horas \\
\hline EMENTA: & $\begin{array}{l}\text { Estudo das linguagens arquitetônicas possíveis com os materiais aço e } \\
\text { madeira. Estudo dos materiais estruturais aço e madeira, dos arranjos e } \\
\text { sistemas estruturais. Elaboração e leitura de projetos estruturais em aço } \\
\text { e em madeira. Estudo das aplicações e patologias dos materiais } \\
\text { estruturais aço e madeira. }\end{array}$ \\
\hline OBJETIVOS: & $\begin{array}{l}\text { Reconhecer o aço e a madeira como material estrutural e sua linguagem } \\
\text { arquitetônica. Reconhecer os arranjos e sistemas estruturais em aço e em } \\
\text { madeira. Reconhecer o processo de projetar e o processo de projetar } \\
\text { com o aço e com a madeira. Reconhecer as patologias inerentes aos } \\
\text { materiais como mecanismo de elaboração consciente do projeto } \\
\text { arquitetônico. }\end{array}$ \\
\hline \multicolumn{2}{|l|}{ CONTEÚDO: } \\
\hline \multicolumn{2}{|c|}{ 1. As estruturas de aço na arquitetura; } \\
\hline \multicolumn{2}{|c|}{ 2. Sistemas usuais em aço; } \\
\hline \multicolumn{2}{|c|}{ 3. Ligações de elementos em aço } \\
\hline \multicolumn{2}{|c|}{ 4. Elaboração e leitura de projetos de estruturas de aço; } \\
\hline \multicolumn{2}{|c|}{ 5. Fabricação e montagens das estruturas em aço; } \\
\hline \multicolumn{2}{|c|}{ 6. Aplicabilidade das estruturas de aço em projetos arquitetônicos; } \\
\hline \multicolumn{2}{|c|}{ 7. Patologias das estruturas de aço; } \\
\hline \multicolumn{2}{|c|}{ 8. As estruturas de madeira na arquitetura; } \\
\hline \multicolumn{2}{|c|}{ 9. Sistemas usuais em madeira; } \\
\hline
\end{tabular}


10. Ligações de elementos em madeira;

11. Elaboração e leitura de projetos de estruturas em madeira;

12. Montagens das estruturas em madeira;

13. Aplicabilidade das estruturas de madeira em projetos arquitetônicos;

14. Patologias das estruturas em madeira

\section{METODOLOGIA:}

- Aulas expositivas teóricas, com aplicação de exercícios;

- Utilização de laboratório didático;

- Atividades práticas extraclasse;

- Utilização de equipamentos áudios-visuais.

\section{BIBLIOGRAFIA BÁSICA:}

ABNT - ASSOCIAÇÃO BRASILEIRA DE NORMAS TÉCNICAS - NBR 8800: Projeto e Execução de Estruturas de Aço de Edifícios - Procedimento, 2008.

ABNT - ASSOCIAÇÃO BRASILEIRA DE NORMAS TÉCNICAS - NBR 7190: Projeto de Estruturas de Madeira, 1997.

DIAS, A. A. et al. Dimensionamento de Elementos Estruturais em Madeira. Editora Manole, 2002.

DIAS, LUÍS A. M. Edificações de Aço no Brasil. Editora Zigurate. São Paulo, 2002.

Estruturas de Aço: Conceito, Técnicas e Linguagem. São Paulo Zigurate., 2006.

Aço e Arquitetura: Estudo de Edificações no Brasil. São Paulo: Zigurate, 2004.

MOLITERNO, A. Projetos de Telhados em Estrutura de Madeira. São Paulo: Edgard Blücher, 2010.

PFEIL, W.; PFEIL, M. Estruturas de Madeira. 6a Ed. Rio de Janeiro: LTC. 2003.

REBELLO, YOPANAN C. P. Estruturas de Aço, Concreto e Madeira - Atendimento da Expectativa Dimensional. $3^{\mathrm{a}}$ Ed. São Paulo: Zigurate, 2008.

\section{BIBLIOGRAFIA COMPLEMENTAR:}

DUDEQUE, I. J. T. Espirais em Madeira: Uma História da Arquitetura de Curitiba. São Paulo: Nobel, 2001.

PFEIL, W. \& PFEIL, M. Estruturas de Aço: Dimensionamento Prático. Rio de Janeiro: Editora LTC, 2000.

PINHEIRO, A. C. F. B. Estruturas Metálicas. 2a Edição, São Paulo: Editora Edgard Blücher, 2005.

REBELLO, YOPANAN. C. P. Bases para Projeto Estrutural na Arquitetura. 2a Ed. São Paulo: Zigurate, 2008.

REBELLO, Y. C. P. A Concepção Estrutural e a Arquitetura. São Paulo: Zigurate, 2000.

ZANI, A. C. Arquitetura em Madeira. São Paulo: Imprensa Oficial do Estado, 2003. 


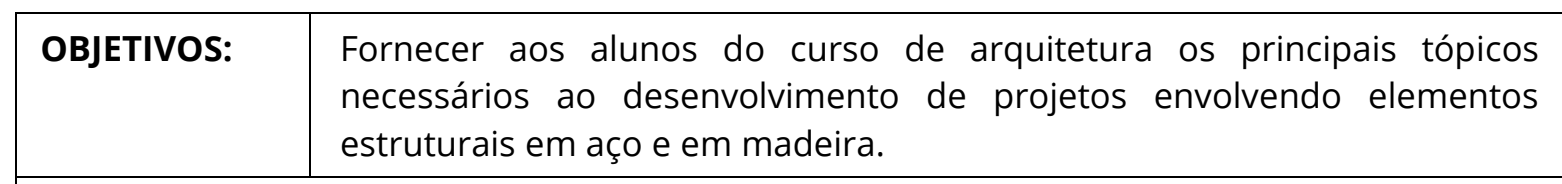

\section{CONTEÚDO:}

Noções básicas sobre a anatomia da madeira: tração, compressão e flexão. Dispositivos de ligação e suas aplicações: adesivos, pregos, parafusos, chapas metálicas, anéis e cavilhas. Obtenção do aço e seus produtos comerciais. Noções básicas sobre o dimensionamento de elementos estruturais em aço: tração, compressão e flexão. Dispositivos de ligação e suas aplicações: soldas e parafusos.

\section{BIBLIOGRAFIA BÁSICA:}

ABNT. ASSOCIAÇÃO BRASILEIRA DE NORMAS TÉCNICAS. ABNT/NBR7190/82 Cálculo e Execução de Estruturas de Madeira. São Paulo: ABNT, 1982.

ABNT. ASSOCIAÇÃO BRASILEIRA DE NORMAS TÉCNICAS. ABNT/NBR8800/86 Projeto e Execução de Estruturas de Aço em Edifícios. São Paulo: ABNT, 1986.

DIAS, A.A., CALIL Jr., C. e LAHR, F.A.R. Estruturas de madeira Arquitetura e Urbanismo. São Carlos, SP: EESC-USP, 2007.

HERZOG, T., NATTERER, J., SCHWEITZER, R., VOLZ, M. e WINTER, W. Timber construction. Basiléia, Suíça: Birkhauser Edition Detail, 2004.

\section{BIBLIOGRAFIA COMPLEMENTAR:}

CALIL Jr., C., LAHR, F.A.R. e DIAS, A.A. Dimensionamento de elementos estruturais de madeira. Editora Manole, 2003.

MALITTE, M. Projeto de uma passarela de pedestre em estrutura de madeira. Apostila. São Carlos, SP: EESC-USP. Noções básicas sobre a anatomia da madeira: tração, compressão e flexão. Dispositivos de ligação e suas aplicações: adesivos, pregos, parafusos, chapas metálicas, anéis e cavilhas. Obtenção do aço e seus produtos comerciais. Noções básicas sobre o dimensionamento de elementos estruturais em aço: tração, compressão e flexão. Dispositivos de ligação e suas aplicações: soldas e parafusos. Vários autores. Estruturas metálicas. Apostilas. São Carlos, SP:

EESC-USP.

\begin{tabular}{|l|l|}
\hline DISCIPLINA: & $\begin{array}{l}\text { IAU0693 PARÂMETROS PARA PROJETOS HABITACIONAIS EM MADEIRA } \\
\text { (OPTATIVA 70 período) }\end{array}$ \\
\hline CH/CRED: & 02 T / 01 P = 03 créditos (60 horas) \\
\hline OBJETIVOS: & $\begin{array}{l}\text { Desenvolver projeto de elementos construtivos em madeira para } \\
\text { edificações. }\end{array}$ \\
\hline $\begin{array}{l}\text { CONTEÚDO: } \\
\text { Introdução aos princípios e conceitos básicos de utilização da madeira na construção de } \\
\text { edifícios. Introdução aos conceitos de sustentabilidade da cadeia da madeira: dimensão social, } \\
\text { ambiental, cultural, ecológica e política da sustentabilidade, as etapas da produção da madeira } \\
\text { (floresta, serraria, secagem, beneficiadora, pré-fabricação, comercialização). Análise dos } \\
\text { problemas quanto ao uso da madeira: análise do ciclo de vida seus impactos, e os } \\
\text { desempenhos técnicos. Descrição dos sistemas construtivos em madeira para edificações: } \\
\text { sistema de parede (sobreposição de toras, wood frame, painel sanduíche, madeira laminada } \\
\text { cruzada, madeira pregada, etc). Tipologia de estrutura de madeira: estrutura em arco, treliças. } \\
\text { Esquadrias de madeira: tipologias de janelas, princípios para detalhamento de esquadrias de } \\
\text { madeira. }\end{array}$ \\
\hline
\end{tabular}




\section{METODOLOGIA:}

Aulas expositivas teóricas. Desenvolvimento de projeto. Visitas a obras, empresas ou indústrias. A partir dos conceitos e princípios da sustentabilidade da cadeia de produção da madeira associados aos conceitos técnicos de desempenho do material madeira e das possibilidades construtivas serão desenvolvidas a prática de projeto utilizando madeira (nativa certificada e de plantios florestais).

\section{BIBLIOGRAFIA BÁSICA:}

GOTZ, K.H. Construire en bois. Lausanne, Polytechniques Romandes, 1987.

Cartilla de construcción con madeira. Lima, Junac, 1980.

TAYLOR, G. La madera. Barrcelona, Blume, 1978.

\begin{tabular}{|c|c|}
\hline IES: & UNIVERSIDADE PRESBITERIANA MACKENZIE \\
\hline MUNICÍPIO: & São Paulo \\
\hline DOC/DATA: & Plano de ensino \\
\hline DISCIPLINA: & ENEX00329 - PROJETO V E TECNOLOGIA ( $5^{\circ}$ período) \\
\hline CH/CRED: & 204 horas (12 créditos) \\
\hline EMENTA: & $\begin{array}{l}\text { Desenvolvimento de exercícios projetivos que visam estabelecer a } \\
\text { estreita relação entre arquitetura e construção na elaboração de uma } \\
\text { linguagem arquitetônica. Busca da compreensão entre a proposição } \\
\text { arquitetônica e tecnológica com os modos de representação para a } \\
\text { simulação e comunicação das soluções adotadas com ênfase nos } \\
\text { modelos físicos. Investigação e demonstração dos materiais e sistemas } \\
\text { construtivos adotados, incluindo detalhes construtivos e pré- } \\
\text { dimensionamentos. Estabelecer parâmetros de qualidade dos espaços } \\
\text { públicos e privados e interfaces com critérios de sustentabilidade. }\end{array}$ \\
\hline OBJETIVOS: & $\begin{array}{l}\text { Desenvolver: } \\
\text { - A capacidade de realizar pesquisas e análises de projetos e obras de } \\
\text { referência. } \\
\text { - A capacidade de criação, invenção e do estabelecimento de um método } \\
\text { projetivo através dos exercícios projetuais em busca de uma unidade de } \\
\text { linguagem entre arquitetura e construção. } \\
\text { - A capacidade de representação, com a utilização de linguagens e escalas } \\
\text { apropriadas, que demonstrem adequadamente a relação do binômio: } \\
\text { arquitetura e construção. }\end{array}$ \\
\hline \multicolumn{2}{|c|}{$\begin{array}{l}\text { CONTEÚDO: } \\
\text { Promove-se a visão histórica do desenvolvimento dos materiais e sistemas construtivos. Os } \\
\text { aspectos da construção industrializada e da modulação, as propriedades dos materiais com as } \\
\text { respectivas técnicas adequadas ao escopo da disciplina, a construção em barras de metal e } \\
\text { madeira, vedações e coberturas em sistemas leves, fachadas duplas e duplas ventiladas, e } \\
\text { sistemas como "Steel frame" e "Wood frame". As experiências em argamassa armada e o } \\
\text { emprego de materiais novos de base sintética como os plásticos. Permeiam os exercícios } \\
\text { conceitos sobre espaços públicos e privados e aspectos de sustentabilidade. }\end{array}$} \\
\hline
\end{tabular}




\section{BIBLIOGRAFIA BÁSICA:}

GALIANO, Luis Fernández. "La cultura de la construccion." Arquitectura y Vivienda Monografias, set out de 1993: 43.

PARICIO, Ignacio. La construcción de la arquitectura. Cataluña : ITEC, 2004

VILLÀ, Joan. "A construção com componentes pré-fabricados cerâmicos: Sistema construtivo desenvolvido entre 1984 e 1994." Mestrado, São Paulo, 2002.

\section{BIBLIOGRAFIA COMPLEMENTAR:}

DIESTE, Eladio. La estructura cerámica. Bogotá: Escala, 1987.

Monografias de arquitectura, tecnologia y construcción. “Envolventes (I)." TECTONICA, n. 01

Madrid: ATC, 1995.

Monografias de arquitectura, tecnologia y construcción. "Envolventes (II)." TECTONICA, n. 02

Madrid: ATC, 1995.

Monografias de arquitectura, tecnologia y construcción. "Acero (I)." TECTONICA, n. 09 Madrid:

ATC, 1995.

Monografias de arquitectura, tecnologia y construcción. “Cubiertas (I)." TECTONICA, n. 08 Madrid: ATC, 1995.

Monografias de arquitectura, tecnologia y construcción. "Vidrio (I)." TECTONICA, n. 10 Madrid: ATC, 1995.

Monografias de arquitectura, tecnologia y construcción. "Maderas (I)." TECTONICA, n. 11 Madrid: ATC, 1995.

Monografias de arquitectura, tecnologia y construcción. “Cerámica (I)." TECTONICA, n. 15 Madrid: ATC, 1995.

PARICIO, Ignacio. La fachada de ladrillo. Barcelona: Bisagra, 2000.

KUBO, M; MOUSSAVI, F. La función del ornamento. Actar Editorial VÍDEOS (DVD)

Série Arquitecturas. Dir. Richard Compans Center Pompidou. Editirama ( ${ }^{\circ} 1,2,3,4$ e 5$)$

\begin{tabular}{|l|l|}
\hline IES: & UNIVERSIDADE FEDERAL DO PARANÁ - UFPR \\
\hline MUNICÍPIO: & Curitiba \\
\hline DOC/DATA: & Projeto Pedagógico de Curso 2013 \\
\hline DISCIPLINA: & TA131 - ESTRUTURAS METÁLICAS E DE MADEIRA (6º período) \\
\hline CH/CRED: & 60 horas (04 créditos) \\
\hline EMENTA: & $\begin{array}{l}\text { Estudo das técnicas de concepção e lançamento de estruturas metálicas e } \\
\text { de madeira. Estudo das características físicas e mecânicas do aço e da } \\
\text { madeira. Análise estrutural, com determinação de deslocamentos e } \\
\text { esforços. Dimensionamento de elementos estruturais tais como terças, } \\
\text { banzos, diagonais e montantes de treliças planas de aço e de madeira. }\end{array}$ \\
\hline OBJETIVOS: & $\begin{array}{l}\text { GERAL: Desenvolver nos estudantes a capacidade para criar estruturas de } \\
\text { metálicas e de madeira, analisá-las e dimensionar as seç̃̃es transversais } \\
\text { de suas principais peças. }\end{array}$ \\
\hline
\end{tabular}




\begin{tabular}{|c|c|}
\hline & $\begin{array}{l}\text { ESPECíFICO: A disciplina objetiva que o(a) estudante desenvolva } \\
\text { competências para: } \\
\text { - Reconhecer as principais características dos diagramas tensão x } \\
\text { deformação de madeira, diferenciando os trechos de comportamento } \\
\text { elástico linear. } \\
\text { - Reconhecer as principais propriedades e os principais tipos de madeira } \\
\text { - Dimensionar ligações } \\
\text { - Conceber treliças planas em madeira; determinar cargas e analisar } \\
\text { visando o dimensionamento das barras. } \\
\text { - Conceber e analisar estruturas planas de madeira. } \\
\text { - Reconhecer as principais características dos diagramas tensão x } \\
\text { deformação de aços estruturais, diferenciando os trechos de } \\
\text { comportamento elástico linear, de escoamento e de encruamento. } \\
\text { - Reconhecer as principais propriedades e os principais tipos de aços } \\
\text { estruturais. } \\
\text { - Dimensionar peças estruturais de perfis metálicos } \\
\text { - Conceber treliças planas metálicas; determinar cargas, modelar } \\
\text { computacionalmente e analisar visando o dimensionamento das barras. }\end{array}$ \\
\hline \multicolumn{2}{|l|}{ CONTEÚDO: } \\
\hline \multicolumn{2}{|c|}{$\begin{array}{l}\text { Estruturas de Madeira: Tensões Admissíveis Básicas, Ensaios de Madeiras; - Ligações de Peças } \\
\text { Estruturais: ligações pregadas, parafusadas, com entalhes; - Peças Tracionadas: Emendas, } \\
\text { disposições construtivas, critério de cálculo; - Peças Comprimidas Axialmente: flambagem. } \\
\text { Estruturas Metálicas: Diagramas tensão x deformação de aços estruturais. - Propriedades e } \\
\text { tipos de aços estruturais. - Perfis estruturais laminados, de chapa dobrada e de chapa soldada. } \\
\text { - Ligações Soldadas - Treliças Planas: tipos construtivos, deformações e contraflechas. }\end{array}$} \\
\hline \multicolumn{2}{|c|}{$\begin{array}{l}\text { Os conteúdos serão trabalhados em aulas expositivas dialogadas e avaliação individual e em } \\
\text { projetos de treliças de madeira de uma cobertura de edifício em concreto armado e projeto } \\
\text { em estrutura de aço de um galpão industrial. }\end{array}$} \\
\hline \multicolumn{2}{|c|}{$\begin{array}{l}\text { Serão utilizados os seguintes recursos: quadro de giz, notebook, projetor multimídia, amostras } \\
\text { de materiais de construção relacionados com estruturas metálicas e de madeira e programas } \\
\text { computacionais de análise estrutural. }\end{array}$} \\
\hline \multicolumn{2}{|c|}{ BIBLIOGRAFIA BÁSICA: } \\
\hline \multicolumn{2}{|c|}{$\begin{array}{l}\text { ASSOCIAÇÃO BRASILEIRA DE NORMAS TÉCNICAS. NBR 8800-Projeto de Estruturas de Aço e } \\
\text { de Estruturas Mistas de Aço e Concreto de Edifícios. Rio de Janeiro, } 2008 .\end{array}$} \\
\hline \multicolumn{2}{|c|}{$\begin{array}{l}\text { SANTOS, A. F. dos. Estruturas Metálicas: Projeto e Detalhes para Fabricação. São Paulo, } \\
\text { McGraw-Hill do Brasil, } 1977 .\end{array}$} \\
\hline
\end{tabular}


BIBLIOGRAFIA COMPLEMENTAR:

ASSOCIAÇÃO BRASILEIRA DE NORMAS TÉCNICAS. NBR 6120-Cargas para o cálculo de estruturas de edificações. Rio de Janeiro, 1980 - versão corrigida 2000.

ASSOCIAÇÃO BRASILEIRA DE NORMAS TÉCNICAS. NBR 6123-Forças devidas ao vento em edificações. Rio de Janeiro, 1988 - versão corrigida 1990.

\begin{tabular}{|c|c|}
\hline IES: & UNIVERSIDADE FEDERAL DE SANTA MARIA - UFSM \\
\hline MUNICÍPIO: & Santa Maria \\
\hline DOC/DATA: & Programa de ensino \\
\hline DISCIPLINA: & $\begin{array}{l}\text { ECC } 8058 \text { - SISTEMAS ESTRUTURAIS E TECNOLOGIA DA CONSTRUÇÃO } \\
\text { VIII ( } 8^{\circ} \text { período) }\end{array}$ \\
\hline CH/CRED: & $02 \mathrm{~T} / 03 \mathrm{P}=05$ créditos (75 horas) \\
\hline OBJETIVOS: & $\begin{array}{l}\text { Conhecer, calcular e projetar estruturas de aço e de madeira, visando à } \\
\text { sua aplicação no desenvolvimento do projeto arquitetônico. }\end{array}$ \\
\hline \multicolumn{2}{|l|}{ CONTEÚDO: } \\
\hline \multicolumn{2}{|c|}{ UNIDADE 1 - MADEIRA COMO MATERIAL DE CONSTRUÇÃO } \\
\hline \multicolumn{2}{|c|}{1.1 - Propriedades físicas e mecânicas. } \\
\hline \multicolumn{2}{|c|}{1.2 - Comentários sobre as normas brasileiras e normas alemãs. } \\
\hline \multicolumn{2}{|c|}{ UNIDADE 2 - BARRAS TRACIONADAS E COMPRIMIDAS } \\
\hline \multicolumn{2}{|c|}{ 2.1 - Problemas de verificação e dimensionamento de peças simples e múltiplas. } \\
\hline \multicolumn{2}{|c|}{2.2 - Flambagem de peças múltiplas. } \\
\hline \multicolumn{2}{|c|}{2.3 - Esforços nas barras de travejamento de peças múltiplas comprimidas. } \\
\hline \multicolumn{2}{|c|}{ UNIDADE 3 - LIGAÇÕES NAS ESTRUTURAS DE MADEIRA } \\
\hline \multicolumn{2}{|c|}{ 3.1 - Ligações por entalhes e encaixes, ligações em dentes. } \\
\hline \multicolumn{2}{|c|}{3.2 - Ligações por parafusos. } \\
\hline \multicolumn{2}{|c|}{3.3 - Ligações com conectores. } \\
\hline \multicolumn{2}{|c|}{3.4 - Ligações com pregos. } \\
\hline \multicolumn{2}{|c|}{3.5 - Ligações com cola. } \\
\hline \multicolumn{2}{|c|}{ UNIDADE 4 - FLEXÃO SIMPLES } \\
\hline \multicolumn{2}{|c|}{4.1 - Viga retangular simples solicitada à flexão simples. } \\
\hline \multicolumn{2}{|c|}{4.2 - Vigas compostas solicitadas à flexão simples. } \\
\hline \multicolumn{2}{|c|}{ UNIDADE 5 - FLEXÃO DESVIADA EM VIGAS DE MADEIRA } \\
\hline \multicolumn{2}{|c|}{5.1 - Flambagem lateral de vigas. } \\
\hline \multicolumn{2}{|c|}{5.2 - Presso-flexão e tenso-flexão. } \\
\hline \multicolumn{2}{|c|}{ UNIDADE 6 - ESTRUTURAS DE MADEIRA } \\
\hline \multicolumn{2}{|l|}{6.1 - Projeto. } \\
\hline \multicolumn{2}{|c|}{6.2 - Dimensionamento. } \\
\hline \multicolumn{2}{|c|}{ UNIDADE 7 - AÇO COMO MATERIAL ESTRUTURAL } \\
\hline \multicolumn{2}{|c|}{7.1 - Perfis estruturais. } \\
\hline \multicolumn{2}{|c|}{7.2 - Propriedades mecânicas do aço. } \\
\hline
\end{tabular}


7.3 - Comentários sobre as normas brasileiras e normas estrangeiras.

7.3 - Utilização arquitetônica de estruturas de aço.

UNIDADE 8 - ESTADOS LIMITES

8.1 - Bases para o dimensionamento nos estados limites.

8.2 - Ações e suas combinações.

UNIDADE 9 - BARRAS TRACIONADAS E COMPRIMIDAS

9.1 - Áreas de peças tracionadas.

9.2 - Esbeltez limite.

9.3 - Barras compostas tracionadas.

9.4 - Flambagem.

9.5 - Curvas para dimensionamento.

9.6 - Barras compostas comprimidas.

UNIDADE 10 - BARRAS FLETIDAS

10.1 - Flambagem localizada.

10.2 - Flambagem lateral e torção.

10.3 - Contenção lateral de barras fletidas.

10.4 - Resistência ao momento fletor e esforço cortante.

UNIDADE 11 - LIGAÇÕES NAS ESTRUTURAS DE AÇO

11.1 - Ligações com parafusos.

11.2 - Ligações com solda.

UNIDADE 12 - PROJETO DE ESTRUTURAS DE AÇO

12.1 - Concepção estrutural em estruturas de aço.

12.2 - Projeto e dimensionamento.

12.3 - Elaboração de projeto de estrutura de aço.

UNIDADE 13 - VISITA TÉCNICA

13.1 - Planejamento.

13.2 - Visita.

13.3 - Relatório.

\begin{tabular}{|l|l|}
\hline IES: & UNIVERSIDADE FEDERAL DE SANTA CATARINA - UFSC \\
\hline MUNICÍPIO: & Florianópolis \\
\hline DOC/DATA: & Programa de ensino 2015 \\
\hline DISCIPLINA: & ECV5650 - ESTRUTURAS DE MADEIRA (8 período) \\
\hline CH/CRED: & 02 créditos (36 horas) \\
\hline EMENTA: & $\begin{array}{l}\text { Análise da estrutura interna do material. Ortotropia do comportamento } \\
\text { mecânico da madeira. Tração, compressão e cisalhamento paralelo às } \\
\text { fibras. Compressão e tração transversal e inclinada às fibras. Flexão } \\
\text { simples. Solicitação de peças múltiplas. Ligações. }\end{array}$ \\
\hline
\end{tabular}




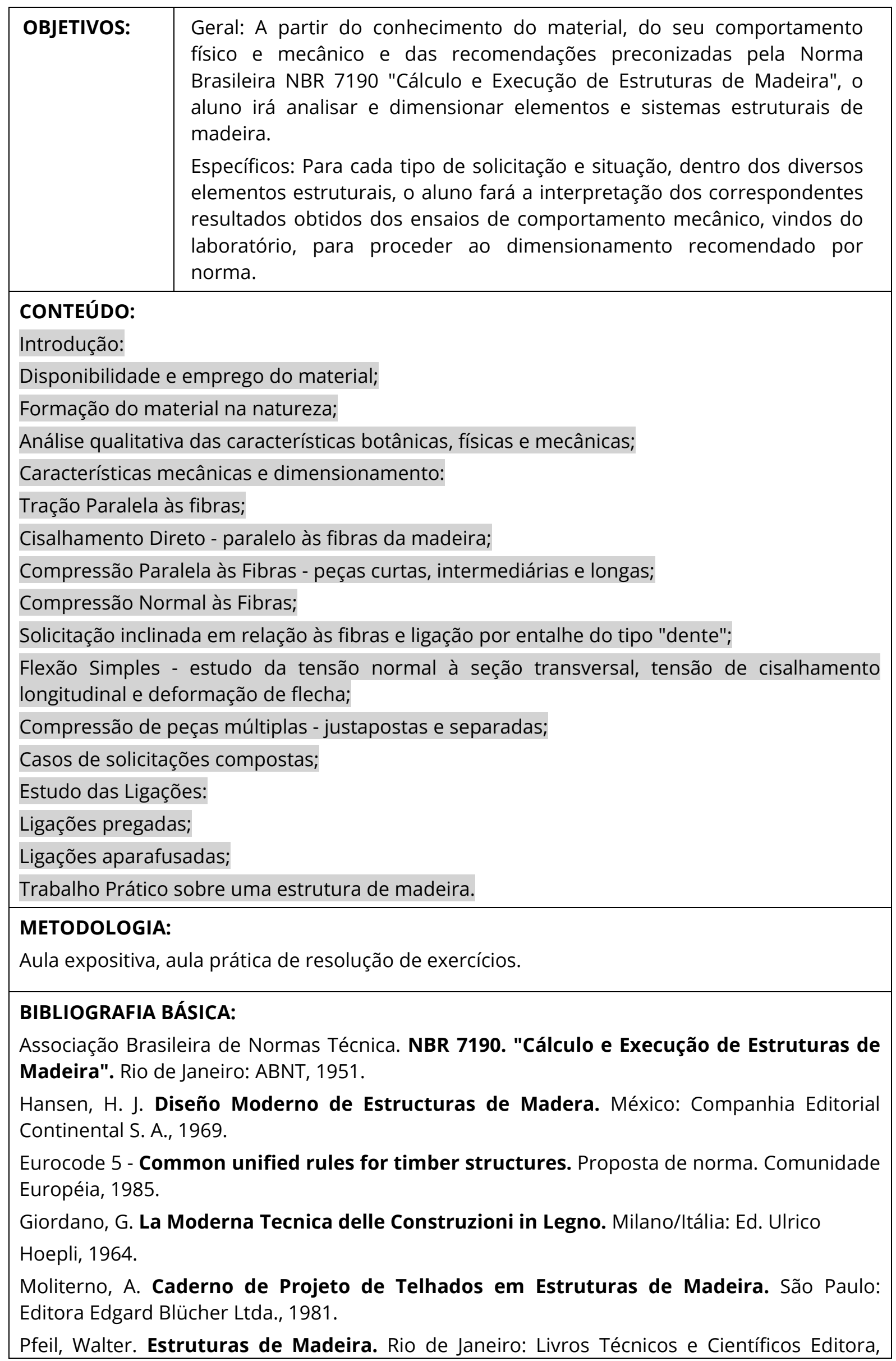


1982.

Mainieri, C.; Chimelo, J. P. Fichas de Características das Madeiras Brasileiras. São Paulo: IPT/ Instituto de Pesquisas Tecnológicas, Divisão de Madeiras, 1989.

Szucs, C. A. Estruturas de Madeira (notas de aula). Florianópolis, 1994. 
ANEXO B: Programa de curso do WOOD PROGRAM - Aalto University

A estrutura do curso e calendário de estudos do período de outono (FALL) e de primavera (SPRING) do ano de 2018-2019 para o WOOD PROGRAM da Aalto University, Finlândia.

Fonte: Website do Wood Program. Disponível em: http://woodprogram.fi/. Acesso em: 19 jul. 2019. 

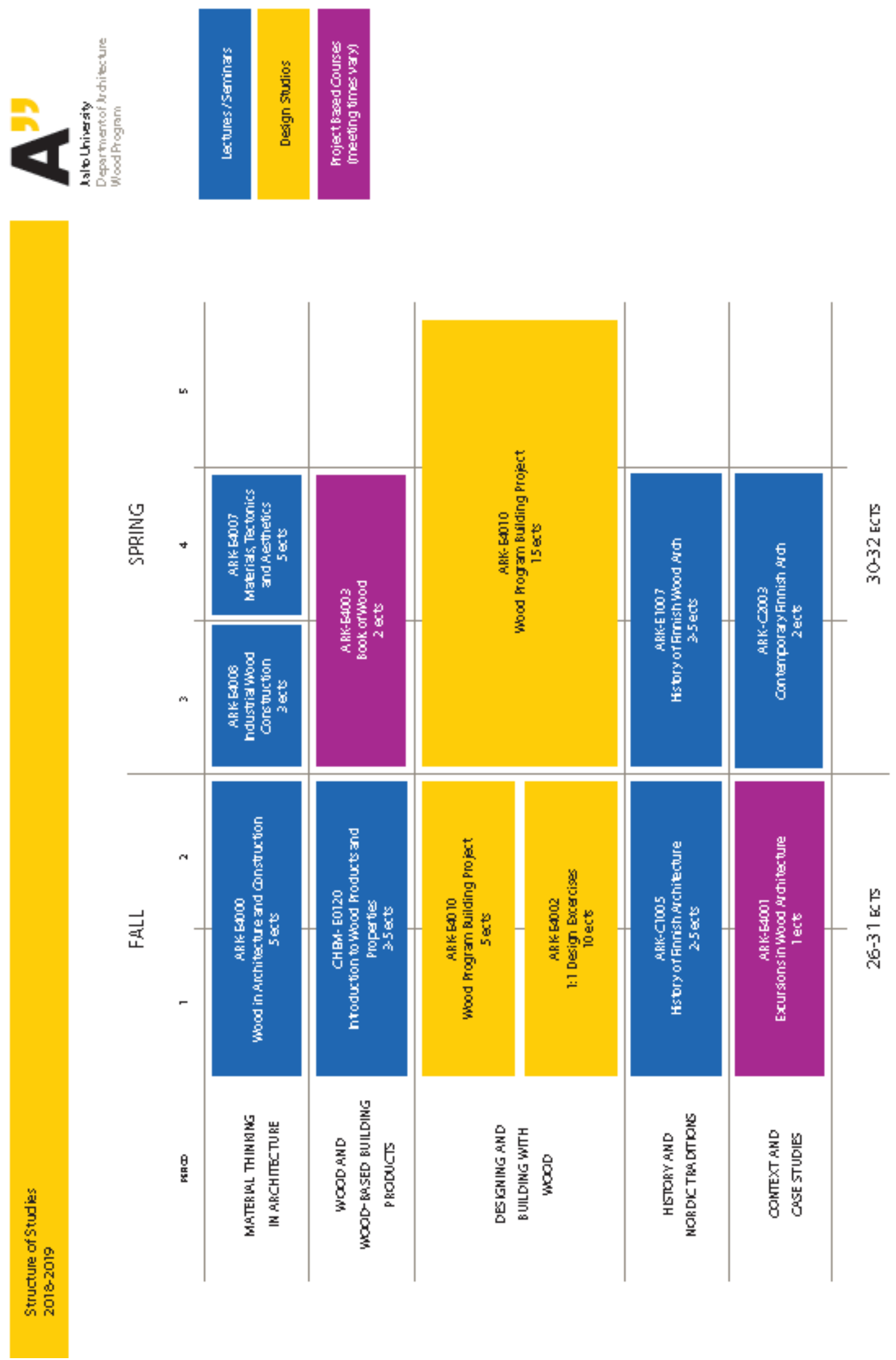


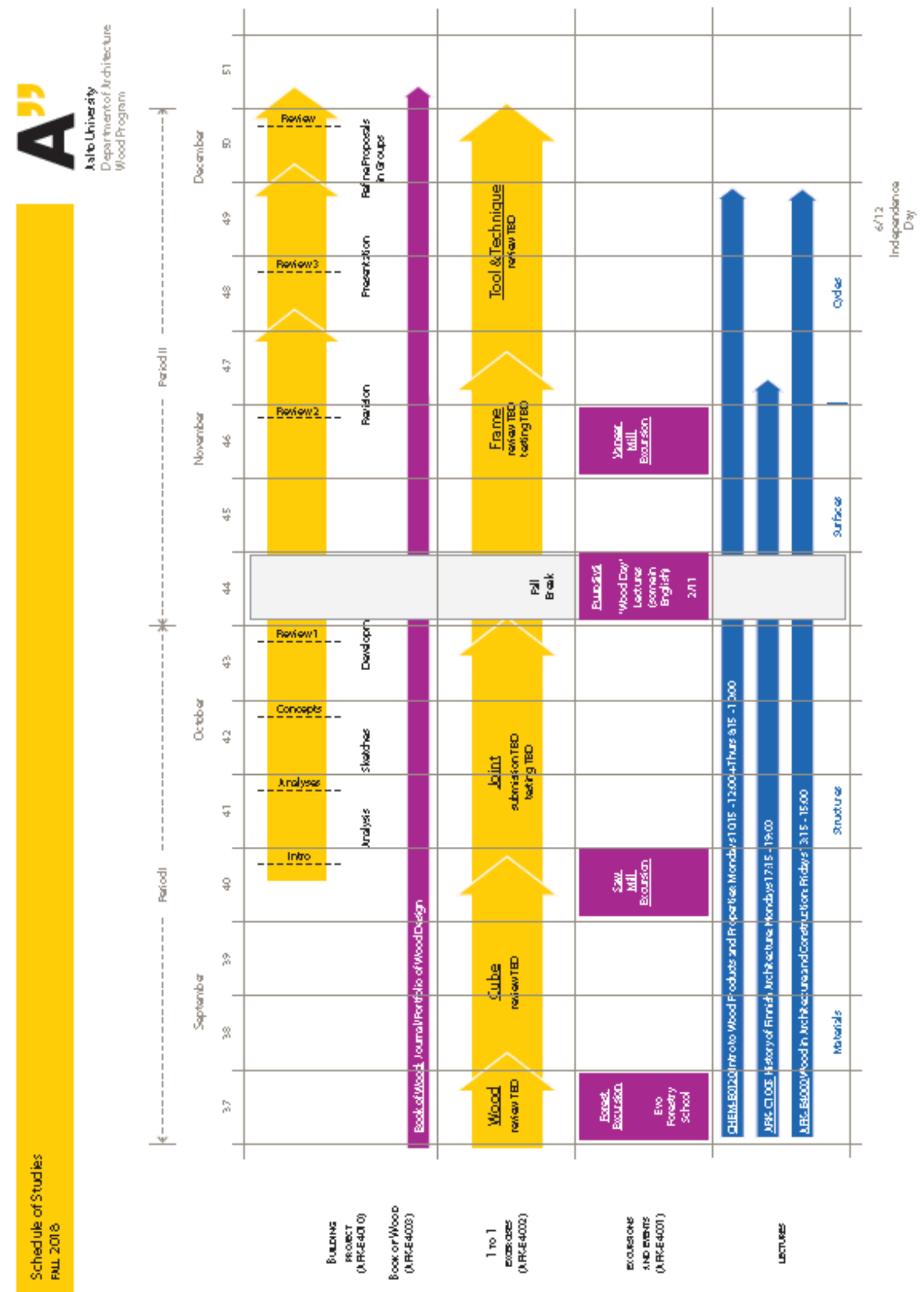




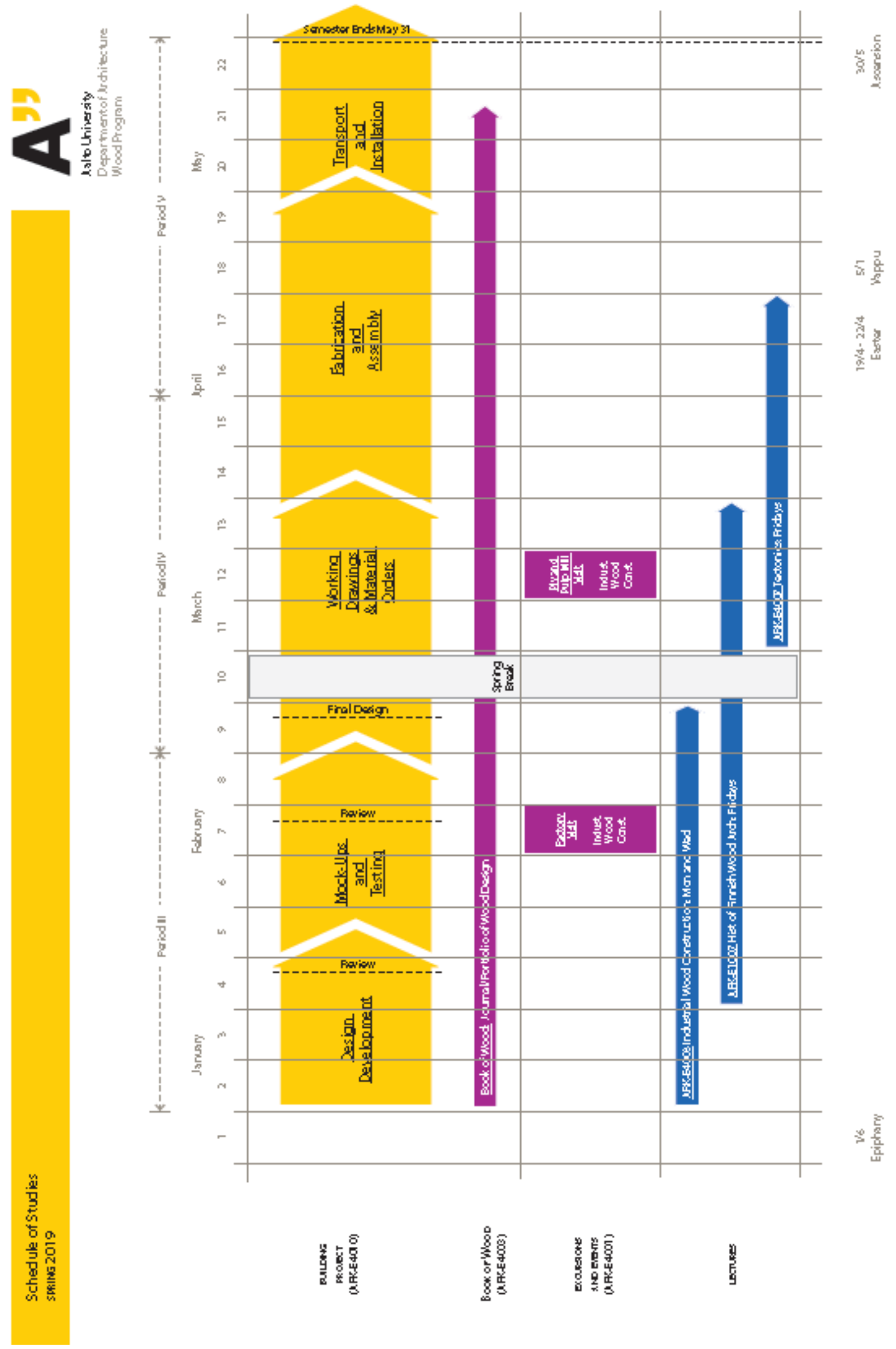


ANEXO C: Grade curricular do curso de Arquitetura da e[ad] PUCV

Grade curricular do curso de Arquitetura da Escuela de Arquitectura y Diseño da Pontificia Universidad Católica de Valparaíso, mudança de currículo de 2018.

Fonte: Website da e[ad] PUCV. Disponível em: http://wiki.ead.pucv.cl/Cambio_Curricular_2018. Acesso em: 25 ago. 2018.

Arquivo disponível em: https://wiki.ead.pucv.cl/Archivo:Malla_ARQ.pdf. 


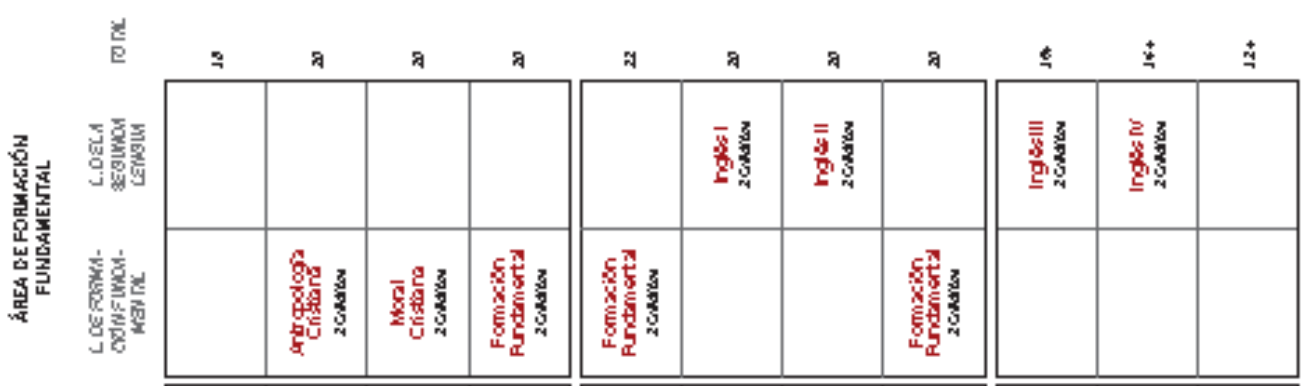

\begin{tabular}{|c|c|c|c|c|c|c|c|c|c|c|c|}
\hline 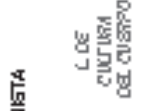 & 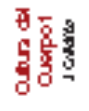 & 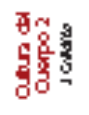 & 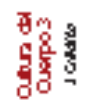 & 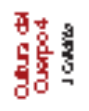 & 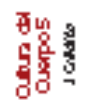 & 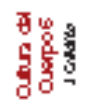 & 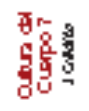 & & & & \\
\hline 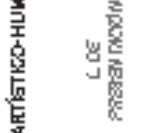 & & 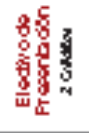 & & 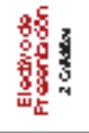 & & 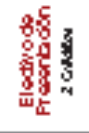 & & 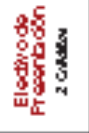 & 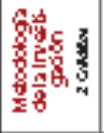 & & \\
\hline 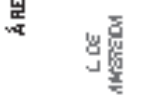 & 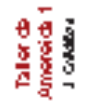 & 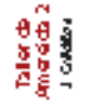 & 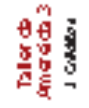 & 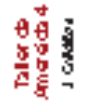 & 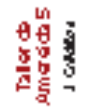 & 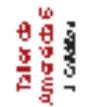 & 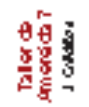 & & & & \\
\hline 童 & 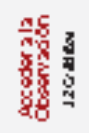 & 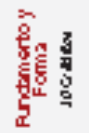 & 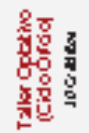 & 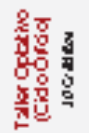 & 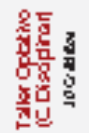 & 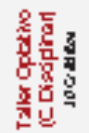 & 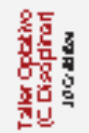 & 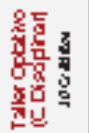 & 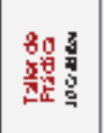 & 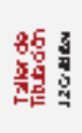 & 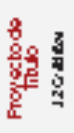 \\
\hline
\end{tabular}

总
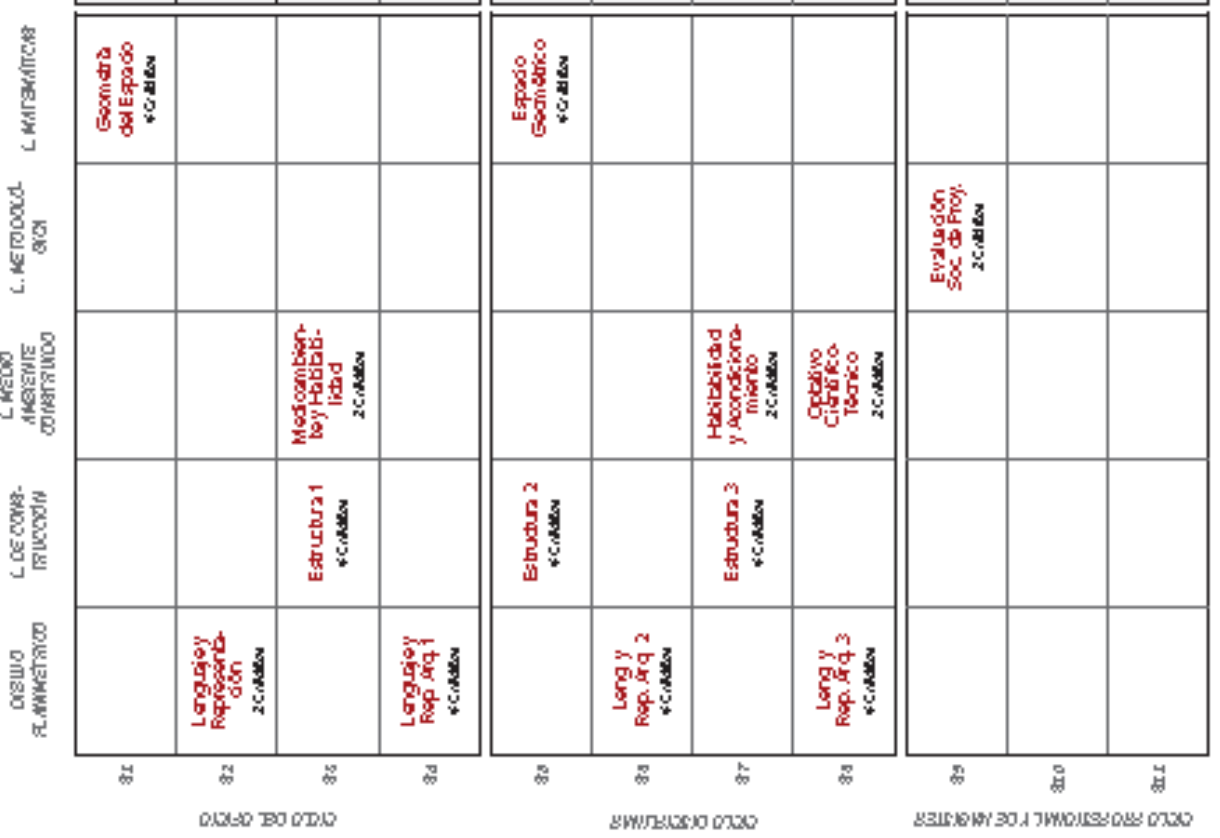
ANEXO D: Curso de Especialização Lato-Sensu em Arquitetura em Madeira: Projeto e Aplicação - FAAP

Programa do curso "Arquitetura em Madeira: Projeto e Aplicação" da Fundação Armando Álvares penteado - FAAP, campus São Paulo, para o ano de 2017-2019.

Fonte: Website da Pós-graduação da FAAP. Disponível em: http://pos.faap.br/descricao/arquitetura-em-madeira-projeto-e-aplicacao/667\#tab-1. Acesso em: 19 ago. 2017 


\begin{tabular}{|l|l|}
\hline IES: & FUNDAÇÃO ARMANDO ÁLVARES PENTEADO - FAAP \\
\hline MUNICÍPIO: & São Paulo \\
\hline DOC/DATA: & Programa do curSo 2017 \\
\hline CURSO: & ARQUITETURA EM MADEIRA: PROJETO E APLICAÇÃO \\
\hline CARGA HORÁRIA: & 432 h/aula \\
\hline COORDENAÇÃO: & Marcelo Aflalo \\
\hline
\end{tabular}

\section{SOBRE O CURSO:}

A madeira, o mais antigo e familiar material de construção é também o mais contemporâneo e tecnológico dos materiais disponíveis. Por outro lado, é o menos difundido e compreendido em toda a cadeia construtiva. As escolas de arquitetura não oferecem cursos específicos na área e nem cobrem as oportunidades de projeto que esse material e mercado oferecem.

O curso de Especialização Lato-Sensu em Arquitetura em Madeira: Projeto e Aplicação da FAAP vem para preencher essa lacuna e ampliar as possibilidades de atuação dos arquitetos, engenheiros e carpinteiros, promovendo o uso intensivo e sustentável da madeira na construção.

Esse programa vai abordar todos os aspectos dessa cadeia construtiva, desde a origem da matéria prima até as questões de linguagem e mercado. Esse amplo enfoque vai permitir que esse material, o único renovável em toda a indústria da construção, torne-se o material do futuro.

\section{OBJETIVO:}

Fomentar a formação continuada de arquitetos, engenheiros e técnicos especialistas no uso da madeira na construção civil, de forma nobre e intensiva, sustentável, com visão tecnológica contemporânea e industrializada. Formar especialistas em criação, experimentação e construção de estruturas em madeira, dentro de concepções inovadoras.

\section{A QUEM SE DESTINA:}

Interessados com formação em curso superior em arquitetura e engenharia. Profissionais atuantes nas áreas de Projeto, Construção, Carpintaria e Indústria da madeira em geral.

\section{METODOLOGIA:}

Aulas expositivas com apoio de imagens, ateliers de desenvolvimento de projetos de estruturas, componentes e conexões; seminários com arquitetos da área; construção de protótipos e maquetes; visitas a oficinas; exercícios de desenho e palestras temáticas.

\section{PROGRAMA: $1^{\circ}$ SEMESTRE}

\section{MEIOS DE REPRESENTAÇÃO}

Introdução às formas de representação gráfica e tridimensional específicas da linguagem de projetos em madeira, fazendo as pontes entre croquis, esquema estrutural, projeto de arquitetura, projeto estrutural, produção e montagem. Serão produzidos desenhos relativos a todas as etapas citadas.

\section{PERSPECTIVA HISTÓRICA GLOBAL DA CONSTRUÇÃO EM MADEIRA}

Abordagem das dimensões culturais da arquitetura em madeira com uma visão histórica global, destacando a diversidade, tradição, linguagem, permanência e impermanência das mais diversas obras em diferentes contextos. 


\section{PROJETO ESTRUTURAL - CONCEITO E APLICAÇÃO}

Essencial para a compreensão dos sistemas estruturais e das escolhas projetuais esse módulo aborda os conceitos formadores das estruturas em madeira, analisando resistência, arranjos, conectores e detalhes, análises gráficas (diagramas, símbolos, design, representação), componentes de projeto (pilares, vigas, elementos compostos, seções variáveis e cascas) e linguagem.

\section{CONCEITOS ESTRUTURAIS EM MADEIRA: WORKSHOP (professor convidado)}

Workshop introdutório ao pensamento projetual em madeira, através da análise de estruturas autoportantes em pequena escala, para a compreensão e aplicabilidade dos princípios estruturais abordados pelo curso. Aplicação em um módulo autoportante em escala real e construído pelo grupo.

\section{MATÉRIA PRIMA: MADEIRA COMO OPÇÃO}

Através da produção contemporânea, esse módulo investiga como interpretar as opções e diferenças, desde a árvore até os produtos derivados, e como fazer escolhas de produtos adequados aos mais diferentes projetos.

\section{$2^{\circ}$ SEMESTRE}

\section{PERSPECTIVA HISTÓRICA E DA PRODUÇÃO CONTEMPORÂNEA NO BRASIL - SEMINÁRIOS}

Produção brasileira sob uma perspectiva histórica complementada por apresentações de projetos pelos seus autores ao longo de seminários, seguidos de análises e discussão de processos.

\section{COMPONENTES, CONEXÕES E ARTICULAÇÕES}

O diferencial de raciocínio projetual em estruturas de madeira está no uso mais apropriado das diversas alternativas de conexões entre elementos estruturais. Nesse módulo analisamse as propriedades das soluções tradicionais e das novas formas de conexão entre componentes construtivos em madeira, usando modelos customizados e componentes industrializados, igualmente.

\section{SUSTENTABILIDADE NA CADEIA CONSTRUTIVA}

Abordagem de todas as instâncias em que o pensamento sustentável pode incidir sobre a cadeia produtiva da construção civil, através do uso da sua única matéria prima renovável. Serão discutidos os ciclos da madeira, do descarte e reuso dos resíduos, a otimização da matéria prima através de projeto e produção, manejo florestal, certificações, economia e bem-estar.

\section{PROJETO ESTRUTURAL - WORKSHOP (professor convidado)}

Aplicação direta dos conceitos discutidos ao longo do curso, em projetos de média complexidade, passando por todas as etapas de projeto características das construções em madeira.

\section{$3^{\circ}$ SEMESTRE}

\section{DETALHES CONSTRUTIVOS}

Análise e elaboração de detalhes, visando durabilidade, comportamento, resistência e adequação aos mais diversos processos construtivos. Serão apresentados detalhes construtivos de projetos abordados nos seminários sobre arquitetura brasileira, bem como detalhes construtivos sobre questões especiais como incêndio, isolamento acústico, 
proteção contra intempéries, etc.

\section{MEIOS DE PRODUÇÃO: INDUSTRIALIZAÇÃO E PROCESSOS}

Introdução às técnicas e procedimentos que vão desde a análise da matéria prima até a montagem final. Cada etapa tem variáveis que dependem do projeto, do local da obra, de custos, de tecnologia e outras tantas que serão apresentadas com exemplos e material de apoio. Complementada por visitas à indústria.

\section{INTRODUÇÃO ÀS ESTRUTURAS COMPLEXAS}

A arquitetura em madeira tem apresentado uma evolução tecnológica veloz, incorporando processos e recursos de concepção que são particulares e merecem análise dedicada. Esse módulo introduz algumas dessas tecnologias através de filmes, seminários e práticas com softwares e equipamentos complexos. Poderão ser desenvolvidos pequenos modelos conceituais em oficina.

\section{MODELAGEM E MAQUETES}

A maquete é um instrumento fundamental de apoio ao projeto, na medida em que a matéria prima é a mesma do produto final, aproximando o conceito da aplicação. Utilização das oficinas no desenvolvimento de modelos com fins de avaliação de montagem, produção, resistência, nos materiais finais em que os projetos serão construídos. Os modelos terão escalas e detalhes variados em função de seu propósito construtivo.

\section{$4^{\circ}$ SEMESTRE}

\section{METODOLOGIA CIENTÍFICA}

Análise do processo de planejamento e desenvolvimento do projeto de especialização. Estabelecimento dos parâmetros para a monografia como obrigatoriedades e formatação. Metodologia operacional do projeto: as etapas de planejamento e desenvolvimento. Aplicação das metodologias e conceitos que sustentam o projeto e a prática professional.

\section{DESENVOLVIMENTO DO PROJETO INTEGRADO}

Desenvolvimento do trabalho de conclusão do curso, incluindo análise, concepção escrita e projetual. 



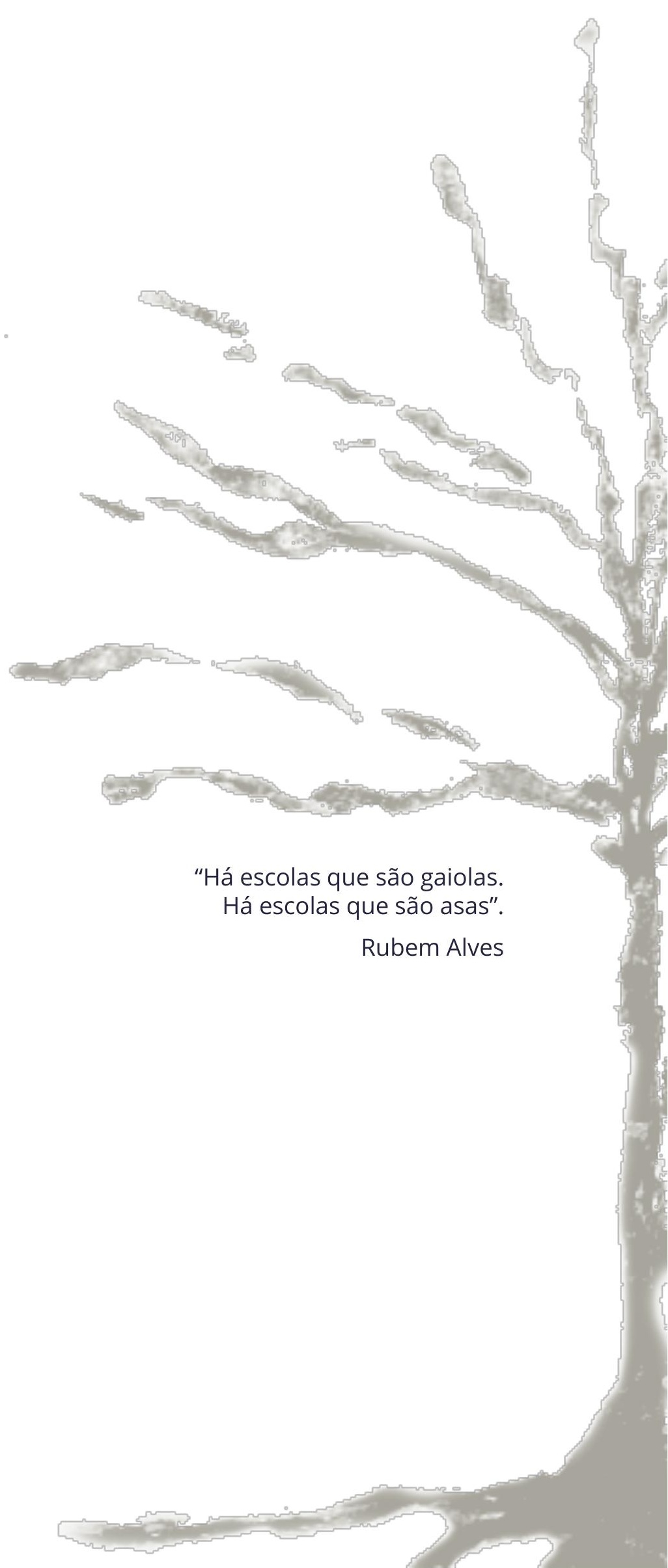

